
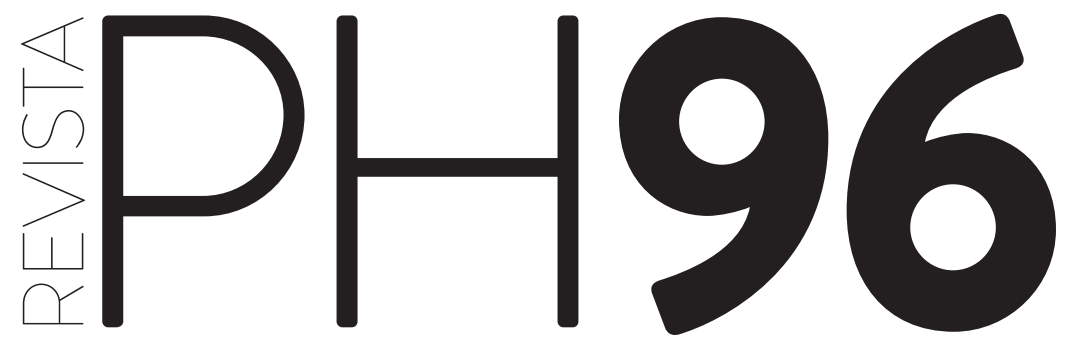

INSTITUTO ANDALUZ DEL PATRIMONIO HISTÓRICO

JUNTA DE ANDALUCÍA

FEBRERO 2019

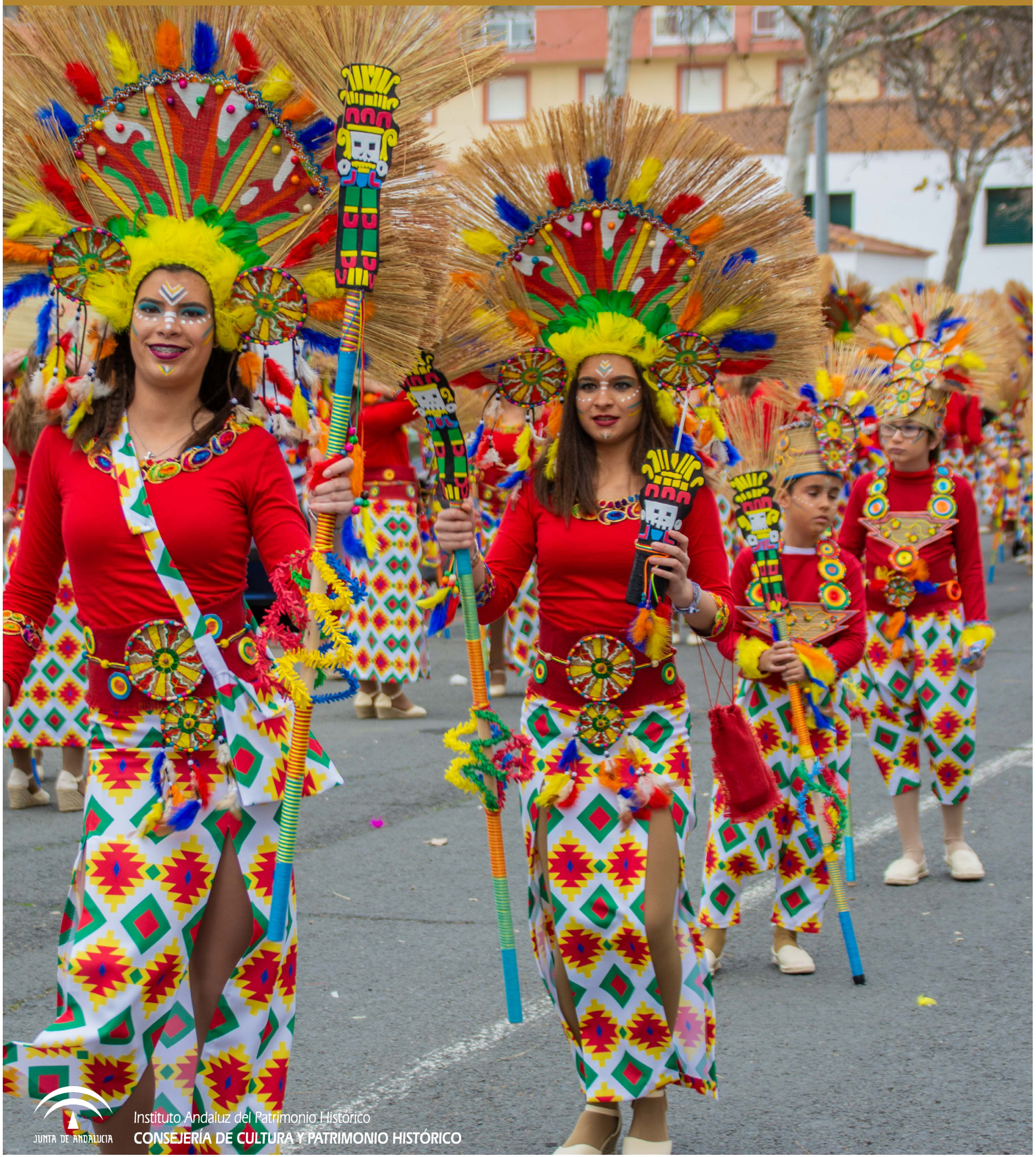




\section{$\mathrm{P} H 96$}

actualidad

002 Technoheritage: ciencia, tecnología y empresa al servicio del patrimonio cultural Manuel Castellano Román, María del Pilar Ortiz Calderón, Francisco Pinto Puerto, Emilio Cano Díaz

004 Lugares de encuentro: crónica del 24 congreso anual de la European Association of Archaeologists

Margarita Sánchez Romero

006 El IAPH bucea y difunde las buenas prácticas para la activación del patrimonio cultural Isabel Luque Ceballos

010 Antropoloops: un acercamiento creativo al patrimonio inmaterial desde la remezcla Rubén Alonso Mallén, Esperanza Moreno Cruz

013 PAX-Patios de la Axerquía y el valor social del patrimonio Gaia Redaelli

016 HeritageCare: "Prevenir mejor que curar" Daniel V. Oliveira, Maria Giovanna Masciotta

019 La recuperación del estandarte real del Ayuntamiento de Sanlúcar de Barrameda Carmen Ángel Gómez

023 HELPS, autocostrucción colaborativa y ecológica

Arturo Jiménez Viera, José Daniel Rodríguez Mariscal, Juan Javier Usero Fernández, Jorge Moya Muñoz

025 La Red Nacional de Maestros de la Construcción Tradicional Alejandro García Hermida

027 Interacciones culturales para la puesta en valor de la arquitectura tradicional construida en tierra

Jorge Moya Muñoz

029 Nueva etapa de la revista ARGO

Silvia Dahl

bienes, paisajes e itinerarios

\section{Huelva y la costa occidental}

Paisajes mutantes de Huelva y la costa occidental Juan A. Márquez Domínguez

Panorama actual de la arqueología urbana en Huelva Juan M. Campos Carrasco

8 Los lugares colombinos de Huelva: historia, cultura y naturaleza Diego Ropero-Regidor

8 La pesca tradicional en Huelva: de las salazones y las conserveras al congelado Juan José García del Hoyo, Celeste Jiménez de Madariaga

80 Los molinos mareales del litoral onubense Patxi Serveto i Aguiló, Diego Vázquez Capelo

El legado de Juan Ramón Jiménez en Moguer Centro de Estudios Juanramonianos

6 Una breve incursión por el Carnaval de Isla Cristina, una celebración centenaria Agustín P. Figuereo

4 La salina de Biomaris (Isla Cristina). La última instalación artesanal de la costa onubense Daniel Martínez Castizo

110 Huelva y costa occidental en el IAPH 
artículos

114 ForSEAdiscovery: la construcción naval y el comercio de la madera del siglo XVI al XVIII Ana Crespo Solana

142 El IVCR+i premio Europa Nostra 2018 por su proyecto de conservación de los bocetos de Sorolla Visión de España

Gemma María Contreras Zamorano, Elena Gandía Guijarro

158 Caracterización radiométrica de una cabeza de flash para su uso en digitalización de obras de arte

José Manuel Pereira Uzal

perspectivas Memoria democrática en la construcción de la historia y el patrimonio coordina Josefina Cuesta Bustillo

170 Introducción al debate

Josefina Cuesta Bustillo

172 Breve reflexión de conjunto: "No se ha dormido aún el pasado" Josefina Cuesta Bustillo

193 La memoria franquista en el espacio urbano. Cuestiones metodológicas e historiográficas para las comisiones locales de memoria histórica

César Rina Simón

197 Memoria democrática versus memorias democráticas Ignacio Muñiz Jaén

199 Debates sobre la memoria como patrimonio colectivo Jordi Guixé Coromines

201 Memoria democrática y verdad

Jorge Benavides Solís

203 ¿Qué hacemos con la División Azul? Sobre la necesidad de una memoria atenta a los detalles Alfredo Francesch

206 El "No se olvida", ¿se puede olvidar?

Francisco José Casado Pérez

208 Función simbólica del patrimonio

Asunción Cobo Gómez

210 La memoria democrática en el juego entre memoria y cultura María del Rosario Zavala

212 Entre la memoria plural y la memoria crítica Olivia Muñoz-Rojas

214 La exposición como medio de difusión y puesta en valor del papel de la mujer en el proceso de construcción de una memoria democrática Jesica Serrano Granados

216 Memoria histórica y democrática con perspectiva de género M. ${ }^{\text {a }}$ Cristina Ferrer González

217 La memoria democrática como elemento de transformación ante la crisis de régimen Daniel Martínez Castizo

219 El futuro de la memoria

Carlos Barros

222 Compromiso democrático, patrimonio y memoria en la enseñanza de la historia Emilio José Delgado-Algarra 
Memoria, patrimonio y ciudadanía: una contribución desde una perspectiva didáctica Jesús Estepa Giménez

227 El olvido está lleno de memorias: memorias y patrimonios de nuestro pasado reciente Andrea Moreno Martín

231 La memoria histórica y su dimensión política, social y académica

Custodio Velasco Mesa

235 La memoria brota de la experiencia, y viceversa

Carlos García de las Bayonas Abelleira

237 ¿Dónde están las mujeres en la memoria democrática?

Asociación Herstóricas. Historia, mujeres y género

239 Cuando la memoria deja de estar en blanco y negro: las exposiciones participativas del museo de La Rinconada (Sevilla)

Maribel Rodríguez Achútegui

241 Memoria, democracia y construcción de lo público Maria Chiara Bianchini

El patrimonio contemporáneo en la construcción de la memoria democrática. La arquitectura que pervivió a los cambios de régimen del siglo XX

Juan-Andrés Rodríguez-Lora

246 Más allá de la connotación franquista. Una reflexión sobre la patrimonialización de las barriadas promovidas por el Instituto Nacional de la Vivienda

Daniel Navas-Carrillo

249 Memoria democrática en la construcción de la historia y el patrimonio

Dirección General de Memoria Democrática, Consejería de Presidencia, Administración Local y Memoria Democrática, Junta de Andalucía

251 Los caminos tortuosos de las defensoras de la(s) memoria(s) de la posguerra peruana José Ramos López

255 La historia es... Reflexiones sobre los conceptos de historia, memoria y patrimonio Antonio Gisbert Santaballa

260 Arte silenciado, arte olvidado. La mujer creadora en la etapa franquista Marcos Serrano-Carrillo, Mercedes Molina-Liñán

entrevista

Maguelonne Déjeant-Pons: "Los cambios de calado que están experimentado nuestras sociedades y paisajes nos llevan a nuevos modelos económicos" por Redacción [pp. 262-271]

reseñas

272 "Digan lo que supieren...": Miradas y lecturas sobre el agua en Tempul por María del Castillo García Romero

274 De lo original a lo auténtico. La restauración de la Mezquita-Catedral de Córdoba durante el siglo XX

por Julián Esteban Chapapría

276 Guía de arquitectura contemporánea. Roquetas de Mar por Jaime Vergara-Muñoz, Miguel Martínez-Monedero

278 Modelado de información para Arqueología y Antropología: Principios de Ingeniería de Software para Patrimonio Cultural

por Silvia Isabel Quinto Fernández 
280 (Aspectos de) La Arquitectura después de Bretton Woods por Simona Pecoraio

282 Sitio de los dólmenes de Antequera. Patrimonio Mundial de la UNESCO por Guido Cimadomo

284 El género en el patrimonio cultural por Gina Monserrat Núñez-Camarena

286 Malaga in the postcards of Purger \& Co. around 1905 por Luis José García Pulido

Revista PH (ISSN 23-40-7565) es una publicación en línea cuatrimestral (febrero, junio y octubre), destinada a los profesionales e invesigadores del patrimonio histórico/cultural.

Sus contenidos están disponibles, de manera gratuita y sin restricciones, en el sitio web www.iaph. es/revistaph. En esa misma dirección encontrará publicadas las contribuciones de la etapa impresa.

Este fichero constituye una recopilación de todos los artículos del número, que pretende facilitar la descarga e impresión personal, pero no es, en ningún caso, una versión impresa de la publicación periódica digital.

Revista PH se edita bajo una licencia creative commons 3.0 BY-NC-ND, por lo que usted es libre de difundir su contenido siempre que cite claramente la fuente original, no utilice la obra para fines comerciales y no altere o transforme la obra. 


\section{Technoheritage: ciencia, tecnología y empresa al servicio del patrimonio cultural}

La Red de Ciencia y Tecnología para la Conservación de Patrimonio Cultural ${ }^{1}$ funciona desde 2011. Aglutina a sesenta y siete grupos distribuidos en tres áreas de actividad: grupos de investigación del CSIC y universidades españolas; instituciones culturales, fundaciones y museos; y empresas del sector. La red pretende fomentar la colaboración entre los actores del sistema ciencia-tecnología-empresa para la puesta en común de ideas y experiencias que ayude a la resolución de problemas y permita la transferencia de tecnología. El objetivo común: contribuir a la conservación del patrimonio cultural. En 2019 celebra su cuarto congreso en Sevilla con la participación activa del IAPH.

Manuel Castellano Román, María del Pilar Ortiz Calderón, Francisco Pinto Puerto, Emilio Cano Díaz | dirección y coordinación Technoheritage 2019

URL de la contribución <http://www.iaph.es/revistaph/index.php/revistaph/issue/view/4254>

Los avances científicos y tecnológicos que inciden sobre la tutela del patrimonio cultural se producen de forma cada vez más acelerada. Sistemas de auscultación, prospección y análisis de su materialidad, de control de las diversas magnitudes que lo caracterizan, o de representación y modelización, han adquirido una dimensión inédita en las últimas décadas. Las tecnologías digitales no sólo mejoran cuantitativa y cualitativamente las posibilidades de aproximación al legado histórico, sino que permiten nuevas formas de interpretarlo y difundirlo. Se abren nuevos horizontes que permiten incorporar miradas muy diversas sobre lo patrimonial, procedentes de disciplinas cada vez más especializadas, con sus propios lenguajes y algoritmos. Resulta necesario interpretar las grandes masas de datos que ofrecen estas disciplinas y, a la vez, abordar las dificultades de gestión y garantías de permanencia de una cantidad de información cada vez más especializada, que además puede evolucionar en tiempo real. Esta visión multidisciplinar y tecnológica de la tutela patrimonial la enriquece, pero a la vez la complejiza, situándola ante el reto de su gestión integrada.

Los sesenta y siete grupos que integran la Red Technoheritage, en funcionamiento desde 2011 , se distribuyen en tres áreas de actividad: investigación (del Consejo Superior de Investigaciones Científicas y de diferentes universidades españolas); instituciones cultu- rales, fundaciones y museos; y empresas del sector. $Y$ las acciones que llevan a cabo se pueden agrupar en cuatro categorías: 1) impulsar a los diferentes grupos mediante la coordinación de actividades, en la actualidad dispersas en diferentes áreas científicas; 2) obtener el reconocimiento institucional de las actividades y la promoción de los grupos miembros a través de acciones prioritarias; 3) fomentar la colaboración entre los grupos de cara a crear una masa crítica mediante su asociación en proyectos de investigación nacionales y europeos; y 4) crear una proyección adecuada de la Red mediante la colaboración con grupos europeos similares para facilitar el acceso a consorcios y proyectos internacionales.

\section{Un congreso internacional sobre el impacto de lo digital en la tutela del patrimonio}

La Red Technoheritage, perteneciente al CSIC, ampara la celebración del International Congress Science and Technology for the Conservation of Cultural Heritage, cuya cuarta convocatoria se celebrará en Sevilla ( 26 al 30 de marzo de 2019), colaborando en su organización y difusión el Instituto Andaluz del Patrimonio Histórico. La convocatoria anterior se celebró en Cádiz en el año 2017, y tuvo una gran repercusión en el ámbito de la investigación ${ }^{2}$.

Se trata de un encuentro internacional de investigadores y especialistas de múltiples áreas vinculadas al conoci- 


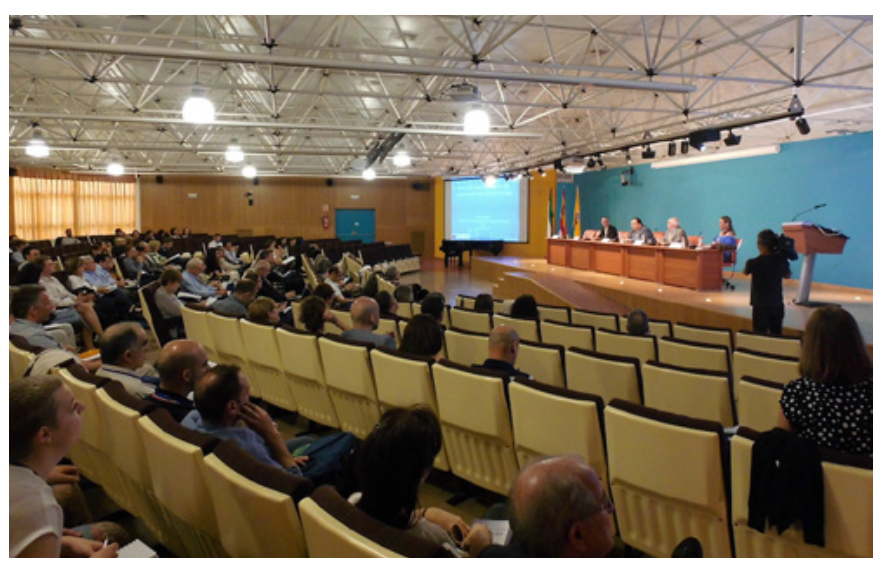

Ceremonia de apertura del III Congreso Technoheritage, 21 a 24 de 2017, Cádiz

miento y conservación del patrimonio cultural -en esta ocasión con varias secciones dedicadas al patrimonio arquitectónico- y que comparten el uso de tecnologías digitales en sus estrategias metodológicas. Se presentarán trabajos sobre nuevas tecnologías, materiales y productos y se tratarán cuestiones candentes sobre gestión, impacto social, riesgos y vulnerabilidad del patrimonio cultural $^{3}$, destacándose el papel y el impacto de las tecnologías digitales para el conocimiento, mantenimiento, gestión y difusión del mismo. Se debatirá sobre cómo los medios digitales no sólo facilitan y mejoran los procesos científicos y técnicos que tradicionalmente son usados para la tutela del patrimonio, sino cómo también modifican la manera de entender el patrimonio, percibirlo y transmitirlo, y ofrecen un nuevo horizonte de estrategias para hacer más sostenible la toma de decisiones sobre su conservación en el tiempo.

El Congreso se desarrollará íntegramente en inglés y las actas serán publicadas posteriormente en una editorial externa indexada con índice de impacto. Se han recibido más de un centenar de contribuciones que serán revisadas por el Comité Científico del Congreso, formado por expertos de varias nacionalidades. Los contenidos y la estructura en áreas temáticas forman parte de las acciones recogidas en dos proyectos I+D+i financiados por el actual Ministerio de Ciencia, Innovación y Universidades, cuyos equipos se han coordinado para organizarlo conjuntamente. Se trata de los proyectos Art-Risk ${ }^{4}$, cuya investigadora principal es Pilar Ortiz Calderón, de la Universidad Pablo de Olavide, y el pro-

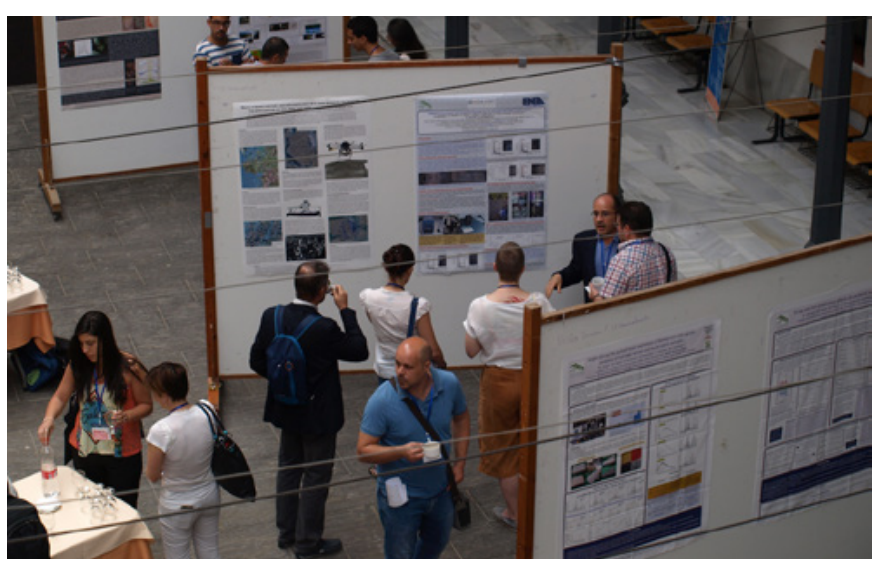

Presentación de Póster durante el III Congreso Technoheritage

yecto TUTSOSMOD ${ }^{5}$, cuyo investigador principal es Francisco Pinto Puerto, de la Universidad de Sevilla. Los IP de ambos proyectos son los directores de este evento que coordina el profesor Manuel Castellano Román.

\section{NOTAS}

1. TechnoHeritage ha contado con financiación del Ministerio de Ciencia e Innovación (Acción Complementaria HAR2010-11432-E) y de la Agencia Estatal de Investigación-Ministerio de Economía, Industria y Competitividad (Convocatoria 2016 de Redes de Excelencia, HAR21681748-REDT), y los recursos propios de los grupos participantes en la misma (http://www.technoheritage.es/).

2. Celebrado en Cádiz entre los días 21 y 24 de mayo de 2017 <https://technoheritage2017.uca.es/>.

3. Los temas de trabajo quedan recogidos en la web del congreso (congreso.us.es/technoheritage19).

4. Proyecto BIA2015-64878-R de la Universidad Pablo de Olavide (https://www.upo.es/investiga/art-risk/).

5. Proyecto HAR2016-78113-R de la Universidad de Sevilla (http://grupo.us.es/tutsosmodhum/). 


\section{$\mathrm{PH} 96_{\text {actualidad }}$}

\section{Lugares de encuentro: crónica del 24 congreso anual de la European Association of Archaeologists}

En septiembre de 2018 tuvo lugar en Barcelona el 24 congreso anual de la European Association of Archaeologists (EAA). Estas reuniones suponen un lugar de encuentro y de debate en una disciplina que cada vez trabaja más en redes y conoce menos fronteras, donde la movilidad de las y los profesionales y la colaboración (o al menos el conocimiento mutuo) entre equipos de investigación está cada día más asentada como práctica; con la certeza de que, sin esos vínculos, es mucho más complicado enfrentarse a los retos, tanto científicos como sociales, de la práctica arqueológica.

Margarita Sánchez Romero | miembro del Comité Científico del EAA meeting 2018

URL de la contribución <http://www.iaph.es/revistaph/index.php/revistaph/issue/view/4270>

Las temáticas elegidas por el comité científico para estructurar la reunión del EAA meeting 2018 trataron de incorporar la diversidad de la asociación y la compleja y múltiple dimensión de la práctica arqueológica: desde la propia interpretación de las sociedades del pasado a través de la disciplina, pasando por cómo tutelar este patrimonio especial y específico, hasta la práctica política desde la arqueología, tanto en el pasado como en el presente.

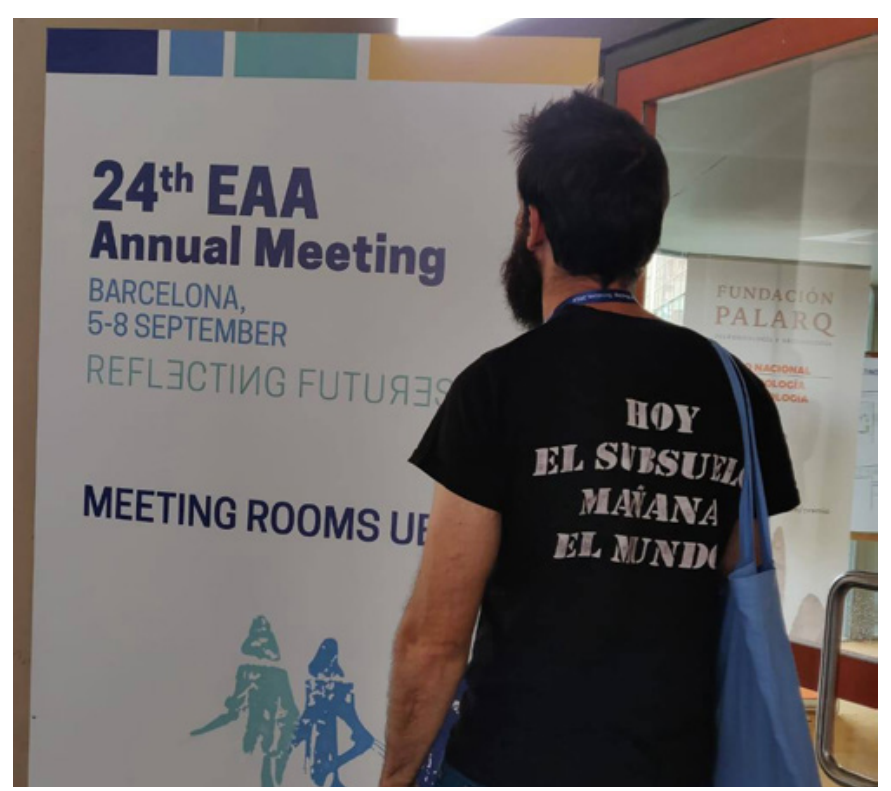

Cartel anunciador del EAA 2018 en el que aparece el logo con las tres figuras femeninas procedentes de la Roca dels Moros del Cogul (Lleida)
Para lograr estos objetivos se definieron inicialmente cinco líneas de trabajo: teoría y método en arqueología; la arqueología de los cuerpos, los paisajes y la cultura material; los paisajes del mar Mediterráneo; la arqueología y el futuro de las ciudades y los paisajes urbanos; y los museos y los retos del patrimonio arqueológico en el siglo XXI. Además, coincidiendo con la celebración del Año Europeo del Patrimonio Cultural, se articuló una sexta línea relativa a esta temática. Sin duda alguna el congreso ha supuesto un éxito en lo que se refiere al cumplimiento de los objetivos científicos y también a la, siempre compleja, organización de este tipo de reuniones, que en esta ocasión se ha concretado en 260 sesiones que convocaron a más de 3.000 participantes. Este año, además, con un importante seguimiento a través de las redes sociales.

No es fácil resumir en pocas líneas la enorme diversidad de debates, experiencias y actividades de diversa índole de las que hemos disfrutado en estos días. Más allá de la obvia, y sin duda importante, relevancia científica del congreso, y de la constatación del impacto que la aplicación de técnicas analíticas de última generación está teniendo ya en la conformación en la disciplina, son destacables una serie de aspectos que dan buena prueba de la pertinencia de la arqueología como poderosa herramienta de transformación social. Por un lado, la propuesta de diferentes colectivos procedentes de la antropología y la arqueología de detectar, escuchar y compartir situaciones de abuso sexual en la profesión. 


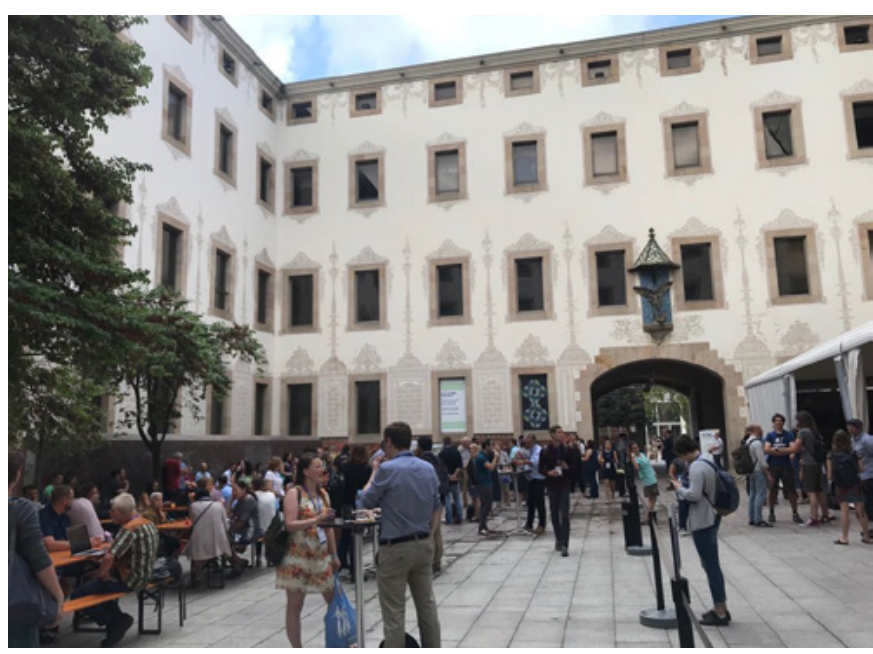

EAA Social Media Team. El patio del Centre de Cultura Contemporània de Barcelona se convirtió en el punto de encuentro central del congreso

Los datos recogidos a través de una encuesta anónima y tratados estadísticamente fueron discutidos en la sesión The Women Dimension in Archeology: Between Politics and Social Constrains. Esta cuestión pretende consolidarse como una de las líneas de trabajo para el EAA en los próximos años.

Por otra parte, la elección tanto de las temáticas como de las personas (mujeres y hombres en igual número) que impartieron las conferencias plenarias marca claramente las principales preocupaciones de la disciplina. Sin duda fue interesante la dictada por José Manuel Fernández de Labastida, jefe del Departamento Científico del Consejo Europeo de Investigación, que trató las fuentes de financiación para proyectos de investigación. Pero me gustaría destacar algunas que versaron específicamente sobre el alcance social de nuestra disciplina. Desde la importancia crucial que tiene reflexionar sobre cómo compartimos con la sociedad la investigación que desarrollamos, temática sobre la que versó la conferencia de Paloma González Marcén (UAB), hasta la necesidad de entender la diversidad y la sostenibilidad del patrimonio arqueológico (impartida por Sophia Labadi de la Universidad de Kent), pasando por la deconstrucción de las narrativas coloniales realizadas durante décadas por la arqueología en distintas partes del mundo, ofrecida por George Abungu, o la relación entre la arqueología y la política en el imprescindible e ineludible tratamiento

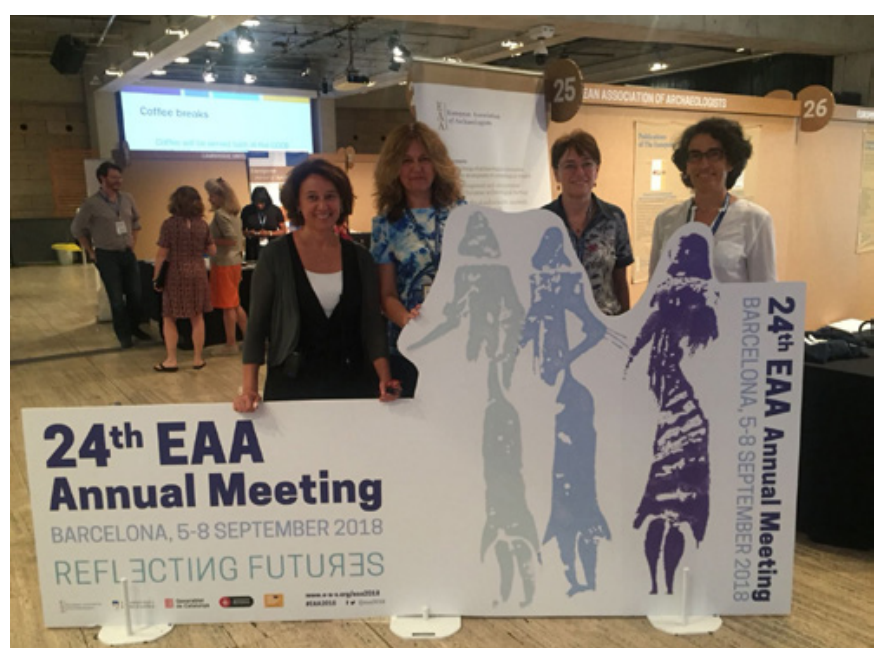

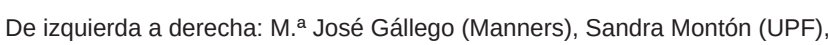
Margarita Díaz (UB) y Raquel Piqué (UAB), miembros del comité local

del conflicto, con el ejemplo de la Guerra Civil española que expuso Alfredo González Ruibal (INCIPIT, CSIC).

Cada año la reunión de la asociación supone una oportunidad, una ocasión para los reencuentros y para nuevas alianzas, unos momentos para forjar y mantener relaciones que nos permitan ser más fuertes, porque la fortaleza de esta asociación tiene que ver con la capacidad de relación que tienen sus miembros. Probablemente algunas de las palabras más escuchadas en estos días en el congreso hayan sido ADN, isótopos o radiocarbono pero también conflicto, sociedad, sostenibilidad, identidad, feminismo, igualdad, cooperación, decolonialismo o educación... es evidente que nos queda mucho, pero vamos por buen camino. 


\section{El IAPH bucea y difunde las buenas prácticas para la activación del patrimonio cultural}

El I Encuentro Patrimonio de Proximidad se celebró en mayo de 2018. La intención: visibilizar el trabajo de los agentes del patrimonio en conexión con el territorio. Resaltando otras formas de gestionarlo. Se pretendía un encuentro de experiencias. Algunas, invitadas por su trayectoria y reconocimiento. Otras, seleccionadas desde una convocatoria abierta al territorio. El resultado fue un Encuentro con un programa que reflejaba el trabajo de profesionales, colectivos y asociaciones vinculadas al patrimonio cultural con algo en común: llevar a cabo buenas prácticas en la activación del patrimonio cultural. La reflexión continuó en enero de 2019 con una segunda reunión de debate celebrada en la Casa del Pumarejo, ejemplo inspirador en la activación del patrimonio cultural desde la comunidad.

Isabel Luque Ceballos | Centro de Formación y Difusión del IAPH

URL de la contribución <http://www.iaph.es/revistaph/index.php/revistaph/issue/view/4356>

¿Y qué son "buenas prácticas"? Los criterios de valoración se establecieron en una primera reunión de trabajo y sirvieron de guía a lo largo de todo el proceso.y fueron los siguientes:

> Una gestión relacional, mapa de agentes equilibrado; $>$ Iniciativas abiertas, accesibles, inclusivas, integradoras;

$>$ Cercanas, que no localistas;

$>$ Medibles cuantitativa, pero también cualitativamente;

> Investigación situada en el territorio, hacia la salvaguarda del patrimonio y la autenticidad;

> Con proyección de futuro y viabilidad;

> De relevancia para la población local, implicación emocional e identitaria, facilitadores de vínculos sociales, apropiación del patrimonio por la comunidad, construcción de espacios de convivencia y relación;

$>$ Con el valor de sostenibilidad económica, social y ambiental;

A esta convocatoria se presentaron 45 proyectos de toda Andalucía, obteniendo un mapa vivo de experiencias de gestión del patrimonio cultural en el territorio desde lo local.

El Encuentro propició el debate entre personas vinculadas a proyectos como el del Campo Arqueológico de Mértola (http://www.camertola.pt/), la Red de Museos de

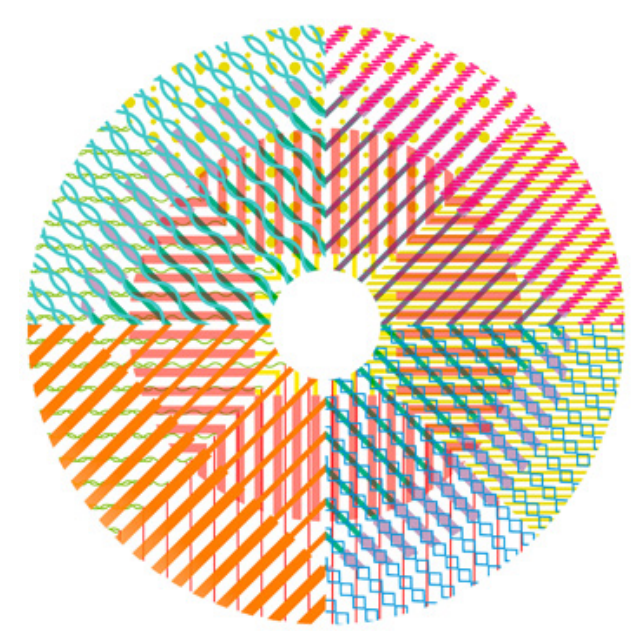

Logotipo de Readtívate

Lugo (http://lugo.gal/es/centros-tipos/red-de-museos), el Ecomuseo del río Caicena de Almedinilla (Córdoba) (http://www.ecomuseoriocaicena.es/), el Proyecto_Pax (patios de la Axerquía, Córdoba, https://www.facebook. com/patiosaxerquia/) y las estrategias de recuperación y puesta en valor del patrimonio que se están llevando a cabo en Alcalá la Real (Jaén) ${ }^{1}$. Surgieron reflexiones en torno a la participación ciudadana²: la necesidad de buscar mecanismos para que la ciudadanía ocupe espacios y se pueda articular la participación de manera real superando trabas administrativas y socioculturales. También alrededor del conflicto entre las corrientes 
centralizadoras y descentralizadoras porque, a menudo, las competencias están en un lugar y, los presupuestos, en otro. ¿Descentralización o multiplicación? Y sobre el concepto innovación: innovación es lo nuevo, pero también es la evolución de lo tradicional. $Y$ todo para hacer mejor nuestras vidas. Como explica Jesús Fernández de la Universidad de Oviedo, las innovaciones sociales "son nuevas ideas, procesos o tecnologías que, a la vez que cubren diferentes necesidades (de manera más eficaz, sostenible y justa que las alternativas), contribuyen a la creación de nuevas relaciones y/o colaboraciones intersectoriales" (FERNÁNDEZ, 2016). Otro de los retos planteados fue la financiación, con ejemplos como el proyecto Memola (Granada) (memolaproject.eu/es), impulsado gracias a la gestión de fondos europeos.

Las mesas se alternaron con sesiones de presentación de experiencias vinculadas a los criterios ya citados en las que la diversidad fue un común denominador y donde se habló de innovación social, de la necesidad de crear comunidades, lazos y conexiones, de las escalas tan diferentes de las iniciativas (en las que hay que diferenciar entre el autoempleo y las grandes empresas), etc. Se vieron en estas sesiones casos tan diversos y enriquecedores como la plataforma ciudadana Huelva te mira (https://www.facebook.com/huelvatemira/), el proyecto de Ecomuseo y agroecología contra la despoblación, Almocita en transición (Almería) ${ }^{3}$, la iniciativa editorial y de crowdfunding Revuelo en el museo (Sevilla) (https://www.facebook. com/revueloenelmuseo/), la participación en redes sociales \#CUATROCARAS del museo de Antequera ${ }^{4}$, la gestión del museo de la Rinconada (Sevilla) ${ }^{5}$, etc.

Completaron este encuentro experiencias prácticas como la del recreacionismo de la Colección museográfica de Gilena (https://www.facebook.com/coleccionmuseograficadegilena/), la acción artística de "semillas" de Miguel Ángel Moreno Carretero o la intervención musical y antropológica de Antropoloops. Iniciativas que son un ejemplo de la diversidad de formas que existen para abordar el patrimonio y de que cuando hablamos del pasado en el presente hablamos de personas.

Como conclusión, se extrae que las experiencias en la activación del patrimonio deben aspirar a ser: trans- versales e integradoras, con un mapa de agentes equilibrado; modelos abiertos, viables y adaptados a las nuevas formas de financiación; proyectos cercanos, que no localistas, resilientes, inclusivos, intergeneracionales y vinculados al territorio; procesos documentados, con evaluaciones que pongan el foco más en lo cualitativo que en lo cuantitativo; experiencias que trabajen con un modelo de Administración facilitadora.

La reunión de enero de 2019, que tuvo lugar en la sede de la Casa del Pumarejo, ejemplo de buenas prácticas en la activación del patrimonio cultural, consistió en una serie de mesas redondas integradas por agentes diversos, procedentes de la administración cultural en distintas escalas territoriales, asociaciones y colectivos, profesionales del patrimonio, la cultura, el turismo y la educación. Equipos que trabajaron desde "lo experiencial", tomando como eje inspirador y motivador el espacio que los acogía, para elaborar un documento colaborativo sobre cómo llevar a la práctica el buen hacer en la activación del patrimonio cultural. Se plantearon cuatro retos, extraídos de las conclusiones del I Encuentro de Patrimonio de Proximidad.

\section{$1^{\circ}$ Investigación aplicada al territorio y salvaguarda del patrimonio. Autenticidad e identidad}

La investigación es un proceso de gestión del conocimiento y de transferencia del mismo. Se trata de sumar agentes en el desarrollo del proceso para implicar a la ciudadanía y difundir los resultados.

La investigación debe formar parte de la gestión del patrimonio histórico. No se pueden dar las distintas facetas de la gestión (inventariado, catalogación, conservación, musealización, difusión, dinamización, formación...) sin investigación previa y/o paralela. Aunque la investigación está más vinculada tradicionalmente a la universidad (o a instituciones específicas como el CSIC) no debería ser exclusiva de estos ámbitos.

Científicos particulares, colectivos, asociaciones, empresas, fundaciones, museos locales o centros de patrimonio deben tener capacidad (a distintos niveles) para investigar, y debe ser reconocida esta capacidad investigadora por las administraciones. 
¿Cómo se podría llevar a cabo? Impulsando los centros de patrimonio como centros de investigación del territorio, promoviendo convenios con la Universidad que además ayudarían a legitimar aún más la labor de instituciones locales. Las administraciones deberían poner en contacto a los diferentes agentes.

La ciudadanía debe ser agente activo en la investigación, señalando el objeto de estudio en función de las necesidades o preocupaciones de cada territorio. Incorporándose al desarrollo del trabajo y a su difusión a distintos niveles, en función de la formación (necesaria para tener capacidad investigadora) que se tenga o que se procure específicamente para una investigación concreta.

En toda investigación deben promoverse: la interdisciplinariedad más que la multidisciplinariedad; el mecenazgo, con una ley acorde y atractiva para la inversión privada; y el micromecenazgo puntualmente. $Y$ debe facilitarse a la ciudadanía el acceso ágil a los resultados de todo tipo de investigaciones (respetando la propiedad intelectual).

¿Cómo se deberían relacionar los distintos agentes? Es importante tener el talante adecuado y formar a la persona investigadora. No obstante, el buen entendimiento con los agentes del patrimonio depende de voluntades individuales, cultivadas a través de los afectos. La investigación debería estar coordinada desde el territorio y la fórmula mixta (comités mixtos) entre investigadores de diferentes ámbitos/población (asociaciones) puede ser una buena solución.

\section{$2^{\circ}$ Mapa de agentes equilibrados}

Para ello es necesario una administración facilitadora, la creación de hábitos de participación y colaboración, cocreación y codecisión. Trabajo en red con los diferentes agentes.

¿Quiénes son los agentes que participan en la activación del patrimonio? Ciudadanía o tercer sector; administración, desde la más cercana territorialmente hasta la más lejana en esta escala. Sector micro-privado. La relación entre estos agentes se establece de forma diversa y es indispensable para su continuidad. Puede darse desde la tensión y el conflicto, el soporte institucional y legal, el impulso económico, la sensibilización, la escucha activa, la inducción y la toma de decisiones.

La generación de beneficios económicos puede provocar tensiones entre los agentes. No siempre es un factor de desarrollo, puede serlo también de desequilibrio.

¿Cómo llegar a un mapa equilibrado de agentes? Mediante la identificación de la población con su medio y su patrimonio, relacionándolo con el sector primario y la sostenibilidad económica, social y medioambiental de este territorio. Con escucha activa. Poner en práctica la participación es difícil, por eso se propone el ámbito de lo local para probar e innovar, ya que es más accesible en escala y medios para la codecisión y cogestión.

$3^{\circ}$ Retorno social y relevancia para la población local. Accesibilidad e integración. Proyectos cercanos que no localistas. Iniciativas intergeneracionales que fomenten la apropiación emocional.

¿Cómo conseguir el retorno social y su relevancia para la población? Visibilizando los logros y el patrimonio en la microeconomía social, una vez que la población se apropia de ella. Mediante el relevo generacional. Con pequeñas acciones y estrategias que construyan barrio desde los patrimonios y sus instituciones. Trabajando lo local y sus necesidades.

El reto es la apropiación emocional. Hay dos fórmulas: por adhesión o por construcción. La segunda es más potente, porque construye sentidos propios; si no hay codiseño no hay apropiación.

¿Qué papel tienen las instituciones? Son sujetos activos, en el papel de protección y soporte económico, legal y técnico. Establecen redes. Pero, si no hay una comunidad detrás que soporte el impulso de las administraciones, el patrimonio no se mantiene, necesita justificación social.

¿Relevante para la población el patrimonio, pero cómo? Mediante la creatividad, la remezcla y la transformación. 
Siendo sujetos activos. Detectando espacios de creación y activación. Desde una administración accesible y facilitadora. Resituando los mapas de agentes. A través del "afecto revolucionario".

¿En qué condiciones brota el afecto? Cuando se respeta la diversidad, la cooperación y se vuelve al grupo. El patrimonio es entonces una excusa para vivir.

\section{$4^{\circ}$ Gestión relacional}

Viabilidad, diversificación de fuentes de financiación.

¿Cómo hacer realidad la gestión compartida? Mediante la viabilidad de los proyectos, consiguiendo que tengan continuidad en el tiempo y financiación de múltiples fuentes. Poniendo en relación a las personas, ayudándolas a que construyan su idea de patrimonio, tejiendo redes.

En la legislación: buscar los huecos en los marcos jurídicos que existen e innovar en torno a los comunes y la gestión patrimonial alternativa (de la ciudadanía). La cultura y el patrimonio no son sectores marginales, sino derechos que deben tratarse en un marco más amplio.

En la transferencia, aprovechar la inteligencia colectiva, crear archivos de conocimiento. Utilizar el interés académico por experiencias. Buscar nuevas fórmulas de trabajo y experimentación. Midiendo los impactos que generan los proyectos, para revertir en ellos. Teniendo siempre presente que estos impactos no son sólo económicos (derivados del turismo), sino que en muchos casos pueden ser también sociales o culturales.

El patrimonio se mantiene por gente a la que le gusta enredarse y compartir con los demás. Esperando que esta energía tenga continuidad, nos vemos en próximo Encuentro de Patrimonio de Proximidad 2020.

Y, dado que el objetivo de redactívate es, además de generar redes, difundir y poner en valor las buenas prácticas de activación del patrimonio, queremos darle cabida en esta revista a algunos de los proyectos participantes. En esta ocasión os contamos, de la mano de sus impulsores, los proyectos Pax (pp. 13-15) y Antropoloops (pp. 10-12).

\section{NOTAS}

1. Ver entrevista a Carlos Calvo Aguilar en https://www. youtube.com/watch?v=HB1K9lvKdOk\&list=PLPyntzoR9s3rc4cqQ9XXtPESSE1YEdAgk\&index=10 [Consulta: 18/01/2019].

2. Es posible visualizar los contenidos íntegros de este debate en la dirección: https://www.youtube.com/watch?v=-YzT9S5hm40\&list=PLPyntzoR9s3rc4cqQ9XXtPESSE1YEdAgk\&index=11 [Consulta: 18/01/2019].

3. https://www.iaph.es/web/canales/formacion/cursos/Redactivate/almocitaentransicion.html [Consulta: 18/01/2019].

4. https://www.iaph.es/web/canales/formacion/cursos/Redactivate/museoantequera.html

[Consulta: 18/01/2019].

5. https://www.iaph.es/web/canales/formacion/cursos/Redactivate/museo_larinconada.html [Consulta: 18/01/2019].

\section{BIBLIOGRAFÍA}

- FERNÁNDEZ FERNÁNDEZ, J. (2016) Proyecto HESIOD. Definiendo e identificando ecosistemas de innovación socialpatrimonial. Revista $\mathrm{PH}, \mathrm{n} .{ }^{\circ}$ 90, 2016, pp. 236-239 [en línea] <http://www.iaph.es/revistaph/index.php/revistaph/article/ view/3824> [Consulta: 18/01/2019] 


\section{$\mathrm{PH} 96_{\text {acculaldad }}$}

\section{Antropoloops: un acercamiento creativo al patrimonio inmaterial desde la remezcla}

Antropoloops es un proyecto artístico que combina remezcla musical y visualización de datos: hacemos canciones con fragmentos de músicas tradicionales de todo el mundo desde el respeto y puesta en valor de las fuentes originales. Los dos principios fundamentales del proyecto son: no modificar los tonos originales de la música que usamos, y visualizar y abrir el proceso de remezcla. Desde su origen en 2012 el proyecto ha ido articulando y desarrollando desde el ámbito creativo un acercamiento basado en la remezcla y las tecnología digitales, que se ha ido abriendo en los últimos años hacia lo educativo y la historia, generando nuevas sinergias.

Rubén Alonso Mallén | doctor arquitecto y músico autodidacta

Esperanza Moreno Cruz | arquitecta y programadora

URL de la contribución <http://www.iaph.es/revistaph/index.php/revistaph/issue/view/4305>

Cuando Rubén estudiaba arquitectura en Berlín a finales de los 90 fantaseaba con la imagen romántica del etnomusicólogo recopilando canciones por el mundo, pero el viaje vendría años después a través de la web y desde la cultura de la remezcla. Trabajamos desde el archivo, la música que usamos proviene de la web: tanto del archivo distribuido y en continua evolución que forma el ecosistema de blogs de coleccionistas de música, como de algunas instituciones que dan acceso a sus fondos sonoros online. Es desde el acceso a toda esta riqueza y diversidad musical desde donde surge el proyecto. Todas las composiciones parten de un fragmento sonoro

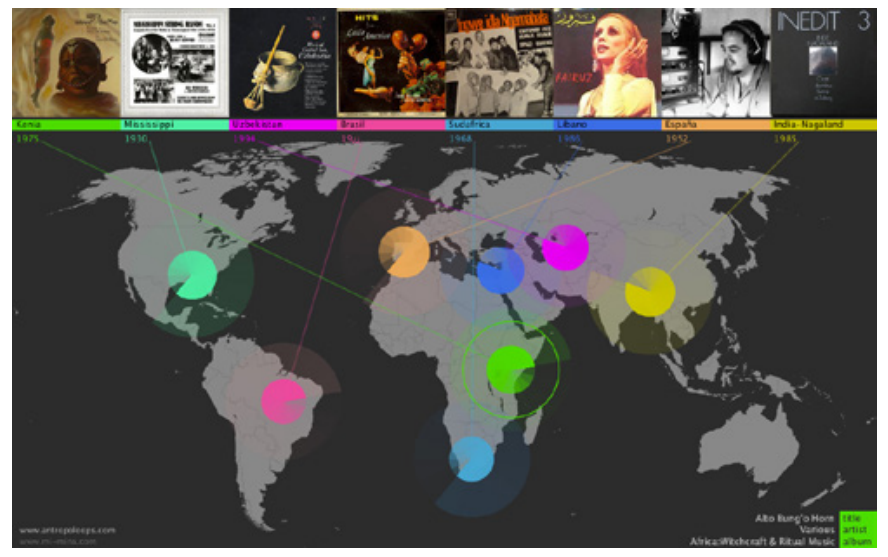

Visualización de una remezcla en directo | imagen Esperanza Moreno y Rubén Alonso inicial, al que se van sumando otros sin modificar los tonos, solo haciendo ajustes de tiempo. Así, músicos y expresiones musicales distantes en el tiempo y el espacio se funden en un collage sonoro y visual que celebra lo común en lo diferente.

El trabajo con las fuentes musicales ha evolucionado con el propio proyecto: Las dos primeras mixtapes (2013 y 2014) partían de fragmentos sonoros de todo el mundo; con el tercer disco, LIK, la serpiente llena de peces, la remezcla se centró en músicas de América del Sur y, más recientemente, hemos compuesto piezas sobre el Mediterráneo y las conexiones que desde España se establecen con otros contextos a través de procesos migratorios ${ }^{1}$.

Con el proyecto Las Rutas de la remezcla ${ }^{2}$ hemos intentado aplicar la lógica de la remezcla para imaginar y recrear encuentros y diálogos culturales históricos: entre los jesuitas ibéricos y los japoneses entre el siglo XVI y XVII. En la actualidad el proyecto sigue generando sinergias y colaboraciones: Kleos, una cartografía sonora ubicua realizada a partir de la remezcla de músicas tradicionales asociadas a los territorios de procedencia de las plantas existentes en Sevilla ${ }^{3}$, y un nuevo espectáculo musical que se estrenará en septiembre de 2019 sobre la evolución de la cartografía en la época de la primera circunnavegación del mundo ${ }^{4}$. 


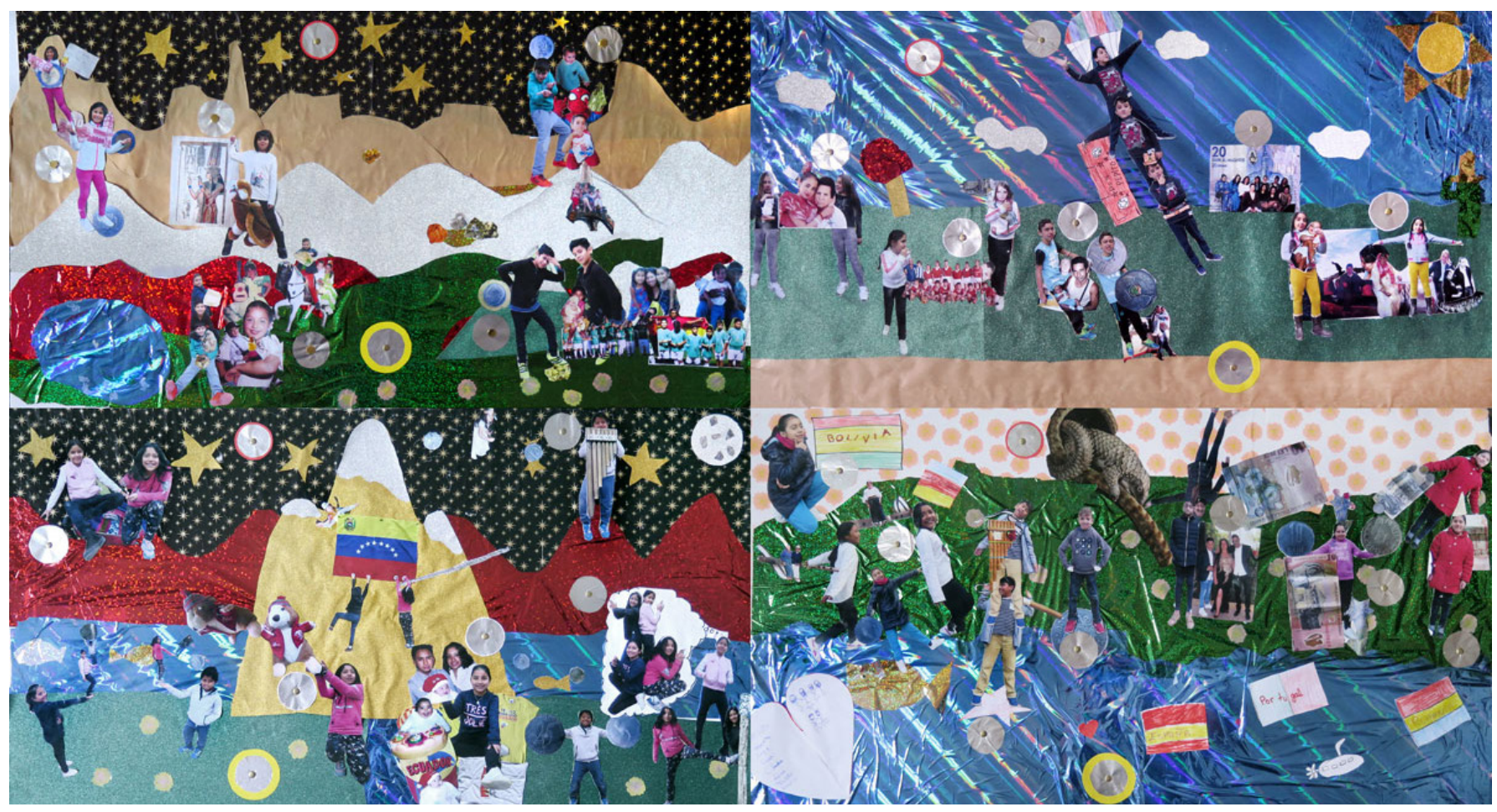

Collages y paneles sonoros realizados por el alumnado de 5² y 5º del CEIP San José Obrero en Sevilla (curso 2017-2018)

Como parte de nuestro proceso inicial de trabajo, cada vez que una nueva remezcla surge la compartimos en la web con toda la información de los fragmentos usados y con links a la web/blog a través de la que hemos tenido acceso a ellos. Cada nueva remezcla se puede interpretar de esta manera como una puerta para acceder a toda la diversidad y riqueza musical de la que ella misma surge, como un proceso de devolución o incluso 'mediación musical'.

Cuando en algunos festivales nos empezaron a pedir la realización de talleres, comenzamos a plantearnos la posibilidad de traducir nuestro acercamiento creativo al ámbito educativo. Esta posibilidad ha tomado forma en los Talleres antropoloops ${ }^{5}$. En 2017 comenzamos a desarrollar una experiencia piloto ${ }^{6}$ de 3 años en el CEIP San José Obrero en Sevilla, en el distrito Macarena, cuyo alumnado refleja la convivencia de distintos orígenes culturales en el barrio. Sumándonos y aprendiendo de la educación en valores e inclusiva que desarrolla el centro, nuestro objetivo es desarrollar herramientas (didácticas y tecnológicas) que usen la remezcla de músicas tradicionales como un medio para fomentar la inclusión cultural y celebrar la diversidad. Durante el primer año hemos realizado distintos acercamientos a la idea de remezcla, re-combinando a sus profesores y asignaturas, indagando en los orígenes e historias de vida musicales del alumnado y construyendo paneles sonoros donde remezclan sus imaginarios e historias familiares.

En el libro La identidad cultural no existe, François Jullien articula sus reflexiones alrededor del término écart, de difícil traducción al español. El significado de écart, aunque implica nociones de distancia, separación y diferencia, remite a una puesta en relación que ayuda a la comprensión de los elementos separados y diferentes: nos habla de una idea de distancia creativa, dinámica e inacabada. Para Jullien (2017) abrir, crear o establecer un écart significa someter a comparación dos recursos culturales y aprovechar el "entre" que los mantiene separados uno frente al otro. Cuando explicamos antropoloops solemos contar que al colocar juntos dos fragmentos musicales de culturas y épocas distantes, que encajan sin modificar sus tonos originales, se abre un 
espacio de juego y creatividad. Es en ese espacio que abre la remezcla donde intentamos situarnos, para compartirlo con los demás.

\section{NOTAS}

1. En esta línea está también la BSO del documental Irioweniasi. El Hilo de la Luna, sobre migración y trata de mujeres de Nigeria a Andalucía.

2. Desarrollado en colaboración con LaPlasita (Lilian Weickert y Jaime Gastalver) y Tangiblex (Miguel Vázquez-Prada) y producido por el ICAS dentro del Banco de proyectos (www.lasrutasdelaremezcla.com).

3. Proyecto impulsado y comisariado por Nomad Garden (Salas Mendoza, Francisco J. Pazos y Sergio Rodríguez) y desarrollado en colaboración con David Solís.

4. Desarrollado en colaboración con Miguel Brieva, Fran Torres, Miguel Vázquez-Prada, Pedro Jiménez y Benito Jiménez.

5. El impulso inicial surge de conversaciones con Nuria García Atienza, y al equipo de desarrollo se suman además Daniel Gómez, Miguel Vázquez Prada, Juan Antonio Ruz, María Delgado y Fran Torres.

6. El proyecto está financiado principalmente por la Fundación Daniel y Nina Carasso dentro de su línea Arte ciudadano, y también co-financiado por el ICAS durante el segundo y tercer año.

\section{BIBLIOGRAFÍA}

- JULIEN, F. (2017) La identidad cultural no existe. Barcelona: Taurus, 2017 


\title{
PAX-Patios de la Axerquía y el valor social del patrimonio
}

\begin{abstract}
La Convención de Faro, aprobada en 2005 por el Consejo de Europa, renueva la definición de patrimonio cultural, "un conjunto de recursos heredados del pasado que las personas identifican, con independencia de a quién pertenezcan, como reflejo y expresión de valores, creencias, conocimientos y tradiciones propios y en constante evolución", e introduce la de comunidad patrimonial, "compuesta por personas que valoran aspectos específicos de un patrimonio cultural que desean conservar y transmitir a futuras

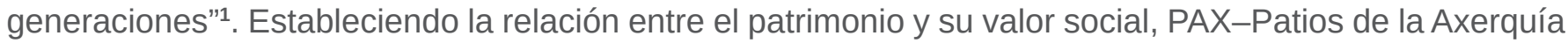
se propone como una acción experimental de gobernanza sobre regeneración urbana e innovación social en el casco histórico de Córdoba. A continuación nos cuentan estrategia.
\end{abstract}

Gaia Redaelli | arquitecta PhD

URL <http://www.iaph.es/revistaph/index.php/revistaph/issue/view/4313>

El Consejo de Europa aprueba en 2005 la Convención de Faro, que establece la relación entre el patrimonio y su valor social². Tras la Convención para la salvaguardia del patrimonio arquitectónico en Europa (Granada, 1985), que incidía en la necesidad de inventariar, conservar y difundir la arquitectura histórica, Faro señala nuevos paradigmas sobre el concepto de patrimonio: por un lado, indica que no es algo exclusivamente de los poderes públicos, sino en estrecha relación con la sociedad que le da vida; por otro, remarca que el patrimonio cultural no es reliquia del pasado, sino una oportunidad para el futuro, en sociedades más inclusivas a partir también de los valores culturales que les acomuna; en tercer lugar, invita a encontrar fórmulas innovadoras de gestión del patrimonio, que incluyan a la ciudadanía para resolver eventuales contradicciones que puedan surgir entre, por ejemplo, su valor cultural y mercantil/turístico.

La Faro Convention Network es una red de iniciativas y comunidades patrimoniales paneuropeas coordinadas por la DG de ciudadanía democrática y participación del CE, que busca, apoya y genera sinergia entre acciones promovidas por la ciudadanía en formato bottom-up. Entre las iniciativas en red, la estrategia PAX-Patios de la Axerquía se propone como una acción experimental de gobernanza sobre regeneración urbana e innovación social en el casco histórico de Córdoba. Impulsada por un grupo de personas ahora constituidas en asociación ${ }^{3}$, PAX es una estrategia de rehabilitación urbana y de casas-patio vacías a través de procesos cooperativos.

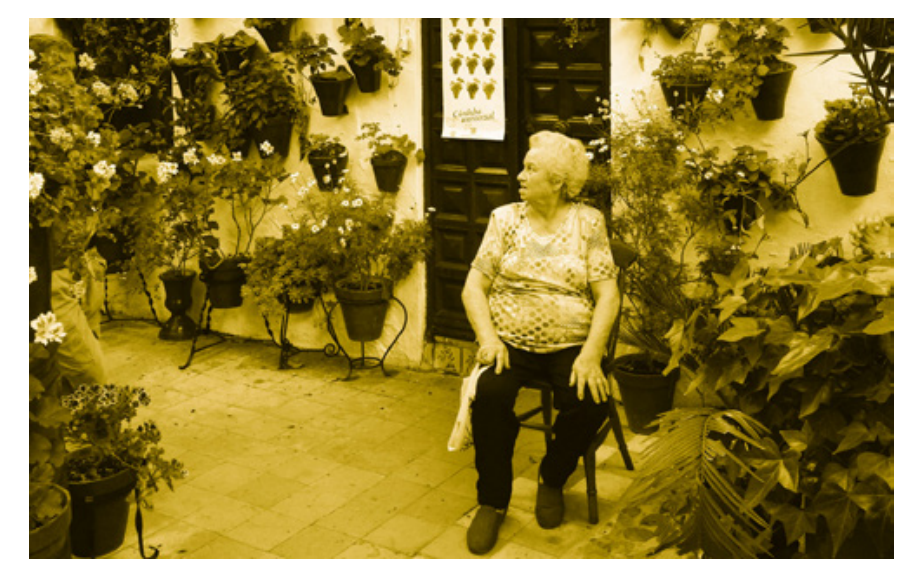

Patio Axerquia | foto PAX, titulares de todas las imágenes de esta contribución

El re-uso de la ciudad existente, en su valor patrimonial material e inmaterial en un barrio objeto de gentrificación ${ }^{4}$, ha sido el impulso para generar una estrategia de abajo arriba en cuanto a política de vivienda, patrimonio, regeneración urbana y cohesión social a través de la actualización del uso de los patios con procesos cooperativos que mantengan el valor residencial ${ }^{5}$. La finalidad y unicidad de PAX -frente a otras experiencias de cooperativismo como alternativa a la propiedad y al alquileres que interviene en un entorno patrimonial de alto valor, actualizando la convivencia que caracteriza la ciudad mediterránea, y se propone constituirse como cooperativa barrial, que ponga en red cada cooperativa habitacional, de técnicos, de rehabilitación y las entidades culturales que surjan alrededor, por ejemplo en generar itinerarios de visitas a los patios recuperados. 


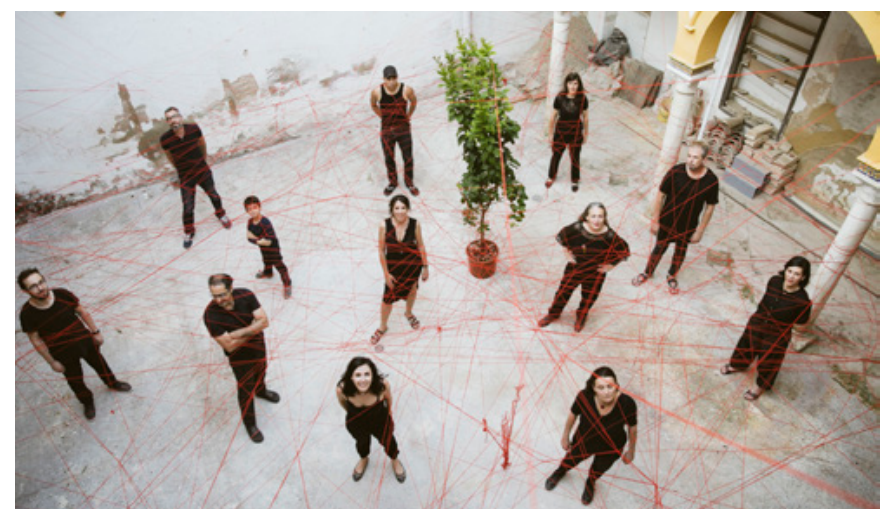

Equipo PAX

La estrategia se coordina con varias entidades públicas y privadas y, sobre todo, con las asociaciones de vecinos y los colectivos de personas que se suman para: definir la modalidad de convivencia alrededor del patio, es decir el valor inmaterial que les acomuna (i); identificar la casa de vecinos en cuanto patrimonio material más acorde a sus necesidades (ii); constituir la cooperativa de vivienda (iii); adquirir o acordar con los propietarios su cesión en uso (iv); realizar el proyecto y la rehabilitación de acuerdo a la contemporaneidad y en el respecto de su valor arquitectónico (v); gestionar la financiación con banca ética (vi). Los colectivos activos son de carácter social diferente, complementario e intergeneracional -jóvenes que buscan en el patio un valor educativo para sus criaturas y mujeres en un proceso de envejecimiento activo -, siendo una red de relaciones sociales y urbana capaz de recopilar la memoria, fotos históricas, planos, entrevistas de los habitantes. Así PAX abarca multíplices dimensiones: la ambiental, densificando la ciudad y poniendo en valor la red "verde" de los patios -como green-cell a sistema- hacia la revegetación y disminución del consumo energético ${ }^{6}$; la dimensión económica, a través de la inclusión de la economía social y los colectivos como protagonistas en el diseño e implementación del proyecto para promover empresas sociales, base para una microeconomía local; la dimensión sociocultural, por la creación de cooperativas que abren a nuevas formas de habitar, donde la recuperación de los espacios comunitarios es central y garantiza la pervivencia y autenticidad del patrimonio; la dimensión tecnológica, en cuanto que el proceso promueve las herramientas para

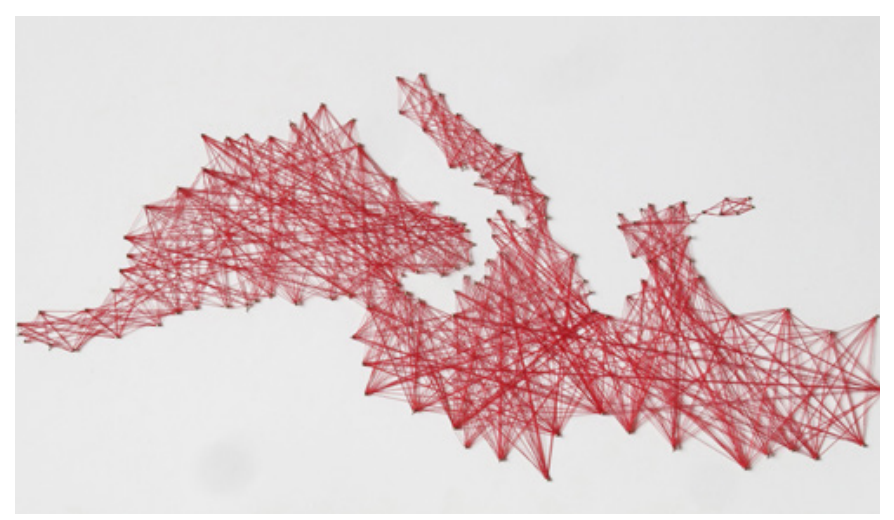

PAX Mediterránea

la formación en rehabilitación desde el uso de materiales tradicionales, como la cal.

Por su transferibilidad a otros contextos mediterráneos, PAX ha estado en la XV Bienal Internacional de Arquitectura de Venecia y es buena práctica por la Oficina de la Economía Social del Ayuntamiento de Madrid ${ }^{7}$. Se propone poner en sintonía instituciones y sociedad civil alrededor de una renovada noción de patrimonio en una ciudad mediterránea a riesgo de gentrificación: de elemento puramente conservativo, del pasado, y, por tanto, de carácter contemplativo o mercantil, el patrimonio y la ciudad se transforman en algo vivo, memoria pero, al mismo tiempo, futuro de una colectividad que es la verdadera activadora de un hábitat urbano sostenible. En coherencia con la dimensión social del patrimonio y como bien común, un recurso estratégico para una ciudad (y una Europa) realmente inteligente, sostenible e integradora.

\section{NOTAS}

1. Art. 2 del Convenio marco sobre el valor del patrimonio cultural para la sociedad.

2. Convenio marco sobre el valor del patrimonio cultural 
para la sociedad (STCE n. ${ }^{\circ}$ 199) Faro, 27/10/2005, con entrada en vigor el 01/06/2011.

3. La Asociación PAX-Patios de la Axerquía es cofundada en 2018 por Gaia Redaelli (presidenta), Jacinta Ortiz (secretaria) y Carlos Anaya (tesorero), y colabora con varias entidades locales e internacionales, como el Ayuntamiento de Córdoba, el Instituto Andaluz de Patrimonio Histórico, la Universidad de Córdoba, la Universidad de Sevilla, Faecta y el propio Consejo de Europa. Más información en www.patiosaxerquia.eu

4. El concepto de gentrificación nace en Inglaterra en los años 60 por la experta en sociología urbana Ruth Glass. Estudia el fenómeno de expulsión forzosa de un sector social de un área urbana concreta, produciendo un cambio de población y nuevos usuarios con mayor capacidad adquisitiva. Sobre la noción de gentrificación, que por su amplitud no es posible agotar en este artículo, se sugiere la lectura de los textos de Lees, Slater y Wyly (2010); Lees, Bang Shin y López Morales (2016); del Observatorio Metropolitano de Madrid (2015). Sobre las dinámicas en el sur del Mediterráneo, véase Annunziata (2017) y Redaelli (2018).

5. En el marco de los procesos globales recientes de gentrificación y desde su declaración en 2012 como patrimonio inmaterial por la Unesco (que se suma a la de patrimonio de la humanidad de la Mezquita en 1984, su ampliación a buena parte del casco histórico en 1994 y, la más reciente, de la Ciudad Califal de Madinat al Zahra en 2018), los patios de Córdoba -así como la ciudad en su conjunto- han experimentado un aumento importante de la actividad turística que incide sobre la salvaguarda de la convivencia que subyace al propio patio y al conjunto urbano. Sobre estos asuntos, se remite, entre otros, al contenido del I Congreso de los Patios de Córdoba, celebrado los días 14-16 de noviembre de 2018 en la Universidad de Córdoba, y a Redaelli (2018).

6. En colaboración con PAX, investigadores de la Universidad de Sevilla, entre julio y agosto de 2017, han monitorizado en la Axerquía las condiciones bioclimáticas en dos patios cuya presencia llega a reducir la temperatura entre 6 y 12 grados sin sistemas activos de
refrigeración.(ROJAS-FERNÁNDEZ, GALÁN-MARÍN, ROA-FERNÁNDEZ Y RIVERA-GÓMEZ, 2017).

7. Véase también Franzoia (2016) y Battistella (2017).

\section{BIBLIOGRAFÍA}

- ANNUNZIATA, S. (2017) Anti-gentrificación nelle città (sud) europee. iQuaderni di UrbanisticaTre [en línea], n. ${ }^{\circ}$ 13, $2017<$ <ttp://www.urbanisticatre.uniroma3.it/dipsu/wpcontent/uploads/2017/12/u3_quaderni_13_Ihr.pdf> [Consulta: 17/01/2019]

- BATTISTELlA, A. (2017) La sostenibile leggerezza de limit. Techne-Journal of Technology for Architecture and Environment, n. ${ }^{\circ} 14,2017$, pp. 65-70

- FRANZOIA, E. (2016) Cordova riscopre il patio mediterraneo. Abitare, n. ${ }^{\circ}$ 558, 2016, pp. $65-70$

- LACOL; LA CIUTAT INVISIBLE (2018) Habitar en comunidad. La vivienda cooperativa en cesión de uso. Madrid: Fundación Arquia, La catarata

- LEES, L.; SLATER, T.; WYLY, E. (2010) The Gentrification Reader. New York: Routledge, 2010

- LEES, L.; BANG SHIN, H.; LÓPEZ MORALES, E. (2016) Planetary Gentrification. Cambridge: Polity, 2016

- LeFEBVRE, H. (1975) El derecho a la ciudad. Barcelona: Península, 1975

- NEL.LO, O. (2015) La ciudad en movimiento. Crisis social y respuesta ciudadana. Madrid: Diaz \& Pons, 2015

- OBSERVATORIO METROPOLITANO DE MADRID (2015)

El mercado contra la ciudad. Globalización, gentrificación y políticas urbanas. Madrid: Traficante de sueños, 2015

- REDAELLI, G. (2018) Spazio pubblico e patrimonio: i paesaggi fragili della gentrification. En BERTELLI, G. (ed.) Paesaggi fragili. Roma: Aracne, 2018

- REDAELLI, G. (2018) Atlas de la A-Gentrificación. Políticas y medidas para la sostenibilidad social en las transformaciones urbanas en ciudades europeas. Papers, 60, 2018, pp. 170-183

- ROJAS-FERNÁNDEZ, J.; GALÁN-MARÍN, C.; ROAFERNÁNDEZ, J.; RIVERA-GÓMEZ, C. (2017) Correlations between GIS-Based Urban Building Densification Analysis and Climate Guidelines for Mediterranean Courtyards. Sustainability, vol. 9, n. ${ }^{\circ}$ 12, DOI:10.3390/su9122255

- SECCHI, B. (2013) La città dei ricchi e la città dei poveri. Roma-Bari: Laterza, 2013

- SENNET, R. (2014) L'espai pùblic. Un sistema obert, un procés inacabat. Barcelona: Arcàdia, 2014

- SETTIS, S. (2014) Se Venezia muore. Torino: Einaudi, 2014 


\section{$\mathrm{PH} 96_{\text {actualidad }}$}

\section{HeritageCare: "Prevenir mejor que curar"}

El proyecto europeo HeritageCare sobresale entre las iniciativas más recientes en el campo de la conservación preventiva por su desarrollo de una nueva metodología, integrada y sostenible, para la monitorización y la conservación preventiva del patrimonio histórico y cultural. Desde septiembre de 2016 Portugal, España y Francia trabajan para generar la primera estrategia conjunta, surgida en respuesta a la necesidad de una aproximación sistemática y proactiva, para la conservación preventiva del patrimonio arquitectónico en el suroeste de Europa.

Daniel V. Oliveira, Maria Giovanna Masciotta | ISISE, University of Minho, Department of Civil Engineering, Guimaraes, Portugal

URL de la contribución <http://www.iaph.es/revistaph/index.php/revistaph/issue/view/4357>

El patrimonio histórico construido representa una expresión irremplazable del desarrollo social y de la variedad cultural de la humanidad. Esté protegido o no, sea público o privado, este patrimonio es un recurso fundamental en la formación y consolidación de la identidad cultural, rico en valores intangibles y provisto de una significación atribuida por la propia sociedad que lo usa. Los edificios patrimoniales representan una parte muy significativa del entorno construido, por tanto asegurar su conservación sostenible resulta esencial para el traspaso de este patrimonio a las generaciones futuras.

Cofinanciado por el Fondo Europeo de Desarrollo Regional, dentro del programa Interreg-SUDOE, con una contribución de 1,6 millones de euros, el proyecto HeritageCare está formado por 8 socios beneficiarios y diferentes colaboradores e investigadores de tres países: Portugal, España y Francia. Además de la Universidade do Minho, socio líder y coordinador del proyecto, forman parte del mismo la Direção Regional de Cultura do Norte y el Centro de Computação Gráfica,

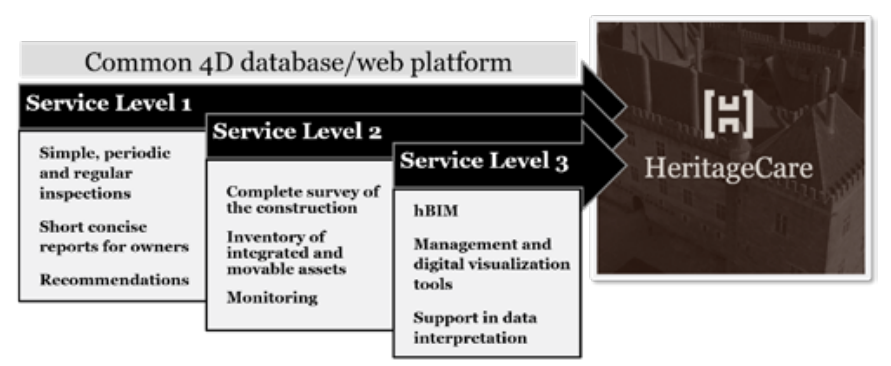

Metodología HeritageCare en Portugal; la Fundación Santa María la Real, la Universidad de Salamanca y el Instituto Andaluz del Patrimonio Histórico, en España; y las universidades de Clermont-Auvergne y Limoges, en Francia.

El consorcio se completa con 11 socios adjuntos. Se trabaja conjuntamente en la difusión e implementación de los objetivos del proyecto, y se persigue llegar a todos los actores sociales que trabajan en campos relacionados con el patrimonio, de manera que se fomente el diálogo y se aúnen esfuerzos para un empeño común.

La mayoría de las prácticas en conservación existentes son intermitentes y de gran coste, además de estar orientadas a la curación, llevándose a cabo únicamente cuando un daño visible compromete el estado de la estructura. Por el contrario, HeritageCare se basa en el principio "prevenir mejor que curar", aspirando a llevar a cabo inspecciones regulares y proveyendo recomendaciones específicas para cada caso sobre las medidas de conservación preventiva más apropiadas que puedan ser aplicadas por los propietarios de forma cotidiana, para minimizar los daños y el proceso de deterioro de sus edificios históricos. De hecho, uno de los objetivos principales del proyecto HeritageCare es incrementar la conciencia pública sobre los beneficios asociados a la conservación preventiva, así como la involucración activa de la sociedad en el proceso de preservación de su propio patrimonio histórico construido.

La metodología HeritageCare se alinea con los estándares CEN y se basa en un sistema de servicios múltiples 


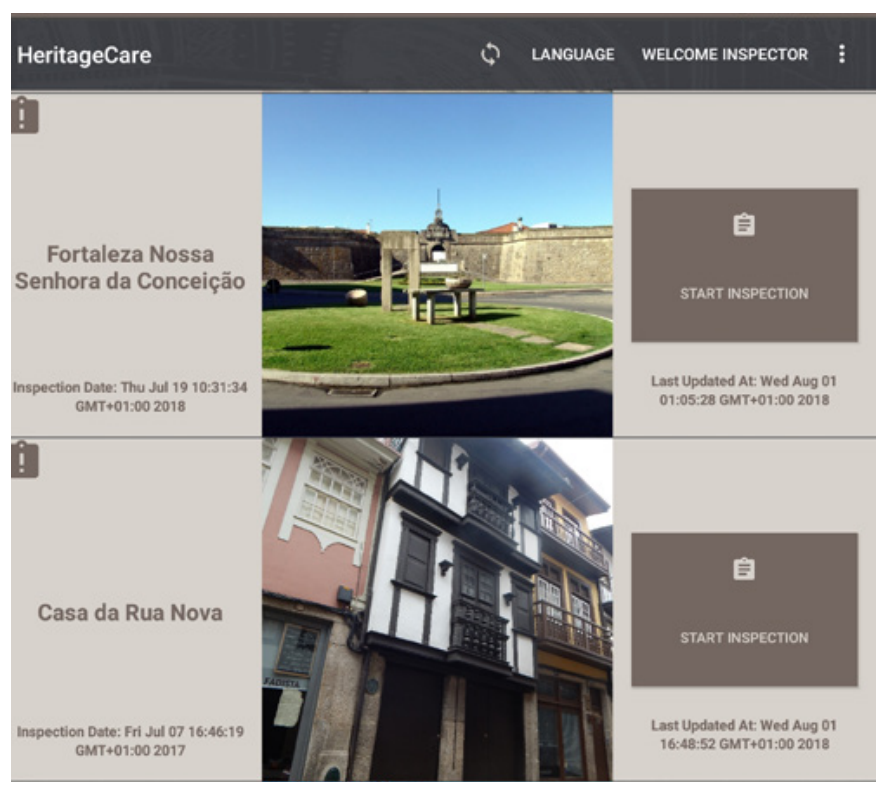

HeritageCare. Visualización de datos

para la inspección, monitorización, conservación y gestión de edificios patrimoniales -protegidos o no-, junto a sus bienes muebles e integrados, de forma sistemática.

El Nivel de Servicio 1 (SL1), también llamado StandardCare, se concibe para permitir una revisión de condición rápida del estado de conservación de los edificios patrimoniales. Con este fin, se llevan a cabo inspecciones in situ donde se identifican las patologías principales del edificio y los bienes muebles, así como su grado de severidad, para la definición de las medidas de mantenimiento prioritarias que se recomendarán seguir a los propietarios para prevenir un mayor deterioro. A diferencia de las inspecciones rutinarias tradicionales, las inspecciones de HeritageCare se realizan a través de una aplicación móvil, desarrollada intencionadamente de acuerdo con el protocolo de inspección definido dentro del proyecto. Esta aplicación permite la digitalización en tiempo real del proceso de inspección al completo, con grandes ventajas en materia de comunicación de datos, tanto in situ como en el trabajo de oficina posterior. De esta forma, la aplicación provee opciones de sincronización, por lo que toda la información recopilada durante la fase de inspección es enviada y almacenada directamente la base de datos HeritageCare, la cual es usada para alimentar una plataforma web para la visuali-

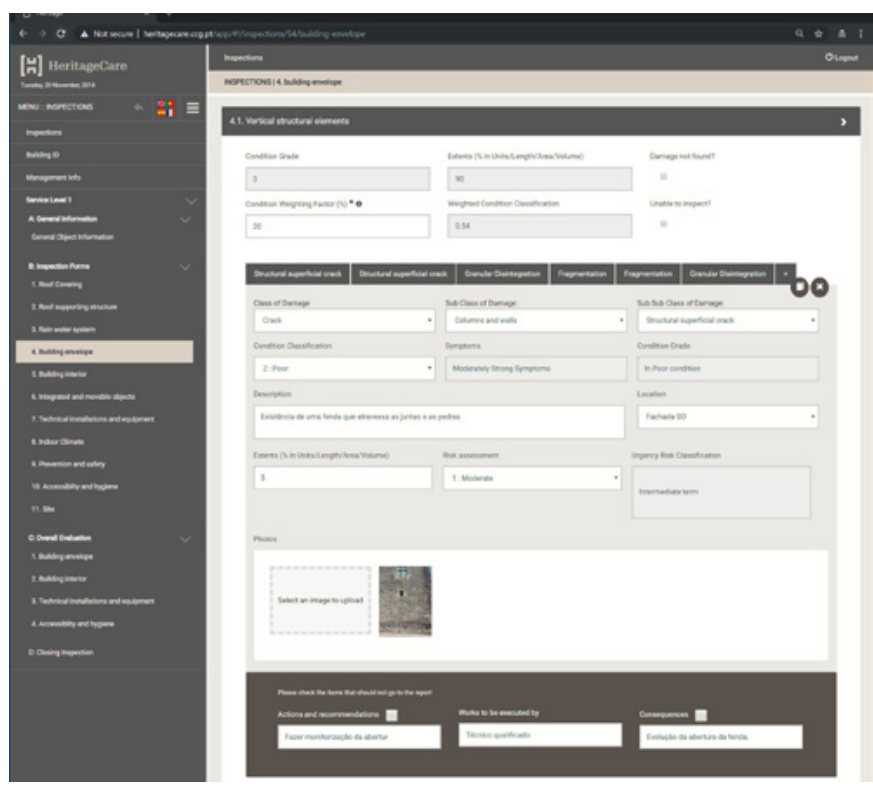

HeritageCare. Visualización de datos

zación de datos. Al suscribirse a esta plataforma, los propietarios -y los interesados en general, dependiendo de la autorización del usuario- pueden acceder y recuperar la información relativa al estado de sus propiedades, haciendo un seguimiento de su estado de conservación a lo largo del tiempo y siendo notificados en caso de síntomas alarmantes.

El Nivel de Servicio 2 (SL2), llamado PlusCare, pretende complementar e integrar la información recogida en el SL1 a través del empleo de los últimos avances en tecnologías de captura aérea y de estrategias de grabación 3D. Se crean réplicas digitales de edificios históricos y se almacenan en un Sistema de Información Geográfica (SIG) optimizado, vinculado a la base de datos HeritageCare. Toda información significativa relativa a las estructuras patrimoniales inspeccionadas se integran en este sistema (por ejemplo, informes de inspección, daños, bienes muebles, información monitorizada, nube de puntos) junto con las imágenes de los edificios registradas más relevantes. A través de una interfaz de fácil uso, compuesta por panoramas esféricas de $360^{\circ}$, los subscriptores pueden navegar virtualmente a lo largo de su bien patrimonial y acceder a la información almacenada pinchando en los puntos de acceso. Además de ser extremadamente atractivos para 

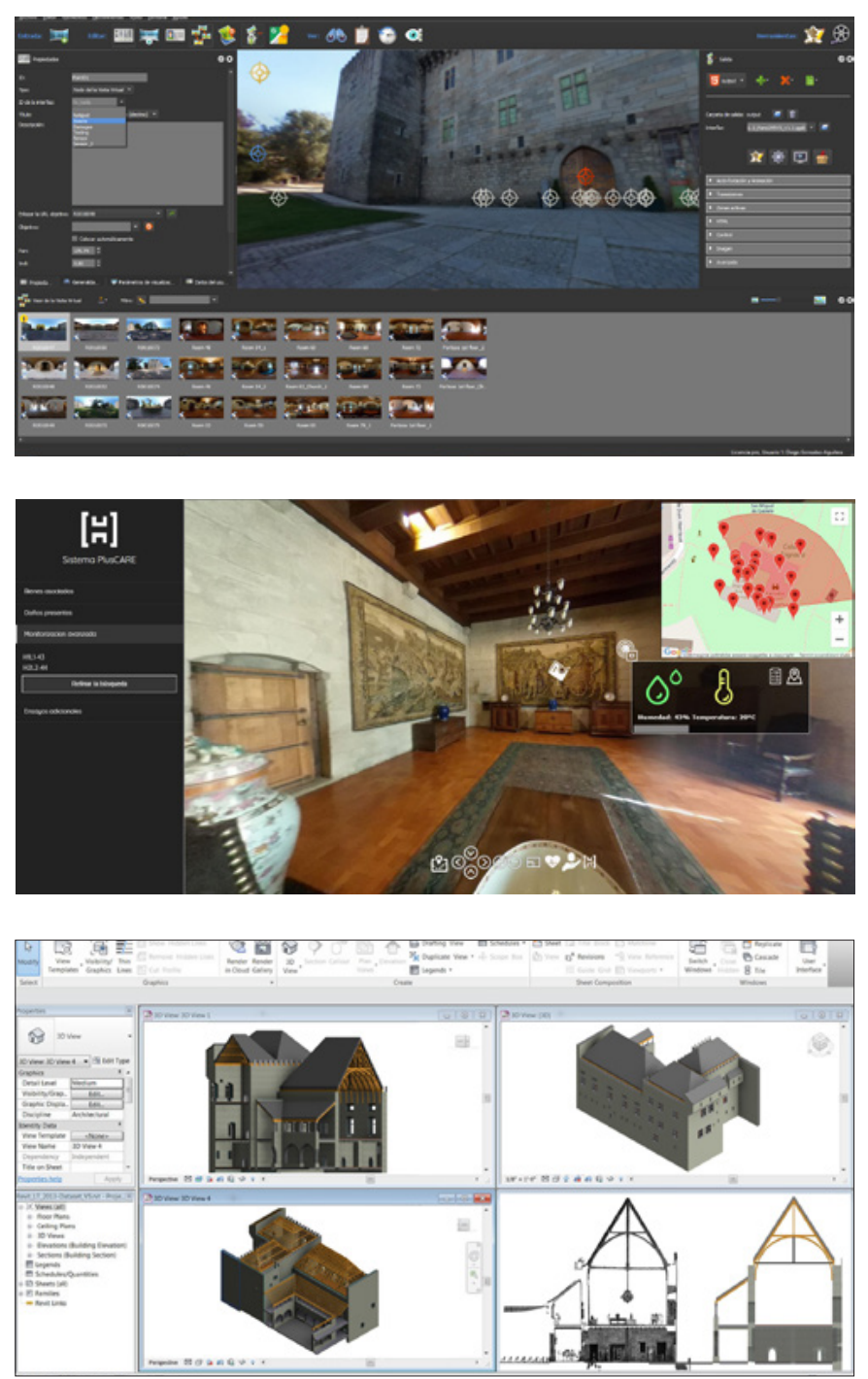

HeritageCare: actualizaciones a tiempo real de los parámetros monitorizados e información detallada

finalidades turísticas, estos tours virtuales ofrecen a los propietarios una experiencia mejorada de conocimiento de sus estructuras, proveyendo en pantalla perspectivas visuales de los aspectos geométricos y de conservación del edificio junto a actualizaciones a tiempo real de los parámetros monitorizados.

El Nivel de Servicio 3 (SL3), llamado TotalCare, se dedica por completo a la digitalización 3D y a la gestión de la información de los edificios inspeccionados a través del Heritage Building Information Modelling. Cada moledo
3D es creado como un 'ensamblaje de objetos', teniendo atributos/propiedades específicos y presentando cierto Nivel de Detalle.Toda la información de entrada significativa, como las propiedades de los componentes del edificio, las relaciones espaciales, la información geográfica, los daños y el sistema de monitorización, se integran en el entorno BIM y son de fácil acceso y manipulación para los inspectores, permitiéndoles optimizar la gestión del proceso de conservación completo. Además, al llevar HoloLens, la información contenido en el modelo BIM puede ser visualizada interactivamente por los inspectores al caminar por los edificios patrimoniales y comparar en tiempo real con la información de inspecciones previas.

Actualmente, la metodología HeritageCare se está implementando y validando en más de 60 casos de estudio representativos en Portugal, España y Francia. Los resultados más relevantes están siendo publicados en destacadas revistas y conferencias internacionales. A su vez, una serie de talleres nacionales están siendo preparados para profesionales e interesados, los cuáles tendrán lugar durante el 2019.

\section{Agradecimiento}

Agradecemos la labor de traducción de este texto del inglés original a Ana Mayoral Moratilla, del Centro de Inmuebles, Obras e Infraestructuras, Departamento de Proyectos del IAPH. 


\section{La recuperación del estandarte real del Ayuntamiento de Sanlúcar de Barrameda}

En el año 2015 el Instituto Andaluz del Patrimonio Histórico recibe el encargo de recuperar el estandarte real de Sanlúcar de Barrameda, propiedad del Ayuntamiento de la ciudad. Este pendón real, cuyo origen se remonta a 1665, y que se había utilizado en la ceremonia de proclamación de al menos cinco monarcas españoles, presentaba un estado de deterioro bastante importante. Para el IAPH el reto de esta actuación era, además de recuperar su unidad estética, consolidar la obra respetando la visibilidad de las dos caras, tal como fue creada en origen.

Carmen Ángel Gómez | Centro de Intervención del IAPH

URL <http://www.iaph.es/revistaph/index.php/revistaph/issue/view/4358>

El estandarte real de Sanlúcar de Barrameda está inscrita en el Catálogo General del Patrimonio Histórico de Andalucía como bien incluido en el Inventario General de Bienes Muebles del Patrimonio Histórico Español, por lo que, para su recuperación, se exigía la realización de un proyecto de conservación con arreglo a lo dispuesto en el art. 21.1 de la Ley 14/2007, de 26 de noviembre, de Patrimonio Histórico de Andalucía. Dicho proyecto, elaborado por el IAPH, contempló la planificación de todas las actuaciones científico-técnicas necesarias para el conocimiento del bien y su posterior restauración, según la metodología y los criterios que deben regir una obra textil de estas características.

El origen del estandarte real parece remontarse al año 1665, relacionado con la proclamación de Carlos II como rey de España. Según la documentación estudiada en el archivo del Ayuntamiento de Sanlúcar de Barrameda, existen datos relacionados con la organización de esta ceremonia y el encargo para realizar un pendón con las armas del monarca, con los escudos de la casa de España y de Austria. Además de otras reseñas, también se acuerda que estuviese siempre guardado en el archivo del Ayuntamiento. Igualmente, se tiene constancia documental sobre la participación de este pendón real en la proclamación de cuatro monarcas españoles más.

\section{Fase cognoscitiva}

En una primera fase, con la implicación de especialistas en diversos campos para obtener un conocimiento glo-

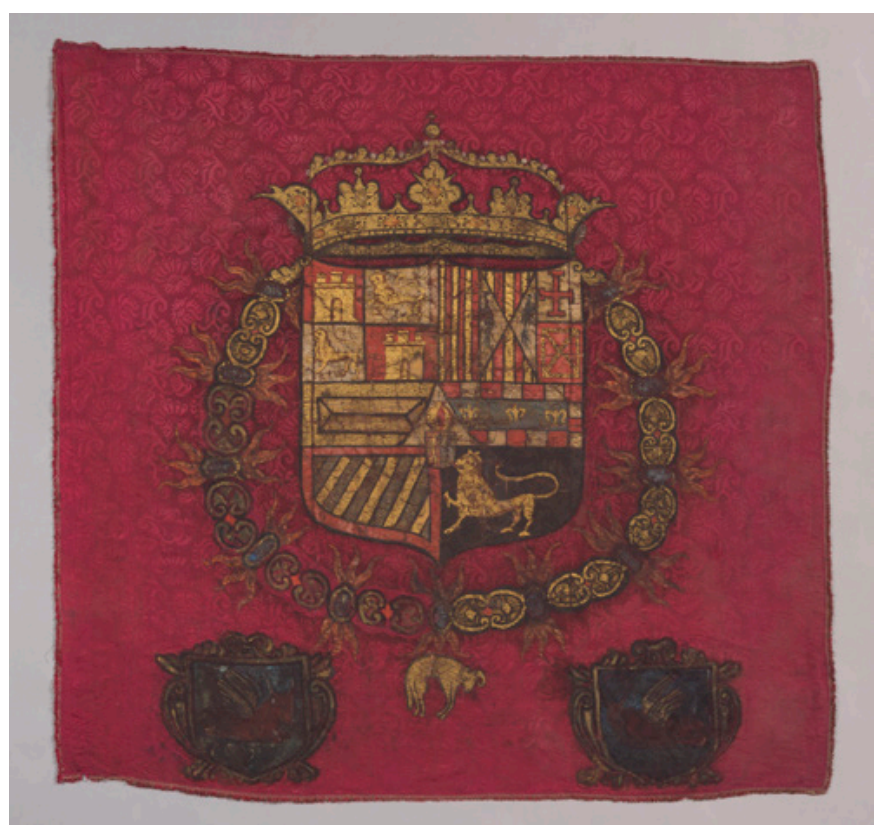

Anverso del estandarte real de la ciudad de Sanlúcar de Barrameda. Obra finalizada | fotos Fondo Gráfico IAPH (José Manuel Santos Madrid)

bal, se recabó toda aquella información relacionada con los antecedentes históricos, las características materiales, la evaluación de los factores de deterioro, las circunstancias de riesgos y las patologías presentes, con el apoyo de medios técnicos y científicos, para configurar una propuesta de tratamiento adecuada a este tipo de bien y a su estado de conservación. Debido a las características formales y la complejidad de conservación de este estandarte, se realizó una búsqueda bibliográfica 

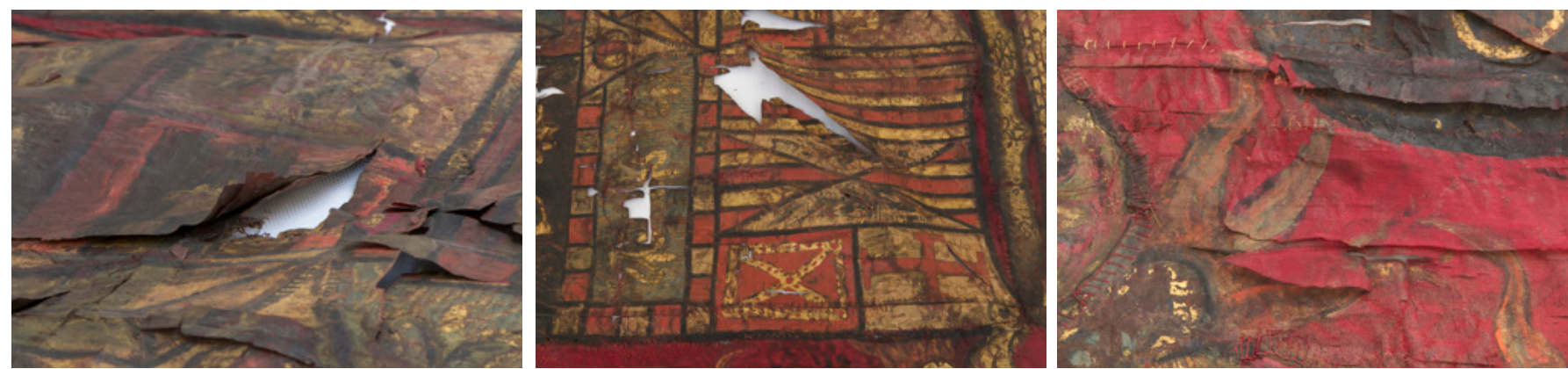

De izquierda a derecha: superposición de parches; eliminación de parches y deformaciones; eliminación de intervenciones

sobre intervenciones en conservación y restauración de obras textiles con características similares, y en particular sobre la consolidación de obras creadas, en origen, para ser vistas por ambas caras. Se completó esta información con los resultados de los análisis de identificación de las fibras por microscopia óptica, examen de los pigmentos de la pintura por fluorecencia de rayos $X$ y estudios técnicos para determinar el tipo de ligamento del tejido y la forma de confección del estandarte.

Esta obra está realizada para ser vista por las dos caras, sobre un tejido de damasco carmesí está pintado el escudo de Carlos II en el centro y otros dos más pequeños en las esquinas de la parte inferior que representan a la ciudad de Sanlúcar de Barrameda. El escudo real está pintado directamente sobre el damasco, con una finísima capa de preparación, una capa de bol sobre ésta y cubierta con láminas de pan de oro, sobre el que se pintan los cuarteles del escudo. Los escudos de la ciudad de Sanlúcar también están pintados directamente sobre el tejido de damasco, aunque con un diseño diferente al cuerpo del estandarte real.

El estado de conservación de la obra textil era muy deficiente sobre todo en las zonas pintadas y alrededores, donde se concentraban la mayoría de las roturas y pérdidas, debidas a la falta de flexibilidad y resistencia de las fibras, evidenciando la necesidad de consolidación de la pieza textil para permitir su manipulación. El conjunto presentaba además suciedad, deformaciones y manchas, debidas tanto a las características técnica de ejecución, como al sistema expositivo, la ausencia de control ambiental y las numerosas intervenciones realizadas en el siglo XIX, detectadas en el análisis por fluo- rescencia de rayos $X$, identificando el uso de pigmentos como blanco de zinc o verde cromo, que se descubrieron en el siglo XIX, y albayalde, que se dejó de usar a comienzos del siglo XX debido a su toxicidad.

Las intervenciones más numerosas son los cosidos que unían las roturas del tejido y parches adheridos por una de las caras para mantener los elementos sueltos. La superposición de elementos indica que se han realizados varias actuaciones, aunque no se han podido determinar el momento de ejecución de cada una de ellas. El tipo de hilo empleado en muchas de las costuras realizadas determina que se cosieron al mismo tiempo que los escudos inferiores de la ciudad de Sanlúcar.

Teniendo presente la problemática que presentaba el estandarte, la propuesta se centró en devolverle la consistencia material al soporte, recuperar la unidad estética de la obra y frenar el grave deterioro y fragilidad producidos por el paso de los años, por su sistema de exhibición y por las numerosas intervenciones anteriores que, si bien en su momento ayudaron a su preservación, en la actualidad ejercían como un agente de degradación. El reto de esta intervención era consolidar esta obra respetando la visibilidad de las dos caras, como fue creada en origen.

\section{Fase operativa}

Tras realizar varias consultas sobre tratamientos de piezas textiles, se decidió llevar a cabo una consolidación con soporte semitransparente y adhesivo, por la cara considerada como el reverso de la obra. Aunque el empleo de adhesivos es un proceso invasivo y no del todo reversible, se descartó el sistema de costura 

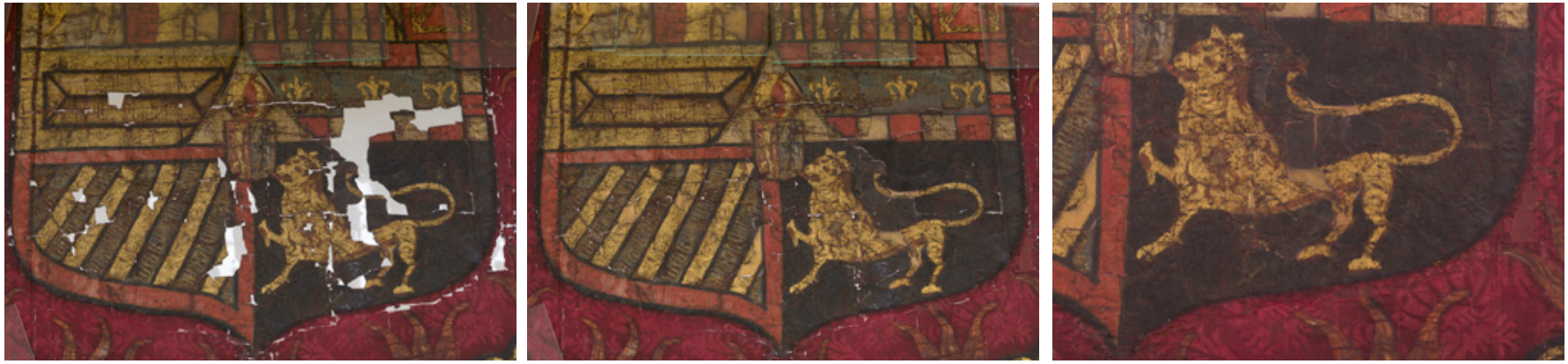

De izquierda a derecha: reintegración de lagunas; detalle tras la reintegración

por la facilidad de fragmentación de la zona pintada durante la manipulación del estandarte. En la elección del soporte de consolidación se optó por un tejido de organza (crepelina) de seda natural que se caracteriza por su transparencia. Este tejido supone una veladura al conjunto, pero permite cierta visibilidad del escudo de la cara del reverso, siendo aún más visible cuando el tejido es teñido.

Para la adhesión del soporte textil y tras las pruebas realizadas de reversibilidad y compatibilidad, se seleccionó un adhesivo de tipo celulósico, aplicado mediante humedad sin necesidad de calor (adhesivo de la familia de polímeros termoplásticos constituidos por poli(2-etil-2oxazolina), empleado como consolidante en capas pictóricas y en papel, conocido como Aquazol ${ }^{\circledR}$.

Con relación a la recuperación de la unidad estética de la obra, se llevó a cabo la reintegración de las lagunas, respetando en todo momento el original. Tras realizar varios ensayos con soportes de tejidos teñidos, sin resultados satisfactorios, se planteó la necesidad de otro sistema de reintegración. Finalmente, se estableció hacer pruebas con injertos de papel, que se podían ajustar al tamaño de cada laguna e insinuar el diseño de los cuarteles perdidos mediante la reproducción del dibujo. Debido a las características de partición del escudo y la posibilidad de comparar ambas caras, la continuidad del diseño era bastante fácil de reproducir.

El papel elegido es artesanal, formado por la mezcla de plantas naturales (cáñamo y algodón), con reserva alcalina y un gramaje de $55 \mathrm{~g} / \mathrm{m}^{2}$. El dibujo se realizó con témpera, por su capacidad de cobertura. Para facilitar el trabajo de integrar las dos caras se consideró utilizar dos fragmentos del mismo tamaño en cada laguna, unidos por el mismo adhesivo utilizado con la crepelina.

El primer paso en la intervención fue el desmontaje de los elementos constitutivos, asta y corbata, para poder eliminar las deformaciones producidas por la costura de la vaina y las numerosas intervenciones realizadas con anterioridad. Las deformaciones se trataron mediante la aplicación de humedad con vapor frío. Debido a la dificultad de manipulación, se realizó una cámara que se pudiese desmontar con facilidad y permitiese aplicar humedad de modo controlado a toda la obra. Para ello, se conectaron dos humidificadores de ultrasonido en esquinas opuestas. El proceso se realizó en varias fases, vigilando el tiempo de humectación, para evitar el exceso de humedad sobre la pintura.

En cuanto a las intervenciones realizadas con anterioridad, se eliminaron los zurcidos y parches que afectaban a la integridad física de la obra, manteniéndose aquellas actuaciones que se consideraron como parte de la historia material de la pieza (escudos de la ciudad de Sanlúcar y añadidos en el Toisón). La retirada de estas intervenciones dejó al descubierto un mayor número de pérdidas que no se veían al inicio, debido a que muchos de los zurcidos se habían realizado casando y montando los bordes para cerrarlos, así como también la existencia de fragmentos de los escudos que estaban ubicados incorrectamente.

Tras la alineación del tejido, se optó por una limpieza mecánica, que permitió eliminar la suciedad y reducir algunas manchas de pintura. El tratamiento consistió en 
la aspiración con una pequeña bomba de vacío, sobre el tejido y la pintura. Puntualmente, se trataron las manchas producidas por los repintes con solventes.

Previo a la consolidación, se ubicaron los fragmentos sueltos que se habían colocado incorrectamente durante las intervenciones anteriores, para determinar el límite de las lagunas a reintegrar. Para su correcta disposición, se utilizó una plantilla con el diseño del tejido de damasco que, a modo de guía, permitió la correcta distribución de los fragmentos dudosos. Las lagunas fueron calcadas en acetato, para usarse como plantilla de los injertos que se tenían que recortar y reintegrar en papel.

El soporte de consolidación fue teñido con Lanaset, tinte sintético para tejidos de seda que presenta una gran estabilidad. Para la obtención del color, se efectuaron varias pruebas de teñido mediante la mezcla de tres colores, hasta conseguir el ajuste definitivo. La crepelina teñida, con el tamaño justo para cubrir los escudos, se impregnó con el adhesivo mediante el uso de brocha y en una proporción del 5\% disuelto en agua desmineralizada. Tras secar, se activó mediante calor de espátula térmica. Las pequeñas roturas del tejido fueron integradas con hilos de seda entonados según el color del damasco y fijados mediante calor a la crepelina. En todo el proceso de adhesión se utilizó como aislante un mylar.

Para evitar riesgo de manipulación, se decidió proteger la cara del anverso con un tul de nailon entonado con el conjunto de la obra, con la mezcla de tres pigmentos de tinte Lanaset. La fijación de este tejido al pendón se realizó al límite del galón perimetral y se complementó con líneas de fijación, realizadas sobre el tejido de damasco que quedaba libre de la crepelina de consolidación.

\section{En conclusión}

Se puede decir que la restauración llevada a cabo logró frenar el deterioro que presentaba el estandarte real, estabilizándola, manteniendo su valor testimonial, simbólico, estético y de antigüedad, y permitiéndole perdurar en el tiempo, a la vez que ser exhibida.

Uno de los aspectos interesantes en la intervención del estandarte, fue la necesidad de recurrir a planteamientos metodológicos de otras especialidades de restauración para el desarrollo de los tratamientos más adecuados para el conjunto de esta obra textil.

La consolidación y reintegración fue todo un reto, por los inconvenientes que planteaba el empleo de calor y adhesivos sobre los tejidos, pero el método aplicado ha resultado el más adecuado para las alteraciones que presentaba la pieza, además de proporcionar una correcta lectura del escudo como elemento principal de la obra.

Los estudios realizados y la recuperación del estandarte real ha supuesto la puesta en valor de un pieza apenas conocida por los sanluqueños y que es parte de la historia de esta ciudad.

\section{BIBLIOGRAFÍA}

- MONTESIONS FERRANDIS, E. M.; VICENTE PALOMINO, S.; FUSTER LÓPEZ, L.; YUSÁ MARCO, D. J.; DOMÉNECH CARBÓ, M. T.; MECKLENBURG, M. F. (2008) Aproximación al estudio de adhesivos para la consolidación y refuerzo de tejidos Históricos: materiales y métodos. ARCHÉ, n. ${ }^{0} 3,2008$, pp. $143-146$

- La BANDERA de Santa Eulalia: un tratamiento de conservación integral (2014) [en línea] Unicum, n. ${ }^{\circ} 13,2014$ pp. 157-178 <https://www.raco.cat/index.php/UNICUM/article/ viewFile/283152/371034> [Consulta: 13/12/2018]

- RIVERA SÁNCHEZ, C.: CAMPOS ÁlVAREZ, F. (2010) Restauración de la bandera de la Jura de la Independencia. Conserva, n. ${ }^{\circ} 14,2010$, p. 37

- SANZ DOMínguEZ, E. (2015) Colecciones textiles en museos militares: Tipología y problemática de conservación y restauración. Tesis doctoral. Universidad Complutense de Madrid, 2015 


\section{$\mathrm{PH} 96$}

\section{HELPS, autocostrucción colaborativa y ecológica}

HELPS Humanity Earth Life Population Solidarity es un proyecto Erasmus Plus que, desde septiembre de 2017, pretende adaptar, en territorios de Francia, Grecia, Italia y España, un sistema de intervención en edificaciones que favorezca la formación en autoconstrucción y la creación de vínculos locales. Surgido de un planteamiento piloto desarrollado en la región francesa de Normandía, en la actualidad el proyecto aglutina a diversas entidades europeas especialistas en bioconstrucción, preservación medioambiental y cohesión social.

Arturo Jiménez Viera, José Daniel Rodríguez Mariscal, Juan Javier Usero Fernández | Asociación Taph Taph Jorge Moya Muñoz | Asociación Taph Taph, Universidad de Sevilla ${ }^{1}$

URL <http://www.iaph.es/revistaph/index.php/revistaph/issue/view/4278>

El proyecto está promovido en España por la Asociación Taph Taph Bioconstrucción, Arquitectura y Paisaje Holístico (www.taphtaph.org) que asume el reto de conseguir una adaptación integral del proyecto en los ámbitos social, cultural, político y ambiental. Bajo la coordinación de la Asociación francesa Les 7 Vents, en este proyecto, además de la asociación española, participan: Mediterranean Centre of Environment en Grecia; Associazione nazionale cittá della terra cruda y Networking Education \& Training en Italia; y Enerterre, responsable de la base metodológica del proyecto, en Francia. Juntas trabajan desde septiembre de 2017.

Los objetivos generales de HELPS (www.helpsproject. eu) son tres:

> Promover la autoconstrucción colaborativa y ecológica, de edificaciones construidas en tierra mediante la puesta en valor y recuperación de técnicas constructivas tradicionales que mejoren las condiciones de habitabilidad a partir de la participación de la población local y el apoyo técnico de profesionales en el ámbito de la construcción.

> Desarrollar lazos sociales locales y prácticas solidarias, para crear una red de ayuda a personas en situación de precariedad.

> Potenciar el uso de materiales locales de construcción y de bajo impacto ambiental, promoviendo la economía y el emprendimiento local.

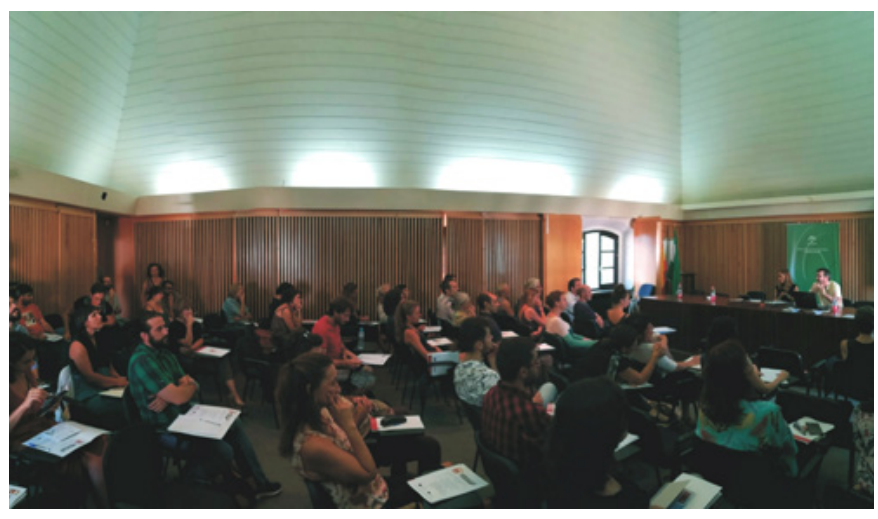

Presentación del proyecto HELPS en el IAPH

De manera específica su labor se concreta en: impulsar obras participativas de autoconstrucción de edificios, especialmente construidos en tierra; servir de soporte técnico y humano en las intervenciones de mejoras de edificios, a personas en situación de pobreza energética, independientemente de las condiciones de tenencia del edificio; facilitar un sistema de intercambio local que apoye los proyectos de mejora de edificios; promover el uso de materiales locales (tierra, fibras vegetales, cal, maderas, etc.) y el desarrollo de técnicas de construcción tradicionales (revestimientos de tierra, calicostrado, reparación de tapia, etc.) y la involucración de profesionales procedentes del ámbito local; cooperar con otros actores del ámbito público en la implementación del proyecto: instituciones, entidades sin ánimo de lucro y profesionales; proveer un lenguaje común y mantener un adecuado nivel de información y comprensión en el desarrollo de los proyectos. 


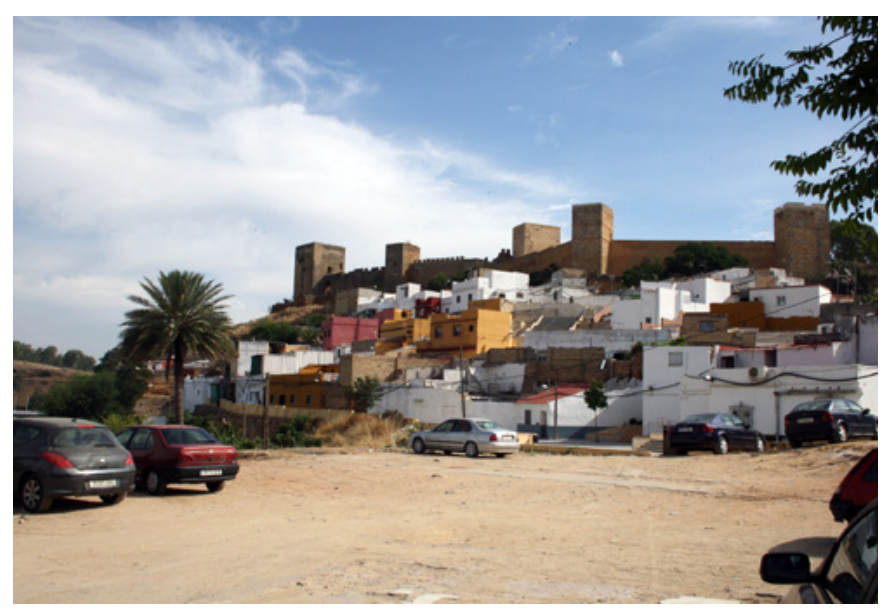

Barrio del Castillo de Alcalá de Guadaíra (Sevilla)

Para desplegar el proyecto en un contexto local, se hace necesario que las edificaciones sobre las que se interviene sean habitadas por personas en situación de pobreza energética; que la ejecución de las obras implique la participación de beneficiarios, voluntarios y técnicos profesionales; y que se empleen materiales locales y se potencien las técnicas de construcción tradicionales de la zona, se asegure la compatibilidad estética y funcional con la arquitectura vernácula sobre la que se interviene.

Para el desarrollo del proyecto se han creado tres herramientas comunes a las entidades socias: un acuerdo de colaboración, una guía de actuación y un repositorio de trabajos realizados.

\section{Acuerdo de colaboración y un sumario del proyecto}

El acuerdo de colaboración es un marco de trabajo para combatir la precariedad en edificaciones en mal estado de conservación y habitabilidad. Esta declaración de principios pretende ser consignada por todas las entidades multiplicadoras, de tal manera que se garantice la coherencia de sus proyectos locales. El sumario del proyecto aporta claves para el desarrollo de la oferta de formaciones, en materia de construcción con tierra, adaptadas a cada territorio.

\section{Guía de identificación y preparación de Obras}

Basada en la experiencia de seis lugares de experimentación (2018-2020), facilita una guía, para las futuras

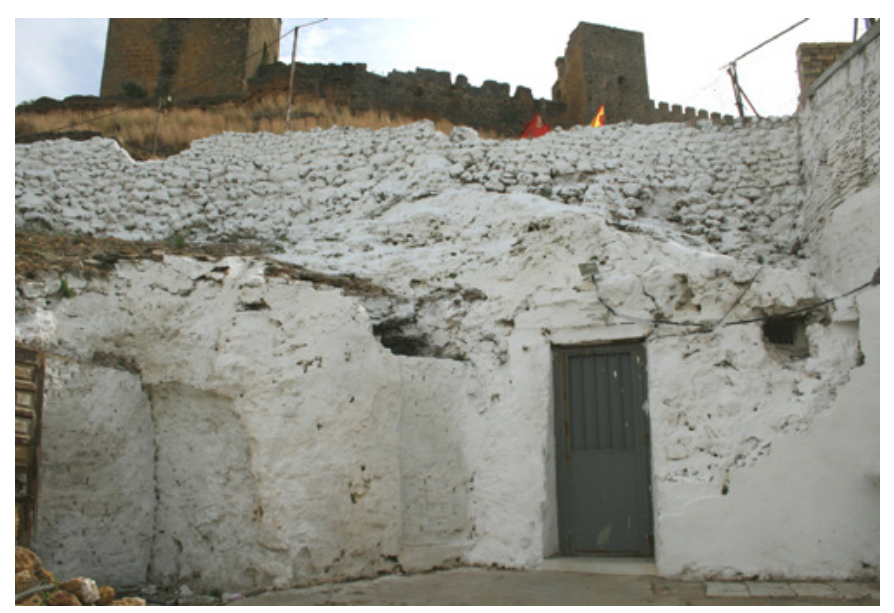

Casa cueva en el barrio del Castillo de | fotos Asociación Taph Taph

entidades multiplicadoras del sistema, en la implementación de acciones de renovación en edificaciones antiguas y hábitats de tierra con habitantes en dificultades socioeconómicas.

\section{Repositorio de habilidades con descripciones documentadas}

Se espera que al menos una entidad socia de cada país adquiera las capacidades y asegure la coherencia del proyecto, garantizando la continuidad mediante la formación especializada de personas y grupos locales en construcción con tierra así como en la coordinación técnica de las obras participativas.

La implementación del Proyecto HELPS supone un reto que debe afrontar dificultades derivadas del desconocimiento y la desprotección que afecta a la construcción tradicional y del desplazamiento de la arquitectura vernácula en favor de otras tipologías constructivas. Y este reto ha de ser entendido desde la colectividad, la cooperación y la transversalidad de forma que se equilibren los hábitats más desfavorecidos a la vez que se asegura la trasmisión patrimonial.

\section{NOTA}

1. Becario FPI. HAR2016-78113-R. Ministerio de Ciencia, Innovación y Universidades. Fondo Social Europeo. 


\title{
$\mathrm{PH} 96$
}

\section{La Red Nacional de Maestros de la Construcción Tradicional}

\begin{abstract}
En 2016 nace la Red Nacional de Maestros de la Construcción Tradicional, desarrollada desde INTBAU en colaboración con el IPCE y con el apoyo del Richard H. Driehaus Charitable Lead Trust. Surge de la necesidad, detectada en España, de contar con un directorio de buenas prácticas que recogiera información sobre los principales maestros de la construcción tradicional en activo, concebido no solo como una herramienta de registro del trabajo artesanal, sino también como una base de datos didáctica, donde se explicaran y pusieran en valor los procesos propios de las distintas actividades.
\end{abstract}

Alejandro García Hermida | coordinador de las iniciativas INTBAU en España

URL <http://www.iaph.es/revistaph/index.php/revistaph/issue/view/4259>

La Red Internacional para la Construcción, la Arquitectura y el Urbanismo Tradicionales, INTBAU, tiene por objetivos el estudio, la promoción y la continuación de las tradiciones constructivas y arquitectónicas. El Richard $\mathrm{H}$. Driehaus Charitable Lead Trust, por su parte, es una entidad sin ánimo de lucro norteamericana. Juntos colaboran en proyectos relacionados con el fomento de la arquitectura y la construcción tradicionales y la conservación del patrimonio.

En este contexto han trabajado para desarrollar un directorio nacional con información sobre los principales maestros de la construcción tradicional que se mantienen en activo, de manera que puedan estar al alcance de posibles clientes interesados en su trabajo o en recibir formación. A menudo al desconocimiento de los oficios tradicionales se suma la falta de difusión de las pequeñas empresas, que no pueden competir en presencia publicitaria y accesibilidad con la gran industria, y muy especialmente en Internet, donde tener una buena y bien posicionada web suele estar fuera de su alcance.

La Red se concreta en una plataforma web, www.redmaestros.com, de libre acceso, en la que se puede localizarse ya un gran número de maestros de la construcción tradicional y su restauración. Durante su puesta en marcha se han identificado más de 2.000 profesionales, entre los cuales, tras un proceso de evaluación, han sido seleccionados más de 370 , que ya cuentan con su perfil en el directorio web. Cada perfil incluye la información de contacto, una descripción tanto de los tipos de

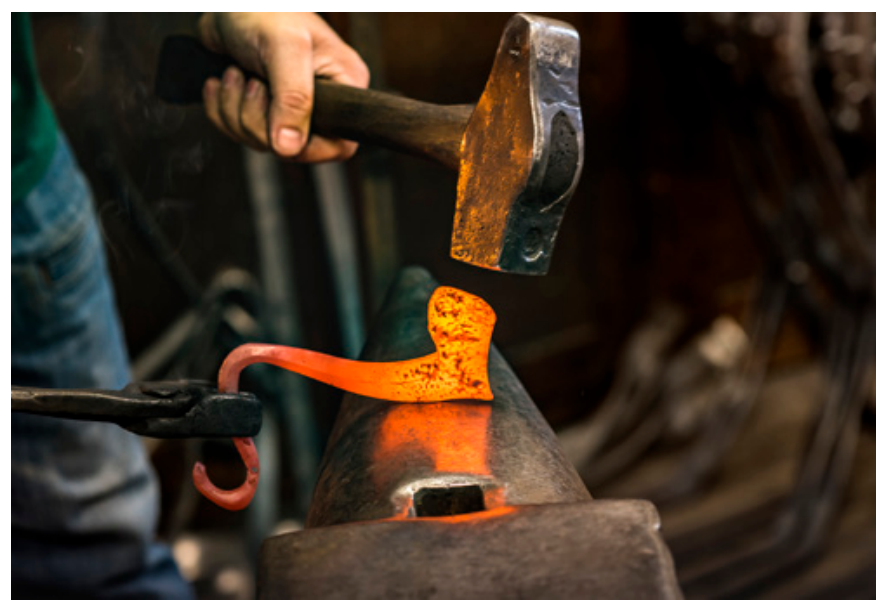

Proceso de forjado de los bancos de la Sagrada Familia | foto cedida por Enric Pla Montferrer

trabajo que realiza como de las técnicas que utiliza en el desempeño de su labor, una relación de sus obras más destacadas, y una explicación de cómo fue su aprendizaje y de si ha formado a algún aprendiz, además de fotografías y/o vídeos tanto de sus trabajos como de sus procesos de ejecución, procurando siempre que todo resulte lo más visual y accesible posible.

El objetivo es acercar los oficios tradicionales a la sociedad, contribuyendo así a su conocimiento y valoración. También se busca favorecer el incremento de la demanda de su trabajo y apoyar de este modo la continuidad y transmisión de este tipo de saber. No menos importante es que aquellos arquitectos o técnicos que tengan que enfrentarse a un trabajo de restauración de un bien patrimonial o a una nueva construcción en 


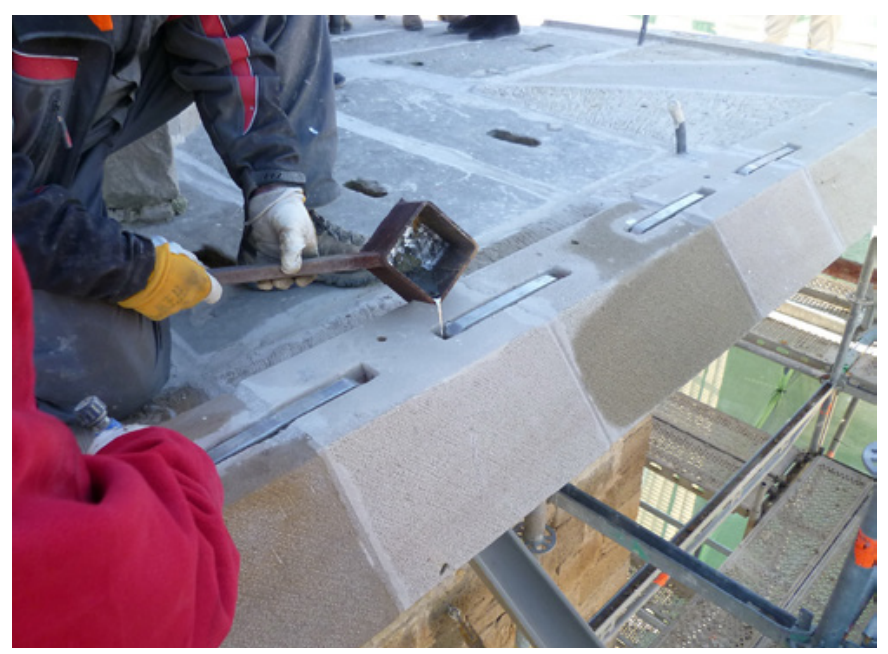

Emplomado de uniones metálicas en la sillería de la Iglesia de San Pedro de Olite | foto cedida por Cantería Jaurrieta

entornos de especial valor puedan localizar fácilmente a los mejores expertos y asesorarse para realizarlo satisfactoriamente.

La colaboración entre INTBAU y Richard H. Driehaus Charitable Lead Trust no se limita la Red de Maestros Artesanos, sino que viene desde 2012. La primera de las iniciativas promovidas en nuestro país por la fundación fue el Premio Rafael Manzano de Nueva Arquitectura Tradicional.

El galardón tiene por fin honrar a arquitectos en activo en España o en Portugal cuyo conjunto de obras haya destacado en la continuación y actualización de nuestras tradiciones arquitectónicas. A este premio siguieron la organización anual de múltiples cursos, conferencias, seminarios y exposiciones, así como la puesta en marcha desde el año 2016 del Concurso de Arquitectura Richard $\mathrm{H}$. Driehaus y de los Premios Richard H. Driehaus de las Artes de la Construcción. El primero está dirigido a promover entre los municipios y jóvenes arquitectos españoles un tipo de arquitectura que respete las formas, los materiales y las técnicas de la tradición constructiva. El segundo, a honrar a los principales maestros en activo de los oficios tradicionales de la construcción. Este último galardón se acompaña de becas formativas anuales que fomentan la transmisión de conocimiento entre maestros y aprendices. 


\section{Interacciones culturales para la puesta en valor de la arquitectura tradicional construida en tierra}

El municipio almeriense de Oria ha acogido las dos ediciones, celebradas hasta la fecha, de las Jornadas patrimoniales sobre la arquitectura de tierra (11-13 de agosto de 2017 y 27-29 de julio de 2018). La elección de la sede respondía a la existencia de una plural arquitectura de tierra y al carácter proactivo de su población. Los resultados positivos, que constatan que la arquitectura tradicional construida en tierra se asume como un elemento identitario de los pueblos, que debe ser salvaguardado, y que representa una alternativa sostenible frente a otros tipos de técnicas y materiales, garantiza la continuidad de las jornadas patrimoniales para 2019.

Jorge Moya Muñoz | Universidad de Sevilla ${ }^{1}$

URL <http://www.iaph.es/revistaph/index.php/revistaph/issue/view/4276>

La iniciativa de las jornadas patrimoniales surge, en primer lugar, de forma teórica como trabajo académico en el desarrollo de la asignatura de Dinamización del Máster en Arquitectura y Patrimonio Histórico de la Universidad de Sevilla y del Instituto Andaluz del Patrimonio Histórico. La preocupación sobre los aspectos perceptivos de esta arquitectura es la que motiva el trabajo. La propuesta se centró en plantear mecanismos que potencialmente fueran capaces de educar la mirada hacia este patrimonio altamente desprotegido y desconsiderado.

Los cambios de forma de vida y los nuevos hábitos de consumo han llevado a la estigmatización paulatina de la arquitectura tradicional construida en tierra. Se puede considerar que la percepción social mayoritaria asume que se trata de una arquitectura desfasada, que pertenece exclusivamente al pasado y a clases o épocas de escasa prosperidad económica.

En segundo lugar, el material tierra ofrece muy poca confianza, viéndose desplazado en favor de otros materiales industrializados. A esta impresión contribuye la obsolescencia del uso primario de parte de estas construcciones, que al ser abandonadas y por lo tanto carecer de mantenimiento, se ven desprotegidas y se muestran cada vez más vulnerables a las inclemencias del tiempo. A este pensamiento hemos de añadir el desconocimiento por parte de personas técnicas o autoconstructoras, que ante la incapacidad de hacer una lectura global de estas construcciones, justifican el intervencionismo destructivo de las mismas en base a criterios cualitativos poco profesionales y menos fundamentados.

Consecuencia de esta reflexión es que resulta necesario incidir fundamentalmente en la erradicación de los estereotipos que rodean a la arquitectura tradicional construida con tierra, proponiendo un discurso objetivo en torno a sus aspectos positivos y negativos a partir de una visión holística que incorpore el discurso patrimonial. El punto de partida radica por lo tanto en el conocimiento, la aceptación y la valoración de la arquitectura tradicional construida en tierra asociada a una forma de vida o uso, que es resultado de la adaptación secular a un determinado medio físico y a unos condicionantes históricos, donde el aprovechamiento de sus recursos naturales determina sus aspectos formales y supone un rasgo identitario de un pueblo.

Con esta premisa se propuso el salto del plano académico a la intervención efectiva. La idoneidad de la aplicación en el municipio de Oria respondió a varios aspectos: la existencia de una ingente y diversa arquitectura construida en tierra (militar, religiosa, hidráulica, civil y doméstica), el estado de conservación y las medidas de intervención en la misma, la disponibilidad que el ayuntamiento ofrecía y la constatación de una actitud activa de su población en respuesta a cualquier propuesta de carácter cultural. 


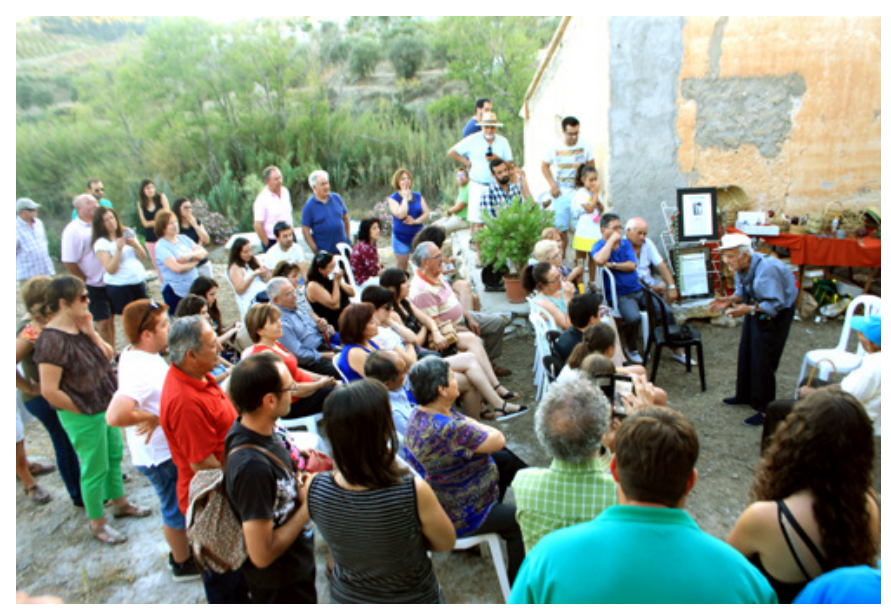

Demostración y exposición de trabajos de esparto de Evaristo Egea en el edificio de las Mazas de esparto de Oria

El éxito de la aplicación metodológica planteada como trabajo de dinamización del patrimonio conllevaba implicar de forma activa a un colectivo lo más plural posible (diversas edades, géneros, profesiones, etc.) en torno a un conjunto de acciones culturales con carácter participativo enmarcadas en unas jornadas patrimoniales. De esta forma, cada persona podría experimentar y compartir la problemática bajo una óptica plural.

La estructuración de las jornadas se articula conforme a una temática (la casa y el agua en estas dos primeras ediciones) en torno a tres acciones principales: charlas a cargo de personas investigadoras de diversas disciplinas (antropología, arquitectura, arqueología, etc.) incidiendo no solamente en sus aspectos arquitectónicos, sino también en sus usos, funcionalidades y profesiones asociadas; talleres prácticos adaptados a diferentes edades sobre técnicas constructivas tradicionales con el apoyo de antiguos alarifes y de artesanía relacionada con el uso de algunas edificaciones, donde se incide en el presente y futuro de las mismas; e itinerarios culturales donde se produce un intercambio de posturas en torno a diferentes ejemplos de arquitectura tradicional.

Estas acciones son complementadas con otras actividades trasversales que facilitan la aproximación a las jornadas a un público a priori menos interesado, a partir de exposiciones fotográficas, de pintura, presentación de revistas locales, recitales poéticos, conciertos o

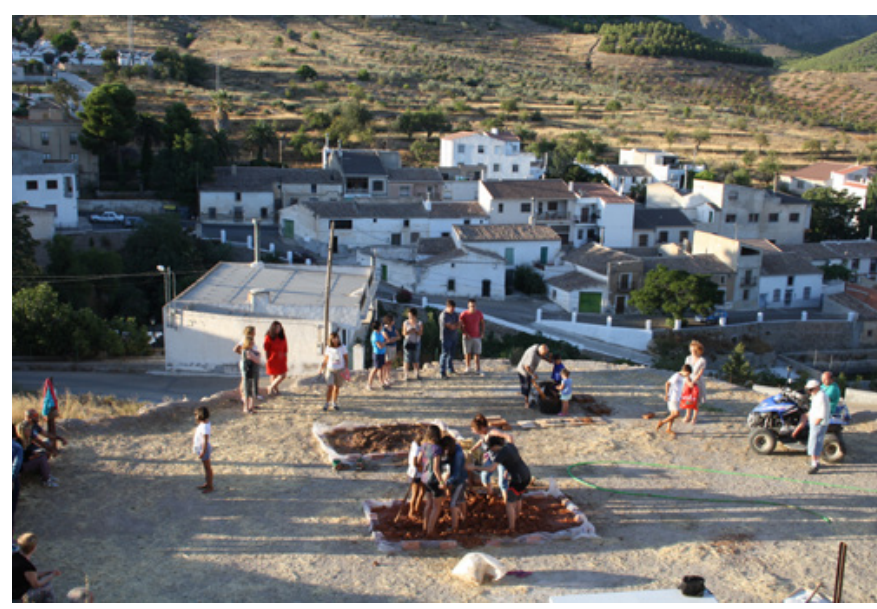

Taller de adobe en la antigua Era de Ciezar en el municipio de Oria | fotos Ginés Reche Reche

comidas vecinales localizadas en enclaves estratégicos que focalizan la problemática hacia un elemento concreto de la temática tratada. Estas interacciones culturales permiten experimentar el patrimonio colectivamente y reflexionar sobre el conjunto de valores asociados a estas arquitecturas.

El resultado de las dos ediciones celebradas hasta la fecha se muestra alentador, no solamente por la aceptación de las jornadas, sino por lo que se deriva de las mismas, donde que cada vez más se asume la arquitectura tradicional construida en tierra como un elemento identitario del pueblo que es necesario salvaguardar y que representa una alternativa sostenible (económica, ecológica y social) frente a otros tipos de técnicas y materiales. Prueba de ello es que se empieza a apostar cada vez más por la rehabilitación responsable así como la incorporación a petición de promotores y profesionales de materiales naturales en la construcción. Estos resultados suponen una motivación añadida para la continuación de las jornadas en los próximos años con la convicción reforzada de que es necesaria una actitud activa en la educación patrimonial.

\section{NOTA}

1. Becario FPI. HAR2016-78113-R. Ministerio de Ciencia, Innovación y Universidades. Fondo Social Europeo. 


\section{Nueva etapa de la revista ARGO}

El pasado mes de junio, el Museo Marítimo de Barcelona (MMB), reeditaba la revista ARGO (segunda época) con la colaboración de Sapiens Publicaciones. La misión de esta especializada publicación, de periodicidad bianual, es impulsar el estudio, conservación y divulgación de la cultura marítima, así como también ser lugar de encuentro de entidades, organizaciones y museos dedicados a la cultura marítima.

Silvia Dahl | Museu Marítim de Barcelona

URL <http://www.iaph.es/revistaph/index.php/revistaph/issue/view/4359>

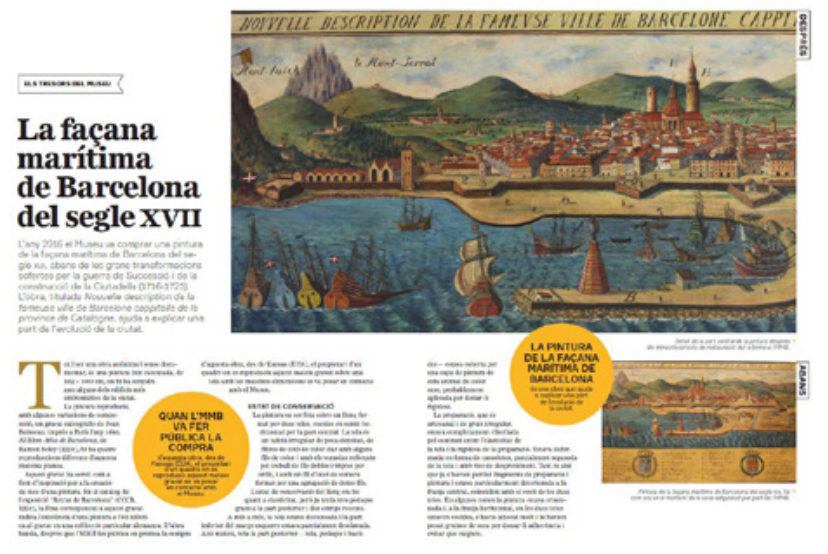

Revista ARGO. http://mmb.cat/

ARGO está destinada a quienes deseen sumergirse en el mar, a través de unas páginas escritas con rigor y con una cuidada imagen. El patrimonio marítimo abarca un extenso conjunto de temas, que explican las maravillosas complejidades del mar: la navegación tradicional y moderna, la pesca, la marina civil y militar, las actividades subacuáticas, así como los deportes náuticos. ARGO narra historias sobre personas y comunidades que protagonizan episodios históricos, explica la restauración de obras patrimoniales, se compromete en la protección y sostenibilidad de mares y océanos, y protege la recuperación de la memoria, entre otros contenidos.

La publicación se compone de secciones fijas. Entre ellas, un espacio dedicado a embarcaciones tradicionales con valor patrimonial, por ejemplo el pailebote Santa Eulàlia, una goleta centenaria que el Museu Marítim de Barcelona recuperó tras un intenso y riguroso trabajo de restauración. Los temas de actualidad social y medioambiental, como la crisis migratoria en el Mediterráneo o la contaminación de mares y océanos por plásticos, han sido abordados en los dos primeros números de esta segunda época de la revista. ARGO dedica un dossier central, de mayor extensión, a profundizar en aspectos de la cultura marítima. El del número 2 se ha centrado en la náutica deportiva y de competición, haciendo un recorrido histórico por la práctica de estos deportes desde sus inicios hasta la actualidad, y señalando la apuesta de futuro de un sector que trabaja por la accesibilidad en todos los sentidos, y que se señala como motor económico, generando una potente y vital industria.

Además la revista se ocupa de dar visibilidad a los estudios de conservación y restauración de objetos de la colección del Museo, como la intervención en una esfera armilar que proviene de la Escuela de la Marina Mercante de la Mediterránea, datada en el siglo XVIII, y atribuida a Charles-François Delamarche, o, más reciente, la restauración de una pintura de la fachada de Barcelona, del siglo XVII, adquirida en 2016, y que ayuda a explicar la evolución del frente marítimo de la ciudad.

ARGO también se encarga de la memoria oral, recogiendo testimonios, mediante entrevistas, de científicos, historiadores, navegantes e investigadores, entre otros perfiles. La entrevista al investigador Vicente GarcíaDelgado, sobre la memoria de la vela latina, es un documento que pone en valor una vida dedicada al estudio de estas embarcaciones. Otra sección destacada es la que dedica a personajes históricos que han dejado un legado de valor patrimonial, como José Pineda, uno de Ios mejores retratistas navales españoles del siglo XVIII autor de unas 3.000 obras, actualmente conservadas en colecciones públicas y privadas. 


\section{$\mathrm{PH} 96$}

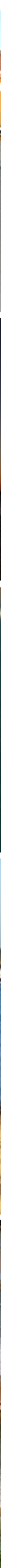



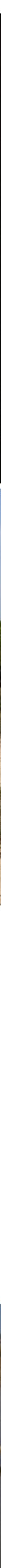

Agradecemos a Luis Colmenero Ruiz, Gerardo Jesús García Olivares y Manuela Fuentes su colaboración para ilustrar gráficamente esta sección. Pueden encontrar más imágenes en el álbum sobre Huelva y la costa occidental en el perfil de Facebook del IAPH. 


\section{Paisajes mutantes de Huelva y la costa occidental}

Juan A. Márquez Domínguez | Dpto. de Historia, Geografía y Antropología de la Universidad de Huelva

URL de la contribución <www.iaph.es/revistaph/index.php/revistaph/issue/view/4287>

\section{RESUMEN}

La comarca de Huelva y la costa occidental se extiende por 1.394 kilómetros cuadrados adosados a una planicie litoral, articulada y diseccionada por los ríos Guadiana, Carreras, Piedras y Tinto-Odiel. Estos ríos conforman en su desembocadura estuarios y marismas, precedidas de caños y esteros, que entablan una enconada lucha con las aguas del mar, cuyas batallas se impresionan en spits o barras de arena. La ocupación de este territorio se inició en los promontorios que garantizaron la seguridad necesaria para la defensa de la vida y las haciendas. Así, los núcleos urbanos más antiguos se localizan en las lomas más elevadas. Los ríos constituyeron, con sus puertos fluviales, las vías de comunicación más importantes. Por ella transitaron hombres y mercancías de un ruedo agrícola consagrado a la trilogía mediterránea y a productos que, como la almendra y los higos, permitieron la travesía de la aventura colombina.

Sin embargo, recientemente, la inercia de la historia se ha roto. La comarca, con apenas el $14 \%$ del territorio provincial, concentra más del $62 \%$ de la población, 323.087 personas en 2017. De forma disruptiva, los paisajes tradicionales han cambiado con el acercamiento a la costa de actividades emergentes como la industria, la agricultura de vanguardia y el turismo. En la carrera de los paisajes mutantes, un pequeño núcleo de pescadores, que no sobresalía de los de su entorno, Huelva, se ha ido convirtiendo en la ciudad primada, articulando desde su puerto un potente tejido productivo industrial, comercial y de servicios.

\section{Palabras clave}

Agricultura | Comarca | Costa occidental | Huelva | Industrialización | Marisma | Paisaje | Territorio | Turismo | 


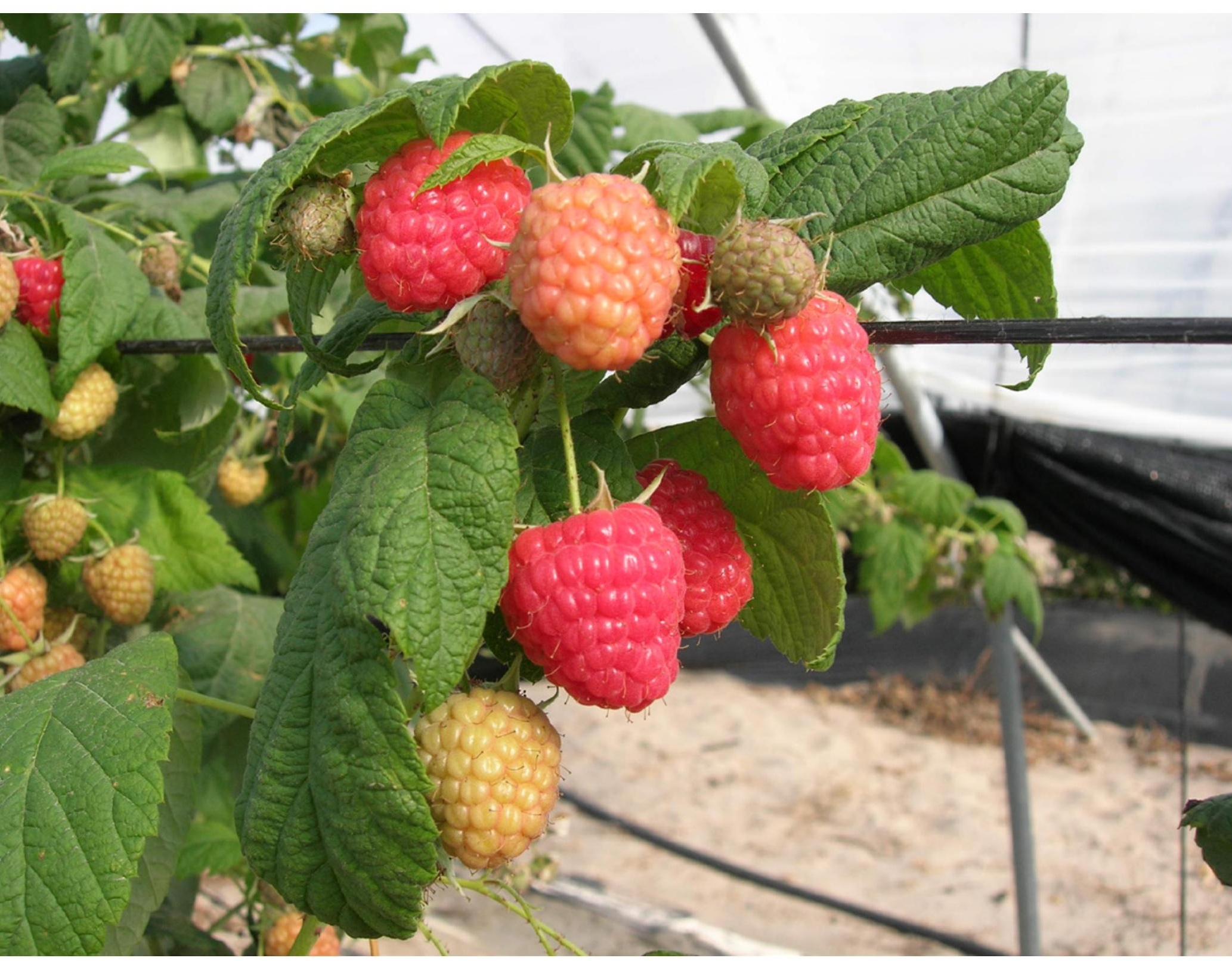

La introducción de berries en la costa occidental de Huelva ha originado una verdadera revolución agraria. Frambuesas | foto Juan A. Márquez y grupo de investigación Instituto de Desarrollo Local 


\section{EL TERRITORIO}

El mundo suratlántico entra en España por la frontera portuguesa, al poniente, y recorre hacia el oriente las provincias de Huelva y Cádiz. En este amplio arco, una comarca, la de Huelva y la costa occidental, se ha ido conformando como un espacio anfibio, que todavía no ha acabado su evolución.

Entre los estuarios de los ríos Guadiana y Tinto-Odiel, se fueron asentando puertos y ciudades, abrigados en las atalayas de formaciones miocénicas, en emplazamientos que hoy se ven como afortunados y herederos de la cultura tartésica.

El espacio de Huelva y la costa occidental se enmarca en un territorio que puede ser perfectamente identificado por su historia y su morfología litoral y de promontorios: marismas y arenas lamidas por el Atlántico al sur; de limos y arcillas que drenan los ríos Tinto-Odiel por el este; de estuarios y marismas del viejo Anás por el oeste; y de campos y glacis hacia el norte, haciendo la transición a la vasta comarca del Andévalo.

La herencia de este pasado ha perfilado un espacio rico, con los centros urbanos más poblados y activos de la provincia, catapultados hoy por la puesta

Perfil territorial de Huelva y la Costa Occidental | fuente Instituto Geográfico Nacional en valor de amplios arenales donde se cultivan fresas, arándanos, naranjos,

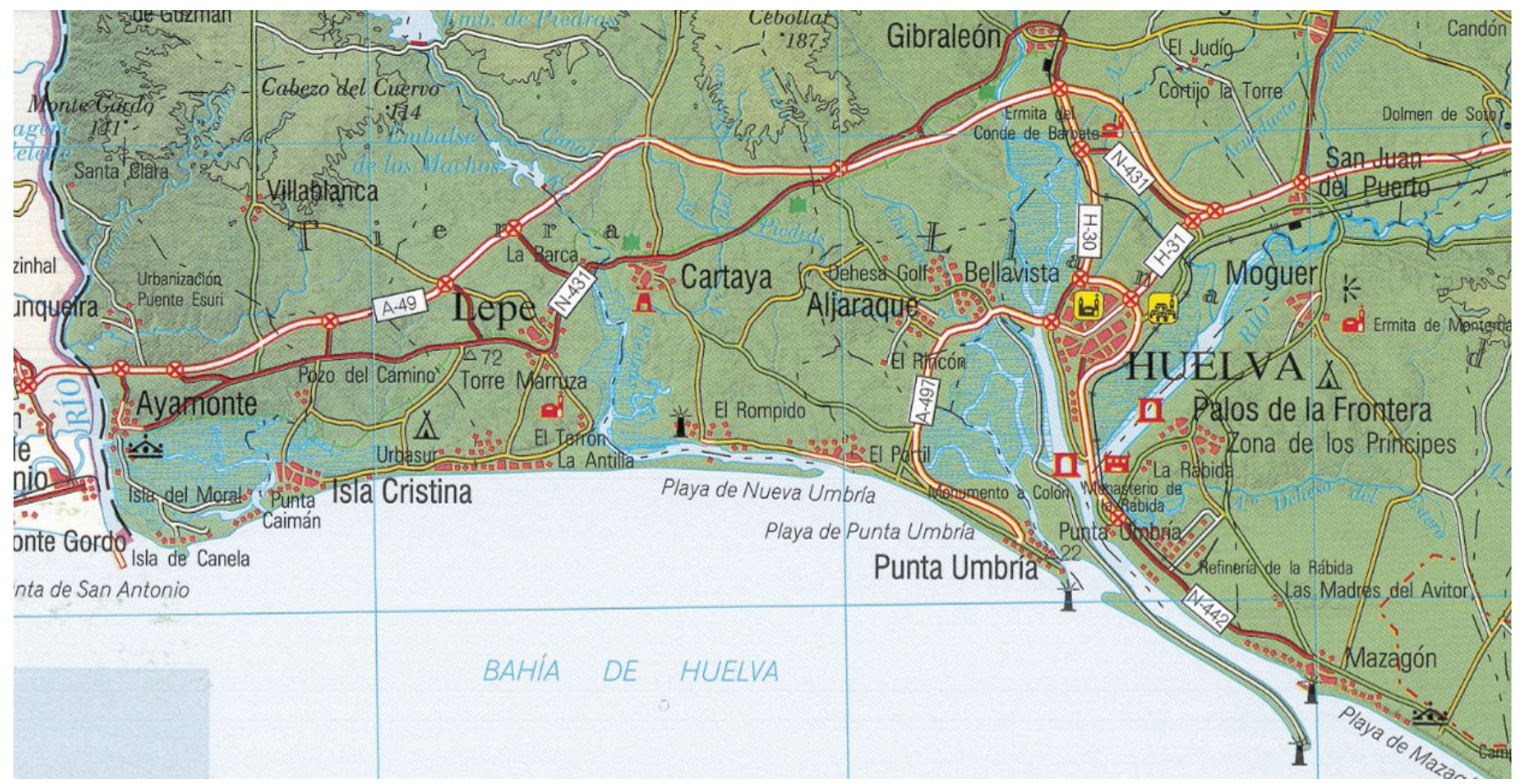




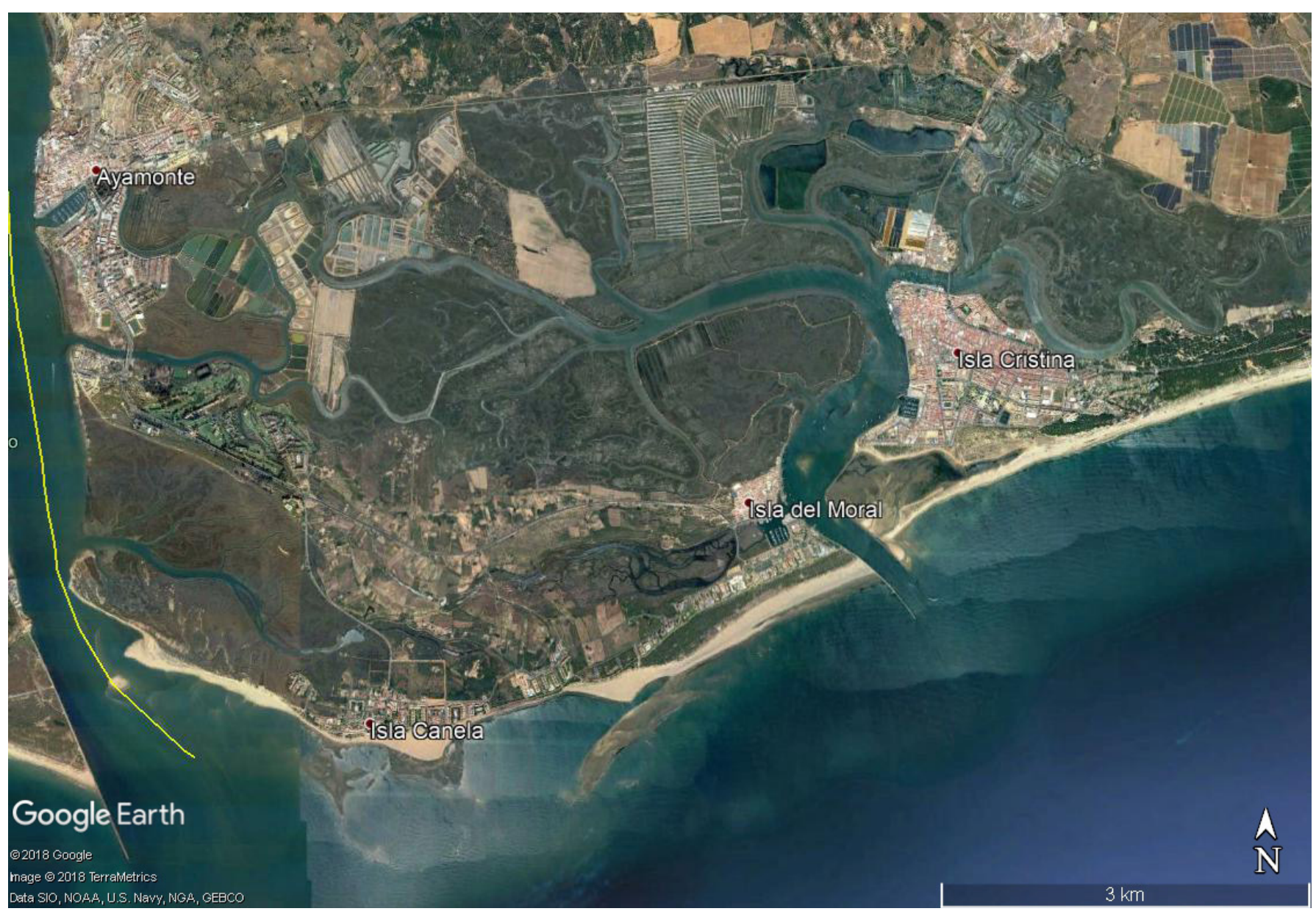

Ayamonte e Isla Cristina | fuente Google Earth 2018. Diseño de la vista Juan A. Márquez

frambuesas y extensas playas para el disfrute del turismo. También la industria se aloja, de forma intensa, en los términos municipales de Huelva y Palos de la Frontera. Completa la dotación, paisajes anclados a los sistemas portuarios, ya sean activos, como el de Huelva, puerto del Estado, y los puertos menores de Ayamonte, Isla Cristina y Lepe, a los que se unen los deportivos de Mazagón, Isla Canela, El Rompido o Punta Umbría. Pero también los puertos perdidos de Moguer, San Juan del Puerto, Palos de la Frontera... o San Miguel Arca del Buey encierran intensas señas de identidad.

La comarca es un espacio muy complejo. Examinando algunos indicadores sensibles de su territorio, se observa que, en apenas el $14 \%$ de la superficie provincial, se concentra el $62 \%$ de la población, el $24 \%$ de los núcleos poblados y $66 \%$ de los inmigrantes. Con una densidad de 231,74 habitantes por kilómetro cuadrado, supera con mucho la media provincial de sólo 51,23. Con todo, la comarca de Huelva y la costa occidental presenta una demografía muy activa, pues frente a la edad media de la provincia de 41,1 años, la 


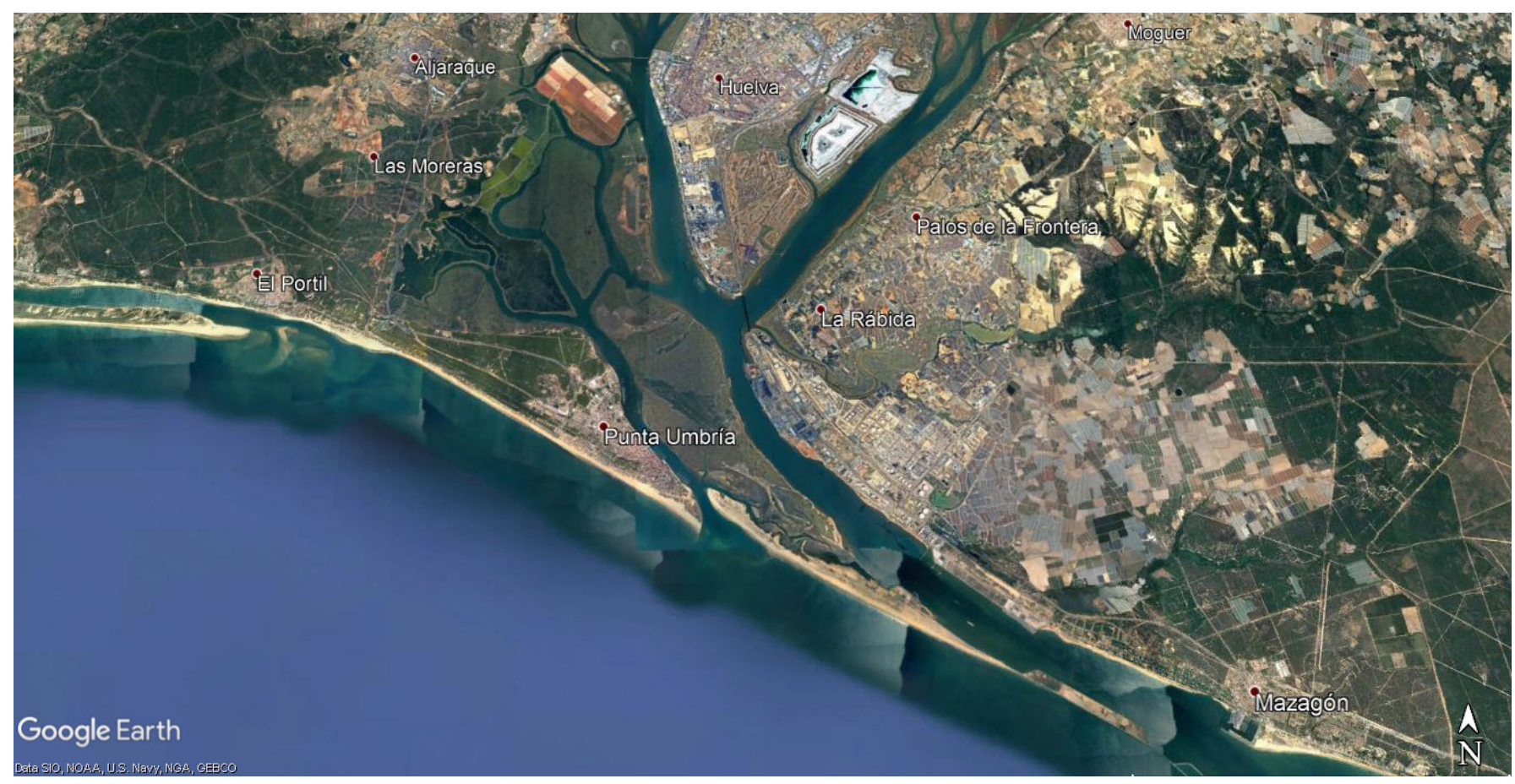

Vista general de Aljaraque, Punta Umbría, Huelva, Palos de la Frontera y Moguer | fuente Google Earth 2018. Diseño de la vista Juan A. Márquez

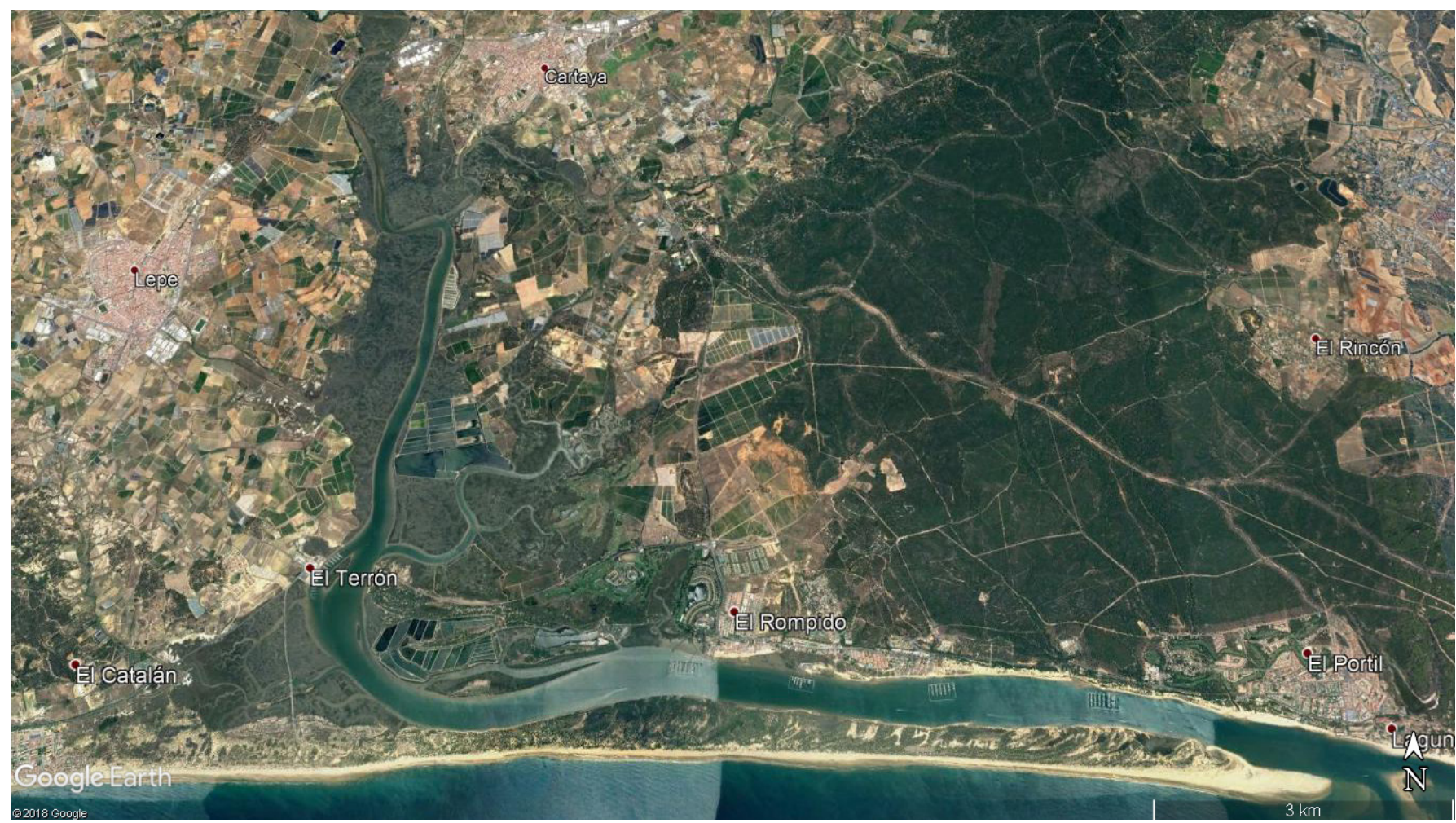

Vista general de Cartaya y Lepe | fuente Google Earth 2018. Diseño de la vista Juan A. Márquez 


\begin{tabular}{|c|c|c|c|c|c|c|c|c|c|}
\hline Municipios & $\mathrm{km}^{2}$ & $\% \mathbf{k m}^{2}$ & $\begin{array}{c}\text { Población } \\
\text { en } 1900\end{array}$ & $\begin{array}{c}\text { Población } \\
\text { en } 2017\end{array}$ & $\begin{array}{c}\text { \% Población } \\
\text { en } 2017\end{array}$ & $\begin{array}{l}\text { Edad media } \\
\text { en } 2017\end{array}$ & Inmigrantes & $\begin{array}{c}\text { N. }{ }^{\circ} \text { núcleos } \\
\text { poblados }\end{array}$ & $\begin{array}{c}\% \text { N. }{ }^{\circ} \text { de núcleos } \\
\text { poblados }\end{array}$ \\
\hline Ayamonte & 141,3 & 10,13 & 7.530 & 20.714 & 6,41 & 41,5 & 761 & 7 & 14,00 \\
\hline Isla Cristina & 49,4 & 3,54 & 5.969 & 21.175 & 6,55 & 39,2 & 660 & 9 & 18,00 \\
\hline Lepe & 127,9 & 9,17 & 5.125 & 26.931 & 8,34 & 37,7 & 972 & 6 & 12,00 \\
\hline Cartaya & 225,3 & 16,16 & 5.552 & 19.193 & 5,94 & 37,9 & 884 & 3 & 6,00 \\
\hline Aljaraque & 33,8 & 2,42 & 1.808 & 20.836 & 6,45 & 37,1 & 794 & 4 & 8,00 \\
\hline Gibraleón & 328,3 & 23,55 & 4.861 & 12.570 & 3,89 & 40,7 & 383 & 5 & 10,00 \\
\hline Huelva & 151,3 & 10,85 & 21.359 & 145.115 & 44,92 & 41,8 & 3.541 & 1 & 2,00 \\
\hline $\begin{array}{l}\text { San Juan } \\
\text { del Puerto }\end{array}$ & 45,3 & 3,25 & 3.541 & 9.116 & 2,82 & 37,7 & 370 & 4 & 8,00 \\
\hline Moguer & 203,5 & 14,60 & 8.455 & 21.514 & 6,66 & 38,2 & 1.049 & 4 & 8,00 \\
\hline $\begin{array}{l}\text { Palos de la } \\
\text { Frontera }\end{array}$ & 49,3 & 3,54 & 1.621 & 10.885 & 3,37 & 36,9 & 464 & 4 & 8,00 \\
\hline $\begin{array}{l}\text { Punta } \\
\text { Umbría }\end{array}$ & 38,8 & 2,78 & 6.606 & 15.038 & 4,65 & 41,4 & 602 & 3 & 6,00 \\
\hline $\begin{array}{l}\text { Total } \\
\text { comarca }\end{array}$ & $1.394,2$ & 100,00 & 72.427 & 323.087 & 100,00 & & 10.480 & 50 & 100,00 \\
\hline $\begin{array}{l}\text { Provincia } \\
\text { Huelva }\end{array}$ & $10.128,5$ & 13,77 & 462.579 & 518.930 & 62,26 & 41,1 & 15.665 & 209 & 23,92 \\
\hline
\end{tabular}

Perfil de indicadores sensibles en la comarca Huelva y costa occidental | fuente Instituto de Estadística y Cartografía de Andalucía, 2018. Elaboración Juan A. Márquez

mayor parte de sus municipios son más jóvenes. En San Juan del Puerto la edad media es de 36,9 años, en Aljaraque $37,1 \ldots$ o en Palos de la Frontera 36,9. Como ejemplo, este último caso significa que la población es cerca de 5 años más joven que la media provincial, con lo que ello puede repercutir en el sistema sanitario, educativo o económico.

\section{LOS DETERMINANTES NATURALES}

Aunque gran parte de la provincia de Huelva tiene como muro materiales paleozoicos, sobre el que se han depositado formaciones mesozoicas, terciarias y cuaternarias, el litoral de Huelva se asienta sobre un sustrato terciario, donde los procesos de subducción y diferentes modelados fluviales y marinos han hecho desaparecer todo vestigio de zócalo.

Por tanto, la base de la comarca es terciaria, sobre la que se han depositado, en un ambiente fluvio-marino, arenas, limos y arcillas. El conjunto territorial es muy reciente, hasta tal punto que se pueden observar cambios espectaculares provocados por la dinámica natural. La zona está compuesta por materiales terciarios, depositados en un ambiente marino. 


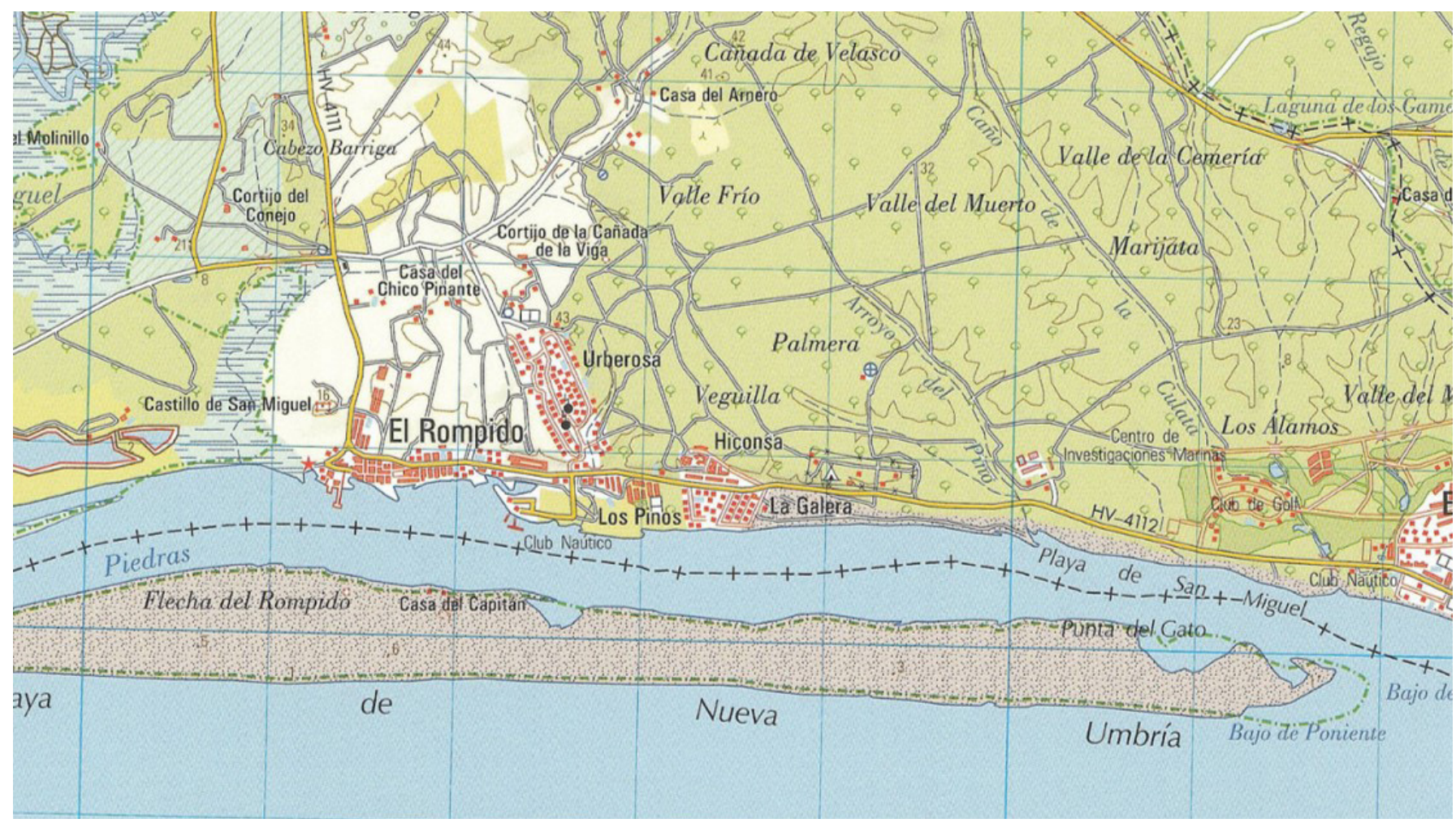

Desembocadura del río Piedras y flecha del Rompido. Cuadrícula UTM | fuente Instituto de Estadística y Cartografía de Andalucía

El retroceso del mar, a partir del Plioceno, dio lugar a un ambiente lagunar y al encajamiento de la red fluvial que aisló cerros testigos. En el Holoceno los ríos Tinto y Odiel constituyeron una bahía abierta, en la cual depositaron sedimentos que dieron lugar a barras e islotes de arenas y lodo. La acumulación de materiales a lo largo de los últimos millones de años y su distribución por las corrientes de marea han originado una compleja morfología de islas, marismas, barras de arena e islotes.

Así, la zona se estructura en franjas disimétricas que tienen su origen más moderno en las gravas, arenas y arcillas. Hacia el norte aparecen las tierras más antiguas, compuestas por limos amarillos y margas del Mioceno Superior, incluso al norte del término de Ayamonte se enlaza con suelos primarios y ya es Andévalo. Mientras tanto, hacia el sur, sureste y oeste, las tierras se conectan, sin solución de continuidad, con gravas, arenas, limos y arcillas de las marismas holocenas. Actualmente existe una subsidencia detectada en una línea de costa pliopleistocena, localizada a unos 30 kilómetros de la actual y a una profundidad de 50 metros (IGME, 1975).

En este contexto físico, la vida se vio favorecida por la disposición de las tierras y su apertura al océano Atlántico. Éste le brinda a la comarca un clima suave de tipo mediterráneo oceánico, que tiene como media anual los $18^{\circ} \mathrm{C}$. 


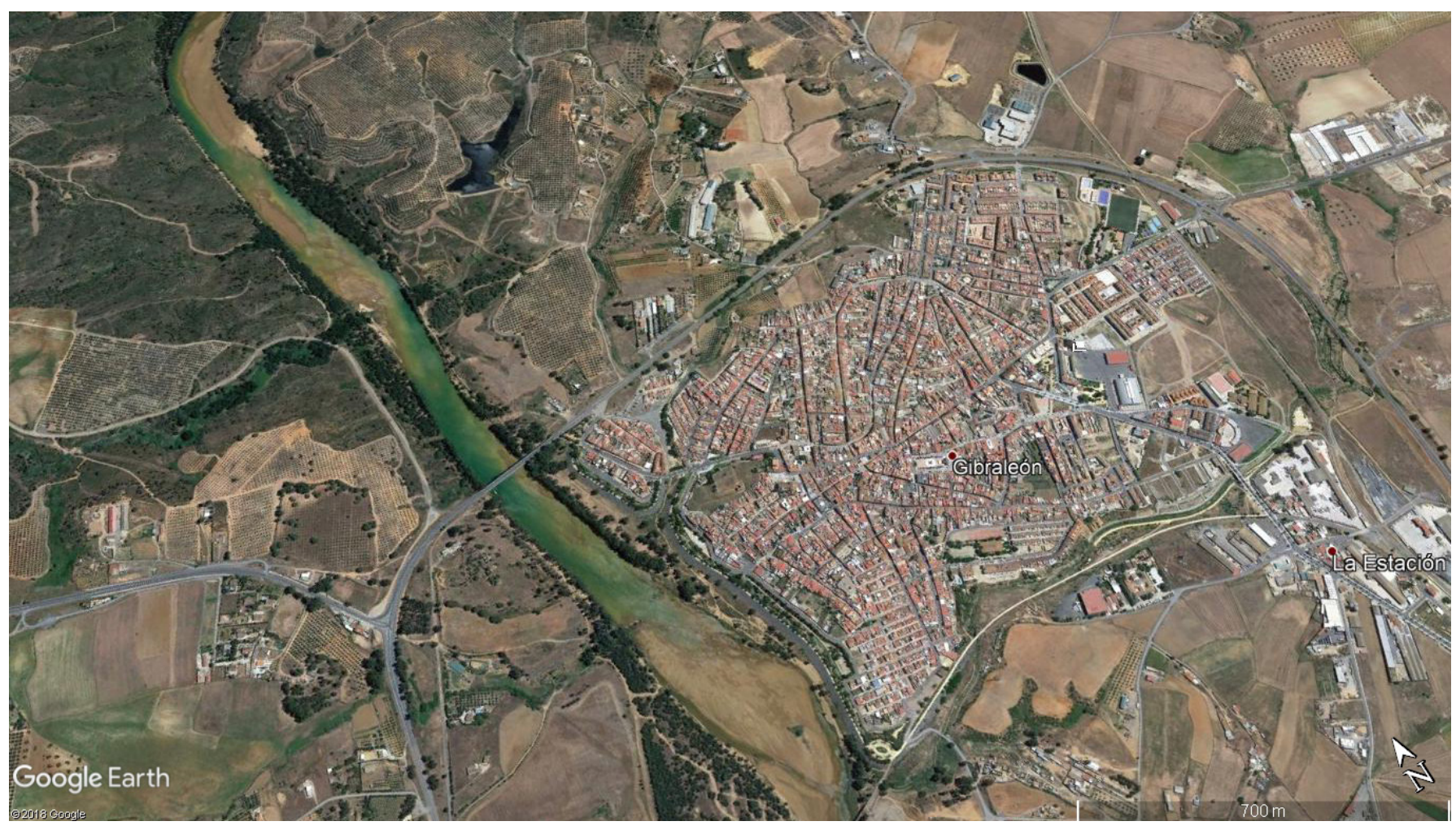

Gibraleón. Transita entre la nueva agricultura y los campos de olivares y almendros | fuente Google

La lluvia es moderada, recogiéndose una precipitación media anual en torno Earth 2018. Diseño de la vista Juan A. Márquez a los $500 \mathrm{~mm}$. Pero la verdadera singularidad del clima de la comarca está en las horas de sol, cerca de 3.000 anuales. La radiación y el calor, paliado por las brisas del mar, conforman soberbios ecosistemas de confort para el hombre y numerosas plantas cultivadas.

\section{LA FRONTERA URBANA Y EL NERVIO ECONÓMICO}

Dunas, marismas y manto eólico constituyeron una frontera para el poblamiento, pero también el espacio que nutre su expansión actual. Históricamente los núcleos urbanos estuvieron agazapados al interior, defendidos en promontorios y áreas miocénicas, calizas-limosas que sustentaban la trilogía mediterránea, trigo, vid y olivo, cultivos imprescindibles en el antiguo modelo alimentario.

Por mucho tiempo, la ciudad primada actual, Huelva, fue una modesta urbe y puerto de mar, emplazado sobre el estuario de los ríos Tinto y Odiel. La ciudad se confinaba sobre cabezos, que no eran sino colinas de 45 a 60 metros, fáciles de defender, frente a una zona llana e insalubre de marismas. Controlando las zonas de cumbres y llanuras, el antiguo castillo de Huelva 
fue símbolo de una enconada lucha contra una piratería que apenas la dejaba sobrevivir. Cercenado este mal, en el siglo XVIII, la ciudad empieza a descender y ocupar los caminos que llevan al puerto, apareciendo un núcleo bastante consolidado, en gran parte destruido por el terremoto de Lisboa de 1755. A partir de 1833 , se produjo la primera expansión urbana de importancia, como consecuencia de su nombramiento como capital. Después, a partir de 1871, una febril exportación de minerales a Europa impactó la trama urbana. Esta expansión, inducida por "la colonización inglesa", atrajo proletarios de otras provincias andaluzas, e incluso de Badajoz, Portugal y Galicia. En 1923, se diseñó el sector de mayor originalidad: el barrio obrero Reina Victoria, compuesto por 90 villas de una o dos plantas con un pequeño jardín.

Durante el siglo XX, Huelva incrementó su número de habitantes. La ciudad, con el $45 \%$ de la población de la comarca, sufre una metamorfosis que la extiende por cabezos y llanuras para alojar cerca de 150.000 habitantes. En la década de 1960 la ciudad tuvo el mayor crecimiento urbano de su historia.

Huelva en el siglo XIX. Una comunidad ligada a las marismas | fuente COELLO, 1848-1870. Coloreado de la vista Juan A. Márquez

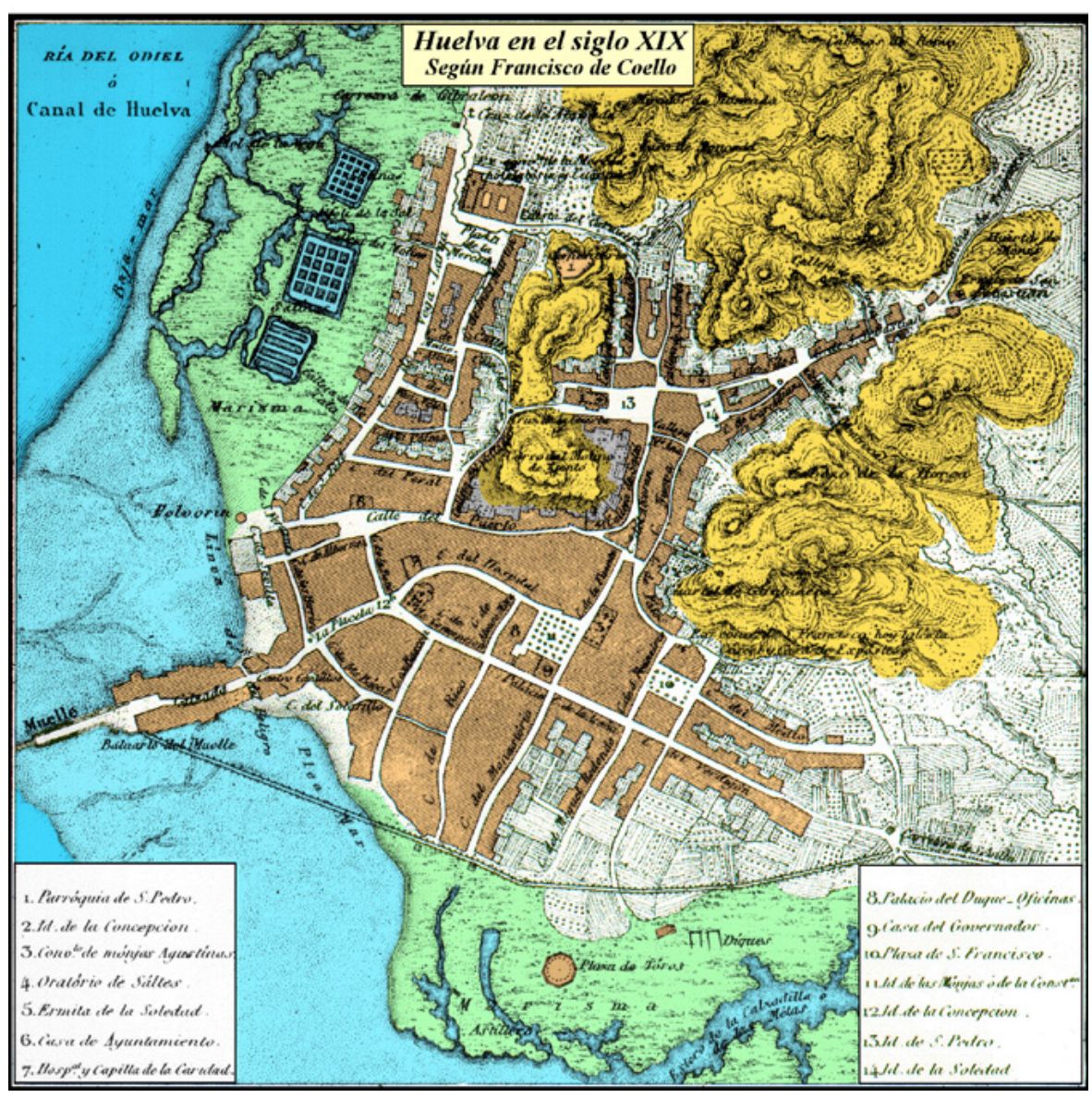




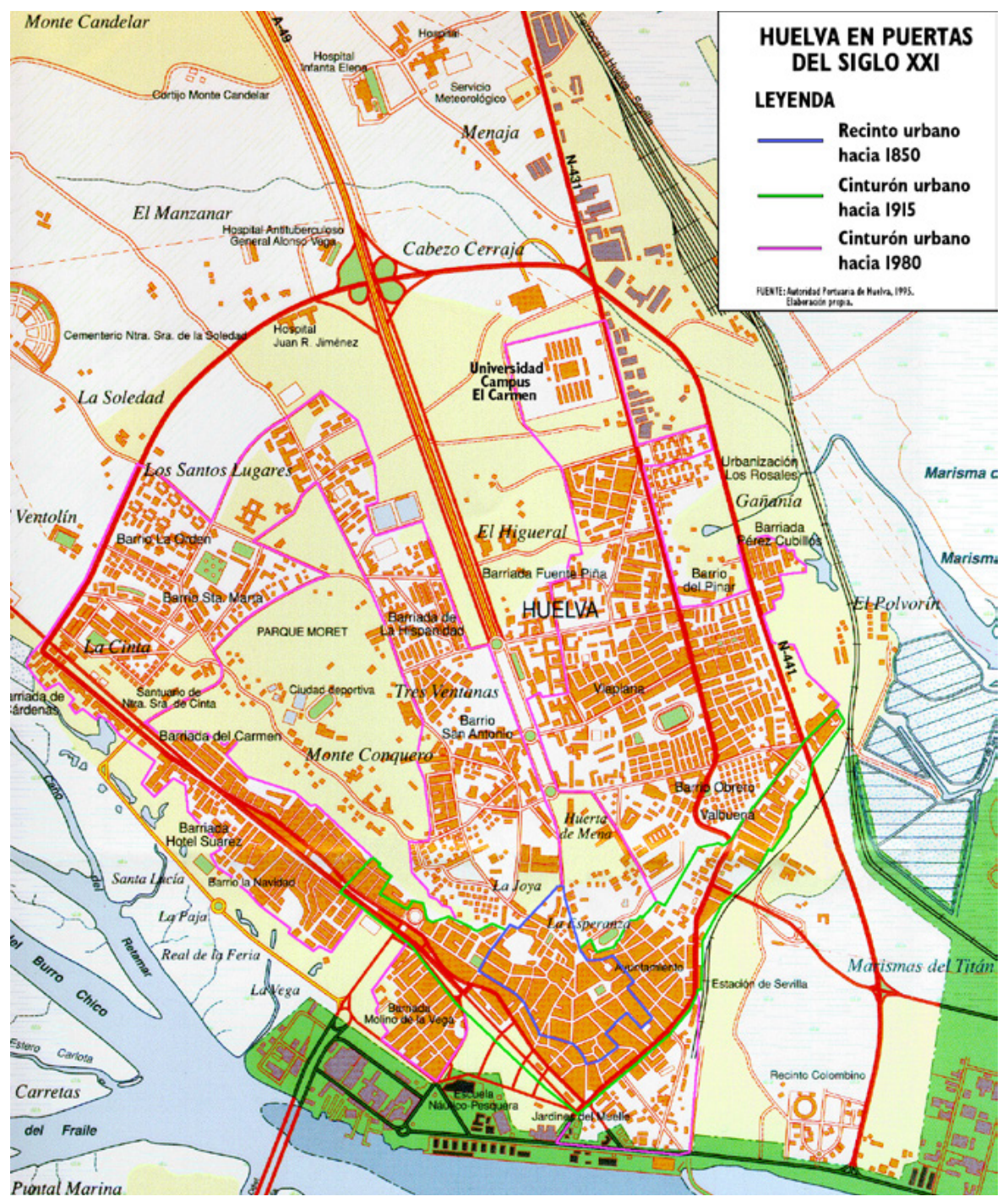

Huelva a las puertas del Siglo XXI | fuente MÁRQUEZ DOMÍNGUEZ, 1995-1997

En 1964 se delimitó una zona para que se beneficiase de un polo de promoción industrial y en 1968 de un polo de desarrollo industrial. La llegada de inversiones y la demanda de empleo atrajo un elevado número de inmigrantes. En poco tiempo la ciudad llegó a duplicar su población.

A partir de entonces, el área industrial de Huelva se constituye en el motor económico del municipio. La industria se extiende por la margen izquierda del río Odiel, desde la avenida Federico Montenegro, hasta llegar a la Punta del Sebo, enlazando con el Nuevo Puerto, ya dentro del término municipal de Palos de la Frontera. La crisis iniciada a principios de la década de 1970 ralentizó el ritmo de crecimiento y de renovación de la ciudad. Pero, superado este periodo de inanición, la Expo1992 fue una excusa para abordar 
Arriba izquierda. Huelva. Santuario de la Cinta, patrona de los marineros | fuente Google Earth 2018. Diseño de la vista Juan A. Márquez

Arriba derecha. Huelva. Punta del Sebo, con la escultura a la Fe Descubridora de la escultora Gertrude Vanderbilt Whitney de 1928 | fuente Google Earth 2018. Diseño de la vista Juan A Márquez

Abajo izquierda. Palos de la Frontera. En la Rábida se encuentra una reproducción de las carabelas que iniciaron la aventura colombina | fuente Google Earth 2018. Diseño de la vista Juan A. Márquez

Abajo derecha. Los Arándanos en la Costa de Huelva apuestan por la agricultura ecológica | foto Juan A. Márquez serios problemas que venían acuciando a la vieja ciudad. En el siglo XXI hay grandes esfuerzos por sanear la marisma e integrar el tejido urbano en el puerto.

Mientras tanto, fuera de la ciudad primada, el espacio urbano quedó durante mucho tiempo anclado en una historia que no despegaba, con interesantes núcleos urbanos que no sufrieron el proceso tranformador de Huelva. Ayamonte seguía con la frontera, Isla Cristina con su pesca y la sal, Lepe y Cartaya con el mar y el campo, Aljaraque con Corrales como apéndice minero, Gibraleón centrado en sus campos y olivares, San Juan del Puerto en la Empresa Nacional de Celulosas, Moguer en su vino y Juan Ramón, Palos de la Frontera en su Rábida y la gesta colombina, y Punta Umbría en su estrenado nacimiento, recién separada de Cartaya.

Sin embargo, a partir de la década de 1980, los municipios citados sufren una verdadera eclosión, provocada por las actividades turísticas y agrícolas. Nuevos espacios emergen en lugares que sólo eran transitados, de tarde en tarde, por campesinos-jornaleros, pescadores o pastores.
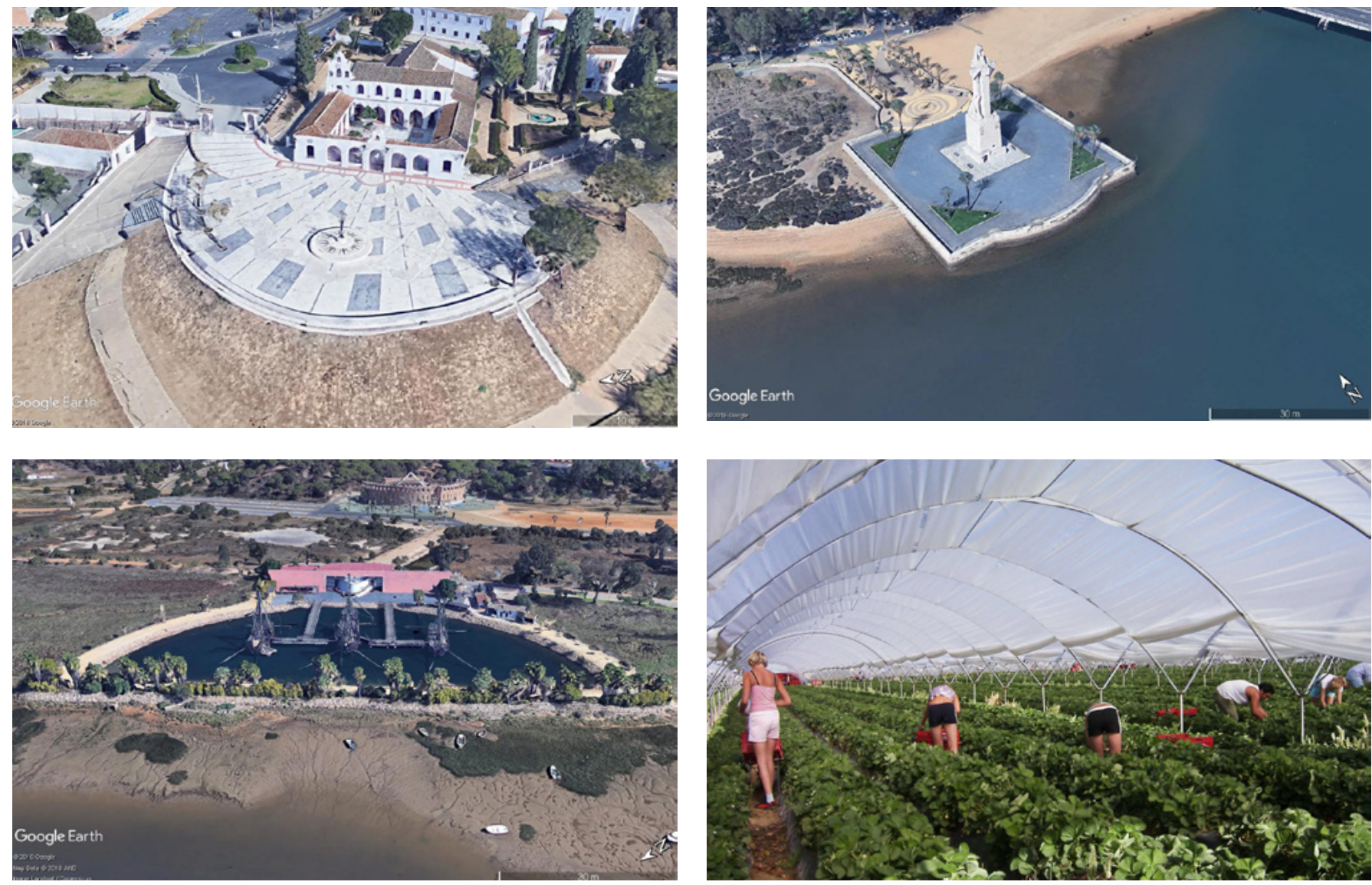


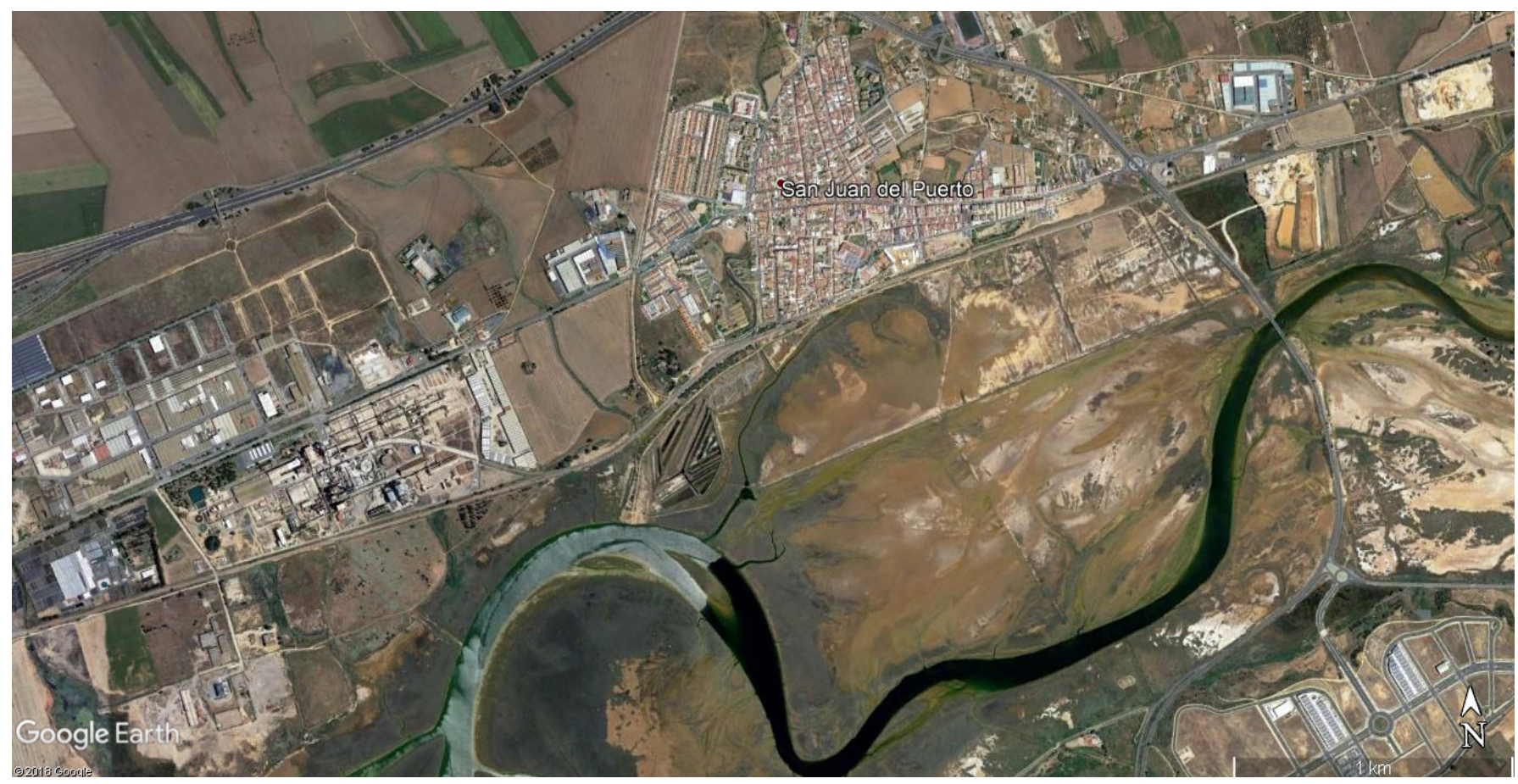

San Juan del Puerto. Entre la campiña y la marisma, perdió su identidad de puerto que hoy quiere recuperar | fuente Google Earth 2018.

El turismo y los campos de golf conquistaron el litoral con procesos especuDiseño de la vista Juan A. Márquez lativos y de segunda residencia. Estos procesos generaron fuertes transformaciones en Isla Canela y Costa Esuri en Ayamonte, en Islantilla, entre Lepe e Isla Cristina, en El Nuevo Portil, en Cartaya, en Bellavista y la Monacilla en Aljaraque, en Mazagón, entre Moguer y Palos, y en el crecimiento imparable de Punta Umbría, con un amplio equipamiento hotelero. Este avance urbano-turístico se ve reforzado por un fuerte nervio económico de los campos de naranjos, fresas, frambuesas y arándanos, que compiten, de forma muy exitosa, en el comercio internacional y se insertan entre los ruedos agrícolas tradicionales y el litoral.

\section{LOS ESPACIOS NATURALES. LAS MARISMAS DEL ODIEL}

La Red de Espacios Naturales Protegidos de Andalucía presenta en la provincia de Huelva un extenso catálogo de riquezas paisajística, pero la comarca Huelva y la costa occidental destaca por la singularidad de sus marismas. Las marismas constituyen espacios anfibios, donde la biodiversidad presenta su máxima expresión. En la comarca existen muchos espacios naturales relacionados con la marisma y los cordones arenosos que marcan la lucha continua entre las aguas continentales y marinas. Esto dificulta el transporte de sedimentos, que se depositan a la entrada de los estuarios, del Guadiana, del Tinto-Odiel, del Carreras, del Piedras, y mantienen 


\begin{tabular}{lllcc}
\hline Denominación & Protección & Municipios & ha & $\%$ ha \\
\hline Enebrales de Punta Umbría & Protección Integral & Punta Umbría & 55 & 0,41 \\
\hline Flecha del Rompido & Protección Integral & Lepe & 390 & 2,89 \\
\hline Lagunas Abalorio & Húmedas bien conservadas & Almonte, Moguer, Lucena del Puerto & 1.888 & 13,98 \\
\hline Marismas del Burro & Húmedas bien conservadas & Punta Umbría, Aljaraque, Huelva y Gibraleón & 597 & 4,42 \\
\hline Isla de Enmedio & Húmedas bien conservadas & Punta Umbría, Aljaraque, Huelva y Gibraleón & 480 & 3,55 \\
\hline Laguna del Portil & Húmedas bien conservadas & Punta Umbría & 60 & 0,44 \\
\hline Laguna de las Madres & Compatible con otros usos & Moguer & 100 & 0,74 \\
\hline Estero Domingo Rubio & Compatible con otros usos & Palos de la Frontera, Moguer & 340 & 2,52 \\
\hline Laguna de Palos & Compatible con otros usos & Palos de la Frontera & 65 & 0,48 \\
\hline Marismas del Piedras & Marismas transformadas & Lepe, Cartaya & 1.950 & 14,43 \\
\hline Del Guadiana y Carreras & Marismas transformadas & Ayamonte, Isla Cristina & 1.870 & 13,84 \\
\hline Marismas del Odiel & Marismas transformadas & Punta Umbría, Aljaraque, Huelva y Gibraleón & 5.714 & 42,30 \\
\hline Total & & & 13.509 & 100,00
\end{tabular}

Espacios naturales de interés en la comarca. Marismas, lagunas y spits | fuente Plan Especial de Protección del Medio Físico y catálogo de la provincia de Huelva (2007). Elaboración Juan A. Márquez las marismas. No obstante, las marismas no presentan un perfil homogéneo y aparecen dispersas en las desembocaduras de ríos, bordeando cauces anastomosados por un laberinto de meandros, que el hombre llenó de molinos de marea y de depósitos de sal. Algunas marismas fueron destruidas, como las del río Tinto, que soportaron durante decenios, frente a la ciudad de Huelva, los depósitos de fosfoyesos. Por su dilatada extensión y ecosistemas, destaca el parque natural Marismas del Odiel, que se extiende por más de 5.000 hectáreas y discurre entre los términos municipales de Punta Umbría, Aljaraque, Huelva y Gibraleón y que, paradójicamente, han sido marismas intensamente manejadas. Las marismas del Odiel "representan el más importante complejo de marismas de la península y uno de los más productivos de Europa" (RUBIO GARCÍA, 1991: 9). En 1983 fue reconocido por la Unesco, que lo declaró Reserva de la Biosfera. Al año siguiente, la Junta de Andalucía lo catalogó como paraje natural, con las reservas naturales de Isla de Enmedio y la Marisma del Burro. En las marismas, islas y esteros se desarrolla una importante biomasa que, debido a las suaves temperaturas, experimentan un crecimiento continuo. En los caños y esteros se han contabilizado más de 200 especies de aves, donde, además, viven gran cantidad de peces, moluscos y crustáceos. En la eclosión de la vida tiene un papel importante la existencia de salinas. En Marismas del Odiel fueron transformadas más de 1.000 hectáreas para la producción de sal. Efectivamente, sobre las Islas de Bacuta, La Liebre y los esteros de Cajabias, la empresa Energía e Industrias Aragonesas S. A. estuvo produciendo sal y cloro. Sin embargo, el cambio del cloro por oxígeno en el blanqueamiento del papel dejó prácticamente abandonadas las inmensas salinas que fueron colonizadas por el flamenco rosa. 


\section{BIBLIOGRAFÍA Y FUENTES DOCUMENTALES}

- BARCO Y GASCA, A. J. (1971) Disertación histórico geográfica, sobre reducir la antigua onuba a la villa de Huelva (Reproducción facsímil de la edición de Sevilla de 1755). Huelva: Diputación de Huelva, 1971

- BLÁZQUEZ, J. M. (1993) El enigma de Tarteso en los escritores antiguos y en la investigación moderna. En BLÁZQUEZ MARTÍNEZ, J. M.; ALVAR, J. (coord.) LoS enigmas de Tartesos. Madrid: Cátedra, 1993, pp. 11-30

- BODEVILLE, J. R. (1972) Aménagement du territoire et polarisation. Paris: MTGenin, 1972

- CANO GARCíA, G. (1992) La provincia de Huelva: un proceso de territorialización. Huelva en su historia, n. ${ }^{\circ} 4$, 1992, pp. $17-34$

- COELLO, F. (1848-1870) Atlas de España y sus posesiones de Ultramar (1848-1870). Madrid : [s.n.], 18481870

- FOURneAu, F. (1983) La provincia de Huelva y los problemas de desarrollo regional. Madrid: Consejo Superior de Investigaciones Cientificas, 1983 (Colección Instituto de Estudios Onubenses)

- GÓMEZ, F.; CAMPOS CARRASCO, J. M.; CASTIÑEIRA SÁNCHEZ, J.; GARCÍA, J. M.; BORJA BARRERA, F. (1994) Territorio y ocupación de la Tierra Llana de Huelva. El poblamiento de la Edad del Bronce. En CAMPOS CARRASCO, J. M.; PÉREZ MACÍAS, J. A.; GÓMEZ, F. (coord.) Arqueología en el entorno del Bajo Guadiana: actas del Encuentro Internacional de Arqueología del suroeste [(celebrado en) Huelva y Niebla, 25 a 27 de febrero de 1993]. Huelva: Universidad, 1994, pp. 329-350

- GONZÁLEZ CRUZ, D. (1995) La tierra y los hombres en la Huelva del Antiguo Régimen. En REY DE LAS PEÑAS, R. (coord.) El tiempo y las fuentes de su memoria (Tomo II). Huelva: Diputación Provincial de Huelva, 1995

- GONZALO Y TARÍN, J. (1886) Descripción física, geológica y minera de la provincia de Huelva. Madrid: Imprenta y Fundición de Manuel Tello, 1886-1887 (Serie Memorias de la Comisión del Mapa Geológico de España)

- JURAdO ALMONTE, J. M. (2014) Turismo de frontera en la provincia de Huelva. En ANTONIO CAMPESINO FERNÁNDEZ, J.; JURADO ALMONTE, J. M. (dir.) Turismo de frontera III. Productos turísticos de la Raya Ibérica. Huelva: Universidad de Huelva, 2014, pp. 113-134

- IGME (1975) Huelva-Los Caños. Madrid: Instituto Geológico y Minero de España (IGME), Ministerio de Industria, 1975 (Colección Mapa Geológico de España)

- MADOZ, P. (1806-1870) (1985) Diccionario geográficoestadístico-histórico España y sus posesiones de Ultramar. Huelva: Diputación de Huelva, Servicio de Publicaciones, 1985 (edición facsímil)
- MÁRQUEZ DOMíngUEZ, J. A. (coord.) (1995-1997) Los pueblos de Huelva. 4 Tomos. Madrid: Editorial Mediterráneo, 1995-1997

- MÁRQUEZ DOMínGUEZ, J. A. (2008) (dir.) Atlas del Suratlántico peninsular: un análisis de la estructura territorial y del potencial productivo. Huelva: Universidad de Huelva, Servicio de Publicaciones, 2008

- MÁRQUEZ DOMÍNGUEZ, J. A. (2012) Desactivación de la frontera. Desvertebración de la Raya lusoandaluza $y$ desenfoque de las políticas territoriales de desarrollo. Saarbrüken (Alemania): Editorial Académica Española, 2012

- MÁRQUEZ DOMínGUEZ, J. A. (2016) Vertebración internacional de los campos de fresas españoles. En VERA REBOLLO J. F.; OLCINA CANTOS, J.; HERNÁNDEZ HERNÁNDEZ, M. (coord.); MORALES GIL, A. (hom.) Paisaje, cultura territorial y vivencia de la geografía. Homenaje a Alfredo Morales Gil. Alicante: Universidad de Alicante, Instituto Interuniversitario de Geografía, 2016, pp. 605-628

- MEMORIA anual. Puerto de Huelva (2016). sl: Ministerio de Fomento, Autoridad Portuaria de Huelva

- MORA NEGRO Y GARROCHO, J. A. (DE) (1762) Huelva ilustrada : breve historia de la Antigua, y Noble Villa de Huelva. Sevilla: en la Imprenta del Dr. Don Geronymo de Castilla, Impresor mayor de dicha Ciudad, 1762

- NúÑEZ ROLDÁN, F. (1987) En los confines del reino. Huelva y su tierra en el siglo XVIII. Sevilla: Servicio de Publicaciones de la Universidad, 1987

- PEÑA GUERRERO, M. A. (1995) La provincia de Huelva en los siglos XIX y XX. En REY DE LAS PEÑAS, R. (coord.) El tiempo y las fuentes de su memoria. Historia moderna y contemporánea de la provincia de Huelva. Volumen IV. Huelva: Diputación Provincial de Huelva, 1995, pp. 9-239

- RESOLUCIÓN de 14 de febrero de 2007, de la Dirección General de Urbanismo, por la que se dispone la publicación del Plan Especial de Protección del Medio Físico y Catálogo de Espacios y Bienes Protegidos de la provincia de Huelva. Boletín Oficial de la Junta de Andalucía, n. ${ }^{\circ} 66$, de 3 de abril de 2007

- RUBIO GARCíA, J. C. (coord.) (1991) Estudio de la gestión integrada de las marismas del Odiel. Sevilla: Agencia de Medio Ambiente, Comisión de las Comunidades Europeas, Dirección General IX 


\section{$\mathrm{PH} 96_{\text {bienes, paisajes e itinerarios }}$}

\section{Panorama actual de la arqueología urbana en Huelva}

Juan M. Campos Carrasco | Dpto. de Historia I de la Universidad de Huelva

URL de la contribución <www.iaph.es/revistaph/index.php/revistaph/issue/view/4290>

\section{RESUMEN}

En esta contribución ${ }^{1}$ se presenta un panorama general de la arqueología urbana en la ciudad portuaria de Huelva. Se analizan las diferentes etapas, marcadas por distintos intereses, metodologías y mecanismos de gestión, por las que han transcurrido las intervenciones arqueológicas en la ciudad desde el año 1966 hasta el presente, que ascienden a 324, para a partir de ahí realizar un balance de los resultados, analizar la situación actual y reflexionar sobre un proyecto de futuro que permita el rescate y la reconstrucción de la memoria histórica de la ciudad de Huelva. Proyecto que ha de desarrollarse en el marco de diálogo entre los ciudadanos, ávidos de conocer su pasado, los agentes de desarrollo inmobiliario, generadores de riqueza y progreso, la Universidad, garante de la investigación, y los poderes públicos, responsables de garantizar el futuro del pasado.

Palabras clave

Arqueología urbana | Onoba | Huelva | Patrimonio arqueológico | Tarteso | 


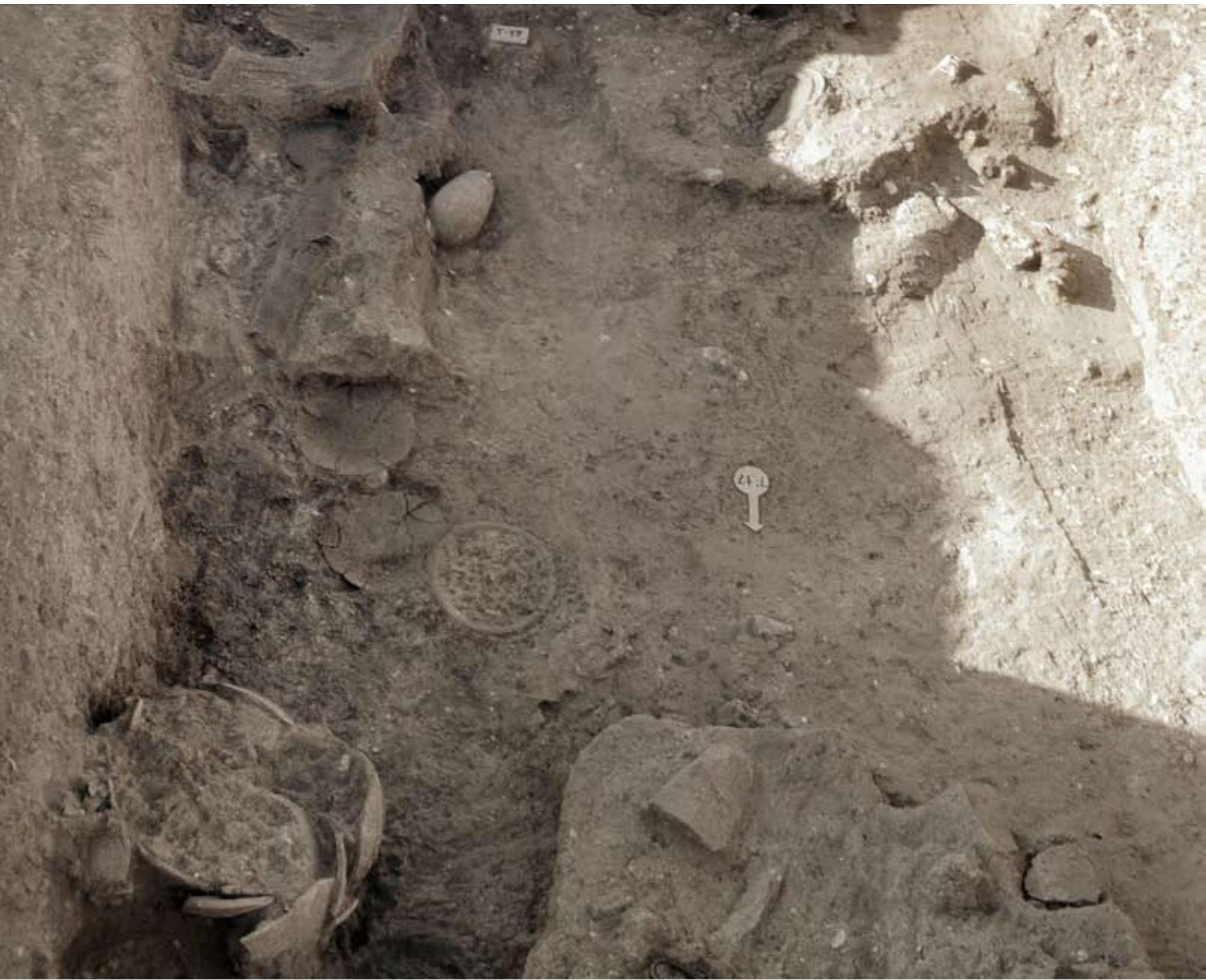

Excavación de la tumba 17 de La Joya | fuente LÓPEZ; GARCíA, 2010 


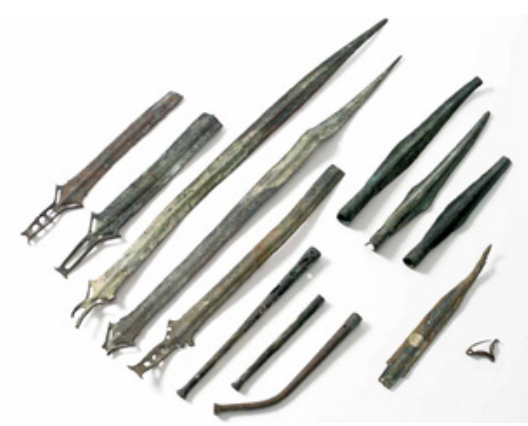

Bronces encontrados en la ría de Huelva | fuente TOSCANO; CAMPOS, 2018

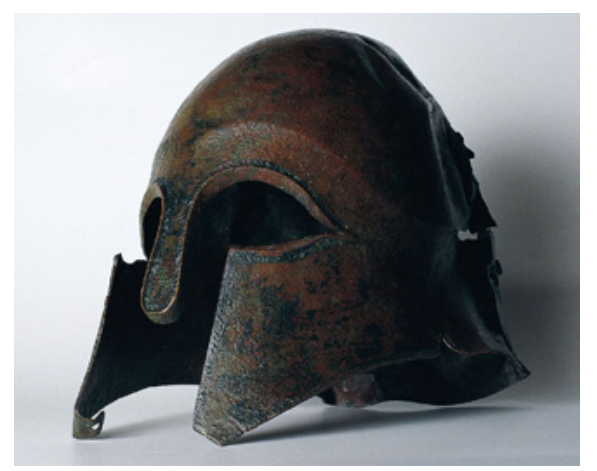

Casco corintio de la ría de Huelva | fuente ALMAGRO-GORBEA; CASADO; FONTES et ál., 2004

1

El presente trabajo se enmarca dentro de las actividades del Proyecto de Investigación de Excelencia del Plan Andaluz de Investigación Ciudades Romanas de la Bética. CORPVS VRBIVM BAETICARVM I (Ref. HUM 2062) y del proyecto del Plan Nacional de I+D De Atlántico al Tirreno ( $2^{\mathrm{a}}$ fase). Los puertos hispanos y su relación comercial con Ostia Antica (HAR2014-58326-P).

\section{INTRODUCCIÓN}

El descubrimiento en 1923 de un lote de bronces en el dragado de la ría de Huelva (ALMAGRO BASCH, 1940; 1957), al que años más tarde se unen un casco y un fragmento de aryballos corintios (ALBELDA; OBERMAIER, 1931; OLMOS ROMERA, 1988; ROUILLARD, 1978) despertaron la curiosidad de la comunidad científica, acrecentada por el descubrimiento en 1945 de una tumba en el cabezo de la Joya, cuya publicación casi veinte años después (ORTA GARCÍA; GARRIDO ROIZ, 1963) estableció una inmediata relación de Huelva con Tarteso, en un ambiente que volvía a ser propicio para la reanudación de la búsqueda de la legendaria ciudad, por los nuevos hallazgos que se estaban produciendo en el resto de Andalucía (MALUQUER DE MOTES, 1969).

Pero no será hasta mediados de los años 60 del pasado siglo cuando, de la mano de los profesores Juan Pedro Garrido y Elena M. ${ }^{\text {a }}$ Orta, comienzan las primeras intervenciones arqueológicas en la ciudad, en los cabezos de la Esperanza y La Joya. Desde entonces hasta hoy se han producido 324 intervenciones que hacen que el yacimiento de Huelva sea el más excavado de la provincia.

\section{LAS INTERVENCIONES EN LA CIUDAD}

El conjunto de intervenciones arqueológicas antes señalado puede considerarse muy desigual, según el momento de que se trate, pudiendo distinguirse varias etapas marcadas por diferentes intereses, metodologías y mecanismos de gestión que a continuación sintetizamos.

La primera etapa, caracterizada por la búsqueda de Tarteso, se desarrollará entre 1966 y 1971. Supone el comienzo de las primeras excavaciones en la ciudad realizadas por diversos equipos de la Universidad Complutense de Madrid. La importancia del hábitat protohistórico de Huelva, a partir de la publicación de la tumba orientalizante de La Joya (ORTA GARCíA; GARRIDO ROIZ, 1963), propició la búsqueda de otros enterramientos que correspondiesen a la misma u otras necrópolis, ubicadas en la ciudad. De esta forma, en la necrópolis de La Joya, en sucesivas campañas de verano, se excavaron varias tumbas en la superficie del cabezo cuyos ajuares las fecharon entre finales del siglo VII y comienzos del VI a. de C. (ORTA GARCÍA; GARRIDO ROIZ, 1963; GARRIDO ROIZ, 1970; GARRIDO ROIZ; ORTA GARCíA, 1978; 1989). El hábitat sincrónico a estas tumbas sería buscado inicialmente en los cabezos de La Esperanza (GARRIDO; ORTA, 1969; SCHUBART; GARRIDO ROIZ, 1967; BELÉN DEAMOS; FERNÁNDEZMIRANDA; GARRIDO ROIZ, 1978). En 1968, en unos trabajos de desmonte que se estaban realizando en el cabezo de San Pedro, aparecieron niveles 


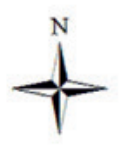

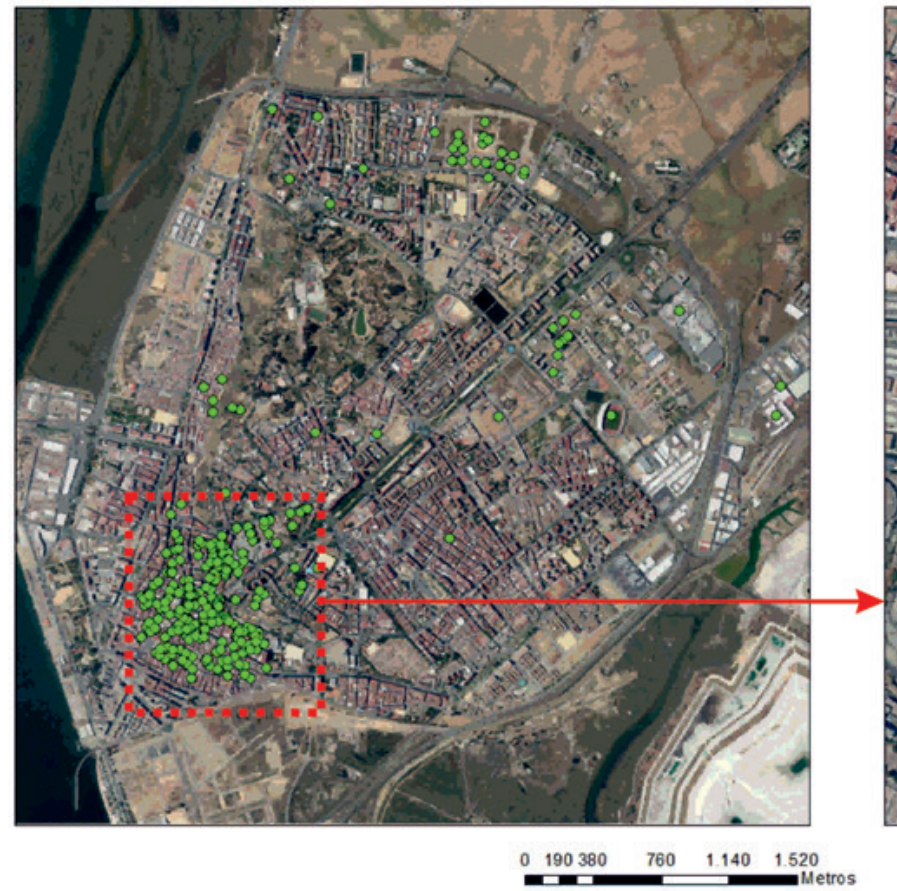

arqueológicos de amplia cronología estableciéndose una primera sistematización de la ocupación del lugar (BLÁZQUEZ MARTíNEZ; LUZÓN NOGUÉ; GÓMEZ et ál., 1970). Como resultado de todas estas intervenciones realizadas sobre los cabezos de la Joya y La Esperanza, que ascendieron a 10, se elabora una primera sistematización del poblamiento prerromano de Huelva, dividido en amplios períodos, desde el más antiguo, Huelva I, indígena aunque con escasas importaciones fenicias, hasta Huelva $\mathrm{VI}$, que significaba el comienzo de la romanización del hábitat situado en los cabezos (AMO Y DE LA HERA; BELÉN DEAMOS, 1981).

Entre 1972 y 1976 se identifica una segunda etapa, protagonizada por el Museo de Huelva, que pone al descubierto restos romanos de la Onoba romana (AMO Y DE LA HERA, 1976).

A partir de 1977 y hasta 1981 se desarrolla una tercera etapa caracterizada por la vuelta a la arqueología tartésica. El siguiente equipo que excavará en la cima de San Pedro (BLÁZQUEZ MARTíNEZ; RUIZ MATA; REMESAL RODRÍGUEZ et ál., 1979; RUIZ MATA; BLÁZQUEZ MARTÍNEZ; MARTÍN DE LA CRUZ, 1981) alcanzó unos resultados que con matizaciones pueden ser considerados todavía vigentes (RUIZ MATA, 1986; 1995). En el

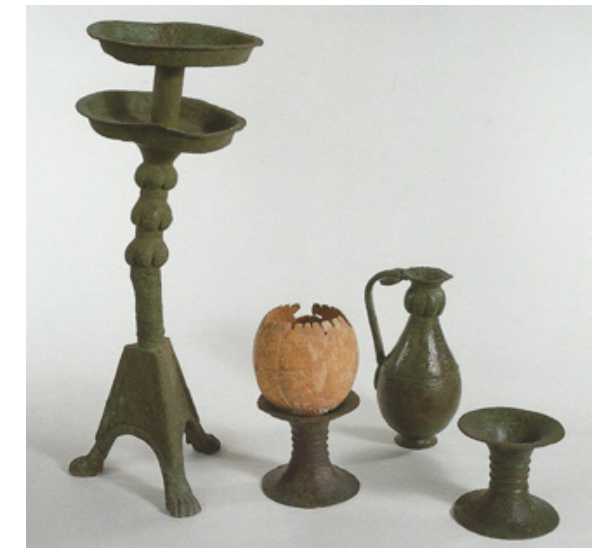

Ajuar de la tumba 17 de La Joya | fuente GARCíA ALFONSO, 2010 


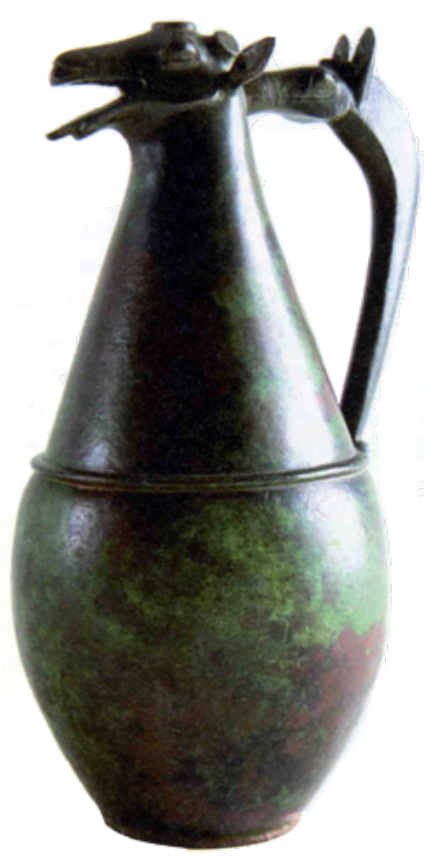

Ajuar de la tumba 18 de la Joya | fuente VALLEJO SÁNCHEZ, 2010

A la derecha, plano de los restos de la cetaria de Huelva | fuente AMO Y DE LA HERA, 1976
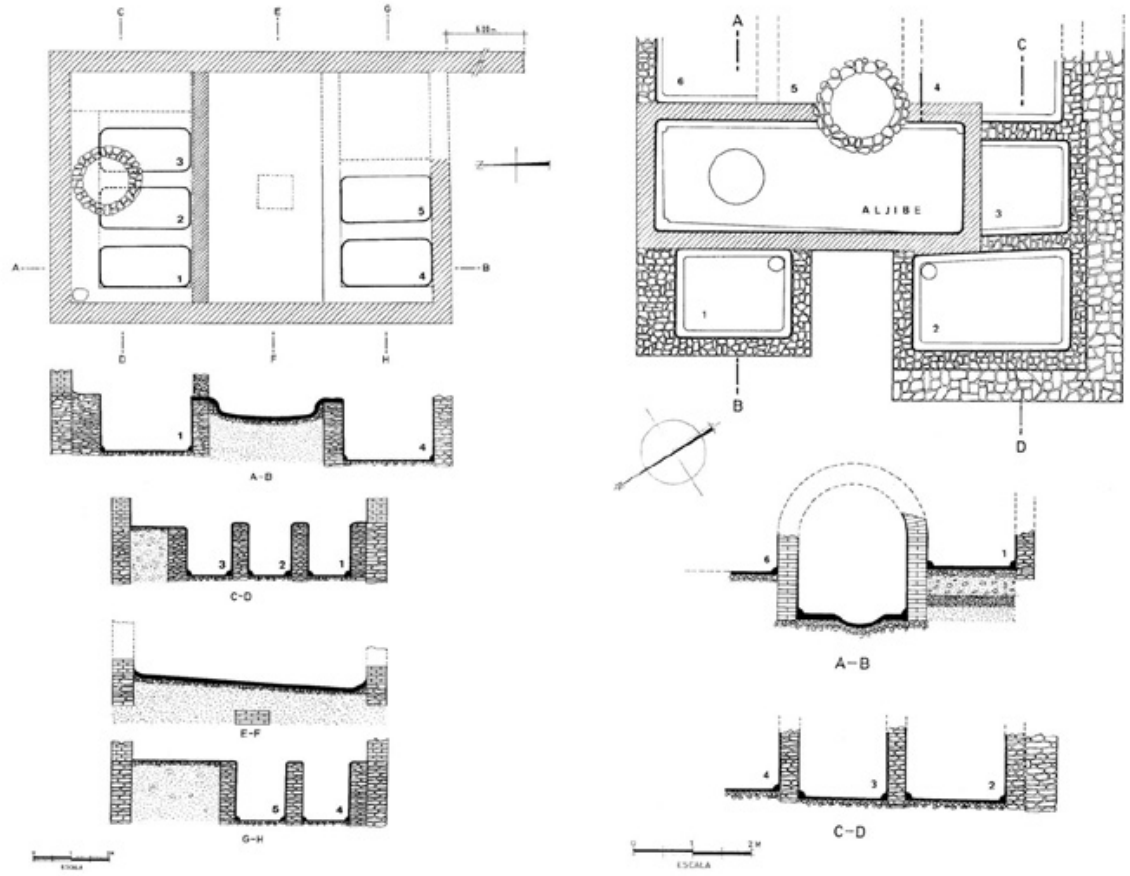

verano de 1980 se realizan algunos sondeos en el solar número 10 de la calle del Puerto. Como resultado, surgen diversos artículos donde se pone el énfasis en las cerámicas griegas arcaicas localizadas (OLMOS ROMERA; CABRERA BONET, 1980; OLMOS ROMERA, 1982; CABRERA BONET, 1986; FERNÁNDEZ JURADO; CABRERA BONET, 1987; GARRIDO ROIZ; ORTA GARCÍA, 1989), que suponen una novedad importante para retomar los planteamientos que se relacionaban con la presencia de los griegos en Tarteso, y que provocarán, en última instancia, que prácticamente se abandone la investigación del período romano y otros posteriores.

Durante casi toda la década de los 80 y 90 se desarrolla la cuarta etapa. Será el equipo de la Diputación Provincial de Huelva el que protagonice, salvo contadísimas excepciones, las excavaciones en la ciudad al amparo del modificado del artículo 104 del Plan General de Ordenación Urbana de 1980. Científicamente, en esta etapa continúa el interés preferencial por el mundo tartésico en detrimento del mundo romano, medieval y moderno. Queda, sin embargo, un número importante de publicaciones, tanto de carácter científico (FERNÁNDEZ JURADO, 1988-1989; FERNÁNDEZ JURADO; RUFETE TOMICO; GARCÍA SANZ, 1992) como divulgativo (FERNÁNDEZ JURADO; GARCÍA SANZ; RUFETE TOMICO, 1997; RUFETE TOMICO; GARCÍA SANZ, 1995), que constituyen un importantísimo corpus de información para el conocimiento de la arqueología onubense, en especial el periodo protohistórico. 
Finalmente, la etapa actual comienza a partir de 1999. La incoación del expediente de Declaración de la zona arqueológica de Huelva cambia radicalmente el panorama anteriormente descrito provocando una nueva política patrimonial para las excavaciones arqueológicas que se realizan en el casco antiguo de Huelva y que, entre otras cosas, conlleva un tratamiento diferente de otros periodos históricos. Una de las consecuencias más destacable ha sido la gran revitalización de la Onoba romana, cuyos restos materiales están viendo la luz de forma más intensa en los últimos años, permitiendo incluso las reconstrucciones virtuales de algunos de los espacios excavados, en especial la zona portuaria (CAMPOS CARRASCO, 2001-2002; 2011; VIDAL; CAMPOS, 2006; CAMPOS CARRASCO; BERMEJO MELÉNDEZ, 2017; DELGADO AGUILAR, 2016; BERMEJO MELÉNDEZ; CAMPOS CARRASCO; RODRÍGUEZ-VIDAL, 2017). Esta nueva realidad se cimenta en dos hechos fundamentales: el aumento del número de intervenciones, unas 220 desde entonces hasta hoy, y la incorporación a las intervenciones de la Universidad de Huelva y de empresas profesionales de arqueología.

Desde fines de 2016 hasta hoy, aunque interrumpido durante casi todo el año 2018, se ha desarrollado un Plan General de Investigación de la zona arqueológica de Huelva, como transición hacia un verdadero proyecto de arqueología urbana, gracias al protocolo firmado entre la Consejería de Cultura de la Junta de Andalucía y la Universidad de Huelva. La finalidad principal es la recuperación e integración de la información arqueológica derivada de las actividades arqueológicas desarrolladas en la ciudad, cuyos materiales se encuentran depositados en el Museo de Huelva. Paralelamente se están realizando diagnósticos de los diversos sectores que conforman la zona arqueológica. Finalmente se está actualizando la carta de riesgo mediante la incorporación en un SIG de toda la información que se va generando así como de las nuevas intervenciones que se producen en la ciudad (CAMPOS CARRASCO, 2016).

Es dentro de esta tendencia de apertura donde hay que valorar el avance producido en la investigación arqueológica de este yacimiento, y especialmente en lo que se refiere a su horizonte romano, carente hasta el momento de una interpretación conjunta de los distintos aspectos que lo integran.

\section{BALANCE DE LAS INTERVENCIONES}

La actividad arqueológica en la ciudad de Huelva, desde los inicios de las primeras intervenciones en 1966 hasta hoy, ofrece luces y sombras, pudiendo destacar las siguientes cuestiones:

Desde el punto de vista de la metodología aplicada, la primera cuestión a señalar, en consecuencia con lo anteriormente expuesto, es el hecho de que

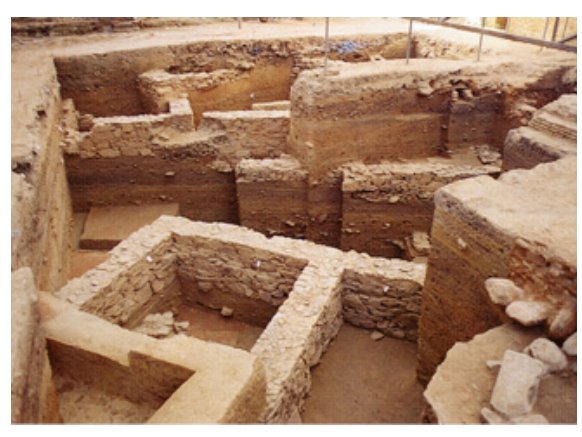

Restos protohistóricos hallados en la C/ Puerto, 12 | fuente RUFETE TOMICO; GARCÍA SANZ, 1995

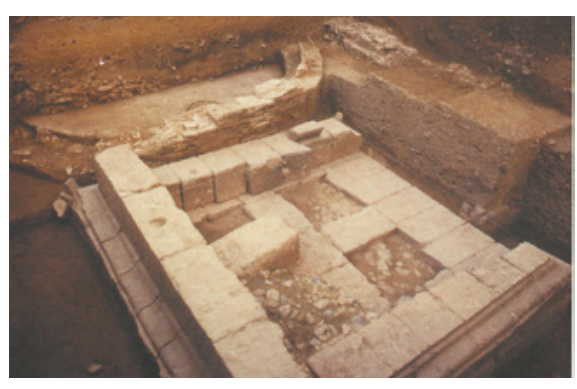

Basamento romano. Convento de las Agustinas | fuente FERNÁNDEZ JURADO; GARCÍA SANZ; RUFETE TOMICO, 1997 

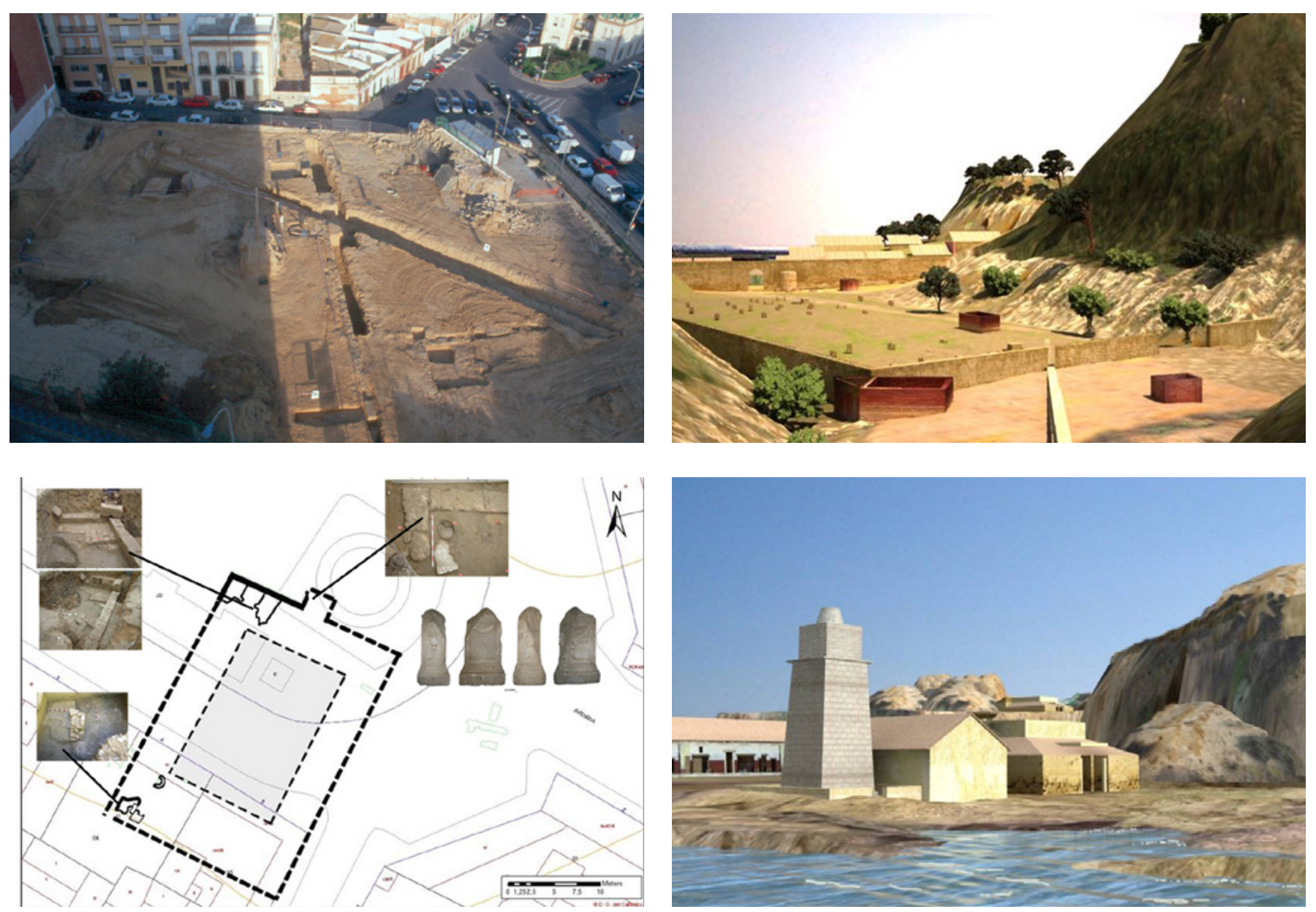

Arriba a la izquierda, necrópolis romana del Colegio Francés

Arriba a la derecha, reconstrucción infográfica de la necrópolis del Colegio Francés

Abajo a la izquierda, restitución del edificio romano de sillares de plaza de las Monjas

Abajo a la derecha, restitución infográfica de la zona portuaria y faro de Onoba | foto, esquema e infografías Grupo de Investigación Vrbanitas Arqueología y Patrimonio el conjunto de las intervenciones no ha estado presidido nunca por un verdadero proyecto de arqueología urbana, limitándose al concepto de intervenciones en medio urbano que difiere notablemente de aquél. La ausencia de un proyecto de ciudad ha impedido, hasta el momento, una síntesis del conjunto del poblamiento y su evolución desde los inicios de la ocupación del espacio, desde la prehistoria hasta la actualidad. Por otro lado, han sido muy diferentes los métodos de excavación puestos en práctica y los planteamientos científicos para la interpretación del registro arqueológico. Por último, y referido a los tiempos presentes, hay que señalar que el hecho de que las actuaciones sean realizadas por diferentes empresas de arqueología dificulta la incorporación de los datos a un proyecto general de investigación, basado en el concepto de arqueología urbana o, al menos, la fluidez de los mismos al banco de datos ya existente en la carta de riesgo, que debería estar siempre actualizado, si se quiere disponer de una herramienta útil tanto para la gestión del patrimonio arqueológico de la ciudad, como para su investigación histórico-arqueológica. El desarrollo del actual 
Plan General de Investigación vigente intenta paliar en parte los problemas señalados.

En cuanto a la orientación de las intervenciones, como ya se ha puesto de manifiesto, salvo el caso de las realizadas por el Museo Provincial a principios de los años 70, el interés de la investigación se centró casi con exclusividad en el mundo tartésico. Esta tendencia ha cambiado notablemente en la etapa que comenzó a fines de los años 90 dándose una mayor importancia a otros periodos históricos que ha contribuido a enriquecer de manera muy notable el conocimiento histórico de la Huelva romana, medieval y moderna.

En relación con lo anterior, el rendimiento científico ha estado muy determinado por esa orientación de forma que el nivel de publicaciones referidas a la etapa protohistórica era abrumadoramente mayor que el de otros periodos históricos. Sólo en los últimos años se ha avanzado en el conocimiento de otras manifestaciones históricas, especialmente el mundo romano. En cualquier caso, el nivel global de interpretación elaborado no se corresponde con el volumen de datos disponibles, según hemos justificado en La Carta de Riesgo de Huelva (CAMPOS; GÓMEZ; LÓPEZ, 2000) y en la, hasta ahora, única síntesis histórico-arqueológica que realiza la puesta al día del conjunto de datos conocidos (GÓMEZ TOSCANO; CAMPOS CARRASCO, 2001).

Pero sin duda, el cambio más significativo se ha producido en la gestión de las intervenciones urbanas. A partir de 1999, como se ha señalado, cambia radicalmente el panorama anteriormente descrito. La redacción de la Carta de Riesgo de la Ciudad de Huelva permitió la elaboración del expediente de incoación de la zona arqueológica de Huelva con una nueva delimitación que perfila una zona arqueológica mucho más amplia y compleja que la contemplada en el PGOU de 1980, estableciendo ámbitos precisos de protección teniendo en cuenta el diagnóstico previo establecido en la Carta de Riesgo del Casco Antiguo de la Ciudad de Huelva y las nuevas experiencias adquiridas en los últimos años. Esto conlleva un nuevo procedimiento que consiste en que a la financiación pública, tanto municipal como autonómica, de las diferentes actuaciones arqueológicas, se incorporan los promotores privados que han de sufragar los costes de las intervenciones arqueológicas en las obras que promueven.

Siguiendo este procedimiento, desde noviembre de 1999, como ya se ha indicado, se han realizado unas 220 excavaciones y seguimientos arqueológicos de diverso alcance que han permitido establecer diferentes acciones encaminadas a la protección, conservación, revalorización y difusión del patrimonio histórico-arqueológico de la ciudad de Huelva.

Finalmente, y relacionado con lo anterior, en lo que a la conservación de restos se refiere, la referida Declaración también establece un punto de inflexión 

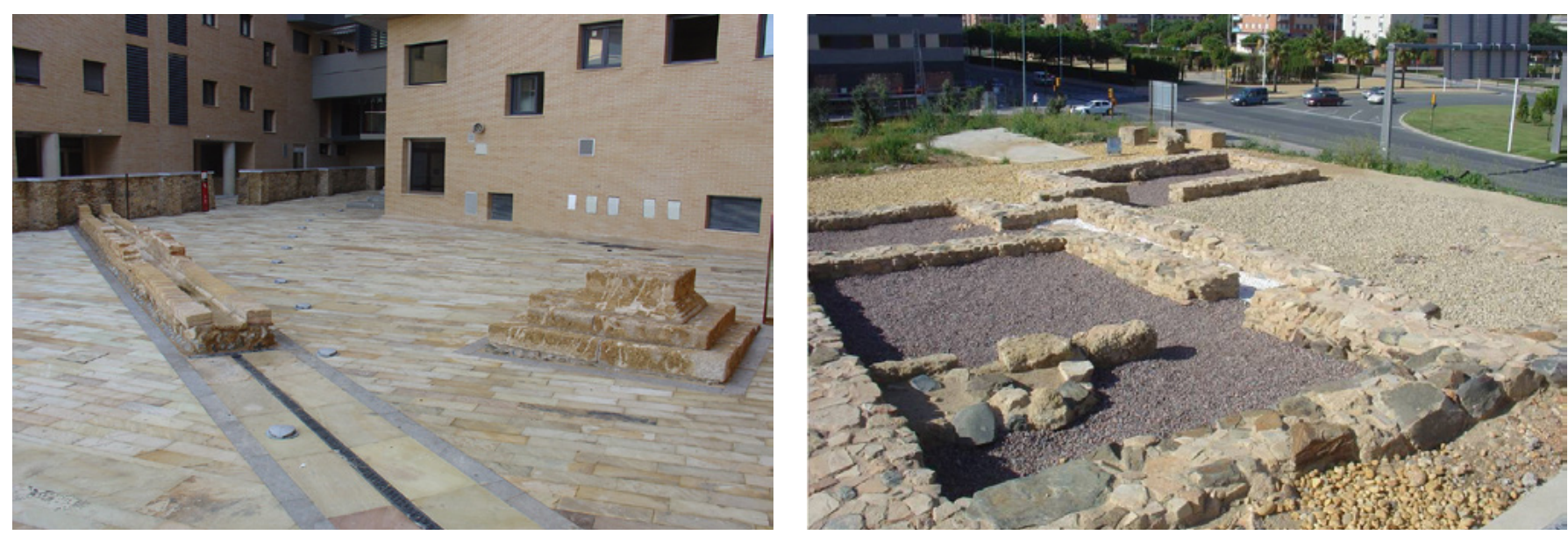

A la izquierda, puesta en valor de la necrópolis del Colegio Francés

A la derecha, puesta en valor de la villa romana de La Almagra | fotos Grupo de Investigación Vrbanitas Arqueología y Patrimonio en este aspecto, pues salvo los restos del conocido Muro de San Pedro, conservado por iniciativa privada, nada se había conservado en la ciudad hasta ese momento, lo que ha supuesto la destrucción de una muestra significativa de restos para comprender la evolución histórica de la ciudad. En los últimos años han sido varias las iniciativas orientadas hacia la conservación y difusión de restos, como son los casos de la calle Arquitecto Pérez Carasa, plaza de San Pedro, antiguo Colegio Francés, villa de La Almagra y Parque Moret. A pesar de ello, creemos que es todavía una asignatura pendiente que la ciudad en su conjunto debe superar con una apuesta más decidida a la hora de tomar decisiones sobre la integración de restos.

\section{LAS PERSPECTIVAS DE FUTURO}

Sin duda, el futuro de la investigación en la ciudad de Huelva pasa por, superando el actual Plan General de Investigación, el diseño de un proyecto de ciudad, donde la arqueología urbana se posicione como una actividad fundamental. El hecho de tratarse de un enclave que se extiende desde los albores del I milenio a. de C. hasta nuestros días sin solución de continuidad y de presentar un alto grado de conservación, no sólo del registro arqueológico sino también de los restos inmuebles, otorga al proyecto un alto valor en lo que al desarrollo cultural y turístico de la ciudad se refiere.

Por otro lado, los beneficios de una investigación de estas características podrían ser aprovechados por la propia dinámica de planeamiento y administración urbanística del ente local mediante la actualización continua de la carta de riesgo.

Con todas las premisas anteriores, la existencia de un proyecto general de arqueología urbana en la zona arqueológica de Huelva, de acuerdo con las 
evidencias mostradas en apartados anteriores, encuentra su más lógica justificación, tanto desde la perspectiva de la gestión del patrimonio histórico de la ciudad por las instituciones responsables de su protección y difusión, como desde las que asuman su investigación y divulgación científica.

Con este proyecto se puede aglutinar la información que se genere en las diversas actuaciones arqueológicas que se realicen en un futuro, cuyo fin, al estar fundamentalmente encaminado al diagnóstico patrimonial de zonas o parcelas urbanas, podría perder el necesario componente histórico-científico que debe presidir la investigación que se lleve a cabo en el ámbito de una ciudad superpuesta como Huelva.

Por otra parte, dado que las intervenciones en la ciudad están garantizadas con las figuras de protección necesarias, un proyecto de arqueología urbana representaría poner en práctica una tendencia que, de acuerdo con la experiencia adquirida en la Comunidad Autónoma de Andalucía en los últimos años, parece la culminación de un modelo de gestión del patrimonio histórico-arqueológico imprescindible en este milenio.

Desde esta perspectiva, serán pues los dos mecanismos citados, la Declaración de Huelva como zona arqueológica, y la redacción de la carta de riesgo, incluidas en el Plan General de Ordenación Urbana, los que faculten un nuevo marco de diálogo entre los ciudadanos, ávidos de conocer su pasado, los agentes de desarrollo inmobiliario, generadores de riqueza y progreso, la Universidad, garante de la investigación, y los poderes públicos, responsables de garantizar el futuro del pasado. Confluyen, de este modo, toda la diversa gama de esfuerzos en planificación e intervención de facto sobre la ciudad, y es en este plano de confluencia donde se pone de manifiesto el carácter sintético y dinámico del problema urbano: la ciudad histórica como proyecto en continuo desarrollo.

Las relaciones actuales entre planeamiento urbanístico, intervención arquitectónica en el patrimonio inmobiliario y arqueología preventiva y sistemática, nos llevan a la consideración de la ciudad histórica como objeto proyectual, donde desde el concepto de arqueología urbana se integraría de forma plena en lo que hemos llamado el proyecto ciudad. Pero esta integración, sin dudas, pasa necesariamente, como se ha defendido, por la articulación de un proyecto general de investigación de futuro donde, respetando la libertad científica de los diferentes investigadores o profesionales de la arqueología que lleven a cabo las intervenciones de urgencia, se pueda generar y procesar el volumen de información obtenida mediante registros homologados, que permita el rescate y la reconstrucción de la memoria histórica de la ciudad de Huelva (CAMPOS; VIDAL, 2013). 


\section{BIBLIOGRAFÍA}

- AlBELDA, J.; OBERMAIER, H. (1931) El casco griego de Huelva. Boletín de la Real Academia de la Historia, tomo 98, cuaderno II (abril-junio, 1931), pp. 642-648

- ALMAGRO BASCH, M. (1940) El hallazgo de la ría de Huelva y el final de la Edad del Bronce en el Occidente de Europa. Ampvrias. Revista de Arqueología, Prehistoria y Etnografía, II, 1940, pp. 85-143

- ALMAGRO BASCH, M. (1957) Las fíbulas de codo de la ría de Huelva. Su origen y cronología. Cuadernos de trabajo de la Escuela Española de Historia y Arqueología en Roma, n. ${ }^{\circ}$ 9, 1957, pp. 7-46

- ALMAGRO-GORBEA, M.; CASADO, D.; FONTES, F.; MEDEROS, A.; TORRES, M. (2004) Casco corintio de la Ría de Huelva. En ALMAGRO-GORBEA, M.; CASADO, D.; FONTES, F.; MEDEROS, A.; TORRES, M. Catálogo del Gabinete de Antigüedades de la Real Academia de la Historia. Prehistoria. Antigüedades Españolas I. Madrid: Real Academia de Historia, 2004, pp. 174-176

- AMO Y DE LA HERA, M. DEL; BELÉN DEAMOS, M. (1981) Estudio de un corte estratigráfico en el Cabezo de San Pedro. Huelva Arqueológica, n. ${ }^{\circ}$ 5, 1981, pp. 57-148

- AMO Y DE LA HERA, M. DEL (1976) Restos materiales de la población romana de Onuba. Huelva Arqueológica, n. ${ }^{\circ} 2,1976$, pp. 11-196

- BELÉN DEAMOS, M.; FERNÁNDEZ-MIRANDA, M.; GARRIDO ROIZ, J. P. (1977) Los orígenes de Huelva: excavaciones en los Cabezos de San Pedro y La Esperanza. Huelva Arqueológica, n. ${ }^{0} 3,1977$, pp. 13-171

- BERMEJO MELÉNDEZ, J.; CAMPOS CARRASCO, J. M.; RODRÍGUEZ-VIDAL, J. (2017) Las estructuras portuarias de Onoba Aestuaria: Un puerto pesquero y de control imperial. En CAMPOS CARRASCO, J. M.; BERMEJO MELÉNDEZ, J. (ed.) Los Puertos Atlánticos Béticos y Lusitanos y su relación comercial con el Mediterráneo. Roma: “L’Erma" di Bretschneide, 2017, pp. 207-243 (Hispania Antigua-Serie Arqueologica)

- BLÁZQUEZ MARTÍNEZ, J. M.; LUZÓN NOGUÉ, J. M.; GÓMEZ, F.; CLAUSS, K. (1970) Huelva Arqueológica. Las cerámicas del Cabezo de San Pedro. Huelva: Diputación Provincial de Huelva, 1970

- BLÁZQUEZ MARTÍNEZ, J. M.; RUIZ MATA, D.; REMESAL RODRÍGUEZ, J.; RAMÍREZ SÁDABA, J. L.; CLAUSS, K. (1979) Excavaciones en el Cabezo de San Pedro (Huelva). Campaña de 1977. Madrid: Ministerio de cultura. Dirección General del Patrimonio Artístico, Archivos y Museos. Subdirección General de Arqueología, 1979 (Excavaciones Arqueológicas en España, 102)

- CABRERA BONET, P. (1986) La presencia griega en Huelva: los materiales griegos. Homenaje a Luis Siret (1934-1984). Sevilla: Consejería de Cultura, pp. 575-583
- CAMPOS CARRASCO, J. M. (2001-2002) La ciudad romana de Onuba (Huelva). Una revisión arqueológica. Anales de Prehistoria y Arqueología, n. ${ }^{\circ}$ 17-18, 2001-2002, pp. 329-340

- CAMPOS CARRASCO, J. M. (2006) Huelva, desde los inicios hasta la Edad Media. En LARA RÓDENAS, M. J. DE; ECHENAGUSIA BELDA, J.; ORTEGA, C.; CAMPOS CARRASCO, J. M. Huelva. Barcelona: Editorial Lunwerg, 2006, pp. 13-25

- CAMPOS CARRASCO, J. M. (2011) Onoba Aestuaria. Una ciudad portuaria en los confines de la Baetica. Huelva: Ayuntamiento, Concejalía de Cultura, 2009

- CAmpos CARRAsco, J. M. (2016) Plan General de investigación arqueológica: Zona Arqueológica de Huelva. Consejería de Cultura. Junta de Andalucía. Inédito

- CAMPOS CARRASCO, J. M.; BERMEJO MELÉNDEZ, J. (2017) Los suburbios de Onoba Aestuaria, el área portuaria. En PANZRAM, S. OPPIDIUM-CIVITAS-URBS. Stadteforschung auf der Iberischen Halbinsel Zwischen Rom und al-Andalus. Berlín: LIT Verlag, 2017, pp. 739-766

- CAMPOS, J. M.; GÓMEZ, F.; LÓPEZ, M. A. (2000) Carta de Riesgo de la Ciudad de Huelva. Excmo. Ayuntamiento de Huelva. Inédita

- CAMPOS, J. M.; VIDAL, N. O. (2013) Arqueología urbana en Huelva: balance y perspectivas de futuro. En GÓMEZ TOSCANO, F. Arqueología en la Provincia de Huelva: homenaje a Javier Rastrojo Lunar. Huelva: Servicio de Publicaciones Universidad de Huelva, Asociación Profesional de Arqueólogos de la Provincia de Huelva, 2013, pp. 27-36

- DElgado Aguilar, S. (2016) Onoba Aestuaria [en línea]. Tesis doctoral inédita. Universidad de Huelva, 2016 <http://rabida.uhu.es/dspace/handle/10272/12086> [Consulta: 08/11/2018]

- FERNÁNDEZ JURADO, J. (1988-1989) Tartessos y Huelva. Huelva Arqueológica, n. ${ }^{\circ}$ 10-11 (1), 1988-1989

- FERNÁNDEZ JURADO, J.; RUFETE TOMICO, P.; GARCÍA SANZ, C. (1992) Análisis y definición de la cultura tartésica según Tejada la Vieja (Escacena) y Huelva. Síntesis de resultados. En CAMPOS CARRASCO, J. M.; NOCETE CALVO, F. (coord.) Investigaciones Arqueológicas en Andalucía (1985-1992). Proyectos. Huelva, pp. 79-85 y 497-499

- FERNÁNDEZ JURADO, J.; CABRERA BONET, P. (1987) "Comercio griego en Huelva a fines del siglo $V$ a.C." Simposio Internacional Grecs et Ibères au IVè siècle $a$. J. C. Revue d'Etudes Anciens, tomo 89, n. ${ }^{\circ} 3-4,1987$, pp. 149-159

- FERNÁNDEZ JURADO, J.; GARCÍA SANZ, C.; RUFETE TOMICO, P. (1997) De Tartessos a Onuba. 15 años de 
arqueología en Huelva. Huelva: Diputación Provincial de Huelva, 1997

- gARCíA ALFONSO, E. (2010) Elementos de carro. En LÓPEZ, M. D.; GARCÍA, E. (ed.) Cádiz y Huelva. Puertos Fenicios del Atlántico. Sevilla: Fundación Cajasol, Junta de Andalucía, 2010, pp. 302-303

- GARRIDO ROIZ, J. P.; ORTA GARCíA, M. E. (1969) Cerámicas prerromanas de Huelva. Trabajos de Prehistoria, 26, 1969, pp. 327-335

- GARRIDO ROIZ, J. P. (1970) Excavaciones en la necrópolis de la Joya (1. a y 2. ${ }^{a}$ campañas). Madrid: Ministerio de Educación y Ciencia. Dirección General de Bellas Artes, Comisaría General de Excavaciones Arqueológicas, 1970 (Excavaciones Arqueológicas en España, 71)

- GARRIDO ROIZ, J. P.; ORTA GARCíA, E. M. (1978) Excavaciones en la necrópolis de La Joya, Huelva II. $\left(3^{a}, 4^{a}\right.$ y $5^{a}$ Campañas). Madrid: Ministerio de Educación y Ciencia. Dirección General de Bellas Artes, Comisaría General de Excavaciones Arqueológicas, 1970-1978 (Excavaciones Arqueológicas en España, 96)

- GARRIDO ROIZ, J. P.; ORTA GARCíA, M. E. (1989) La necrópolis y el hábitat orientalizante de Huelva. Itinerarios de Monumentos. Huelva: Consejería de Cultura, Delegación Provicial de Huelva, 1989, pp. 5-93

- gÓMEz toscano, F.; CAMPos CARRASCO, J. M. (2001) Arqueología en la Ciudad de Huelva (1966-2000). Huelva: Universidad, 2001

- LÓPEZ, M. D.; GARCíA, E. (eds.) (2010) Cádiz y Huelva. Puertos Fenicios del Atlántico. Sevilla: Fundación Cajasol, Junta de Andalucía, 2010

- MALUQUeR DE MOTES, J. (1969) Tartessos y sus problemas: Actas del V Symposium Internacional de Prehistoria Peninsular (Jerez de la Frontera. 1968). Barcelona: Universidad de Barcelona, 1969

- OlMOS ROMERA, R. (1982) La cerámica griega en el Sur de la Península Ibérica. La aportación de Huelva. La Parola del Passato, n. ${ }^{\circ}$ 37, 1982, pp. 393-406

- OlMOS ROMERA, R. (1988) El casco griego de Huelva. Clásicos de la arqueología de Huelva, n. ${ }^{\circ} 1,1988$, pp. 3778

- OlMOS ROMERA, R.; CABRERA BONET, P. (1980) Nuevo fragmento de Clitias en Huelva. Archivo Español de Arqueología, vol. 53, n. ${ }^{\circ}$ 141-142, 1980, pp. 5-14

- ORTA gARCÍA, E. M.; GARRIDO ROIZ, J. P. (1963) La tumba orientalizante de la Joya, Huelva. Madrid: Consejo Superior de Investigaciones Científicas, Instituto Español de Prehistoria (Trabajos de Prehistoria, XI)

- ROUILLARD, P. (1978) Fragmentos griegos de estilo geométrico y corintio medio en Huelva. Huelva Arqueológica, III, 1978, pp. 397-401

- RUFETE TOMICO, P.; GARCíA SANZ, C. (1995) Huelva en época tartésica. Huelva: Diputación de Huelva, 1995

- RUIZ MATA, D. (1986) Aportación al análisis de los inicios de la presencia fenicia en Andalucía Sudoccidental según las excavaciones del Cabezo de San Pedro (Huelva), S. Bartolomé (Almonte, Huelva), Castillo de Doña Blanca (Puerto de Santa María, Cádiz) y El Carambolo (Camas, Sevilla). En Homenaje a Luis Siret (1934-1984). Sevilla: Consejería de Cultura, 1986, pp. 537-556

- RUIZ MATA, D. (1995) Las cerámicas del Bronce Final. Un soporte tipológico para delimitar el tiempo y el espacio tartésico. Tartessos 25 años después (1968-1993). Jerez de la Frontera: Ayuntamiento, 1995, pp. 265-313

- RUIZ MATA, D.; BLÁZQUEZ MARTÍNEZ, J. M.; MARTÍN DE LA CRUZ, J. C. (1981) Excavaciones en el Cabezo de San Pedro (Huelva). Campaña de 1978. Huelva Arqueológica, n. ${ }^{\circ}$ 5, 1981, pp. 149-316

- SCHUBART, H.; GARRIDO ROIZ, J. P. (1967) Probegrabung auf dem Cabezo de la Esperanza un Huelva. Madrider Mitteilungen, n. ${ }^{\circ} 8,1967$, pp. 123-158

- toscano, C.; CAMPOS, J. M. (2018) Elementos religiosos orientales en la Turdetania atlántica: ¿novedad o perduración del período orientalizante? Folia Phoenicia, n. ${ }^{\circ}$ 2, 2018, pp. 341-348

- VIDAL, N. O.; CAMPOS, J. M. (2006) Las necrópolis de Onuba. Anales de Arqueología Cordobesa, 17, vol. II, 2006, pp. 13-34

- VALLEJO SÁNCHEZ, J. I. (2010) Recipientes de bronce. En LÓPEZ, M. D.; GARCíA, E. (ed.) Cádiz y Huelva. Puertos Fenicios del Atlántico. Sevilla: Fundación Cajasol, Junta de Andalucía, 2010, pp. 310-311 


\section{Los lugares colombinos de Huelva: historia, cultura y naturaleza}

Diego Ropero-Regidor | Archivo Histórico Municipal, Biblioteca Iberoamericana de Moguer

URL de la contribución <www.iaph.es/revistaph/index.php/revistaph/issue/view/4292>

\section{RESUMEN}

La historiografía americanista dedicó en el pasado siglo una atención especial a los lugares colombinos de la provincia de Huelva. Los preparativos y la realización del viaje de Colón forman parte del relato histórico de La Rábida, Palos de la Frontera y Moguer, tríada espacial con el tiempo dentro que ha sabido recuperar y potenciar un legado que comparten como una de las señas de identidad que más han marcado su devenir. En el siglo XIX se dieron las condiciones para que el monasterio de La Rábida no fuera destruido, sumándose a los planes de su rehabilitación el gobierno y muchas personalidades de la política y la cultura de España y América. EI IV Centenario del Descubrimiento supuso el punto de inflexión hacia la modernidad; desde entonces este rincón onubense, su historia, los edificios vinculados a la gesta colombina, como el modesto cenobio franciscano, la iglesia de San Jorge, de Palos, y el monasterio de Santa Clara, de Moguer, y su entorno urbano y paisajístico proyectan unos valores que son reconocidos por la sociedad en general. Las últimas y recientes inversiones públicas en estos lugares colombinos, especialmente las realizadas en torno a 1992, fueron destinadas a restaurar y revitalizar sus monumentos históricoartísticos, y, además, a dotar dicho espacio con nuevas instalaciones culturales. Las huellas de Colón, los Pinzón y los hermanos Niño, y las tres naves descubridoras -cuyas réplicas se encuentran en el recinto museístico del Muelle de las Carabelas-, igual que entonces, siguen rememorando en el estuario del río Tinto una de las epopeyas más universales.

\section{Palabras clave}

América | Colón | Descubrimiento | España | Gestión | La Rábida (Huelva) | Lugares colombinos | Moguer (Huelva) | Palos de la Frontera (Huelva) | Patrimonio | 1492 | 


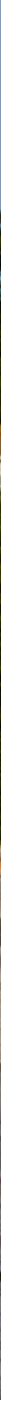

Santuario de Nuestra Señora de la Cinta. Huelva | foto J. Miguel Marchena 
El espacio que alberga los lugares colombinos en la provincia de Huelva proyecta la memoria de la aventura americana, episodio que ha tenido momentos de olvido y reivindicaciones. En 1828, el escritor Washington Irving visitó dichos lugares y alertó al mundo del abandono del monasterio de La Rábida, epicentro donde Colón fue arropado por los frailes franciscanos que le pusieron en contacto con armadores y navegantes notables de Palos y Moguer. Tras siete años deambulando por la corte en busca de apoyos para su viaje, los Reyes Católicos finalmente dispusieron que fueran atendidas sus demandas. El 17 de abril de 1492 se firmaron las Capitulaciones en Santa $\mathrm{Fe}$, en las inmediaciones de Granada, capital del reino nazarí que había sido tomada a principios de ese año. El apoyo de los frailes Antonio de Marchena y Juan Pérez, y de Martín Alonso Pinzón, de Palos, y los hermanos Niño, de Moguer, fue decisivo para conseguir las naves y atraer a la tripulación que protagonizaron una de las epopeyas más importantes de la historia de la humanidad. El viaje de descubrimiento de la nao Santa María y las carabelas Pinta y Niña, revolucionó -en opinión de Johannes Stradanus (1580)- la forma de pensar del Renacimiento.

La recuperación para el acervo cultural de tan singular espacio han llevado a los responsables de su gestión a optimizar los recursos de los elementos que componen dicho ámbito, con el objetivo de destacar su valor excepcional universal para que La Rábida y los lugares colombinos sean incluidos en la lista de Patrimonio de la Humanidad. Las reivindicaciones del protagonismo onubense en el Descubrimiento se inician en el siglo XIX, a partir de las reacciones que provocó la desaparición del modesto cenobio rabideño tras la desamortización. El gobernador Mariano Alonso del Castillo influyó para impedir su derribo. Tras la oportuna visita de los duques de Montpensier, el monasterio fue declarado monumento nacional en 1856. Con posterioridad se sucedieron intervenciones de calado en el edificio y su entorno a cargo del arquitecto Ricardo Velázquez Bosco para que pudieran acoger los fastos del IV Centenario del Descubrimiento.

Tras varias décadas sin avances significativos, salvo algunos eventos y actuaciones puntuales como el vuelo transatlántico del hidroavión Plus Ultra (1926) y la erección del monumento a Colón en la Punta del Sebo (1929), obra de la artista norteamericana Gertrudis Whitney, fue creada la Universidad Hispanoamericana (1943), institución que ha pasado por distintas etapas, aunque sigue profundizando en las estrechas relaciones que Huelva mantiene con Iberoamérica (en la actualidad es una de las sedes de la UNIA). Coincidiendo con los planes de desarrollo industrial en la década de los sesenta de siglo pasado, los lugares colombinos fueron declarados conjunto histórico-artístico, protección que ha sido reforzada y ampliada recientemente como sitio histórico en el Catálogo General del Patrimonio Histórico Andaluz. En 1992, fecha emblemática para la comunidad iberoamericana, La Rábida, Palos de la Frontera y Moguer cogieron de nuevo el testigo con 


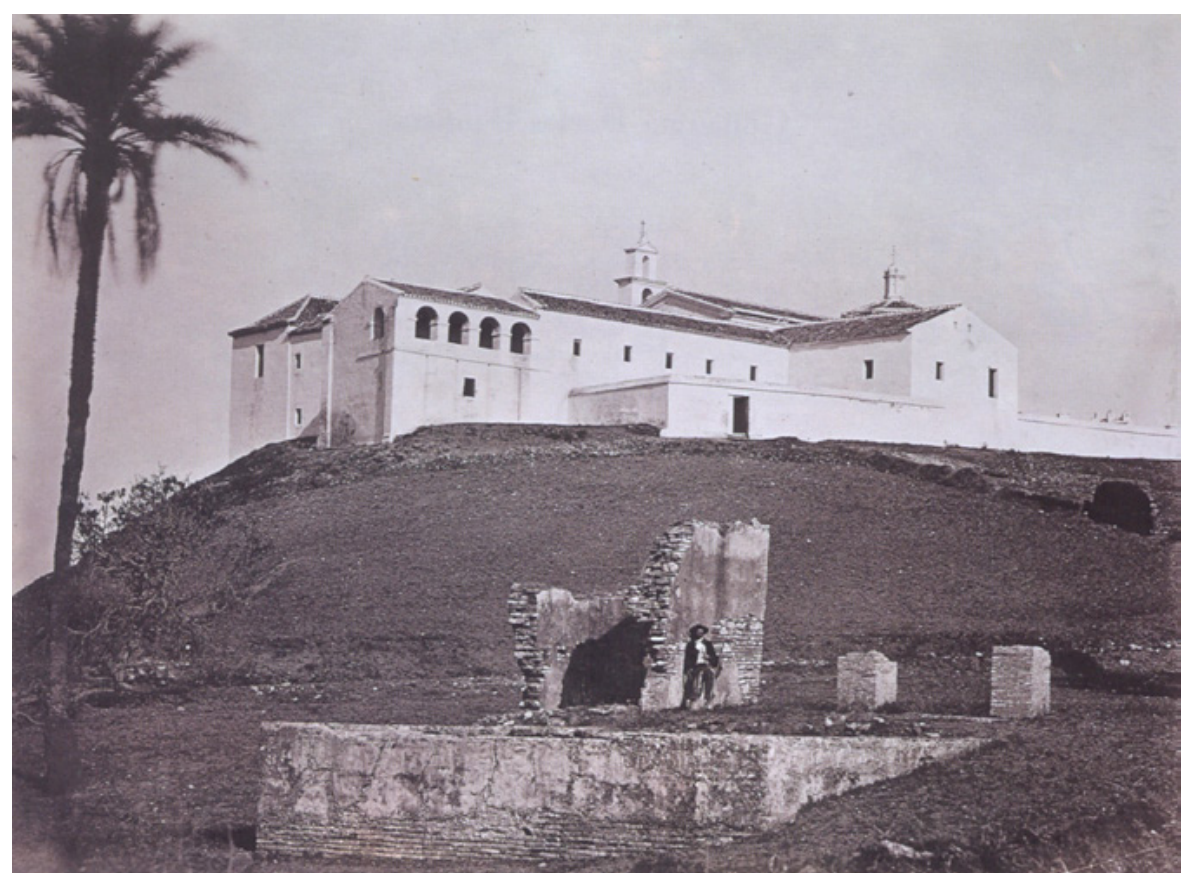

motivo del $\vee$ Centenario. En esta ocasión se produjo un avance extraordinario en cuanto a la modernización de programas, infraestructuras y nuevas dotaciones para los espacios colombinos: reformas y ampliación del monasterio, construcción del auditorio y edificio administrativo del parque botánico "Celestino Mutis", en La Rábida; rehabilitaciones de los conventos de Santa Clara y San Francisco, y construcción del teatro Felipe Godínez, en Moguer; iglesia de San Jorge, de Palos; y el Gran Teatro y la Casa Colón, en Huelva. También se realizaron mejoras en la red viaria con la puesta en servicio de la autopista del $\vee$ Centenario, los puentes del Odiel y el internacional del Guadiana. Los reyes visitaron los lugares colombinos y en el monasterio de La Rábida hubo un consejo de ministros presidido por el monarca. Al año siguiente, el papa Juan Pablo II visitó las poblaciones colombinas, culminando en La Rábida su periplo con la coronación de la imagen de la patrona de Palos de la Frontera.

La Rábida y los lugares colombinos gravitan sobre una zona de escarpes y marismas con el río Tinto que desemboca en un amplio estuario hacia donde viene a morir también su hermano el Odiel. Este entorno, formado de gravas y arenas del Pleistoceno inferior, fue en la antigüedad asentamiento de tartesios, romanos y árabes, y en la época del Descubrimiento refugio estratégico de embarcaciones autóctonas y extranjeras. La ciencia náutica y la pericia de sus marineros atrajeron la atención de Cristóbal Colón, quien debía tener información precisa de ellos por los viajes comerciales que realizaban a Canarias y la costa africana (Guinea y Mina del Oro) donde se con-
El convento de La Rábida, 1875. José Spreafico | foto Biblioteca del Palacio Real, Madrid, reproducida en ROPERO-REGIDOR, D. (dir.) (1992) Los lugares colombinos y su entorno. Madrid: Fundación Ramón Areces, p. 96 

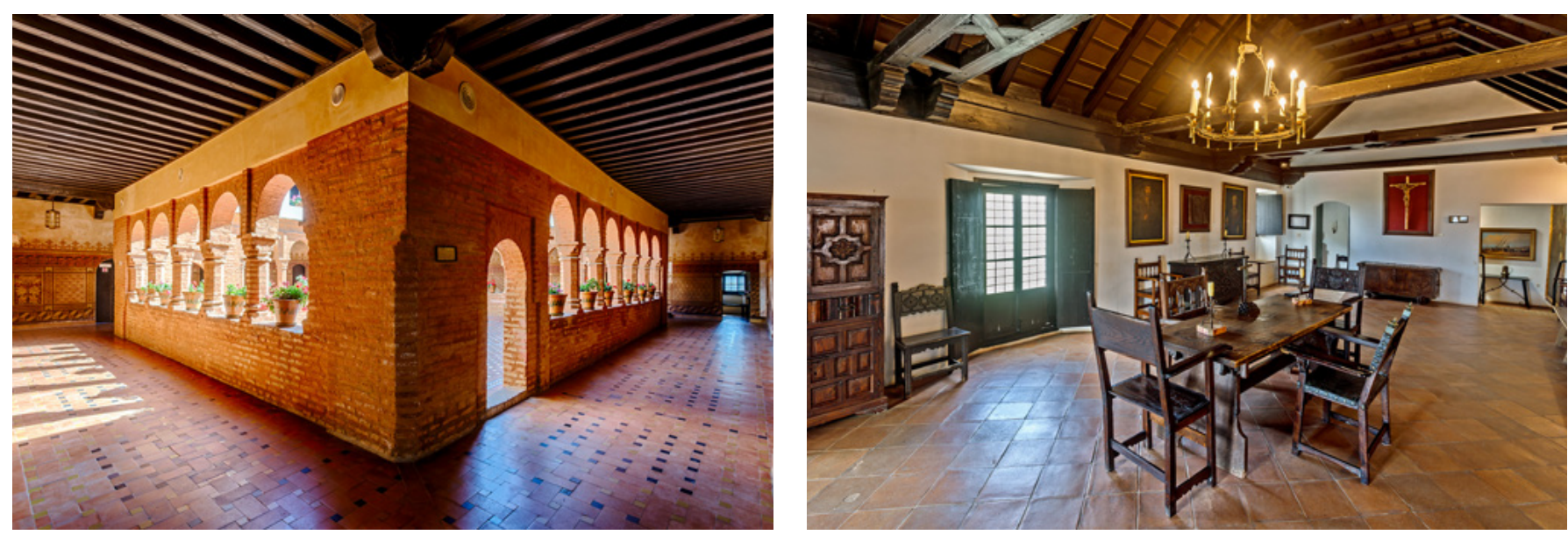

A la izquierda, claustro mudéjar del monasterio de La Rábida

A la derecha, sala del Padre Marchena en el convento de La Rábida | fotos Miguel Ángel Muñoz

centraban para las pesquerías y practicaban el corsarismo. En la Baja Edad Media, Palos, Moguer y Huelva eran poblaciones volcadas al mar, compartían negocios y embarcaciones y, aunque había rivalidad, nunca llegó la sangre al río, pues supieron aprovechar las oportunidades. Sus habitantes eran gente recia y competente, nada timorata, sabios por naturaleza, de lo contrario habría sido improbable que se sumaran los mejores marinos a la expedición colombina.

Desde el estratégico emplazamiento del monasterio de La Rábida, se contempla todo el estuario de los ríos Tinto y Odiel. Es, junto con la iglesia parroquial de San Jorge de Palos y el monasterio de Santa Clara de Moguer, uno de los monumentos colombinos. Sobre su origen existen opiniones encontradas; no obstante, los restos arqueológicos romanos e islámicos corroboran que esta zona ya estuvo habitada en la antigüedad. La fundación del convento parte del año 1412; ya entonces existía en dicho emplazamiento un marabito o ribat. Se trata de una construcción gótico-mudéjar, en la que destaca el uso del ladrillo, tapial y mampostería en muros, así como sillería de piedra en fachada principal, modelo repetido en las iglesias sevillanas de esta época. La fábrica fue completada a lo largo del siglo XV. En etapas posteriores, se llevaron a cabo distintas intervenciones, sobre todo las realizadas en el siglo XVII y en la segunda mitad del XVIII, como la cúpula de la iglesia, la espadaña o la galería alta del claustro mudéjar.

El convento, de factura modesta, nos retrotrae al tipo de cenobio o eremitorio franciscano alejado de los núcleos urbanos (entre 1623 y 1835, La Rábida fue centro de recolección de la Provincia Observante de Andalucía). El acceso al mismo se hace a través de una pequeña portería que conecta con la antigua sacristía donde podemos admirar los frescos de Vázquez Díaz el Poema del Descubrimiento (1929), que narran los momentos previos al viaje colombino, y el claustro de la Hospedería. La iglesia es de planta rectangu- 
lar con capillas laterales y presbiterio. El claustro mudéjar es de la primera mitad del XV; sus galerías son de ladrillo tallado, con arcos de medio punto peraltados, remarcados por alfices y apoyados en columnas octogonales. La planta alta fue construida coincidiendo con las reformas barrocas. En torno al mismo se encuentran las celdas primitivas, el refectorio, la sala capitular y otras dependencias anejas.

El histórico recinto franciscano acoge un museo colombino cuyo programa se complementa con el relato que ofrece el muelle de las Carabelas, donde se encuentran las réplicas de las tres naves que fueron construidas por la Sociedad Estatal con motivo del $\mathrm{V}$ Centenario del Descubrimiento. Otros edificios e instalaciones refuerzan el discurso y la identidad americanista de La Rábida: la Universidad Hispanoamericana (desde 1994 Internacional de Andalucía), el auditorio o foro Iberoamericano, el parque botánico "Celestino Mutis", donde podemos contemplar especies del continente americano, la Casita de Zenobia, la columna del IV Centenario, el monumento a Colón o el
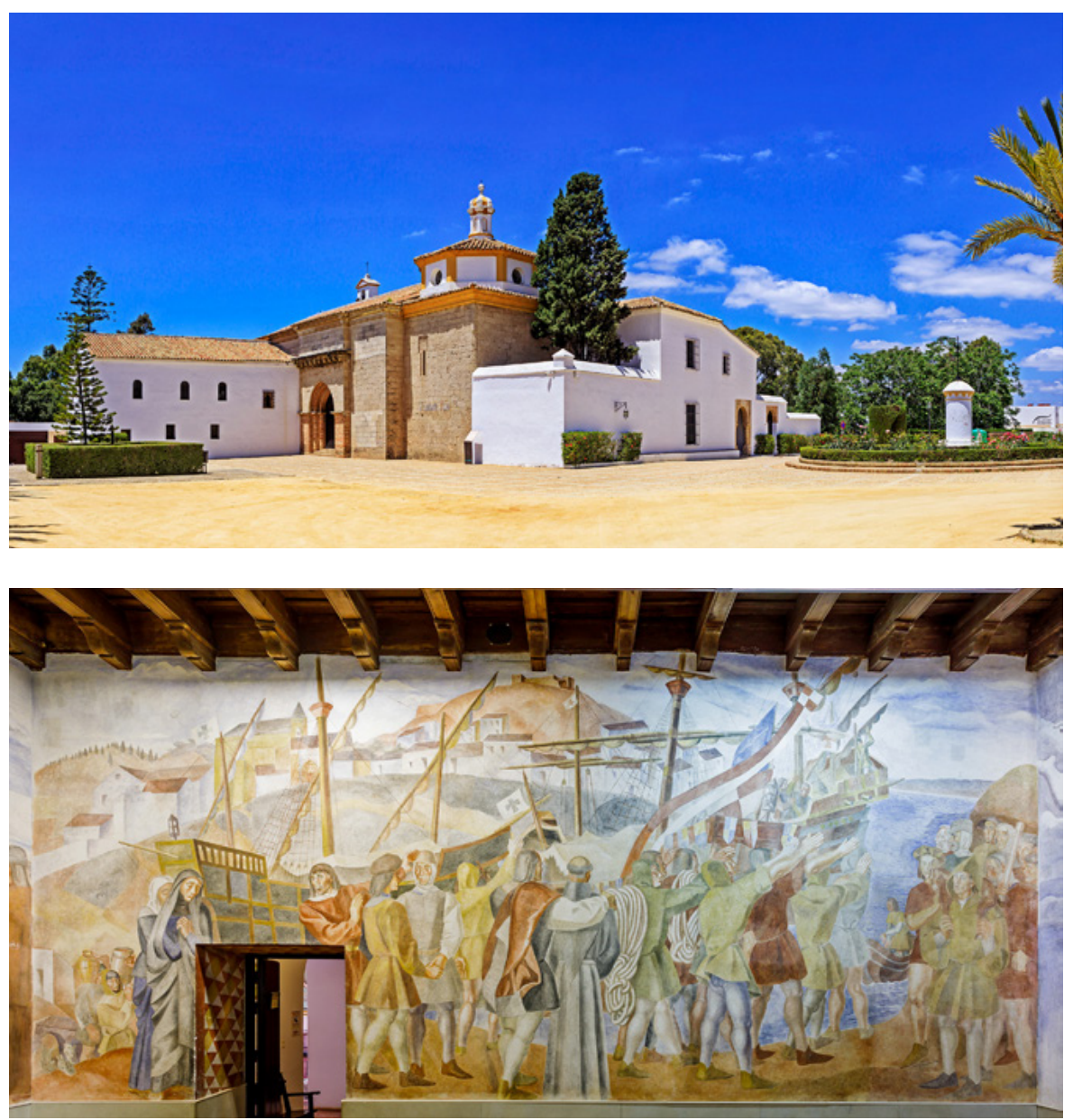

Panorámica del monasterio de La Rábida

Poema del Descubrimiento, "La partida", 1929. Daniel Vázquez Díaz. Monasterio de La Rábida | fotos Miguel Ángel Muñoz 


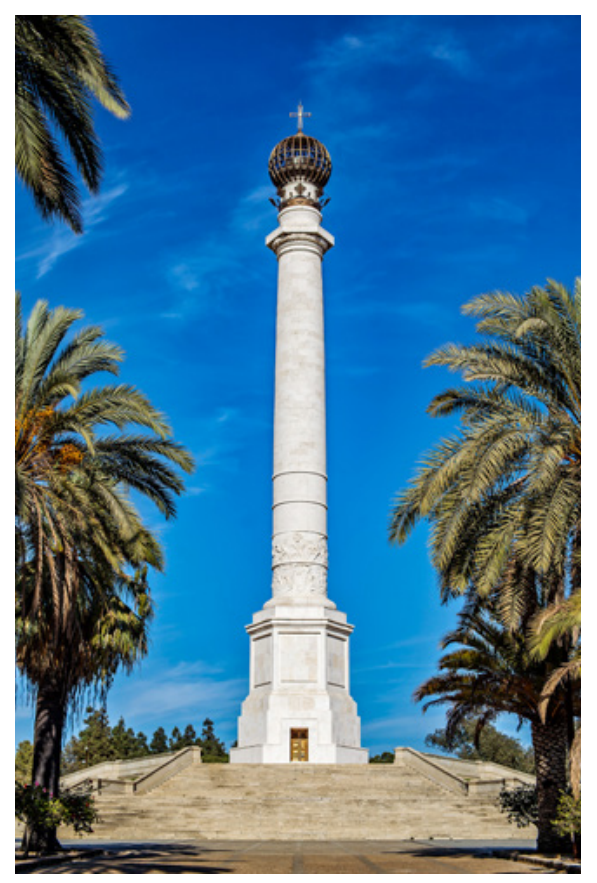

A la izquerda, columna conmemorativa del IV Centenario. La Rábida

Muelle de las Carabelas. La Rábida | fotos Miguel Ángel Muñoz

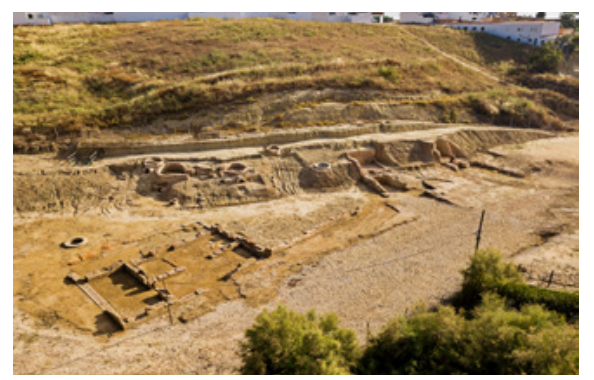

Restos del antiguo puerto de Palos de la Frontera | foto Miguel Ángel Muñoz

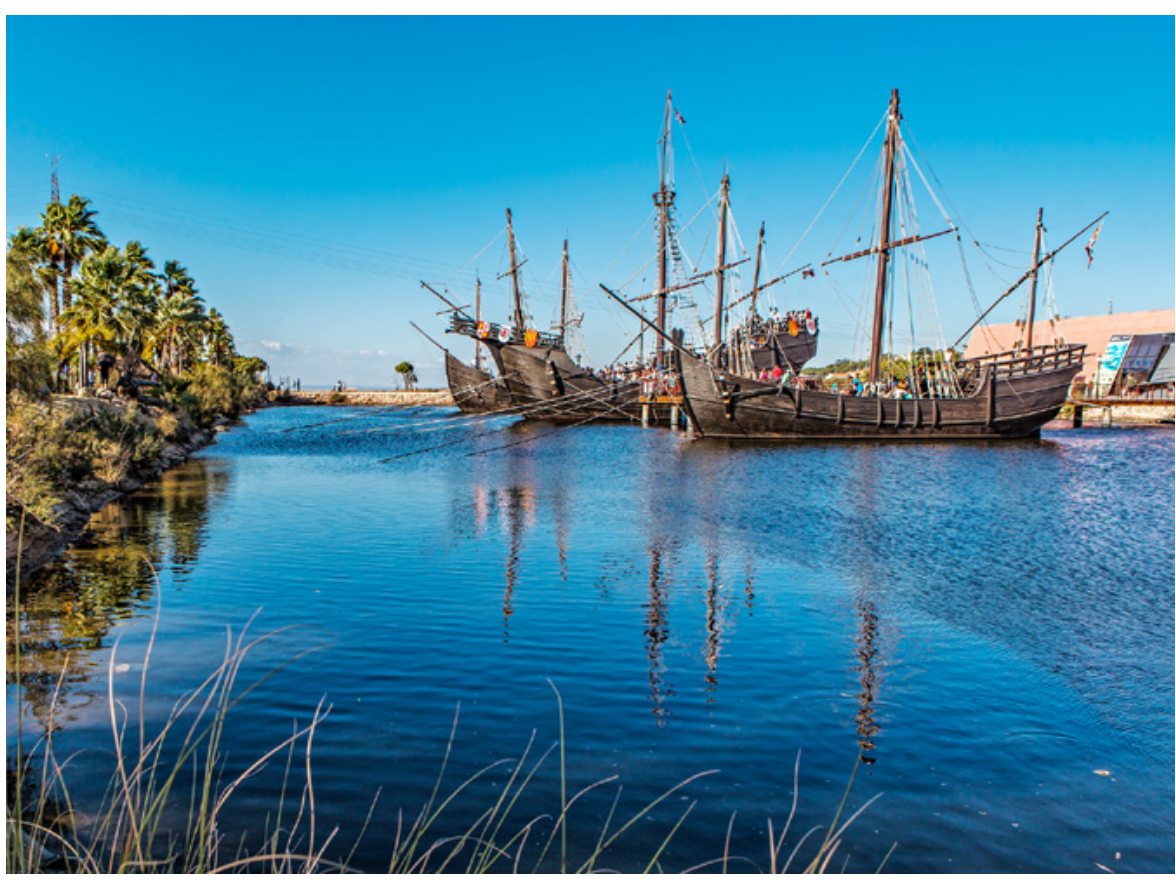

Ícaro, alegoría en homenaje al vuelo Plus Ultra, en el muelle de la Reina. El recinto rabideño cuenta con abundante arboleda, destacando el pino piñonero, y zonas ajardinadas.

Dejamos La Rábida y llegamos a Palos de la Frontera, una población muy pujante dedicada al cultivo del fresón, en cuyo término se localiza gran parte de la industria química, como la refinería y las instalaciones del puerto exterior de Huelva. En torno a la iglesia de San Jorge, edificio gótico-mudéjar construido en el siglo XIV, reformado o ampliado en los siglos XVI-XVIII, tuvo lugar la lectura de la pragmática real que ordenaba a los vecinos a entregar dos carabelas al futuro almirante de las Indias y el alistamiento de la tripulación. En sus inmediaciones se encuentran los restos del castillo, la casa museo de Martín Alonso Pinzón -solar que habitaron el ilustre marino y su familia-, la Fontanilla -un templete que abastecía de agua a la población y a las embarcaciones- y el antiguo puerto, cuyos cimientos han salido recientemente a la luz, tras varios años de campaña arqueológica, en lo que fue una ensenada del río Tinto, navegable en tiempos del Descubrimiento.

Moguer es, después de su vecina Palos de la Frontera, la segunda población colombina por su contribución al Descubrimiento. Si los Pinzón representan la élite entre los navegantes y armadores de la zona, los moguereños hermanos Niño estuvieron a la misma altura. La actividad pesquera, la construcción de barcos en el astillero de la Ribera y el intercambio entre los pueblos vecinos y otras plazas extranjeras, los estamentos sociales más favorecidos, 


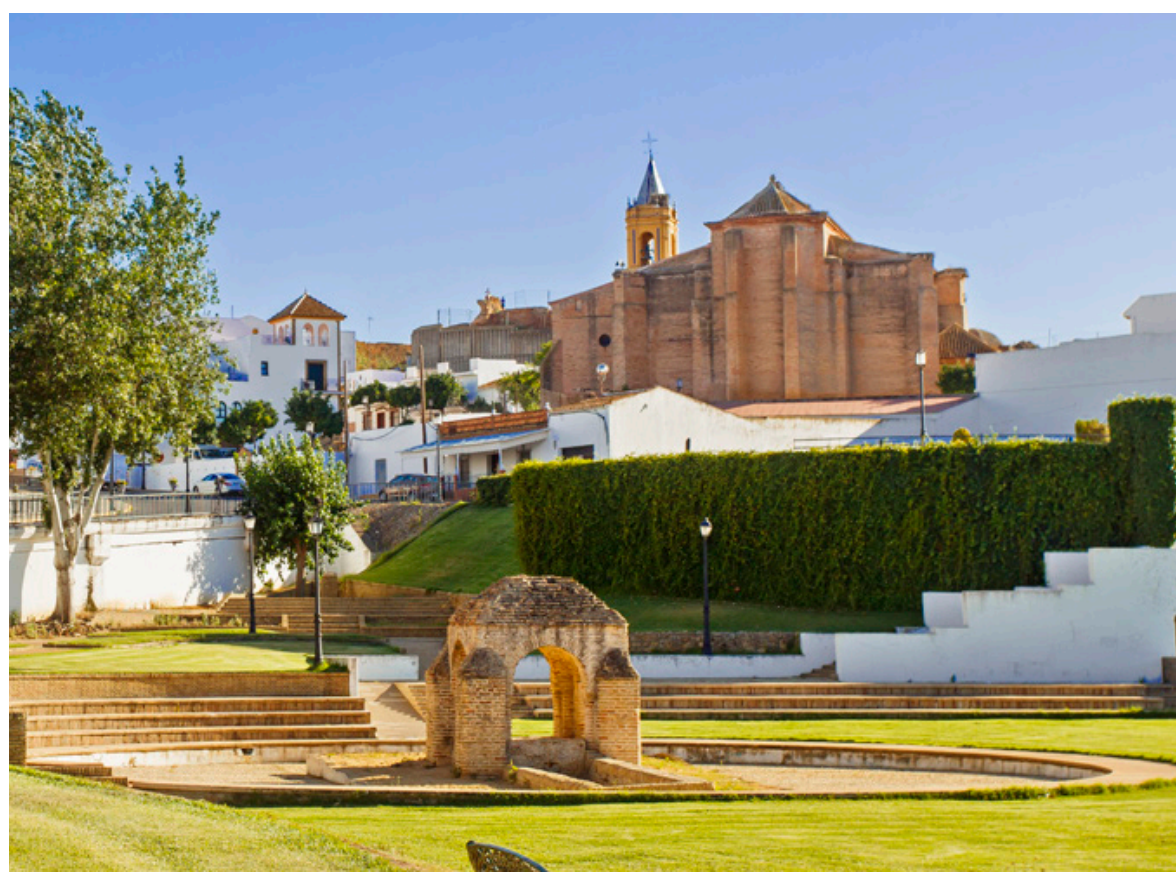

especialmente el religioso y aquellas personas que detentaron el poder local y controlaron la economía, contribuyeron a la prosperidad de la población, tradicionalmente agrícola y marinera, coincidiendo en el tiempo con las visitas que Cristóbal Colón realizó a Moguer, donde también negoció su viaje a las Indias con personas que tenían influencia dentro y fuera de la villa, destacando Inés Enríquez, abadesa del monasterio de Santa Clara, pariente del rey Fernando el Católico y, por supuesto, los hermanos Niño, dueños de la carabela Niña o Santa Clara, construida pocos años antes de la partida en la ribera de Moguer, y cuya participación en los viajes de descubrimiento dejaron huella en la historia de las navegaciones. Los preparativos del viaje se hicieron en Palos y en Moguer; por tanto, fue una empresa colectiva auspiciada por los reyes con el esfuerzo de Colón y la contribución de los Pinzón y los Niño y el resto de la marinería del estuario del Tinto.

El monasterio de Santa Clara es el edificio colombino de Moguer. Su fábrica gótico-mudéjar nos transporta a épocas de esplendor y poderío. Fue fundado en 1337 por Alonso Jofre Tenorio, almirante mayor de Castilla, para religiosas clarisas de la orden de San Francisco. De aspecto robusto, como si de una fortaleza se tratara, acoge en su planta irregular el templo de tres naves rematado con nervaduras góticas, en cuyo presbiterio se encuentra el cenotafio de los fundadores. El claustro principal o de las Madres es del siglo XIV; de estilo mudéjar, es el más antiguo de Andalucía; la doble galería sustentada por columnas de mármol toscanas es una ampliación de la segunda mitad del siglo XVI. De esta época son las construcciones y las reformas
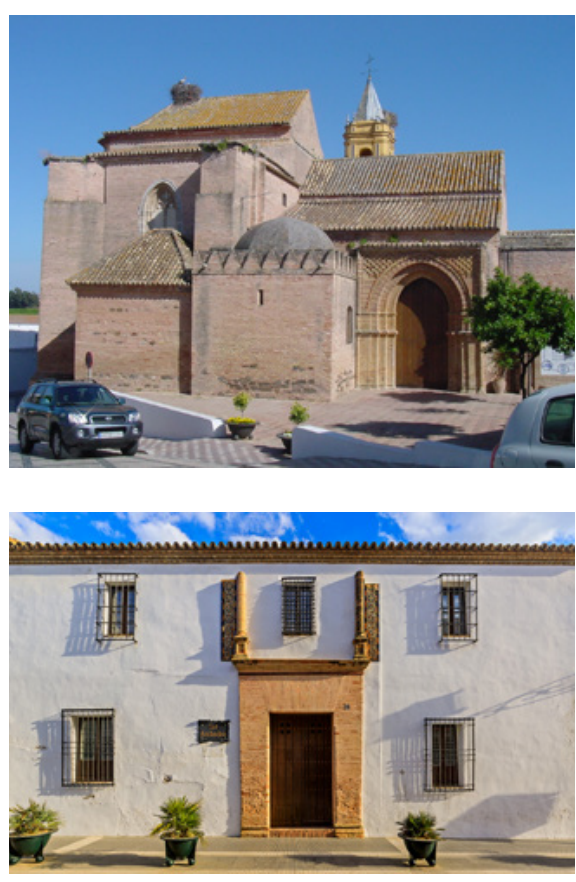

A la izquierda, iglesia de San Jorge Mártir. Palos de la Frontera | foto Miguel Ángel Muñoz

A la derecha arriba, iglesia de San Jorge Mártir. Puerta de los Novios. Palos de la Frontera | foto Diego Ropero

Casa Museo de Martín Alonso Pinzón. Palos de la Frontera | foto Miguel Ángel Muñoz

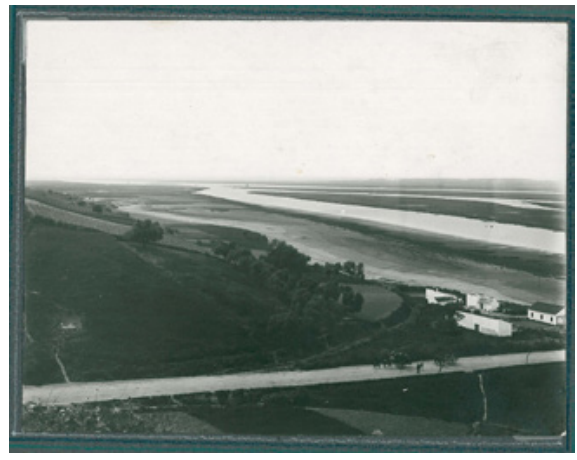

Arrecife y el río de Moguer. Principios del siglo XX | foto Archivo Histórico Municipal de Moguer 

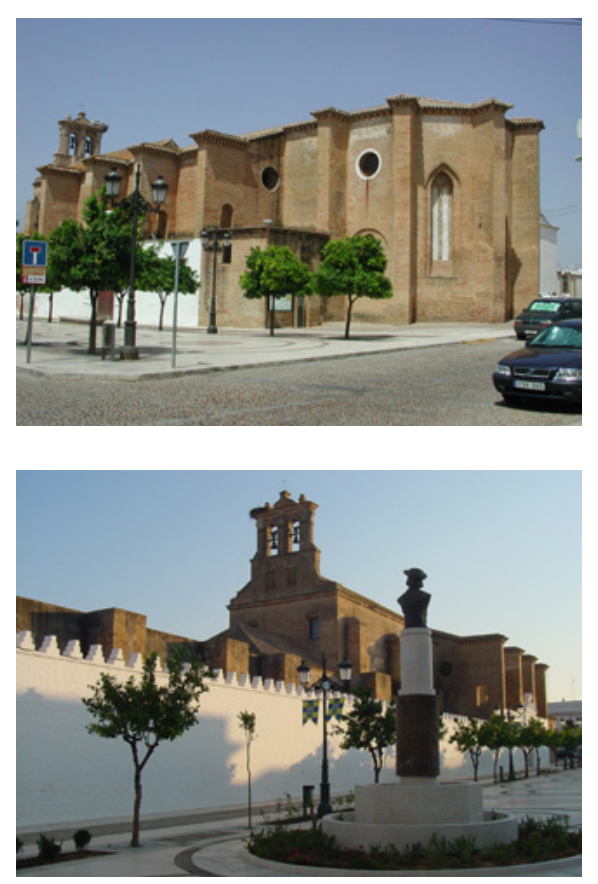

Arriba, ábside de la iglesia del monasterio de Santa Clara. Moguer

Abajo, monasterio de Santa Clara y el monumento a Colón. Moguer

A la derecha, castillo de Moguer | fotos Diego Ropero

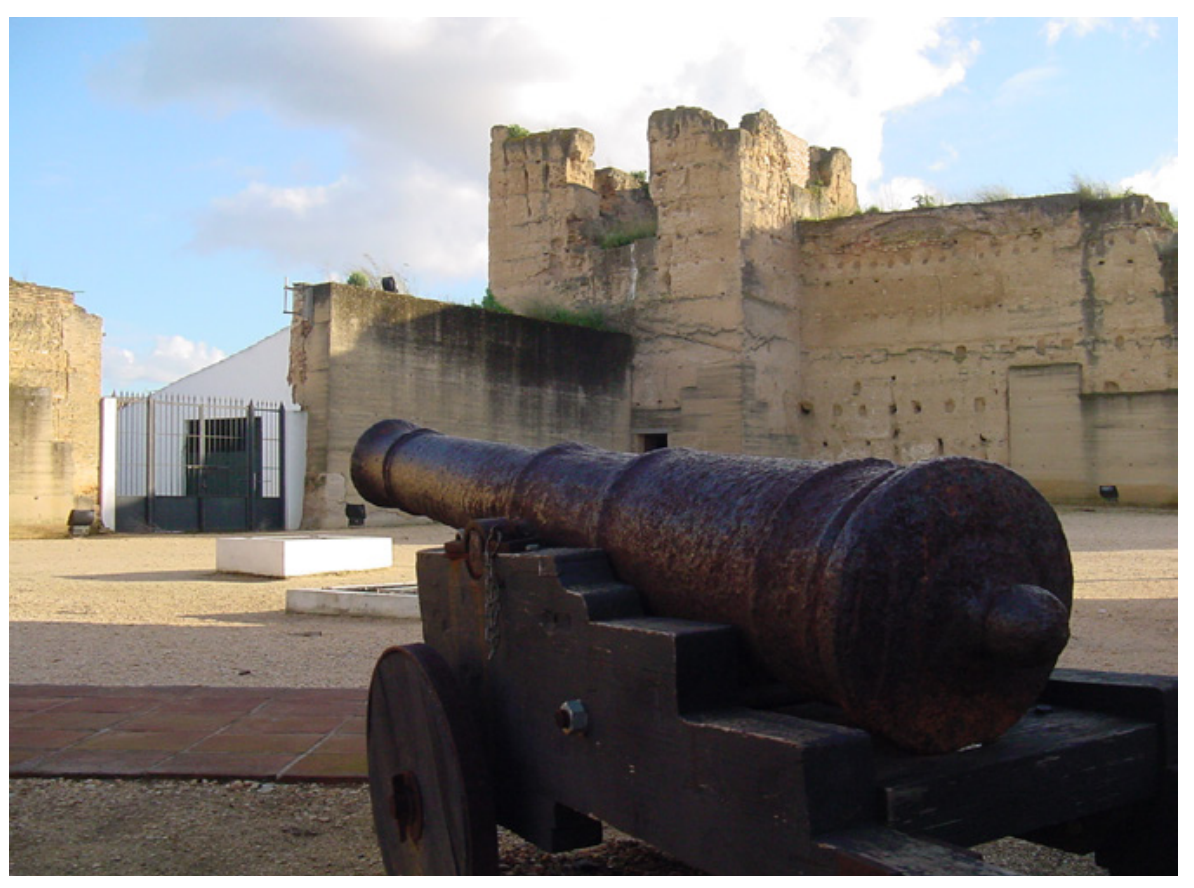

más importantes, como los dormitorios y la enfermería, a la que se llega a través del claustrillo mudéjar del siglo XV. Este modelo de construcción se reproduce en las iglesias fortificadas del valle de México y los claustros de la ciudad de Tunja (Colombia). En el interior del monasterio destacan, además del panteón de los fundadores, la sillería nazarí y las pinturas del coro bajo, y el retablo mayor, obra realizada por Jerónimo Velázquez en 1642. Cristóbal Colón oró e hizo decir una misa de acción de gracias en el interior del templo de las clarisas a su regreso del viaje de descubrimiento.

En sus inmediaciones, se encuentra el convento de San Francisco, edificio manierista sede del Archivo Histórico Municipal y la Biblioteca Iberoamericana, institución que contribuye a defender y proyectar la vocación americanista de Moguer. Merecen atención también el castillo medieval, la capilla del antiguo hospital del Corpus Christi, el ayuntamiento y la parroquia, estos dos últimos de la segunda mitad del siglo XVIII. Recorrer las calles de su casco histórico nos traslada a otras urbes hispanoamericanas, pues las relaciones con América fueron, durante siglos, una realidad ininterrumpida. La figura de Juan Ramón Jiménez, exiliado con su esposa Zenobia a América al inicio de la Guerra Civil, ha contribuido a conectar aún más ambas orillas. La casa museo del poeta reúne su biblioteca y muchos de los muebles y enseres que pertenecieron a la pareja.

Los lugares colombinos se localizan en la zona agroindustrial de Huelva, en cuya capital se encuentra el santuario de la Cinta, otro hito colombino que 


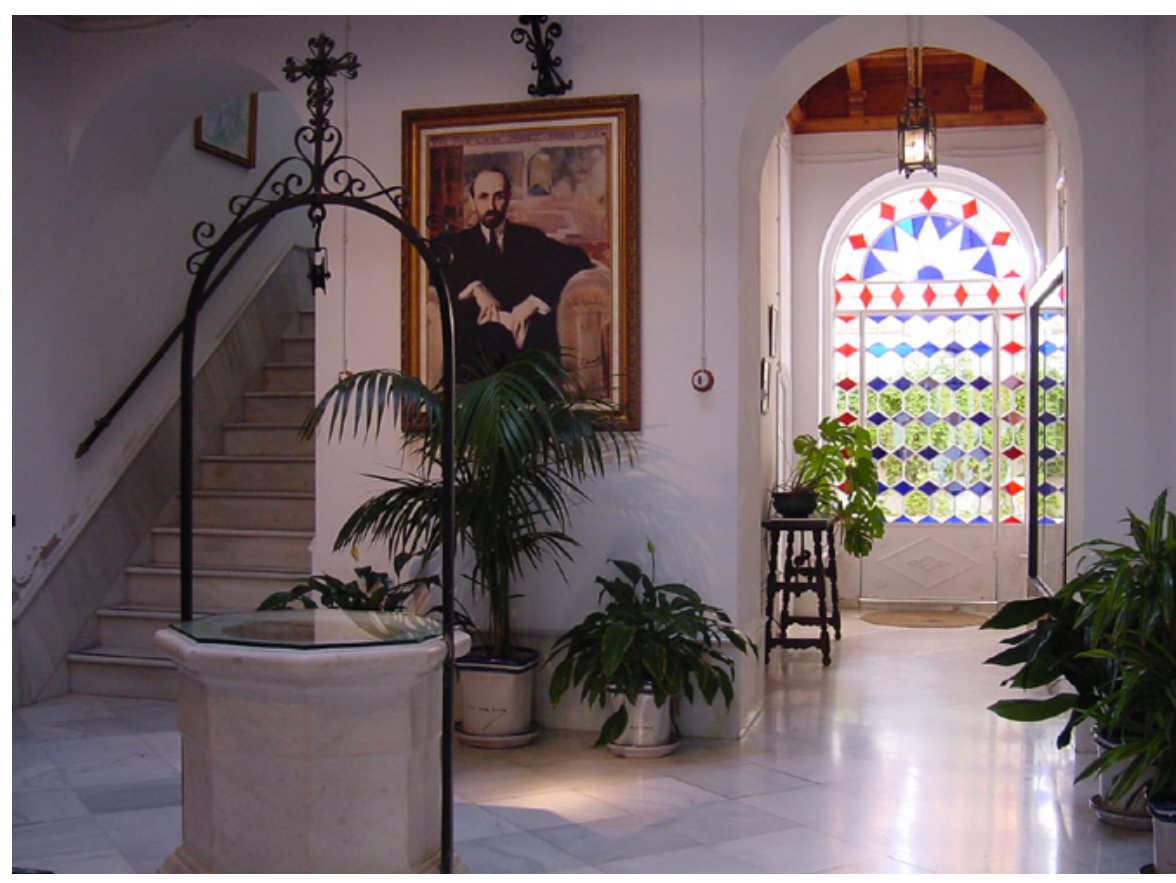

destacó como centro devocional entre la marinería. El estuario del río Tinto está considerado lugar de importancia comunitaria. En su entorno hallamos espacios protegidos como las marismas del Odiel (reserva de la Biosfera), el estero de Domingo Rubio y las lagunas de Palos y las Madres, que es paraje natural, y el Parque Nacional de Doñana, declarado Patrimonio de la Humanidad. Se trata de un paisaje de marismas de alto valor ecológico donde existe una variada avifauna acuática, invertebrados, anfibios y peces entre praderas de espartinas, almajos, verdolagas de mar y fangos. El sotobosque acoge una amplia extensión de pinos que en las últimas décadas se ha reducido para dar paso a las plantaciones de fresas.
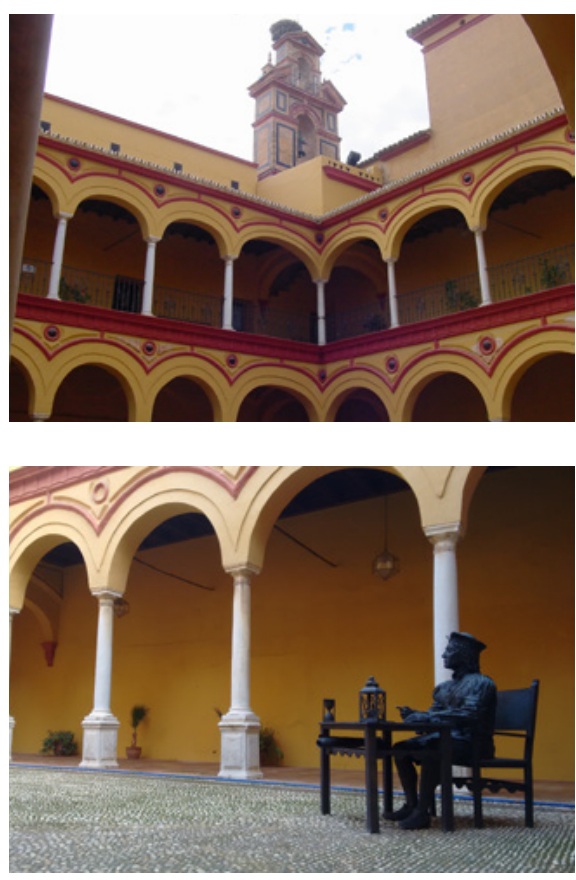

Claustro del convento de San Francisco, sede del Archivo Histórico Municipal. Moguer

Monumento al piloto Pedro Alonso Niño. Claustro de San Francisco. Moguer

Casa Museo de Zenobia y Juan Ramón Jiménez. Moguer | fotos Diego Ropero 


\section{La pesca tradicional en Huelva: de las salazones y las conserveras al congelado}

Juan José García del Hoyo, Celeste Jiménez de Madariaga | Universidad de Huelva

URL de la contribución <www.iaph.es/revistaph/index.php/revistaph/issue/view/4257>

\section{RESUMEN}

La pesca en la costa onubense ha sido una actividad que no solo puede y debe ser analizada como producción económica, sino también por las implicaciones culturales y sociales que conlleva. En este texto, mostramos una panorámica histórica de la importancia de la pesca tradicional en la provincia de Huelva y sus transformaciones hasta la actualidad. En este recorrido por la historia y las tradiciones pesqueras, nos detenemos en las artes y modos de pesca, y en otras ocupaciones vinculadas a ésta que han destacado en el litoral onubese, como las salinas y las fábricas conserveras.

Palabras claves

Congelados | Conserveras | Huelva | Pesca | Salazón | 


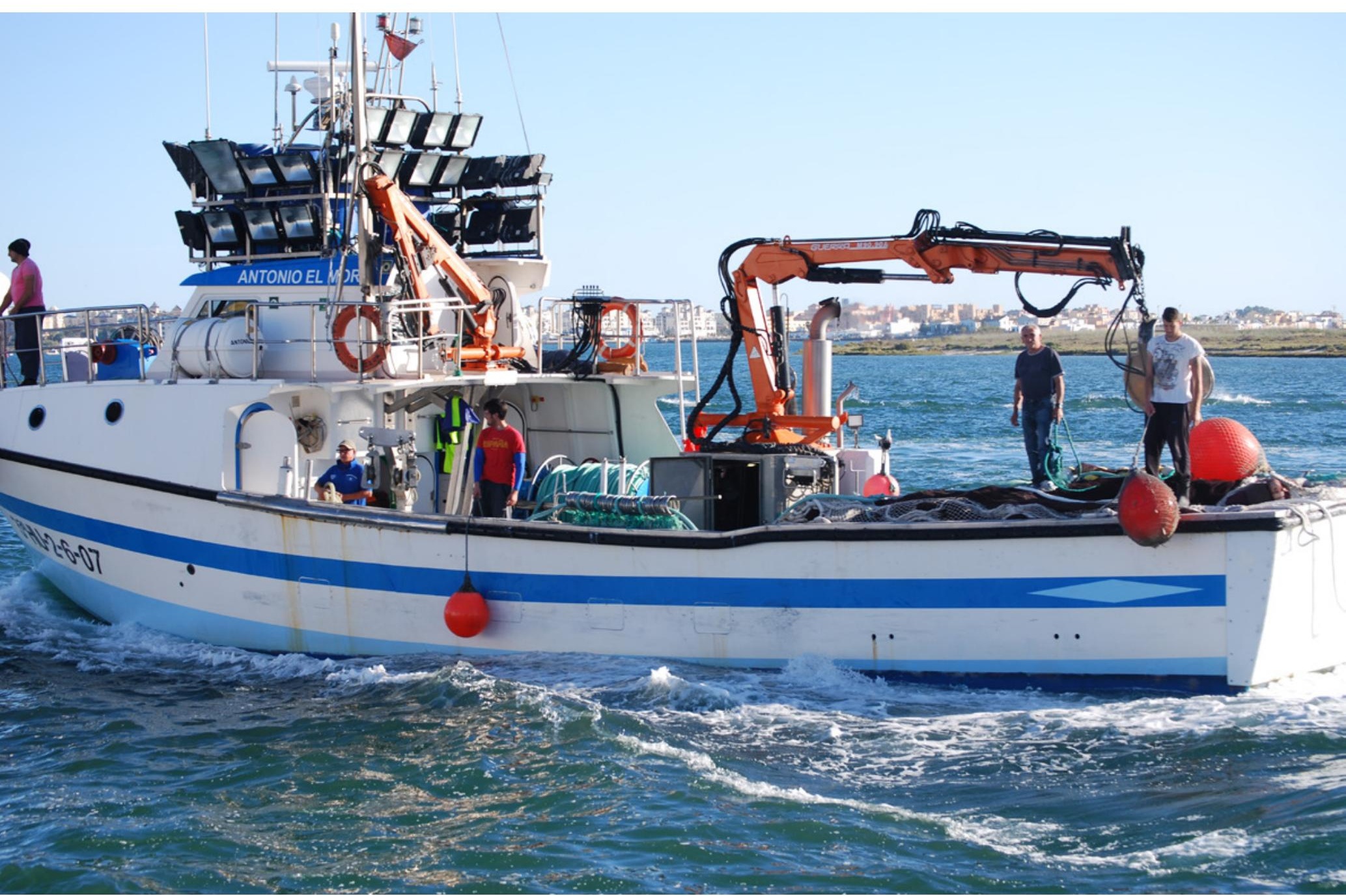

Buque de cerco de poliéster en la ría de Carreras en Isla Cristina (Huelva) | foto Celeste Jiménez de Madariaga, autora de todas las imágenes que ilustran este artículo 
La costa de la actual provincia de Huelva ha sido, desde tiempos inmemoriales, una de las zonas pesqueras más productivas de la Península Ibérica. Los grandes ríos que la acotan, las marismas y esteros, las playas abiertas $\mathrm{y}$, sobre todo, una extensa plataforma continental plagada, hasta tiempos recientes, de prados de posidonia, como citaba Miravent en 1850, la configuraban y configuran aún, a pesar de los pesares, como un lugar plenamente idóneo para el desarrollo de las actividades pesqueras y marisqueras. Yacimientos del calcolítico, como Papauvas o El Rincón, localizados en la Ría de Huelva, en cuyos vertederos abundan los restos de mariscos, y factorías de salazones romanas y anteriores, localizadas no sólo en la actual ciudad de Huelva, sino también en toda la línea costera desde Isla Canela (Ayamonte) al Cerro del Trigo en Doñana, evidencian una continuidad histórica en la que nuestros ancestros explotaban los recursos del litoral no sólo para la mera subsistencia, sino también integrándose en grandes circuitos comerciales, iniciados por fenicios y púnicos, y desarrollados plenamente durante los primeros siglos de ocupación romana. Y, además, se mantuvieron las referencias al "garum" como uno de los presentes que un monarca visigodo remitía a la corte merovingia, las descripciones bizantinas de la historia del potentado Dúnala, enriquecido con las exportaciones de salazones de sus posesiones de Saltés, o los propios textos árabes sobre dicha isla y sus producciones de salazones de sardinas que eran consumidas en Sevilla y en Córdoba, denotan una continuidad de aprovechamientos que evidencian la pervivencia de usos, técnicas, hábitos y saberes.

Barcas artesanales en el río Tinto junto a La Rábida (Palos de la Frontera, Huelva)

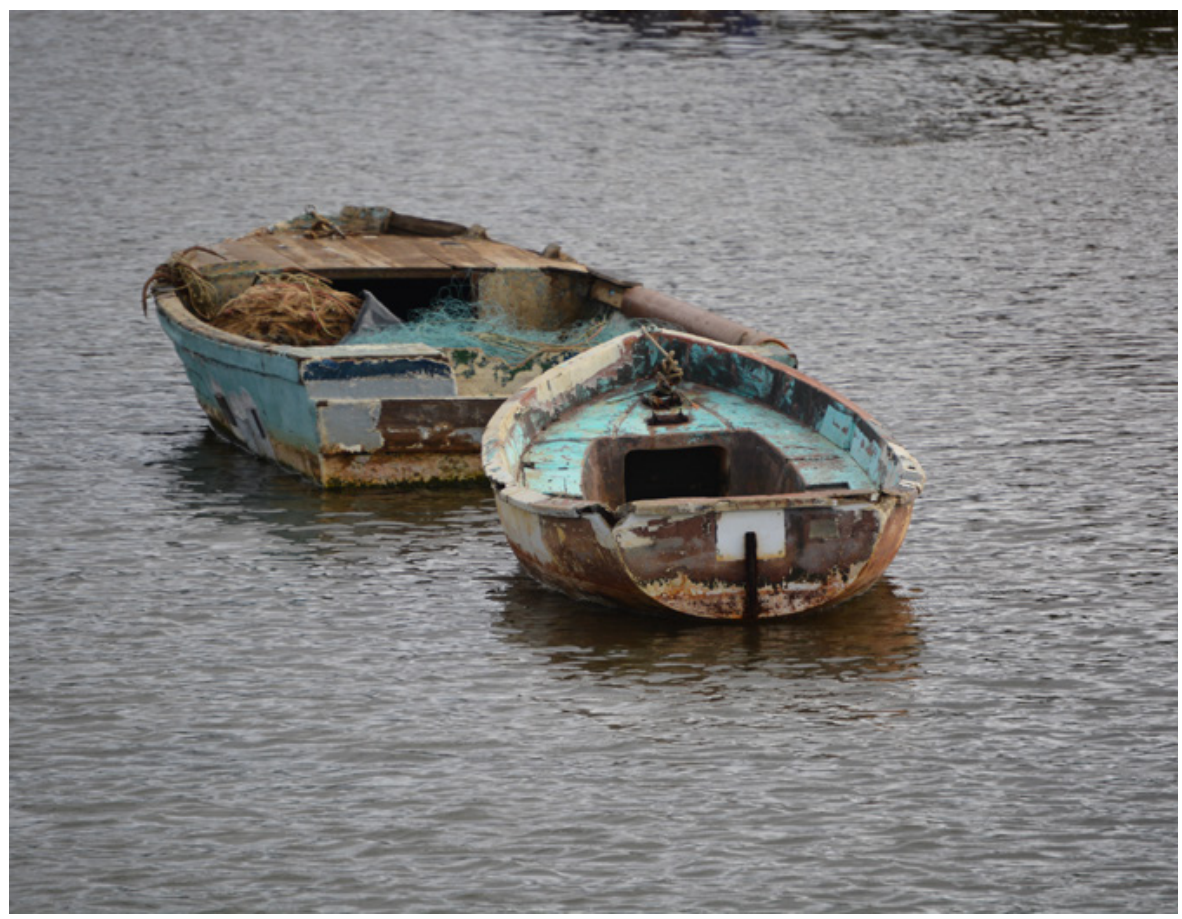




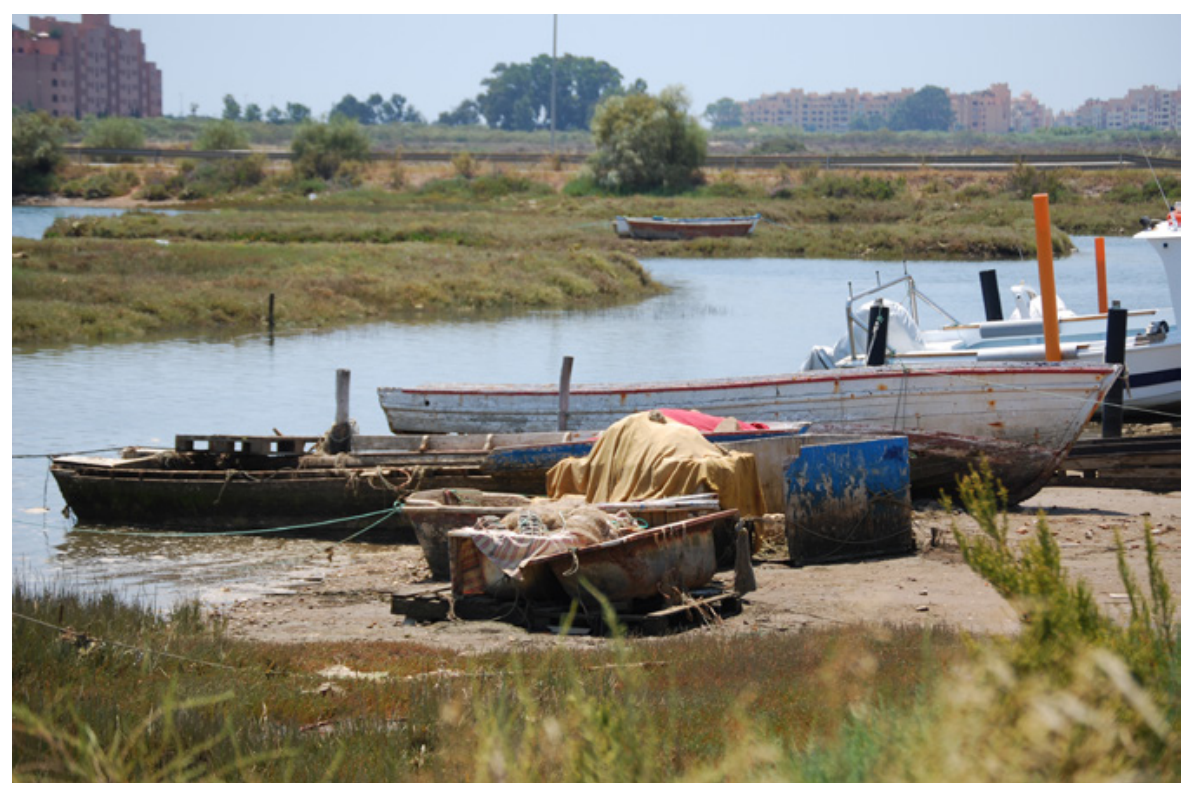

La pesca de sardinas mediante jábegas, la de atunes con almadrabas de tiro, o los sedales para corvinas, dentones y hurtas, son artes que, a pesar de su etimología árabe, ya habían sido descritas por Opiano de Apamea y Claudio Eliano en el siglo III. La presencia de estas artes está documentada en las playas de Huelva a lo largo de toda la Edad Media, y también las abundantes exportaciones que se realizaban a la costa del levante peninsular e Italia durante los siglos XV y XVI. Con posterioridad, en el siglo XVIII, se produce su etapa de mayor apogeo, bien descrita por Oyarbide, siendo la causa, incluso, de la fundación de poblaciones como Isla Cristina. Esta bonanza fue interrumpida bruscamente por los conflictos bélicos de finales del XVIII y, sobre todo, por los gravámenes sobre la sal. Aun así, todavía se usaban jábegas en los años sesenta del pasado siglo en las playas de La Antilla, El Hoyo o El Portil. Sardinas, bonitos, caballas y boquerones, junto a la abundancia de sal, permitían impulsar la producción a escala industrial de salazones y salmueras, en las chancas de las poblaciones de la costa. Junto a las jábegas y sedales, las almadrabas completaban el repertorio de las artes de pesca intensivas en capital. Se caló alguna en Ayamonte, a finales de la Edad Media, en pleitos con el conde de Niebla, y otras en las playas de Doñana o en la Barra de El Terrón. Fue precisamente en El Terrón, ya en el siglo XVIII, donde se caló la primera almadraba de Buche de Andalucía, arrendada por compañías locales al Marqués de Villafranca. En esa época, existían chancas para la salazón de atunes, no sólo en La Higuerita, sino también en Ayamonte, Huelva, en El Terrón o en El Rompido. Precisamente, esta última población, El Rompido, aparece por primera vez representada en un grabado del Diccionario de Sañez-Reguart como "lugar donde se salan los atunes".
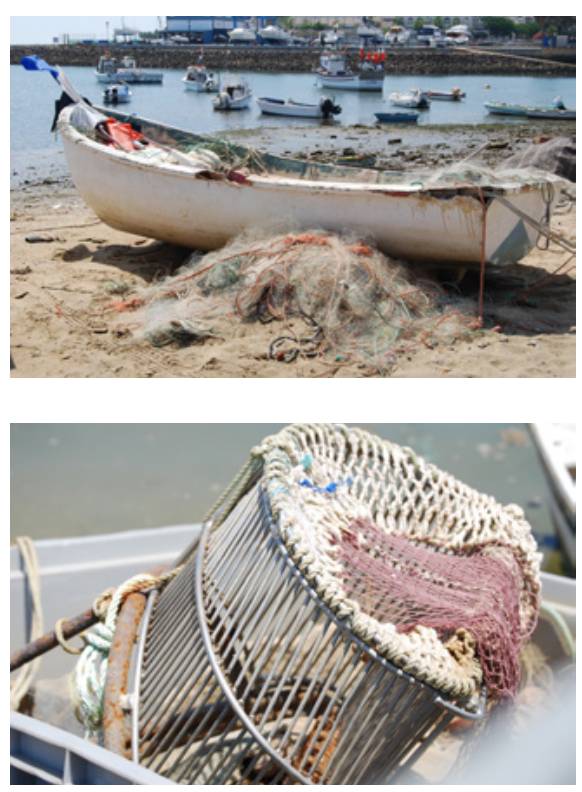

A la izquierda, pateras y botes artesanales en Punta del Moral (Ayamonte, Huelva)

Arriba, bote artesanal de trasmallo en Punta del Moral (Ayamonte, Huelva)

Abajo, moderno rastro remolcado para coquina en Punta del Moral (Ayamonte, Huelva) 
Montaña de sal en las salinas industriales de la Isla de Bacuta (Huelva)

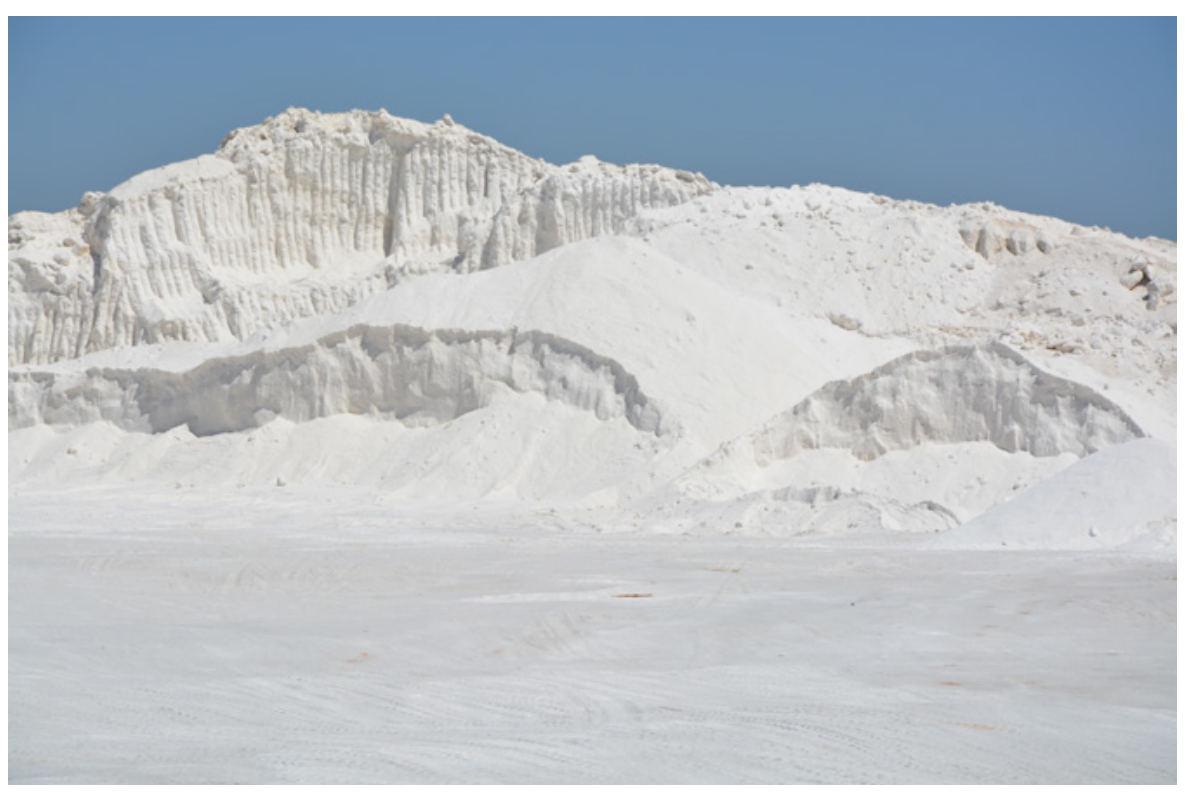

El comercio de la sal, y muchas salinas, fueron monopolio estatal y producto estancado, cuyo tributo pasó entre 1780 a 1850 de 12 rs. vn. la fanega a 50 rs. vn., provocando revueltas y motines en los pueblos de la costa que dieron al traste con el predominio moderado. Al establecerse una exención para aquellos que exportasen salazones a más de 20 leguas, relocalizó dichas actividades en los puntos más lejanos del mercado tradicional, Sevilla y su entorno. Pero no sólo hubo artes playeras y almadrabas; modestos boliches, junto a tapaesteros y lavadas de mar o de río, permitían a los no matriculados ganarse el sustento y mantener a sus familias. $Y$ es que, el privilegio de pesca a los matriculados, a cambio de servir en la Armada, sólo se limitaba a los que remaban en las barca o botes, o navegaban en faluchos, místicos o laudes. Los "terrestres", los no matriculados, tiraban de esas artes playeras, ayudados a veces por mujeres, niños y, en ocasiones de grandes capturas, por animales.

Pero también nuestros pescadores se alejaban de la costa; los marineros palermos, moguereños, leperos, ayamontinos y onubenses de los siglos XIV-XVI se dirigían a la costa africana a la captura de cazones y otros pescados de cuero, comerciando con los locales e incluso salando las capturas en tierra firme y conduciéndolas a puertos del Levante peninsular y de todo el mediterráneo occidental. Estos negocios fueron frustrados al inmiscuirse empresarios ingleses que luchaban por hacerse con el mercado ibérico de salazones y ahumados. Y es que este gran mercado -los reinos católicos peninsulares- se abastecía de diferentes fuentes: los arenques del Mar del Norte, monopolizados por las Provincias Unidas; el bacalao norteamericano, bajo control británico tras el Tratado de Utrech; y de las salazones de sar- 


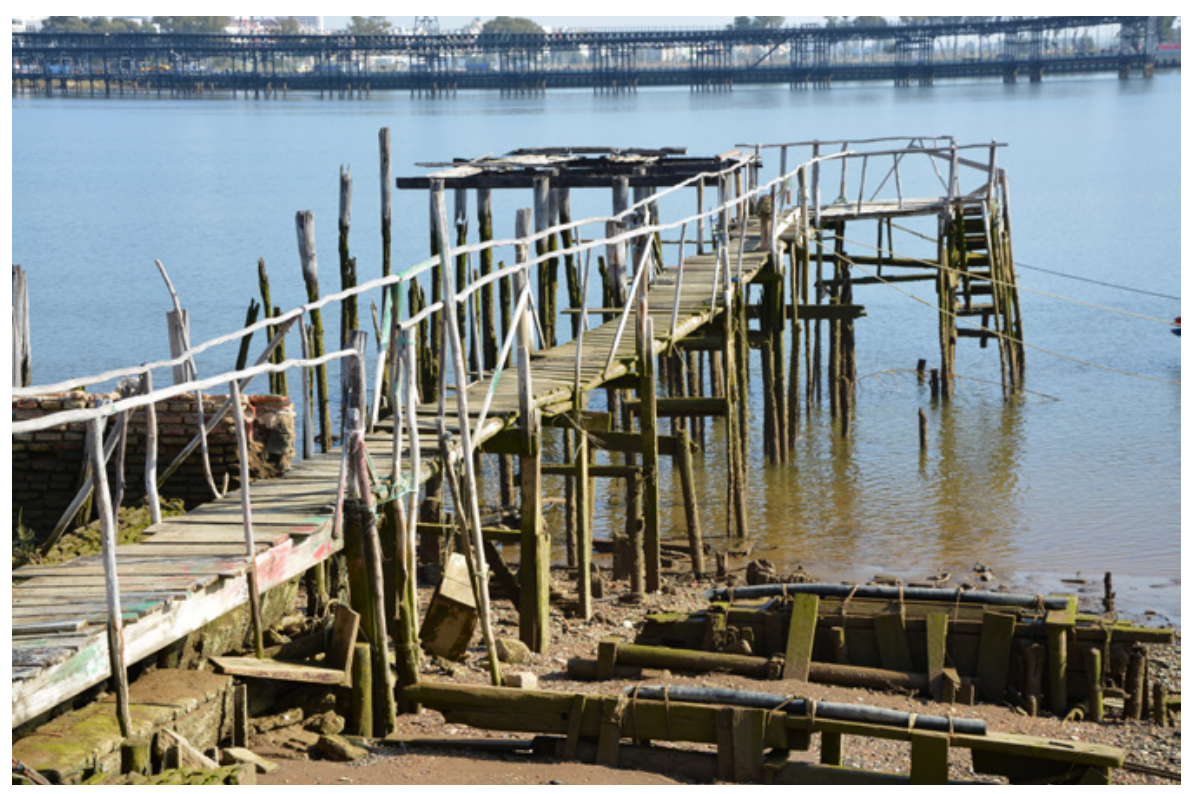

dina, atunes, bonitos, merluzas y cazones, siendo este rincón andaluz uno de los principales lugares de producción. Sin sal no podía entenderse la producción a gran escala, dado que los mercados locales no podían consumir más que una exigua porción de las potenciales capturas. Pero, una vez producidas las salazones, había que competir con las ingentes importaciones, hasta el punto de que, en periodos bélicos con Gran Bretaña, se autorizaban a buques de dicha bandera a desembarcar bacalao en puertos peninsulares para evitar el desabastecimiento y, cómo no, incluso sin autorización, a través del contrabando.

A finales del XVIII, llega la crisis: la matrícula de mar, conflictos bélicos, buques armados, marinería, deserciones y abandono de la pesca y desaliento. Si en 1776 las estimaciones de Oyarbide sitúan sólo la producción de salazones de sardina en torno a las 3.200 Tm anuales, sesenta años después los niveles de producción dados por Miravent en su "Memoria sobre las pescas..." son similares; finalizado el periodo de conflictos bélicos (17841824), se ha superado la gran crisis del sector, y sólo el tributo sobre la sal resulta una amenaza a su desarrollo.

A mediados del XIX, cuando publicaba Miravent su trabajo o cuando Berthelot salía de la Ría de Huelva en dirección a Cádiz, tratando de estudiar las pesquerías, aún predominaban las artes de tiro playero. Las almadrabas de buche, desamortizadas desde 1818, comenzaban a ser un negocio próspero; la de La Tuta, iniciada en 1828 y explotada por un grupo de empresarios isleños, la de El Portil, heredera de la del Duque, que comenzó a calarse en 1841; la de La Mojarra, que databa de 1839, junto a otras autorizadas

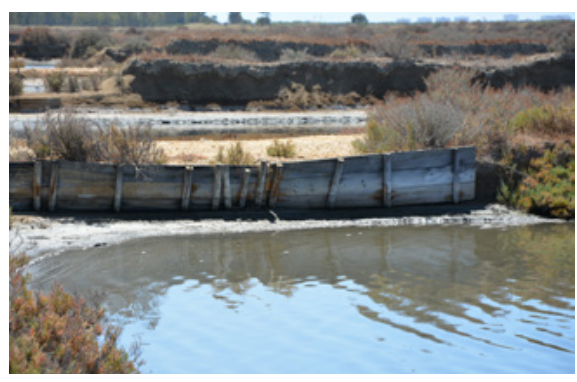

Estructuras y compuertas en la antigua salina de Bacuta (Huelva)

Embarcadero de las antiguas salinas de Bacuta (Huelva) 
a finales de siglo, totalizando siete almadrabas de atún y tres de sardinas, vinculadas al desarrollo salazonero y, sobre todo, al inicio del negocio conservero, circunscrito en su origen a la exportación de conservas de atún al mercado italiano.

Pero también se reinician las pesquerías de altura; faluchos ayamontinos y onubenses acudían a la costa de Larache cada verano para dedicarse a la pesca de la merluza con artes de cordel e incipientes palangres y, una vez capturadas, eran remitidas a Málaga, Cádiz y Sevilla para su comercialización.

Las décadas de 1860-1870 constituyen el inicio de la liberalización del sector, se elimina la exclusividad de los matriculados, facilitando la entrada de capitales, se suprime el estanco de la sal y, entonces, comienza el despegue pesquero. La liberalización de la producción y venta de la sal impulsa el negocio salinero, multiplicándose las explotaciones en las rías onubenses. Las de Bacuta, Cardeñas, El Astur, junto a otras cinco en la ría de Huelva; nueve en Isla Cristina, otras siete en Ayamonte e, incluso, una en Lepe y otra más en Almonte. Sobre 1874 se introducen los primeros galeones a remo para la pesca de sardina, que permitía a los pescadores alejarse de las playas buscando los cardúmenes que, según los documentos de la época, huían de las desembocaduras del Guadiana y del estuario del Tinto-Odiel a causa de las aguas sulfurosas que la expansión minera y las teleras provocaban. Documentos de la época nos hablan de almadrabas consumidas en Ayamonte por las aguas ácidas vertidas por la mina portuguesa de Sao Domingos, de bancos de ostras y almejas muy productivos en Huelva que

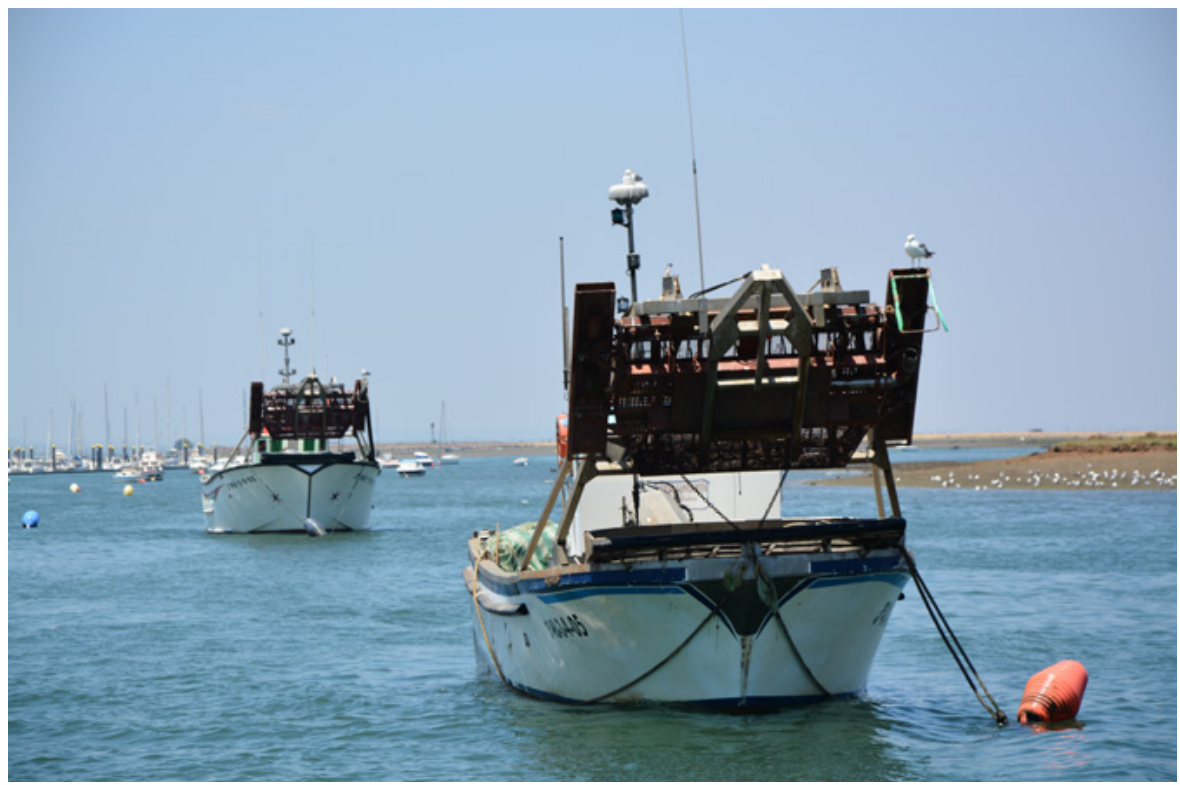


desaparecen para siempre, de sardinas que no se acercan a las playas y de atunes espantados y almadraberos que renuncian a sus concesiones. $Y$ ante esos problemas, el sector debe reconvertirse, surgiendo nuevas artes y nuevos barcos.

En Huelva capital se introducen los primeros bous o arrastres a vela en esa década de la mano de la familia Narváez, origen de lo que llegará a convertirse en la principal flota arrastrera de España a finales de los sesenta y primeros setenta. En Isla Cristina y Ayamonte y, en menor medida, Lepe y Huelva, se introducen las primeras artes de cerco -tarrafas- de origen norteamericano. En 1904 el empresario Guillermo Sundheim junto a otros onubenses adquieren dos vapores ingleses para iniciar una empresa de pesca de arrastre en el Golfo de Cádiz y las costas de Marruecos.

Los isleños y ayamontinos no se quedan atrás. En 1908 se adquiere el primer vapor para la pesca de cerco de tarrafa; en 1921 ya son cerca de 36 vapores de cerco con 1.250 TRB, pero, poco después, la sardina, huidiza, comienza uno de sus ciclos y desaparece de estas aguas. Las casi 21.000 Tm de sardina capturadas por los 36 vapores tarraferos existentes en 1923 se reducen a poco más de $400 \mathrm{Tm}$ en 1936. Crisis, cierre de fábricas, huelgas, exportación de vapores a Portugal, son las características del sector en los años anteriores a la Guerra Civil.

Las almadrabas, monopolizadas en 1928 bajo el todopoderoso Consorcio Nacional Almadrabero, comienzan a cerrar algunos de los pesqueros y fábricas, dejando sólo una almadraba operativa en la provincia desde 1940. A

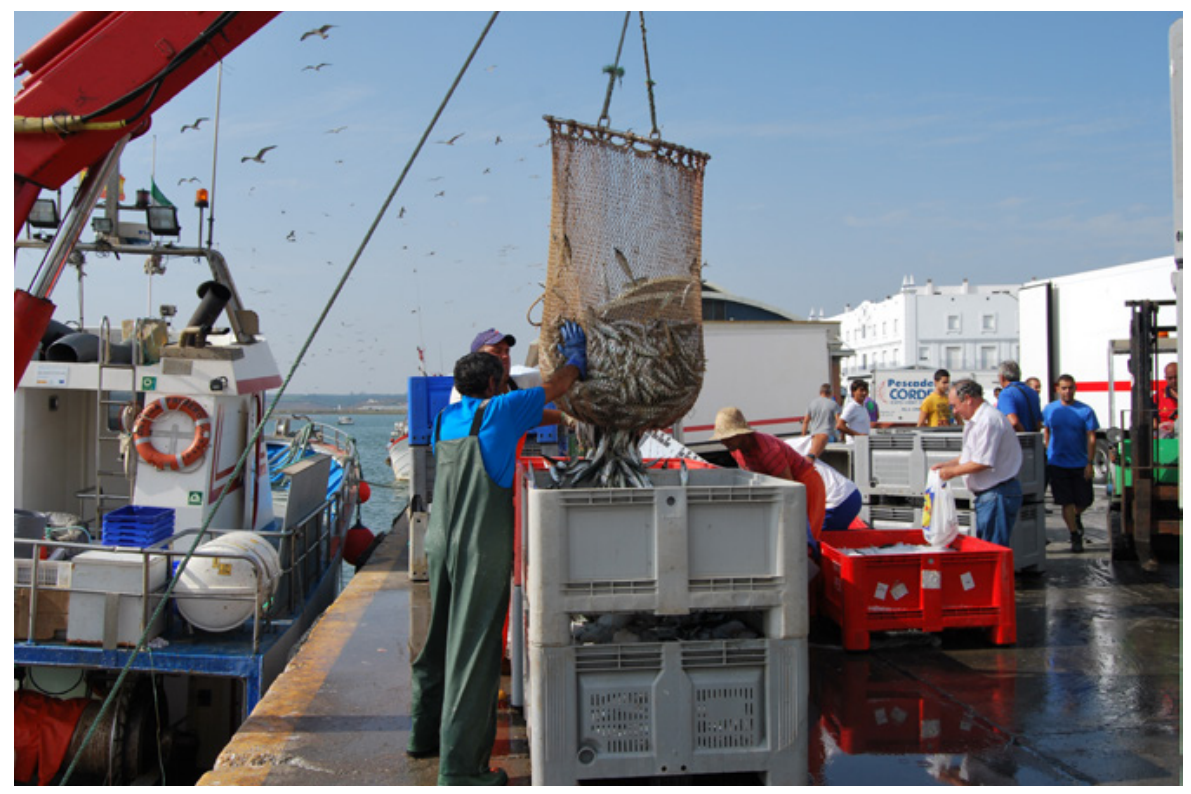


Antigua fábrica de Conservas Tejero en el estero de Domingo Rubio (Palos de la Frontera, Huelva)

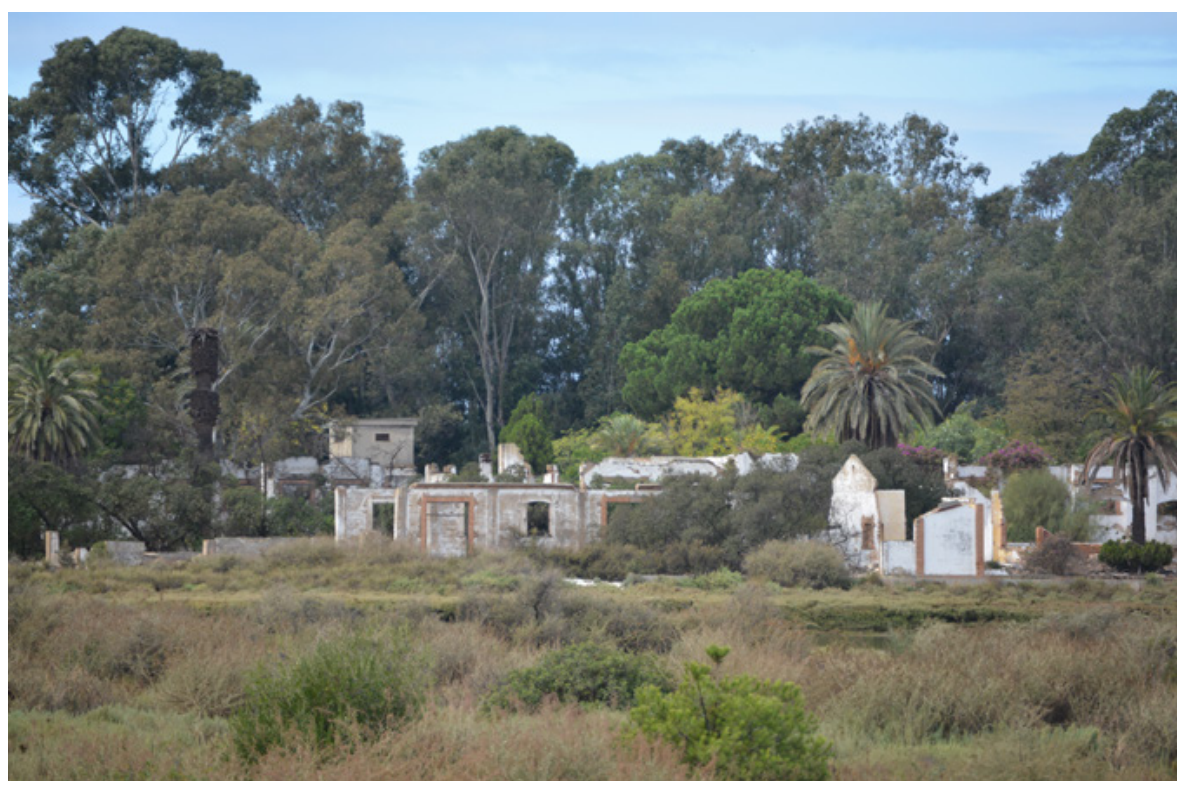

finales de los cincuenta intentó rehabilitar alguna de las que había cerrado, como Las Cabezas en Isla Cristina o La Cinta en Huelva. Pero las capturas no compensaban los esfuerzos. La almadraba de Nueva Umbría realizó su última campaña en 1965, con una captura irrisoria de tan sólo 158 atunes, cuando en 1937 había capturado 25.200 atunes.

Tras la guerra se agudiza la crisis del sector. No hay carbón, los buques apenas faenan entre 1940 y 1948, las capturas son testimoniales y sólo el sector artesanal subsiste a duras penas. Barcas de vela y botes de remo, dedicados a trasmallos y rastros, son los encargados de abastecer los mercados locales. Pero, poco a poco, se normaliza el suministro de combustibles; los vapores van siendo sustituidos por buques más modernos. En Huelva, en la capital, la flota de arrastre dedicada a la captura de crustáceos sigue su expansión; con casi un centenar de vapores y motores dedicados al arrastre en 1948, junto a un par de vapores tarraferos para cerco.

Por su parte, en Isla Cristina y Ayamonte, la sardina no regresa y las campañas posteriores a la Guerra Civil son decepcionantes. Los viejos vapores tarraferos van siendo sustituidos por modernos buques de casco de acero y motores de gasoil orientados a la captura de sardina en aguas norteafricanas, como medio para abastecer a las fábricas de conservas y salazón, que necesitan materia prima para satisfacer una demanda creciente de los mercados interiores, donde la salazón de sardinas se ha convertido en un alimento común. Se busca a la sardina, se la persigue, y la flota sardinera de altura se consolida. Es la época dorada de la pesca de sardinas, siendo Ayamonte e Isla Cristina puertos situados a la cabeza de capturas en 


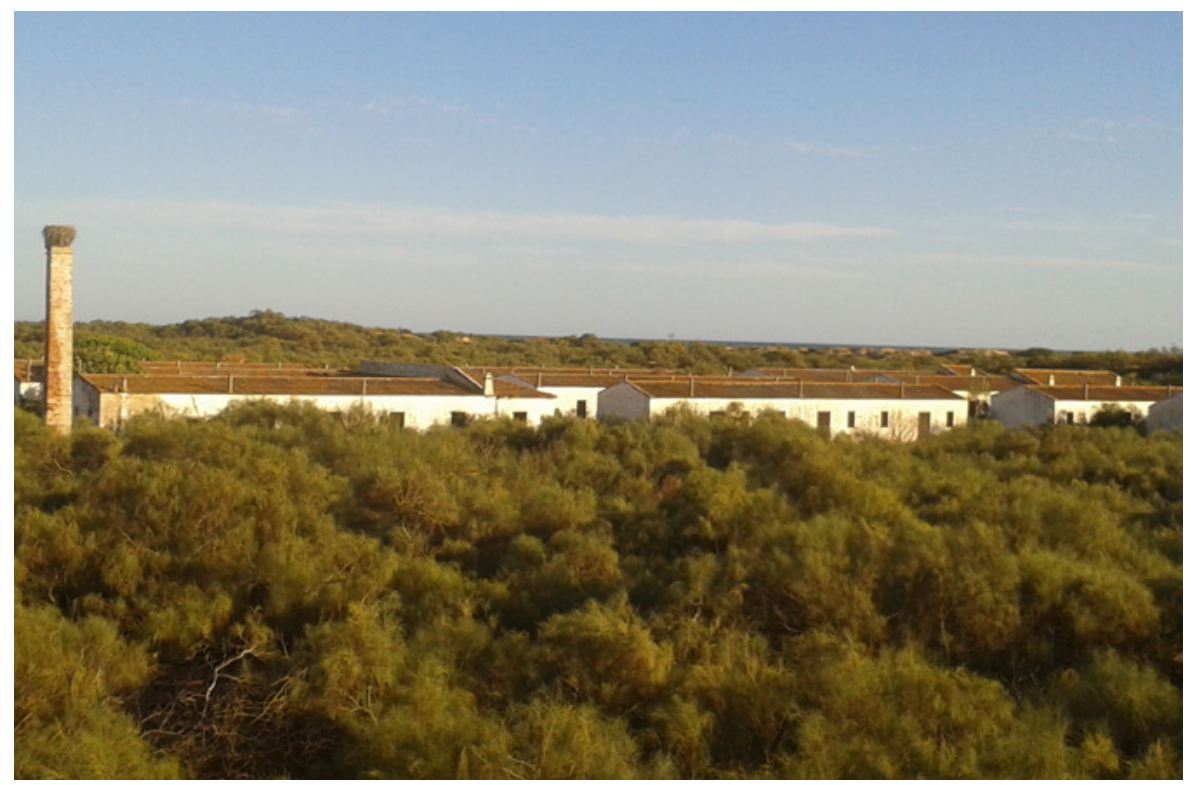

Antiguo Real de la Almadraba de Nueva Umbría (Lepe, Huelva)

España. Pero los cambios en los hábitos de consumo, con la irrupción de los productos congelados desde mediados de los sesenta, hundió la demanda de salazones e, incluso, la de conservas. De las más de ochenta fábricas existentes en 1970, tan sólo una decena subsistían en 1978, habiéndose agrupado muchos empresarios en Usisa (Unión Salazonera Isleña, SA) en Isla Cristina y Pesasur (Persca y Salazones del Suroeste, SA) en Ayamonte, empresas que aún subsisten con modernas instalaciones.

La flota artesanal de botes de vela y remo, integrada por 487 unidades y cerca de 2.000 TRB en 1940, va siendo sustituida lentamente por pequeños buques de madera dotados de motor. Son barcos polivalentes, dedicados, a veces, al arrastre, a la acedía y el langostino cerca de la costa; y en otras, al rastro remolcado, capturando chirlas, el "mechillón", cuyas capturas alcanzan niveles extraordinarios a finales de la década de 1960, con más de $30.000 \mathrm{Tm}$ de bivalvo que se convierte en un producto habitual en los mercados del centro de la Península. Pero, sorpresivamente, en 1969, el caladero se hunde, y las capturas son nulas en 1971 ¿Qué había pasado? ¿Sobreexplotación? Eso indicaban algunos trabajos de la época. Pero no, la puesta en marcha del polo industrial en Huelva cobró su peaje; doscientos barcos se pudrían en la Isla de Saltés o en los esteros de Carreras. La pesca en Huelva parecía estar condenada siempre a ser la hermana pobre de las actividades económicas.

Mientras, los vapores arrastreros de Huelva, dedicados a la captura de crustáceos en aguas marroquíes y del Golfo de Cádiz, comienzan a dar origen a un segmento de flota. El 1964 el pesquero Onuba, que había sido equipado 
con cámaras de congelación, realiza una campaña exploratoria en aguas de Mauritania y Senegal. Es el primer buque de arrastre congelador de Huelva, segmento que comienza una rápida expansión hasta alcanzar unas 250 unidades en 1978 desplazando 81.982 TRB y que operaban en todo el litoral africano, desde Mozambique a Mauritania. Pero la extensión de las aguas territoriales y las ZEE (Zona Económica Exclusiva) a partir de 1978, limitó drásticamente la actividad, reduciéndose progresivamente el número de unidades y comenzando un proceso de exportación de buques a empresas pesqueras conjuntas y sociedades mixtas. En la actualidad sólo 33 buques con bandera española siguen manteniendo esta actividad.

Ya no hay flotas de altura -se dejó de faenar en el caladero marroquí- y la flota congeladora es testimonial. La pesca subastada, las capturas, es semejante en volumen a la de 1915, pero la flota es mucho mayor y de mayor potencia. Ya no se construyen buques de madera; el último se botó en 2000. Pero, es más, si en 1987 tan sólo había 29 barcos de poliéster frente a 548 de madera, en la actualidad hay 342 de poliéster y sólo 50 de madera que van curso a su desaparición, y con ellos una actividad inmemorial, la carpintería de ribera, cuyas principales empresas ya han cerrado.

Con esta breve trayectoria histórica de lo que ha sido la pesca en la costa de Huelva, se vislumbra la importancia que esta actividad ha tenido y que aún mantiene, a pesar del descenso en el nivel de capturas y flota. Pero la importancia de la pesca en las sociedades locales onubenses no solo se mide en productividad económica. La pesca implica un modo de vida, unas formas de relaciones laborales que influyen en la cotidianidad social (asociacionismo, cooperación, cofradías), familiar y vecinal; unos conocimientos y saberes que, por lo general, se trasmiten de generación en generación; labores y trabajos vinculados al hecho de pescar (rederos, estibadores, mujeres que trabajan en fábricas de conservas y salazones, salinas, etc.); poblaciones con un urbanismo de cara al mar, con edificios e instalaciones que les dan una fisonomía característica (muelles, lonjas, tinglados, embarcaderos, astilleros); barcos (de todas las tipologías), botes, pateras de ría; y un sinfín de utensilios, aparejos e instrumentos cuyo uso requiere de habilidades y el aprendizaje casi siempre informal. Hablamos, en definitiva, de la cultura de la pesca, una tradición que, como todas las tradiciones, se ha ido transformando y adaptando con los avatares de la política, la economía y la incorporación de las nuevas tecnologías. Pero, aun pasando de las salazones a las conservas, y de éstas al congelado y a nuevas presentaciones comerciales, la pesca destaca como seña de identidad de estos pueblos de la propia provincia de Huelva y como expresión de su patrimonio cultural. 


\section{BIBLIOGRAFÍA}

- BERTHELOT, S. (1856) Exploración de la costa meridional de España. Cádiz: Imprenta y Litografía de la Revista Médica, 1856

- GARCíA DEL HOYO, J. J. (2006) Economía Clásica, Liberalización Pesquera y Sobreexplotación en Andalucía. En IFAPA (ed.) Historia de la Pesca en el ámbito del Estrecho. Sevilla: Consejería de Agricultura y Pesca de la Junta de Andalucía, vol. II, 2006, pp. 961-1001

- garcía del hOYO, J. J. (2009) El desarrollo de las estadísticas del sector pesquero durante los siglos XVIII y XIX. En BASULTO SANTOS, J.; GARCÍA DEL HOYO, J. J. (ed.) Historia de la Probabilidad y Estadística (IV). Huelva: Servicio de Publicaciones de la Universidad de Huelva, 2009, pp. 265-310

- JIMÉNEZ DE MADARIAGA, C.; DELGADO MÉNDEZ, A. (2016) Marismas del Odiel: usos y recursos tradicionales. En CAMPOS CARRASCO, J. M. (dir.) El patrimonio histórico y cultural en el paraje natural Marismas del Odiel. Un enfoque diacrónico y transdisciplinar. Huelva: Servicio de Publicaciones de la Universidad de Huelva y Autoridad Portuaria de Huelva, 2016, pp. 468-490

- JIMÉNEZ DE MADARIAGA, C.; GARCÍA DEL HOYO, J. J. (2014) Cultura de la Pesca, Patrimonio y Turismo. En GARCÍA DEL HOYO, J. J. (ed.) Cultura, Mercado y Gestión de la Pesca Artesanal en el Golfo de Cádiz. Huelva: Universidad de Huelva, 2014, pp. 107-131

- JIMÉNEZ DE MADARIAGA, C.; GARCÍA DEL HOYO, J. J. (2016) Cultura y Pesca. Actas de las Jornadas de Patrimonio Cultural Pesquero. Huelva: Servicio de Publicaciones de la Universidad de Huelva, 2016

- MIRAVENT y SOLER, J. (1850) Memoria sobre las pescas que se cultivan en las costas de España, desde el cabo San Vicente hasta el Estrecho de Gibraltar. Huelva: Imprenta Reyes, 1850

- OYARBIDE, J. M. (1776) Informe a la Real Sociedad Patriótica de Sevilla. Obra manuscrita. Archivo Histórico de Sevilla. Papeles del Conde del Águila, tomo 61, número 4. Sevilla

- RODRÍGUEZ SANTAMARÍA, B. (1923) Diccionario de artes de pesca de España y sus posesiones. Madrid: Imprenta de los sucesores de Rivadeneyra, 1923

- SAÑEZ-REGUART, A. (1791-1795) Diccionario Histórico de los Artes de la Pesca Nacional. Madrid: Imprenta de la Viuda de D. Joaquín Ibarra, 1791-1795 


\section{Los molinos mareales del litoral onubense}

Patxi Serveto i Aguiló | Asociación Amigos de los molinos mareales del Litoral

Onubense

Diego Vázquez Capelo | Platalea, Sociedad Cooperativa Andaluza

URL de la contribución <www.iaph.es/revistaph/index.php/revistaph/issue/view/4261>

\section{RESUMEN}

La invención de los molinos hidráulicos revolucionó el desarrollo de la humanidad, al facilitar la utilización de los recursos naturales para su alimentación. Los molinos instalados en la costa fueron una aplicación ingeniosa a las mareas; los molinos mareales constituyeron una potente industria en el litoral atlántico europeo.

El molino mareal más antiguo del continente data del siglo VII d. de C., difundiéndose a lo largo de la Edad Media y durante los siglos XVII y XVIII. En el sudoeste peninsular se instalaron molinos de agua salada a partir del siglo XIII, tras su conquista a los musulmanes. En Huelva, en las marismas de las desembocaduras de sus ríos, llegaron a existir más de cincuenta. Con la llegada de la revolución industrial comenzó su lenta agonía, debida a la pérdida de rentabilidad y competitividad a lo largo de los siglos XIX y XX.

Uno de los molinos mareales onubenses más singulares y de mayor envergadura fue EI Pintado (Ayamonte); adquirido mediado el siglo XVIII, fue reconstruido y funcionó hasta 1946. Su historia expresa el vínculo existente entre las poblaciones costeras y el aprovechamiento de los recursos naturales, así como su vinculación con el comercio con América.

La reconstrucción del molino mareal El Pintado, y su rehabilitación como centro de interpretación del patrimonio cultural y natural, como ecomuseo, ha constituido un hito en la divulgación y puesta en valor de los molinos mareales de Huelva. Actualmente, este ecomuseo constituye un equipamiento de la Red de Espacios Naturales Protegidos de Andalucía.

\section{Palabras clave}

Costa occidental | Ecomuseos | Huelva | Interpretación del patrimonio | Molino de mareas | 


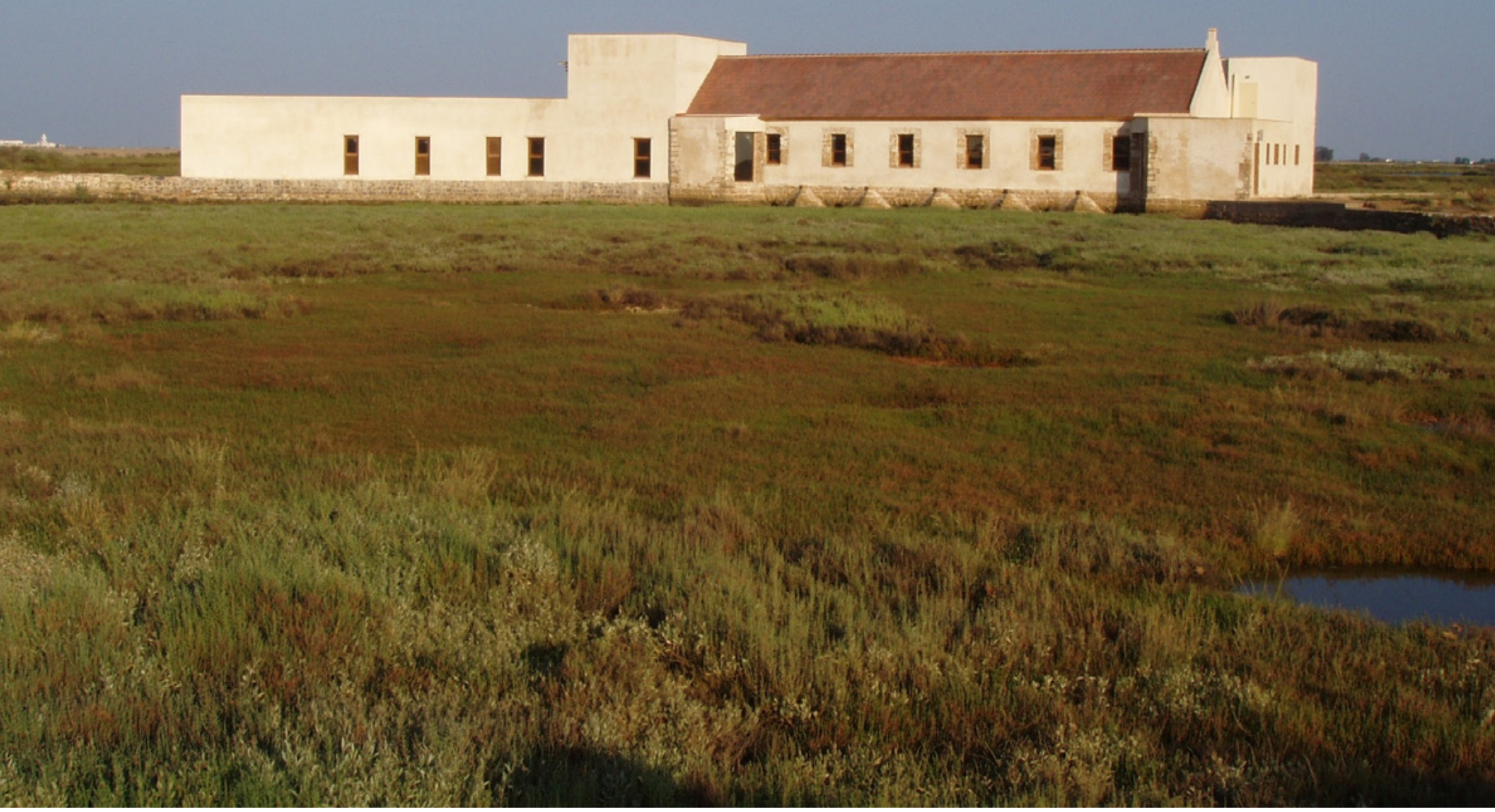

Molino mareal El Pintado reconstruido | foto Patxi Serveto (Ayamonte, 2007) 
“¡Qué ilusión cuando entró en el corral por vez primera, Platero! Era marismeño y con él venía a mí un cúmulo de fuerza, de vivacidad, de alegría. ¡Qué bonito era! Todas las mañanas, muy temprano, me iba con él ribera abajo y galopaba por las marismas levantando las bandadas de grajos que merodeaban por los molinos cerrados. Luego, subía por la carretera y entraba, en un duro y cerrado trote corto, por la calle Nueva".

(Juan Ramón Jiménez; Platero y yo, 1917: "Almirante" 144).

Distribución de los molinos mareales en el litoral atlántico europeo | fuente AZURMENDI PÉREZ; GÓMEZ CARBALLO; GRUPO ENTORNO; Ecomuseo del Molino El Pintado, 2009

\section{LOS MOLINOS MAREALES; IMPORTANCIA HISTÓRICA EN EUROPA}

La invención de los molinos hidráulicos constituyó una auténtica revolución en el desarrollo de la humanidad al ampliar nuestra capacidad de utilización de los recursos naturales, por ejemplo la molienda para la obtención de harina, vital para nuestra alimentación.

Los molinos instalados en la costa fueron una aplicación ingeniosa al fenómeno de las mareas, aprovechando su flujo para rotar las piedras molineras; los molinos mareales constituyeron una potente industria, llegando a existir a lo largo de la historia más del millar en el litoral atlántico europeo.

El molino mareal más antiguo conocido hasta la fecha en Europa data del siglo VII d. de C. (Irlanda del Norte). A lo largo de la Edad Media se difun-

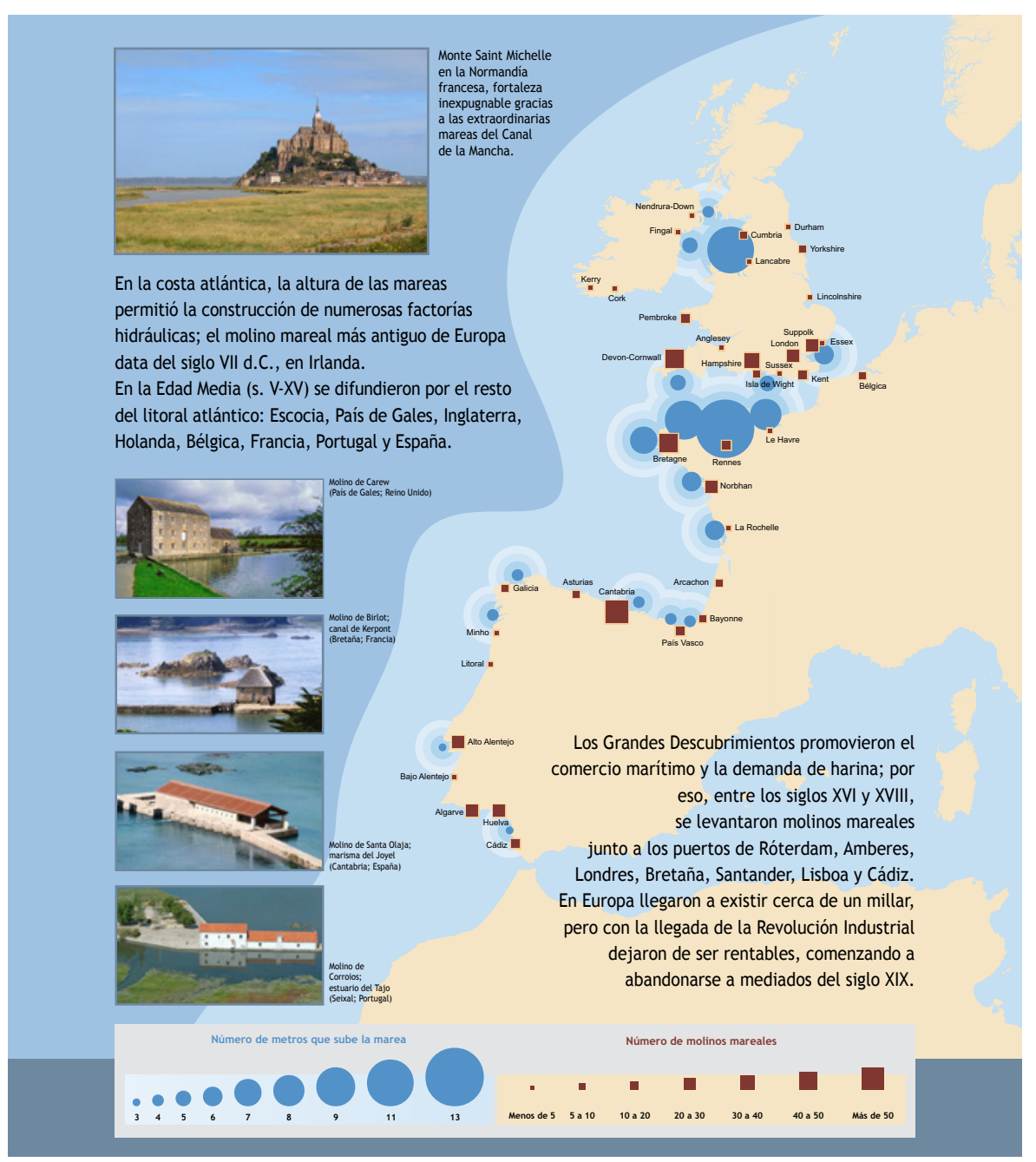




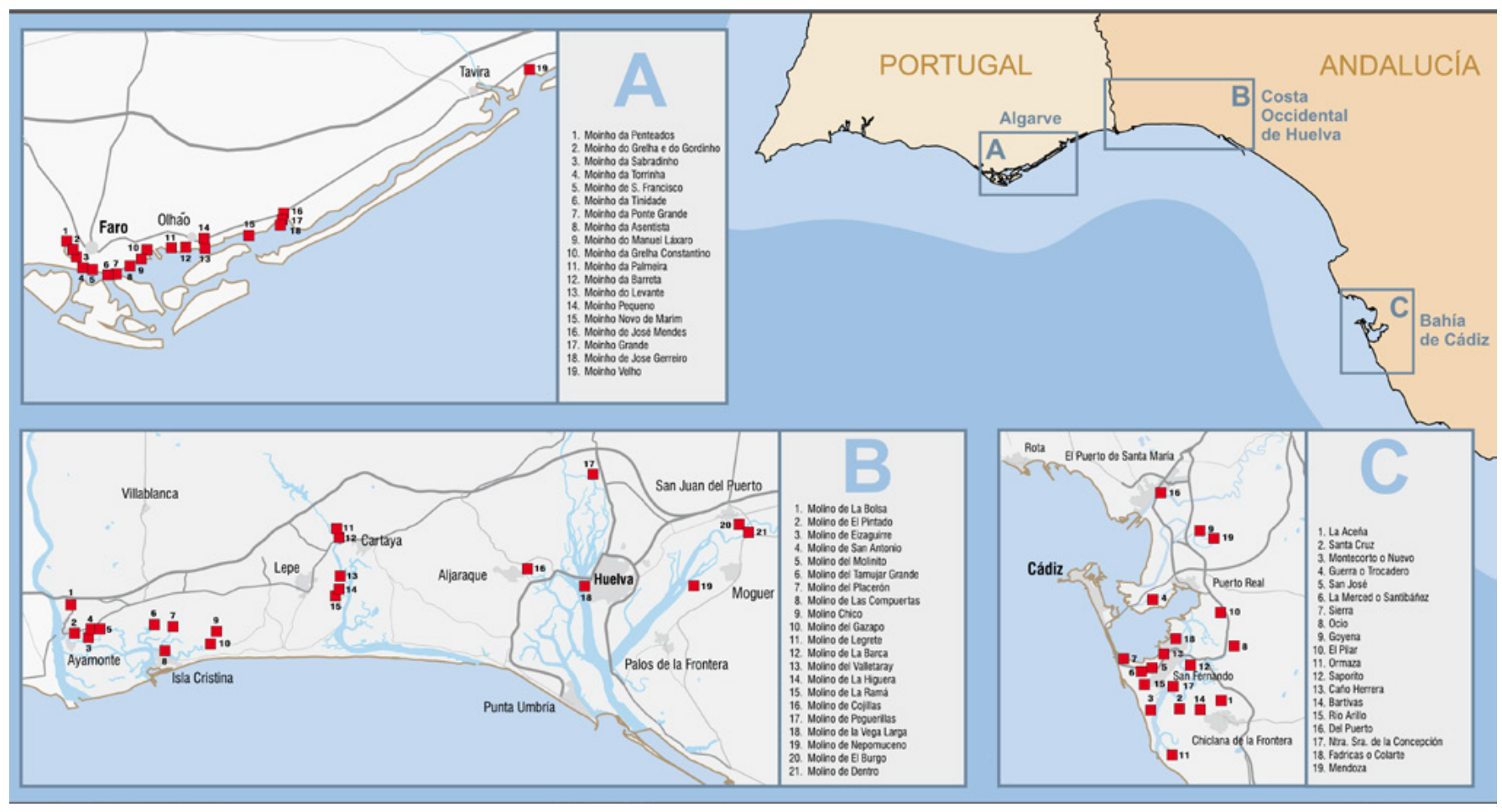

Localización de los molinos más representativos del sudoeste peninsular | fuente SERVETO AGUILÓ; GRUPO ENTORNO; Ecomuseo del Molino El

dieron por el litoral Atlántico (Escocia, País de Gales, Inglaterra, Holanda, Pintado, 2009 Bélgica, Francia, Portugal y España), continuando durante los siglos XVII y XVIII.

En el sudoeste peninsular se instalaron molinos de agua salada a partir del siglo XIII, tras su conquista a los musulmanes por parte de lusos y castellanoleoneses, ya que gran parte del arco Atlántico, desde Faro hasta Cádiz, presenta unas características geomorfológicas idóneas para el aprovechamiento de las mareas debido a su amplitud, y al complejo sistema de rías, estuarios y marismas, llegando a existir bastantes más de la centena.

En el litoral Atlántico andaluz, los molinos se extendieron en Huelva en las marismas de las desembocaduras de sus ríos, mientras que en Cádiz lo hicieron alrededor de su metrópolis, importante por su actividad comercial con Las Indias, llegando a funcionar más de 20; con su harina se elaboraban unas galletas especiales (biscuits) para avituallar las naves que realizaban las travesías transoceánicas.

Con la llegada de la revolución industrial comenzó su lenta agonía, debido a la pérdida de rentabilidad y competitividad; mientras algunos fueron reconvertidos para diversas actividades, otros sufrieron el abandono y destrucción a lo largo de los siglos XIX y XX.

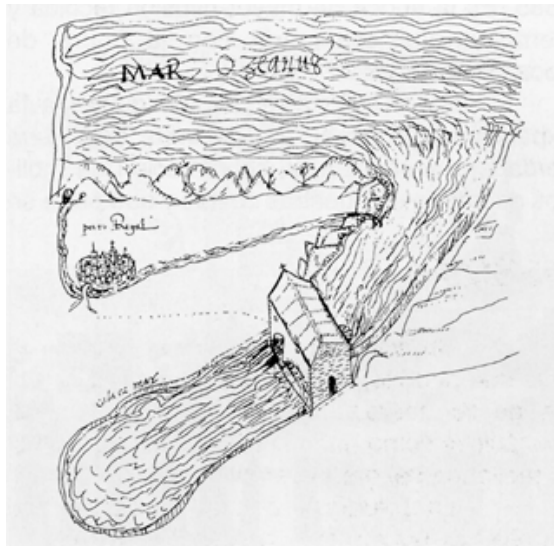

Primera representación conocida de un molino mareal en España (Lobato del Canto, F. [c.15471585] Puerto Real | fuente AZURMENDI PÉREZ; GÓMEZ CARBALLO; MARCHÁN FIZ et ál., 2005: 20 


\section{LOS MOLINOS MAREALES DEL LITORAL ONUBENSE}

A comienzos del siglo XV, se citan en Gibraleón y Moguer (1436); y, comenzando el XVI, funcionaba al menos uno en Ayamonte. En este periodo de expansión demográfica y desarrollo, estos molinos aparecen en las principales urbes, centros administrativos, nobiliarios y políticos -Ayamonte, Gibraleón y Moguer-, por entonces frontera occidental del reino de Sevilla. Fueron propiedad bien de órdenes religiosas, bien de los señores de las villas -condados de Niebla y Gibraleón, y marquesado de Ayamonte-, aunque se arrendaban a particulares. No se privatizaron hasta los siglos XVIII y XIX.

1

Se denominaba comúnmente "molino de pan moler" al dedicado a la molienda de los diferentes cereales destinados a la elaboración de pan, independientemente de la fuerza motriz que los impulsara: "Un molino de pan moler, todo de cantería de Puerto Real, con su pieza principal de techumbre de tijera, cana y redoblón de Sevilla..." Descripción realizada por Manuel Rivero "El Pintado" de su molino en el aprecio de sus bienes fechado en 1767 (MORENO ALONSO, 2000: 73).
El Molino de la Vega Larga (edificio blanco del extremo superior-derecho) a comienzos del siglo $\mathrm{XX}$, del que tomó nombre una popular barriada de Huelva | fuente Huelva Información y Autoridad

Portuaria de Huelva [2008] 100 postales antiguas de Huelva
Finalizando el siglo XVI ya se contabilizaban once molinos en Ayamonte, sobrepasando el medio centenar los existentes en el litoral onubense. Probablemente pudieran aparecer algunos molinos de mar de pan moler ${ }^{1}$ más, de seguir investigando en los archivos municipales; como fue el caso del molino mareal hallado en San Juan del Puerto en 2013.

Tras la crisis del siglo XVII, Europa vive un desarrollo demográfico, social y económico que impulsa un incipiente desarrollo industrial, en el que los molinos jugaron un importante papel en el abastecimiento de productos básicos como la harina y el aceite; en el siglo XVIII se intensificó la actividad en el litoral onubense hasta que, a finales del siglo XIX, decayó por la competencia de procesos productivos más rentables. Platero ya vio los molinos de Moguer cerrados.

Concluida la Guerra Civil se produjo un breve resurgir, clandestino, de la actividad debido a la escasez de harina. Por último, algunas estructuras de

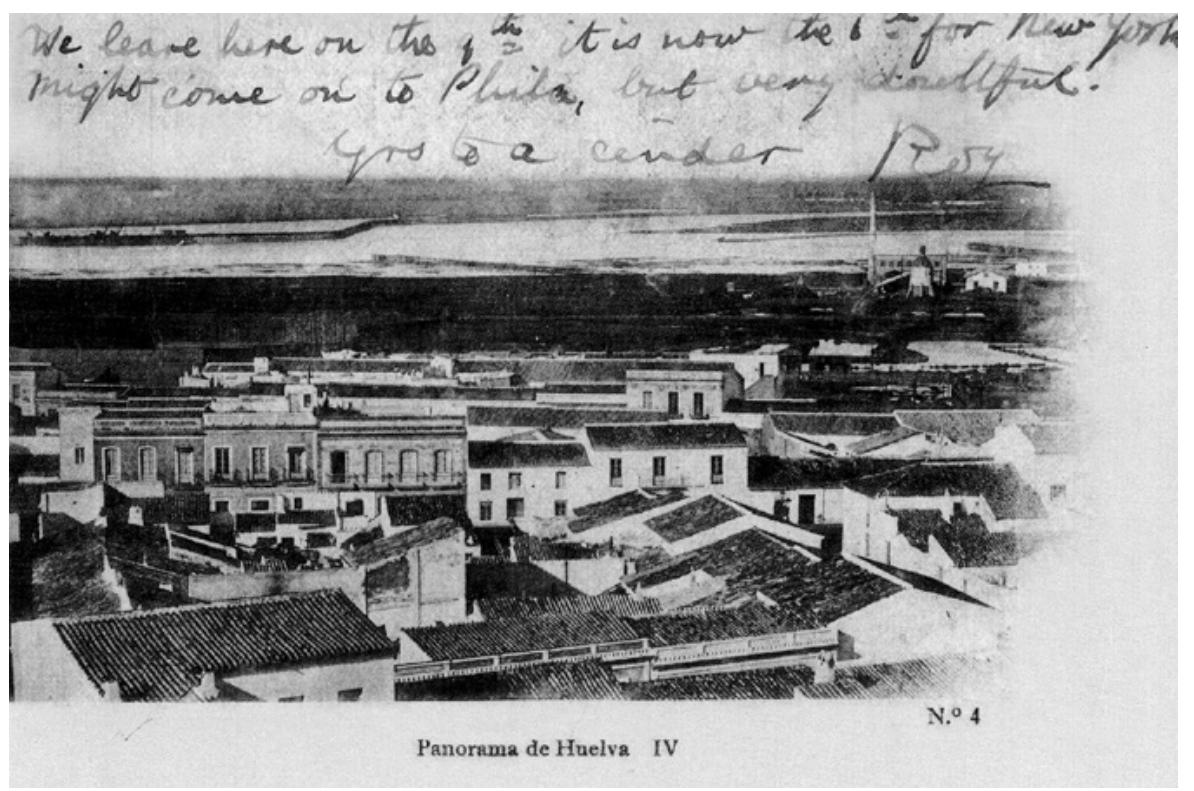


Ios molinos se aprovecharon para los "pesqueros"; pero a finales de siglo, la mayoría estaban ya ruinosos, si no desaparecidos, claro ejemplo de patrimonio cultural industrial disperso.

Este abandono contribuyó al cambio que se estaba produciendo en la relación de las poblaciones costeras con sus marismas, basada ancestralmente en el aprovechamiento sostenible de los recursos naturales -molinos mareales, salinas, pesca, marisqueo y ganadería-, aflorando tan sólo los "inconvenientes" al decaer este: insalubridad, improductividad, aislamiento...

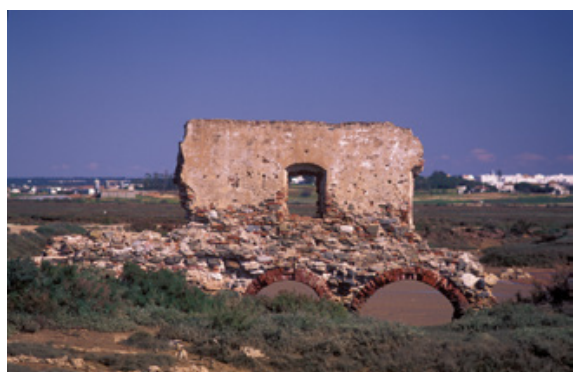

Molino de Valletaray en el río Piedras | foto Patxi Serveto (Lepe, 2006)

\section{EL MOLINO MAREAL EL PINTADO: RECONSTRUCCIÓN Y REHABILITACIÓN COMO CENTRO DE INTERPRETACIÓN DEL PATRIMONIO}

Uno de los molinos mareales onubenses más singulares fue El Pintado (Ayamonte). Adquirido mediado el siglo XVIII, entre la llustración y la Revolución Industrial, por el indiano y mecenas ayamontino Manuel Rivero González, El Pintado (1697-1780), quien lo reconstruyó renombrándolo como San José; funcionó hasta mediado el siglo XX (1946).

Desde el punto de vista fabril fue uno de los molinos de mayor envergadura del litoral de Huelva, con seis muelas. Arquitectónicamente se trata de una edificación proyectada en Cádiz, en la que destaca el empleo de piedra ostionera, caliza marina traída en sus naves desde Puerto Real, como elemento tanto de basamento como decorativo.

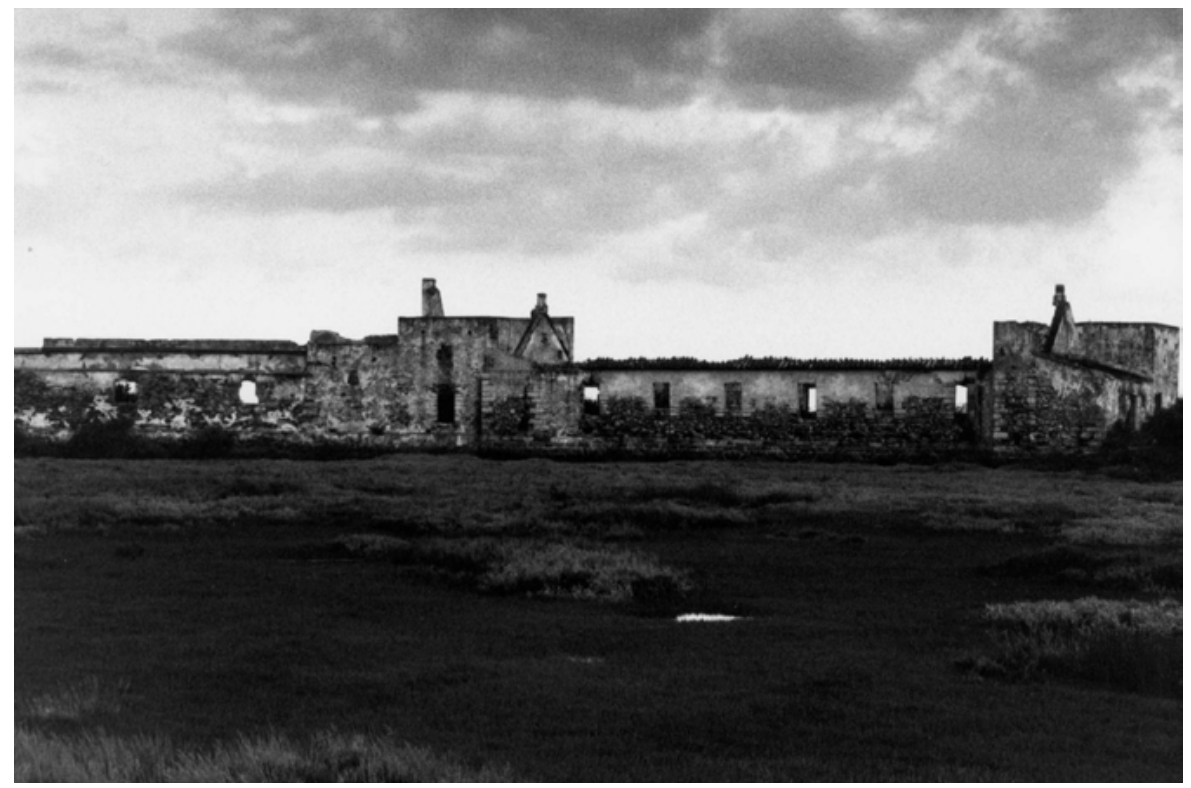


Biodiversidad de avifauna en el pesquero de las marismas del río Guadiana y ría Carreras | foto Patxi Serveto (Isla Cristina, 1990)

El Molino mareal El Pintado una vez reconstruido en su marisma | foto Toño Méndez (Ayamonte, c. 2016)
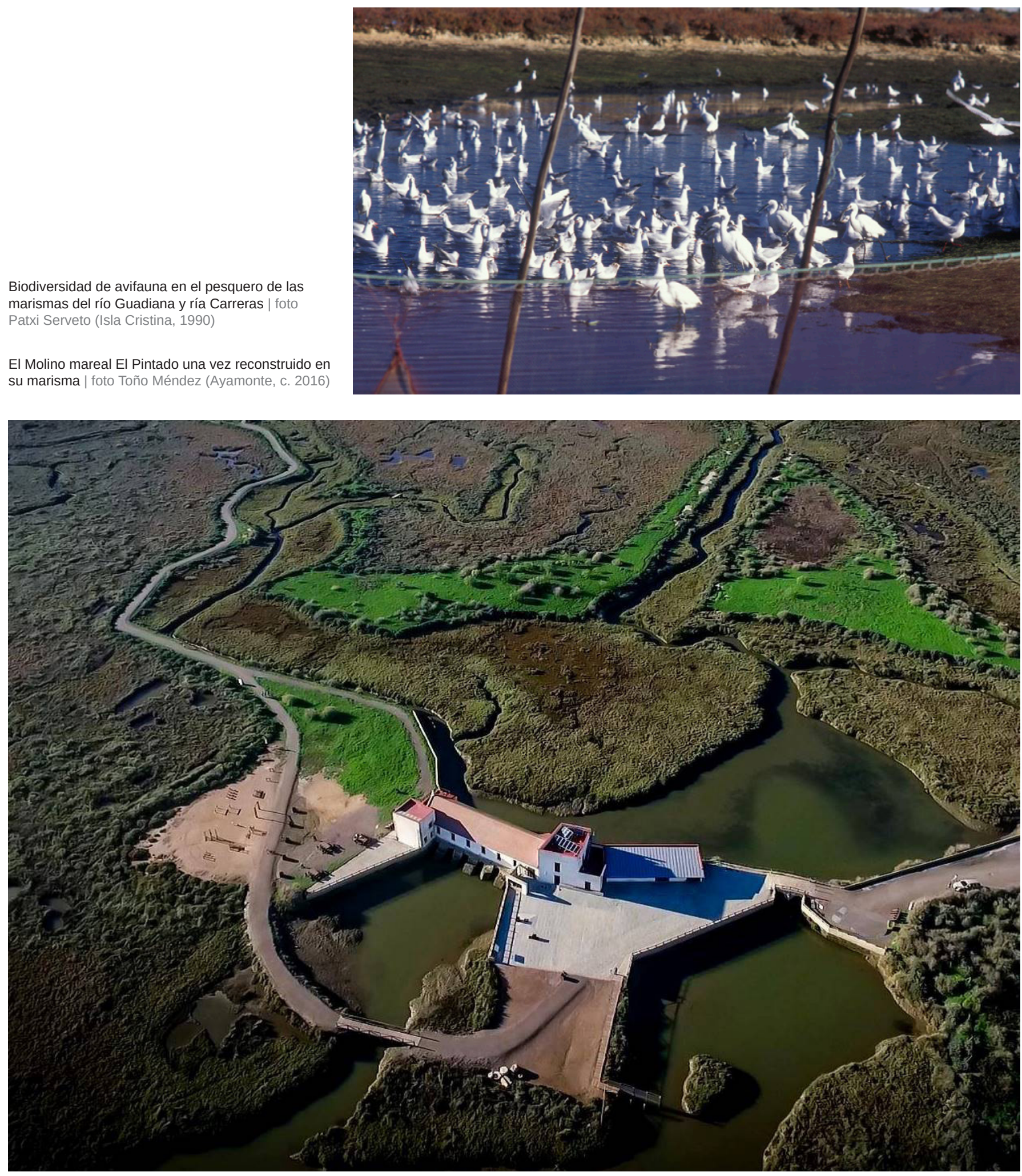


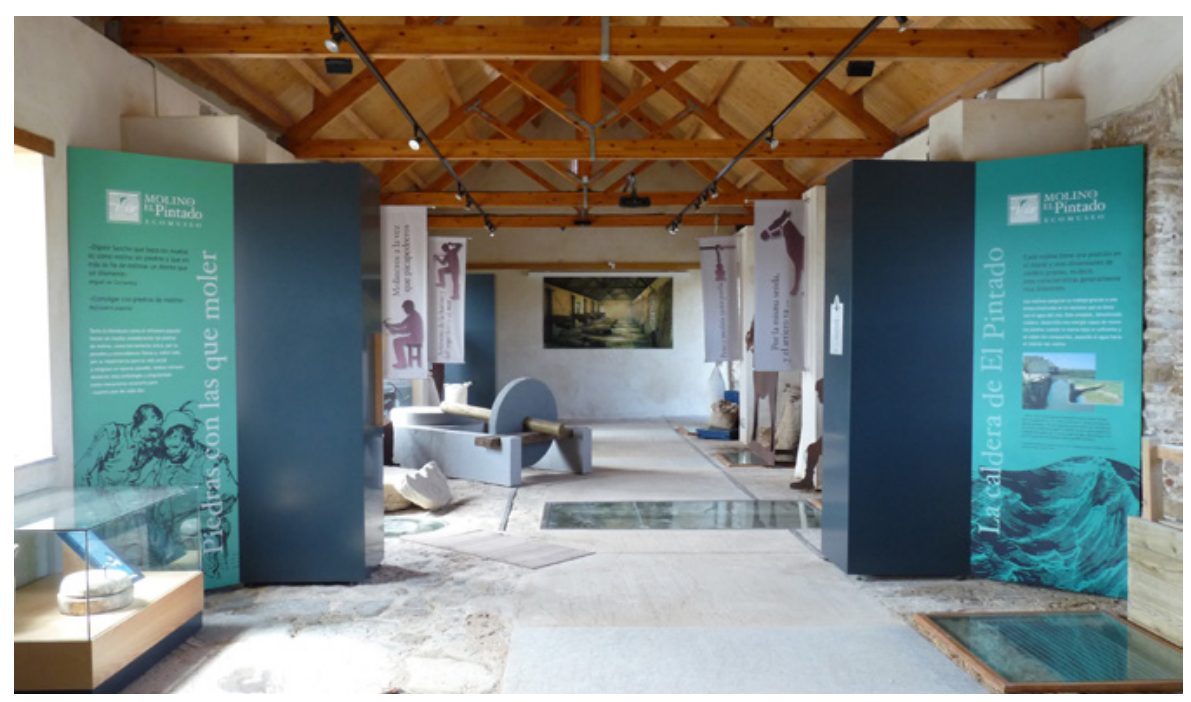

Su historia no solo expresa el vínculo existente entre las poblaciones costeras y los ámbitos marismeños como espacios de aprovechamiento de recursos naturales y de comunicación, sino que pone de relieve la vinculación del lugar con el mundo colonial de América.

La reconstrucción del molino mareal El Pintado (2007), y su rehabilitación como centro de interpretación del patrimonio cultural y natural para la creación de un ecomuseo² (2009), constituyó uno de los fines más emblemáticos que se propuso la Asociación de Amigos de los Molinos Mareales del Litoral Onubense, creada en Ayamonte en 1996 y dedicada al estudio, divulgación y puesta en valor de los molinos mareales de Huelva.

Paralelamente, en 2004 la Asociación solicitó a la Consejería de Cultura la inscripción, como bienes de catalogación general de manera colectiva, de los molinos mareales del litoral onubense en el Catálogo General del Patrimonio Histórico Andaluz, produciéndose en 2010.

Actualmente, el Ecomuseo del Molino Mareal El Pintado constituye un equipamiento de la Red de Espacios Naturales Protegidos de Andalucía, actuando como recepción del visitante, punto de información y ecomuseo del Paraje Natural Marismas de Isla Cristina; su gestión, mediante concesión administrativa, corresponde a Platalea XXI. Además de las actividades propias de la atención al visitante, desde el ecomuseo se desarrolla un amplio programa de dinamización en el que destacan:

1. Actividades educativas enmarcadas en los programas Naturaleza y Tú y Naturaleza para todos, ofertados por la Consejería de Medio Ambiente y Ordenación del Territorio.
Exhibición interpretativa en la sala de molienda del ecomuseo El Pintado | foto Patxi Serveto (Ayamonte, 2010)

$$
2
$$

Equipamiento destinado a revelar al visitante elementos del patrimonio ambiental (elementos geológicos, especies de flora y fauna, hábitat o paisajes) y cultural (actividades, construcciones o expresiones humanas como comportamientos y tradiciones, etc.) del espacio natural y su entorno (CONSEJERÍA DE MEDIO AMBIENTE, 2007: 43). 

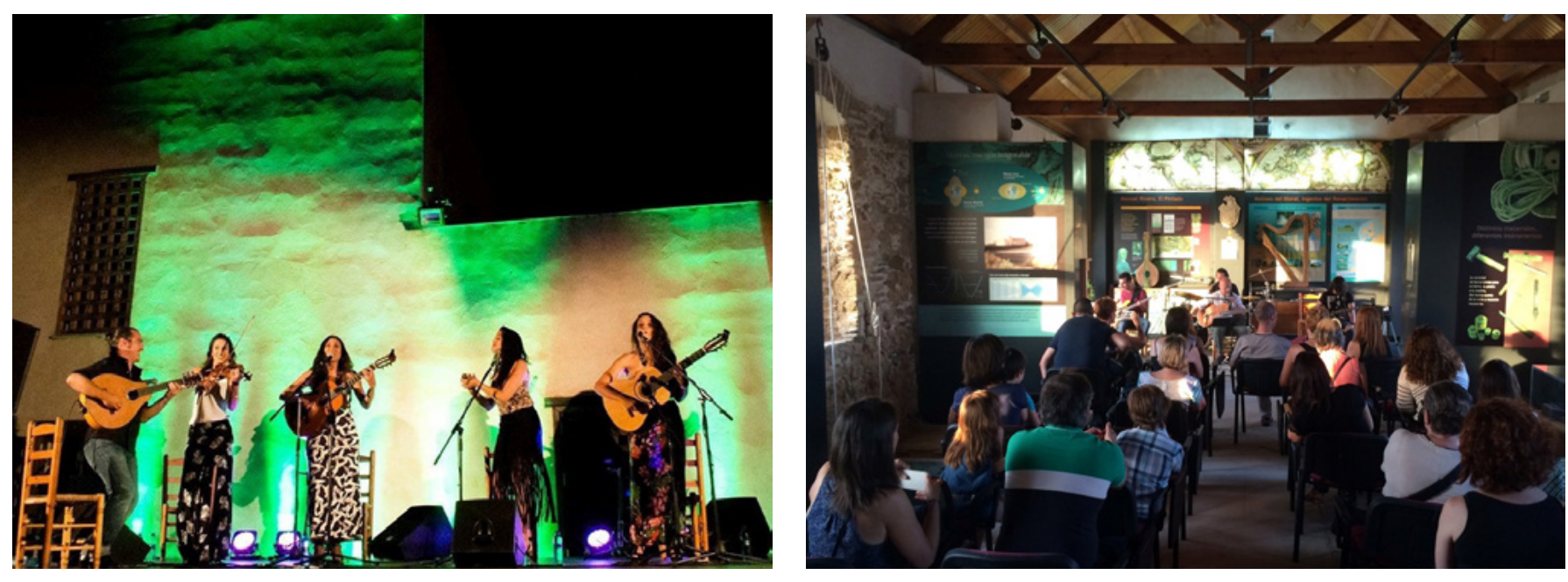

A la izquuierda, actuación de Las Migas en el exterior del Ecomuseo

Actuación de Dasare y Tolajarca en el interior del Ecomuseo | fotos PLATALEA
2. Celebración de efemérides, como el Día Mundial de las Aves, Día Mundial del Medio Ambiente o el Día Mundial de la Música.

3. Otras acciones: conciertos, actividades astronómicas, recitales de poesía, talleres de pan, etc. Sobresalen sin duda los conciertos y festivales, que atraen a numerosas personas. Es el caso del Festival de la luna llena "Lunáticos", que cuenta con actuaciones relevantes en cada edición.

El Ecomuseo Molino El Pintado es un espacio único donde poder conocer de primera mano la vinculación entre el ser humano y la marisma; un lugar donde confluyen naturaleza, historia, etnografía, cultura y tecnología. Un lugar que no puede dejar de visitar. 


\section{BIBLIOGRAFÍA}

- AZURMENDI PÉREZ, L. (1985) Molinos de mar. Santander: Colegio Oficial de Arquitectos de Cantabria, 1985

- AZURMENDI PÉREZ, L.; GÓMEZ CARBALLO, M. A.; MARCHÁN FIZ, S. et ál. (2005) Molinos de mar y estuarios. Litoral Atlántico. Santander: Litoral Atlántico-Asociación para la Conservación de la Arquitectura Tradicional (Tajamar), 2005

- BAS, B. (1991) Muiños de marés e de vento en Galicia. A Coruña: Fundación Pedro Barrié de la Maza, 1991

- CONSEJERÍA DE MEDIO AMBIENTE (2007) Manual de Equipamientos Medioambientales. Uso público en los espacios naturales de Andalucía. Sevilla: Junta de Andalucía, 2007

- CONSEJERÍA DE MEDIO AMBIENTE; GRUPO ENTORNO (2009) Exhibición interpretativa. Ayamonte: Ecomuseo del Molino de El Pintado, 2009

- ECOMUSEU MUNICIPAL DO SEIXAL (2005) Moinhos de Maré do Ocidente Europeu: revalorição do património natural e cultural enquanto recurso de desemvolvimento. En Encontro Moinhos de Maré do Ocidente Europeu 200405. Seixal: Câmara Municipal do Seixal (Portugal), 2005, p. 56

- GONZÁlEZ díAZ, A. M.; JARILLO MÁRQUEZ, F. J.; LÓPEZ ABREU, J. M.; LÓPEZ ABREU, T. (1996) LoS molinos mareales de Ayamonte. Andalucía Educativa, Año I, n. ${ }^{\circ} 3,1996$, pp. 38-39

- GONZÁleZ díAZ, A. M. (2004) Molinos de marea en Ayamonte: un modelo de utilización de los recursos naturales durante la Edad Moderna. En Actas de las VIII Jornadas de Historia de Ayamonte. Ayamonte: Área de Cultura (Ayuntamiento de Ayamonte), 2004, pp. 127-155

- GONZÁlEZ TASCÓN, I. (1992) Fábricas hidráulicas españolas. Madrid: Biblioteca CEHOPU, Centro de Estudios y Experimentación de Obras Públicas (Ministerio de Obras Públicas y Transportes), 1992

- GOZÁLVEZ ESCOBAR, J. L. (1996) Antiguos Molinos de viento, agua y mareales en la provincia de Huelva. Huelva Viva, n. ${ }^{\circ} 2,1996$, pp. 6-15

- JIMÉNEZ MANTECón, J. R. (1917) Platero y yo. León: Everest, 2007

- MADOZ E IBÁÑEZ, P. (1999) Diccionario GeográficoEstadístico-Histórico de España y sus posesiones de Ultramar. (1 ${ }^{a}$ ed. 1847) Huelva: Diputación Provincial, 1999

- MOLINA FONT, J. (2001) Molinos de Marea de la Bahía de Cádiz (siglos XVI-XIX). Cádiz: Junta Rectora del Parque Natural Bahía de Cádiz (Consejería de Medio Ambiente) e Instituto de Medio Ambiente (Mancomunidad de Municipios de la Bahía de Cádiz), 2001
- MOREnO Alonso, M. (2000) Retrato de familia andaluza con las Indias al fondo. El Memorial de El Pintado (1697-1780). Sevilla: Alfar, 2000

- MORENO ALONSO, M.; SOlESIO LILLO, J. (2001) Ayamonte en tiempos de El Pintado (1697-1780). En Actas de las $V$ Jornadas de Historia de Ayamonte. Ayamonte: Patronato Municipal de Cultura (Ayuntamiento de Ayamonte), 2001, pp. 155-173

- ORDEN de 11 de junio de 2010, por la que se inscriben en el Catálogo General del Patrimonio Histórico Andaluz, como bienes inmuebles de catalogación general, de manera colectiva, los molinos mareales del litoral, en los términos municipales que se citan. Boletín Oficial de la Junta de Andalucía, n. ${ }^{0}$ 122, de 23 de junio de 2010

- PARQUE NATURAL DA RIA FORMOSA (1993) Moinho de Maré. Olhão (Portugal): Instituto da Conservação da Natureza, 1993, folleto divulgativo

- Pleguezuelo HeRnÁNDEZ, A. (2005) Manuel Rivero. Los encargos artísticos de una mercader andaluz del siglo XVIII. Huelva: Diputación Provincial, 2005

- POULIQUEN, P. (2005) Moulins en Bretagne. Spézet: Coop Breizh, 2005

- RESOlución de 17 de diciembre de 2008, de la Dirección General de Bienes Culturales, por la que se incoa el procedimiento para la inscripción como Bienes de Catalogación General de manera colectiva en el Catálogo General del Patrimonio Histórico Andaluz, los molinos mareales del litoral de Huelva. Boletín Oficial de la Junta de Andalucía, n. ${ }^{\circ}$ 6, de 12 de enero de 2009

- ROSA SANTOS, L. F. (1992) Os moinhos de mare da Ria Formosa. Quarteira (Algarve; Portugal): Parque Natural da Ria Formosa (Instituto da Conservação da Natureza), 1992

- RUBIO GARCÍA, J. C.; SERVETO AGUILÓ, P. (2004) Molinos mareales del litoral onubense. En Salinas de Andalucía. Sevilla: Consejería de Medio Ambiente (Junta de Andalucía), 2004, pp. 78-79

- RUIZ GONZÁLEZ, J. E. (1999) Los pueblos de Huelva en el siglo XVIII (Según el Diccionario del Geógrafo Real D. Tomás López). Huelva: Diputación Provincial, 1999

- SANZ GARCÍA, I.; CALVENTE COCA, A. (1995) Molinos mareales de Ayamonte. Ayamonte: Escuela-Taller Guadiana (Ayuntamiento de Ayamonte), 1995

- SERVETO AGUILÓ, P.; LÓPEZ RIVERA, J.; GONZÁLEZ MARTíN, D. J. et ál. (2007) El molino mareal de El Pintado: proyecto de rehabilitación como Centro de Interpretación del Patrimonio Cultural y Natural del litoral onubense. En XI Jornadas de Historia de Ayamonte. Ayamonte: Área de Cultura (Ayuntamiento de Ayamonte), 2007, pp. 115-135 


\title{
El legado de Juan Ramón Jiménez en Moguer
}

\author{
Centro de Estudios Juanramonianos \\ URL de la contribución <www.iaph.es/revistaph/index.php/revistaph/issue/view/4253>
}

\section{RESUMEN}

La presencia del autor de Platero aún se hace patente en cada calle, en cada rincón y en cada esquina de su pueblo, Moguer. Hacia 1947, a iniciativa de un grupo de moguereños, se decide homenajear al poeta en el exilio creando una biblioteca pública con su nombre. En 1955, se complementa con un espacio expositivo dedicado al poeta. El matrimonio Jiménez, ilusionado con el proyecto, colabora activamente en la dotación de contenido. El 14 de noviembre de 1958 abre oficialmente al público sus puertas la casa museo.

La casa museo inicia su singladura como espacio museográfico, convirtiéndose en el eje vertebrador de la visita turística a Moguer. En ella se preserva todo el patrimonio que el poeta decide legar a su pueblo: su biblioteca personal de la etapa madrileña, su colección de revistas y periódicos, enseres personales, etc., elementos gracias a los cuales el visitante, al recorrer sus estancias, puede evocar ese Moguer en el que Juan Ramón Jiménez escribió la mayor parte de su producción literaria.

Hoy, el museo se presenta no solo como espacio de contemplación, sino como un instrumento multifuncional, y como eje vertebrador de propuestas en el marco de creación literaria, cultural, pedagógica y turística.

Moguer abarca un conjunto patrimonial imbricado tanto en la vida como en la obra de su poeta. Conocer a Juan Ramón es conocer Moguer. Y conocer Moguer es conocer a Juan Ramón.

\section{Palabras clave}

Casa Museo Zenobia-Juan Ramón Jiménez | Juan Ramón Jiménez | Moguer (Huelva) | Zenobia Camprubí | 


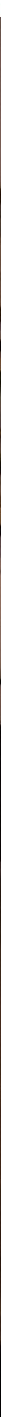

Despacho principal | foto Salvador Aguilar (Fototeca del Centro de Estudios Juanramonianos, titular de todas las imágenes que ilustran este texto) 
1

La casa situada en la Calle Juan Ramón Jiménez n. 10 continúa siendo en la actualidad la sede del museo y de la Fundación Zenobia-Juan Ramón Jiménez.

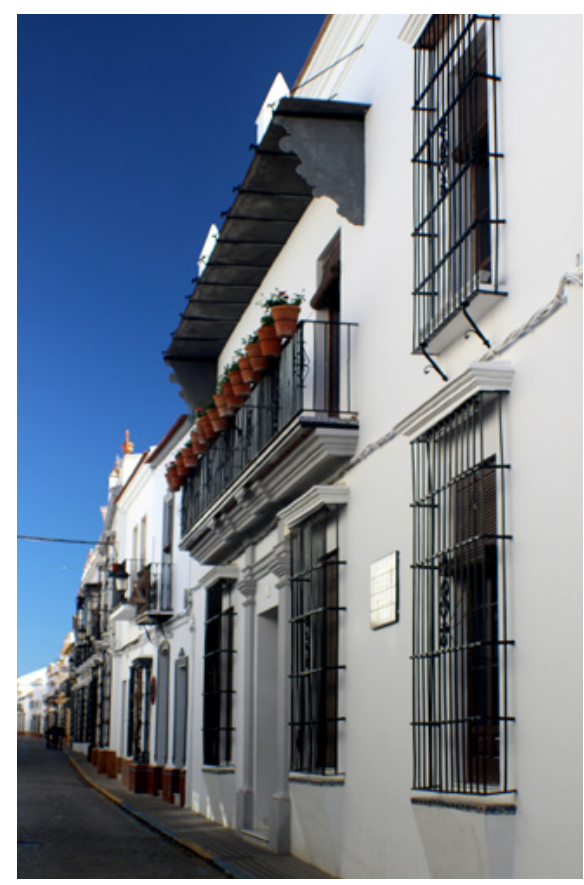

Fachada de la Casa Museo Zenobia-Juan Ramón Jiménez | foto José Manuel Millán
"Moguer, la blanca maravilla, la luz con el tiempo dentro..." (JIMÉNEZ, 2006). Así describía el poeta su pueblo natal, al que llevó durante toda su vida en forma de piedras en su bolsillo, muy cerca del corazón, para no perder el arraigo y la fuerza de su tierra (JIMÉNEZ, 1961). A pesar del paso de los años, la presencia del autor de Platero aún se hace patente en cada calle, rincón y esquina del municipio. Gracias a Juan Ramón, Moguer se universalizó y aún hoy son muchos los que acuden a su pueblo natal en busca de la tácita presencia del Nobel, queriendo ilustrar con imágenes lo que describe magistralmente a través de su obra.

Años antes de que fuese galardonado con el Premio Nobel, en 1947, a iniciativa de un grupo de moguereños, se decide homenajear al poeta en el exilio creando una biblioteca pública con su nombre (INAUGURACIÓN, 1947: 10). En 1955, se complementa con un espacio expositivo dedicado al poeta, que, a elección del autor, se ubicó en la casa familiar donde vivió desde sus cinco años ${ }^{1}$ y cuyas menciones son muy numerosas en sus Elegías andaluzas. También por expreso deseo de Juan Ramón, el nuevo museo se denominaría Casa Museo Zenobia Juan Ramón Jiménez, en homenaje también a su compañera de vida y, gracias al impulso y las gestiones del entonces alcalde de Moguer y diputado provincial, Juan de Gorostidi, la Diputación Provincial de Huelva adquiere el inmueble. El matrimonio Jiménez, ilusionado con el proyecto, colabora activamente en la dotación de contenido con varios envíos y da indicaciones para que casi todos los fondos que se conservaban en el Museo Romántico de Madrid, procedentes del piso de la calle Padilla -que tuvieron que dejar en la salida a su exilio en agosto de 1936fueran a Moguer. Además, destinan la mitad de la dotación económica del Premio Nobel al museo. El 14 de noviembre de 1958 abre oficialmente al público sus puertas la casa museo, tal y como se publica en el diario provincial Odiel Información (FLERY, 1958: 5-6).

La casa museo inicia su singladura como espacio museográfico, convirtiéndose en el eje vertebrador de la visita turística a Moguer. En ella se preserva todo el patrimonio que el poeta decide legar a su pueblo: su biblioteca personal de la etapa madrileña, su colección de revistas y periódicos, enseres, etc., elementos gracias a los cuales el visitante, al recorrer sus estancias, puede evocar ese Moguer en el que Juan Ramón Jiménez escribió la mayor parte de su producción literaria de la etapa española como Platero y yo, Elegías Andaluzas, Apartamiento, Baladas de primavera, Las hojas verdes...

En el año 2000 el inmueble sito en la calle Nueva debe ser cerrado al público para acometer labores de restauración, a la vez que se decide dar un giro y renovar el discurso museográfico adaptándolo a los nuevos tiempos (RAMÍREZ ALMANZA, 2006). De forma provisional, se habilita otro de los espacios juanramonianos de Moguer, la casa donde Juan Ramón Jiménez 


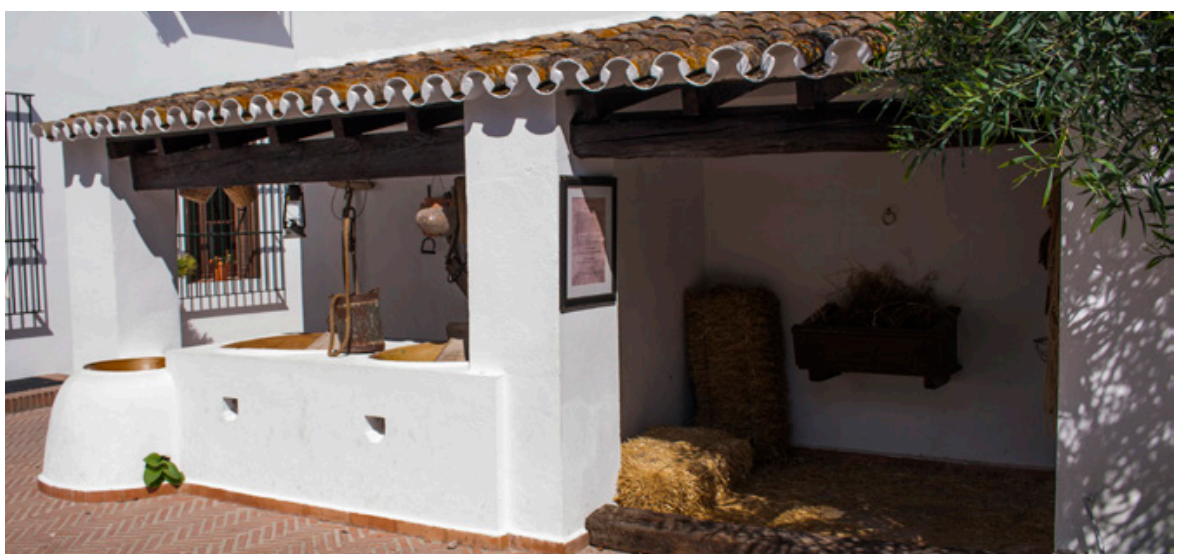

Corral y cuadra de Platero | foto Salvador Aguilar

nace, situada en el barrio de pescadores, en la calle Ribera, para que el legado continuase a disposición del visitante (JIMÉNEZ FERNÁNDEZ, 2006). Son años en los que se trabaja en la rehabilitación del espacio del poeta por excelencia, la casa museo, desarrollándose nuevos discursos museográficos y una nueva ordenación de los fondos del legado juanramoniano (BEJARANO ÁLVAREZ; RODRÍGUEZ DOMÍNGUEZ, 2006).

En diciembre de 2007, concretamente el 26, modernizadas las instalaciones museísticas, puesta al día la gestión y organizadas y digitalizadas todas las colecciones que alberga, abre sus puertas una remozada casa museo que en conjunto ofrece diferentes ámbitos de actuación, concebidos bajo una estructura más innovadora. Se ofrece una nueva visión que, sin perder el sabor de los espacios en los que vivió el poeta, introduce al público en una dimensión lírica, de evocación y conocimientos. Se presenta no solo como espacio de contemplación, sino como un instrumento multifuncional, y como eje vertebrador de propuestas en el marco de creación literaria, cultural, pedagógica y turística (RODRÍGUEZ DOMÍNGUEZ; MUÑOZ MORENO; BEJARANO ÁLVAREZ et ál., 2007).

La rehabilitación de la Casa Museo Zenobia Juan Ramón Jiménez permitió la ampliación de sus salas y asumir nuevas funciones de programación o actividades. Es un nuevo espacio creativo y cultural, donde se entrecruzan los planteamientos tradicionales junto a otros espacios que interpelan al mundo de las nuevas tecnologías multimedia. Se ha articulado otra imagen del legado a difundir.

Como mayoritariamente su público procede del ámbito educativo, el nuevo entorno se pensó como un instrumento pedagógico, intentando llegar a él con aplicaciones didácticas (guías pedagógicas, aulas especiales, talleres literarios, etc.). La casa se concibe como un espacio pedagógico donde cohabita la cultura didáctica de forma recreativa y lúdica.

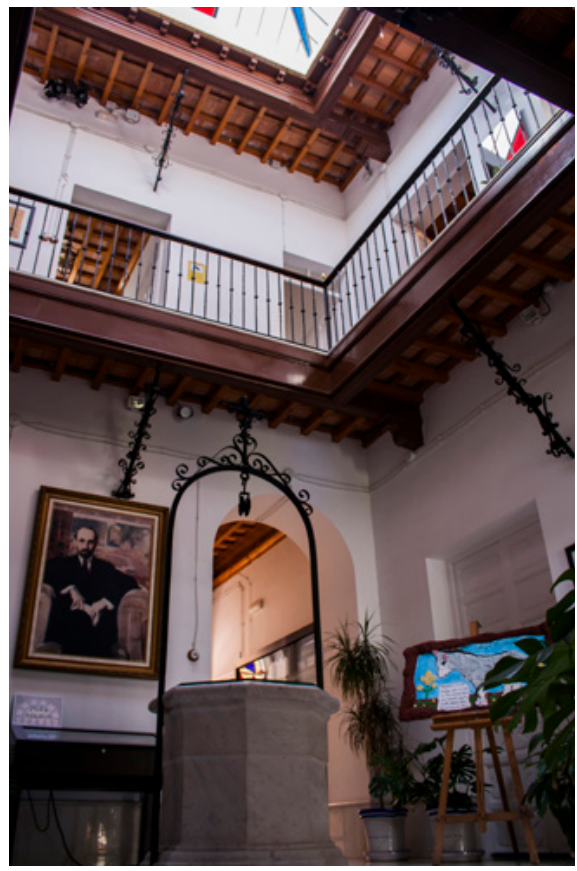

Interior Casa Museo Zenobia-Juan Ramón Jiménez | foto Salvador Aguilar 


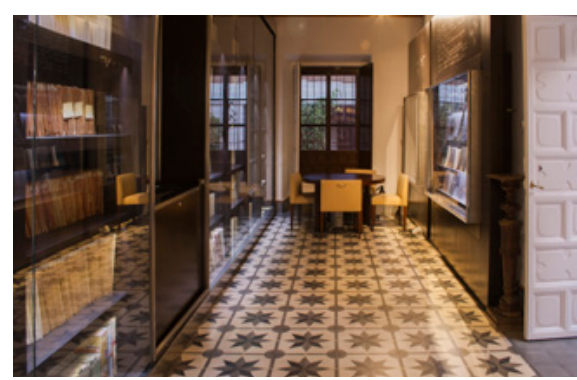

Hemeroteca personal de Juan Ramón Jiménez | foto Salvador Aguilar
2

Espacio web Año Platero <http://www. aytomoguer.es/es/ano-platero/> [Consulta: 21/09/2018]
Uno de los aspectos más importantes de la casa museo, al margen de su sentido de espacio visitable, es el legado que alberga, sus fondos puestos a disposición del investigador. Se articula como un espacio de investigación que tiene como fin último el acercamiento de la cultura bajo el aspecto de la exposición y de la consulta bibliográfica. Uno de los pilares fundamentales para esta faceta ha sido la creación del Centro de Estudios Juanramonianos, centro de documentación en torno a las figuras de Zenobia y Juan Ramón Jiménez, que se encarga de recuperar, adquirir, analizar, custodiar, conservar y difundir todo el patrimonio documental y bibliográfico existente en sus instalaciones.

Resultaría difícil entender hoy cualquier plan turístico de Moguer sin la presencia de la casa museo, no sólo por su faceta como garante del legado juanramoniano y espacio visitable, sino porque todo el municipio conforma el ámbito de creación del poeta. Moguer abarca un conjunto patrimonial imbricado tanto en la vida como en la obra de su poeta. Conocer a Juan Ramón es conocer Moguer, conocer la provincia de Huelva. Y conocer Moguer es conocer a Juan Ramón. Entendemos que ambos, en su universalización literaria e histórica, nos llevan a una oferta turística y cultural de primer nivel.

La promoción turística y cultural de la Casa Museo Zenobia Juan Ramón Jiménez no está exclusivamente en la casa donde vivió, contemplar sus pertenencias personales, muebles, enseres, libros, documentos... Juan Ramón Jiménez ofrece a través de su obra un paisaje, un ambiente, la traza de un Moguer descrito, vivido, con una atmósfera de tiempo y personajes latentes en un pueblo que puede ofrecer lo material e inmaterial del andaluz universal.

Desde el año 2014 en que se celebró el centenario de la primera edición de Platero y yo, se estructuró además una ruta por el patrimonio monumental y literario juanramoniano que se extendió por diferentes espacios de la localidad. Se crea un pasaporte del Año Platero, con el que se insta al visitante a recorrer todo el patrimonio juanramoniano e ir completando etapas para conseguir al final de ellas una edición conmemorativa de dicha obra. En ese recorrido se incluyen espacios como la casa natal de la calle Ribera, la visita al cementerio donde descansan los restos del matrimonio Jiménez, y a monumentos singulares como el monasterio de Santa Clara o la parroquia Nuestra Señora de la Granada. Además, se crea un museo al aire libre, Platero EsCultura, ubicando esculturas de personajes del inmortal Platero como Aguedilla, Darbón, el Tío de las vistas o Platero, en diferentes lugares estratégicos de su casco histórico².

Gracias a esta perfecta simbiosis entre la obra y los lugares donde el poeta desarrolla su actividad creadora, Moguer se ha convertido en el principal referente y epicentro del patrimonio material e inmaterial juanramoniano. 


\section{BIBLIOGRAFÍA}

- BEJARANO ÁlVAREZ, R.; RODRÍGUEZ dOMíngueZ, T. (2006) Juan Ramón Jiménez, su biblioteca personal. Revista Mi biblioteca, n. ${ }^{\circ}$ 7, 2006, pp. 22-28

- FLERY (1958) La Casa Zenobia y Juan Ramón de Moguer abre sus puertas al público. Odiel Información, 18 de noviembre de 1958, pp. 5-6

- INAUgURACIÓN de la nueva biblioteca municipal de Moguer (1947) ABC. Edición de Andalucía, 12 de octubre de 1947, p.10

- JIMÉNEZ, J. R. (2006) Nubes sobre Moguer. Leyenda (1896-2006). Madrid: Visor, 2006

- JIMÉNEZ, J. R. (1961) La Corriente infinita. Crítica y evocación. Madrid: Aguilar, 1961

- JIMÉNEZ FERNÁNDEZ, C. (2006) Un paseo por la casa natal del padre de Platero y yo. Revista Mi biblioteca, n. ${ }^{\circ} 7$, 2006, pp. $16-21$

- RAmírez ALMANZA, A. (2006) Síntesis del proyecto museográfico para la Casa-Museo Zenobia-Juan Ramón Jiménez. Revista Montemayor, 2006, pp. 36-43

- RODRÍGUEZ DOMíNGUEZ, T.; MUÑOZ ROMERO, R.; BEJARANO ÁLVAREZ, R.; GONZÁLEZ ZAPATERO, M. (2007) Casa Museo Juan Ramón Jiménez-Zenobia Camprubí Moguer, Huelva. En III Encuentro Internacional Actualidad en museografía. Mérida, 24-26 de septiembre de 2007. Madrid: ICOM-España, 2008, pp. 61-83 


\section{Una breve incursión por el Carnaval de Isla Cristina, una celebración centenaria}

Agustín P. Figuereo | historiador

URL de la contribución <www.iaph.es/revistaph/index.php/revistaph/issue/view/4348>

\section{RESUMEN}

El Carnaval de Isla Cristina, declarado de Interés Turístico de Andalucía, es la fiesta por antonomasia de la localidad. Celebrada desde el propio origen de la población a mediados del siglo dieciocho, ha ido creciendo a lo largo del tiempo, tanto en duración como en componentes que lo hacen único frente a otros de la zona y conjugando un período especial donde el pueblo se manifiesta tal cual, siendo capaz de enfrentarse abiertamente al poder establecido y demostrando su fuerza.

\section{Palabras claves}

Carnaval | Comparsas | Concurso de agrupaciones | Coros | Fiesta | Isla Cristina (Huelva) | Murgas | 


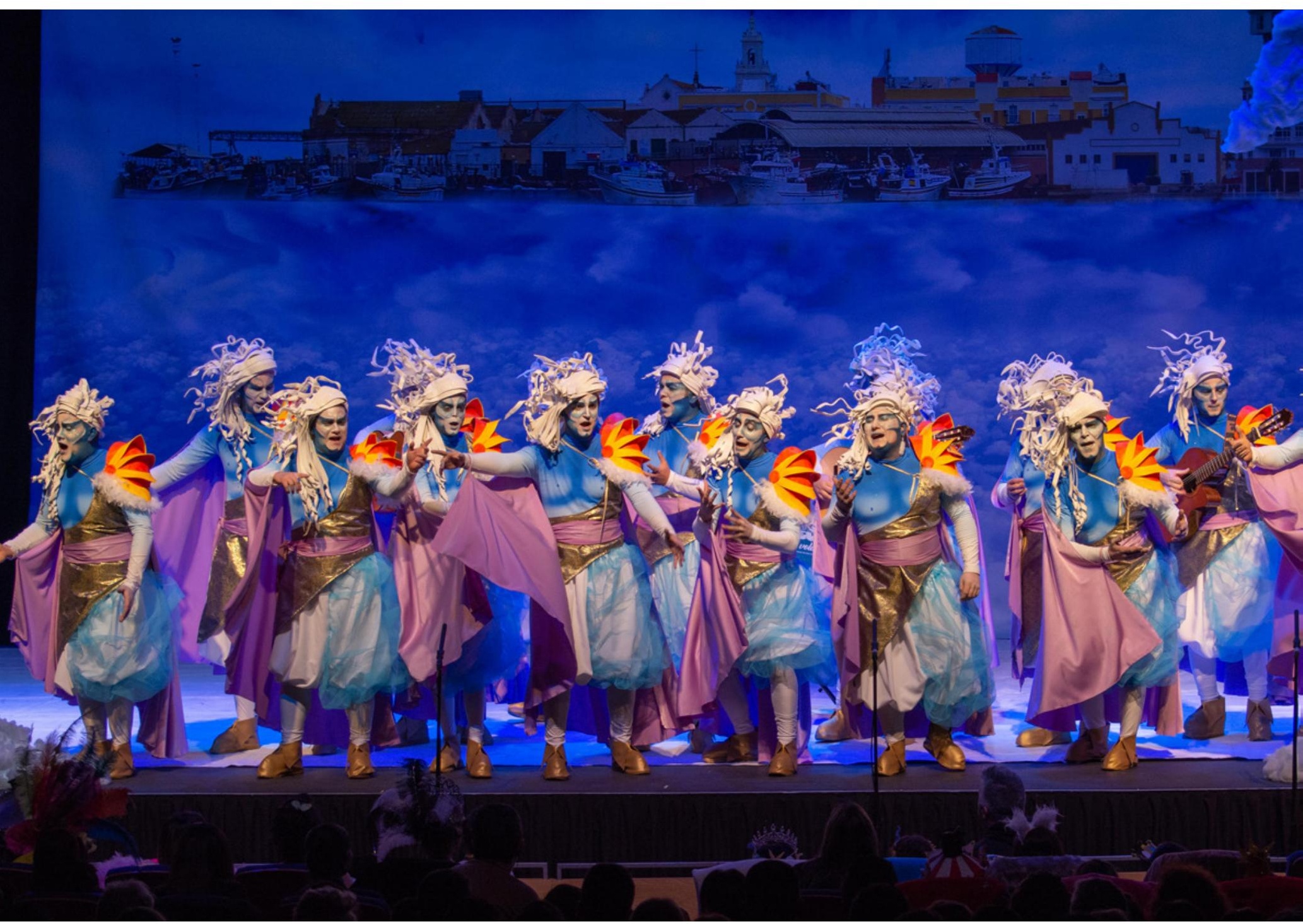

Actuación de una comparsa en el Teatro Municipal "Horacio Noguera" | foto Joaquín Cristóbal, autor de todas las imágenes que ilustran este artículo 
1

Archivo Municipal de Isla Cristina (en adelante, AMIC), Leg. 46, Bando con las normas para la salvaguarda del orden y la moral en la ciudad, 1832

2

AMIC, Leg. 46, Bando, 1858
El Carnaval de Isla Cristina es, sin duda, la fiesta más auténtica y genuina de todas las que se celebran en la localidad.

Tiene su origen, probablemente, en el siglo XVIII, cuando se configura el actual núcleo urbano a raíz del terremoto-maremoto llamado de Lisboa, ocurrido el 1 de noviembre de 1755 . Desde fechas muy tempranas hay constancia de algún tipo de celebración en torno a las fechas de Carnaval, históricamente los tres días anteriores al Miércoles de Ceniza, donde los Ilamados "traficantes de salados" de procedencia catalana y levantina daban por finalizada la temporada en nuestra tierra y emprendían el retorno a sus lugares de origen para volver, de nuevo, en torno a la festividad de San Pedro a finales del mes de junio.

Una vez que la población fue asentándose y consolidándose en el territorio, el Carnaval fue desarrollándose, apareciendo las primeras referencias escritas, de manera transversal, en torno al año 1832, cuando el regidor Lorenzo Elías dicta unas "prevenciones" para proteger la moralidad de los habitantes de la Real Isla. Dos de ellas afectan directamente a nuestra fiesta:

" $33^{a}$. No se prohíben las mascaras y diversiones racionales en los tres días de Carnestolendas autorizadas por el tiempo y la costumbre.

$34^{a}$. No se consideran contenidas en la prevención $33^{a}$ la multitud de prácticas abusivas que ni tienden al placer ni desahogo público ni guarden conformidad con la seguridad personal, el decoro popular, la decencia ni las buenas costumbres"1.

Otro bando, esta vez de 1858, recoge la prohibición de vestir con trajes de ministros de la religión, militares o institucionales, llevar armas o verter aguas fecales sobre los enmascarados. A su vez, se permitía una mayor apertura de los establecimientos de juego y de bebidas, que permanecerían abiertos "hasta el toque de ánimas"2.

En esos años se produce un cambio sustancial en las fiestas, ampliándose su celebración al fin de semana anterior al miércoles de ceniza, además de los tres días ya consabidos, y aunque en 1867 hay un intento de volver a los días concretos, no fue posible conseguirlo por parte de la autoridad.

Isla Cristina, que contaba con un teatro estable al menos desde 1868, incorpora este elemento a su Carnaval a partir de entonces. Desde aquel primitivo teatro, cuyo nombre se desconoce, pero que estaba establecido en la calle San Salvador, hoy denominada Diego Pérez Milá, pasando por el Teatro Flores (levantado por Juan Flores Amo en terrenos de su propiedad en la llamada por él calle Flores) o, ya avanzado el siglo XX, por el Salón Circo 
Victoria, el Gran Vía, el Cine Victoria, el Palacio del Carnaval y, desde principios del siglo XXI, el Teatro Municipal "Horacio Noguera", los diferentes coliseos han jugado un importantísimo papel en las fiestas, primero como lugar de celebración de bailes públicos y luego como sede de un genuino concurso de agrupaciones musicales.

Las ordenanzas municipales de $1876^{3}$ ya recogen formalmente al Carnaval dentro del epígrafe de "Festividades populares", dedicándole doce artícu-
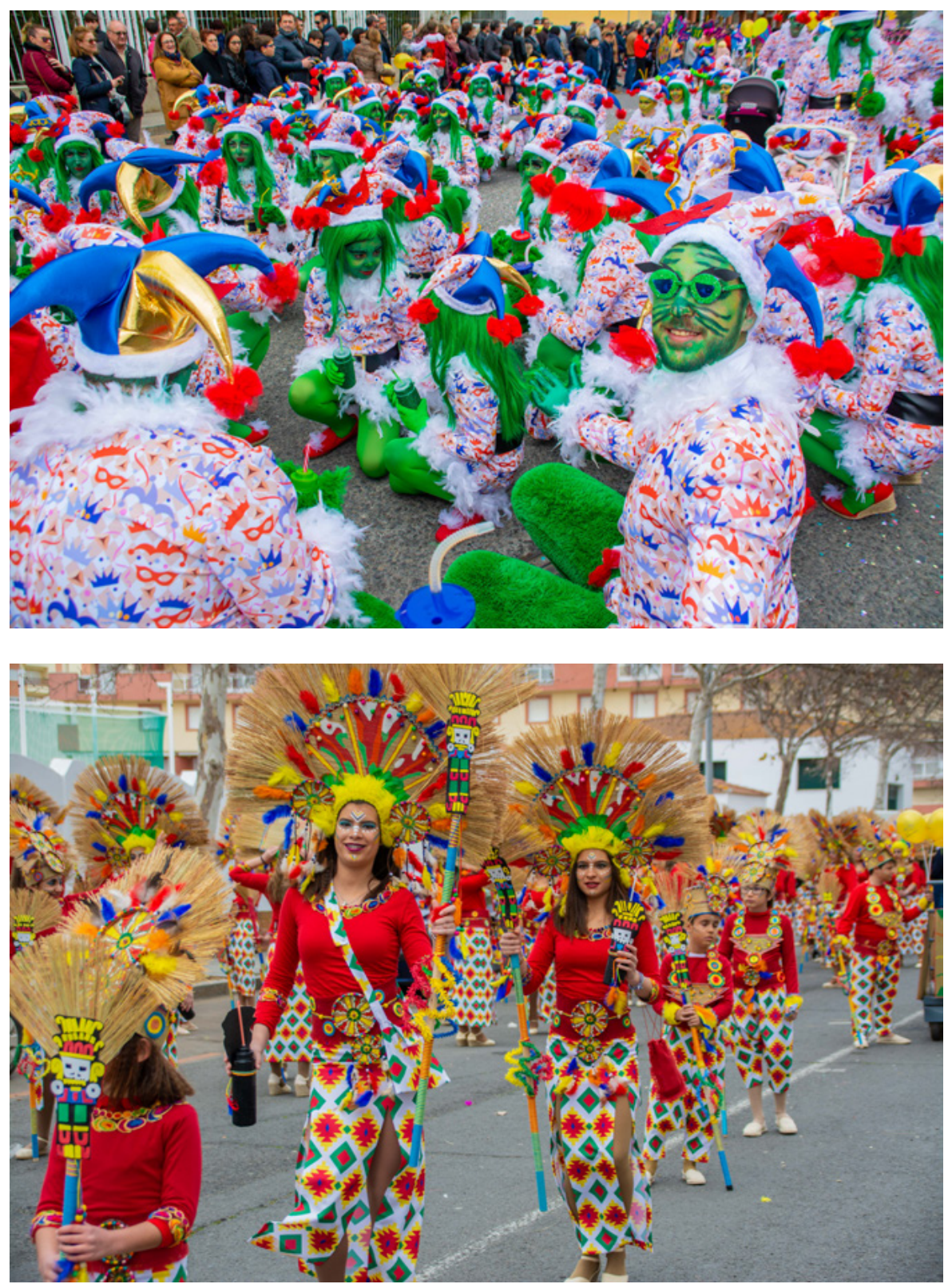

3

AMIC, Leg. 93, Ordenanzas Municipales, 1876.

Grupo de disfraces en la Gran cabalgata 


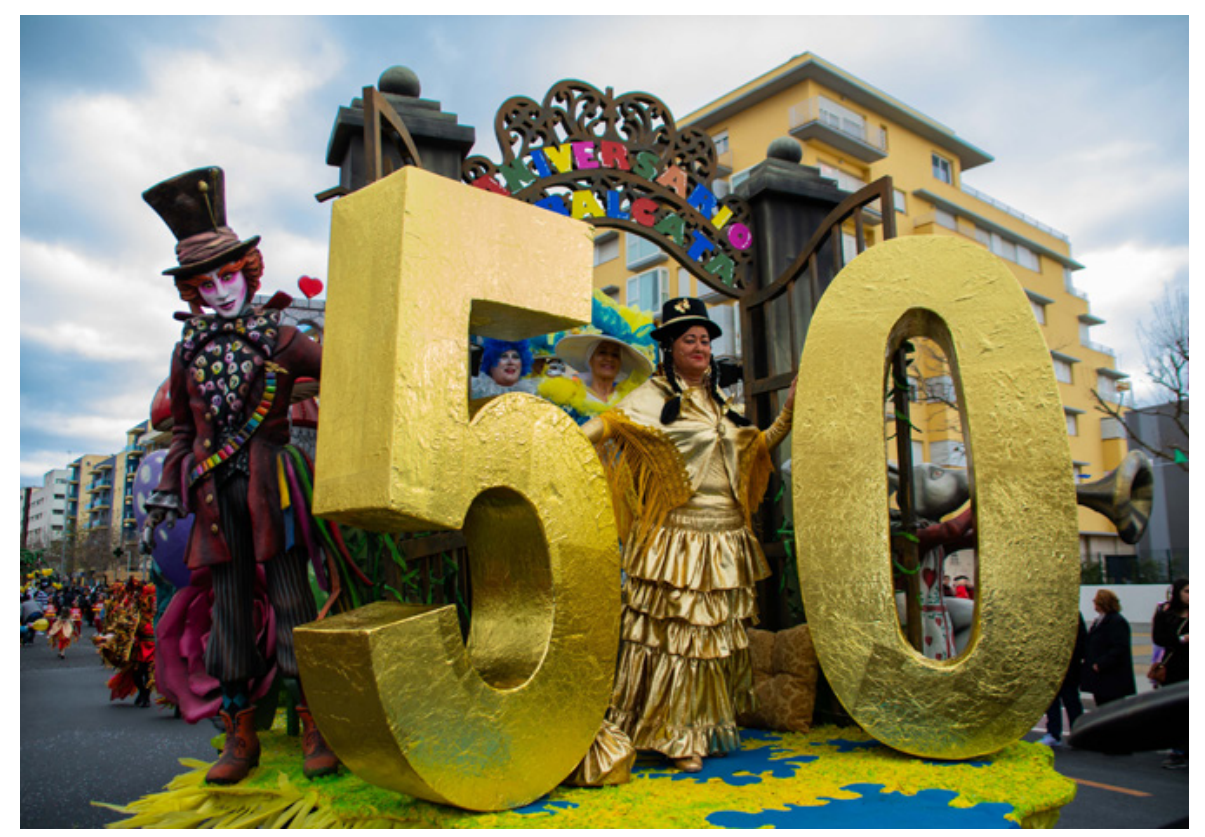

los, donde además de insistir en lo expuesto en bandos anteriores en relación con la prohibición de disfrazarse de miembros del ejército o del clero, de portar armas "o espuelas", arrogaban a la autoridad municipal competente el derecho a desenmascarar a aquellos que cometieran alguna falta, a presidir las funciones del teatro, al comportamiento del público en el mismo $y$, por primera vez, fijaban unas multas que oscilaban entre cinco y diez pesetas.

Contamos ya con el esquema básico por el que será conocido el Carnaval de Isla Cristina: por un lado, la importancia de la calle, de la diversión espontánea de la gente disfrazada dando paseos, gastando bromas y divirtiéndose sanamente, culminando todo ello en el día más importante del Carnaval, el Miércoles de Ceniza, día en el que se celebra el Entierro de la Sardina como verdadero fin de fiestas; de otro, con la aparición del teatro, nacen los bailes de sociedad y también entra en escena el elemento musical.

La influencia que recibe el Carnaval de Isla Cristina es triple, actuando como verdadero lugar donde se produce un choque de culturas: los primitivos fundadores, provenientes del noreste peninsular traen sus celebraciones $y$, casi con total seguridad, aportan el Entierro de la sardina; Cádiz está presente, como capital marítima de la cual dependió la Real Isla de la Higuerita (antigua denominación de Isla Cristina) durante muchísimos años, en la forma de entender las agrupaciones musicales; por último, la cercanía de Portugal, de donde no solo llegaron muchísimos trabajadores sino también la idea de los desfiles, los disfraces más elaborados, etc. 


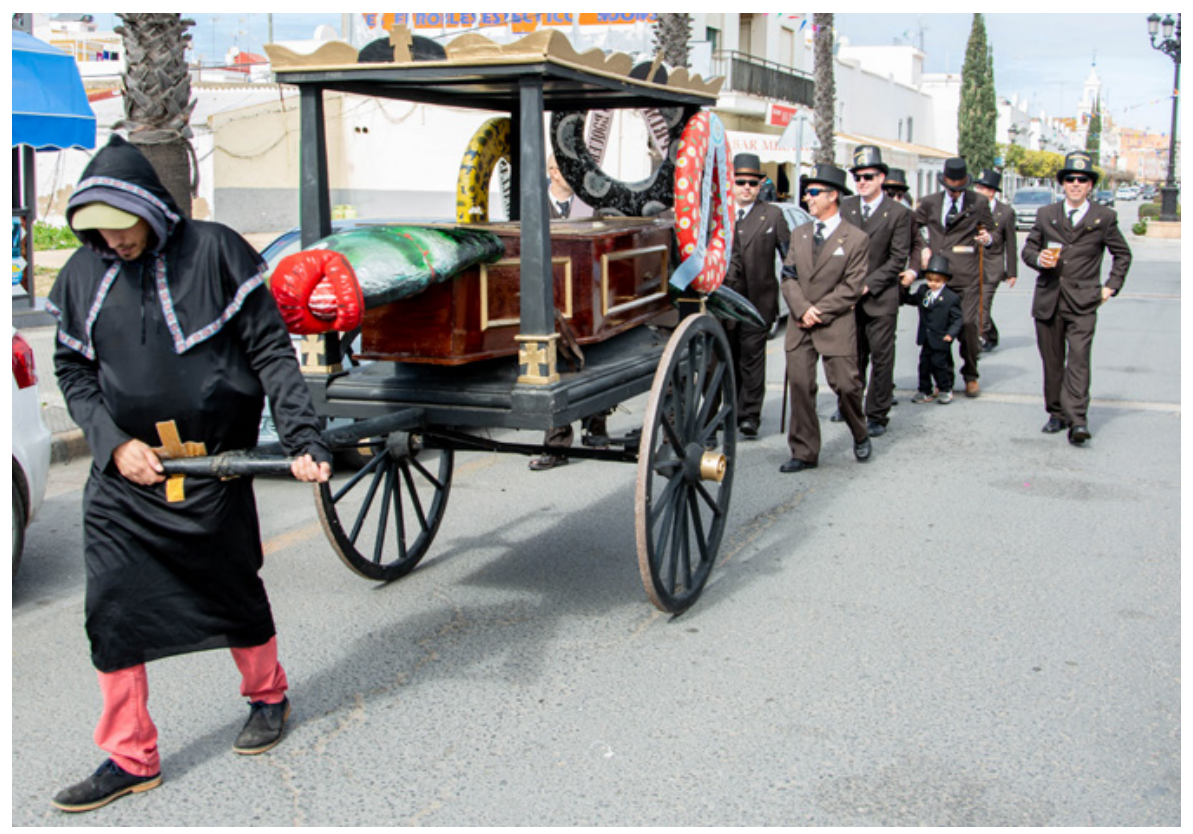

Cortejo fúnebre previo al Entierro de la sardina

Al hilo de la influencia gaditana, por ejemplo, cabe destacar la visita realizada a nuestra ciudad por el mítico coro Los Anticuarios, en la temprana fecha de 1906, en una gira como las que hoy en día se realizan, y que dejó flotando en el aire los sones de aquel mítico tanguillo de "Los duros antiguos". No obstante, la primera letra de carnaval documentada en Isla Cristina se fecha aproximadamente hacia 1880-1881.

Tres modalidades musicales se convertirían en las básicas durante el primer tercio del siglo XX, el coro, la comparsa y la murga. El coro lo conformaban alrededor de cuarenta componentes, acompañados de multitud de instrumentos musicales: violines, guitarras, laúdes, flautas, saxofones, etc.; la comparsa, formada por un número bastante inferior de miembros, llevaban, como hoy, guitarras, bombos y pitos, siendo su repertorio más serio; por último, las murgas aportaban la parte más cómica y grotesca, con letras humorísticas y donde no solía haber instrumentos de cuerda, únicamente bombos, cajas y pitos de caña.

Del año 1919 data una histórica fotografía que recoge dos hechos fundamentales del Carnaval de Isla Cristina, documentando, de una parte, a una comparsa, "Las Regiones Españolas", siendo la primera imagen que tenemos de una agrupación, pero, de otra parte, nos la muestra en una actuación en plena calle, en algo así como la primera carroza que podemos fechar, con la importancia que para la fiesta tiene hoy en día la Gran cabalgata. En dicha imagen los miembros de la comparsa están sobre un carro decorado con los mismos escudos que lucía la agrupación, siendo el carro tirado por un mulo. 


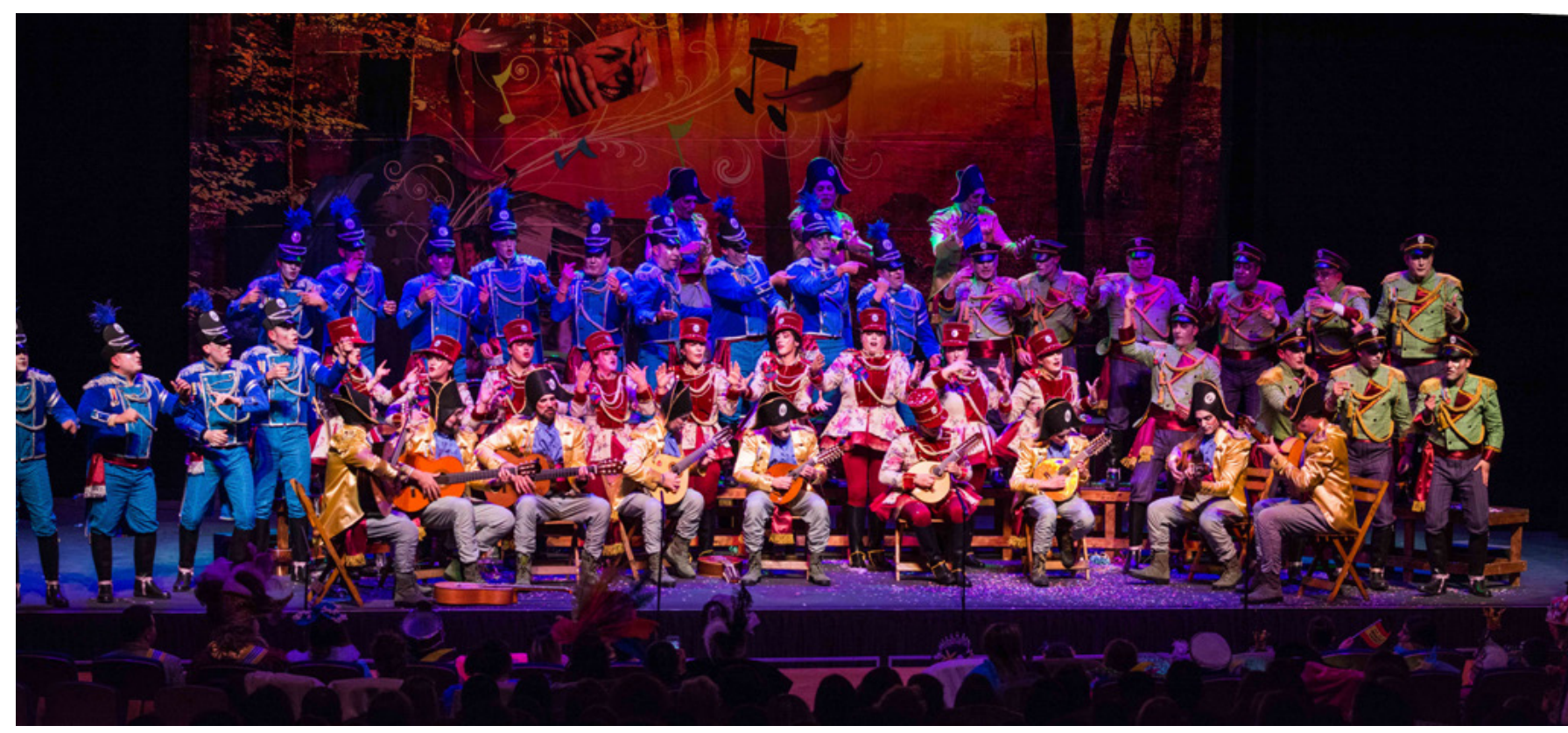

Actuación de un coro en el Teatro Municipal "Horacio Noguera" | foto Joaquín Cristóbal

A partir de entonces nacerán los reñidos concursos entre agrupaciones, a la vez que continuaba celebrándose la calle, ahora alargándose hasta el domingo posterior al Miércoles de Ceniza con la tradicional rotura de piñatas, y los bailes celebrados en teatros, casinos y sociedades de recreo.

La Guerra Civil de 1936 acabaría con todo esto, siendo muchos de los autores y directores más destacados del carnaval fusilados $u$ obligados a marchar al exilio.

Sin embargo, y pese a la prohibición oficial del Carnaval por parte de la dictadura, a partir de mediados de la década de 1940 se conservan los primeros testimonios gráficos de disfraces callejeros, convirtiéndose el salir a la calle en todo un desafío a la autoridad que, sin embargo, fue bastante permisiva.

Las carrozas empezarían a tomar las calles prácticamente una década después, mientras que el concurso de agrupaciones volvió a celebrarse a partir del año 1968 bajo el nombre de Fiestas Típicas de Invierno, siguiendo fiel a su fecha invernal, a diferencia de otras localidades.

El crecimiento del Carnaval, declarado Fiesta de Interés Turístico, ha ido a más, contando con una duración aproximada de tres semanas incluyendo todos sus formatos, desde el concurso de agrupaciones hasta el Domingo de Piñatas, con días que pasan por mayor predilección del público al socaire de las modas y los gustos porque, al final, el carnaval lo hace el pueblo y poco control tiene. 


\section{BIBLIOGRAFÍA}

- BIEDMA VISO, J. (2004) Carnavales de Isla Cristina. $2^{a}$ Ed. Isla Cristina: Ayuntamiento, 2004

- BIEDMA VISO, J. (1992) Carnavales de Isla Cristina (1982-1992). José Biedma Viso, 1992

- FiguereO, A. P. (2001) El Sexenio Revolucionario en Isla Cristina. Boletín de Estudios Históricos ELD, Asociación Cultural El Laúd, Isla Cristina, 2001

- LÓPEZ MÁRQUEZ, V. (2006) Isla Cristina. Por los caminos de la Historia. Huelva: Diputación Provincial, 2006

- SOSA RODRíGuEZ, J. (1970) Historia de Isla Cristina (Biografía sentimental). José Sosa Rodríguez, 1970 


\section{La salina de Biomaris (Isla Cristina). La última instalación artesanal de la costa onubense}

Daniel Martínez Castizo | historiador y antropólogo

URL de la contribución <www.iaph.es/revistaph/index.php/revistaph/issue/view/4256>

\section{RESUMEN}

Desde la antigüedad, la costa de Huelva se ha caracterizado por una intensa y dinámica actividad salinera. Hoy día, la única instalación que de forma activa da fe de dicho pasado es la salina de Biomaris en Isla Cristina. Esta instalación es heredera de la industria salazonera que, desde el siglo XVIII y hasta mediados de siglo XX, transformó la economía del territorio y configuró un particular paisaje de muros, esteros y calentadores en el interior de las marismas onubenses. Para poder sobrevivir a la dura competencia del sector industrial, Biomaris apostó en 2005 por la revalorización del patrimonio paisajístico y cultural salinero, así como por conservar la producción artesanal e introducir nuevos productos.

\section{Palabras clave}

Biomaris | Ecoturismo | Isla Cristina (Huelva) | Producción artesanal | Revalorización | Sal | Salinas | 


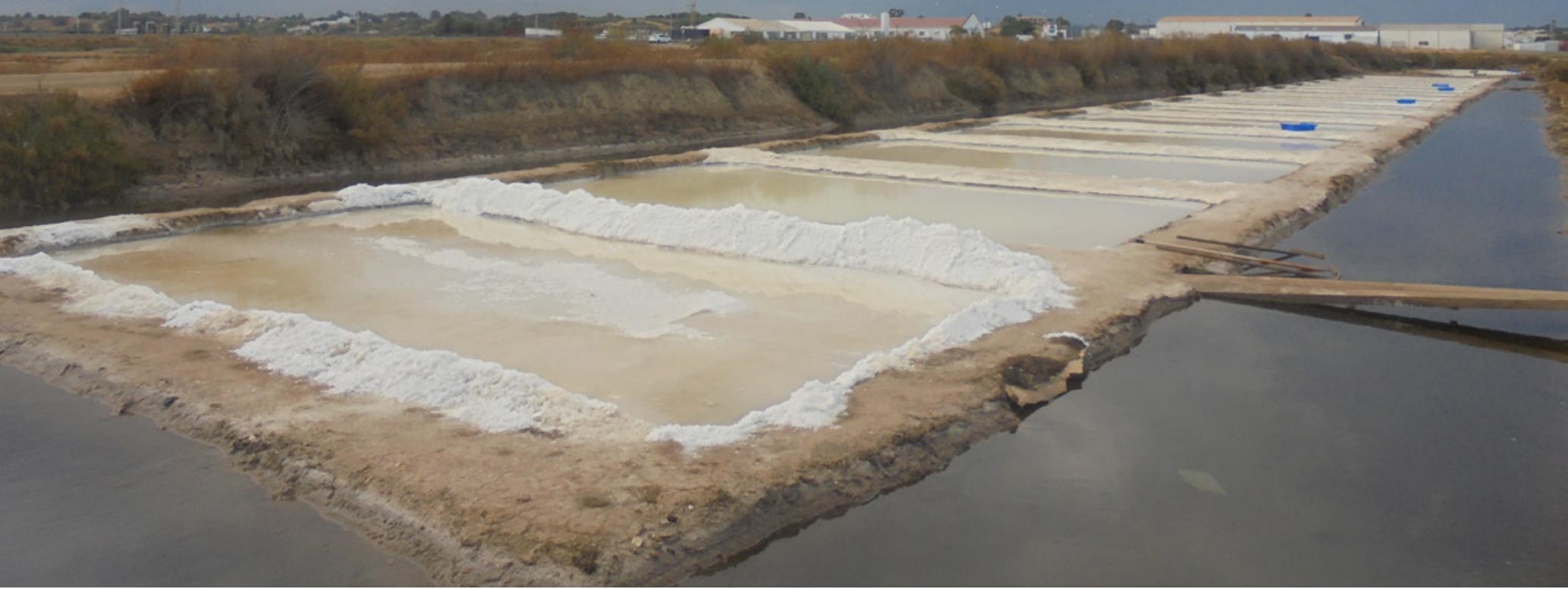

Eras de precipitación desde la que se extrae la Flor de sal | foto Daniel Martínez Castizo, 2017, autor de todas las imágenes que ilustran esta contribución 
En el paraje natural Marismas de Isla Cristina, entre el Caño del Puntal y el Placerón, se encuentra ubicada la salina de Biomaris, la última instalación salinera de la costa onubense que mantiene la actividad tradicional en el cosechado de la sal.

Esta pequeña salina, cuyas dimensiones no van más allá del kilómetro cuadrado, se ha convertido en todo un símbolo de resistencia y representatividad de lo que un día fue el patrimonio salinero en esta parte del Golfo de Cádiz. Y es que, desde Ayamonte hasta la desembocadura del Guadalquivir, entre los siglos XVIII y XIX, la costa se fue plagando de salinas al socaire de la industria salazonera que catalanes y levantinos habían introducido en torno al boquerón, la sardina y el atún.

A comienzos de siglo XX ya se había alcanzado el punto álgido con la consolidación de 22 salinas para, desde la década de los cincuenta, empezar una progresiva decadencia provocada por la reducción de los caladeros, la incapacidad competitiva de las salinas frente a las modernas industriales y la aparición de nuevos métodos de procesado y conservación de alimentos.

Puntualmente se viviría unos años de repunte asociado al hambre de la posguerra que disparó la demanda de sardinas en salazón. Además, el Estado franquista permitió la instalación de sociedades y altos mandos nazis en diferentes sectores productivos como medio de pago económico y político a los préstamos efectuados (372 millones de marcos según convenio MadridBerlín de agosto de 1941), por la Alemania del III Reich.

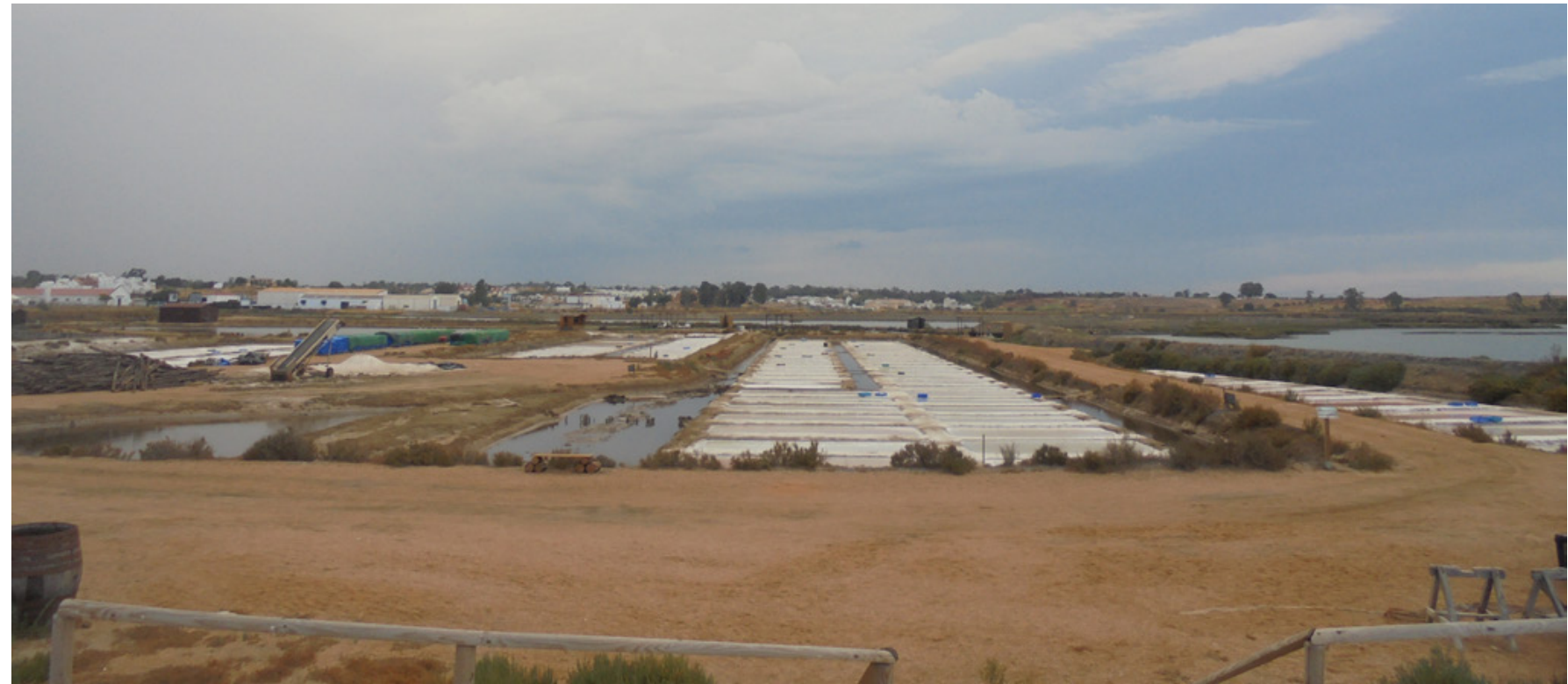




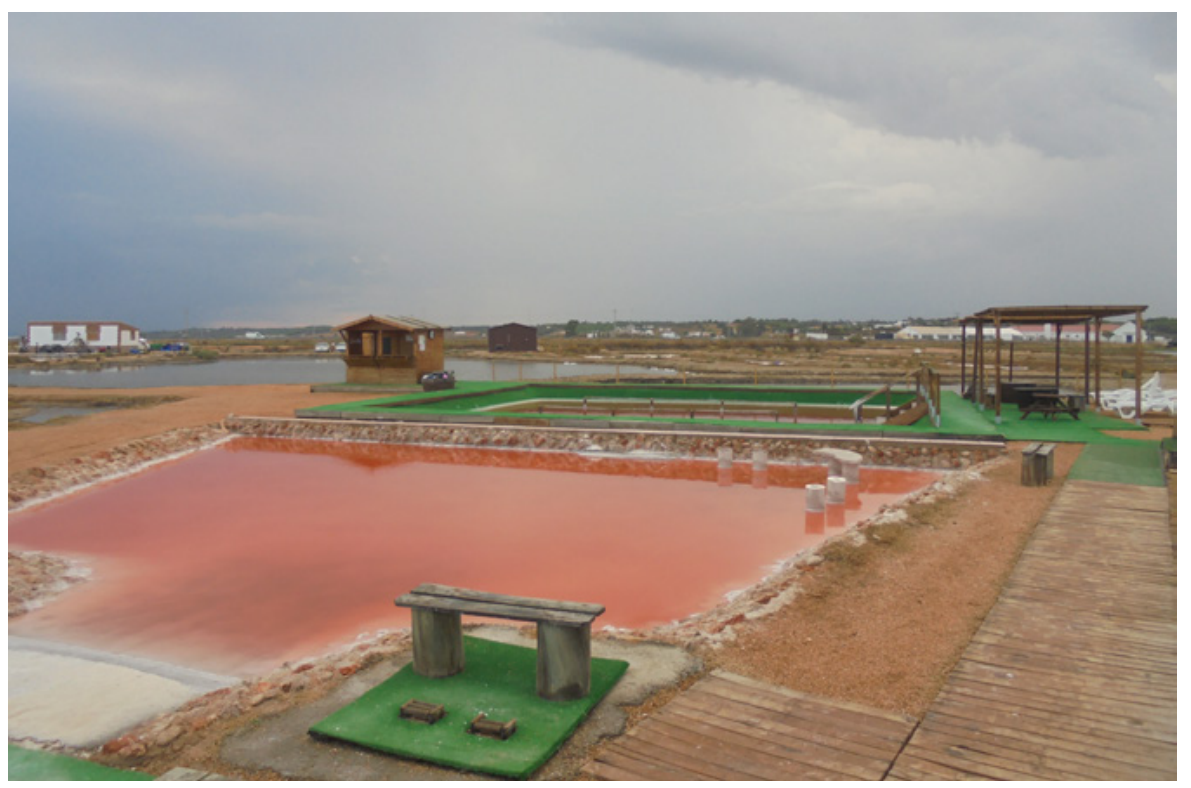

A través de este contexto se explica la aparición en Isla Cristina de Adolf Clauss (jefe de la Abwehr), conocido en la localidad como "Juan El Alemán". En 1954 Clauss llega a la localidad como representante de la empresa de cosméticos alemana Biomaris, una compañía interesada en la obtención de sal para su exportación. Un año después, el "empresario" logra que la salina se encuentre en funcionamiento con la particularidad de que la cristalización, para lograr una mayor pureza en cloruro de sodio, tenía lugar en lebrillos y no en eras de precipitación.

A la muerte de Clauss, es Manuel Rodríguez, maestro salinero de Biomaris, quien se hace con las riendas de las instalaciones y reorienta la producción hacia la sal gorda que puede colocar en las fábricas salazoneras de Isla Cristina y Ayamonte. Durante casi 40 años mantiene viva las instalaciones, asiste a la desaparición del resto de salinas artesanales -convirtiéndose así en el único ejemplo activo del pasado salinero onubense-, y contempla con resignación la aparición de un duro competidor industrial como es Marismas del Odiel.

En 2003 la propiedad pasa a su hija Manuela, quien para sostener la herencia se suma a la incipiente generación de nuevos salineros del medio rural que, como en el resto de Europa, reorientan la producción hacia nuevos productos y aprovechamientos.

Para ello y, en primer lugar, decide mantener como seña de identidad la producción artesanal con la creación de la sociedad "Flor de Sal Salinas de Isla Cristina-Biomaris", a través de la cual apostará por la calidad y no la can-

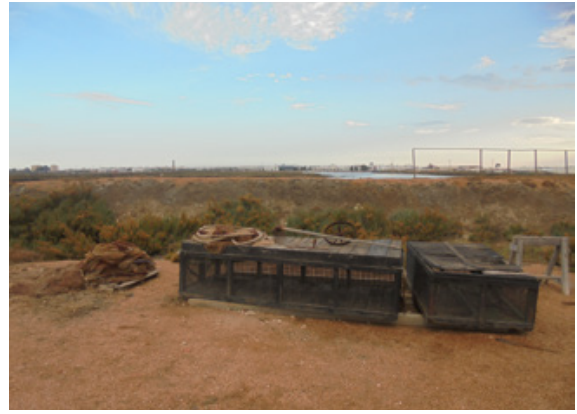

Aperos tradicionales de cosecha y pesca 


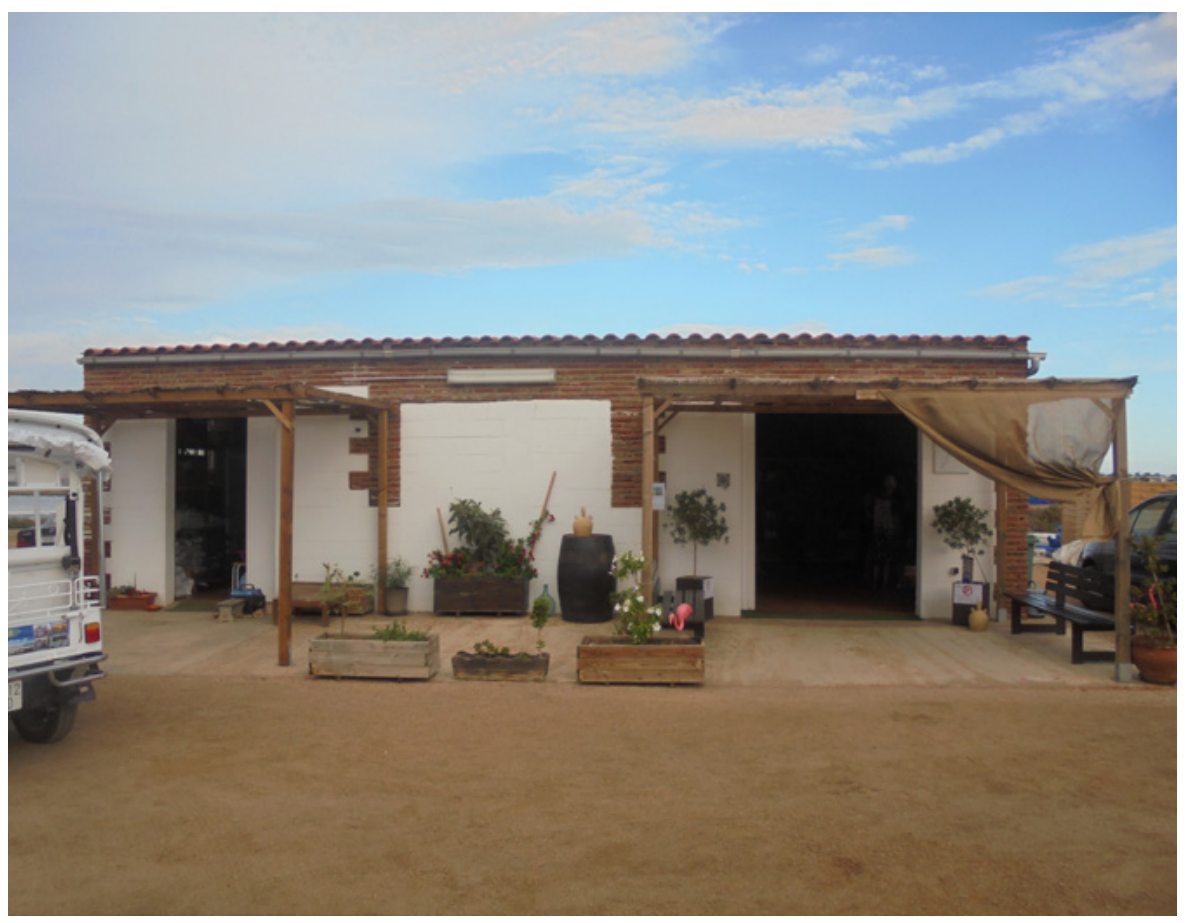

tidad. Posteriormente se centra en la revalorización de las potencialidades naturales del entorno (visitas guiadas y talleres de sal); también amplía la oferta de servicios (baños de magnesio); así como la línea de productos derivados de la sal (flor y escamas de sal; salmuera, aceite, sal y jabón de magnesio; y hasta 35 tipos de sal con distintas especias). En definitiva, apuesta por un aprovechamiento responsable y sostenible del medio natural del que salen casi 300 T/año de sal artesanal.

Además, desde 2011, Biomaris pasó a formar parte (junto con otras 10 salinas de España, Francia, Portugal y Reino Unido), del proyecto EcoSal Atlantis a través de la Ruta Sal Tradicional Ruta del Atlántico. Este programa, cuya base fundamental es la potenciación del ecoturismo y la consolidación así de la actividad en el territorio, pone de relieve la mejora de la gestión de los respectivos paisajes salinos mediante la investigación, el intercambio de experiencias y la colaboración de las instituciones y agentes locales.

De esta forma, la salina de Biomaris, sin renunciar a su legado patrimonial pues las instalaciones siguen siendo las mismas que entre muros de piedra y salicornia se viene trabajando desde hace más de 60 años-, y mediante un inteligente proceso de revalorización y diversificación, ha logrado consolidarse y ser reconocida como una de las actividades económicas más importantes de la provincia de Huelva. 


\section{BIBLIOGRAFÍA Y OTRAS FUENTES}

- ECOSAL ATLANTIS <http://ecosal-atlantis.ua.pt/ index.php?q=es/content/lista-de-actividades> [Consulta: 05/09/2018]

- FLOR DE SAL BIOMARIS <http://flordesalbiomaris. com> [Consulta: 05/09/2018]

- GOZÁLVEZ ESCOBAR, J. L. (2017) El final de las salinas artesanales. En CAMPOS, J. M. (coord.) El patrimonio histórico y cultural en el Paraje Natural Marismas del Odiel. Huelva: Servicio de Publicaciones de la Universidad de Huelva, 2017, pp. 390-404

- PAISAJE de Interés Cultural pesquero de Isla Cristina (Huelva) [en línea] Instituto Andaluz del Patrimonio Histórico, $2005<$ http://www.iaph.es/export/sites/default/ galerias/patrimonio-cultural/documentos/paisaje-cultural/ huelva/paisaje_interes_cultural_pesquero_isla_cristina_ huelva.pdf> [Consulta: 05/09/2018]

- PATRIMONIO cultural en los puertos de interés pesqueros en Andalucía. Isla Cristina (2013-2015) [en línea] En Atlas del Patrimonio Cultural en los Puertos de Interés Pesquero de Andalucía. Universidad de Sevilla, Consejería de Fomento y Vivienda. Agencia Pública de Puertos de Andalucía, 2013-2015 <http://grupos.us.es/ puertosandaluces/pdf/Ficha_IslaCristina.pdf> [Consulta: 05/09/2018]

- RUBio garcía, J. C.; SERVETO AGUILÓ, P. (2004) Historia de las salinas del Golfo de Cádiz. En PÉREZ, A. (coord.) Salinas de Andalucía. Sevilla: Junta de Andalucía, 2004, pp. 42-46

- Rubio garcía, J. C.; SERVETO AGuiló, P. (2004) Tipos funcionales de las salinas atlánticas: salinas artesanales y salinas industriales. En PÉREZ, A. (coord.) Salinas de Andalucía. Sevilla: Junta de Andalucía, 2004, pp. 177-190

- SOlER GARCÍA, M. Espionaje en Huelva: Operación Mincemeat. El hombre que nunca existió [en línea] <http://www.culturandalucia.com/gce/operaci\%C3\%B3n mincemeat_el_hombre_que_nunca_existi\%C3\%B32.htm> [Consulta: 05/09/2018] 


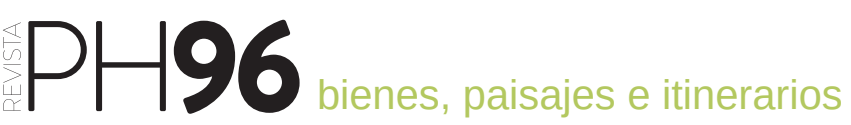

\section{Huelva y costa occidental en el IAPH}

Huelva y la costa occidental es una demarcación paisajística que se localiza en el suroeste de Andalucía. Los municipios que comprende esta demarcación son Ayamonte, Isla Cristina, Lepe, Cartaya, Aljaraque, Gibraleón, Huelva, San Juan del Puerto, Moguer, Palos de la Frontera y Punta Umbría.

A través de la Guía Digital del Patrimonio Cultural de Andalucía (https://guiadigital.iaph.es/inicio), se podrá encontrar la información de patrimonio mueble, inmueble, inmaterial y paisajes culturales, además de otros contenidos como rutas culturales, imágenes, referencias bibliográficas, productos multimedia y obras restauradas de esta demarcación.

URL de la contribución <www.iaph.es/revistaph/index.php/revistaph/article/view/4349>

\section{Patrimonio inmueble}

En la Guía Digital del Patrimonio Cultural se encuentra la información referida a un total de 809 inmuebles de esta demarcación, de los cuales el $48 \%$ corresponden al patrimonio arqueológico, el $42 \%$ al arquitectónico y el $9 \%$ al etnológico.

\section{Patrimonio mueble}

En la mencionada guía se puede consultar la información referida a 796 objetos muebles de carácter artístico en la costa occidental de Huelva distribuidos en diez municipios. Algunos de estos bienes pertenecen al Inventario de Bienes Muebles de la Iglesia Católica; otros

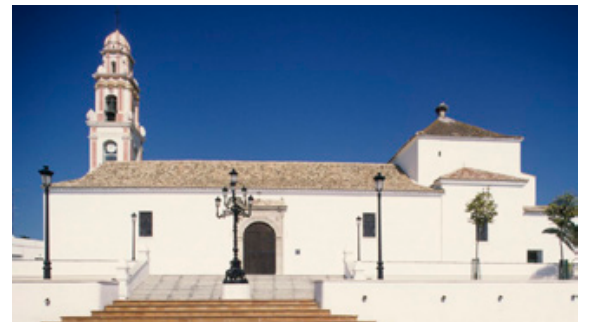

Iglesia de Nuestro Señor y Salvador.en Ayamonte foto Fondo Gráfico IAPH (Javier Romero García) a la obra escultórica de Antonio León Ortega en la provincia de Huelva, que se encuentran inscritos como bienes de catalogación general de manera colectiva en el Catálogo General del Patrimonio Histórico de Andalucía.

\section{Patrimonio inmaterial}

Respecto a los bienes de patrimonio inmaterial que podemos consultar, encontramos un total de 24 registros, de los cuales diez corresponde al ámbito de rituales festivos, otros diez al de oficios y saberes, dos a modos de expresión y otros dos de alimentación.

Las actividades relacionadas con el mar son las que tienen una mayor presencia entre los registros existentes, así como actividades estrechamente relacionadas con estos trabajos. La venta de pescado en Ionja, las salinas, la recogida de coquinas o la elaboración de guiso marinero, son algunos ejemplos de esto. Respecto a los rituales festivos, podemos encontrar ejemplos como la

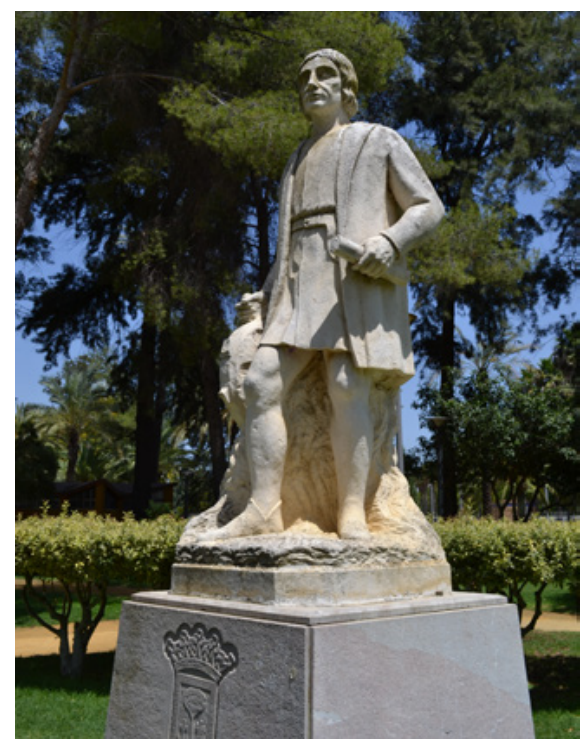

Monumento a Alonso Sánchez (Antonio León Ortega, 1970) en Huelva | foto Fondo Gráfico IAPH (Juan Antonio Arenillas Torrejón)

Semana Santa de Cartaya, la romería de la Virgen Bella o los carnavales.

\section{Paisajes culturales}

Al suroeste de la provincia de Huelva, entre el sur del Andévalo y la costa, se extiende un territorio llano poblado de pinares y ocupado con plantaciones de cítricos y culti- 
vos intensivos de invernadero en el que se ha delimitado la demarcación paisajística de Huelva y costa occidental.

En este espacio, la mayor parte de los asentamientos se concentran al oeste, en el entorno de la capital, y al noreste, en el eje GibraleónAyamonte, cercano al Algarbe portugués. Entre estas dos zonas, un vasto espacio avanza hasta el mar convirtiéndose en amplias marismas, mayoritariamente concentradas en las desembocaduras de los ríos Odiel y Tinto, en las proximidades de la capital; del río Piedras, bajando entre Lepe y Cartaya hasta El Rompido y El Portil; y en los esteros del Guadiana, cercanos a Isla Cristina y Ayamonte. Esta demar-

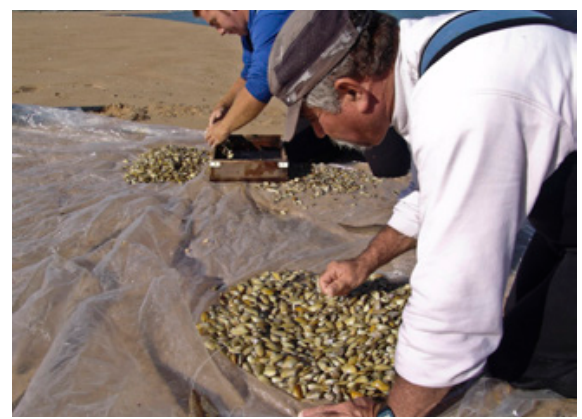

Marisqueo a pie en Cartaya | foto Fondo Gráfico IAPH (Alberto Granados Román)

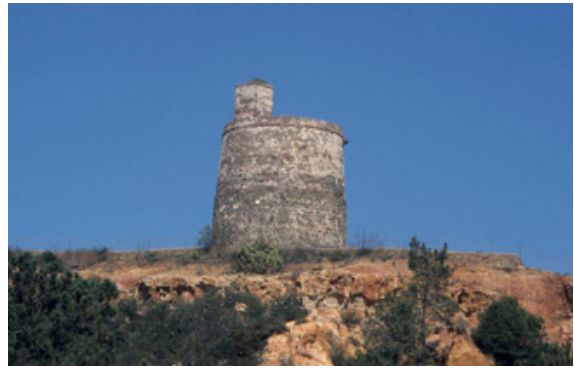

Torre del Catalán en Lepe | foto Fondo Gráfico IAPH (Javier Romero García) cación conserva un medio de gran singularidad paisajística y valor medioambiental que conecta con las playas alineadas en la práctica totalidad de la costa, entre la desembocadura del Guadiana, en la frontera con Portugal, y el término de la localidad de Mazagón, donde contactan con el entorno del Parque Nacional de Doñana.

En esta demarcación paisajística de Huelva y costa occidental ha quedado identificado el siguiente paisaje de interés cultural de Andalucía: paisaje pesquero de Isla Cristina.

\section{Rutas culturales}

En la guía digital hay una ruta cultural de la cual una parte se encuadran en la zona que estudiamos: La arquitec- tura defensiva en la costa andaluza, que constituye un rico patrimonio inmueble íntimamente ligado a los núcleos de población, que en ocasiones nacen a su amparo, y en otras, por su existencia previa, justifican la construcción de estas tipologías arquitectónicas.

Las diversas disputas que existían entre Castilla y Portugal propiciaron que en Huelva desde la Baja Edad Media se realizaran multitud de esfuerzos para la creación de espacios defensivos costeros.

\section{Bibliografía}

En cuanto a la bibliografía, podemos encontrar en el repositorio de activos digitales un total de 895 referencias bibliográficas sobre la costa occi-

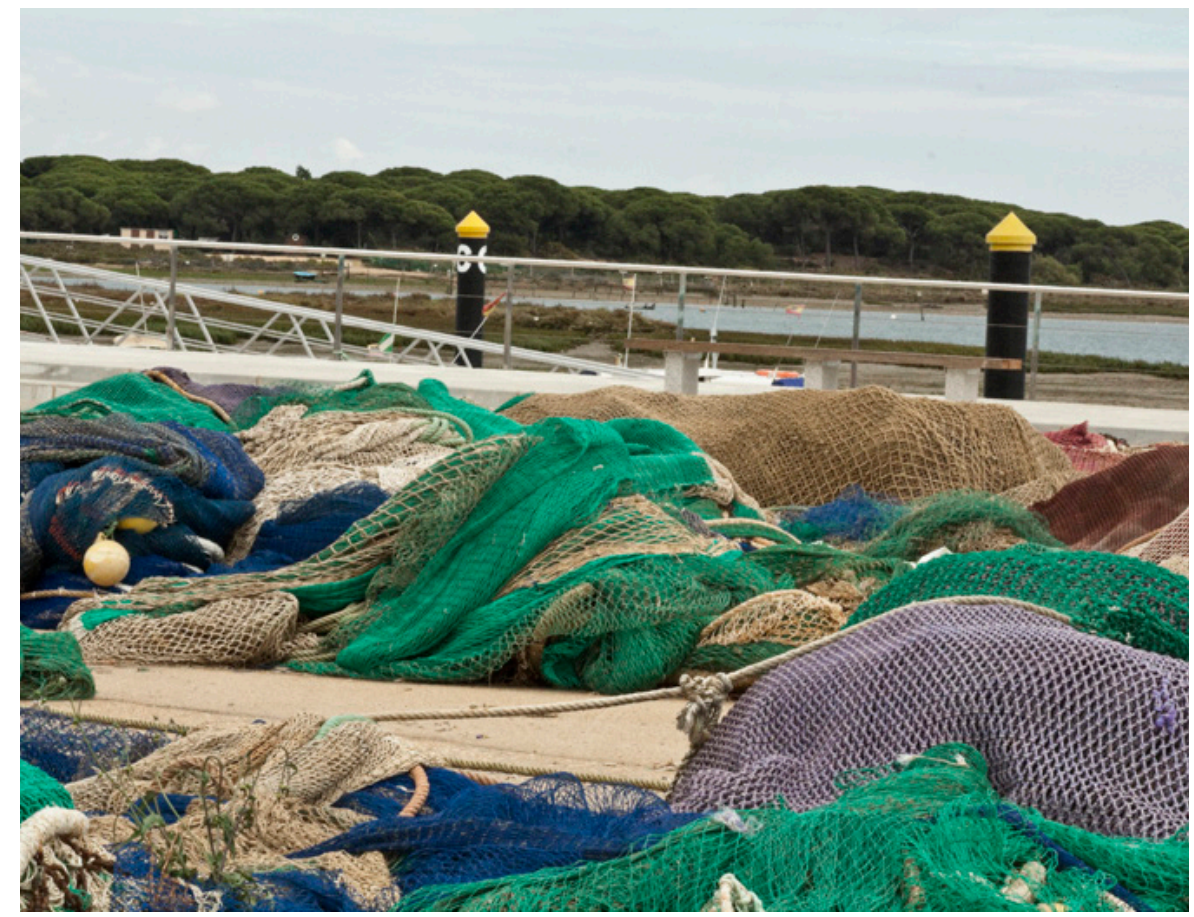

Confección de redes de pesca en Punta Umbría (Huelva) | foto Fondo Gráfico IAPH (María del Rosario Ortiz Amores) 
dental de Huelva. El municipio que posee mayor cantidad de referencias es Huelva (535), seguido de Palos de la Frontera (75) y Moguer (65).

\section{Cartografía}

Se encuentran georreferenciados en la zona un total de 320 inmuebles, 104 son puntuales y 216 poligonales, algunos de los cuales pueden consultarse a través del localizador cartográfico del patrimonio cultural.

\section{OBRAS RESTAURADAS}

\section{Materiales arqueológicos de la} necrópolis de La Joya

La necrópolis de La Joya, ubicada en el cabezo del mismo nombre en la ciudad de Huelva, constituye uno de los referentes fundamentales sobre el mundo funerario del periodo orientalizante en la Península Ibérica, no sólo por la riqueza y calidad de los ajuares en ella localizados, sino también por la diversidad en los rituales y tipologías de las estructuras funerarias documentadas.

Según se desprende del estudio de los materiales, su cronología puede establecerse desde la segunda mitad del siglo VIII a. de C. hasta la primera mitad del siglo VI a. de C., presentando un margen temporal de uso de unos dos siglos aproximadamente. La riqueza tecnológica y artística de algunas piezas del ajuar funerario, en su mayoría fabricados en bronce, halladas en las distintas campañas de excavación, y su delicado estado de conservación, impulsaron la ejecución de un proyecto para el estudio, conservación y museali- zación de los materiales depositados en el Museo de Huelva. De esta forma, se inició la restauración-conservación de una parte de los mismos en las dependencias del IAPH en 2006. La vasta información obtenida durante su desarrollo demuestra la importancia de esta necrópolis y sus amplias posibilidades de estudio. Por esta razón, en el año 2010 se desarrolló como proyecto de I+D. Poniendo de manifiesto que, a pesar de ser un yacimiento referente en la Protohistoria peninsular, aún existen numerosos interrogantes que las nuevas investigaciones deberán desvelar.

\section{Crucificado del Cementerio}

El Cristo del Cementerio es una de las imágenes de Jesús Crucificado más antigua de la provincia de Huelva por ello sorprende la escasa información que se conoce sobre su origen e historia existiendo varias hipótesis al respecto. Fue estudiada y posteriormente intervenida en el Instituto Andaluz del Patrimonio Histórico durante los años 2009 y 2010. Dicha actuación daba respuesta a la petición realizada por el Ayuntamiento de la localidad onubense de Gibraleón, propietario de la obra.

Es una escultura de madera de álamo tallada y policromada cuya ejecución se puede encuadrar entre finales del siglo XIV y principios del $\mathrm{XV}$, habiendo sido objeto de algunas intervenciones posteriores derivadas de su continua readaptación a nuevos contextos y/o usos.

Posee un notable interés histórico-artístico además de un signifi-

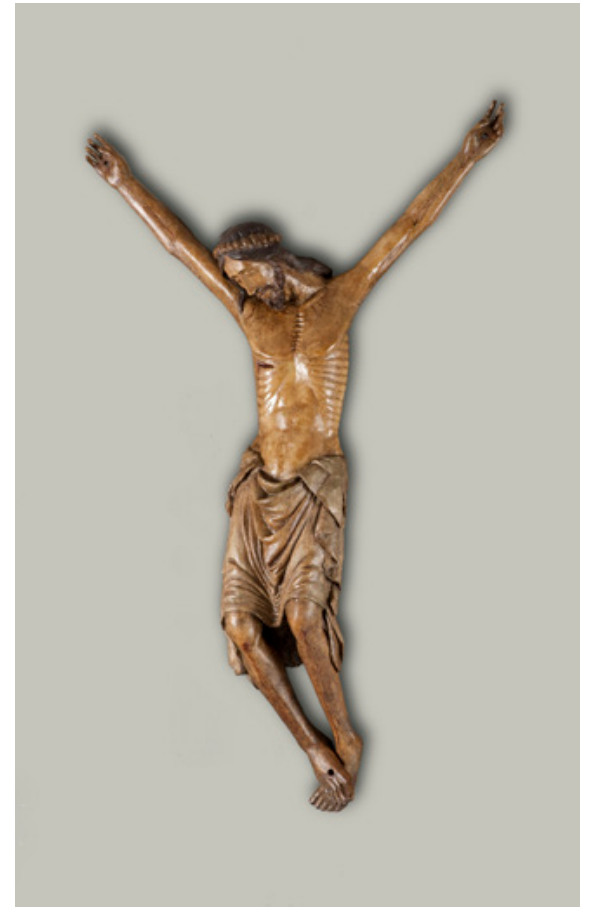

Crucificado del Cementerio de Gibraleón | foto Fondo Gráfico IAPH (Eugenio Fernández Ruiz)
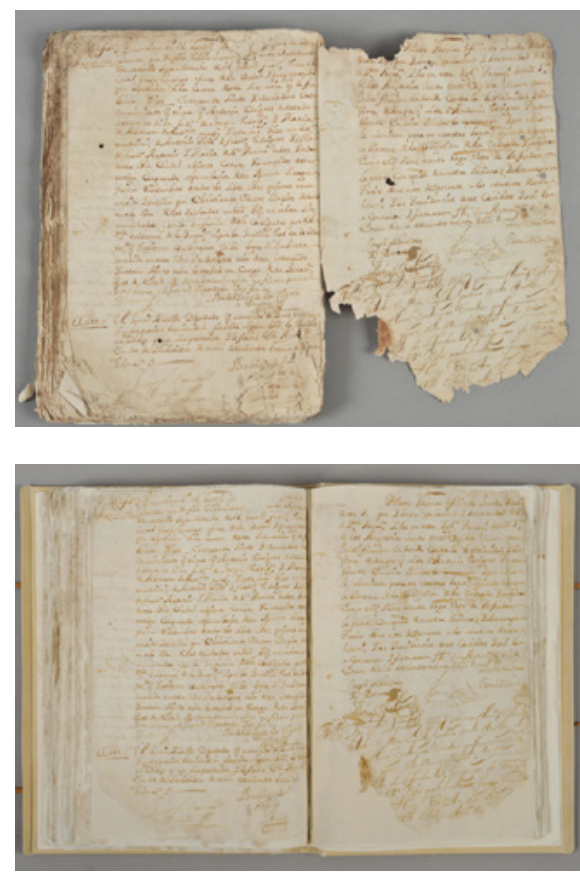

Expediente de Limpieza de Sangre. Ayamonte. Estado inicial (arrriba) y final (debajo) | foto Fondo Gráfico IAPH (Eugenio Fernández Ruiz) 
cativo aprecio social. Está incluida en el Inventario General de bienes Muebles del Patrimonio Histórico Español, según lo dispuesto en la Ley 14/2007 de 26 de noviembre de Patrimonio Histórico de Andalucía, disposición adicional sexta.

\section{Expedientes de Limpieza de Sangre en Ayamonte}

El IAPH restauró en 2010 dos interesantes volúmenes propiedad de la Cofradía Sacramental de las Angustias, cedidos en calidad de depósito permanente al Archivo Municipal de Ayamonte.

Se trata de una colección de Expedientes de Legitimidad y Limpieza de Sangre comprendidos entre los años 1725 y 1760, pertenecientes a la entonces cofradía ayamontina del Santo Sacramento de Ayamonte antes de su fusión con la cofradía del Descendimiento.

Aunque este tipo de expedientes constituye un tipo documental difícil de localizar entre los fondos de cofradías y hermandades religiosas, fue una práctica muy extendida entre estos colectivos. La idea de documentar el origen y procedencia de los individuos y su legitimación como "cristianos puros" fue un requisito indispensable para la admisión en cualquier colectivo público religioso, civil o militar en España desde el siglo XV hasta su supresión por Real Orden en 1835.

\section{Un plano de Isla Cristina}

El Archivo Municipal de Isla Cristina conserva una copia del plano general de la población realizado en 1922 , por orden del ayuntamiento isleño, por el entonces ayudante de obras públicas de la Jefatura Provincial de Isla Cristina, Carlos Rubio.

Durante las primeras décadas del siglo $\mathrm{XX}$, surgió el debate sobre el planeamiento urbano y la necesidad de una gestión municipal más eficaz, promoviéndose la ampliación de las competencias municipales para la mejor y más racional gestión urbanística que desembocaría en los nuevos planes urbanísticos encaminados a optimizar el espacio y encauzar racionalmente el crecimiento de las ciudades.
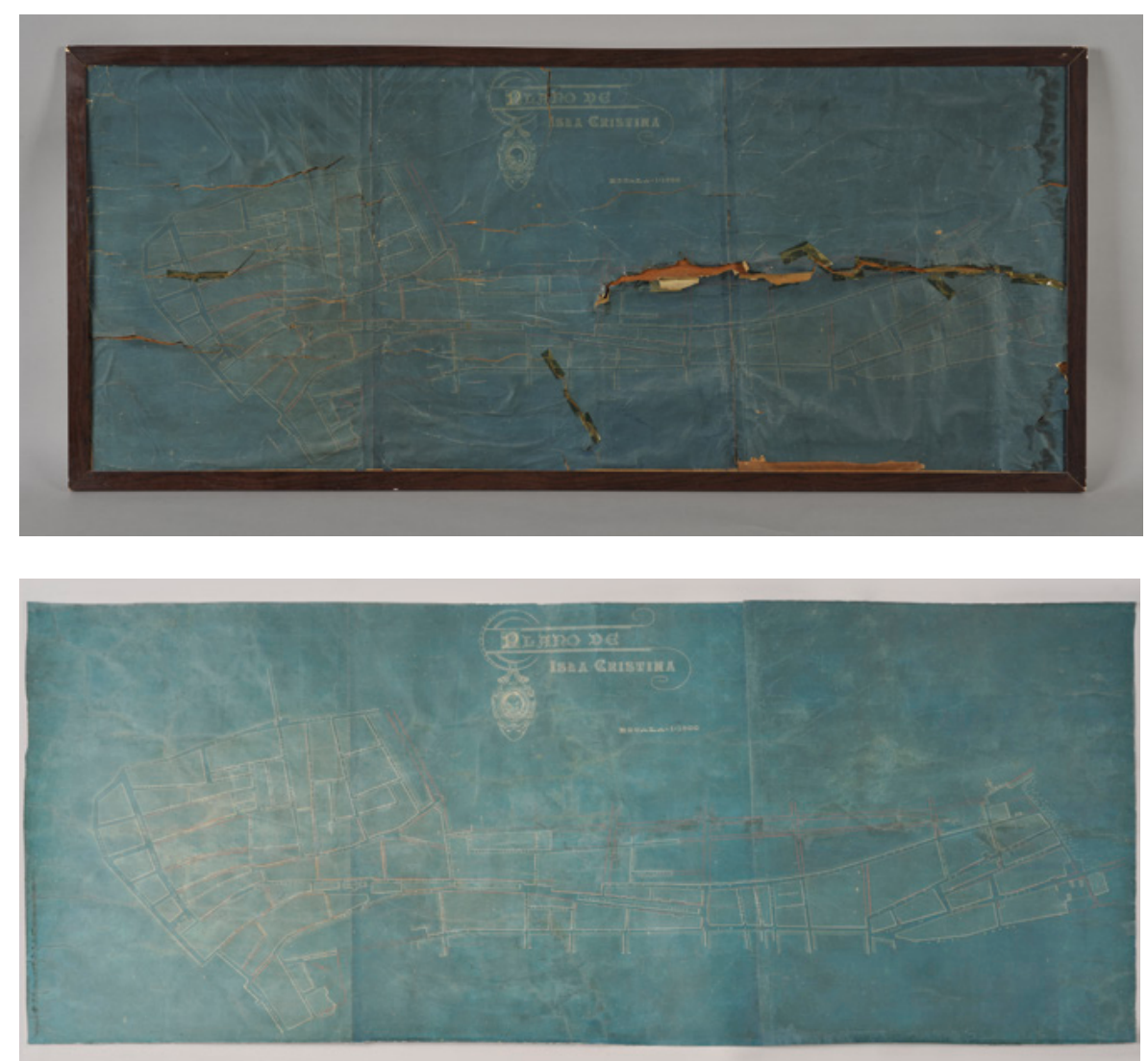

Plano de Isla Cristina. Estado inicial (arriba) y final (debajo) | foto Fondo Gráfico IAPH (Eugenio Fernández Ruiz)
El plano de Isla Cristina, restaurado en el IAPH en 2011, es un ejemplo de estas nuevas políticas. Realizado a escala 1:1000, su particularidad principal es el uso de un papel de fabricación industrial denominado cianotipo o ferroprusiato, que otorga el aspecto de un dibujo en blanco resaltado sobre un fondo azul fuerte.

El uso de este papel se generalizó comercialización en grandes rollos que posibilitaba todo tipo de formatos, fue muy empleado en la reproducción de mapas y planos, hasta su desuso a mediados del siglo XX. hacia 1880, y por su bajo coste y su 


\section{ForSEAdiscovery: la construcción naval y el comercio de la madera del siglo XVI al $\mathrm{XVIII}$}

Ana Crespo Solana | Instituto de Historia, CSIC

URL de la contribución <www.iaph.es/revistaph/index.php/revistaph/article/view/4279>

\section{RESUMEN}

ForSEAdiscovery es un proyecto fuertemente interdisciplinar que relaciona la historia marítima de la Edad Moderna y la arqueología subacuática con las Ciencias de la Información Geográfica (SIG), con la Dendrocronología, así como con diversas técnicas analíticas sobre la procedencia de la madera, especialmente la datación por radiocarbono. Es el primer proyecto financiado por el programa Marie Curie de la Unión Europea (Programa PEOPLE) orientado a la investigación histórica-arqueológica de pecios ibéricos. Durante sus cuatro años de desarrollo primigenio el proyecto ha logrado situar el estudio histórico-arqueológico de la historia marítima en el centro de un discurso teórico-técnico que abre nuevas líneas de investigación interdisciplinar y sobre todo en la generación de new data. Es así un proyecto holístico que se espera sea continuado por una amplia red de discípulos, científicos y colaboradores de diversas disciplinas.

\section{Palabras clave}

Arqueología Subacuática | Ciencias de la Información Geográfica | Comercio | Construcción naval | Edad Moderna | Historia marítima | Madera | 


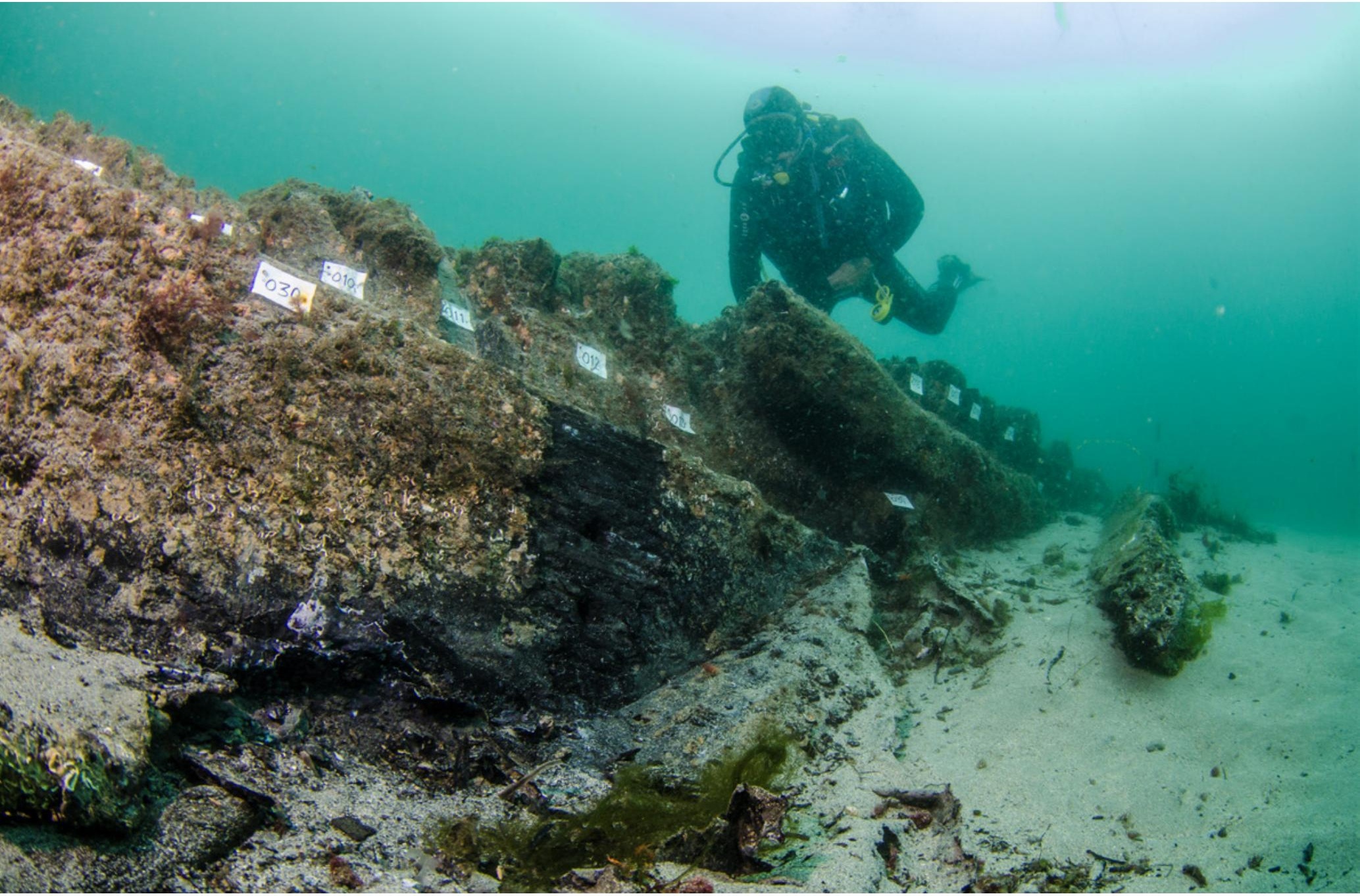

Galeón de Ribadeo: área de excavación (Junio de 2018) | foto MALTd, ForSEAdiscovery, Xunta de Galicia 
La investigación llevada a cabo y resultante de este proyecto ha sido financiada con fondos del People Programme (Marie Curie Actions) of the European Union's Seventh Framework Programme (FP72007-2013) under REA grant agreement no PITN-GA 2013-607545. Forest Resources for Iberian Empires: Ecology and Globalization in the Age of Discovery (16th18th centuries). Acronym: ForSEAdiscovery. Más información en <www.forseadiscovery. eu>
ForSEAdiscovery ${ }^{1}$ es un proyecto fuertemente interdisciplinar que relaciona la historia marítima de la Edad Moderna y la arqueología subacuática con las Ciencias de la Información Geográfica (SIG), con la dendrocronología, así como con diversas técnicas analíticas sobre la procedencia de la madera, especialmente la datación por radiocarbono. Es el primer proyecto financiado por el programa Marie Curie de la Unión Europea (Programa PEOPLE) orientado a la investigación histórica-arqueológica de pecios ibéricos. Durante sus cuatro años de desarrollo primigenio las investigaciones llevadas a cabo están procurando un mayor conocimiento sobre el origen y abastecimiento de la madera para la construcción naval, el análisis de las redes mercantiles que operaban en torno a este comercio, las políticas navales del período y su relación con la politización y canalización de los recursos forestales, así como su incidencia en la evolución de la arquitectura de barcos. Aparte de su planteamiento interdisciplinar y empírico que lo convierte en un proyecto único e innovador en el campo de las humanidades y las ciencias sociales, la conjunción metodológica logra situar el estudio histórico-arqueológico de la historia marítima en su verdadero contexto científico internacional, en el centro de un discurso teórico-técnico que abre nuevas líneas de investigación interdisciplinar y sobre todo en la generación de new data. Es así un proyecto holístico que parte de un amplio conocimiento histórico y que, esperemos, no solo será continuado por los miembros del Consorcio ForSEAdiscovery sino por una amplia red de discípulos, científicos y colaboradores de diversas disciplinas.

Un estado del arte actual sobre la economía, el medioambiente y el estudio de las actividades marítimas de España y Portugal durante los siglos XVI al XVIII aporta un estado de conocimientos historiográficos considerablemente amplio. Un capítulo menos señalado, o menos visible, ha sido la aplicación interdisciplinar de métodos dendroarqueológicos, especialmente en escenarios subacuáticos y marítimos, que facilite poder avanzar en los conocimientos sobre la procedencia de la madera que se utilizó para la construcción de barcos. Estos tipos de estudios han conocido interesantes aplicaciones en el campo de la arqueología subacuática española anteriormente pero casi siempre dedicado a pecios de época anterior al siglo XV, especialmente romanos y fenicios. Para épocas posteriores a las primeras décadas de la expansión ultramarina ibérica estos estudios deben ser, sin duda, contextualizados en un nuevo marco historiográfico que aporta novedosas asunciones primarias. En el contexto de la emergencia del capitalismo mercantil de la Edad Moderna, el comercio global de madera, el control de estos recursos y el desarrollo tecnológico eran aspectos inherentes al trasfondo ideológico de los imperios. Dos paradigmas claves surgen en esta investigación: en primer lugar, la evolución del navío ibérico, desde naos y galeones a fragatas y navíos mercantes con todas sus variantes. Esta cuestión resulta más problemática y, sin duda, urgente, dados los difíciles condicionantes a la hora de conocer un barco de la edad moderna bajo el agua. En segundo 
lugar, y considerado como un auténtico análisis de investigación multidisciplinar, una cuestión fundamental es la pregunta de cómo evolucionó tanto el comercio de madera como el uso que se llevó a cabo de estos recursos forestales. Ambos análisis son, sin duda, paralelos a los estudios sobre construcción naval ibérica que no pueden llevarse a cabo solo teniendo en cuenta la información histórica recogida en tratados de construcción y en archivos, dada la importante fuente de información que suponen los restos arqueológicos sumergidos, necesario además de confrontar con datos recogidos en archivos que hasta el momento han permanecido inéditos o menos valorados, y siempre desde una perspectiva histórica medioambiental y económica (CRESPO SOLANA, 2016).

En su esencia, el proyecto fue resultado de la conjunción de diversos esfuerzos individuales, que ya tuve oportunidad de explicar, reunidos en torno a un plan preliminar destinado a integrar estrategias para la configuración y establecimiento de una dendrocronología histórica de la Península Ibérica orientada además a establecer futuras línea de actuación en este campo. Se trataba del proyecto Filling in the blanks in European dendrochronology: building a multidisciplinary research network to assess Iberian wooden cultural heritage worldwide ${ }^{2}$. En poco tiempo ha sido posible presentar casos de uso interesantes sobre esta materia (SOBERÓN; PUJOL; LLERGO et ál., 2012: 411-422; DÓMÍNGUEZ-DELMÁS; NAYLING; LOUREIRO et ál., 2012: 118-136; DOMÍNGUEZ-DELMÁS; ALEJANO-MONGE; DAALEN et ál., 2015: 180-196); con especial mención del The Newport Ship Project, ejemplo paradigmático de la datación e identificación de madera de barcos gracias a la dendrocronología y que constituye la base metodológica de ForSEAdiscovery (NAYLING; JONES, 2014: 239-278; NAYLING; SUSPÉRREGUI, 2014: 279-291). Como valor añadido, las investigaciones a las que ha dado lugar el proyecto han sido prolíficas en cuanto que implican la realización de 10 tesis doctorales y 8 trabajos individuales de investigación, aparte de las diversas líneas aún pendientes y que están al cabo de salir a la luz en diversas publicaciones ${ }^{3}$. En estos trabajos se están culminando análisis con datos procedentes de archivos históricos y literatura sobre construcción naval, evidencias arqueológicas recogidas en prospecciones, muestreos de árboles vivos y madera de edificios históricos (para lo cual se han solicitado los permisos pertinentes) así como el análisis y catalogación de estas muestras en laboratorio. La dendroarqueología y otras técnicas para el estudio de la procedencia de la madera implican métodos utilizados para valorar la madera de los pecios que están siendo intervenidos y estudiados en las actividades científicas del proyecto. Esta disciplina permite datar las maderas arqueológicas para determinar el año en el que los árboles fueron talados, transportados y utilizados en la construcción de los barcos (NAYLING, 2008: 64-73). Ello supone un valor añadido al conocimiento histórico de estos pecios y permite validar la información extraída de fuentes documentales. En tres casos de uso en donde se han podido
2

Citado en: CRESPO SOLANA, A. (2016) ForSEAdiscovery: Génesis y marco histórico-metodológico de un Proyecto interdisciplinary en Humanidades. En VARELA GOMES, R.; VARELA GOMES, M. (coord.) A Gestâo dos Recursos Florestais Portugueses na construcâo naval da Idade Moderna: História e Arqueologia. Lisboa: IAP, pp. 1-15. Cf. SUSPÉRREGUI, J.; JANSMA, E. (2017) Towards A Better Chronology of Basque Heritage Using Time-Series from Renovation Waste. Tree-Ring Research, pp. 126-35. El proyecto duró entre 2009 y 2011 (Ref.: 236-61-001) dirigido por la profesora E. Jansma (Universiteit Utrecht) y Marta Domínguez-Delmás. Información sobre este proyecto en la web: $<$ https://www.nwo.nl/onderzoek-en-resultaten/ onderzoeksprojecten/i/17/5417.html>

3

Más información sobre las publicaciones en: http://forseadiscovery.eu/results/publications 
Toma de medidas sobre la construcción del buque por Arnaud Cazenave de la Roche | foto MALTd

ForSEAdiscovery, Xunta de Galicia

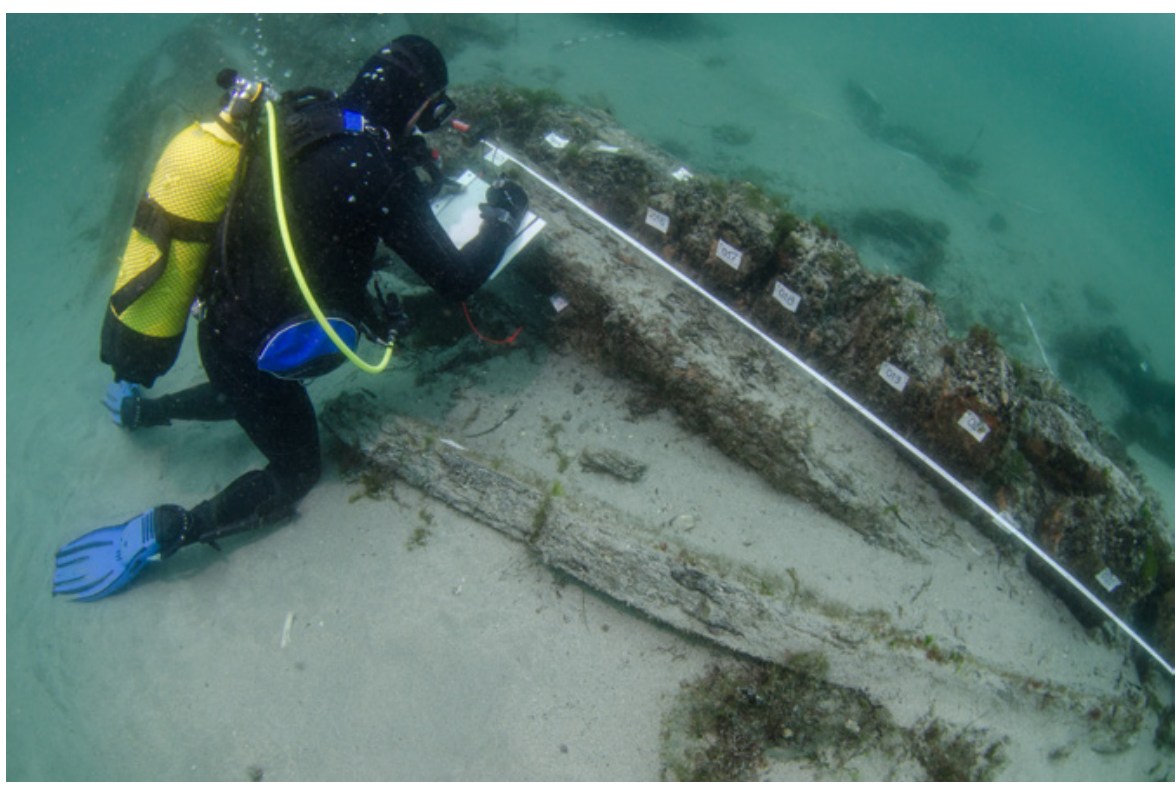

identificar los barcos (casos del Galeón de Ribadeo, la fragata Magdalena y el pecio de Belinho), gracias a una minuciosa investigación documental y dendroarqueológica, se demuestra la factibilidad de esta metodología (EGUILUZ MIRANDA; TRAPAGA MONCHET; DOMÍNGUEZ-DELMÁS, 2015; TRINDADE; DOMÍNGUEZ-DELMÁS; TRAORÉ, et ál., en prensa). Como valor adicional, este análisis se ha llevado a cabo de forma exitosa en otros trabajos y en tesis doctorales (CAZENAVE DE LA ROCHE, 2018). Además de los estudios histórico-arqueológicos, que luego comentaré someramente, tres ejemplos notables han sido las tesis doctorales de los ITN fellows, Fadi Hajj (HAJ, 2017), Marta Domínguez-Delmás (DOMÍNGUEZ-DELMÁS, 2015) y Mohamed Traoré (TRAORÉ, 2018). Como culminación se han logrado publicar dos importantes textos que reportan información valiosa sobre guías e instrucciones prácticas a la hora de seleccionar, muestrear y cortar madera de barcos sumergidos. En orden a poder extraer muestras válidas para el laboratorio es necesario implicar el trabajo de dendroarqueólogos en las etapas de selección de muestras bajo el agua (RICH; NAYLING; MOMBER at ál., 2017; DOMíNGUEZ-DELMÁS; RICH; DALY at ál., 2018).

Las técnicas de análisis sobre la procedencia de la madera suponen un auténtico código de barras útil para el entrecruzamiento, experimentación e integración de toda la información, siempre y cuando se proceda de acuerdo a un determinado protocolo de muestreo y extrayendo datos útiles que tras su depuración y procesamiento también pasan a formar parte de las dendrocronologías históricas así como de la propia base de datos del proyecto (The ForSEAdiscovery Database) que está sirviendo para realizar análisis entrecruzados de información (CRESPO SOLANA; CASTRO, 2016). Para que las 
muestras de madera sean factibles para la datación arqueológica es necesario que dichas muestras sean de una especie que produzca anillos con resolución anual, con una muestra con suficientes anillos (Tree-rings), y en un contexto geográfico en el cual se hayan establecido previas cronologías de referencia espacio-temporales (DOMíNGUEZ-DELMÁS, 2013: 1080-1094). Junto a la historia y la arqueología, estas técnicas se relacionan tanto desde el punto de vista teórico (en el planteamiento de las hipótesis primarias del proyecto y en su epistemología) como en el uso de diversas metodologías complementarias a la hora de dar respuesta a los problemas que se plantean en la propuesta de investigación. Estas disciplinas son también suplementarias a la hora de dar respuesta a las preguntas relacionadas con el dilema de si realmente los recursos forestales ibéricos pudieron mantener el aumento de la demanda de madera experimentado entre los siglos XV al XVIII o si fue ésta importada desde otras partes, como en muchos casos sí sucedió desde la perspectiva de las evidencias históricas y documentales, especialmente a partir de la denominada crisis de la Armada de 1580. Esta clásica teoría historiográfica ha condicionado tanto la propia historia marítima y naval ibérica como los estudios arqueológicos en pecios.

\section{EL MARCO HISTÓRICO-ARQUEOLÓGICO}

La justificación de la investigación se basa en que, durante los siglos de la Edad Moderna, denominados como la primera edad global (siglos XVI al $X V I I I)$, la construcción naval era una industria relacionada con el desarrollo de los imperios. Las técnicas de construcción naval evolucionaron y se perfeccionaron desde el punto de vista tecnológico, se mejoraron los barcos destinados a las exploraciones oceánicas, el diseño y aparejamiento de los buques de guerra y mercantes, así como la propia organización naval. Este desarrollo fue importante para los imperios ibéricos, pioneros en la construcción de ese mundo atlántico de interacciones políticas, culturales, económicas y sociales. Junto al escenario abierto por España y Portugal, la interacción socio-cultural, tecnológica y económica con otras naciones marítimas, especialmente con los maritime powers, Holanda e Inglaterra, supone la inclusión en este esquema de análisis de una perspectiva comparada y de análisis de transferencia de tecnología en un mundo mucho más conectado y entangled de lo que se ha señalado en estudios anteriores. Efectivamente, hubo más interferencia y traspaso de conocimientos tecnológicos y económicos gracias a la constante migración de mano de obra especializada en oficios relacionados con el comercio y el sector naval, tal como se demuestra en los estudios sobre arquitectura naval de las distintas épocas en diferentes localizaciones geográficas. De hecho, la transferencia de tecnología sobre construcción naval, las diferencias entre la teoría y la práctica comprobada en evidencias arqueológicas y la consideración de astilleros y arsenales como centros neurálgicos de experimentación, son temas aún pendientes en 
4

Entre estos trabajos destaco: QUINTERO GONZÁlEZ, J. (2000) El arsenal de la Carraca (1717-1736). Madrid: Ministerio de Defensa, Instituto de Historia y Cultura Naval, 2000; SERRANO ÁLVAREZ, J. M. (2018) E astillero de La Habana en el siglo XVIII. Historia y Construcción naval. Madrid: Ministerio de Defensa. Cf. ALBEROLA ROMÁ, A.; MAS GALVÁN, C.; DIE-MACULET, R. (ed.) (2015) Jorge Juan Santacilia en la España de la Ilustración. Alicante: Universidad de Alicante, Casa de Velázquez.

Han sido muy estudiados desde el punto de vista legal: MARTÍNEZ GONZÁLEZ, A. J. (2014) La Elaboración de la Ordenanza de Montes de Marina, de 31 de enero de 1748 base de la política oceánica de la Monarquía española durante el siglo XVIII. Anuario de Estudios Americanos, 71, 2 Sevilla, pp. 571 602. la investigación a pesar de los buenos estudios existentes sobre astilleros. No obstante, es en estos valiosos trabajos en donde se deduce este continuo trasvase de experimentación, transferencia de conocimientos y conocimiento científico, más estudiado para el siglo XVIII, como, por ejemplo, fue la doble influencia entre España e Inglaterra o el caso de la influencia francesa en Cuba. De entre estos trabajos es quizás la obra de Quintero González la que más ha profundizado en las cuestiones relativas a la madera de los barcos desde un punto de vista histórico ${ }^{4}$.

Como centro neurálgico de la investigación histórica-arqueológica se logra la elaboración de una narrativa espacio-temporal e interdisciplinar sobre la historia y evolución de los modelos navales de los imperios ibéricos en el contexto de la expansión marítima, la politización de los recursos forestales, sus causas y consecuencias medioambientales, y en la dinámica social y económica del comercio global de madera durante los siglos XVI al XVIII. Sobre estas cuestiones es posible extraer algunos resultados preliminares que hacen referencia a la relación entre la administración forestal y la reglamentación relativa a la construcción naval. Se han establecido también las características de las regiones originarias de las cuales se extrajo madera, no solamente de los "montes de marina" sino que se han incluido algunos Reales Sitios, así como otras áreas cercanas a emplazamientos marítimos costeros, montes y dehesas, sobre todo en Andalucía y en el País Vasco, centros importantes de construcción naval, en donde se ubicaban diversos astilleros y careneros. Uno de los trabajos más importantes del proyecto es una tesis doctoral en curso sobre el surtimiento de madera en Andalucía (TRINDADE, 2015: 57-65).

Además, se ha analizado también las diversas casuísticas de los aprovechamientos forestales en localizaciones administradas directamente por la Corona, como el denominado Soto de Roma (en Fuente Vaqueros, Granada), y en las regiones de Asturias, Cantabria, Galicia, o amplias zonas de Portugal (VARELA GOMES; TRAPAGA MONCHET, 2017; TRAPAGA MONCHET; SANTOS, 2015: 62-68). Unos datos recogidos sobre estos estudios espaciales permiten conocer la fuerte presión que sobre los bosques ibéricos tuvo tanto la Corona como las élites nobiliarias y eclesiásticas locales que intentaron organizar desde muy pronto una reorganización de los recursos forestales y en regiones que sobredimensionaban las áreas establecidas por las posteriores (y curiosamente tardías) reglamentaciones sobre los montes de marina y la creación de los Departamentos marítimos entre 1726 y $1748^{5}$. De hecho el control de los bosques y su relación con la marina es muy anterior tal como aparece reflejado en la Novísima Recopilación de las Leyes de España y en la constitución de la Superintendencia de montes y plantíos en 1574 y sus importantes antecedentes desde el siglo XV (LEYES, 1805-1829: vol. 6, pp. 193-194; cf. MARTÍNEZ GONZÁLEZ, 2015: 43 y ss.). 

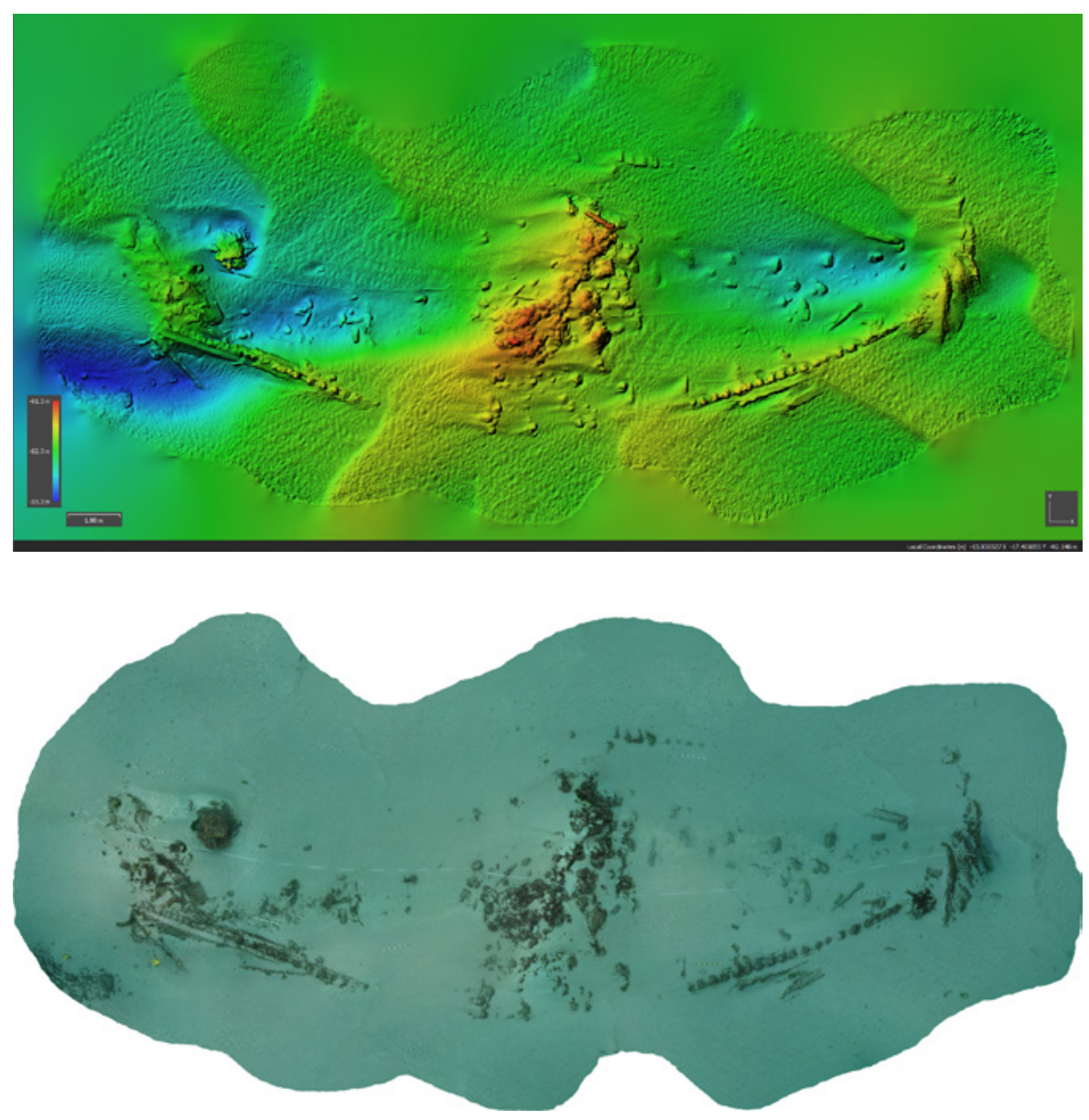

Screenshot Ribadeo I site | imagen Brandon Mason (MALTd, ForSEAdiscovery, Xunta de Galicia)

Desde el punto de vista económico y social, precisamente en los litorales de las costas europeas, se empezaron a desarrollar sociedades marítimas relacionadas con el comercio, las finanzas, las actividades portuarias y nuevos oficios vinculados a la expansión atlántica. Todo lo relacionado con la construcción naval estuvo también presente en dicho desarrollo socio-económico (CRESPO SOLANA, 2016: 3; 2017: 83-105). El establecimiento de nuevas rutas comerciales, el crecimiento demográfico y la migración coincidieron con el desarrollo de una industria integrada de artillería para la navegación marítima: navíos mercantes armados, galeones, flotas organizadas y pequeños barcos. El barco de la primera edad global, en sus modelos diferentes, constituía una tecnología puntera para la época que no solo influyó en el desarrollo de estas sociedades marítimas sino en las formas de canalizar recursos naturales. Estos procesos se desarrollaban en ciudades portuarias que de alguna u otra manera se empezaron a conectar con nuevos usos económicos y comerciales a partir del siglo XVI. Como coordinadora del proyecto de investigación, ya traté ampliamente tanto la historia naval 


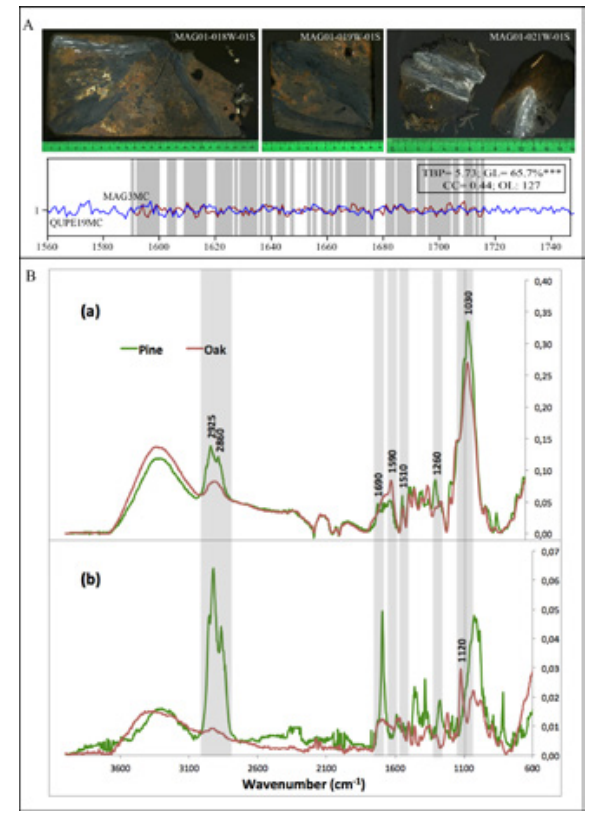

Equipo FTIR-ART Agilent Cary 630 FTIR Expectometro, equipado con "single-reflection diamond crystal" | fuente TRINDADE, DOMÍNGUEZ-DELMÁS, TRAORÉ et ál., en prensa

$$
6
$$

Un estado de la cuestión sobre estos problemas en: ALMAGRO-GORBEA, M (2008) La arqueología submarina hoy en España. En ALCALÁ-ZAMORA, J.; QUEIPO DE LLANO, J. (coord.) La España oceánica de los siglos modernos y el tesoro submarino español. Madrid: Real Academia de la Historia, 2008, pp. 11-47 como las redes mercantiles y su relación con la logística del comercio global que tuvo en la explotación de recursos naturales una de sus más importantes consecuencias (CRESPO SOLANA, 1996; 2001; 2014). Ambos temas se han tratado tanto desde el punto de vista comparado, empírico (con la creación de bases de datos y aplicación de SIG) y socio-económico, con especial hincapié en las rutas del comercio español de la Carrera de Indias y su relación con el mundo comercial del Golfo Caribe y el norte de Europa, básicamente Holanda y el Báltico. Gracias a la información contenida en la base de datos del Sound Toll Register online, ha sido posible desarrollar una investigación que destaca la importación de madera a la Península Ibérica, además de cotejar con otras fuentes de archivo, especialmente de la sección Tribunal Mayor de Cuentas, del Archivo General de Simancas, a partir de los cuales ha sido posible reconstruir unas series completas para los años comprendidos entre 1730 y 1770 con relación al Departamento de Cádiz (GALLAGHER, 2016: 752-773; CRESPO SOLANA, 2009; CRESPO SOLANA, 2018a: 77-94). Gracias a esta investigación se ha podido realizar un completo trabajo sobre la fragata de guerra del siglo XVIII Santa María Magdalena, construida en los astilleros de Estero en Ferrol (Galicia) en 1773 y hundida en 1810 en la bahía de Viveiro en el contexto de la Guerra de la Independencia (1808-1814) (TRINDADE; DOMÍNGUEZ-DELMÁS; TRAORÉ et ál., en prensa).

La historia naval y marítima española es muy amplia, pero con escasos estudios arqueológicos completos dedicados al análisis del diseño constructivo del barco ibérico de los siglos XVI al XVIII. Por lo que se puede observar de los trabajos existentes, y aunque en distintos contextos legislativos y administrativos, es un problema bastante generalizado en los países de la Unión Europea en la actualidad, al poseer un patrimonio sumergido enorme pero continuamente acosado por el expolio de los cazatesoros, como los ejemplos del Nuestra Señora de Atocha, el pecio de la Armada de Irlanda, La Girona, o los navíos de la flota de Manuel de Velasco de 1702 hundidos en la bahía de Rande, y, especialmente, el lamentable episodio que ha trascendido internacionalmente, el caso del pecio de Nuestra Señora de las Mercedes, que sin duda ha abierto un antes y un después en el campo de la arqueología subacuática española ${ }^{6}$. No obstante, existe una notable contraposición con los modelos de estudios sobre historia y arqueología marítima de la Edad Moderna que se tienen en el Reino Unido, Países Bajos o Portugal. Sin embargo, en el caso español existen trabajos importantes dedicados a galeones y navíos de las flotas españolas de los siglos modernos, que enlazan estos patrimonios sumergidos con una hermosa narrativa sobre el devenir de los naufragios históricos (PÉREZ-MALLAINA BUENO, 2015).

Recientemente destacan los trabajos realizados en el navío de línea El Triunfante, hundido en 1795 en la Bahía de Rosas, y que es uno de los pocos pecios de la Edad Moderna intervenidos en España, con un estudio histó- 
rico y arqueológico muy completo, que aporta información sobre los detalles constructivos, la arqueología de la batalla y la artillería (FUENTE DE PABLO, 2006; PUJOL I HAMELINK; VIVAR I LOMBARTE; FUENTE DE PABLO, 2011). Hormaechea, Rivera y Derqui mencionan en su obra, sobre los galeones españoles del siglo XVII, unos pocos yacimientos arqueológicos objeto de prospecciones arqueológicas de buques ibéricos (pecio de Cais de Sodre, en Lisboa; la nao vasca San Juan en Red Bay, o la nau Nossa Senhora dos Martires, el Pepper wreck, también en Lisboa) (HORMAECHEA; RIVERA; DERQUI, 2012; CASTRO; YAMAFUNE; EGINTON at ál., 2011: 328-34; LOEWEN, 1998: 193-199; CASTRO, 2005). A estos importantes trabajos se suman los trabajos de Carlos León Amores sobre la flota de azogue de 1724, los estudios de Miguel San Claudio sobre navíos de la Armada hundidos en Galicia, el Galeón de Gerona, hundido en 1654 (estudiado por Xavier Nieto) o el pecio Deltebre, de época algo más tardía (LEON AMORES, 2009: 178 y ss.; SAN CLAUDIO SANTA CRUZ; GONZÁLEZ GALLERO; CASABAN at ál., 2014: 169-178; MARTÍNEZ LILLO; BLANQUEZ, 1993: 163-169; VIVAR LOMBARTE; GELI; NIETO PRIETO et ál., 2014: 221-227); y el interesante caso del denominado Mercante San Sebastián, y otros pecios de la Edad Moderna estudiados por el Centro de Arqueología Subacuática de Cádiz (MARTÍ SOLANO, 2014: 109-118; GARCÍA RIVERA; MARTÍ SOLANO; ALONSO VILLALOBOS et ál., 1995: 105-124; RIDELLA; ALZAGA; ENRÍQUEZ MARCÍAS et ál., 2017: 11-65). En verdad, desde el punto de vista tecnológico e histórico, no hay nada más completo como los trabajos sobre los galeones del siglo XVII de Hormaechea, o de especialistas como Esteban Mira Caballos, Casado Soto o Serrano Mangas, por citar algunos relevantes, y que suponen una referencia del marco histórico fundamental para los anteriores trabajos arqueológicos (HORMAECHEA; RIVERA; DERQUI, 2012; MIRA CABALLOS, 2005; CASADO SOTO, 2009: 393-410; CASADO SOTO, 2003: 37-70; SERRANO MANGAS, 1989). En estas obras se han estudiado los barcos tal como aparecen descritos en las ordenanzas de principios de siglo XVII y aquellas variantes de los mismos hasta muy entrado el siglo XVII cuando en las últimas décadas empieza a emerger la figura única de Antonio Gaztañeta que entronca con las reformas del comercio y la armada de inicios del siglo XVIII y el comienzo de una nueva etapa de experimentación en la construcción de navíos. Políticas ilustradas en el siglo XVIII en materia de conservación forestal, cuando se produce un cambio sensible basado en la importancia dada a la demanda sobre la comercialización de la madera.

Además se ha valorado en varias ocasiones la teoría de la denominada transición ibérica (el trasvase arquitectónico evolutivo del barco mediterráneo al Atlántico), aún falta de comprobar bajo el mar con datos arqueológicos, y especialmente se ha analizado sobre la teoría los cambios y alteraciones en las medidas de las partes del barco y la razón de ello. No obstante, en un trabajo compilatorio, Carla Rhan Philips señalaba el enorme avance de 

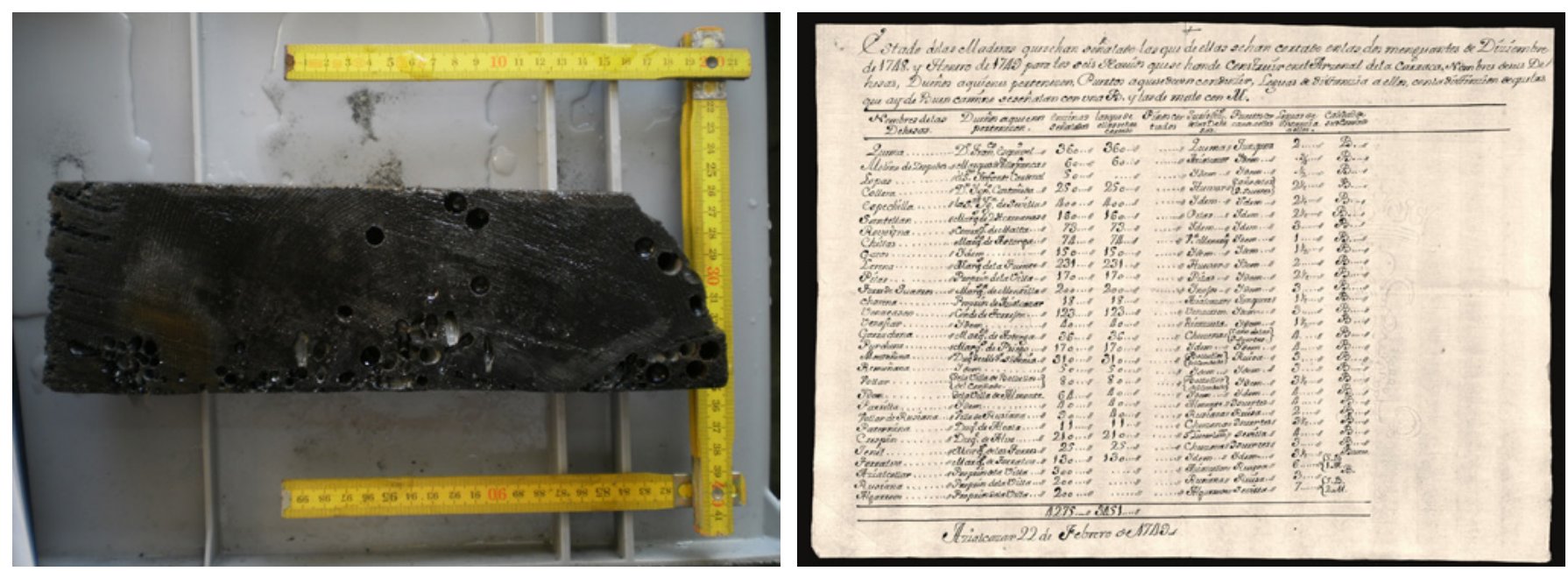

Muestras de tablas del casco de pino procedentes de La Magdalena, 18th c. Fragata española, Viveiro, Galicia | foto USC, ForSEAdiscovery

Documento del Archivo General de Simancas, Secretaría de Marina, Asientos, 608, "Estado de las Maderas que se han señalado las de que de ellas sen han cortado...", Aználcazar, 22 de Febrero de 1749 | foto Ana Rita Trindade, CSIC

la historia naval hispana en la que, sin embargo, apenas se ha contemplado la perspectiva de la madera como recurso natural de primera importancia para la industria, camuflada en la mayoría de los estudios como otro recurso más en el rico campo de los conocimientos sobre las batallas navales y la lucha por la hegemonía marítima (RAHN PHILIPS, 2013: 254-269). Algunas extraordinarias excepciones, especialmente para el siglo XVIII, han valorado su importancia desde diversos puntos de vista (BAUDOT MONROY, 2012: 297-328; QUINTERO GONZÁLEZ, 2004b: 81-94; 2004a: 27-40; 2004c); sin contar interesantes valoraciones para épocas anteriores como las que realiza Serrano Mangas, uno de los pioneros en señalar la relación entre importación de madera a Andalucía, explotación y construcción naval en un contexto bélico, como fue la Guerra de los 80 años, que incrementó la demanda peninsular y el papel holandés en el comercio de pertrechos. Hay que señalar que fue Alcalá-Zamora y Queipo de Llano el primero en percatarse de la dependencia que la construcción naval en astilleros y la importación de materiales tenía en las fases de las guerras de la Monarquía Hispánica en el norte de Europa, sobre todo en Flandes (SERRANO MANGAS, 1989: 102107; ALCALÁ-ZAMORA Y QUEIPO DE LLANO, 2001).

No obstante, el papel de la madera se ha estudiado más desde la ingeniería forestal y la ecología, aunque incluyendo el problema de la deforestación histórica relacionada con otros problemas económicos como la ganadería o su uso como carburante energético (URTEAGA, 1991: 17-43). Especialmente en el siglo XVIII se establecieron unas pautas administrativas forestales encaminadas a dos cuestiones principales, por un lado, una política coactiva de plantíos para remediar la escases de oferta forzando a los pueblos a la repoblación forestal; y la regulación de la demanda limitando las talas e intervención y control estatal sobre producción y precios. Su relación con la política naval puede detallarse a lo largo de la enorme producción llevada 
a cabo por los pensadores político-económicos del período ilustrado, como fue el estadista Gerónimo de Uztáriz, en su Theoria y práctica del comercio y marina, quien dedica un capítulo, poco conocido (el LXIII), a "las grandes utilidades que a los armamentos marítimos y navíos del comercio se siguen de haber establecido dentro de España, así el corte y conducción de árboles, tablazón y otras maderas para mástiles y demás obras de ellos, como la Fábrica de brea, alquitrán y jarcias" (UZTÁRIZ, 1724).

Relacionado con ello es importante conocer cómo se organizaron las redes de comercio de madera desde las áreas de producción. Historiográficamente se ha analizado la importancia de los recursos necesarios para la política naval teniendo en cuenta la evolución del capitalismo mercantil y los procesos de centralización y formación del Estado versus la dinámica de los negocios privados llevados a cabo por asentistas y constructores (VALDEZ-BUBNOV, 2018: 105-125; TORRES SÁNCHEZ, 2013: 159-199). Pero el principal problema planteado en el proyecto hace referencia a los diferentes orígenes de la madera localizada en pecios y la gran cantidad de información disponible en bases de datos históricas sobre cómo se transportaba la madera desde el norte y este de Europa a la Península Ibérica entre los siglos XVI al XVIII, algo que sin duda está relacionado con la especulación que en la propia época se tenía sobre los recursos forestales. En verdad, bosques e imperio son aspectos que se reflejan en el trasfondo económico y medioambiental de esta narrativa histórica, además de los fenómenos de comercio, migración de mano de obra así como la transferencia de tecnología, todo ello claves para comprender la evolución de la construcción del barco ibérico y el uso de la madera. Desde una época aún no definida de acuerdo a los datos históricos, el denominado "borne" de Flandes llegaba a los puertos españoles, especialmente andaluces, importados por las comunidades neerlandesas (flamencos y holandeses) asentadas en Sevilla y otros puertos marítimos. Un dato histórico lo da, como ejemplo, Mira Caballos, en un documento de 1652 sobre el reparo del órgano de una iglesia en Carmona: "Primeramente, con condición que de reparar y hacer sus fuelles de tablillas de madera de borne sazonados, dobles los valdreses y guarnecidos con sus cajas enlazados de madera de borne con las tablas principales de borne y los de debajo de pino de Flandes con sus cajas en que entren las pesas que han de ser de plomo"7. Esa era la razón de su nombre, borne de Flandes, aunque en verdad se refería a árboles de la familia de las Fagáceas (roble, Quercus spp), común en Europa del norte y occidental (Escandinavia, norte de Alemania, Holanda, Rusia y norte de España). Era su uso habitual tanto en el arte policromado, como en la construcción de edificios y barcos sin que hasta el momento no haya una cronología que lo defina aunque sí muchos trabajos además de otras investigaciones sobre los Pinus spp que constituían también un material muy utilizado (RODRÍGUEZ TROBAJO, 2008: 33-53). Las redes de los mercaderes flamencos de Sevilla eran solo una, pero importante y singular, ejemplo de la importación de madera para múltiples usos, pero sobre
7

Citado en MIRA CABALLOS, E. (1999) Carmona en la Edad moderna. Religiosidad y arte, población y emigración a América. Sevilla: Muñoz Moya editor, 1999, p. 218. Cf. DOMÍNGUEZ-DELMÁS, M.; VAN DEN BERSELAAR, H. (2009) Nederlands' hout op drift. Over houthandelsroutes en de herkomst van hout van de Late Middeleeuwen tot in de 18de eeuw ('Dutch' wood adrift: Timber trade and provenance of wood from the late Middle Ages until the 18th century). VITRUVIUS, n. ${ }^{\circ}$ 6, pp. 12-18 
8

Existen estudios de bosques desde la perspectiva histórica, como: ARAGÓN RUANO, Á. (2001) El bosque guipuzcoano en la Edad Moderna: aprovechamiento, ordenamiento legal y conflictividad. Donostia: Sociedad de Ciencias Aranzadi; REY CASTELAO, O. (1995) Montes y política forestal en la Galicia del Antiguo Régimen. Santiago de Compostela: Universidade de Santiago de Compostela. todo eran el reflejo de las complejas redes de agentes que actuaban detrás de la canalización de recursos forestales. Especialmente durante la dominación Habsburgo en Europa, y asentado durante la Unión de las coronas de Portugal y Castilla (1580-1640), la madera entró en un proceso dinámico y evolutivo de control, monopolización, almacenamiento, transporte y distribución por parte de las elites financieras relacionadas fuertemente con los círculos del imperio. Durante los siglos XVI y XVII los recursos madereros y la construcción naval llegaron a politizarse y reglamentarse en una paradoja medioambiental que podría definirse como "proteger es expoliar". Estas políticas se unieron a los designios navales especialmente durante la centralización administrativa de la época Borbónica en un auténtico negocio de estado militar y naval que ha sido ampliamente estudiado aunque escasamente desde el punto de vista de la madera como recurso (BAUDOT MONROY, 2012; REICHERT, 2016). No obstante, las cuestiones forestales y el poder marítimo se convirtieron en dos cuestiones ligadas, que crearon tensiones geopolíticas y alianzas, reflejadas a veces en los tratados de la época, en las leyes, en los reglamentos forestales y en la emergencia de nuevas actitudes para la gestión de los recursos naturales. Estas dos últimas cuestiones se han podido apreciar en la evolución de la Superintendencia de Montes y plantíos entre 1574 y 1748 (MARTíNEZ GONZÁLEZ, 2015). Se ha prestado atención a la organización de las pinadas en localizaciones regionales y a las importaciones de madera desde el Báltico (KUMAR, 2018a: 1-19; 2018b: 129-157; LÓPEZ ARANDIA, 2018: 127-168). Aún contado con estas valiosas investigaciones sobre la relación existente entre construcción naval, organización de recursos forestales y comercio de madera, aún quedan por conocerse más detalles sobre algunas cuestiones importantes: cómo se explotó y cómo se comercializó, especialmente a través de los agentes. De hecho, el análisis de las redes de mercaderes es el trasfondo principal del negocio de la madera, el interés de control por parte de las administraciones y es también uno de los temas de investigación del proyecto que ha producido varios trabajos individuales (alguno ya publicado) y dos tesis doctorales en vías de finalización, con especial mención del trabajo de Germán Jiménez Montes (GASCH-TOMAS; TRAPAGA MONCHET; TRINDADE, 2017: 187192; JIMÉNEZ MONTES, 2016: 693-702).

Hay que señalar una cuestión, escasamente considerada hasta ahora, es que en estos nuevos escenarios tecnológicos, sociales y económicos, hubo una presión y una demanda sin precedentes tanto sobre los bosques ibéricos como sobre otras zonas de Europa para el suministro de la madera adecuada para la construcción naval. Algunos trabajos son análisis regionales que ofrecen una rica información sobre la deforestación debida a problemas rurales y las políticas de repoblación forestal destinada a la construcción naval, como sucedió en Galicia ${ }^{8}$. Esta madera era en su mayoría roble (Quercus spp.) y pino (Pinus spp.), pero durante el proyecto ForSEAdiscovery se ha descubierto la importancia que otras especies tenían en la Península 
Ibérica para la provisión naval. Y su demanda llevó a que se crearan presiones para el abastecimiento de estos recursos y el desarrollo de nuevas redes de comercio de madera en el que estaban involucrados miembros de las redes y elites conectados con los intereses dinásticos y los centros de poder del imperio en Europa y en América.

Las cuestiones forestales y el poder marítimo se convirtieron en dos cuestiones ligadas, que crearon tensiones geopolíticas y alianzas, reflejadas a veces en los tratados de la época, en las leyes, en los reglamentos forestales y en la emergencia de nuevas actitudes para la gestión de los recursos naturales. Puede incluso llegar a decirse que durante este período la madera se convirtió en algo tan importante estratégicamente como el petróleo lo iba a ser en los siglos XX y XXI. En este contexto histórico y metodológico, el proyecto plantea una serie de preguntas que tratan de ser respondidas gracias a la relación entre el análisis de las rutas marítimas, las redes mercantiles relacionadas con el comercio global de la madera, la extracción de madera de pecios y muestreos en edificios históricos (con el fin de sustituir la escasez de árboles vivos residentes en los bosques ibéricos en la actualidad) y el análisis de la procedencia de la madera. Estas preguntas refieren si los recursos forestales ibéricos podían mantener este aumento de la demanda de madera o fue la madera importada desde otras partes. Si fue así, ¿cómo se organizaron las redes de comercio de madera desde las áreas de producción? La escasez de materias primas, ¿hizo que se alentaran los cambios tecnológicos que se produjeron en la construcción naval en el siglo XVI, o fueron estos resultados del intercambio socio-tecnológico entre el Mediterráneo y las tradiciones de construcción naval del Atlántico? ¿Dio lugar la demanda de madera a cambios sostenibles en las prácticas forestales en la Península Ibérica, o a la deforestación y al aumento de la dependencia de la importación?

\section{LA ESTRUCTURA ADMINISTRATIVA DEL PROYECTO}

El proyecto ITN (Initial Training Network) ha sido diseñado en seis programas de trabajo o Work Packages (WP). Tres de ellos están dedicados a investigación: WP1, Historical wood supply and dynamic trade networks; WP2, Nautical archaeology and shipbuilding; WP3, Wood provenancing. Los otros tres se han dedicado a gestionar la organización interna de la ITN: training activities (WP4), project management (WP5) y Dissemination and outreach activities (WP6), cuya responsabilidad cae sobre la coordinadora (Ana Crespo Solana) y dos de los miembros del consorcio (Nigel Nayling e Ignacio García González). Hay que subrayar que un buen management en la organización y dirección de un equipo formado por 15 investigadores seniors y 18 investigadores fellows contratados está en la base de poder acceder a las fuentes de financiación que ofrecen los programas europeos ${ }^{9}$.

9

Más información sobre el Consorcio ForSEAdiscovery en: http://forseadiscovery.eu/itn-supervisory-board 
https://forseadiscovery.wordpress.com/category/nautical-archaeology/; y algunas de las intervenciones en prensa: http://forseadiscovery.eu/news

\section{1}

Información sobre los investigadores fellows; http://forseadiscovery.eu/itn-fellows
Todos los WPs han estado fuertemente relacionados entre sí y sus componentes han colaborado mucho entre ellos, en la organización de campañas, organización de seminarios, conferencias y talleres (Network meeting) así como en actividades de dissemination (divulgación) del proyecto. Las actividades de divulgación se han llevado a cabo en muchos foros y ambientes, en la prensa, radio y televisión; y en la web del proyecto y en su blog ${ }^{10}$. La investigación está supervisada y en parte realizada y dirigida por un consorcio formado por 10 investigadores principales (PI) de 5 países y 9 instituciones y centros de investigación; así como 5 Associated partners (o socios) de Estados Unidos, Dinamarca, España, Polonia y Suecia.

Un total de 18 fellows, 15 de ellos Early Stage Researcher (ESR) y 3 Experienced Researcher, contratados de acuerdo a las exigencias del programa $^{11}$, han llevado a cabo proyectos individuales de investigación con diversos resultados, incluida la realización de 6 tesis doctorales, 4 (a fecha de esta publicación) ya presentadas en las correspondientes universidades. Además, los jóvenes investigadores han participado en todas las actividades del proyecto, incluyendo campañas, organización de eventos y seminarios.

A nivel general, los objetivos generales del programa Initial Training Network (ITN) son la formación para la investigación multidisciplinar y el aumento de la experiencia de los alumnos en las diferentes áreas de investigación con el fin de que puedan desarrollar habilidades transferibles para futuras carreras o profesiones en el mundo académico o en el sector privado. Además, se pretende la promoción de determinados campos de investigación gracias a la integración de herramientas, el conocimiento de metodologías que pue-

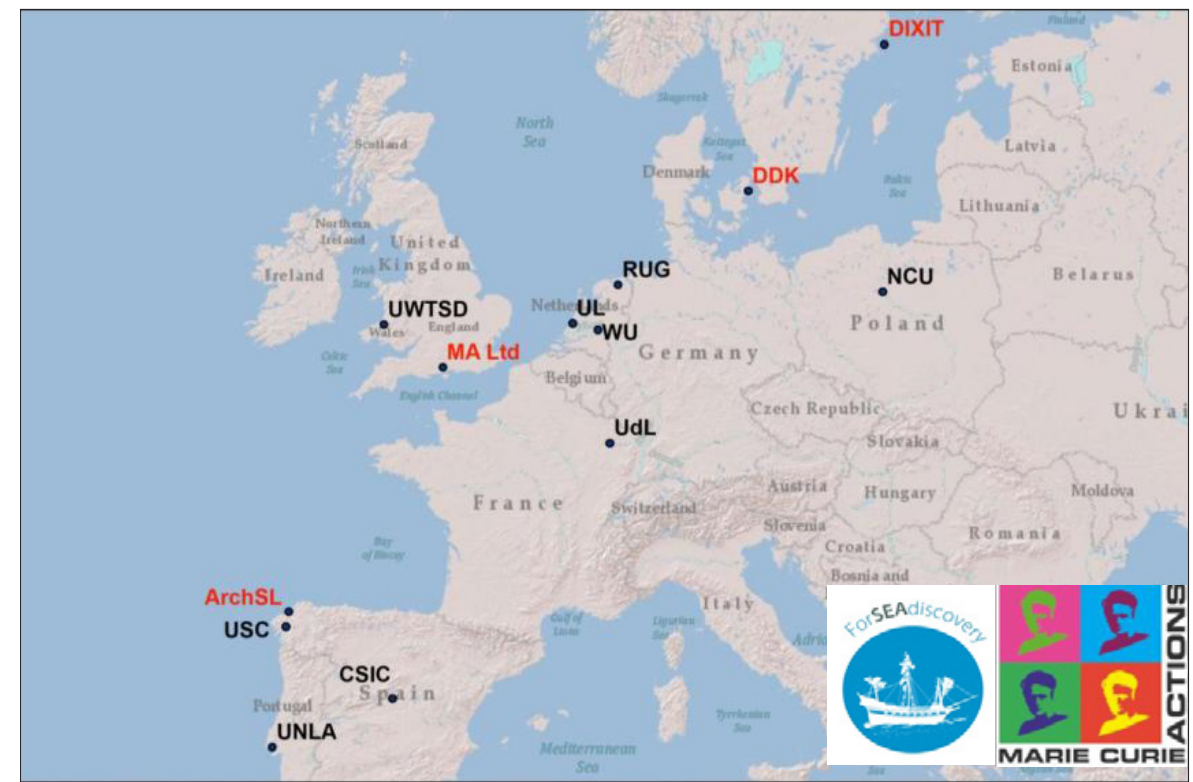


dan utilizarse de forma interdisciplinar, el desarrollo de conjuntos de datos de referencia en bases de datos que sean de open source, o acceso abierto, en la web. En definitiva, una integración de la investigación interdisciplinar. En el programa de trabajo ForSEAdiscovery esto se ha logrado mediante: primero, la participación de los becarios contratados en los cursos y talleres de capacitación destinados a desarrollar sus capacidades científicas, comunicación, gestión y liderazgo; y en segundo lugar, en la aplicación recíproca de técnicas metodológicas de las ciencias históricas, arqueológicas y las técnicas de análisis geo-químicos sobre la procedencia de la madera a diferentes casos de uso sobre el estudio de la historia de la explotación de los recursos forestales y su uso en la construcción naval durante diferentes estadios álgidos de la expansión marítima. El resultado, como se ha indicado, se ha reflejado en diversas publicaciones y trabajos de investigación en curso y una ingente profusión de datos compartidos de forma interdisciplinar en la base de datos ForSEAdiscovery. Precisamente, esto último ha producido una formación integrada y prolífica gracias al uso de los Sistemas de información geográfica (SIG), bases de datos y conocimientos de técnicas paralelas, como los Social Networks Analysis (SNA) o herramientas de análisis de redes, de acuerdo a una metodología establecida (CRESPO SOLANA, 2013). La base de datos, el SIG y la web mapping (o visualizador cartográfico resultante) tiene como objetivo integrar y visualizar las diferentes capas de información que se obtienen de las distintas disciplinas, permitiendo el estudio de la utilización histórica de los recursos forestales ibéricos, y la interacción entre las diferentes redes del comercio de madera en Europa. En el proyecto ForSEAdiscovery el modelo de datos orientado a SIG (que se explicará más adelante) se ha desarrollado a partir de un prototipo existente creado por mí, como coordinadora del proyecto, en anteriores proyectos $^{12}$. El contenido de los datos ha sido implementado con datos durante otro proyecto financiado por el Plan Nacional de Investigación I+D13. La base de datos y SIG ForSEAdiscovery está sirviendo como plataforma de manejo de datos para la investigación y los fellows se han iniciado con estas bases de datos en el conocimiento de la aplicación de los SIGs a las distintas disciplinas del programa.

\section{BREVE EXPOSICIÓN DE RESULTADOS}

El proyecto ForSEAdiscovery ofrece ya sus primeros resultados. De forma breve serán sumariados a continuación, aunque desarrollaré en un epígrafe aparte solo algunas cuestiones sobre la base de datos, como herramienta de integración para el análisis de resultados. En respuesta a las preguntas y problemas de investigación se han producido diversos trabajos interdisciplinares que arrojan algunas luces sobre conocimientos previos, así como generar datos inéditos. De acuerdo a las directivas del proyecto algunos de estos conjuntos de datos se están, o estarán en breve, dándose a conocer
12

Se trató del proyecto DynCoopNet, y cuya base de datos está localizada en el repositorio digital del CSIC. (Ref. EUROCORES,TECTESF project FP-004/DynCoopNet, 20052010).

13

Es el proyecto GlobalNet HAR2011-27694. Cf. CRESPO SOLANA, 2014: 2-44. 
http://forseadiscovery.eu/content/deliverables

15

Puede consultarse la información relativa en http://forseadiscovery.eu/content/maritimecampaigns

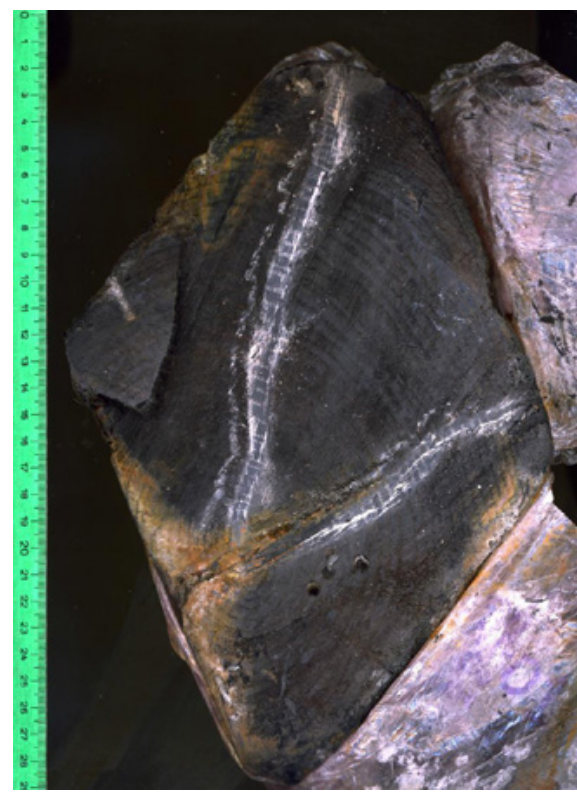

Yarmouth Road Wreck. Muestras del pecio recogidas durante la campaña del año 2015 para el análisis dendrocronológico e identificación de la madera | foto MALTd, ForSEAdiscovery en forma de deliverables, tal como quedaba estipulado en nuestro Annex 1, documento de trabajo incluido en el Grant Agreement. Estos resultados aparecerán en breve en la web del proyecto $^{14}$, y ofrecen, entre otras herramientas, un inventario exhaustivo de las fuentes históricas y geográficas sobre los suministros de madera (siglos XVI-XVIII). Este inventario sirve de base para el conocimiento sobre las fuentes de especies arbóreas, especialmente roble y pino utilizados para la construcción naval en el Atlántico ibérico durante la era de los descubrimientos y la expansión europea. Además, se dispone de un amplio catálogo de literatura y datos de archivos históricos. Una detallada información sobre los diferentes procesos de adquisición de la madera, su selección, comercio y transporte, son el objetivo de una tesis doctoral en curso llevada a cabo por Ana Rita Trindade que aporta un valioso e inédito SIG sobre las áreas de aprovisionamiento forestal.

Por último, un detallado estudio sobre las prácticas de gestión y las leyes específicas promulgadas para sostener y proteger los recursos forestales aspiran a completar los conocimientos actuales. Aparte de toda esta conjunción de datos que el proyecto ForSEAdiscovery deja en herencia a los seguidores de esta línea de investigación, el grueso de las actividades más importantes se basa, sin duda, en la organización de un modelo de datos orientado a SIG con información histórica, arqueológica y dendrocronológica de barcos y naufragios históricos. En segundo lugar, el modelo de trabajo llevado a cabo en campañas de arqueología subacuática y el establecimiento de unas dendrocronologías que, aunque hasta el momento son solo parciales y no abarcan todo el panorama geográfico de la Península Ibérica, suponen un verdadero motor para futuras aplicaciones en la datación de madera de pecios. Dentro del proyecto se han organizado varias campañas de arqueología subacuáticas en torno de hasta un total de cinco sitios arqueológicos en España: Finisterra/Costa da Morte, Ribadeo, la Fragata Magdalena y el pecio conocido como La Bayonnesa. En Portugal se ha organizado una campaña en cooperación con el proyecto coordinado por la Universidade Nova de Lisboa y la Cámara Municipal de Esposende en el denominado pecio de Belinho ${ }^{15}$. En breve saldrán a la luz nuevas publicaciones sobre cada una de estas intervenciones, aunque algunos de los resultados han sido ya divulgados ampliamente, incluso con la realización de la tesis doctoral de Miguel San Claudio (SAN CLAUDIO, 2017). Estos pecios fueron ya objeto de estudio anteriormente, e incluso de expolio o destrucción, como fue el caso de la fragata Magdalena. Los métodos llevados a cabo por nuestro equipo se orientaron al buceo en los sitios arqueológicos con objeto de establecer un registro y extraer muestras de madera. Uno de estos pecios, la corbeta de guerra francesa Bayonnaise posee abundante madera estructural en conexión. El pecio de la fragata de la Armada española Santa María Magdalena es uno de los ejemplos más interesantes, al conocerse su identidad, para la reconstrucción de sus características dendroarqueológicas (TRINDADE; DOMíNGUEZ-DELMÁS; TRAORÉ at ál., en prensa). Además se han reali- 
zado dos temporadas de excavaciones en un barco ibérico en Reino Unido, el Yarmouth Road wreck, hundido en el Solent cerca de la costa de la Isla de Wight (WATSON; GALE,1990: 183-192). Se trata de una carraca española, quizás nombrada Santa Lucía, que se perdió en la zona alrededor de 156716. El Pecio de Ribadeo, o Galeón de Ribadeo, es quizás la flag ship del proyecto ForSEAdiscovery que ha coordinado y participado en dos intervenciones. Este pecio, un galeón del siglo XVI, presenta características excepcionales y al momento están siendo objeto de estudio tanto su estructura arquitectónica como su madera (SAN CLAUDIO SANTA CRUZ; GONZÁLEZ GALLERO; CASABAN et ál., 2014: 169-178; CASABAN, 2017: 238-260).

Aparte de estos trabajos arqueológicos, el proyecto ForSEAdiscovery ha colaborado con otros proyectos en curso, como en la excavación de Delta III, en la bahía de Cádiz; en la excavación del Highbourne Cay wreck, un navío del siglo XVI en las Bahamas (OERTLING, 1989: 244-253; SMITH; KEITH; LAKEY, 1985: 63-72), y en los estudios sobre la expedición de Tristán de Luna, hundida en 1559, cuyos navíos fueron localizados en las costas de Pensacola (BENDING, 2018) ; aparte de la prospección llevada a cabo en los navíos sumergidos de la flota de Apodaca, en las costas de Trinidad y Tobago (CRESPO SOLANA; NAYLING 2016). En todos estos casos la misión del equipo de buceo del proyecto dirigido por Nigel Nayling ha sido siempre la recogida adecuada de muestras de madera.

\section{LA BASE DE DATOS FORSEADISCOVERY}

Como base para los estudios histórico-arqueológicos se están utilizando bases de datos, en algunos casos con datos geolocalizados, que han sido ya creadas en anteriores trabajos de investigación por parte de los miembros del Consorcio ${ }^{17}$. Estas bases de datos han experimentado un proceso de integración en un Sistema de Información Geográfica (SIG) que logra ofrecer una visualización cartográfica de la información. Precisamente, uno de los objetivos del proyecto era tanto la recogida de información cualitativa y cuantitativa de documentos y literatura como de bases de datos que aportan conocimientos valiosos sobre el comercio global de la madera que afectaba a la Península Ibérica. En este apartado contamos con la base de datos The Sound Toll Registers Online, que da mucha información sobre las exportaciones de madera a la Península Ibérica ${ }^{18}$. Pero es importante señalar que la base de datos y SIG ForSEAdiscovery integra importante información sobre las características de naufragios de buques ibéricos con el procesamiento de datos en bases de datos pre-existentes, principalmente la base de datos de The ShipLAB (TAMU A\&M) de Filipe Castro y la base de datos DynCoopNetData Collection (o CrespoDatabase Atlantic Trade) de la que escribe estas líneas. Estos datos están sirviendo aún para el cotejo de la información histórica y arqueológica sobre las características de construc-
16

SATCHELL, J.; RICH, S.; MOMBER, G. (FECHA) Yarmouth Roads Shipwreck Evaluation and Timber Sampling campaign: Assessing the local seabed archive to answer research questions of international importance. Documento de trabajo. Memoria de la intervención arqueológica realizada por Maritime Archaeology Tust, en el proyecto ForSEAdiscovery. Vease RICH, S. (2015) What's in a name? The Yarmouth Roads shipwreck and the Iberian connection <https://forseadiscovery. wordpress.com/whats-in-a-name-the-yarmouth-roads-shipwreck-and-the-iberian-connection/> [Consulta: 20/02/2019].

17

CRESPO SOLANA: http://digital.csic.es/handle/10261/28394 (Repositorio Digital CSIC); CASTRO: Early Modern Shipwrecks: http:// tamu.maps.arcgis.com/apps/MapJournal/ index.html? appid=da41bddb126241fea235ec934428d48c; NAYLING: http://archaeologydataservice.ac.uk/archives/view/newportship_2013/ (The Newport Ship); MOMBER: http://www.maritimearchaeologytrust.org/a2s (The Atlas of the Two Seas).

18

Esta base de datos: http://www.soundtoll.nl/ index.php/en/over-het-project/str-online está dirigida por el Dr. Jan Willem Veluwenkamp. 


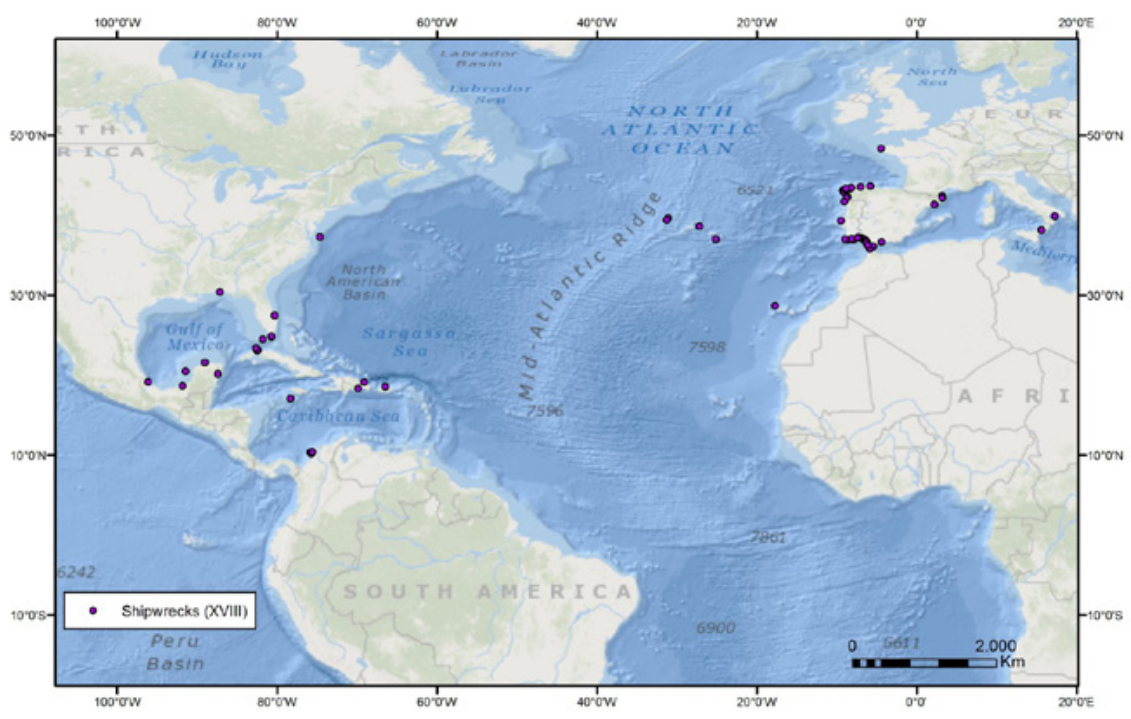

ForSEAdiscovery Database: Ejemplo de análisis sobre naufragios. Estadísticas

ción de los buques específicos en los astilleros del Atlántico ibérico y el uso de la madera contemporánea en un momento de importantes avances tecnológicos entre los siglos XVI y XVIII. La depuración y manejo de estos datos están sirviendo para poder cotejar esta información con la literatura precedente, a la que hice referencia en mi anterior estado de la cuestión, pero sin duda, y dada la enorme cantidad de información, será objeto de futuras investigaciones. Es el próximo objetivo la realización de una web mapping o visualizador que estará disponible online en el CSIC.

Para la elaboración de este SIG sobre historia y arqueología se ha realizado un trabajo muy minucioso durante cuatro años en el que han participado varios componentes del equipo del proyecto. Se ha desarrollado un modelo de datos orientado a SIG que combina la información de las diferentes disciplinas de historia, arqueología y técnicas de análisis de la madera. La base de datos ForSEAdiscovery no solo integra datos de las referidas bases de datos pre-existentes (cuyos datos han sido ya insertados convenientemente) sino que se ha visto enriquecida con una gran cantidad de datos procedentes de diversas fuentes de información: en primer lugar se trata de una investigación de base histórica básica que se ha llevado a cabo con la ingente documentación localizada en archivos españoles (especialmente Simancas, General de Indias de Sevilla) archivos holandeses y en Portugal. En este apartado se ha conseguido un catálogo de referencia básicamente sobre comercio atlántico que reúne identificación de navíos históricos (con datos históricos sobre cada barco) y navíos arqueológicos (con datos sobre pecios excavados y con información arqueológica. Además se ha obtenido una rica información en archivos y bibliotecas en relación con el comercio de madera y las rutas marítimas en los siglos de la Edad Moderna, así como la propia 


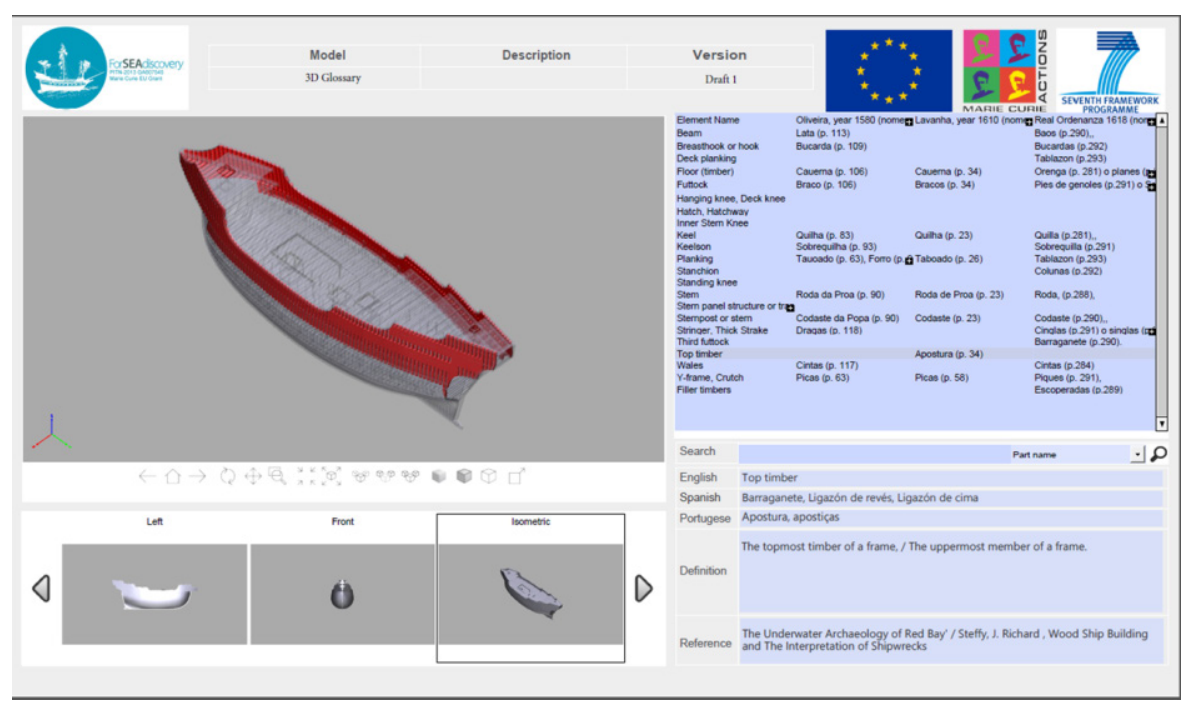

dinámica de las redes mercantiles (Merchant Networks) en esta economía de explotación forestal y de recursos. En relación con esta recopilación histórica se han llevado a cabo estudios complementarios históricos-arqueológicos sobre casos de uso concreto realizando intervenciones arqueológicas puntuales en pecios de la Edad Moderna, de construcción ibérica, previamente localizados en bases de datos. En estos pecios se ha procedido a la recogida de muestras de madera estructural con el fin de cotejarla con análisis dendrocronológicos y de procedencia de las maderas realizados en laboratorios. Estas muestras de madera se han obtenido en trabajo de campo con árboles vivos (Living trees) y en edificios históricos. Estos datos se están procesando para ser introducidos en el SIG, aunque hasta el momento se cuenta con, al menos, tres bases de datos intercalados con varias mapeos de barcos y naufragios.

El resultado de este SIG y base de datos ForSEAdiscovery integra así información de tres disciplinas diferentes, pero fuertemente relacionadas en lo que a datos se refiere. El modelo es la base para una plataforma GIS que puede además ser usada como herramienta de integración y de visualización para diferentes capas de información acerca de la localización geográfica de naufragios, objetos de estudio histórico-arqueológico y para ofrecer una adecuada narrativa al estudio de la navegación y su contexto. Su diseño está orientado a la identificación de comportamientos o modelos (patterns) en la evolución de la tecnología de construcción naval y del empleo de la madera y su procedencia. La base de datos está organizada en tablas, campos de atributos y relaciones entre tablas. Los resultados obtenidos ofrecen una visión muy amplia sobre cómo se llevaba a cabo, distribuía y monopolizaba el comercio de la madera entre España, Portugal y el norte de Europa
Tesauro de características de construcción naval. Referencia a maderas descritas en fuentes históricas y registros arqueológicos 
identificando las fuentes de recursos, el proceso de cómo se controlaba el talado de bosques, el transporte de la madera, la selección y las prácticas de organización de este comercio, así como la legislación que se produjo en torno a esto en los distintos países involucrados. En este marco se da vital importancia a las organizaciones y avatares de las flotas de Indias en sus viajes entre Europa y América con la intención de poder aglutinar información arqueológica, histórica y dendrocronológica de los navíos conocidos y localizados, aunque estos solo constituyen una pequeña parte en el estado actual de conocimientos (CRESPO SOLANA, 2018b). Se tiene la esperanza de poder avanzar en su conocimiento y protección y es un largo camino y trabajo por hacer en el que se necesita una cooperación de muchos especialistas y acceso a financiaciones internacionales, algo totalmente viable como el proyecto ForSEAdiscovery ha demostrado.

Relacionado con los trabajos de la base de datos se ha producido un glosario y una herramienta de representación 3D de los modelos de barcos teniendo en cuenta las piezas que lo componen y las especies utilizadas en su construcción. Este trabajo ha sido supervisado en la Universidad de Gales (UWTSD), por Nigel Nayling, como director de las campañas subacuáticas del proyecto.

\section{A MODO DE CONCLUSIÓN ¿UNA DENDROCRONOLOGÍA HISTÓRICA?}

La madera se convirtió en un recurso estratégico fundamental. Y ahora estamos conociendo más acerca de su explotación como recurso, su gestión, las políticas forestales y su evolución durante diversos períodos históricos, gracias también a los estudios realizados por ecólogos e ingenieros forestales. Como materia prima históricamente insostenible, la madera ha sido sometida a una gobernanza a partir de factores políticos y disponibilidad de recursos en cada tiempo histórico y ello ha influido en su explotación, pero también en la tecnología relacionada con su aplicabilidad, de acuerdo a la teoría de Jared Diamond sobre el materialismo cultural. Esto es algo que puede apreciarse en la evolución de la construcción naval. Ese materialismo cultural ayuda a entender en la historia las causas de las diferencias y similitudes socioculturales y la evolución en el proceso tecnológico. Aunque parezca increíble, en la historiografía española, la historia forestal, salvo honrosas excepciones, ha sido poco tratada desde el aspecto medioambiental. En el caso español sí se ha estudiado el siglo XVIII con una aproximación a dicha perspectiva, gracias a trabajos inolvidables como la Historia de un roble del siglo XVIII (ARANDA Y ANTÓN, 1990). A diferencia de este bien estudiado siglo, queda más por conocer de las épocas precedentes como ya algunos trabajos han señalado, en especial llevados a cabo durante este proyecto. La necesidad de los recursos del bosque es algo presente en el surgir de las ideas conservacionistas sobre la naturaleza a lo largo de los siglos y fue 
precisamente la politización de los problemas forestales por la "escasez de madera" la que dio lugar a la acumulación de conocimiento ecológico-forestal, siempre, especialmente durante los siglos XVII y XVIII, desde un punto de vista empírico-práctico.

Este proyecto aspira a integrar información sobre la procedencia de la madera con los datos históricos-arqueológicos. Tarea ardua dado que los conocimientos existentes se han centrado más parcialmente en la perspectiva histórica-tecnológica y menos en una consiliencia (consilience), en una disposición por unir conocimientos de distintas disciplinas para crear un marco unificado de entendimiento (VALBUENA-CARBAÑA; HEREDIA; FUENTES-UTRILLA et ál., 2010: 492-506; HALDONA; MORDECHAIA; TIMOTHY et ál., 2018: 3210-3218). Los análisis sobre la procedencia de la madera (Wood Provenance) no solo se aplican en restos extraídos en sitios sumergidos sino en las localizaciones de madera estructural o en conexión en zonas intermareales o costeras que puedan suponer un posible aporte a la elaboración de un catálogo de maderas históricas o de una dendrocronología histórica. Queda por hacer una adecuada dendrocronología de la Península Ibérica que nos dé datos de conexión entre la fragmentada información histórico-arqueológica que poseemos.

En el proyecto, los trabajos de muestreo en árboles vivos (Living Trees) y en edificios históricos han constituido un avance importante que aún está pendiente de producir datos en los laboratorios. Los avances recientes en la dendrocronología histórica, que permiten la datación junto a la creación de

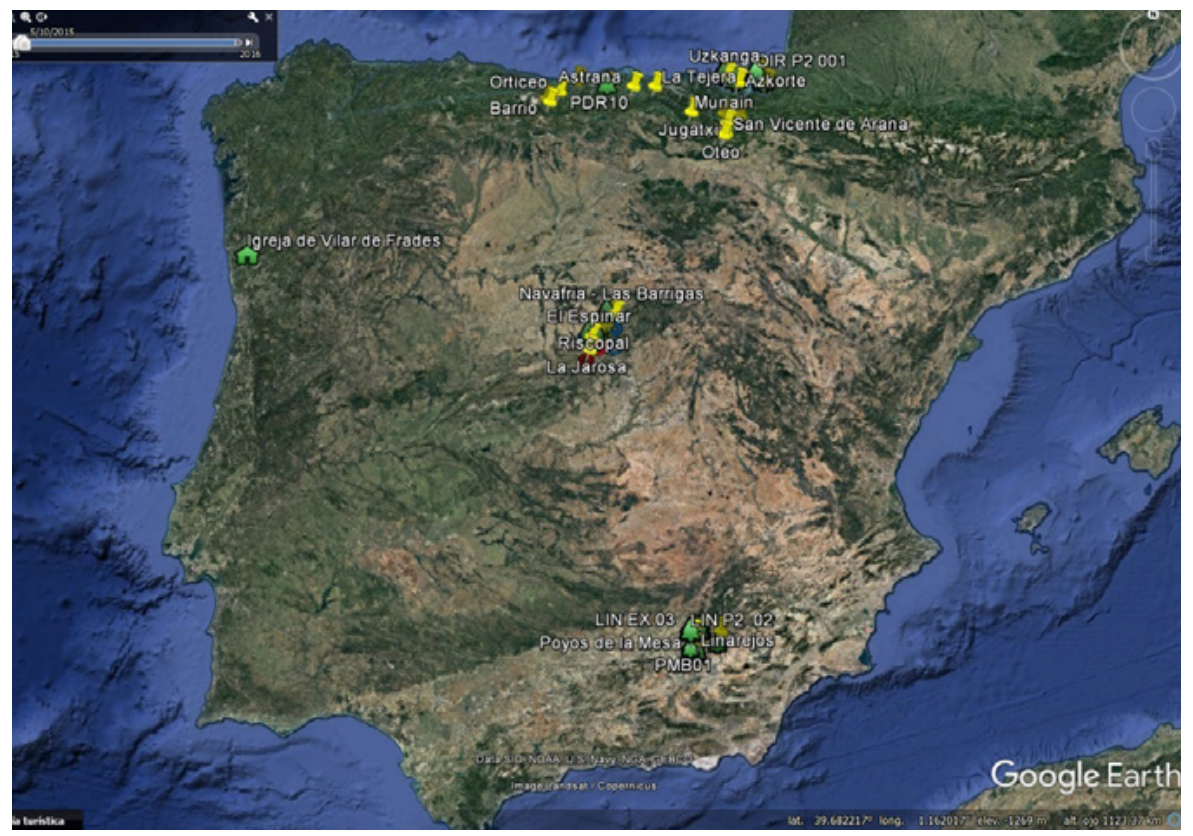


estas cronologías y los análisis químicos y de ADN relacionados, los cuales han experimentado mucho avance para algunas zonas de Europa (en Europa central y norte), están aún menos desarrollados en la Península Ibérica. Por lo tanto, el desarrollo de referencias cronológicas de anillos de árboles en zonas de la Península Ibérica que suministraban madera para la construcción naval, ampliado a otras zonas históricamente explotables como, aparte de la Cordillera Cantábrica, el Sistema Central, Cazorla o la Sierra de Segura, sería un primer paso para la evaluación de las fechas y procedencia de los recursos utilizados en la construcción naval en España y Portugal. Además, durante el proyecto se han implementado nuevos análisis que están dando lugar a técnicas emergentes como el análisis de isótopos estables (especialmente estroncio) y de ADN. La recogida de muestras ha tenido lugar en diversas zonas geográficas identificadas como "montes de marina" en la documentación histórica.

Ahora bien, dado el proceso de deforestación que ha sufrido la Península Ibérica, a veces es difícil localizar árboles vivos (de más de 300 o 400 años de antigüedad) que sirvan para datar madera de un galeón del siglo XVI o XVII. Los escasos especímenes de mayor edad están localizados y protegidos por el ministerio español de Medioambiente, al igual que también sucede para el caso de Portugal. Por ello, se ha realizado un importante y paralelo muestreo de madera en edificios históricos. En este apartado la dendrocronología histórica ha servido para poder datar madera antigua que se encuentra en la importante arquitectura del patrimonio español y portugués, como ha sucedido, por ejemplo, con las catedrales de Segovia y Jaén, que han sido útiles para la datación de pecios (DOMÍNGUEZ-DELMÁS; ALEJANO-MONGE; DAALEN at ál., 2015; DOMÍNGUEZ-DELMÁS; ALEJANO-MONGE; WAZNY at ál., 2013: 635-652).

En definitiva, el análisis dendrocronológico sobre la procedencia de la madera que se utilizó para la construcción naval requiere un nuevo enfoque integrado: se ha estado complementando la información de las fuentes históricas con un estudio de los anillos de los árboles, su anatomía y su ADN. Esta información se encuentra en las bases de datos dendrocronológicas. Ello está permitiendo realizar una identificación fiable de madera, así como para caracterizar las áreas de origen de la madera en la Península Ibérica y diferenciar qué madera se usó de origen local de la importada, sobre todo de área Scando-Báltica. A su vez, se han realizado estudios que comparan muestras de árboles vivos con la madera que se proporcionaba a los astilleros o que se suministraban para la construcción de edificios históricos, y que venían de diversos lugares. Las muestras de maderas de pecios, recogidas durante las campañas de arqueología subacuática, previamente identificados se utilizan también como material de prueba para hacer verificaciones sobre el origen de la madera. La importancia de este análisis radica en el cotejo comparado (Data-crossing) con la información histórica existente. 
Tanto la recogida de muestras de madera llevada a cabo por los dendrocronólogos (de árboles vivos) como por los arqueólogos marítimos (muestras de madera de los pecios) es fundamental con objeto de cotejar ambos resultados y dejar lo más claro posible la identificación de la procedencia de la madera que fue utilizada en la construcción de un determinado barco. Gracias a ello se podrá averiguar si los datos químicos coinciden con la información que proporciona la información histórica. Aunque la diferenciación de las especies de robles y pinos es directa por la observación de los árboles vivos, esto no se ha logrado con éxito para el estudio de la anatomía de la madera. Y ello es crucial para determinar si un barco se construyó en un astillero de la Península Ibérica o en otro lugar. El roble y la madera de pino se importaron a España y a Portugal en la Edad Moderna, pero la madera ibérica no se exportó a otra parte para uso en los astilleros. Quercus Faginea y Quercus Pyrenaica son endémicas de la Península Ibérica y se encuentran en grandes cantidades como maderas estructurales originales en un barco. Esto podría ser una indicación a la hora de determinar si un barco fue construido en un astillero de la Península Ibérica. Esto es básicamente nuestro reto futuro en la investigación interdisciplinar. 


\section{BIBLIOGRAFÍA}

- ALCALÁ-ZAMORA Y QUEIPO DE LLANO, J. (2001) España, Flandes y el Mar del Norte (1618-1639). La última ofensiva europea de los Austrias madrileños. Madrid: Centro de Estudios Políticos y constitucionales, 2001

- ARANDA Y ANTÓN, G. (1990) Los bosques flotantes. Historia de un roble del siglo XVIII. Madrid: Icona, 1990

- BAUDOT MONROY, M. (2012) Barcos para el rey: Juan de Arroaga, la madera y la construcción naval (1752-1759). En GARCÍA HURTADO, M. (coord.) La Armada española en el siglo XVIII: ciencia, hombres y barcos, 2012, pp. 297328

- BENDING, CH. (2018) Amidships Assembly of the Sixteenth-Century Emanuel Point II Shipwreck. International Journal of Historical Archaeology. https://doi.org/10.1007/ s10761-018-0477-y

- CASTRO, F. V. (DE) (2005) The Pepper Wreck: A Portuguese Indiaman at the Mouth of the Tagus River. Texas: Ed. Rachal Foundation Nautical Archaeology Series, 2005

- CASTRO, F.; YAMAFUNE, K.; EGINTON, C. DERRYBERRY, T. (2011) The Cais do Sodré Shipwreck. International Journal of Nautical Archaeology, 40- 2, 2011, pp. 328-34

- CASABAN, J. L. (2017) Santiago de Galicia and the Illyrian squadron: Characteristics, dimensions and tonnages of Mediterranean-built galleons for Philip's II Atlantic fleets (1593-1597). The International Journal of Maritime History, vol. 29(2), 2017, pp. 238- 260

- CASADO SOTO, J. L. (2009) La construcción naval hispana en época moderna. En CAU ONTIVEROS, M. A.; NIETO PRIETO, X. (coords.) Arqueologia nàutica mediterràni. Girona: Centre d'Arqueologia Subacuàtica de Catalunya, 2009, pp. 393-410

- CASADO SOTO, J. L. (2003) La invención del galeón oceánico de guerra español. RIBOT GARCIA, L.; DA ROSA, L. (coord.) Naves, puertos e itinerarios marítimos en la época moderna. Madrid: Editorial Actas, 2003, pp. 37-70

- CRESPO SOlANA, A.; NAYLING, N.; GARCÍAGONZÁLEZ, I. (2014-2018) ForSEAdiscovery. Forest Resources for Iberian Empires: Ecology and Globalization in the Age of Discovery (XVI-XVIII centuries). Madrid: Consejo Superior de Investigaciones Científicas, 20142018. DOI: http://dx.doi.org/10.20350/digitalCSIC/8587

- CAZENAVE dE LA ROCHE, A. (2018) La construction navale au XVlème siècle en Méditerranée: l'apport de l'épave de la Mortella III (Saint-Florent, Haute-Corse). Tesis doctoral Université de Paris-Sorbonne, 2018

- CRESPO SOlANA, A. (2018a) Dutch Trade and Spatial Integration between the Baltic and Spain, 1700-1778. En VELUWENKAMP, J. W.; SCHELTJENS, W. (ed.) Early
Modern Shipping and Trade Novel Approaches Using Sound Toll Registers Online. Leiden: Brill, 2018, pp. 77-94

- CRESPO SOlANA, A. (2018b) La organización de las flotas hispano-caribeñas y su logística (1717-1746). Una aproximación desde la Arqueología náutica. En GRAFENSTEIN, J. VON; REICHERT, R.; RODRÍGUEZ TREVIÑO, J. C. (coord.) Entre lo legal, lo ilícito y lo clandestino. Prácticas comerciales y navegación en el Gran Caribe, siglos XVII al XIX. México: Conacyt, 2018

- CRESPO SOLANA, A. (2017) Merchants and the beating of a butterfly's wings: from local to global in the transfer of economic behavior models in the 18th century. En HERRERO SÁNCHEZ, M.; KAMPS, K. (ed.) Merchants and Trade Networks in the Atlantic and the Mediterranean, 1550-1800: Connectors of Commercial Maritime Systems. London: Pickering \& Chatto Publishers LTD, 2017, pp. 83105

- CRESPO SOlANA, A. (2016) Wood Resources, shipbuilding and Social Environment: The Historical context of the ForSEAdiscovery Project. Skyllis. Journal of the German Society for the Promotion of Underwater Archaeology, 15, n. ${ }^{\circ}$ 1, 2015

- CRESPO SOlANA, A. (2014) Spatio-Temporal Narratives: Historical GIS and the study of Global Trading networks (1500- 1800). Cambridge Scholar Publishing, 2014

- CRESPOSOLANA,A. (2013)LaHistoriageográficamente integrada y los Sistemas de InformaciónGeográfica (SIG): concepto y retos metodológicos. Tiempos Modernos, 26/ 1 (Monográfico Historia moderna y Sistemas de Información Geográfica, coordinado por David Alonso)

- CRESPO SOlANA, A. (2009) Mercaderes Atlánticos. Redes del comercio flamenco y holandés entre Europa y el Caribe. Córdoba: Editorial, 2009

- CRESPO SOlANA, A. (2001) El comercio marítimo entre Cádiz y Amsterdam, 1713-1778. Madrid: Banco de España, 2001

- CRESPO SOlANA, A. (1996) La Casa de la Contratación y la Intendencia General de la Marina en Cádiz, 1717-1730. Cádiz: Servicio de Publicaciones Universidad de Cádiz. 1996

- CREspo solanA, A; CASTRO, F. (2016) The ForSEAdiscovery database. The origin <https://www. academia.edu/20167289/The_ForSEAdiscovery_ Database._The_origin> [Consulta: $20 / 03 / 2019]$

- CRESPO SOlANA, A.; NAYLING, N. (2016) Archaeohistorical and dendrochronological study of the wrecks of the fleet of Apodaca. ForSEAdiscovery Project, Report (literatura gris)

- DOMínguEZ-DELMÁS, M.; ALEJANO-MONGE, R.; 
DAALEN, S. VAN; RODÍGUEZ-TROBAJO, E.; GARCÍAGONZÁLEZ, I.; SUSPÉRREGUI, J.; WAZNY, TH.; JANSMA, E. (2015) Tree-rings, forest history and cultural heritage: current state and future prospects of dendroarchaeology in the Iberian Peninsula. Journal of Archaeological Science, 2015, pp. $180-196$

- DOMÍNGUEZ-DELMÁS, M.; ALEJANO-MONGE, R.; WAZNY, TH.; GARCÍA GONZÁLEZ, I. (2013) Radial growth variations of black pine along an elevation gradient in the Cazorla Mountains (South of Spain) and their relevance for historical and environmental studies. European Journal of Forest Research, 132, 2013, pp. 635-652

- DÓMÍNGUEZ-DELMÁS, M.; NAYLING, N.; LOUREIRO, V.; LAVIER, J. (2012) Dendrochronological Dating and Provenancing of Timbers from the Arade 1 Shipwreck, Portugal. The International Journal of Nautical Archaeology 42.1, pp. $118-136$

- DOMÍNGUEZ-DELMÁS, M.; RICH, S.; DALY, A.; NAYLING, N.; HANECA, K. (2018) Selecting and Sampling Shipwreck Timbers for Dendrochronological Research: practical guidance. The International Journal of Nautical Archaeology, 0.0, 2018, pp. 1-14

- DOMÍNGUEZ-DELMÁS, M. (2015) Forest History, Timber supply and Tree Rings. A dendroarchaeological approach to the study of Iberian cultural heritage. Tesis doctoral inédita. Universidad de Huelva, 2015

- DOMíngueZ-DELMÁs, M. (2013) Avances de la dendrocronología al servicio de la Arqueología subacuática española, ¿Qué información podemos extraer de la madera de los pecios? En NIETO PRIETO, X.; RAMÍREZ PERNÍA, A.; RECIO SÁNCHEZ, P. (coord.) Actas del I Congreso de Arqueología Naútica y Subacuática Española, Cartagena, 14, 15 y 16 de marzo de 2013, pp. 1080-1094

- EGUILUZ MIRANDA, B.; TRAPAGA MONCHET, K.; DOMÍNGUEZ-DELMÁS, M.; SAN CLAUDIO SANTA CRUZ, M.; GASCH-TOMÁS, J. L.; CRESPO SOLANA, A.; NAYLING, N. (2015) The Ribadeo shipwreck (c.1600): can we identify the ship through a multidisciplinary approach? En Actas del VI Congreso Internacional de Arqueología Subacuática (IKUWA VI), del 28 de noviembre al 2 de diciembre de 2015, Fremantle, Australia (en prensa)

- FUENTE DE PABLO, P. (DE LA) (2006) El Triunfante: tecnología y ciencia en la España de la llustración. Barcelona: Museo Marítimo, 2006

- GALLAGHER, N. (2016) A methodology for estimating the volume of Baltic timber to Spain using the Sound Toll Registers: 1670-1806. The International Journal of Maritime History, Vol. 28(4), 2016, pp. 752-773

- garcía RIVERA, C.; MARTí SOlANO, J.; ALONSO VILLALOBOS, C.; GALLARDO ABÁRZUZA, M. (1995) Carta arqueológica Subacuática de la Bahía de Cádiz.
Cuadernos de arqueología marítima, n. ${ }^{\circ} 3,1995$, pp. 105124

- gASCH-TOMAS, J. L.; TRAPAGA MONCHET, K.; TRINDADE, A. R. (2017) Shipbuilding in times of war: Contracts for the construction of ships and provision of supplies in the Spanish Empire in the early seventeenth century. The International Journal of Maritime History, vol. 29(1), pp. 187-92

- GUIMERÁ, A.; CHALINE, O. (2018) (dir.) La Real Armada. La Marine des Bourbons d'Espagne au XVIIle siécle. Paris-Sorbonne: PUPS, 2018

- HAJ, F. (2017) Utilisation des isotopes stables et radiogéniques du stron@um pour tracer la provenance des bois: application à des épaves sous-marines. Tesis doctoral defendida el 14 de noviembre 2017 en Nancy, Universidad de Lorraine (Francia)

- HALDONA, J.; MORDECHAIA, L.; TIMOTHY, P.; NEWFIELB, C.; CHASED, A. F.; IZDEBSKIE, A.; GUZOWSKIG, P.; LABUHNH, I.; ROBERTSI, N. (2018) History meets palaeoscience: Consilience and collaboration in studying past societal responses to environmental change. PNAS, marzo 27, vol. 115/3, 2018, pp. 3210-3218

- HORMAECHEA, C.; RIVERA, I.; DERQUI, M. (2012) Los galeones españoles del siglo XVII. 2 tomos. Barcelona: Museu Marítim de Barcelona, 2012

- JIMÉNEZ MONTES, G. (2016) Las redes comerciales del norte de Europa en el suministro de madera a Andalucía de 1581 a 1621. GARCÍA FERNÁNDEZ, M. (ed.) (2016) Familia, cultura material y formas de poder en la España moderna. Madrid: FEHM, 2016, pp. 693-702

- KUMAR, M. (2018a) A method for estimating the volume of the Baltic timber products exported through the Sound and its application to Portugal, 1669-1815. Scandinavian Economic History Review, 2018, pp. 1-19

- KUMAR, M. (2018b) In defence of Bang and Korst's Sound Toll Tables. International Journal of Maritime History, 2018, pp. 1-6

- LEON AMORES, C. (2009) Buceando en el pasado. Los grandes naufragios de la Historia. Madrid: Espasa, 2009, pp. 178 y ss.

- Novisima recopilación de las LEYES de España: dividida en XII libros. (1805-1829) Volumen 6, Madrid:, [s.n.], 18051829, pp. 193-194

- LOEWEN, B. (1998) The Red Bay vessel. An example of a Sixteenth century Biscayan ship. Itsas Memoria. Revistas de Estudios Marítimos del País Vasco, 2. Donostia, San Sebastián: Untzi Museoa- Museo Naval, 1998, pp. 193-199;

- LÓPEZ ARANDIA, A. (2018) Aprovisionando de madera el arsenal de Cartagena: el proyecto de Manuel Bernia y 
las flotaciones por el río Segura (1784-1793). Tiempos Modernos, 36 (2018/1), pp. 127-168

- MARTí SOLANO, J. (2014) Actuaciones en Andalucía en desarrollo del Plan Nacional de Arqueología subacuática. En NIETO PRIETO, F. X.; BETHENCOURT, M. (coord.) Arqueología subacuática española: Actas del I Congreso de Arqueología Naútica y Subacuática Española, vol. 2, 2014, pp. 109-118

- MARTÍNEZ GONZÁLEZ,A. J. (2015) La superintendencia de montes y plantíos (1574-1748). Valencia: Ed. Tirant Lo Blanch, 2015

- MARTÍNEZ LILLO, S.; BLANQUEZ, J. (ed.) (1993) II Curso de Arqueología subacuática. Madrid, 1993, pp. 163169

- MIRA CABALlOS, E. (2005) Las Armadas imperiales. La guerra en el mar en tiempos de Carlos $V$ y Felipe II. Madrid: Ed. La esfera de los libros, 2005

- NAYLING, N. (2008) The application of dendrochronology to underwater archaeology. En TSANG, C. (ed.) International Symposium on Underwater Archaeology. Taiwan: 2008, pp. 64-73

- NAYLING, N.; JONES, T. (2014) The Newport Medieval ship, Wales, United Kingdom. The International Journal of Nautical Archaeology, vol. 43, 2, pp. 239-278

- NAYLING, N.; SUSPÉRREGUI, J. (2014) Iberian Dendrochronology and the Newport Medieval ship. The International Journal of Nautical Archaeology, vol. 43, 2, pp. $279-291$

- OERTLING, T. J. (1989) The Highborn Cay Wreck: The 1986 Field Season. International Journal of Nautical Archaeology, 18 (3), pp. 244-253

- PÉREZ- MALlainA BUENO, P. E. (2015) Naufragios en la Carrera de Indias durante los siglos XVI y XVII. El hombre frente al mar. Sevilla: Universidad de Sevilla, 2015

- PUJOL I HAMELINK, M.; VIVAR I LOMBARTE, G.; FUENTE DE PABLO, P. (2011) El navío Triunfante: Jorge Juan y la construcción a la inglesa. En AA. VV. Actas de las Jornadas de ARQUA 2011. Cartagena, 3 y 4 de diciembre de 2011. Ministerio de Educación, Cultura y Deporte, 2011

- QUINTERO GONZÁlEZ, J. (2004a) Las gentes de la maestranza y los reclusos del arsenal de La Carraca en el siglo XVIII. Revista de historia naval, año n. ${ }^{\circ} 22, n .{ }^{\circ} 84$, 2004, pp. 27-40

- QUINTERO GONZÁLEZ, J. (2004b) La arboladura en la construcción naval del siglo XVIII. Revista de historia naval, año $n^{\circ} 22$, n. ${ }^{\circ} 87,2004$, pp. 81-94

- QUINTERO GONZÁLEZ, J. (2004c) La madera en los pertrechos navales: Provisión de motones, remos y bombas al arsenal de La Carraca. Tiempos modernos: Revista Electrónica de Historia Moderna, vol. 4, n. ${ }^{\circ}$ 10, 2004

- RAHN PHILIPS, C. (2013) Guerra en el mar. Tecnología y armamento en el Mundo Atlántico. En O'DONNELL Y DUQUE DE ESTRADA, H. (coord.) Historia Militar de España. Edad Moderna, vol. I (Ultramar y la Marina). Comisión Española de Historia Militar, Real Academia de la Historia, Ministerio de Defensa, 2013, pp. 254-269

- REICHERT, R. (2016) El comercio directo de maderas para la construcción naval española y de otros bienes provenientes de la región del Báltico sur, 1700-1783. Hispania, 76, 252, pp. 129-157

- RICH, S.; NAYLING, N.; MOMBER, G.; CRESPO SOLANA, A. (2017) Shipwrecks and Provenance. In Situ timber sampling protocols with a focus on wrecks of the Iberian shipbuilding tradition. Archaeopress Publishing Ltd., 2017

- RIDELLA, R. G.; ALZAGA, M.; ENRÍQUEZ MARCÍAS, G.; GALLARDO ABÁRZUZA, M.; HIGUERAS MILENA, J. M.; CIACCHELA, F. (2017) The Cadiz-Delta II wreck: the "San Giorgio" a Genoese merchantman sunk by Francis Drake in 1587. Archeologia Post Medievale. Società, Ambiente, Produzione, 20, 2017, pp. 11-65

- TRINDADE, A., DOMÍNGUEZ-DELMÁS, M. TRAORE, M., GALLAGHER, N., RICH, S. MARTINS, A. (2015) From Forests to the Sea, from the Sea to the Laboratory: the Timbers of the Frigate Santa Maria Magdalena (18th century). En Actas del VI Congreso Internacional de Arqueología Subacuática (IKUWA VI), del 28 de noviembre al 2 de diciembre de 2015, Fremantle, Australia (en prensa)

- RODRígueZ TROBAJO, E. (2008) Procedencia y uso de madera de pino silvestre y pino laricio en edificios históricos de Castilla y Andalucía. Arqueología de la Arquitectura, pp. 33-53

- SAN CLAUDIO, M. (2017) El Atlántico norte español, un espacio estratégico para un imperio. Siglo XVI: una visión arqueológica. Tesis doctoral inédita. Universidad de Zaragoza

- san ClaUdio SANTA CRUZ, M.; GONZÁlez GALLERO, R.; CASABAN, J. L.; CASTRO, F. (2014) El precio de Ribadeo, un excepcionalmente bien conservado pecio español del siglo XVI. En NIETO PRIETO, F. X.; BETHENCOURT, M.(coord.) Arqueología subacuática española: Actas del I Congreso de Arqueología Naútica y Subacuática Española, vol. 1, 2014, pp. 169-178; pp. 221227

- SERRANO MANGAS, F. (1989) Armadas y flotas de la plata (1620-1648). Madrid: Banco de España, 1989

- SMITH, R. G.; KEITH, D. H.; LAKEY, D. (1985) The Highborn Cay Wreck: Further Exploration of a 16th-Century 
Bahaman Shipwreck. International Journal of Nautical Archaeology, 14 (1), 1985, pp. 63-72

- SOBERÓN, M.; PUJOL, M.; LLERGO, Y.; RIERA, S.; JULIÁ, R.; DOMÍNGUEZ, M. (2012) El Barceloneta I. Una embarcación medieval a tingladillo en Barcelona. ITSAS. Memoria. Revistas de Estudios Marítimos, 7, Untzi MuseoaMuseo Naval, Donostia-San Sebastián, 2012, pp. 411-422

- TORRES SÁNCHEZ, R. (2013) Administración o asiento. La política estatal de suministros militares en la Monarquía Española del siglo XVIII. Studia Historica, 35, pp. 159-199

- TRAORÉ, M. (2018) Potential Biomarkers of provenance of the wood from Iberian Typology shipwrecks $\left(15^{\text {th }}-17^{\text {th }}\right.$ centuries). Tésis doctoral inédita. Universidad de Santiago de Compostela, 2018

- TRAPAgA MONCHET, K.; SANTOS, A. (2015) Forestry and timber supply in the Royal Forests of the Iberian Peninsula through the $16^{\text {th }}$ century. Skyllis, 1, 2015, pp. 6268

- TRINDADE, A. R. (2015) Bourbon Naval Policy, Forestry and Timber Supply for Shipbuilding inAndalucia (1700-1759): Brief introductory research notes. En VARELA GOMES, R.; VARELA GOMES, M. (coord.) The management of Iberian Forest Resources in the Early Modern Shipbuilding: History and Archaeology. Lisboa: IAP, 2015, pp. 57-65

- TRINDADE, A.; DOMÍNGUEZ-DELMÁS, M.; TRAORE, M.; GALLAGHER, N.; RICH, S.; MARTINS, A. (en prensa) From forests to the sea, from the sea to the laboratory: the Santa Maria Magdalena frigate. En Actas del VI Congreso Internacional de Arqueología Subacuática (IKUWA VI), del 28 de noviembre al 2 de diciembre de 2015, Fremantle, Australia (en prensa)

- UZTÁRIZ, J. (DE) (1724) Theorica y practica del comercio y marina. Madrid: s.n., 1724, cap. LXIII, p. 162

- VALBUENA-CARBAÑA, M.; HEREDIA, U.; FUENTESUTRILLA, P.; GONZÁLEZ-DONCEL, I. G. (2010) Historical and recent changes in the Spanish forests: A socio-economic process. Review of Palaeobotany and Palynology, 162, 2010, pp. 492-506

- VALDEZ-BUBNOV, I. (2018) Shipbuilding administration under the Spanish Habsburg and Bourbon regimes (15901834): A comparative perspective. Business History, 60:1, 2018, pp. $105-125$

- VARELA GOMES, R.; TRAPAGA MONCHET, K. (ed.) (2017) Árvores, barcos e homens na Península Ibérica (Séculos XVI-XVIII). Lisboa: IAP, 2017

- VIVAR loMbarte, G.; Geli, R.; NIETO PRIETO, X.; DELTEBRE I. (2014) Un barco hundido en la desembocadura del Ebro durante la guerra del francés. En NIETO PRIETO, F. X.; BETHENCOURT, M. Arqueología subacuática, vol. 1, 2014, pp. 221-227
- WATSON, K.; GALE, A. (1990) Site evaluation for marine sites and monuments records: the Yarmouth Roads Wreck investigations. International Journal of Nautical Archaeology, 19.3, 1990, pp.183-192 


\section{El IVCR+i premio Europa Nostra 2018 por su proyecto de conservación de los bocetos de Sorolla Visión de España}

Gemma María Contreras Zamorano, Elena Gandía Guijarro | Subdirección General del Institut Valencià de Conservació, Restauració i Investigació (IVCR+i) Generalitat Valenciana

URL de la contribución <www.iaph.es/revistaph/index.php/revistaph/article/view/4308>

\section{RESUMEN}

La Comisión Europea y Europa Nostra, la red más importante en materia de patrimonio europeo, ha otorgado el Premio Unión Europea de Patrimonio Cultural/Premios Europa Nostra 2018 al Institut Valencià de Conservació, Restauració i Investigació (IVCR+i), por su proyecto de conservaciónrestauración de Los bocetos de Sorolla de Visión de España, pertenecientes a la Hispanic Society of America (New York).

Este proyecto tuvo su culminación en la gran exposición temporal Sorolla íntimo, bocetos de "Visión de España", que permitió mostrar el proceso creativo de Sorolla a través de sus dibujos preparatorios y el complejo proceso de intervención de restauración realizado por los profesionales del IVCR+i, que utilizaron la técnica japonesa "soko" y los criterios más respetuosos y avanzados en conservación y restauración.

\section{Palabras clave}

Bocetos | Conservación | Grandes formatos | Institut Valencià de Conservació, Restauració i Investigació | Laminación | Premio Unión Europea de Patrimonio Cultural | Premio Europa Nostra | Restauración | Soko | Sorolla | 2018 | 


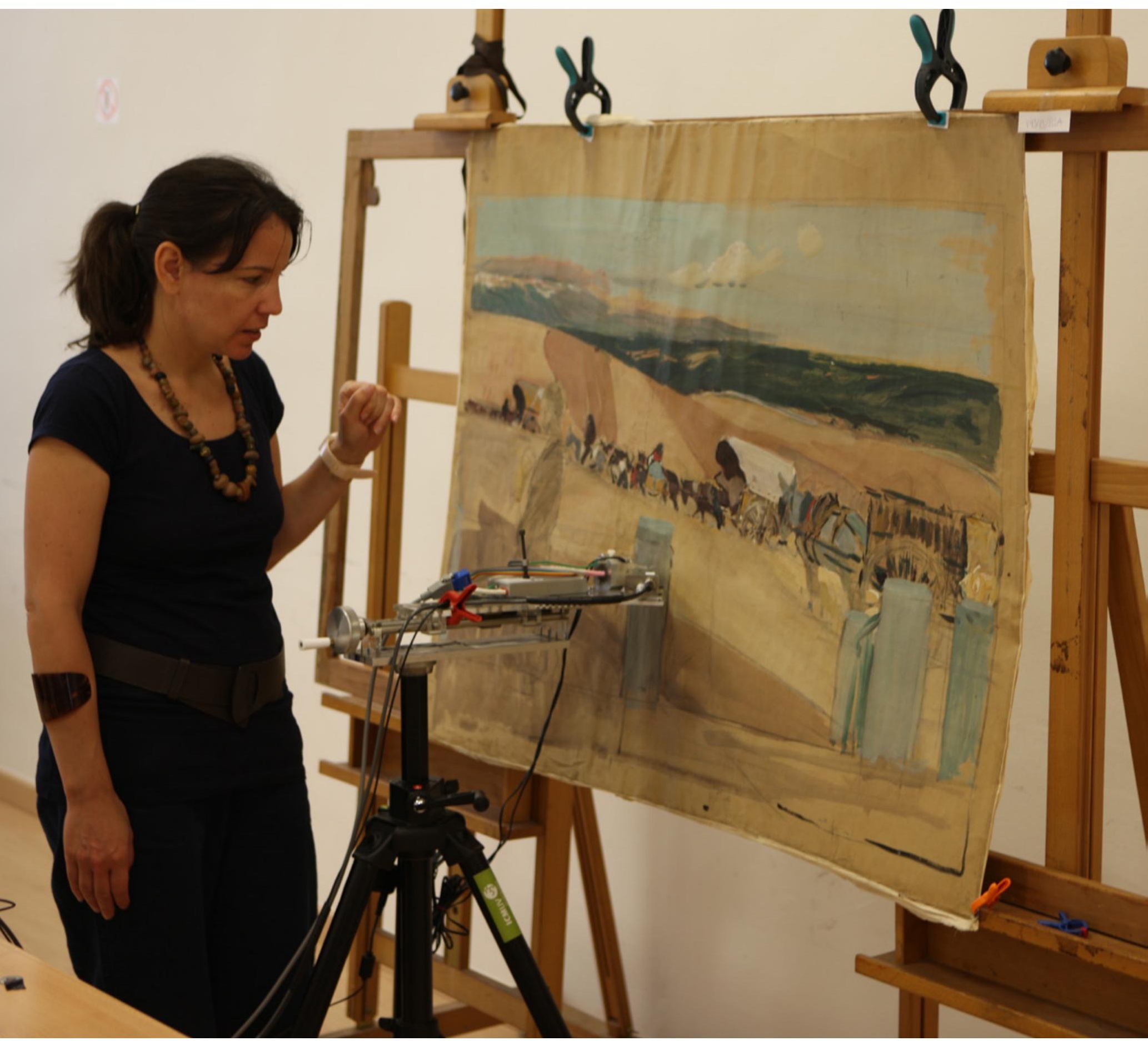

Estudio de los pigmentos con fluorescencia de Rayos X | foto Institut Valencià de Conservació, Restauració i Investigació (IVCR+i), titular de todas las imágenes que ilustran este artículo 
La Comisión Europea y Europa Nostra, la red más importante en materia de patrimonio europeo, han otorgado al Institut Valencià de Conservació, Restauració i Investigació (IVCR+i) el Premio Unión Europea de Patrimonio Cultural/Premio Europa Nostra en su edición de 2018, por el proyecto de restauración de los bocetos que Joaquín Sorolla realizó para su monumental serie pictórica Visión de España, premiando la contribución de este proyecto en el ámbito de la conservación del patrimonio cultural.

El IVCR+i es un organismo dependiente de la Generalitat Valenciana cuya misión principal es la salvaguarda del patrimonio cultural valenciano a través de proyectos de conservación, restauración e investigación, y su posterior difusión y comunicación. Para ello cuenta con un equipo multidisciplinar y con la colaboración de instituciones académicas y culturales a nivel nacional e internacional. El premio recibido supone un gran reconocimiento para el IVCR+i y, en especial, para el Departamento de Obra Gráfica y Material de Archivo, que ha demostrado ser puntero en su especialidad desde que se creara en 2006.

La otra gran institución que ha permitido la consecución de este proyecto de conservación es la Hispanic Society of America, con sede en Nueva York, creada para la divulgación y estudio de la cultura española en los Estados Unidos de América. Uno de los fondos artísticos más importantes que posee es la obra que Joaquín Sorolla realizó para decorar la Biblioteca de la Hispanic titulada Visión de España, cuyos dibujos preliminares han sido objeto de esta restauración y exposición.

La decisión de los conservadores de la Hispanic Society ha tenido como motivación recuperar obras de difícil intervención y al mismo tiempo hacerlas visibles a un público más amplio, ya que hasta ahora habían sido pocas las personas que habían podido apreciar su impacto no sólo en relación con los lienzos murales, sino como obras de arte extremadamente expresivas por sí mismas. Para ello se firmó un convenio con la Generalitat Valenciana, a través del IVCR+i, por el que la Hispanic Society financiaba el traslado de las obras a Valencia (España) y el IVCR+i se hacía cargo de la restauración de las obras y de organizar su posterior exhibición en una muestra itinerante, con la colaboración de la Fundación Bancaja.

Joaquín Sorolla nació en 1863 en Valencia, una ciudad española, mediterránea. En ella aprendió su oficio y se desarrolló como artista pero, sobre todo, se empapó de su luz y de sus paisajes. Su éxito lo lanzó a nivel internacional todavía en vida. Primero dio el salto a Madrid, después a París y Londres y, tras conocer a Archer Milton Huntington, traspasó el Atlántico y cautivó con su pintura al pueblo americano. La culminación de su obra fue el encargo que le realizó Huntington en 1911 de la serie de paneles al óleo conocida como Visión de España destinada a ilustrar, en las paredes de la 


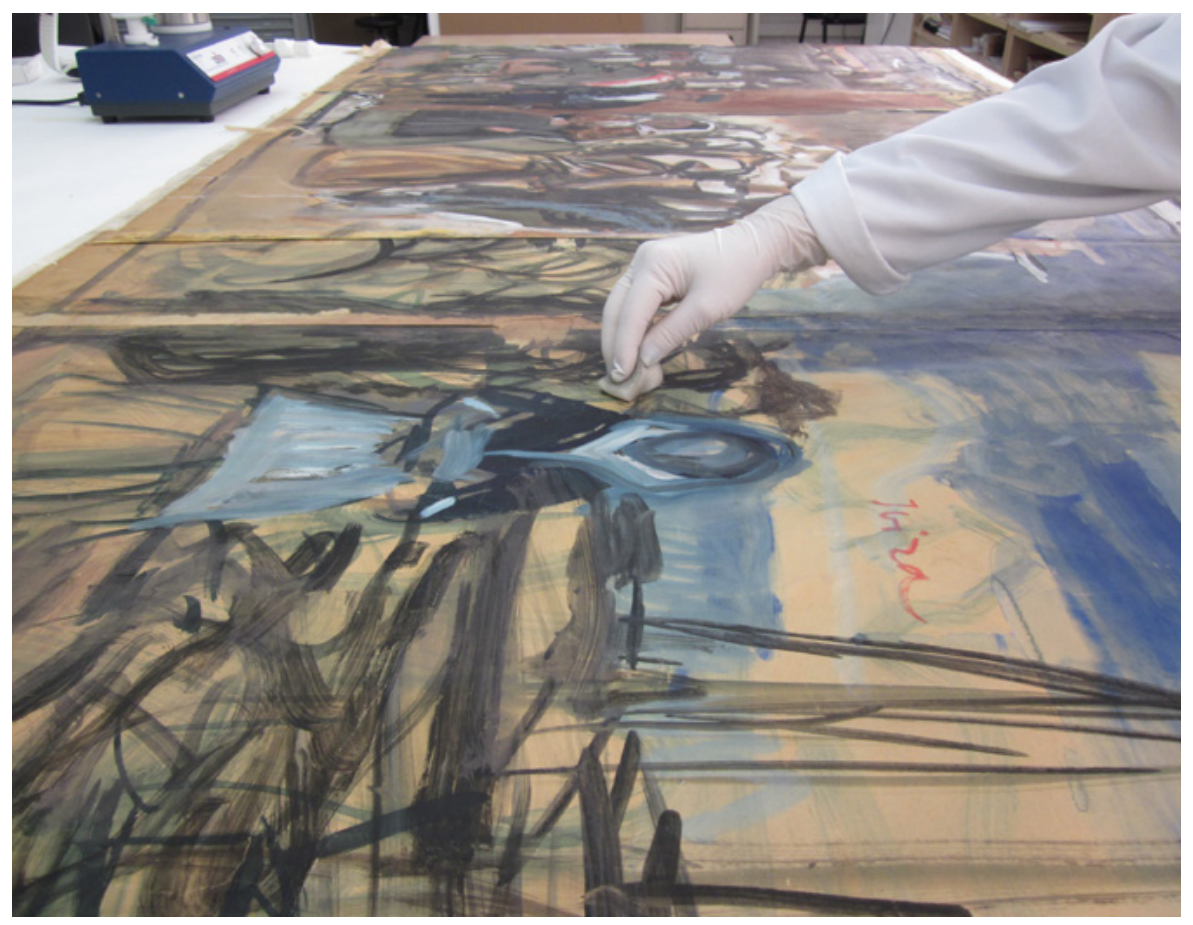

Biblioteca de la Hispanic Society, las diferentes regiones y tradiciones de España. En ella, Sorolla recogió el testigo de una España a punto de desaparecer y retrató personajes y costumbres de cada una de sus regiones. Huntington, conocedor del arte y capacidad de Sorolla, estipuló en el contrato que no sólo le correspondía la obra final, sino también sería suyo todo el proceso creativo, de gestación, previo. Sorolla viajó durante nueve años por España con rollos de papel que colgaba con chinchetas, en los que esbozaba del natural los aspectos que más le interesaban de esa España plural. Llegó a realizar un importante número de dibujos y lienzos preparatorios que, a modo de bocetos o apuntes directos, fue tomando por las distintas regiones de España.

El proyecto de restauración de los bocetos de Sorolla, abordado por el IVCR+i, puede considerarse la culminación de otro de mayor envergadura que comenzó en 2007 cuando la Fundación Bancaja promovió y financió la restauración de los 14 grandes lienzos de Visión de España que decoran la Biblioteca de la Hispanic Society of America. En aquella ocasión los lienzos se restauraron y viajaron por primera vez a España para ser mostrados en una gran exposición que se celebró en 2007 en el Centro Cultural Bancaja y, entre 2008 y 2009, en el Museo de Bellas Artes de Sevilla, en el Museo Municipal de Málaga, en el Museo Nacional de Arte de Cataluña y en el Museo de Bellas Artes de Bilbao, para finalizar su peregrinaje con la gran muestra celebrada en el Museo del Prado. 
1

BURKE, M. B.; PONS-SOROLLA, B.; PÉREZ, C. (2015) Sorolla Íntimo. Bocetos de Visión de España. [Valencia]: Fundación Bancaja, D. L. 2015, $189 \mathrm{p}$
Como colofón a este gran proyecto se decidió restaurar la obra gráfica que acompaña a este conjunto pictórico y devolverle así su inicial esplendor. Para ello, la Hispanic Society confió en los profesionales del IVCR+i, tanto del Departamento de Obra Gráfica y Material de Archivo, como de los departamentos de Pintura de Caballete y del Laboratorio de Materiales, que contó con la especial colaboración del Instituto de Estudio de Materiales de la Universitat de València.

Fue en el mes de abril de 2013 cuando llegaron al IVCR+i, desde Nueva York, treinta y dos bocetos totalmente inéditos de Sorolla, para ser intervenidos durante un periodo de 18 meses en su sede de Valencia. La segunda parte del proyecto, la puesta en valor tanto de las obras como del proceso de restauración, se plasmó en la exposición Sorolla Íntimo. Bocetos de Visión de España, organizada por la Fundación Bancaja en su Centro Cultural de Valencia en 2015. Dado el gran éxito de la muestra, se continuó con esa labor de difusión de la obra de Sorolla y, aprovechando los meses de verano que son los más turísticos en la Comunidad Valenciana, se exhibió en los Museos de Bellas Artes de Alicante y Castellón, para terminar su periplo español en el fantástico Museo de Bellas Artes de A Coruña a principios de 2017.

Gracias a la intervención se ha asegurado la pervivencia de estos grandes dibujos, algunos de los cuales miden más de un metro de altura por ocho de longitud, y cuya fragilidad los hace especialmente vulnerables. Se les ha dotado de soportes y marcos que garantizan su conservación preventiva a largo plazo. Los frágiles papeles con los que Sorolla aprehendió la España de inicios del siglo XX tienen asegurado un largo futuro que podrán apreciar y estudiar futuras generaciones. Por su parte, la exposición Sorolla Íntimo. Bocetos de Visión de España y el catálogo que la acompañaba ${ }^{1}$, han permitido dar a conocer estos singulares estudios que nunca se habían visto fuera de la Hispanic Society of America y, paralelamente, mostrar el proceso de investigación y restauración realizado por los técnicos del IVCR+i que han utilizado la técnica japonesa soko, y han adoptado los criterios más respetuosos y avanzados en conservación y restauración.

\section{ESTADO DE CONSERVACIÓN DE LAS OBRAS Y VALORACIÓN DEL PROYECTO DE CONSERVACIÓN-RESTAURACIÓN}

A finales de los años sesenta del siglo XX los conservadores de la Hispanic Society of America ya eran conscientes de que este importante conjunto de obra gráfica formado por más de ciento setenta bocetos, realizados con carboncillo o gouache sobre papel, necesitaba tratamiento de conservación. Numerosos acercamientos por parte de la Hispanic Society al Fondo Nacional para las Artes de los Estados Unidos a partir de 1968 fructificaron 
finalmente durante los años ochenta en la concesión de ayudas destinadas a una primera campaña de restauración. A ella le siguieron otras durante los noventa (asociadas con la exposición de 1998-99 Sorolla y la Hispanic Society en el Museo Thyssen-Bornemisza de Madrid), y también durante esta última década, ya en el siglo XXI.

Ahora, gracias a la dilatada colaboración entre la Hispanic Society y las instituciones culturales valencianas, el grupo final y más grande de bocetos, compuesto por 25 obras realizadas bajo la técnica del gouache sobre papel (32 hojas en total), ha podido ser restaurado, con lo que concluyen más de cuarenta años de esfuerzos por la conservación del conjunto.

Estos bocetos descubren el modo de trabajar de Joaquín Sorolla a la hora de componer los grandes lienzos de Visión de España, pues responden a apuntes del natural de personajes, objetos y paisajes, que posteriormente fue recomponiendo en su estudio mediante una técnica similar al collage, basada en recortar aquellas figuras o elementos que le gustaban y, con ellos, componer otro boceto hasta llegar a la composición definitiva. En otros casos son sólo los propios bocetos y apuntes, o en un tercer caso se trata de figuras recortadas y pegadas sobre otro papel para tener un catálogo de figuras o personajes que posteriormente pudiese utilizar en la composición pictórica. Por ello podemos decir que son tres modalidades de bocetos los que se han intervenido en esta ocasión.

En el IVCR+i se apuesta por un trabajo multidisciplinar que garantice un profundo conocimiento de las obras y permita una aproximación a las mismas desde distintos puntos de vista obteniendo un resultado más completo en función de las aportaciones y métodos empleados y determinando así tanto el estado de conservación como el protocolo y método de actuación que garanticen la preservación de las piezas.

Los bocetos que realizó Joaquín Sorolla son, en su mayoría, obras de gran formato y están realizados con gouaches (con pinceladas puntuales de óleo) sobre papel de baja calidad, un material industrial que los hacía resistentes pero relativamente efímeros. Además, los métodos de trabajo de Sorolla resultaban una complicación adicional, ya que había recortado figuras y escenas individuales para después pegarlas en nuevas composiciones, en muchos casos con la adhesión de varios estratos en un mismo panel.

Con anterioridad a la intervención se realizó un informe pormenorizado del estado de conservación de cada uno de los treinta y dos bocetos. Presentaban un deterioro acusado, consecuencia, sobre todo, de la adherencia de distintos materiales y la diferente tracción que estos provocan por la interacción con los agentes ambientales. Por un lado, todos descansaban sobre una tela de algodón como soporte auxiliar que se encontraba en un proceso de 

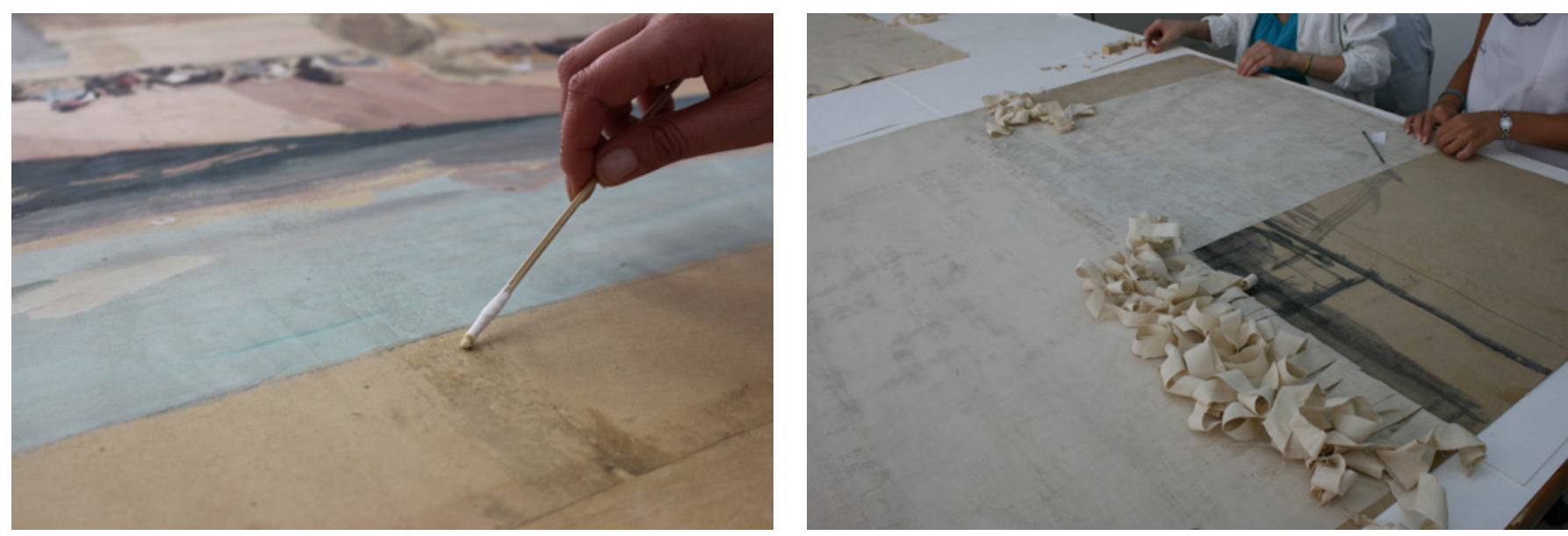

Limpieza de los restos de adhesivo del reverso, a la izquierda

degradación bastante avanzado y que no resolvía el problema de sujeción tal y como fue concebido; además, originaban importantes tensiones al tener ambos soportes un comportamiento diferente ante las variaciones de los parámetros de humedad relativa ambiental. Por otro lado, se ha podido constatar que Sorolla "reparó" algunos de estos bocetos con una tela engomada por el reverso, lo que resulta evidente en algunas intervenciones ya que los dibujos se componen, en muchos casos, de recortes realizados por el artista en los que solapa figuras y diferentes vestimentas e incluso ambientes. Estas estructuras también han generado importantes problemas de craquelados, distensiones, deformación e incluso rasgados de gran tamaño, por el empleo de adhesivo en exceso y la no preocupación en su superposición. Se trata de obras que Joaquín Sorolla pintó para él, sin esperar que salieran a la luz. De hecho, se advierte en su factura un artista muy diferente al que nos tiene acostumbrados, más estructural y conceptual, con una pincelada muy rápida con la que es capaz de construir "con poco un todo" en una importante composición. En muchos de los bocetos se advierte el trazo previo de carboncillo y algunos de ellos se conservan en esta técnica, sobre todo los referidos al estudio y diseño de la distribución de los grandes paneles en la biblioteca de la Hispanic Society. La capa pictórica presentaba una capa de suciedad superficial provocada por la polución ambiental. En la época en que llegaron los dibujos a Nueva York (hacia 1920) la calefacción de la zona de Harlem era de carbón, esto explica que estas piezas soportaran una capa superficial bastante intensa de partículas sólidas de carbón que terminó apagando la viveza de los colores empleados por el artista.

\section{ESTUDIOS PREVIOS Y PROCESO DE INTERVENCIÓN}

Tal y como se ha señalado, la técnica de ejecución de todos los bocetos es al gouache sobre papel por una cara, a excepción de uno de ellos, que se 


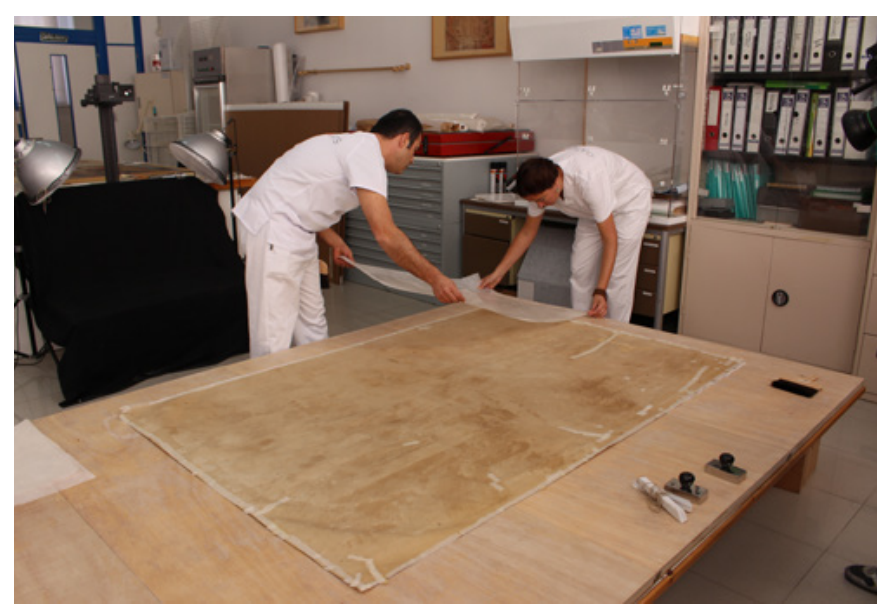

encuentra dibujado por las dos caras, de las cuales una ha sido esbozada con carboncillo.

Al tratarse de obras de gran formato sobre papel con elementos sustentados solubles, después de evaluar los resultados de los diversos estudios previos e investigaciones y barajar distintas posibilidades, se estimó que la técnica que mejor se podía adaptar al proceso de recuperación de la obra era la técnica japonesa sōkō que ha demostrado su eficacia por la simplicidad, ductilidad y respeto a la obra sobre papel, gracias al empleo de materiales naturales que respetan al máximo la obra y la impronta creativa del artista.

La necesidad de retirar la tela fue la más ponderada y valorada por el peligro estructural que esto suponía, por lo que la decisión fue tomada después de realizar varias pruebas, y con una propuesta de sustitución del soporte auxiliar que pasaba por una laminación con papel japonés.

En primer lugar, se llevó a cabo la documentación fotográfica de alta resolución que permitía examinar la naturaleza de estas piezas y ver con detalle los deterioros, para facilitar su posible y posterior intervención.

Acontinuación se realizaron análisis "no destructivos" mediante Fluorescencia de Rayos X Dispersiva en Energía (EDXRF), en colaboración con el Instituto de Ciencia de los Materiales de la Universidad de Valencia (ICMUV).

Los espectros EDXRF de los bocetos de Sorolla fueron registrados "in situ" en el IVCR+i mediante un espectrómetro portátil integrado por un tubo de rayos-X miniaturizado con ánodo de transmisión de plata que puede operar hasta $35 \mathrm{kV}$ y $0.1 \mathrm{~mA}$ y un detector de semiconductor Si-PIN con una resolución en energía de 165eV (FWHM @ 5.9 keV). Los análisis se efectuaron con incidencia normal del haz de rayos- $X$ sobre los bocetos y manteniendo 


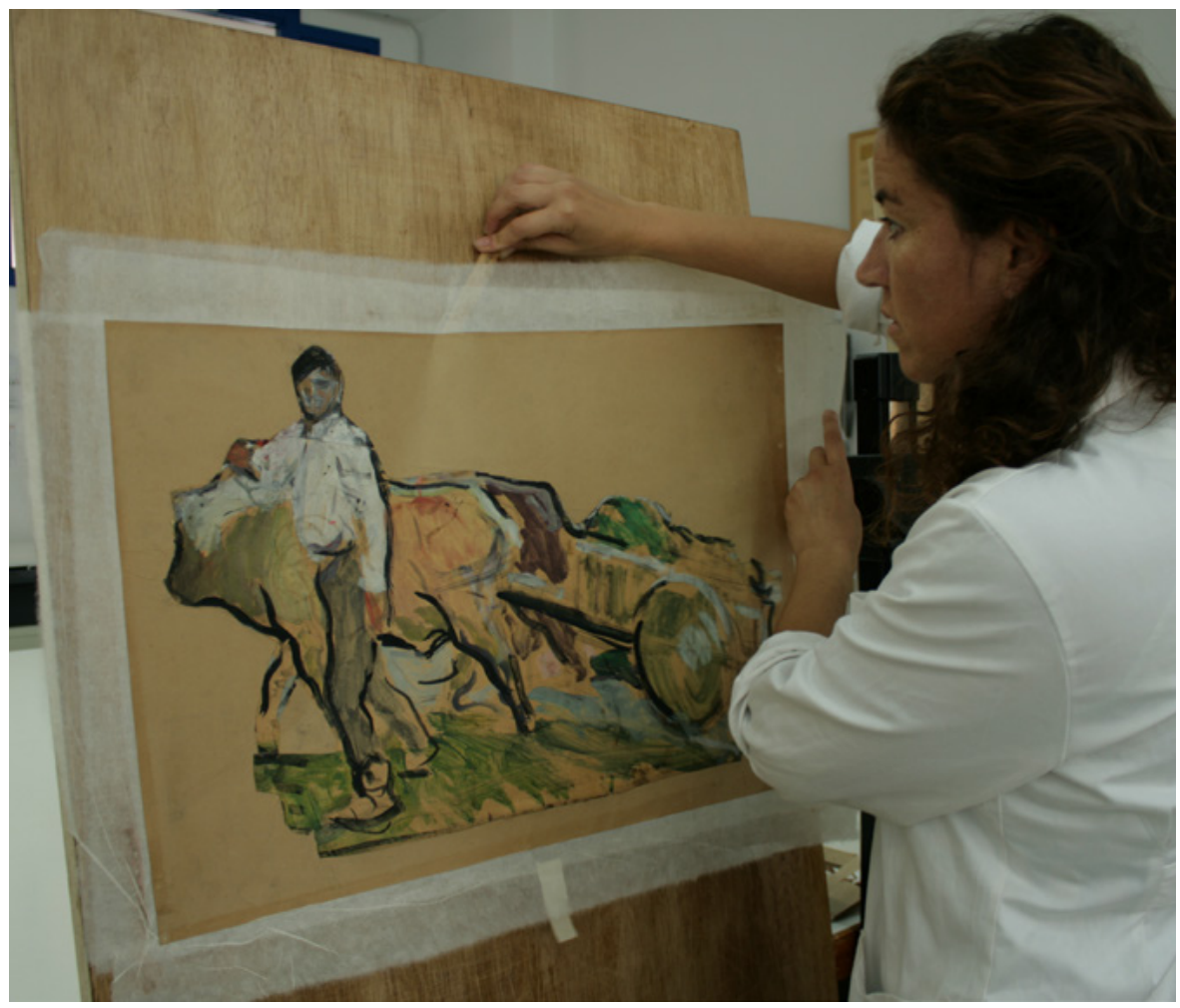

Secado y reparación de un boceto laminado del soporte de madera fenólica

el detector a un ángulo de $45^{\circ}$ respecto a dicha normal y con un tiempo de excitación-detección de 180 s. Se realizaron un total de 640 análisis de pigmentos y soportes de papel de los bocetos. El número de puntos analizados en cada boceto está en función de sus dimensiones y de las variedades cromáticas observadas. En cada uno de los puntos de análisis correspondientes a los pigmentos se registraron los elementos químicos característicos y a partir de ellos se procedió a su identificación, basada en el color característico y la correlación entre los elementos detectados y los denominados "key elements" de un pigmento dado (p. e., la detección de S y $\mathrm{Hg}$ en un pigmento rojo se correlaciona con el pigmento rojo bermellón, cuya composición química es sulfuro de mercurio, HgS). Mediante esta técnica analítica se procedió a la identificación de la paleta cromática empleada por Sorolla en los bocetos.

Por otro lado, y de forma puntual, se tomaron micro muestras de algunos pigmentos en los que era más difícil determinar su naturaleza con la técnica descrita con anterioridad. Con este tipo de muestras se han realizado análisis de determinación elemental mediante microscopia óptica y microscopia electrónica de barrido (SEM) acoplada a un equipo de análisis mediante dispersión de rayos $X$. Con estas técnicas se han determinado los diferentes tipos de pigmentos, principalmente en los tonos azules y grises. También ha 
permitido evaluar si existe superposición de capas pictóricas en los bocetos, lo que es indicio de modificaciones en su composición y elaboración.

Una vez realizados todos los estudios previos a la intervención, se optó por realizar varias pruebas y valorar el peligro estructural de sustituir el soporte auxiliar de tela del reverso por una laminación con papel japonés.

Antes de proceder a la eliminación de la tela de algodón, se llevó a cabo la limpieza en seco de la película pictórica. Después de realizar pruebas con gomas de distinta dureza, se comprobó que las esponjas de látex de textura muy suave y flexibles (usadas para maquillaje) no alteraban la superficie pictórica y eran las que menos residuo dejaban. Por otro lado, para la limpieza del soporte sin presencia de gouache, se optó por una esponja de caucho vulcanizado natural con carga de carbonato cálcico, cuya fuerza de arrastre de la suciedad es mayor y deja poco residuo.

Dada la naturaleza de las obras, bocetos pintados in situ, se ha considerado que la limpieza debía ser limitada y poco insistente. Del mismo modo, se han respetado, como parte del proceso artístico y como datos inherentes a la obra, los restos de adhesivo de los collages realizados por Sorolla, así como las manchas de carboncillo e incluso las huellas dactilares encontradas, que probablemente sean del artista.

El proceso de restauración se inició con los bocetos más pequeños con el fin de calibrar el alcance de la intervención y su problemática.

Tras la limpieza de la superficie pictórica, se procedió a la eliminación de la tela. Previamente, se estimó que, como medida preventiva, convenía una mínima consolidación de la capa pictórica que conferiría más seguridad al proceso de remoción del soporte auxiliar. De entre los consolidantes naturales se seleccionaron la gelatina (Tipo B, bloom 200), por ser las la más efectiva en la fijación de carboncillos, y el funori, por su inocuidad para el gouache.

Con el fin de evaluar si el proceso de consolidación producía algún tipo de alteración en el color, se escogieron zonas de diferente tonalidad y se realizaron medidas de color antes y después del proceso de consolidación. Los resultados mostraron que el cambio de color era imperceptible. La aplicación de ambos adhesivos se hizo al $1 \%$ a través de un nebulizador de ultrasonidos. Sólo en aquellas zonas donde la capa pictórica alcanzaba un volumen mayor y existían craqueladuras, la consolidación necesitó de una intervención más directa, esta vez con pincel y al $2 \%$, evitando un exceso de humedad que pudiera remover el pigmento.

En el reverso de las obras la suciedad acumulada era mayor que en el anverso, por lo que se aspiraron cada uno de los bocetos antes de retirar 
la tela. Para esta intervención, dado que el adhesivo había cristalizado, se aplicó una presión moderada al separar la tela de la obra. Con el fin de evitar daños colaterales al papel, se comenzó con la extracción de la tela a tiras y se frenó la tensión con el apoyo de la mano contraria. Después se efectuó el lijado manual de la superficie (con lijas de agua con abrasión reducida) con el propósito de eliminar los restos de adhesivo y, por último, se concluyó la operación con una aspiración final del reverso que deja el papel libre de residuos sólidos.

En la mayoría de los bocetos la eliminación de la tela se realizó siguiendo el mismo procedimiento, excepto la serie "Escena de Castilla", formada por tres paneles separados referentes a Castilla que conforman un solo en conjunto. Estos tres paneles eran los que estaban en peor estado de conservación, con numerosos rasgados, lagunas y deformaciones, que fueron ya reparadas por el propio autor con cinta de tela adhesiva y en los que se solapan distintas capas de papel. Para la remoción de la cola que adhería la tela al soporte, se necesitó la ayuda de geles que revirtieran su poder adhesivo. Se realizaron pruebas con Vanzan, Carbopol y Laponite (en agua al 5-10\%); este último fue el que mejor resultado ofreció. La dificultad con estos tres bocetos venía acrecentada por la deformación que producía el aporte mínimo de humedad de este tratamiento. Se decidió aprovechar esta coyuntura para ir eliminando, paralelamente, las deformaciones más importantes. Para remover los restos de adhesivo que quedaron tras la aplicación del gel, se emplearon torundas de algodón levemente impregnadas en agua templada.

Para proseguir con la restauración se reforzó prácticamente toda la zona perimetral por el reverso y se repararon los rasgados con papel Mino Tengujo $(9 \mathrm{~g} / \mathrm{m})$.

La fase más importante de la intervención fue la laminación de las obras por el reverso, con un papel cuya flexibilidad y resistencia fuera capaz de soportar el original. Para ello se eligió el papel japonés Sekishu. Este papel está realizado con la corteza interior de un arbusto, Kozo, que se cuece con un agente alcalino -mortero de cal- para eliminar sustancias no deseadas como la pectina y la lignina. Posteriormente, se blanquea con sustancias químicas y se seca al sol sobre planchas de acero inoxidable. Tiene un gramaje medio de $19 \mathrm{~g} / \mathrm{m}^{2}$ y unas fibras largas de kozo que lo han dotado de la elasticidad y fortaleza necesaria para la laminación. Como único adhesivo se ha utilizado el almidón de trigo. Para realizar este proceso, fue necesaria la fabricación de una mesa con maderas fenólicas y acabado con cera microcristalina, apta para la laminación, con el propósito de regular el exceso de humedad.

Para los bocetos de menor tamaño la metodología fue la siguiente: primero, se realizó el tensado perimetral de la obra con el uso de bandas y, en segundo lugar, se procedió a la laminación. 


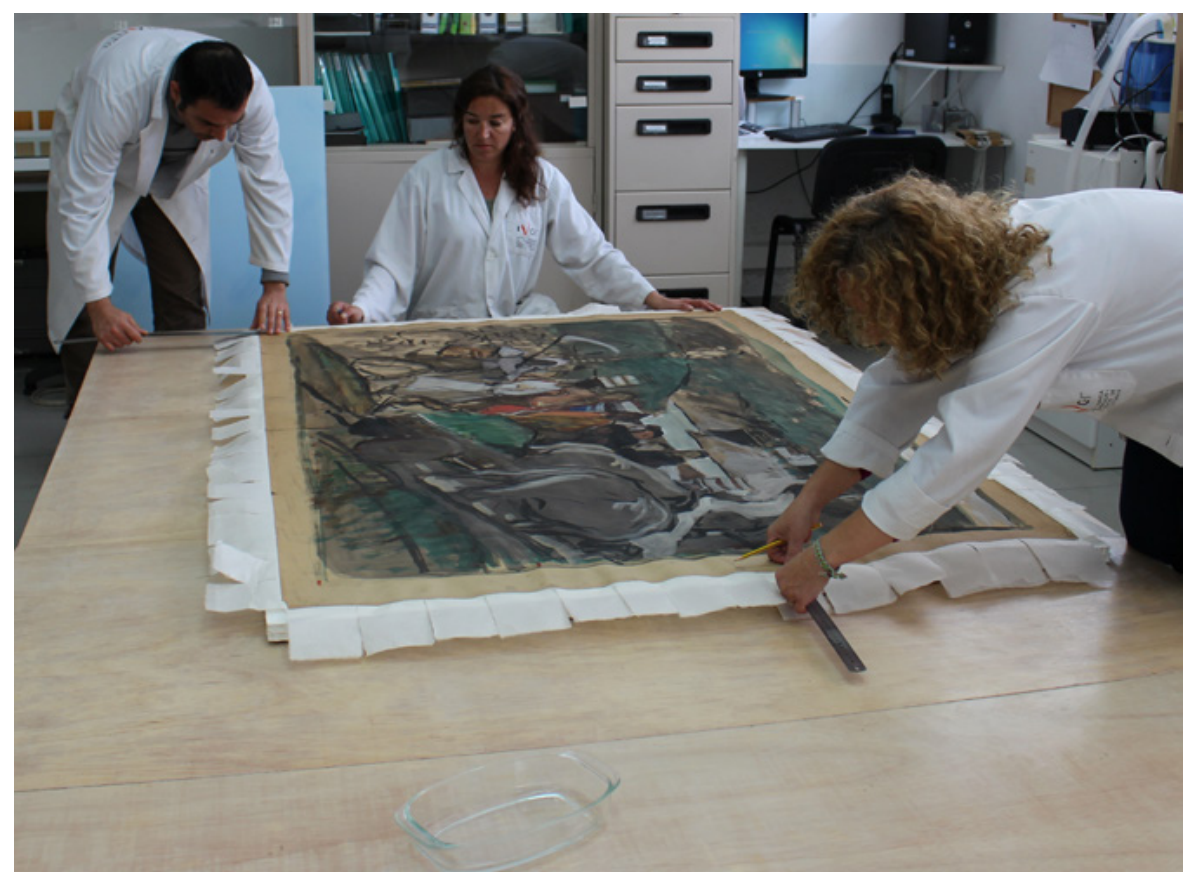

Preparación de las bandas de sujección flotante para su adhesión en el cartón Tycore

A continuación, se describen los pasos que se siguieron:

Se humectó levemente la obra por el anverso utilizando el nebulizador de agua Preservation pencil, que permite un aporte mínimo de humedad en frío. Por el reverso se aplicó propionato de calcio en espray, con el fin de dejar una reserva alcalina, ya que a pesar de que los resultados de medición del pH dieron valores en torno al 6,5\%, muy cercanos a la neutralidad, se estimó que un leve aporte alcalino podría contribuir a la preservación del original. La humedad se repartió de un modo homogéneo con ayuda de una brocha tipo Nadebake (brocha de fibra vegetal de palma). Se colocó el original con el dibujo hacia abajo sobre la mesa descrita y se cortaron tiras de papel sekishu de $12 \mathrm{~cm}$ de ancho y a contrafibra del original. Las tiras de papel se impregnaron con almidón y se adhirieron un centímetro sobre el borde del reverso del original, mientras que el resto se adhirió a la madera. A medida que las tiras de papel secaban, el boceto se tensaba y una vez seco la obra se separaba de la madera con ayuda de una plegadera de bambú (takebara).

El proceso de laminación se comenzaba cortando los papeles a contrafibra de la obra y diseñando el modo en el que se iban a colocar los fragmentos para cubrir todo el soporte, con el objeto de repartir las tensiones, evitando de esta manera que coincidieran las esquinas de los trozos y dejando un sobrante de unos 10-12 cm que coincidía con las bandas ya colocadas. La operación de humectación de la obra era igual en este caso, siempre 


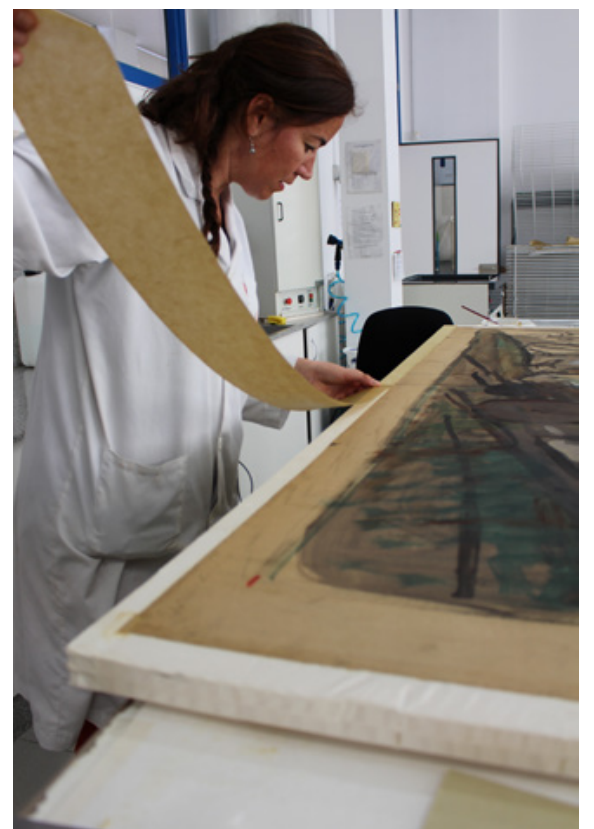

Adhesión de bandas coloreadas para homogeneizar los márgenes teniendo la precaución de interponer un hollytex entre la pieza y la madera fenólica. A continuación se aplicaba almidón (con una brocha de pelo de caballo o cabra, denominada Noribake) en los fragmentos de papel japonés sobre la mesa, con el fin de eliminar la máxima humedad posible antes de colocarlos sobre la obra; en la ejecución de esta acción era necesario apoyar los recortes de papel japonés sobre un hollytex, que facilitara su separación de la madera, transportarlos y adherirlos al reverso del boceto. Se han utilizado unas guías como referente al distribuir los fragmentos de papel sobre el original, una vez que éstos eran colocados, se asentaban con la ayuda de una brocha tipo Nadebake, realizando enérgicos movimientos de dentro hacia fuera que eliminaban el aire. El papel sobrante de la laminación se adhería a las bandas previamente colocadas y con una brocha se aplicaba nuevamente almidón, adhiriendo el papel a la madera. Durante el secado, de manera gradual se eliminaban las deformaciones, obteniendo el alisado de la obra. Una vez que la laminación y los bordes estaban totalmente secos, el sobrante de papel japonés alrededor del perímetro del original se separaba de la madera y se empleaba en el montaje final de la obra sobre cartones.

En los bocetos de tamaño superior a un metro, se comenzaron a tener dificultades con las bandas de tensión, por lo que se tuvieron que realizar pruebas hasta encontrar la solución adecuada para los grandes formatos. A pesar de que las maquetas eran de menor tamaño, por la dinámica de secado y comportamiento de los papeles, se consideró que la solución más adecuada pasaba por una doble laminación, una a contrafibra, y otra a fibra, ambas con el mismo papel y gramaje empleado hasta el momento.

La dificultad se hizo mayor con los grandes formatos de más de dos metros. El principal problema fue la humectación de la pieza, el girarla cuando estaba húmeda y la realización del secado con la obra boca abajo.

Para los japoneses la restauración de papel es el dominio en el control de la humedad y el modo de aplicarla, y no hay afirmación más cierta cuando se trata de operaciones de este tipo. Ya que, para una correcta laminación, la obra debe estar húmeda durante todo el proceso, con el fin de provocar tensiones y deformaciones. Del mismo modo, conviene que las laminaciones se efectúen una inmediatamente después de la anterior para evitar someter al papel a un nuevo momento de estrés con la aplicación de humedad. Estas laminaciones requieren tiempo y una actitud relajada, y se necesita un equipo de, al menos, cuatro personas para poder acompasar los tiempos. La colocación de los fragmentos de papel en húmedo, ahora de tamaño mayor, requiere de la ayuda de un listón de madera que los mantenga firmes. Una vez colocados, se confunden con el color del original y la madera, por lo que resulta harto complicado ir completando y casando los distintos fragmentos. Para ello se utilizó como apoyo un hilo de cáñamo sujetado a dos listones de 


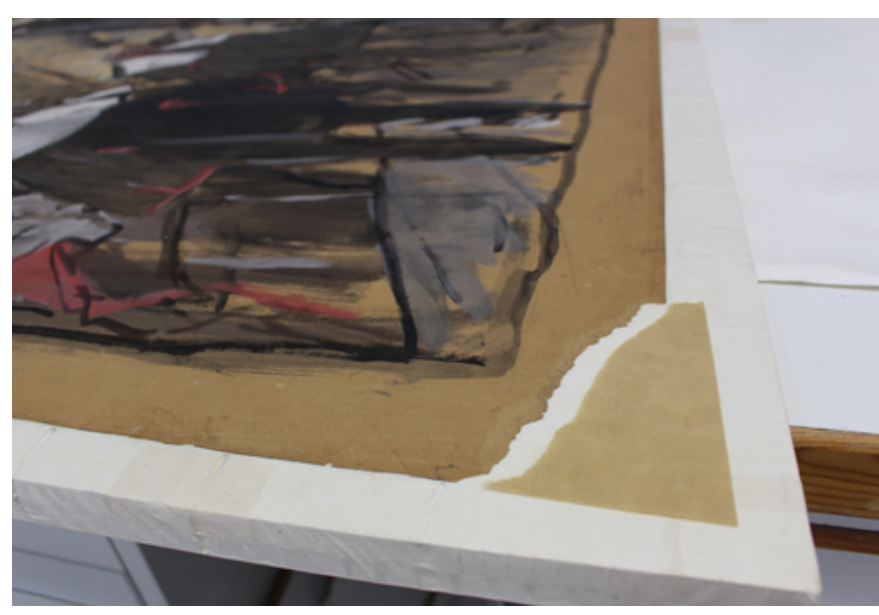

mármol, a modo de nivel, que marcaban la línea de colocación, solapando, en medio centímetro, uno sobre otro.

En este caso concreto, el resultado, aunque ha mejorado notablemente el original, no ha sido suficiente para eliminar todas las deformaciones del soporte, por el hecho de que, como hemos comentado, muchos de los bocetos no se componen solamente de una capa de papel, sino que el artista ha realizado sus composiciones con la adhesión de hasta 11 capas documentadas.

Durante este proceso, el secado se prolongaba varias horas por lo que era conveniente vigilar la obra durante este tiempo para evitar el rasgado de las bandas. Finalmente, convenía separarlo de la tabla una vez seco.

Con el fin de preservar los bocetos de cara a exposiciones y su futuro almacenamiento, se consideró que era conveniente dotarlos de un soporte rígido que facilitara su manipulación y movilidad. Después de evaluar los cartones disponibles aptos para la conservación, se optó por el Tycore como solución más conveniente, tanto por su neutralidad de Ph aprox. 8, como por su estabilidad dimensional, que lo convierten en un material ideal para un montaje de grandes dimensiones ligero y resistente.

Así pues, a los bordes que sobresalían de cada boceto se recortaban longitudinalmente, desfibradas tiras del papel sekishu de $34 \mathrm{~g} / \mathrm{m} 2$ que habían sido adheridas sobre el canto, en pestañas para el montaje al cartón con almidón, de modo que la obra quedaba "flotando" sobre este soporte rígido y las tiras regulaban la tensión y los posibles cambios de humedad.

Para las obras de gran tamaño se adhirieron dos cartones con adhesivo en espray para evitar un aporte de humedad innecesario. A la izquierda, realización de injertos con papel
sekishu

A la derecha, adhesión de las bandas perimetrales al soporte auxiliar 


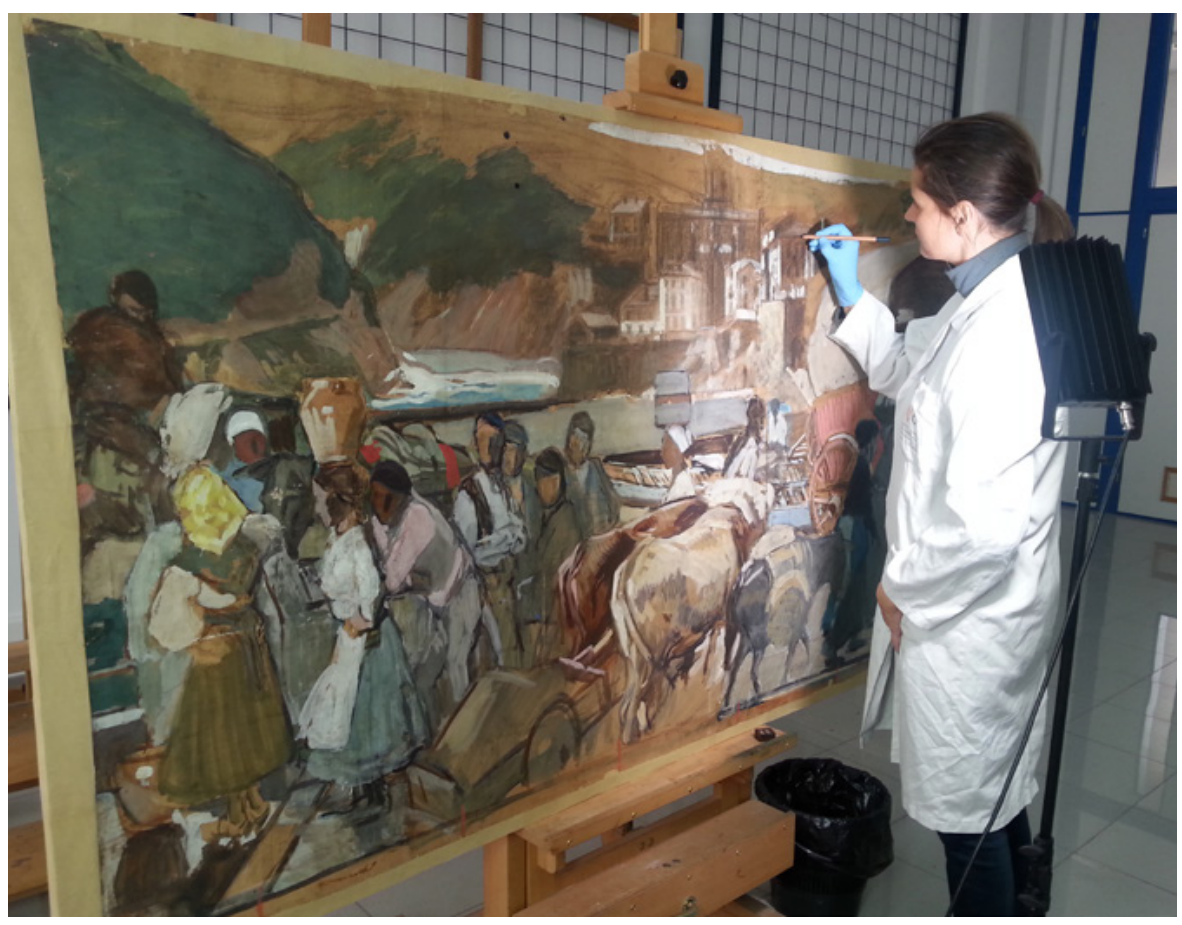

A petición del conservador de la Hispanic Society, se dejó un margen de unos tres centímetros para facilitar el transporte y la manipulación de las piezas. No obstante, una vez montados los dibujos, se consideró que ese borde resultaba agresivo para la legibilidad de la obra, por lo que se decidió su coloración.

El nivel de acabado de estos bocetos dista mucho de los preceptos de una obra "terminada", por lo que la reintegración cromática se limitó a la integración de aquellas partes que por su deterioro dificultaban la lectura del diseño inicial. Con el propósito de que fuera un proceso lo más reversible posible, se emplearon lápices de pastel y acuarelables y, sólo de manera puntual, acuarelas.

Ha sido un auténtico reto y un privilegio intervenir obras de esta categoría, de un Sorolla más íntimo y, a pesar de las numerosas dificultades, nos hemos sentido recompensados con los resultados obtenidos en la aplicación de esta técnica tradicional japonesa.

\section{CONCLUSIÓN}

Para terminar, nos gustaría resaltar la importancia que ha supuesto ver reconocido nuestro trabajo con el Premio Unión Europea de Patrimonio Cultural/ Premio Europa Nostra en su edición de 2018. 
Europa Nostra es la Federación pan-Europea de Organizaciones No Gubernamentales relacionadas con el Patrimonio, apoyada por una amplia red de instituciones públicas, organizaciones privadas y particulares de 40 países. Fundada en 1963, representa la voz de la sociedad civil para la conservación del Patrimonio Cultural y Natural de Europa, y actualmente se la reconoce como la organización de patrimonio más representativa e influyente en el continente europeo. Esta institución reconoce la excelencia mediante el Premio Unión Europea de Patrimonio Cultural/Premios Europa Nostra, que han servido para potenciar el sector del patrimonio en Europa destacando las buenas prácticas, fomentando el intercambio de conocimientos entre fronteras y conectando a las partes interesadas en redes más amplias. Además han permitido otorgar una mayor difusión a nivel nacional e internacional de las instituciones premiadas, además de favorecer un incremento del interés del público en general por nuestro patrimonio común destacando su intrínseco carácter europeo.

Joaquín Sorolla constituye uno de los valores universales que simbolizan lo mejor del talento artístico valenciano. Este proyecto de conservación y restauración ha permitido que un artista valenciano y por ende europeo haya sido estudiado y valorado desde un punto de vista muy diferente al habitual, dado que estos bocetos los hizo Sorolla para sí mismo y muestran su personalidad, su esfuerzo y dedicación en cada trabajo, y una capacidad de innovación que no resulta tan evidente en sus obras finales. Supone el acto creativo cumbre de este gran artista valenciano, además del verdadero epílogo y síntesis de toda su producción.

Con este trabajo que incluye instituciones europeas y americanas, se ha conseguido dar a conocer (en su momento íntimo de creación) a un artista europeo y se ha proyectado la imagen nueva de un Sorolla más innovador del que la historia del arte había catalogado.

Tal y como destacó el Jurado de Europa Nostra cuando concedió al IVCR+I el premio Unión Europea de Patrimonio Cultural/Premio Europa Nostra: "Este proyecto muestra una reflexión sobre la evolución de una obra de arte poniendo el foco de atención en el proceso y no sólo en el resultado final. Este conjunto muestra el interés de Norte América por un artista fundamental para la cultura europea del siglo XX. Este trabajo ha sido llevado a cabo por un Instituto europeo que ha respondido a ese interés de una forma ejemplar. El vínculo entre ambas instituciones es digno de mención". 


\section{Caracterización radiométrica de una cabeza de flash para su uso en digitalización de obras de arte}

José Manuel Pereira Uzal | conservador y restaudador de bienes culturales, editor de DigitalHeritage

URL de la contribución <www.iaph.es/revistaph/index.php/revistaph/article/view/4085>

\section{RESUMEN}

El uso del flash fotográfico como fuente de iluminación es un recurso habitual en las tareas de documentación y digitalización de obras de arte y bienes culturales; sin embargo, no está exento de sospecha por parte de algunos investigadores como factor de alteración. A lo largo de este trabajo hemos reproducido diversas experiencias de caracterización de un equipo de flash extensamente documentadas en la bibliografía de nuestro sector sin que, a priori, podamos plantear el uso racional del flash como un factor de alteración.

\section{Palabras clave}

Bienes culturales | Digitalización | Flash | Fotografía | Fuentes de iluminación | Obras de arte | Reproducción | 


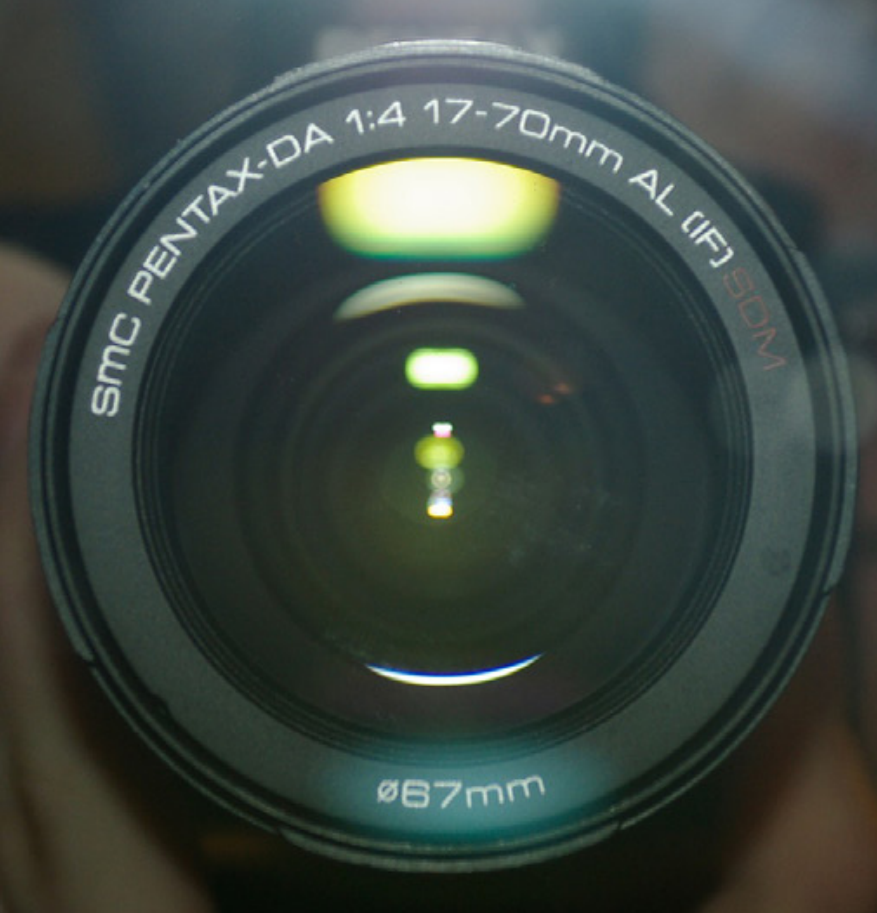

Pentax k200d | fuente Pixabay 


\section{INTRODUCCIÓN}

En la actualidad las tareas de digitalización o documentación de bienes culturales a través de equipos fotográficos o de captación de imagen son casi una actividad cotidiana. De esta forma, las fuentes de iluminación son una herramienta intrínseca a todas estas actividades.

Las fuentes o dispositivos de iluminación usados en bienes culturales pueden ser divididos en dos grandes grupos: los de luz continua, en los cuales se incluyen sistemas basados en la fluorescencia, LED, incandescencia, HMI, etc.; y los de luz no continua, basada en destellos producidos por un arco de xenón, conocida comúnmente como luz de flash.

El uso de destellos como fuente de iluminación posee la ventaja de ofrecer una gran intensidad con tiempos de destello muy breves, lo cual permite anular cualquier trepidación en cámara, por lo que la proponen como un sistema ideal para lograr una máxima reproducción de detalle al mismo tiempo que presenta una gran eficiencia entre consumo y potencia.

En el presente artículo vamos a realizar una revisión de las estrategias de caracterización de una fuente de iluminación, así como las fuentes bibliográficas referentes a dichos dispositivos.

\section{METODOLOGÍA}

El presente estudio estará basado en la evaluación de una cabeza de flash Elinchrom RX600 sobre la cual vamos a realizar diversas mediciones, con herramientas fácilmente asequibles para cualquier profesional, a diferentes intensidades del destello y usando un modificador de luz a modo de pantalla difusora, especialmente habitual en el uso con este tipo de iluminación, con el fin de suavizar el haz de luz emitido.

Los aspectos analizados durante los ensayos se centrarán en estudiar el tiempo del destello, el contenido en radiaciones ultravioleta (UV) del mismo, así como la iluminancia y la irradiancia.

Para ello nos hemos servido de diversos instrumentos, como un espectrofotómetro i1pro de X-Rite con una sensibilidad de entre $380 \mathrm{~nm}-730 \mathrm{~nm}$, con el software de análisis BabelColor CT\&A a fin de realizar mediciones relativas a la iluminancia, CRI y Temperatura de Color Correlacionada.

Así como un microcontrolador Atmega328 montado sobre una placa Arduino, con el fin de determinar el tiempo del destello con un fototransistor de alta sensibilidad y respuesta. $Y$ un sensor GUVA-S12SD de Roithner 


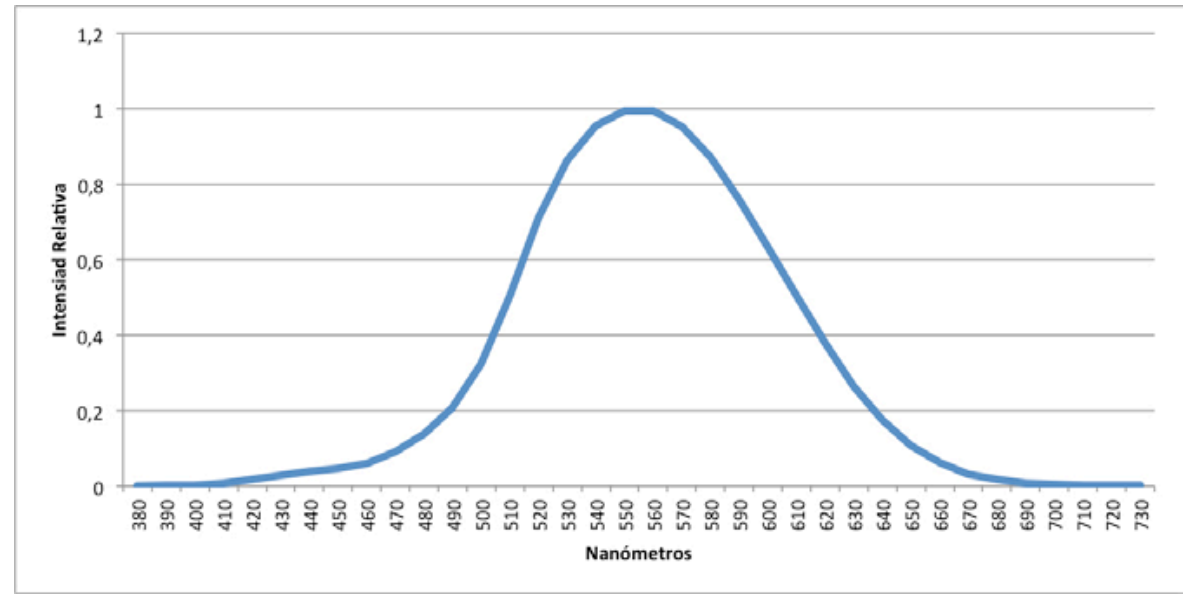

Lasertechnik con una sensibilidad entre los $240 \mathrm{~nm}$ y los $380 \mathrm{~nm}$ con el fin de estudiar la región del UV.

Las unidades utilizadas para el estudio de las diferentes características de este tipo de luz serán las siguientes:

La iluminancia descrita en Lux por segundo (Lux s), que nos informa sobre la cantidad de luz emitida por el destello en términos fotométricos; es decir, en base a la curva de respuesta fotópica a la luz del ser humano. Y en segundos, ya que al tratarse de un destello debe ser referido al tiempo tal y como lo cita el National Institute of Standards and Technology (OHNO, 2002).

Este mismo concepto de expresar la cantidad de luz en función del tiempo es igualmente utilizado para cuantificar la radiación lumínica recibida por un bien cultural; hablaríamos entonces de "exposición lumínica" descrita habitualmente por las unidades $\mathrm{H}_{\mathrm{v}^{\prime}}$ donde:

$H_{v}=E_{v}{ }^{*} t$

Donde $E_{v}$ es la iluminancia medida en lux y $t$ el tiempo en segundos.

La problemática del estudio de la iluminancia de un destello no está exenta de dificultades, ya que la intensidad de éste raras veces es constante a lo largo del tiempo del mismo, por tanto habrá momentos del destello donde la intensidad es mayor o menor.

Por causa de este fenómeno los fabricantes de equipos de flash orientados a la fotografía hablan de las métricas T0.5 o T0.1, donde la intensidad del destello referido al tiempo del mismo se estudia cuando este ha alcanzado del 50\% de su intensidad (T0.5) o el 10\% (T0.1), de forma que los datos de
Función de luminosidad fotópica del sistema de visión del ser humano | fuente CIE 
intensidad arrojados no serán los mismos, así que un destello con un tiempo dado, para T0.1, posee más duración y por tanto emite más energía que para T0.5.

De esta forma, desde el punto de vista de la conservación, es más interesante hablar en términos de irradiancia, es decir, cantidad de energía que llega a una superficie, descrita por la métrica $\mathrm{W} / \mathrm{m}^{2}$.

Otra dificultad de cuantificar con propiedad la energía recibida por una obra en términos fotométricos es que dicha energía está siendo ponderada por la función fotópica que nos describe la sensibilidad a la luz del sistema de visión humano, de esta manera no estamos cualificando como energía que llega a una obra de arte aquellas zonas del espectro no visibles por el ojo humano.

Otro aspecto fundamental en el estudio de una fuente de iluminación es conocer su radiancia espectral, es decir la cantidad de energía emitida a lo largo de las diferentes longitudes de onda, habitualmente expresadas en $\mathrm{W}$ $\mathrm{nm}^{-1} \mathrm{~m}^{-2}$, pero que al estar hablando de un destello relativo a un periodo de tiempo se suele usar $\mathrm{J} \mathrm{nm}^{-1} \mathrm{~m}^{-2}$.

Conocer la distribución del espectro de una fuente de luz es fundamental no solo para el cálculo de la irradiancia, sino también para el de la Temperatura de Color Correlacionada (Color Correlated Temperature, CCT) o el Índice de Reproducción Cromática descrita por el CRI (Color Render Index).

Todas las mediciones han sido realizadas a 1 metro de distancia con un ángulo de haz aproximado de $65^{\circ}$ lo cual nos produce un área aproximada de $1 \mathrm{~m}^{2}$ con el fin de que 1 lux $\mathrm{m}^{2}=1$ lumen y simplificar los cálculos y apreciaciones.

\section{RESULTADOS}

A continuación se presentan algunos de los resultados obtenidos

\section{Medición del tiempo de destello}

Los tiempos de destello alcanzados fueron los siguientes:

\begin{tabular}{|lll}
\hline & Máxima potencia & Mínima potencia \\
\hline T0.5 & $1 / 446 \mathrm{~s}(0.0024 \mathrm{~s})$ & $1 / 578 \mathrm{~s}(0.0017 \mathrm{~s})$ \\
\hline T0.1 & $1 / 390 \mathrm{~s}(0.0025 \mathrm{~s})$ & $1 / 459 \mathrm{~s}(0.0021 \mathrm{~s})$ \\
\hline
\end{tabular}




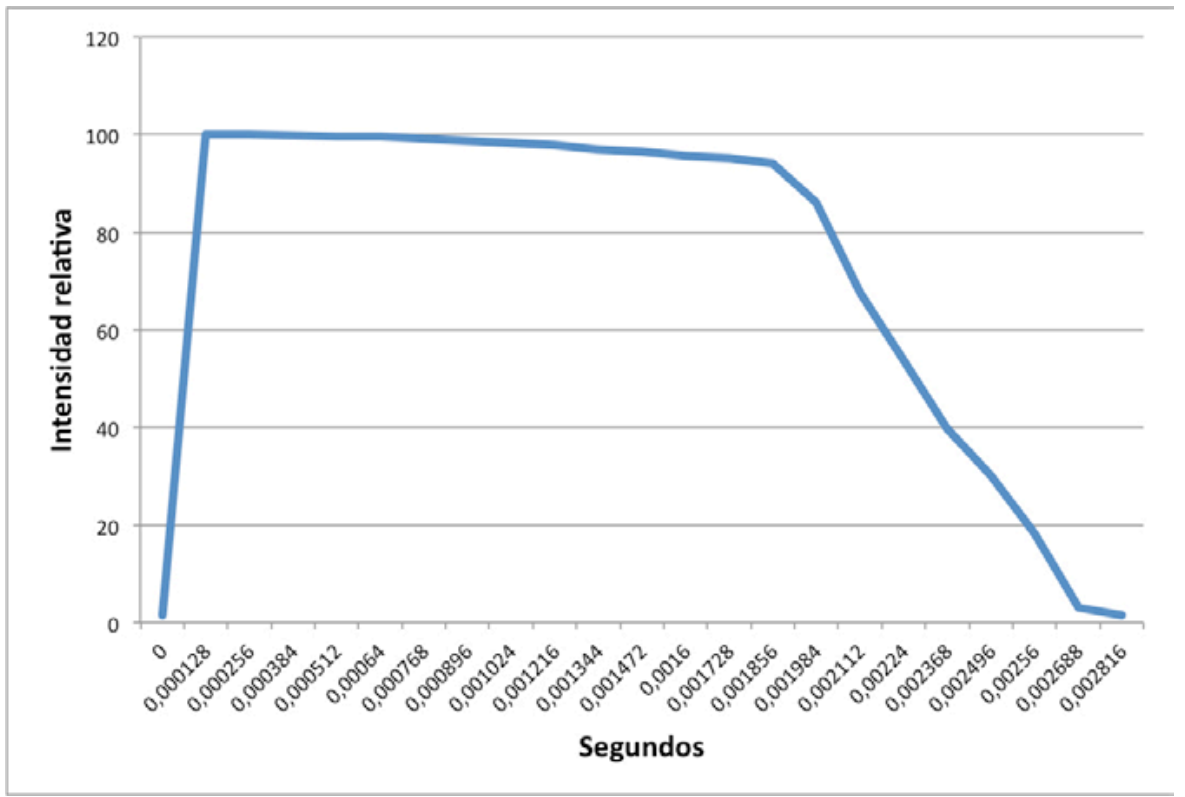

Tiempo de destello a máxima potencia

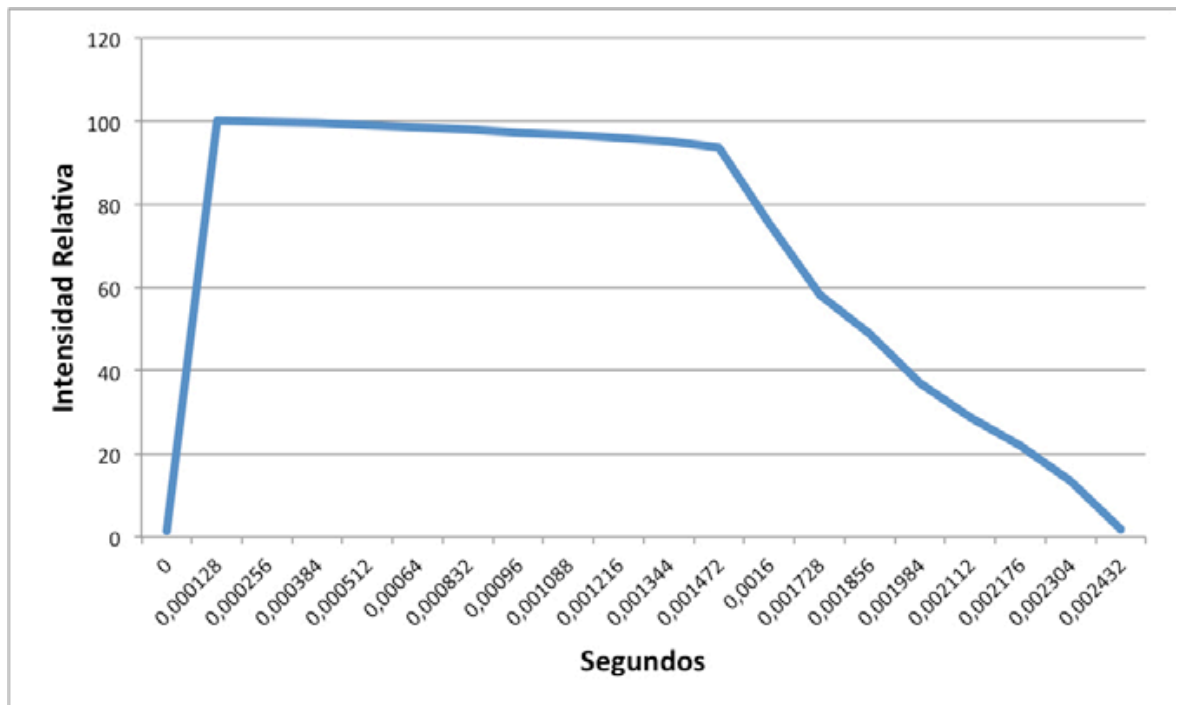

Tiempo de destello a mínima potencia

\section{Medición del contenido en ultravioleta}

\begin{tabular}{|lllllc|}
\hline \multicolumn{2}{l}{ Máxima potencia } & \multicolumn{2}{l}{ Mínima potencia } & \multicolumn{2}{l}{ Mínima potencia + Modificador } \\
\hline Promedio & Máximo & Promedio & Máximo & Promedio & Máximo \\
\hline $0.9 \mathrm{~W} / \mathrm{m}^{-2}$ & $1,16 \mathrm{~W} / \mathrm{m}^{-2}$ & $0.057 \mathrm{~W} / \mathrm{m}^{-2}$ & $0.07 \mathrm{~W} / \mathrm{m}^{-2}$ & $0.0015 \mathrm{~W} / \mathrm{m}^{-2}$ & $0.01 \mathrm{~W} / \mathrm{m}^{-2}$ \\
\hline
\end{tabular}


Relación del contenido ultravioleta y el tiempo del destello a diferentes potencias y con modificador de luz
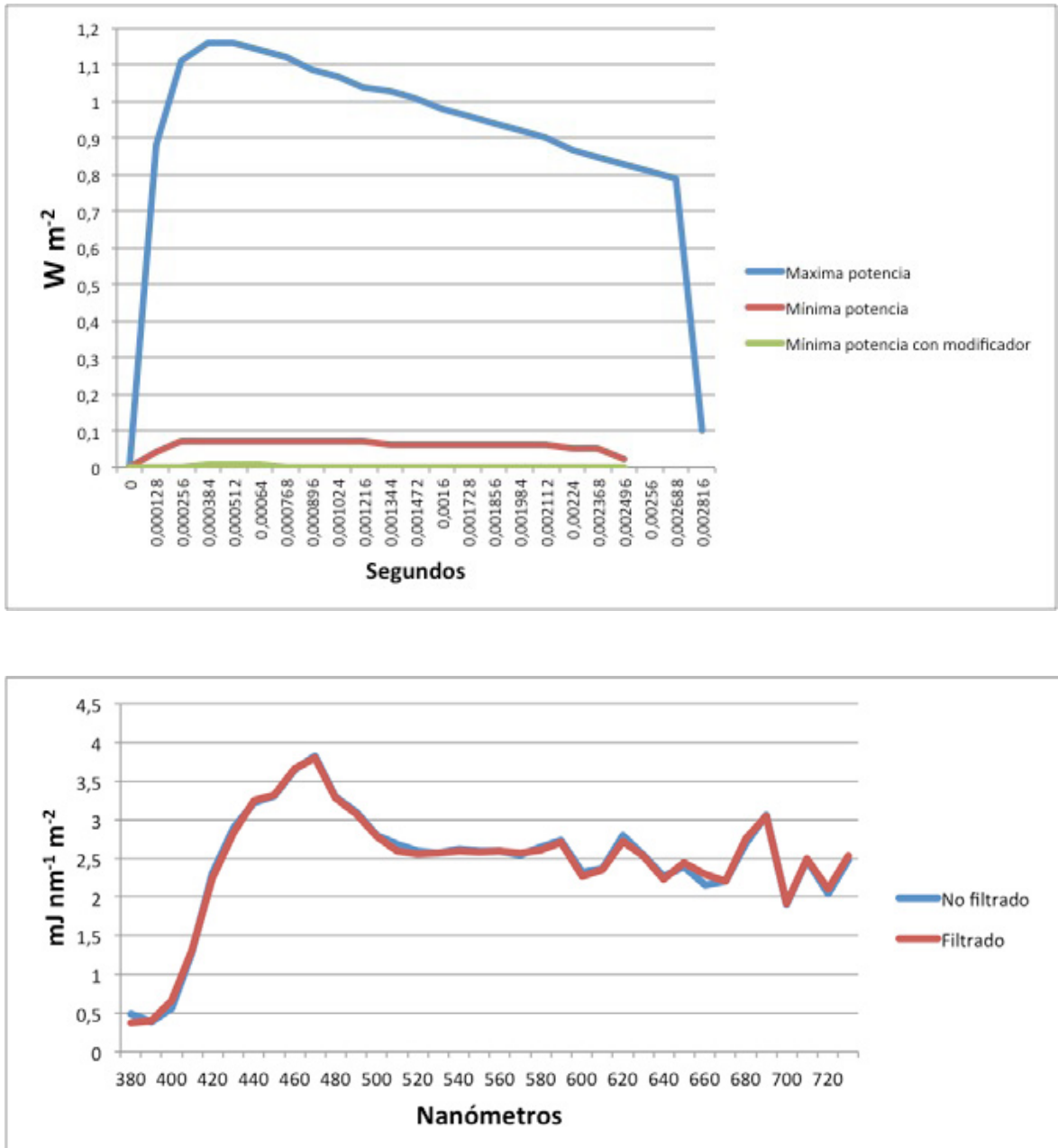

Medición de la iluminancia, CCT y CRI

\begin{tabular}{llll} 
& Iluminancia & CCT & CRI \\
\hline Sin modificador & 360 lux s & $5733 \mathrm{~K}(\mathrm{D} 57)$ & 96 \\
\hline Con modificador & 189 lux s & $6641 \mathrm{~K}(\mathrm{D} 66)$ & 93
\end{tabular}

Las mediciones aportadas son a mínima potencia, con el fin de simplificar las mediciones.

\section{Irradiancia para el espectro completo}

Además de los datos fotométricos, que pueden ser de relevancia para una estimación desde el punto de vista de la percepción del ser humano, cono- 
cer la irradiancia es mucho más relevante para evaluar la energía que llega a nuestros bienes culturales, ya que computamos el espectro completo y no solo aquella parte relativa a la sensibilidad del sistema de visión humano tal y como lo han abordado trabajos previos como el Technical Report 157 de la CIE, basado en los trabajos anteriores de Harrison (HARRISON, 1953) o los trabajos de Terry Schaeffer (SCHAEFFER, 2001).

Para ello partimos de la siguiente ecuación:

$H_{i}=\Delta \lambda \cdot F\left(\lambda_{i}\right)$

Donde $\mathrm{H}$ es la irradiancia, o densidad radiada expresada en $\mathrm{W} \mathrm{m^{-2 }}, \mathrm{F}(\lambda)$ es la irradiancia espectral expresada en $W^{-2} \mu m^{-1}$ y $\Delta \lambda$ son las longitudes de onda estudiadas.

De esta forma para un tiempo de destello de $0.0021 \mathrm{~s}$, la irradiancia de nuestro equipo sería:

\begin{tabular}{|ll|} 
& Irradiancia a baja potencia \\
\hline Sin modificador & $0.9753 \mathrm{~W} \mathrm{~m}^{-2}$ \\
\hline Con modificador & $0.9782 \mathrm{~W} \mathrm{~m}^{-2}$ \\
\hline
\end{tabular}

Si por la contra evaluamos la irradiancia exclusivamente en la fracción del UV que nuestro espectrofotómetro nos aporta entre los 380nm y los 400nm, obtenemos los siguientes datos:

\begin{tabular}{|ll|} 
& Irradiancia a baja potencia \\
\hline Sin modificador & $0.5614 \mathrm{~W} \mathrm{~m}^{-2}$ \\
\hline Con modificador & $0.2668 \mathrm{~W} \mathrm{~m}^{-2}$ \\
\hline
\end{tabular}

Estos valores de emisión en el UV380-400nm se encuentran particularmente próximos a los cálculos realizados por Terry Schaeffer (SCHAEFFER, 2001) donde propone $4.5 \times 10^{-5} \mathrm{~W} \mathrm{~cm}^{-2}\left(0.45 \mathrm{~W} \mathrm{~m}^{-2}\right)$.

\section{DISCUSIÓN}

Si nos remitimos a los últimos resultados en materia de radiancia, de forma paradójica, vemos cómo para dos emisiones, con diferente iluminancia en términos de Lux s (360lux s y 160Lux s), la irradiancia es prácticamente la 
misma $0.9753 \mathrm{~W} \mathrm{~m}^{-2}$ y $0.9782 \mathrm{~W} \mathrm{~m}^{-2}$, siendo incluso menor la que no utiliza modificador de luz, a pesar de tener mayor iluminancia. Esto es debido al modificador de luz, ya que al variar la temperatura de color, ofrece más energía en las zonas de longitudes de onda más corta y hace que aumente levemente la irradiancia, aun teniendo una menor iluminancia. Esta situación nos alerta sobre las implicaciones en el uso de fuentes de iluminación más "frías", es decir, ricas en longitudes de onda más cortas frente al uso de fuentes de iluminación más "cálidas" o neutras.

De esta forma podemos adentrarnos en la transcendencia de remitirnos a la irradiancia como métrica más representativa que la propia iluminancia, ya que valoramos la energía aportada por todo el espectro estudiado y no solo aquella relativa a la percepción del ser humano.

Y, aunque podamos hablar de valores de iluminancia más o menos altos, los valores de irradiancia, sobre todo en términos relativos al contenido de radiación ultravioleta, son particularmente bajos, siempre y cuando usemos algún tipo de modificador de luz o filtro UV delante del bulbo de nuestro flash, que, habitualmente, y es la práctica de muchos fabricantes, ya ha sido montado de serie.

A nivel fotométrico nuestro equipo emite aproximadamente un flujo luminoso de 190 Lux s o 0.05 lux h, que es la intensidad necesaria para disparar a una distancia aproximada de $1 \mathrm{~m}$ a f8 y una sensibilidad de 100 ISO, ya que debe cumplirse la relación:

f-stop $=(0.003 * 100 * 190)^{1 / 2}$

f-stop $=7.5$

Donde 0.003 es una constante relativa al cálculo de la exposición referida a la ISO 2720: 1974 Photography. General purpose photographic exposure meters (photoelectric type)-Guide to product specification.

Por tanto, para una sesión aproximada de 1000 fotografías, la cantidad de energía luminosa que llega a la obra es de:

$0.05 \mathrm{Luxh} * 1000=50 \mathrm{Luxh}$

Sin embargo, aunque pueda parecer una cifra alta, si la comparamos con una emisión que proviene de una luz continua de, por ejemplo, 12 lux, tendremos que para una jornada de ocho horas de exposición al público ha emitido 96 Lux h, por lo que podemos observar que en una jornada de ocho horas de exposición se ha emitido casi el doble de radiación sobre la obra que en 1000 disparos de flash (WARE, 1994). 
Unas estimaciones similares las podemos encontrar en el trabajos de Mike Ware (1994) donde se realizan estimaciones entre los umbrales de exposición para luz continua y flash, así, por ejemplo, si un material posee un umbral de exposición de 3h a 50 lux (540.000 Lux s), podrá ser fotografiado más de 4000 veces con un flash que emita 128 lux s.

De esta forma, por ejemplo, David Saunders del National Gallery (SAUNDERS, 1995) estima una cantidad media de 0.17 lux h por cada disparo a una apertura de f8, que para una exposición anual de 600.000 lux $\mathrm{h}$ recomendado para óleo y témpera por dicha institución representan más de tres millones de disparos de flashes necesarios para alcanzar dicho umbral de tolerancia.

Garry Tompsom (2013) describe una relación similar donde le atribuye a cada disparo de flash una energía promedio de 20 lux minuto (1200 lux s; 0.3 lux h) para una apertura de f22.

Uno de los primeros estudios referente en la alteración de materiales por el efecto de la luz del flash fue el llevado a cabo por Hanlan (1970), que concluye en su trabajo con la sentencia: "No parece existir ninguna razón para ver el uso normal del flash electrónico como algo injustamente peligroso". A raíz de los resultados mostrados en el trabajo de Hanlan, el propio Garry Tompsom (2013) concluye que "podemos asegurar tranquilamente que en condiciones reales y usado con prudencia, el flash electrónico continuado es menos perjudicial que la exposición continuada bajo lámparas incandescentes. De forma similar el propio comité francés del ICOM ha llegado a unas conclusiones similares en 1969 y así lo refleja en sus recomendaciones para reproducciones de textiles "La luz más segura para la fotografía de textiles es considerada la del flash electrónico dado que las fuentes de tungsteno o lámparas de cuarzo tienen altos niveles de luz infrarroja".

En función a estos estudios previos, la National Gallery en sus recomendaciones para la fotografía y grabación profesional dentro de las salas, Guidelines for Lighting for Photography and Televisión (marzo del 2010), toma en consideración las sugeridas por Garry Tompsom y establece que para el ámbito de la fotografía profesional: "el flash electrónico está permitido y es preferido al uso de lámparas fotográficas" y éste no debe superar los 1250 lux s por cada disparo así como el uso de filtros UV específicos sobre el tubo.

En lo relativo al contenido UV, el simple uso de un modificador de luz tipo "softbox" o paraguas traslucido, en modo difusor, presenta una fuerte absorción a la región del UV motivado por la composición química de las propias fibras de poliéster del modificador. De esta forma, para el equipo estudiado, donde para una irradiancia en la región del UV de $0.0015 \mathrm{~W} \mathrm{~m}^{-2}$, y para un contenido máximo recomendado de $75 \mu \mathrm{W}$ por lumen (SCHAEFFER, 2001) 
vemos que para una iluminancia de 190 Lumen por segundo obtenemos $0.0015 \mathrm{~W} \mathrm{~m}^{-2}$, para 1 lumen tenemos $0.126 \mu \mathrm{W}$ por tanto nos encontramos muy por debajo de las recomendaciones expuestas por Schaeffer. De esta forma el propio autor estima un contenido de UV de un flash electrónico en $4.5 \times 10-5 \mathrm{~W} \mathrm{~cm}-2$ o $4.5 \times 10-7 \mathrm{~J} \mathrm{~cm}-2$ para un tiempo de destello de 1/100.

\section{CONCLUSIONES}

Finalmente, a raíz de estos ensayos y experiencias de diversos autores a lo largo de las últimas décadas, es complejo encontrar argumentos donde el flash electrónico o flash fotográfico, correctamente filtrado en UV, supongan un daño evidente para la obra.

Según Terry Schaeffer (2001), los daños potenciales ejercidos por un flash fotográfico han podido ser relacionados con procesos bifotónicos vinculados con pulsos de luz extremadamente intensos en comparación con las emisiones de luz continua habituales. Sin embargo, según el propio Terry Schaeffer, "dichos procesos son extremadamente improbables durante el uso de flashes fotográficos" y dichos fenómenos se relacionarían, por tanto, con fuentes de luz de alta energía como los láseres.

Por tanto, no parecen justificadas las restricciones en el uso de flash sobre patrimonio cultural, ya que a raíz de nuestras observaciones, y en relación con las fuentes bibliográficas consultadas, no tenemos a día de hoy indicios suficientes para proponer el uso del flash como un factor de alteración. Por la contra, se hace conveniente fijar la atención en la iluminación a través de luces continuas de alta intensidad, ya que los tiempos de exposición de la obra se incrementan considerablemente frente al uso de luz no continua.

\section{RECOMENDACIONES}

A pesar de no tener evidencias claras del flash como factor de alteración de un bien cultural, cabe plantear un uso racional del mismo y como cualquier intervención o acción sobre un bien cultural, sus parámetros de uso, tales como potencia expresada en las unidades correspondientes, distancia, números de disparos, marca y modelo, modificadores usados, etc. debería quedar oportunamente registrado en una memoria de intervención, con el fin de dejar constancia de la radiación emitida sobre la obra para su evaluación en un tiempo futuro. 


\section{BIBLIOGRAFÍA}

- BLACKWELL, B. (2000) Light exposure to sensitive artworks during digital photography. Spectra, vol. $26, n .{ }^{\circ} 2$, 2000, pp. $24-28$

- FELLER, R. L. (1995) Accelerated aging: photochemical and thermal aspects. S. I.: Getty Publications, 1995

- GUIDELINES for Lighting for Photography and Television. National Gallery of London (2010) [en línea], The National Gallery, 2010. <https://www.nationalgallery. org.uk/media/15989/press-and-media_photography-andtelevision-lighting-guidelines.pdf> [Consulta: 06/03/2019]

- HANLAN, J. F. (1970) The effect of electronic photographic lamps on the materials of works of art. Museum news, vol. 48, n. ${ }^{0} 10,1970$, pp. 33-41

- HARRISON, L. S. (1953) Report on the deteriorating effects of modern light sources. S. I.: Metropolitan Museum of Art New York, 1953

- international COMMISSION on ILLUMINATION. TECHNICAL COMMITTEE TC 3-22 "MUSEUM LIGHTING". Control of Damage to Museum Objects by Optical Radiation. Commission internationale de l'eclairage, 2004.

- OHNO, Y. (2002) Physical measurement of flashing lights-now and then. Proc. CIE Expert Symposium on Temporal and Spatial Aspects of Light and Colour Perception and Measurements. S. I.: s.n., 2002

- SAUNDERS, D. (1995) Photographic flash: threat or nuisance? National Gallery Technical Bulletin, vol. 16, 1995, pp. 66-72

- SCHAEFFER, T. T. (2001) Effects of light on materials in collections: data on photoflash and related sources. S. I.: Getty Publications, 2001

- THOMSON, G. (2013) The museum environment. S.I.: Elsevier, 2013

- WARE, M. (1994) Mechanisms of image deterioration in early photographs. London: Science Museum and National Museum of Photography, Film \& Television, 1994 


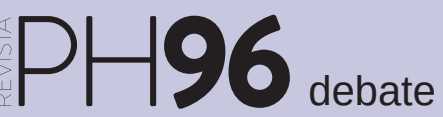

Memoria democrática en la construcción de la historia y el patrimonio

coordina Josefina Cuesta Bustillo

La remoción de la tumba de Franco ha reverdecido el permanente debate sobre las memorias en España. Sería más exacto preocuparnos por la memoria(s) democrática(s), aspiración común de los españoles, que referirnos a las denominadas "memoria(s) histórica(s)" -en plural. Puede haber experiencias históricas que no sean democráticas. No se pueden borrar de la historia, pero tampoco pueden proponerse como modelo para un presente democrático. La memoria democrática no es un problema de tiempos pasados, sino del más vivo presente, es una exigencia democrática de la Constitución y del sistema político -una democracia- aprobado por los españoles.

Hace ya casi veinte años que un artículo de Le Monde afirmaba: "España está bien asentada en su democracia, pero su memoria, su memoria no ha encontrado la paz". Verdaderamente aún podría afirmarse algo similar, mientras las huellas de la dictadura se resistan a desaparecer, cuando hubieran debido eclipsarse con el régimen que las creó; mientras permanezcan son un obstáculo a la democracia, a la convivencia y al patrimonio común de una memoria democrática en una sociedad democrática. Cuando se pretexta que "la memoria reabre las heridas", solo trata de cicatrizar heridas mal o no curadas y, como Antígona, sigue buscando "enterrar el cadáver del hermano" perdido en las cunetas.

Por ello es necesario que desde los gobiernos hasta los ciudadanos de a pie-usamos masculino inclusivo-, velen por eliminar los resquicios dictatoriales con los que convive nuestra sociedad, velen por socializar los espacios públicos, que resplandezcan de modelos, ejemplos y motivos que privilegien genealogías democráticas. Un simple nombre o un personaje no representa los mismos valores, referencias o herencias que otro. $Y$ todos estos elementos socializan la vida cotidiana de los y las ciudadanas, también de los niños y niñas que conviven en ellos. No es lo mismo jugar o pasear en la plaza de la Libertad, que en la de la División Azul. Con el nombre de la plaza se interioriza y se socializa un valor u otro. Todos los demás debates incluidos en esta discusión se refieren a la pluralidad de memorias que conviven en una sociedad: familiares, políticas, sindicales, religiosas, históricas, nacional(es), e incluso locales, de barrio y otras. Precisamente la memoria democrática engloba todos los plurales que conviven en una sociedad.

Solo cuando todos los españoles sean tratados por igual, incluso después de muertos, solo cuando todas las clases de ciudadanos, también las ciudadanas y las minorías, y todas las memorias democráticas encuentren su hueco en las calles, en los monumentos, en los libros de texto, -en el patrimonio inmaterial de nuestra cultura y de nuestras mentalidades, podremos hablar una "memoria en paz". 


\section{Dinámica de funcionamiento de la sección DEBATE (antes PERSPECTIVAS)}

Este espacio de revista $\mathrm{PH}$ pretende poner en común los distintos puntos de vista sobre los temas de debate que se propongan, atendiendo a dos principios básicos: máxima libertad y respeto.

Tres veces al año, se sugerirá un tema para discutir, con un texto de presentación, redactado por la persona que coordine el debate, y un guión de cuestiones que puedan animar el intercambio de ideas.

A partir de este momento se abrirá un plazo de envío de contribuciones breves (1000 palabras +1 o 2 imágenes). Dichas aportaciones deben adecuarse a los temas planteados en el texto y guión de presentación del debate. Estas contribuciones se revisarán y publicarán todas, siempre y cuando se ajusten al hilo argumental propuesto.

Para facilitar la posibilidad de comentar las distintas aportaciones que vayan llegando, se incluirán de manera provisional como preprints en el número de la revista en preparación, hasta una segunda fase en la que se maquetarán y paginarán en el número definitivo. Los comentarios de los lectores a los preprints continuarán visibles incluso después de la publicación del número que origina el debate, igualmente permanecerá abierta la posibilidad de seguir comentando.

Recuerda que para enviar contribuciones y comentarios hay que registrarse como autor y lector respectivamente. Si tienes perfil en alguna red social profesional o mantienes un blog especializado incorpora a tu texto sus direcciones para aumentar las posibilidades de comunicación.

Las discusiones que se plantean en la sección "Debate", antes (preprint) y después de la publicación de la revista, pueden seguir enriqueciéndose con tu aportación. Regístrate en revista $\mathrm{PH}$ y las diversas perspectivas con tus comentarios. Los debatessedifundiránatravés de los perfiles deFacebook, LinkedIny TwitterdelIAPH:<www.facebook.com/patrimoniolAPH>; <https://twitter.com/IAPHpatrimonio>; <https://www.linkedin.com/company/instituto-andaluz-del-patrimonio-hist-rico> 


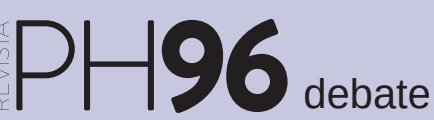

a debate Memoria democrática en la construcción de la historia y el patrimonio

| coordina Josefina Cuesta Bustillo

\section{Breve reflexión de conjunto: "No se ha dormido aún el pasado"1}

Josefina Cuesta Bustillo | catedrática y profesora emérita de Historia Contemporánea, Universidad de Salamanca

URL de la contribución <www.iaph.es/revistaph/index.php/revistaph/article/view/4347>

La sección Perspectivas de la revista $P H 96$ (febrero, 2019) en su debate n. ${ }^{\circ} 12$, con nombre Memoria democrática en la construcción de la historia y el patrimonio, ha suscitado una participación de verdadero interés, por sus contenidos, por sus críticas, observaciones y aportaciones, por su carácter multidisciplinar, interterritorial, y por la pluralidad de instituciones y de países de proveniencia de sus participantes. La riqueza de ideas y de propuestas merece una reflexión de conjunto y un eco-altavoz de las mismas. En este número han participado antropólogos, arquitectos ${ }^{2}$, estudiantes de máster, historiadores, sociólogos, profesores, investigadores, responsables de museos, miembros de Comisiones municipales u Observatorio de las Memorias, Departamentos de Educación, y voces colectivas femeninas o no, entre otros. Su procedencia se extiende desde Andalucía a Cataluña, Extremadura, Galicia, Madrid, Navarra o País Vasco, además de Alemania, Argentina, Gran Bretaña, México o Perú... La gratitud ante esta nutrida, cualificada y muy interesante participación, espontánea o invitada, no puede ser mayor. La red memorial refleja el interés del tema, la fortaleza de una sociedad civil que, en este caso, traspasa fronteras.

Se proponía un debate, que para algunos no ha resultado serlo (ver en este número Jorge Benavides, pp. 201-202), y que se ha traducido sobre todo en diálogo abierto, "intercambio de ideas", y -pensamos- ¿por qué no? debate implícito, diferido, y soterrado en la confrontación y en el diálogo de las distintas perspectivas o posiciones de los autores. Éstas abren nuevas líneas de reflexión horizontal, de intercambio de argumentos, de cuestiones pendientes, de "puntos ciegos" (César Rina, pp. 193-196) o de "agujeros de escape" (José Ramos, pp. 251-254). Los títulos de las participaciones son ya exponentes de la pluralidad de ángulos de mirada y de la omnipresencia de la perspectiva de la memoria.

\section{Puntos de tangencia}

En ese diálogo abierto afloran varios puntos de tangencia. La revisión de los autores clásicos sobre la memoria y la preocupación por los conceptos ${ }^{3}$ es una de las contribuciones de la mayoría de los participantes, valor inestimable en una materia tan manoseada y utilizada con demasiada ligereza.

Partiendo de autores clásicos sobre el tema (Halbwachs, Ricoeur), gran parte de los textos se preguntan sobre las relaciones entre "memoria e historia", distinción y diferencia ya puestas de manifiesto por P. Nora (Custodio Velasco en pp. 231-234; también señalada por Andrea Moreno en pp. 227-230 y Antonio Gisbert en pp. 255259), y que alcanza hasta las propuestas docentes para la experiencia de una ciudadanía democrática como nos cuentan Emilio José Delgado-Algarra (ver pp. 222224), Jesús Estepa (pp. 225-226), Maribel Rodríguez (pp. 239-240) y José Ramos. La memoria como constructo debe ser pública, social y democrática -otro punto de confluencia-, "sin pretensiones de sustituir a la historia como discurso científico", afirma algún autor. Consideramos de interés la "necesaria diferenciación" entre ambos conceptos para poder explicar después el campo de sus mutuas relaciones (CUESTA, 2008: 32-37), menos antitéticas que lo que pudiera parecer, y de sus mutuas aportaciones, que quedan bien esclarecidas en los temas propuestos.

Algunos autores se esfuerzan por definir los conceptos de memoria, ya bien definidos por los especialistas citados y por otros desde los años 80. Pues, como señala Ignacio Muñiz (pp. 197-198), es preciso "definir y analizar las palabras que utilizamos en el debate", y en este tema los conceptos están ya muy acuñados, aunque demasiado desconocidos para un público, en general, que se lanza en esta compleja temática (Antonio Gisbert, 
CUESTA BUSTILLO, 2008: 63-112). Recordamos aquí la necesaria disección entre los distintos conceptos de memorias (individual, social, colectiva) y, dentro de ésta, las tipologías o géneros definidos por Gerard Namer ${ }^{4}$ (familiar, popular, obrera, histórica ${ }^{5}$, política, religiosa, oficial, nacional, etc.) y los trabajos de aquella (recuerdo, silencio, olvido ${ }^{6}$, cambio, nostalgia y mito) (CUESTA BUSTILLO: 2008, 74-91), que Emilio José Delgado recuerda como cinco dimensiones de la memoria: "individual, social, histórica, conflictiva y selectiva".

Después de muchos años de reflexión sobre la historia de la memoria y de profundizar en sus tipologías, la experiencia nos ha enseñado a trabajar en plural, las memorias. Multiplicación memorial, también mencionada por Jordi Guixé en este debate (pp. 199-200). Plural que permite diseccionar en ellas conceptos, movimientos, sentimientos ${ }^{7}$. Esta es una de las conclusiones colectivas más extendida y la principal llamada de atención de Ignacio Muñiz en su colaboración, precisamente titulada: "Memoria democrática versus memorias democráticas".

Los textos no eluden ahondar en la relación y el juego de los tiempos en la memoria -pasado, presente y futuro-, y acertadamente ponen el acento en el presente, como horizonte de la memoria (Antonio Gisbert). Tema fundamental para entender los procesos memoriales y cómo el tiempo presente constituye el horizonte de sentido, el vector de significación y el eje direccional de aquella: "el eco de los pasos del tiempo" que permite la reelaboración permanente de la memoria en los distintos presentes. Disección de los tiempos en los que se apoyan también las propuestas didácticas presentadas (Emilio José Delgado Algarra, Jesús Estepa y Maribel Rodríguez Achútegui).

Por ello la memoria es también "conflicto, proceso y transgresión", como apuntan Jordi Guixé y otros autores. La historia de la memoria no puede soslayar el carácter conflictual de las memorias ${ }^{9}$. En estas páginas se menciona con frecuencia la memoria-conflicto (o, en otras palabras, "guerras de memorias") entre periodos

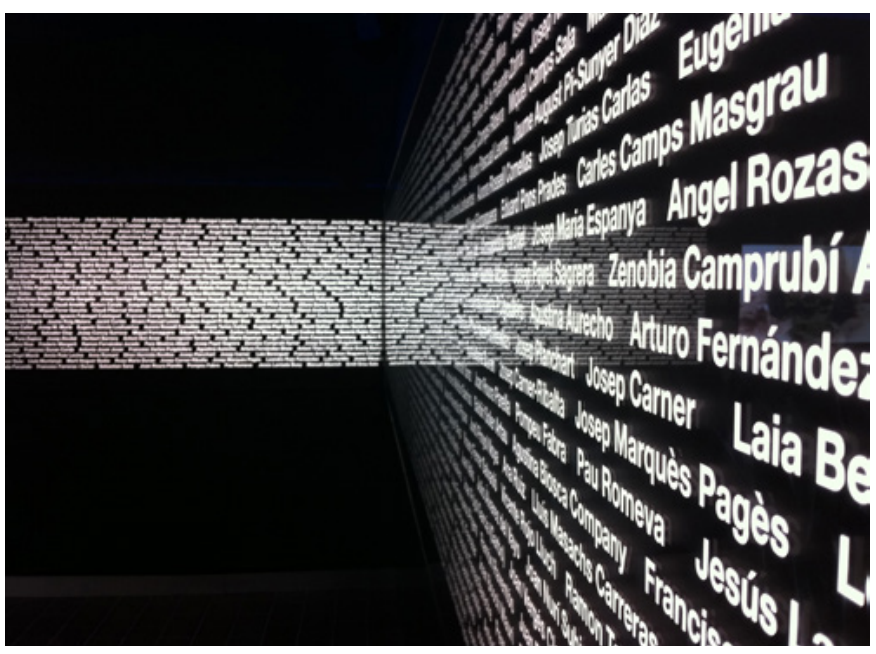

MUME-Museu Memorial de l'Exili | foto Daniel García Peris

represivos y periodos democráticos, entre las diversas memorias, especialmente las hegemónicas y las contrahegemónicas, como se atestigua en numerosos países, afirma Custodio Velasco. Problema no exclusivamente español, sino inserto en el conflicto europeo del siglo XX -"el siglo de los genocidios" (BRUNETTEAU, 2006)-, entre una "cultura de la guerra" o de la violencia, y una "cultura de la paz", base de una convivencia democrática (Custodio Velasco). Observaciones que Andrea Moreno hace extensibles a la memoria en España, que no puede ignorar el lastre de un recuerdo amputado y de un silencio impuesto durante la larga dictadura, en un relato escrito por los vencedores y apoyado en "criterios antidemocráticos" de "adoctrinamiento, censura y violencia e instrumentación del pasado y del patrimonio" (Moreno). Herencia que se hace demasiado palpable en la transición española y en la "retirada de simbología, en las fosas, cunetas, juicios" o en la tardía exhumación de Franco (Custodio Velasco). Reflexiones que pueden enriquecer la perspectiva propuesta por Asunción Cobo (pp. 208-209), pues precisamente la complejidad de las memorias y de sus sujetos portadores la sitúan más allá del "sentido común", en un territorio conflictual; dolor, perdón sí (como afirma Asunción Cobo)... y ¿dónde situar el derecho a la verdad, a la justicia, y a la reparación? ${ }^{10}$ Se ha insistido ya suficientemente sobre las limitaciones de "la teoría de los dos demonios", de la 


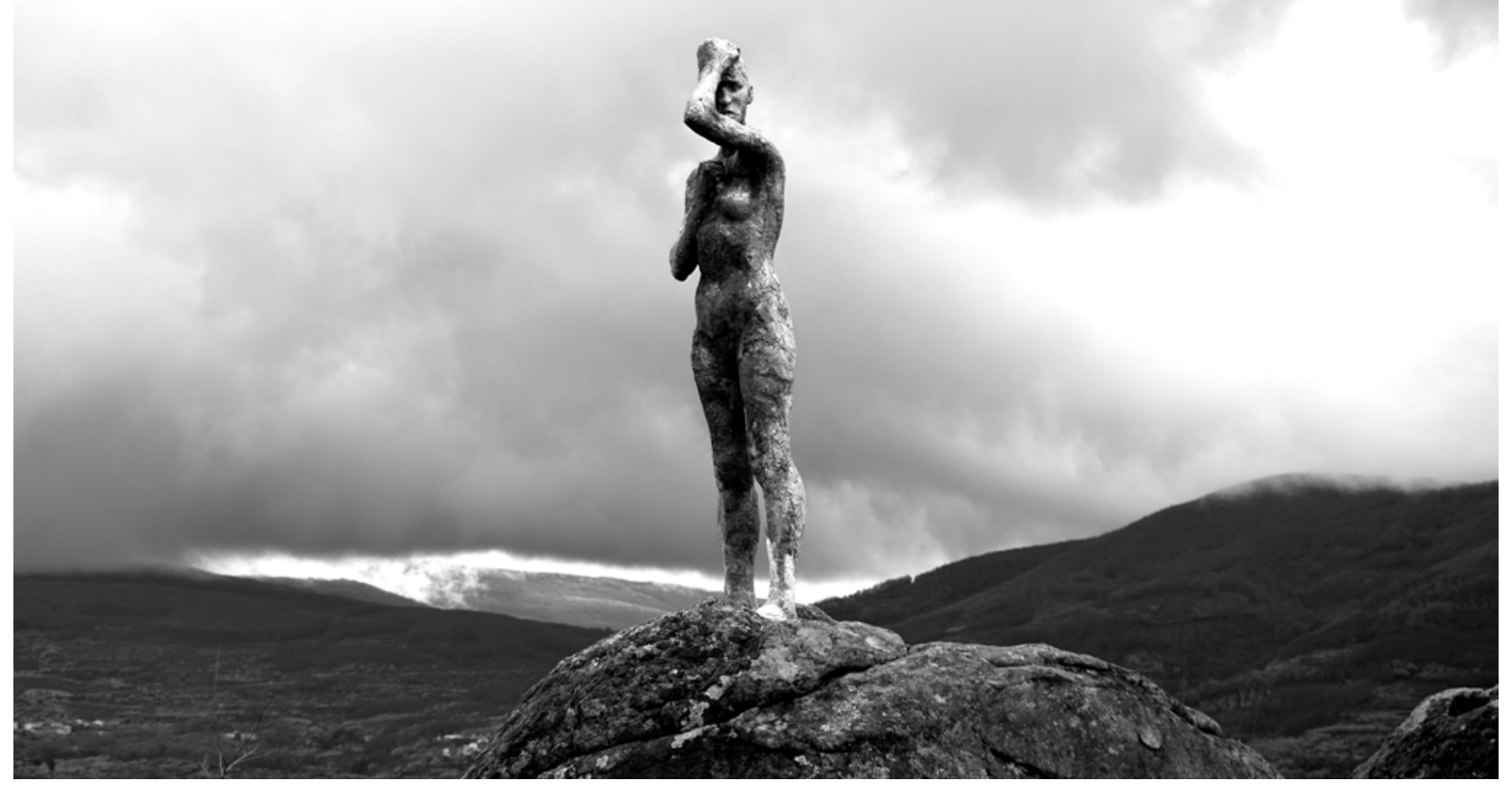

Mirador de la Memoria, en El Torno (valle del Jerte, Cáceres). Obra escultórica dedicada a los olvidados de la Guerra Civil y la dictadura | foto Manu Mateos

equidistancia. Asunción Cobo tiene razón al afirmar que "no hemos sido capaces de superar etapas pasadas de nuestra historia reciente"11, pero precisamente ese es el objeto de abordar en profundidad; el desafío memorial para la construcción de memoria(s) democrática(s).

\section{"Cuestiones clave": el quién y el qué. El sujeto y el objeto del recuerdo}

"La propuesta de Paul Ricoeur en el análisis de la memoria se estructura en torno a dos cuestiones clave, ya planteadas en la fenomenología de Husserl: qué se recuerda y quién recuerda (...) la cuestión egológica y la cuestión intencional" (CUESTA BUSTILLO, 2003: 43 y ss.); el objeto y el sujeto del recuerdo. Cuestiones a las que el propio Ricoeur añade una tercera ¿cómo?
Respondiendo a estos interrogantes, algunos autores se decantan por el qué (Francisco José Casado, Andrea Moreno, César Rina, Custodio Velasco, entre otros), que pone de manifiesto, en primer lugar, el carácter inabarcable de la memoria: "Nuestra ignorancia en cuanto a cómo suceden las cosas no se debe a la inherente imposibilidad de acceso a las causas primeras sino solo a su multiplicidad, a la pequeñez de las entidades últimas y a nuestra incapacidad para ver, oír, recordar, registrar y coordinar suficiente cantidad del material disponible" (Berlin, citado por Francisco José Casado); Antonio Gisbert y María del Rosario Zavala destacan "cómo la memoria, apoyada en los recuerdos, contribuye a forjar la identidad y forma parte de los procesos culturales: éstos dicen el qué y el sentido subsiguiente". 
Aunque son muchos los textos que acentúan el quién. Custodio Velasco subraya el papel de los actores sociales; María del Rosario Zavala, el de los productores, también Olivia Muñoz Rojas; en algunos casos se acentúa el rol de las organizaciones femeninas, como la asociación Herstoricas, las mujeres andinas (José Ramos) o las de la cárcel de les Corts (Jordi Guixé); o el de las víctimas, en general: "pero su dimensión humana y social queda reflejada fundamentalmente en las víctimas, y que supone una expresión de la necesaria verdad, justicia y reparación, en apelación a jueces y políticos" (Custodio Velasco). En otros casos, el sujeto se amplía a las administraciones (texto de Jorge Benavides, la contribución a cargo de la Dirección General de Memoria Democrática de la Junta de Andalucía o el citado Custodio Velasco) ${ }^{12}$ y al asociacionismo, en general. En efecto, atañe a toda la ciudadanía. En ocasiones, se oponen las decisiones de distintos actores, por ejemplo, la administración o las autoridades (memoria oficial) y la ciudadanía: "Pero ¿qué piensa la ciudadanía? ¿cuál es ese sentir que dice o cómo se enteró? Aquí cabe la discusión que hermana familias y naciones: los acontecimientos traumáticos -vividos o ejercidos- ¿se deben visibilizar o desaparecer?" (Francisco José Casado). Es "tarea colectiva de la ciudadanía, de los movimientos sociales y de las instituciones" la "revisión de espacios patrimoniales, históricos y culturales para que se tengan en cuenta los espacios femeninos de memoria histórica y democrática", afirma Herstóricas en su contribución ${ }^{13}$. Maria Chiara Bianchini (pp. 241-242) pone el acento no tanto en el sujeto agente de la memoria, sino en los sujetos receptores: "me interesa (...) plantear que lo 'democrático' de la memoria tal vez haya que buscarlo principalmente en el 'patrimonio humano' que se genera en torno a los monumentos: en los experimentos, ensayos y aprendizajes de los procesos colectivos que intervienen en la construcción de la memoria pública" (ver, en esta misma línea, a Maribel Rodríguez Achútegui).

En varios trabajos se invoca el rol insustituible de los organismos internacionales, con su definición de crímenes de lesa humanidad, o la imprescriptibilidad de los crímenes de desaparición de personas o los informes de las organizaciones de derechos humanos sobre la justicia restitutiva en países de pasados dictatoriales (Jorge Benavides, Custodio Velasco) ${ }^{14}$. Alguna autora, como Paloma Aguilar, fuera ya de este número, ha puesto de manifiesto el efecto multiplicador de unos actores sobre otros: "No hay que subestimar la influencia de los organismos internacionales. El Informe sobre España del Relator especial de Naciones Unidas para la promoción de la verdad, la justicia, la reparación y las garantías de no repetición ha influido enormemente en la capacidad de las asociaciones para organizar acciones colectivas" (AGUILAR FERNÁNDEZ; PAYNE, 2017: 170).

La tercera cuestión fenomenológica citada, el cómo, subyace en múltiples aportaciones, desde el texto de César Rina hasta el de Maria Chiara Bianchini o José Ramos. Bianchini plantea de entrada la elección de la cuestión: "pensando que lo 'democrático' de la memoria tal vez no tenga tanto que ver con qué conmemoramos sino con cómo lo hacemos. Sugiero -afirma Bianchini- dejar en segundo plano los objetos y dedicarnos principalmente a los procesos". En el proceso de emancipación de las mujeres andinas, de la guerra a la postguerra, y en sus fases, se detiene José Ramos (analizaremos más adelante el cómo vinculado al qué).

Jordi Guixé propone otro interrogante en este número, que no figura en la fenomenología descrita por Paul Ricoeur. Hace emerger la eterna pregunta ¿por qué España es diferente en su asunción de las memorias del pasado? Su respuesta apunta a que no están ausentes "mitos, intereses de casta, el orgullo de victoria, cierta impunidad chulesca -patrimonializada por algunos colectivos que han recibido un tratamiento privilegiado", o es fruto de la timidez de políticas públicas; tampoco han dejado de influir los relatos de las dos memorias, o de los dos demonios, o de la equidistancia, comentados por Ignacio Muñiz. Se señala como una de las dificultades de la memoria en España "la recuperación y creación de espacios patrimoniales memoriales", en síntesis, la recuperación de "lugares de memoria" (Benavides, Casado), "lugares pedagógicos, de aprendizaje, de reparación, de dignificación, de conservación, de interpreta- 
a debate Memoria democrática en la construcción de la historia y el patrimonio

| coordina Josefina Cuesta Bustillo

ción histórica y memorial" (Delgado, Estepa y Rodríguez Achútegui). Dificultades fruto del miedo o de la timidez, aunque se pretexten argumentos presupuestarios. Este mismo interrogante asoma en algunos de los trabajos ante decisiones adoptadas sobre la retirada de símboIos: ¿por qué? "Juzgar deliberadamente, como en este caso, el retiro de un elemento conmemorativo de un acto ejercido por un personaje relacionado con otro acontecimiento podría considerarse un acto contra la memoria y la sociedad misma. ¿Por qué? Es fácil elegir qué se mira y qué se queda, pero hacerlo por medio de una justificación deliberadamente vaga como que 'ha cumplido su ciclo' es sentenciar la ausencia de varias piezas del porvenir" (Francisco José Casado, pp. 206-207).

\section{El patrimonio, en el territorio del ¿qué? ¿cómo?}

"El patrimonio es la manifestación más visible y tangible de la memoria, es su 'objetivación' (...) en esta perspectiva, el patrimonio construido es principalmente una oportunidad para desarrollar 'ejercicios de democracia' (Maria Chiara Bianchini). Custodio Velasco reconoce que un ejercicio "proactivo de la ciudadanía" puede contribuir al cuidado de la herencia cultural y a la calidad de la democracia (Jorge Benavides, Francisco José Casado). En esta profunda y positiva relación se apoyan también los proyectos educativos propuestos (Delgado-Algarra, Estepa Giménez, García de las Bayonas Abelleira, Rodríguez Achútegui). También "la memoria democrática es patrimonio tangible e intangible (Casado) y la inmaterialidad del testimonio puede resignificar una fosa, una cárcel, una trinchera, un monumento. Reclama intervenciones valientes, y en ocasiones, esfuerzos presupuestarios, para activar el efecto reparador, dignificante, socializador y educador que se convierte en una herramienta de consolidación y crecimiento democráticos", como afirma Jorge Benavides.

Ante esta recuperación patrimonial -o no- varias cuestiones asedian al arquitecto, al experto, al historiador 0 al político: "1) ¿Qué memorias rescatar, en aras de una decencia democrática y de una justicia social? 2) ¿Cómo lograr esa transformación creadora en el presente?"15. También apoyado en la práctica de historiador y experto,
César Rina se pregunta conjuntamente: ¿Qué y cómo recordar? La experiencia emanada de su participación en una Comisión municipal impulsa a Rina a reflexionar sobre el espacio urbano como portador de significaciones, de identidades, de legitimidades, y cuyo uso público le transforma en espacio constructor de lecturas y narrativas del pasado, de memorias(s) colectivas(s), y por tanto de valores e ideologías. El historiador, en su oficio de experto en "esa temática muy escurridiza" que es la memoria, puede aportar herramientas, experiencia metodológica y conocimientos conceptuales para su "participación en los procesos de redefinición de la memoria colectiva en clave democrática", acentuando la función societal y de sociabilidad de la memoria y su contribución a la convivencia de las distintas memorias colectivas que pueden darse cita en una democracia. Su experiencia municipal le impulsa a proponer un debate historiográfico y en la sociedad sobre ¿qué y cómo recordar? ${ }^{16}$, a la hora de la construcción de esas memorias democráticas, especialmente en algunos de los por él denominados "puntos ciegos" de la Ley de Memoria Histórica (2007). Rina destaca entre ellos: las cruces de los caídos y las placas conmemorativas ${ }^{17}$. Puntos ciegos son también otros "marcadores con múltiples significaciones, según contextos", como determinadas instituciones militares, o victorias militares de los sublevados, que señalan "puntos de fuga" a la hora de identificar lo que es o no memoria franquista. La práctica de Jordi Guixé en la elaboración del censo de simbología franquista en Cataluña contribuye a despejar algunas de estas cuestiones, a la vez que resalta la decisión de "no destruir o demoler todos los símbolos"; es decir, lejos de hacer "tabla rasa del pasado", pueden adoptarse múltiples respuestas de conservación, museización, reinterpretación, traslado, memorialización, pedagogía, como "vías de avance democrático", en las que reinciden otros trabajos.

Otras iniciativas provienen de la reflexión entre patrimonio y memoria culta (o experta); en este caso, la de los arquitectos Jorge Benavides, Francisco José Casado y Juan Andrés Rodríguez Lora). Los dos últimos centran su atención en la producción arquitectónica moderna del 
periodo de dictadura en España ${ }^{18},(\ldots)$ y abogan por su protección alegando que "representa valores creadores que deben ser protegidos, de la misma forma que las creaciones de épocas precedentes" (DECLARACIÓN de 1971, citada por Rodríguez Lora ${ }^{19}$ ), especialmente "los insertos en los inventarios especializados de este patrimonio y (...) en los registros de la arquitectura del Movimiento Moderno (DOCOMOMO Ibérico) ${ }^{20}$. No obstante esta propuesta ${ }^{21}$, sus defensores no ignoran las dificultades o "debilidades" para "un reconocimiento generalizado y (...) para la protección" de este tipo de arquitectura, entre las que destacan: 1) una necesaria distancia temporal, 2) su carencia de "criterios de representatividad y singularidad por su carácter de producción en masa", 3) están "desprovistas de cualquier atisbo de excepcionalidad por su carácter de cotidianeidad", 4) han perdido su "autenticidad e integridad por los altos índices de alteración", 5) carecen de atractivo para la inversión, 6) carecen de un reconocimiento patrimonial generalizado, 7) "presentan altos niveles de vulnerabilidad social y económica", en suma, mayor vulnerabilidad que otras, 8) y generan una percepción negativa por asociación al régimen franquista, como exponen Rodríguez Lora y Daniel Navas Carrillo. Autor, este último, de una segunda contribución que, proveniente del mismo equipo y departamento, "propone abordar el reconocimiento patrimonial de las barriadas residenciales de promoción pública construidas en España durante la dictadura franquista" (Daniel Navas Carrillo, pp. 246-248). A los argumentos negativos que pesan sobre esta arquitectura, apuntados por Rodríguez Lora, Navas-Carrillo incide en otros conservacionistas, en este caso: 1) "valores "relacionados con los lazos emocionales de la sociedad"22, 2) por autenticidad, o autoría, etc., 3) por la importancia del contexto y entorno en que se inscriben, 4) por su inserción en el "devenir del urbanismo europeo del siglo XX", 5) por el "valor científico o técnico en cuanto a la importancia y relevancia de su concepción", 6) por "su posición estratégica en el tejido urbano actual, (o) lugar donde se implantan", 7) por "valores de contexto, que a nivel internacional era el reflejo de la creación de un nuevo orden social: el Estado del Bienestar", 8) o por "el establecimiento de la identidad social y cultural de la

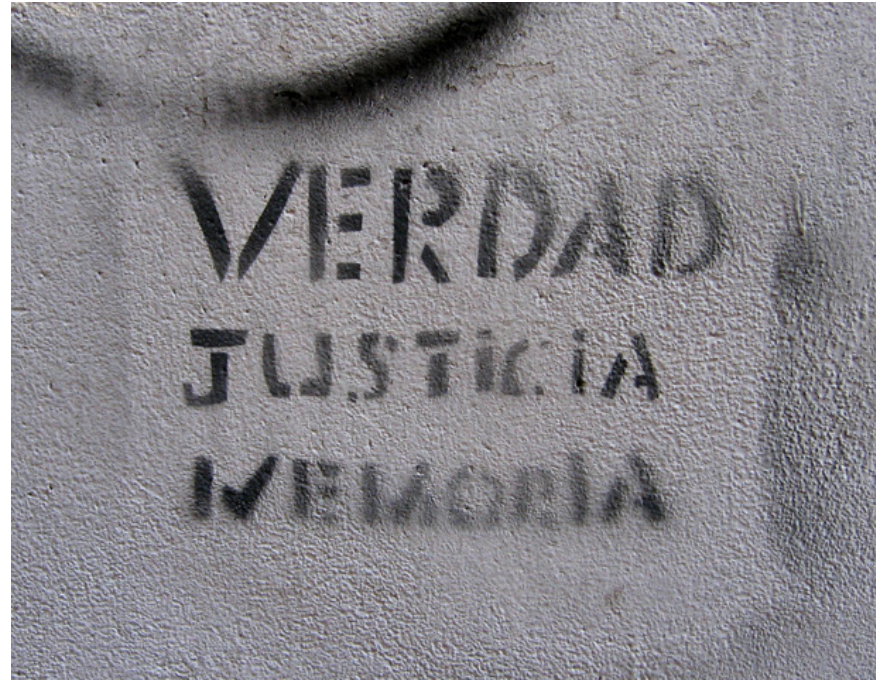

Verdad Justicia Memoria | foto Diodoro

población que allí reside, (de) sentimiento de pertenencia, de un patrimonio compartido, publico".

Estos puntos de debate han surgido especialmente con ocasión de la retirada de las placas del Instituto Nacional de la Vivienda con yugo y flechas. Ante la eliminación de símbolos de los espacios públicos, la propuesta de Jorge Benavides insiste en que debería respetarse la información histórica que las acompaña: especialmente año y proyectista ${ }^{23}$. Una llamada de atención, y de memoria cultural, frente a posturas absolutamente iconoclastas. En una línea similar se precisa la propuesta de Francisco José Casado para las placas relativas a la inauguración de una línea de metro en la capital de México, quien se pregunta "si verdaderamente tenemos la madurez emocional para enfrentar algunas de las infinitas cicatrices de la historia, en lugar de simplemente voltear hacia otro lado". En cualquier caso, afirma la Dirección General de Memoria Democrática de la Junta de Andalucía: En España "se prohíbe la exhibición pública de aquellos elementos que enaltezcan el golpe militar y la dictadura franquista, que son contrarios a la propia dignidad de las víctimas o constituyen una exaltación del enfrentamiento. Es, por tanto, (preciso) retirar del espacio público esos elementos $y$, en otros casos, mantener y explicar por qué es un símbolo que constituye una ofensa con- 
a debate Memoria democrática en la construcción de la historia y el patrimonio

| coordina Josefina Cuesta Bustillo

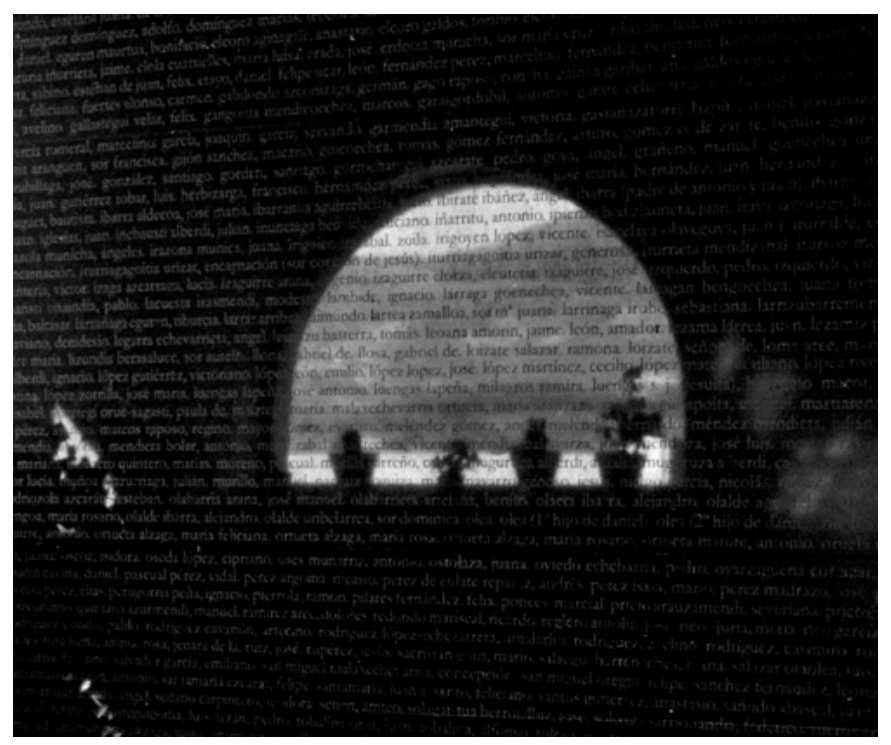

Placa en el mausoleo conmemorativo de Durango donde se recuerda a las víctimas | foto Jon Roman

tra las víctimas, con arreglo a nuestras leyes de memoria"24. Posición que puede compararse con la defendida por Guixé anteriormente.

De muy otro orden son las exposiciones, que documentan bien ese proceso memorial. Por ejemplo, la experiencia patrimonial realizada en Benalup-Casas Viejas, desde hace veinte años, hasta culminar en su resignificación y reconocimiento como bien de interés cultural (BIC), con la participación de distintos actores (especialmente presentada aquí por Carlos García de las Bayonas desde la perspectiva del IES), realizada como "un ejercicio de memoria colectiva, a través de la oralidad, la inclusión de testimonios, de documentación gráfica, de inclusión de la perspectiva de género y el reconocimiento del valor simbólico del hecho en sí"25. O la exposición, profundamente participativa de La Rinconada, sobre el Canal de los Presos que, en un proceso intergeneracional, incorpora las distintas memorias y sujetos locales, desde los adolescentes (agentes y receptores), en un proceso de descubrimiento, reflexión y construcción de memorias democráticas (Rodríguez Achútegui, experiencia que bien podría contemplarse también en el apartado de transmisión educativa).
Un "espacio" y otros objetos de la memoria atraen la atención en algunas de las participaciones: el valle de Cuelgamuros (¿Caídos?) ${ }^{26}$-como potencial recurso didáctico y exclusivo de memoria de las víctimas ${ }^{27}$ y una monografía se interroga sobre la "asombrosa" presencia de la División Azul (Alfredo Francesch), en comparación con otras memorias europeas sobre "los otros derrotados"28. La memoria franquista que permanece viva en estos temas permite alertar al autor sobre el "reciclado de las memorias" y la necesaria atención memorial a "los detalles", recordando las necesidades ${ }^{29}$, "coacciones y presiones que diluyen el carácter voluntario de aquellos soldados" o "la necesidad de limpiar sus expedientes", por lo que propone una mirada más matizada sobre este colectivo ${ }^{30}$.

\section{En el territorio del quién: "la otra mitad de la humanidad"}

Memorias democráticas quiere decir también incorporación de toda la sociedad, no solo los soldados de la guerra o los dirigentes políticos, por lo general varones. La integración de las mujeres no constituye una "ideología de género", como algunos se esfuerzan en divulgar, significa incorporar en una memoria inclusiva, a la mitad de la sociedad, a las mujeres que durante tanto tiempo han quedado oscurecidas en el olvido. No es ideología, es estadística, es familia, es ciudadanía, es recuerdo desdibujado pero integra una gran parte de la humanidad gravemente silenciada por la historia. Memoria con perspectiva de género significa "reconocer, incorporar, visibilizar y difundir toda la aportación de las mujeres" (M. ${ }^{2}$ Cristina Ferrer, p. 216), supone un acto de justicia, de verdad, de democracia. Pues no solo han permanecido en hondo desconocimiento las vejaciones de género en los conflictos bélicos (FREEDMAN; VALLUY, 2007), también se ha ignorado su participación en los movimientos democráticos en la transición española, en la que además han pagado el plus de representar nuevos modelos de feminidad (Jesica Serrano, pp. 214-215), o en la postguerra peruana, como informa José Ramos López en su contribución a este debate. Con ello "se sustituye el tiempo del silencio por el tiempo de la palabra". "¿Dónde están las mujeres en la memoria democrática?”, se pre- 
gunta la Asociación Herstóricas, que llama la atención sobre una costumbre demasiado arraigada aún ${ }^{31}$. Su iniciativa no se detiene solo en elaborar "proyectos culturales y educativos para visibilizar y valorar la aportación histórica de las mujeres en la sociedad" y así "realizar una transferencia de conocimientos" que promueva el interés por las mujeres, que "también estaba allí". Insisten en la necesidad de "incluir mayor variedad de relatos históricos y de memoria democrática", de generar "espacio intergeneracional, plural y diverso", de "ampliar el espectro de relatos y hacerlo de una forma participativa" y de forjar "espacios seguros para el debate y el pensamiento crítico" a través de los diversos soportes de la comunicación... incluidos los audiovisuales. Un ejemplo notable es el recordado por Jordi Guixé, con la recuperación de la memoria democrática de la cárcel de mujeres de les Corts, de Barcelona, desde una perspectiva de género y fruto de una memoria participativa. El proyecto, impulsado por un colectivo de mujeres, lucha contra la invisibilidad de género, patrimonial pública, y en especial, contra la invisibilidad represiva de las mujeres presas ${ }^{32}$. Como en otros procesos de eliminación de la memoria, un Corte Inglés se eleva sobre el espacio que ocupó la cárcel. Mejor respuesta memorial ha recibido la cárcel de Lugo, por ejemplo, aunque no figura en estos trabajos ${ }^{33}$.

Similar objetivo e importancia revisten las exposiciones como medio de difusión, comunicación y puesta en valor del colectivo femenino, de las que aquí se presentan algunos ejemplos. Se insiste en la necesidad de la introducción de la perspectiva de género como categoría analítica que "pone de relieve ciertas acciones que pretenden dar valor al colectivo constituido por las mujeres" (Jesica Serrano) ${ }^{34}$. Reivindicar los avances de estas mujeres resulta fundamental para la concienciación de la sociedad hacia una memoria democrática igualitaria para todos los ciudadanos y ciudadanas. Un exponente de ello fue la exposición Las andaluzas y la política (1931-2006), organizada en el año 2006 con motivo de la celebración del 75 aniversario de la conquista del voto femenino (Jesica Serrano) ${ }^{35}$. Otro exponente, con una fuerte incidencia en la transmisión, es el aquí presentado por Carlos García de las Bayonas, ya citado, sobre

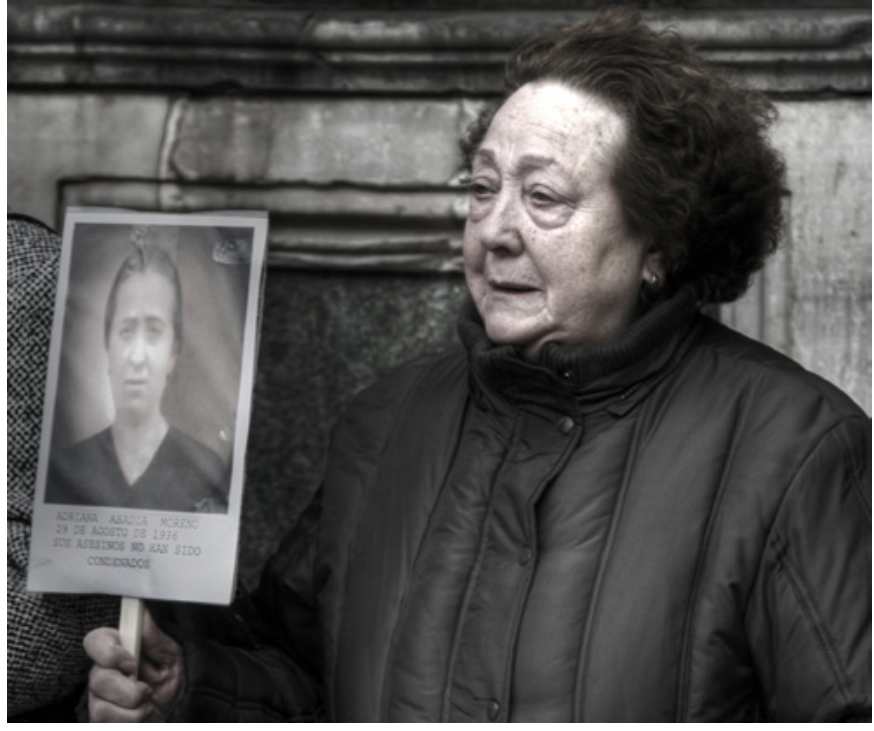

Verdad, justicia y reparación | foto Javi

la recuperación del patrimonio en Benalup-Casas Viejas (Cádiz) que también incluyó la perspectiva de género. La política autonómica de Andalucía se presenta también como una muestra del tratamiento que, desde las políticas públicas de memoria, se ha otorgado de manera específica a las mujeres, y desde varios ámbitos, como explica la contribución a cargo de la Dirección General de Memoria Democrática Junta de Andalucía ${ }^{36}$.

Del otro lado del Atlántico, el prototipo de empoderamiento de la memoria femenina indígena quiebra los límites de género, etnia, clase, de espacios rural/urbano, señalados hasta ahora ${ }^{37}$. Como España, también Perú se ha cobijado más en la sombra de la reparación que de la memoria. En Perú, como en otras latitudes latinoamericanas, la sociedad civil presenta modelos y experiencias de memoria democrática y responsable, también femenina: "la vivencia del conflicto armado interno y la violencia rutinizada no terminan consumiendo y opacando a las actrices sociales" (José Ramos). Acaso entre lo más interesante de esta aportación figure el proceso, el cómo se transforman en actoras femeninas, en la apropiación y el empoderamiento de las nativas andinas, hasta lograr su "agencia política y el papel de reconstruir la sociedad peruana", franqueando sus etapas, desde la in-visibili- 
a debate Memoria democrática en la construcción de la historia y el patrimonio

| coordina Josefina Cuesta Bustillo

zación, pasando por el conflicto, hasta "ganar la postguerra", con su proceso de resignificación del género (mujer-varón) ${ }^{38}$, de los roles atribuidos y reconquistados, de la resignificación del cuidado, de la resiliencia cultivada hasta transitar "del dolor hacia la acción y construcción de ciudadanía y desarrollo" (Reynaga, citado por Ramos), convirtiendo los puntos negros en "agujeros de escape"39.

\section{¿Qué, cómo, a quién? Memoria y transmisión docente}

Se ha señalado "la memoria como un espacio público que crea espacios de convivencia y de respeto mutuo, a la vez que ayuda a asentar en nuestra tierra una verdadera cultura democrática fundamentada en los derechos humanos". Se ha mencionado la escuela como espacio emergente y nuevo escenario de producción de valor y de sentido (Maria del Rosario Zavala), por ello "la conversión de la escuela en espacio público necesita la multiplicación de prácticas sociales que habiliten la posibilidad (...) de una ciudadanía de distinto tipo", afirma Raimundo Cuesta en otro lugar (CUESTA FERNÁNDEZ, 2007: 152).

Desde la docencia y la didáctiva, el trabajo con (sobre) la memoria supone una autentica aportación, abriendo el cauce desde el aprendizaje del pensamiento crítico, al de habilidades, capacidades y experiencia de análisis (Jesús Estepa); el acceso a bienes y servicios culturales garantiza el desarrollo de la creatividad, la fantasía, la comprensión, la reflexión: herramientas para la elaboración de un juicio crítico sobre la realidad social (Maria del Rosario Zavala). Supone otra manera de hacer historia, distinta de la tradicional -anclada en la transmisión memorialística y fosilizada-. Se privilegian en aquella la historia del presente, y el análisis y significado de las relaciones entre pasado, presente y futuro. Ofrece "otros modos de articulación entre prácticas, hechos y mundo social". Puede contribuir a la formación de una ciudadanía informada, activa, participativa, que exige partir desde el sujeto, tanto desde el docente, con su necesaria formación, como desde el estudiante, desde su entorno, su propio presente y su espacio urbano/rural.
En gran parte de los casos, se convoca a las memorias "desde abajo", que respondan a criterios democráticos y puedan ser patrimonializadas por la sociedad (Francisco José Casado, Jesús Estepa, Emilio José Delgado Algarra, Custodio Velasco); partir del "análisis de nuestra propia situación" y cultura (invocan Emilio José Delgado Algarra, Jesús Estepa, Maribel Rodríguez, Custodio Velasco y Maria del Rosario Zavala) y escribir las situaciones constitutivas de la memoria de la cultura como proyecto (Maria del Rosario Zavala). La metodología participativa, defendida por todos los autores, así entendida, suscita un interés conceptual, de reflexión y de transmisión (desde la memoria familiar a la memoria local y medios de comunicación), como señalan Juan Andrés Rodríguez Lora y Maribel Rodríguez Achútegui). Este arraigo del sujeto, en la base, pretende la "relocalización del (...) campo de significaciones de una comunidad específica" (Maria del Rosario Zavala).

En efecto, la educación patrimonial puede arrancar de cuestiones actuales, de carácter socioambiental; por ejemplo, la búsqueda de resquicios dictatoriales en el espacio urbano ("antipatrimonio"), en un ejercicio experimental de conocimiento, de consciencia y de juicio. El potencial de la enseñanza de la historia se refuerza así con su función reparadora y normalizadora, de comprensión y compromiso.

La reflexión sobre las propuestas docentes presentadas supera y enriquece la dualidad entre historia y memoria. Dualidad que abre paso a una nueva conciliación entre ambas y se formula una nueva dialéctica enriquecedora, "una historia con memoria", que acentúa el potencial de la enseñanza de la historia para la recuperación de las memorias y su contribución al compromiso con la democracia y la ciudadanía (Jesús Estepa, Emilio José Delgado Algarra, Daniel Martínez Castizo). Generar una memoria colectiva, democrática, inclusiva, e intergeneracional supone reflexionar colectivamente sobre nuestra historia, adoptar la memoria como herramienta crítica de la historia, del pensamiento crítico, cívico y participativo, recuerdan Francisco José Casado ${ }^{40}$, Custodio Velasco y Antonio Gisbert. 


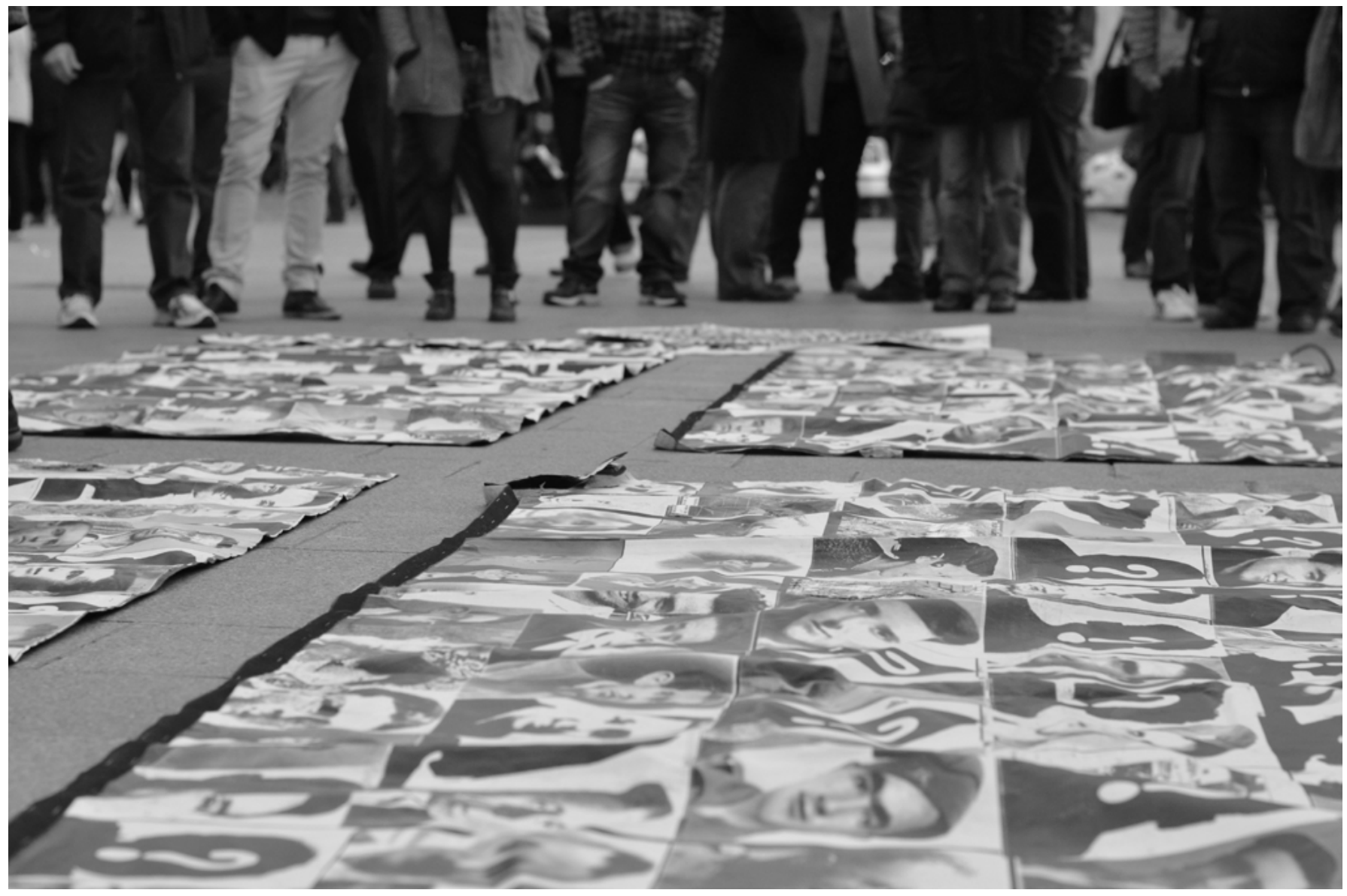

Representación de las víctimas del franquismo en Sol, Madrid | foto Xanti Fakir

La historia con memoria desemboca en una historia crítica, definida por Raimundo Cuesta como "una relación que implica la práctica de una historia del presente capaz de problematizar nuestro mundo merced al método genealógico"41. "Esa es la historia con memoria, una mirada, frente al presentismo dominante, volver a reconsiderar las relaciones entre pasado, presente y futuro dentro de una perspectiva crítica capaz de impugnar el capitalismo global y su lógica de producción de la verdad" (CUESTA FERNÁNDEZ, 2015: 129).

Y aquí confluyen la propuesta de Raimundo Cuesta, con la de Daniel Martínez en su contribución: para quien percibe en la crisis actual una crisis de régimen, "lo que se precisa es reconstruir un discurso sobre la posibilidad de otro mundo distinto y un sujeto colectivo capaz de imaginarlo y buscarlo en la acción colectiva" ${ }^{\text {"2 }}$.

\section{Balance provisional}

Lejos de un afán la exhaustividad, no pretendemos una síntesis de la riqueza de propuestas sino solo poner de relieve algunas cuestiones de notable interés e incitar a proseguir en las reflexiones suscitadas. Una línea transversal, que jalona los textos enviados, radica en la relación entre memoria, ciudadanía, democracia y patrimonio. Se ha acentuado la función de la memoria como exponente de la "evolución de la ciudadanía hacia una mayor expresión en el espacio público" y de participación política en las democracias, siempre inacabadas, que necesitan ser completadas ${ }^{43}$. Pues "una democra- 


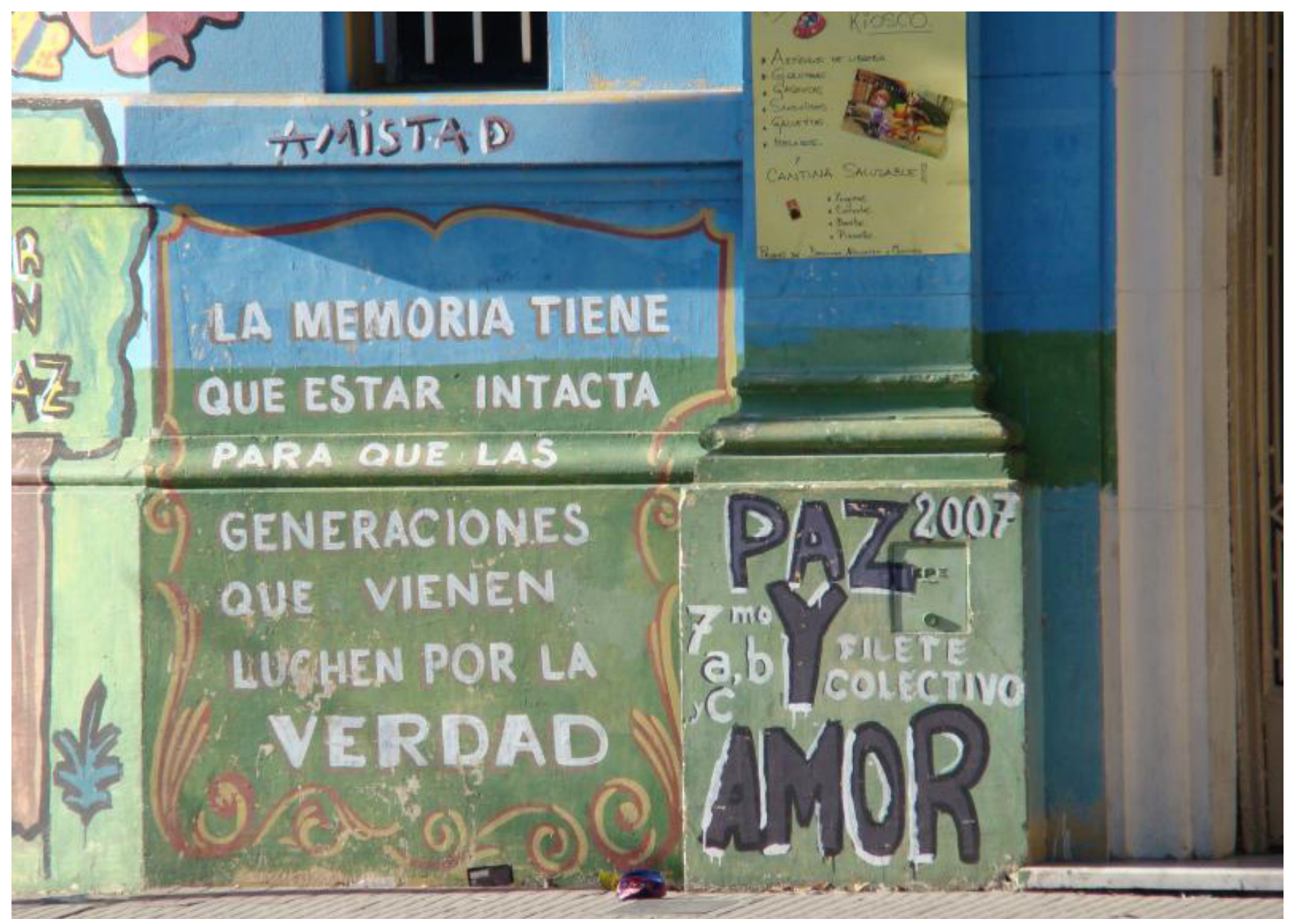

Para no olvidar. Mural en la pared de la escuela de Av. Alberdi y Almafuerte | foto Pablo Flores

cia sin memoria es una democracia débil" (como dice Carlos Barros). Se ha subrayado la cercanía y proximidad de la(s) memoria(s) como factor de democracia, cuando son asumidas desde la institución escolar o por la comunidad local. Se ha reflexionado sobre la importancia de la puesta en valor de espacios y lugares, sobre la recuperación de testimonios, del patrimonio gráfico y documental, y de la cultura material, crucial para explicar la historia de un pasado traumático y no democrático, apuntando razones y obstáculos en esta tarea. Se registra la esperanza de los últimos años, en los que "nuevos marcos legislativos dibujan un horizonte inédito en relación con el tema de la memoria en España, que se inscribe paulatinamente en la doctrina internacional de los derechos humanos" (Custodio Velasco), pero también las resistencias y el anómalo modelo español.

Este número se ofrece al "debate mediático, social y político sobre la necesidad o no de políticas públicas de la memoria" (Custodio Velasco). En él se acentúa la necesidad de impulsar políticas de memoria(s) democrática(s) como "responsabilidad colectiva (...), transnacional, interdisciplinar, social, participativa, institucional, universitaria y profesional", que exigen "conocimiento, formación profesional y comparación transnacional" (Jordi Guixé) ${ }^{44}$. 


\section{NOTAS}

1. Lucía, joven de 16 años, La Rinconada (Sevilla). Ver el texto de Maribel Rodríguez Achútegui: Cuando la memoria deja de estar en blanco y negro: las exposiciones participativas del museo de La Rinconada (Sevilla). Agradezco a Lucía, la estudiante que aportó esta frase tan sugerente.

2. Utilizamos el masculino como fórmula genérica incluyente de todos los géneros, según propone la Real Academia Española.

3. Es destacable la riqueza y variedad de la bibliografía aportada en las colaboraciones que puede consultarse al final.

4. Sin duda el mejor especialista de Maurice Halbwachs, aunque no citado en ninguno de los trabajos presentados (ver bibliografía final).

5. Un concepto recurrente, que aparece más en nebulosa y, por tanto, suficientemente banalizado, utilizado generalmente sin delimitar bien sus perfiles, es el de memoria histórica. "Llamaremos memoria histórica a los usos del pasado y de la historia tal y como grupos sociales, partidos, iglesias, naciones o Estados se la apropian. Apropiaciones dominantes o dominadas, apropiaciones plurales y selectivas, en todo caso, marcadas por el sello del anacronismo, de la semejanza entre el pasado y el presente, mientras que la historia tendería en su principio a la unidad, al menos a la crítica de las memorias históricas y al establecimiento de diferencias entre el pasado y el presente" (LAVABRE, 2006: 43).

Más concreta es la acepción que le otorga Carlos Barros en este número (ver pp. 219-221), no tanto como concepto sino como movimiento social en España: "La memoria histórica es un joven movimiento social, político y académico: no llega a 20 años de vida, si bien se refiere a hechos represivos que tuvieron lugar hace $80-40$ años" (lo identifica con la Asociación para la Recuperación de la Memoria Histórica); y para este autor, la memoria histórica no ha dejado de desarrollarse en una multiplicidad de vías de actuación de ámbito local, regional, nacional o internacional.

6. El olvido, también "trabajo" o acción de la memoria, es invocado en algún texto como revisable, "el olvido está lleno de memoria", en palabras de Benedetti, citadas por Custodio Velasco en su contribución a este debate. En efecto, se ha escrito: "El rasgo más constante de las filosofías del olvido consiste en demostrar que ningún olvido es irreparable, que todo es, en cierta medida, inolvidable" (J.-L.Chrétien, citado por CUESTA, 2008: 84).

7. Esta multiplicidad de memorias aporta, a quien trabaja sobre el tema, la convicción de que el uso más adecuado del concepto es en plural, memorias, noción que atraviesa la mayoría de los trabajos presentados que invocan este plural en sus acepciones.

8. Plural también aplicado a las memorias democráticas (Ignacio Muñiz), y que resulta fundamental en la reflexión abierta por esta revista. Muñiz subraya, además, su empeño en diseccionar las diversas memorias "que pueden darse cita en el concepto plural de memoria(s) democrática(s), todas ellas integradas en el ámbito común de la reivindicación de los Derechos Humanos, paradigma en el que se inserta la reivindicación de la(s) memoria(s)". Las colaboraciones contenidas en esta sección constituyen un buen mosaico para la aproximación al concepto de memorias democráticas. A pesar de ello, Carlos García de las Bayonas (pp. 235-236) señala el "difícil encaje" de este concepto, objeto de debate en sí mismo, cajón de sastre que hay que depurar, señala (¿no da cabida a la pluralidad y a la colectividad?).

9. Carácter conflictual también atribuido a la cultura, una cultura definida como "campo de posibilidades" que incluye el conflicto social, como señala la contribución de María del Rosario Zavala (pp. 210-211).

10. Y no contribuiría a una memoria democrática que las calles o edificios "lleven nombres de todos los "participantes' en la Guerra Civil" (como afirma Asunción Cobo), 
a debate Memoria democrática en la construcción de la historia y el patrimonio

| coordina Josefina Cuesta Bustillo

pues los hay que participaron precisamente contra la propia democracia.

11. Y alude a que el "exacerbado deseo de recordar acciones nefastas de una guerra y sobre todo a sus dirigentes no deja de parecerme algo morboso que nos impide avanzar hacia una sociedad democrática, igualitaria y consciente de su pasado. El recuerdo es necesario, pero cuando se convierte en obsesión anula cualquier posibilidad de asumir los hechos con serena imparcialidad" (Asunción Cobo). Sobre imparcialidad, objetividad, honestidad y coherencia hay algunas reflexiones en los textos, que remiten a una cuestión más compleja, suficientemente debatida por los historiadores y por las ciencias humanas y sociales. $Y$ nos preguntamos ¿por qué no invocar criterios o condiciones de veracidad, en las que ya se adentró Paul Ricoeur? (CUESTA, 2008: 127-131).

12. Velasco considera esta responsabilidad de la recuperación de las "memorias colectivas" propia de la administración, y deberían estar próximas a la verdad y al ejemplar comportamiento de los políticos. Podría alegarse que esta función de la administración, en la construcción de memorias "oficiales" y "públicas", no debería estar reñida y podría enriquecerse con la aportación social de otras "memorias colectivas" de los diversos grupos, ya que cualquier organización social desarrolla una narrativa o una política, respecto a su pasado, como afirma el propio Velasco.

13. Multiplicidad de actores en la que se redunda "desde la colaboración entre administraciones, entidades y asociaciones; desde la investigación y el conocimiento, la divulgación y la pedagogía", apoyados en el principio de cooperación (Dirección General de Memoria Democrática Junta de Andalucía, pp. 249-250).

14. Con razón Benavides sugiere la inclusión de este "intercambio de ideas" en el marco general y necesario de la doctrina internacional de los derechos humanos. Propone el recurso del derecho a la verdad y recuerda los marcos de la memoria (y de la democracia), no solo internos, sino también internacionales, invocando las normas internacionales penosamente conquistadas también por estas organizaciones. Pues la cuestión que aquí se aborda es "común a otras geografías y otros espacios", como Japón, ejemplo invocado por Emilio José Delgado-Algarra, o como el espacio europeo, como expone Jordi Guixé.

15. "Suscitando la memoria, la experiencia, los sentimientos y las recepciones, mediante las emociones y adecuadas herramientas de transmisión e interpretación" (Jordi Guixé).

16. Poniendo el dedo en la llaga de cuestiones centrales, ya señalados por Paul Ricoeur, en el abordaje de las memorias colectivas.

17. Placas conmemorativas que son objeto de reflexión en varios de los trabajos presentados (además de César Rina y Francisco José Casado, Juan Andrés Rodríguez Lora -ver pp. 243-245-, entre otros).

18. Inscribiéndola en el contexto de "los avances en el reconocimiento de esta arquitectura a nivel institucional e internacional", que cuenta con un recorrido que ya casi ronda el cincuentenario.

19. "Quedarían como legado para las generaciones posteriores ejemplos relevantes de arquitectura racionalista y moderna construida durante la dictadura".

20. Fundación Docomomo Ibérico para la documentación y conservación de la arquitectura y el urbanismo del Movimiento Moderno (www.docomomoiberico.com) [Consulta: 01/12/2018].

21. Invocan, en su favor, su continuidad en un proceso arquitectónico más amplio en el que se inserta. "Esta arquitectura no solo sobrevivió a la época dictatorial y se consolidó en España -y en el resto de Europa- durante dicha etapa, sino que su asentamiento supuso la base para otras expresiones tardías en torno a la misma a lo largo de la etapa final del siglo XX. Esta pervivencia 
a través de los cambios de sistemas experimentados, desde la Segunda República, pasando por la Dictadura hasta llegar a la democracia actual, merecería ser tenida en cuenta en la articulación de unos valores patrimoniales que vayan más allá de la etapa en que se construyó" (Rodríguez Lora).

22. Los conjuntos de vivienda social pueden ser poseedores de valores "relacionados con los lazos emocionales de la sociedad [...] que tienen un fuerte impacto en su salvaguarda, conservación y restauración (...). Se hace necesario llevar a cabo acciones que abunden en la consideración patrimonial de estos edificios yendo más allá de las vinculaciones con el periodo en que se construyeron (...) La valoración objetiva de estos bienes se presenta indispensable en este cometido, pues realmente suponen una expresión contemporánea que ha ido traspasando los cambios de sistemas de gobierno del convulso siglo XX" (Daniel Navas Carrillo).

23. "Convendría retirar los símbolos de los espacios públicos, pero no la información histórica que les acompaña. Es el caso de las placas en obras civiles y edificios construidos en el período franquista: año y proyectista. Información distinta de la tan abundante sobre las autoridades que inauguraron el edificio o monumento, tan laudatorias para el régimen o "el Caudillo", que constituyen una verdadera exaltación y, por lo tanto, son objeto de la Ley de Reparación (2007), como propone la Dirección General a renglón seguido.

24. "No hay una sola receta ni se puede hacer tabla rasa con todo, y por ello se encuentra actualmente en última fase de tramitación un decreto que regula un comité técnico compuesto por personas expertas" (Dirección General de Memoria Democrática Junta de Andalucía).

25. Otros proyectos en esta línea, "como Belchite o el proyecto BAMSA, pueden ser claves en el camino del encuentro", afirma García de las Bayonas.

26. ¿También hay que recuperar los nombres originarios? Es una propuesta, no expresada en este número, que tarda en hacerse reconocer. Recuperando el antiguo nombre de Paracuellos perdería con ello la connotación de una memoria dictatorial exclusiva, y el valle volvería a inscribirse en una larga duración.

27. Lejos de otras iniciativas, formuladas hace años, de convertirlo en memorial de todas las víctimas de la Guerra Civil (Asunción Cobo), que están perdiendo apoyo. Las distintas propuestas sobre el Valle (valor histórico, simbólico, patrimonial o turístico) inciden en un debatido presente: el Valle cementerio común y memorial de las Víctimas, condensador de memorias y de debates (Asunción Cobo); potencial recurso didáctico (Emilio José Delgado-Algarra); como "emergencia "80 años después de Guerra Civil, del franquismo sociológico oculto" (Carlos Barros).

28. Derrotados que, en el caso español, han llegado hasta fin del siglo XX con una presencia "perturbadora", llegando algunos a protagonizar el golpe de 23 de febrero de 1981, como Milán del Bosch y Armada, en un ejemplo claro de reproducción de la violencia (A. Francesch).

29. "El rancho: comida (...) algo nada despreciable (...) en una España paupérrima y hambrienta" (como expresa Alfredo Francesch). Una reciente reflexión sobre los "voluntarios" de la Guerra Civil española en Fernández Prieto y Artiaga Rego (2018).

30. Por eso vindico que la División Azul no fue tan azul, tan monolíticamente azul, y por eso no puede ser condenada a un olvido igual de monolítico. Tanta derrota justificaría algún honor. Por modesto que sea" (A. Francesch).

31. "Es bastante común que los espacios patrimoniales ignoren la relación, usos y vínculos emocionales de estos mismos con la población femenina", relación oculta "bajo mensaje(s) paternalistas y sexistas fruto de siglos de marginación y patriarcalismo" (Herstoricas).

32. El autor ofrece información para el seguimiento de este proyecto: www.presodelescorts.org; http://presode dones.wordpress.com [Consulta: 03/12/2018]. 
a debate Memoria democrática en la construcción de la historia y el patrimonio

| coordina Josefina Cuesta Bustillo

33. Para más información consultar: http://praza.gal/cul tura/o-vello-carcere-de-lugo-reabre-como-espazo-decultura-e-memoria; https://memoriahistorica.org.es/tag/ o-vello-carcere/; https://www.eldiario.es/galicia/antiguaCoruna-puertas-emerge-memoria_0_605790393.html; https://antiguaprisionprovincialcoruna.wordpress.com/; https://www.laopinioncoruna.es/coruna/2018/08/04/ decenas-personas-visitan-antigua-carcel/1316313.html; https://cadenaser.com/emisora/2018/12/25/radio_co runa/1545762727_259644.html [Consulta: 03/12/2018].

34. El análisis mediante la perspectiva de género "permite observar cómo los roles desempeñados por hombres y mujeres se conforman a partir de una relación mutua en un contexto histórico y cultural concreto y, por lo tanto, permite destruir la consideración natural de las mismas. La inclusión de la perspectiva de género, en este caso, posibilita asimismo observar cómo los pequeños cambios de roles basados en las diferencias de género, como el acceso a la educación, permiten cambiar las relaciones de género a niveles superiores, como el acceso a las Cortes y, como consecuencia, el sufragio universal" (Jesica Serrano). En esta misma línea, ver la aportación de José Ramos López.

35. Puede consultarse el interesante catálogo de la exposición Las andaluzas y la política (1931-2006) editado por el Instituto Andaluz de la Mujer (Consejería de Cultura de la Junta de Andalucía) en 2006.

36. La aprobación de normativa que recoge indemnizaciones específicas a mujeres vejadas y ultrajadas como consecuencia de la represión franquista, como desde la investigación y divulgación (subvenciones en las que se ha valorado la perspectiva de género de los proyectos, documentales en las que el protagonismo era ostentado por mujeres), o intervenciones específicas en "fosas de mujeres" (las "17 rosas" de Guillena, las mujeres de Grazalema, las "niñas" de El Aguaucho, o la fosa de las mujeres de Higuera de la Sierra).

37. "El sujeto, que es mujer y procedente de la comunidad andina, está lleno de memorias (...), se moviliza a la ciudad y opta por diferentes mecanismos para poder solventarse, tener una vida digna, un techo propio y, en pocos casos, reclamar sus derechos. Ubicadas en los asentamientos humanos, caracterizados por abismales brechas sociales, económicas, étnicas donde se les percibe como 'insignificantes: pobres, rurales, indígenas, mujeres. $Y$ vuelve a reaparecer la trenza de discriminaciones y desprecios' (José Ramos López).

38. "Las mujeres éramos como los varones (...) mucho más que una mujer o doblemente mujer" (José Ramos López).

39. "Abordar estos problemas debería de 'contribuir a discernir lo que somos como país, incluyendo la exclusión y las desigualdades persistentes, la falta de ciudadanía y la débil institucionalidad política'. Carlos Iván Degregori proponía que una política de memoria en el Perú debía contribuir a un 'nunca más' de la violencia, pero también a un 'nunca más' de la exclusión, un 'nunca más' de poca ciudadanía y un nunca más de extrema pobreza" (Del Pino; Agüero, citados por Ramos). Es decir, dar un buen tratamiento y lectura cultural de la memoria para poder vivir en una sociedad, en la cual potenciemos la convivencia y coexistencia social con criterios tolerantes. Las experiencias anteriores son una forma de ganar la posguerra de poco a poco" (José Ramos). Movimiento femenino que trae a la memoria otros procesos innovadores como el de las Madres de Plaza de Mayo, en Argentina.

40. "Aspirar a una historia que escape al maniqueísmo e intente arrojar una mirada crítica y lúcida sobre el pasado de nuestra comunidad" (GASCÓN, citado por Casado).

41. "La historia con memoria es una invitación a afrontar las paradojas que pueblan un mundo evanescente cuyo conocimiento y transformación a menudo se nos escapan" (CUESTA, 2015: 128-129).

42. "La memoria democrática es, desde el punto de vista estructural, un elemento de transformación del liberalismo democrático y de la sociedad de consumo (...) 
La memoria democrática puede constituir, para algunos autores, un elemento de transformación ante la crisis y una esperanza para sectores progresistas descontentos" (Daniel Martínez).

43. Benavides también recuerda que las democracias (como la historia) no son perfectas ni están acabadas, sino proyectos en permanente construcción, "procesos dependientes de múltiples variables, con inciertos comportamientos".

44. En esta línea recuerda que Memorial Dèmocratic colabora con otras redes internacionales, elaborando un tipo de decálogo profesional de memoria, a escala europea, como miembro de los programas comunitarios, programas que también recuerda Custodio Velasco: Europe for Citizen Programme (2004-2007) y Uses of the Past (2014-2020).

\section{BIBLIOGRAFÍA}

- AGUILAR FERNÁNDEZ, P.; PAYNE, L. A. (2017) El resurgir del pasado en España. Fosas de víctimas y confesiones de verdugos. Madrid: Taurus, 2017

- ARAVENA, P. (2014) François Hartog: La historia en un tiempo catastrófico. Cuadernos de historia, n. ${ }^{\circ} 41,2014$, pp. 229-230

- ARIÑO, A. (2002) La expansión del patrimonio cultural. Revista de Occidente, n. ${ }^{\circ} 250,2002$, pp. 129-150

- ARÓstegul, J. (2004) La historia vivida. Madrid: Alianza Editorial, 2004

- ARÓsteguI, J. (2009) La Ley de Memoria Histórica: reparación e insatisfacción. Patrimonio Cultural de España [en línea], n. ${ }^{\circ}$ 1, 2009, pp. 41-60. <http://ccfib.mcu.es/patrimonio/ docs/MC/IPHE/PatrimonioCulturalE/N1/08_PCE1_Ley_ Reparacion.pdf> [Consulta: 23/11/2018]

- ARRARÁs, J. (1940) Historia de la cruzada española. Madrid: Ediciones Españolas S. A., 1940

- BARROS, C. (2011) Historia de la memoria, memoria de la historia [en línea] Conferencia impartida en la Escuela Nacional de Antropología e Historia, México D.F., México, 5 de diciembre de 2011; <https://www.youtube.com/watch?v=euRNzJOHMcl> [Consulta: 20/11/2018]

- BARROS, C. (2013) Historia, memoria y franquismo [en línea], 2013 <http://www.h-debate.com/wp-content/olddebates/cbarros/spanish/articulos/memoria/Historia memo ria_y_franquismo.htm> [Consulta: 15/11/2018]

- BARROS, C. (2014) Historia, memoria y franquismo. Historia Actual Online, n. ${ }^{\circ} 33,2014$, pp. 153-171

- BARROS, C. (2016) El historiador y la memoria [en línea] En II Jornadas internacionales sobre memoria y comunicación "Las políticas de memoria histórica en Europa", Facultad de Geografía e Historia, Universidad de Sevilla, 28 de noviembre de 2016, <https://youtu.be/QaMQSdWdKJo> [Consulta: 15/11/ 2018]

- BERLIN, I. (2000) El erizo y la zorra. México: Muchnik Editores, S.A., Editorial Océano de México, S.A., 2000

- BERMEJO, X. C. (2006) La ideología del patrimonio y el nacimiento de la historia basura. Gallaecia, n. ${ }^{\circ} 25,2006$, p. 292

- BIANCHINI, M. C. (2016) "Patrimonios disonantes y memorias democráticas: una comparación entre Chile y España". En Kamchakta, Revista de Análisis Cultural [en línea] n. ${ }^{\circ}$ 8, 2016, pp. 303-322 <https://ojs.uv.es/index.php/ kamchatka/article/view/9148> [Consulta: 07/12/2018]

- BOULlosA, P. (2017) El corazón es un resorte. México: Penguin Random House Grupo Editorial, 2017 
a debate Memoria democrática en la construcción de la historia y el patrimonio

| coordina Josefina Cuesta Bustillo

- BRITTAN, D. (1997) Historia pública y memoria pública. The Public Historian, vol. 19, n. ${ }^{\circ} 3,1997$, pp. 11-23

- CANDAU, J. (2002) Antropología de la memoria. Buenos Aires: Ediciones Nueva Visión, 2002 (Colección Claves y Problemas)

- CANNADINE, D. (2005) ¿Qué es la historia ahora? Granada Ediciones Almed, 2005

- CARR, E. H. (2010) ¿Qué es la historia? Barcelona: Ariel, 2010

- CASPISTEGUI, F. J. (2003) Sobre el papel social del historiador o ¿para qué servimos? Memoria y civilización: anuario de historia, n. ${ }^{\circ} 6,2003$, pp.193-199

- CARRETERo, M. (2008) Documentos de identidad. La construcción de la memoria histórica en el mundo global. Buenos Aires: Paidós, 2008

- CARRIÓN GÚtIEZ, A. (2015) Plan Nacional de Conservación del Patrimonio Cultural del Siglo XX [en línea] Madrid: Secretaría General Técnica. Centro de Publicaciones. Ministerio de Educación, Cultura y Deporte, $2015<$ <ttp://www.culturaydeporte.gob.es/planes-nacionales/ eu/dam/jcr:fafab665-7e31-4da9-b897-180d8fd0eb0d/06-ma quetado-patrimoniocultural-sxx.pdf> [Consulta: 29/11/2018]

- CASTILLA DEL PINO, C. (2006) La memoria como moral. En CHECA, S.; DEL RÍO, A.; MARTíN, R. Andaluces en los campos de Mauthausen. Sevilla: CEA, 2006 pp. 13-15

- CHAUMONT, J-M. (1997) La concurrence des victimes, génocide, identité, reconnaissance. París: La Découverte, 1997

- CHIENTAROLI, N. (2014) Los 10 suspensos de la ONU a España en memoria histórica. eldiario.es [en línea] 28 de agosto de 2014. <https://www.eldiario.es/sociedad/ ONU-Espana-Guerra-Civil-franquismo_0_297120710.html> [Consulta: 11/01/2019]

- CHOMSKY, N. (2004) La objetividad y el pensamiento liberal. Los intelectuales de izquierdas frente a la guerra de Vietnam y a la Guerra Civil española. Barcelona: Península, 2004

- ClOSA MONTERO, C. (2010) Negociating the Past: Claims for Recognition and Policies of Memory in the EU [disponible en línea]. Madrid: Consejo Superior de Investigaciones Científicas (España), 2010 (Serie Documentos de trabajo, n. ${ }^{\circ}$ 8, Instituto de Políticas y Bienes Públicos -IPP-). <http://hdl. handle.net/10261/24430> [Consulta: 14/11/2018]

- CORAL, I. (1999) Las mujeres en la guerra: impacto y respuestas. En STERN, S. Los senderos insólitos del Perú: guerra y sociedad, 1980-1995. Lima: IEP-UNSCH, 1999, pp. 337-363

- COSTA, X. (1999) La coordinación internacional del proyecto de documentación y conservación del del MOVIMIENTO MODERNO. En VV. AA. La arquitectura moderna en Andalucía: un patrimonio por documentar y conservar. La experiencia DOCOMOMO. Sevilla: Consejería de Cultura de la Junta de Andalucía, Instituto Andaluz de Patrimonio Histórico, 1999, pp. 6-11 (Serie Cuadernos, 11)

- CUÉ, C. E. (2002) El PP condena el golpe de Franco y promete honrar a todas las víctimas de la Guerra Civil. El País [disponible en línea] 21 noviembre de 2002 <https://elpais. com/diario/2002/11/21/espana/1037833222_850215.html> [Consulta: 11/01/2019]

- Cuesta Bustillo, J. (2007) Memorias históricas de España. Madrid: Fundación Francisco Largo Caballero, 2007

- CUESTA BuSTILlO, J. (2008) La Odisea de la memoria en España. Madrid: Alianza Editorial, 2008

- CUESTA FERNÁNDEZ, R. (2011) Historia con memoria y didáctica crítica. Con-ciencia Social, n. ${ }^{\circ} 15,2011$, pp. 15-30

- CUESTA FERNÁNDEZ, R. (2007) Los deberes de la memoria en la educación. Madrid: Minsiterio de Educación y Ciencia y editorial Octaedro, 2007

- CUESTA, R. (2015) La venganza de la memoria y las paradojas de la historia. Salamanca: Lulú.com, 2015

- DE JONGE, W. (2017) Sleeping Beauty. En KUIPERS, M.; DE JONGE, W. (dir.) Designing from Heritage. Strategies for Conservation and Conversion. Delft: TU Delft - Heritage and Architecture, 2017, pp. 14-29

- DECLARACIÓN de Praga. Resolución para la protección de los monumentos culturales de los siglos XIX y XX, de 8 de octubre de 1971. Praga: Comisión de Resolución, 1971

- DEGRÉGORI, C. I. (2015) Heridas abiertas, derechos esquivos. Derechos humanos, memoria y Comisión de la Verdad y Reconciliación, Obras escogidas (Vol. IX). Lima: IEP, 2015

- DEL PINO, P. (2003) Uchuraccay: Memoria y representación de la violencia política en los Andes. En DEGRÉGORI, C. I. Jamás tan cerca arremetió lo lejos: Memoria y violencia política en el Perú. Lima: IEP, 2003, pp. 49-93

- DEL PINO, P.; AGÜERO, J. C. (2014) Cada uno, un lugar de memoria. Fundamentos conceptuales del Lugar de la Memoria, la Tolerancia y la Inclusión Social. Lima: LUM, 2014

- DELGADO-ALGARRA, E. J. (2018) Education for Citizenship and Social Studies in Japan: Historical Evolution and Challenges for a Cosmopolitan Identity. En PINEDAALFONSO, J. A.; DE ALBA-FERNÁNDEZ, N.; NAVARROMEDINA, E. (ed.) Handbook of of Research on Education for Participative Citizenship and Global Prosperity. United States: IGI Global, 2018

- delgado-AlgarRA, E. J.; ESTEPA, J.

(2014) E 
Patrimonio como huella de la memoria histórica: análisis didáctico de dos monumentos en España y Japón. Clio: history and history teaching, n. ${ }^{\circ} 40,2014$

- DELGADO-ALGARRA, E. J.; ESTEPA-GIMÉNEZ, J. (2016) Ciudadanía y memoria histórica en la enseñanza de la historia: análisis de la metodología didáctica en un estudio de caso en ESO. Revista de Investigación Educativa, n. ${ }^{\circ} 34$ (2), 2016, pp. 521-534

- DROIT, E. (2007) Le Goulag contre la Shoah. Mémoires officielles et cultures mémorielles dans l'Europe élargie. Vingtième Siècle. Revue d'histoire, n. ${ }^{\circ}$ 94, 2007, pp. 101-120

- DUBY, G. (1994) Escribir la historia. Reflexiones, vol. 25 n. ${ }^{\circ} 1,1994$

- ECHEVERRÍA, B. (2001) Definición de la cultura. México: Ítaca, 2001

- ELTON, G. R. (1967) The Practice of History. Londres: Fontana Books, 1967

- ESCUDERO ALDAY, R. (2017) La Ley de memoria histórica y su desarrollo normativo: ni verdad ni justicia [en línea] <https://memoriahistorica.org.es/ambito-juridico/> [Consulta: 14/11/2017]

- ESCUDERO, R. (2013) Jaque a la transición: análisis del proceso de recuperación de la memoria histórica. Anuario de filosofía del derecho, n. ${ }^{\circ}$ 29, 2013, pp. 319-340

- ESCUDERO, R. (coord.) (2011) Diccionario de memoria histórica: conceptos contra el olvido. Madrid: Libros de la Catarata, 2011

- ESTEPA, J. (2007) Investigando las sociedades actuales e históricas. Proyecto curricular Investigando Nuestro Mundo (612). Sevilla: Diada Editora, 2007

- ESTEPA, J. (2017) Otra didáctica de la Historia para otra Escuela. Huelva: Servicio de Publicaciones de la Universidad de Huelva, 2017

- ESTEPA, J.; MARTíN-CÁCERES, M. (2018) Competencia en conciencia y expresiones culturales y educación histórica. Patrimonios en conflicto y pensamiento crítico. En GÓMEZ CARRASCO, C. J.; MIRALLES, P. (coord.) La educación histórica ante el reto de las competencias. Métodos, recursos y enfoques de enseñanza. Barcelona: Octaedro, 2018

- FABER, S.; SÁNCHEZ LEÓN, P.; IZQUIERDO MARTÍN, J. (2011) El poder de contar y el paraíso perdido. Polémicas públicas y construcción colectiva de la memoria en España. Política y sociedad [en línea], vol. 48, n. ${ }^{\circ} 3,2011$, pp.471-472 <https://revistas.ucm.es/index.php/POSO/article/view/36423> [Consulta: 08/01/2019]

- FEILDEN, B. (1995) Conservation of the 20th Century Building. Seminar on 20th century heritage. Helsinki: International Council on Monuments and Sites, 1995
- FERNÁNDEZ PRIETO, L.; ARTIAGA REGO, A.(ed.) (2018) Soldados para el frente. Madrid: Marcial Pons, Ediciones de Historia (Colección Revista Ayer, n. ${ }^{0}$ 111).

- FERNÁNDEZ-BACA CASARES, R.; PÉREZ ESCOLANO, V. (coord.) (2012) Cien años de arquitectura en Andalucía. El Registro Andaluz de Arquitectura Contemporánea, 1.900-2.000 [en línea] Sevilla: Instituto Andaluz de Patrimonio Histórico, 2012 <https://juntadeandalucia.es/export/drupaljda/RAAC-WEB_0 .pdf> [Consulta: 04/12/2018]

- FRASER, R. (1979) Recuérdalo tú y recuérdalo a otros. Historia oral de la Guerra Civil española (2 vols). Barcelona: Crítica, 1979

- gamarRA, J. (2002) Las dificultades de la memoria, el poder y la reconciliación: documento de discusión. Ayacucho: IPAZ, UNSCH, 2002

- GAMARRA, J. (2010) Resiliencia social y cambio en comunidades campesinas afectadas por conflicto armado interno: el caso de las comunidades de Incaraccay y Tanquihua en la provincia de Cangallo, Ayacucho. Lima: IPEDEH, 2010

- GASCÓN, D. (2015) La memoria tiene una potencia que la historia nunca alcanza. En Letras Libres [en línea], 11 de junio de $2015<$ <ttps://www.letraslibres.com/espana-mexico/ historia/la-memoria-tiene-una-potencia-que-la-historia-nuncaalcanza> [Consulta: 31/10/18]

- GENSBURGER, S.; LAVABRE, M-C. (2005) Entre devoir de mémoire et abus de mémoire: la sociologie de la mémoire comme tierce position. En MÜLLER, B. (2005) Histoire, mémoire et épistémologie. A propos de Paul Ricoeur. Lausanne: Payot, 2005, pp. 76-95

- GILLIGAN, C. (1982) La moral y la teoría: Psicología del desarrollo femenino. México: Fondo de Cultura Económica, 1982

- GÓMEZ, J. A. (2017) El informe del Grupo de Trabajo de la ONU muestra la consternación por la falta de investigación judicial y la impunidad que rodea a los delitos de desaparición forzada de la Guerra Civil y del franquismo. Diario16, 15-92017 <https://diario16.com/la-onu-da-90-dias-espana-aplicarpoliticas-favor-las-victimas-del-franquismo/> [Consulta: 14/11/ 2017].

- GONZÁLEZ DE LANGARICA MENDIZÁBAL, A.; LÓPEZ DE MATURANA DIÉGUEZ, V. (2018) Catálogo de símbolos y monumentos públicos existentes en Euskadi que supongan una exaltación de la guerra civil y de la dictadura. VitoriaGasteiz: Area Audivisual, 2018

- GONZÁleZ MARTíNEZ, P. (2013) Aspectos Legislativos del Plan Nacional de Conservación del Patrimonio Cultural del Siglo XX. Madrid: Ministerio de Educación, Cultura y Deporte, Instituto del Patrimonio Cultural de España, 2013

- GRIMSON, A. (2011) Los límites de la cultura. Buenos Aires: 
a debate Memoria democrática en la construcción de la historia y el patrimonio

| coordina Josefina Cuesta Bustillo

\section{Siglo XXI, 2011}

- HALBWACHS, M. (1950) La mémoire collective. Paris: Presses Universitaires de France, 1950

- HARTOG, F. (2005) Tiempo y Patrimonio. Museum International, n. ${ }^{\circ} 227,2005$, pp. 4-15

- HERNÁNDEZ, F. (2011) Patrimonio arquitectónico y sociedad en América Latina. En HERNÁNDEZ LEÓN, J. M.; ESPINOSA DE LOS MONTEROS, F. (coord.) Criterios de Intervención en el Patrimonio Arquitectónico del Siglo XX. Madrid: Ministerio de Cultura, 2011, pp. 69-79

- HERNÀNDEZ I MARTí, G. M. (2010) La memoria oscura: El patrimonio cultural y su sombra. En RIVERA BLANCO, J. (coord.) VI Congreso Internacional "Restaurar la Memoria": La gestión del patrimonio : hacia un planteamiento sostenible, Vol. 2 (Comunicaciones), 2010, pp. 629-637 [en línea] <http://www. academia.edu/2201415/La_memoria_oscura. El patrimonio cultural_y_su_sombra> [Consulta: 24/11/2018]

- HOMOBONO, J. I. (2008) Del patrimonio cultural al industrial. Una mirada socioantropológica. En PEREIRO, X.; Prado, S.; TAKENAKA, H. (coord.) Patrimonios culturales: educación e interpretación. Cruzando límites y produciendo alternativas. San Sebastián: Ankulegi Antropologia Elkartea, 2008, pp. 57-74

- IBÁÑEZ FANÉS, J. (2009) Antígona y el duelo. Una reflexión moral sobre la memoria histórica. Barcelona: Tusquets editores, 2009

- IZQUIERDO MARTIN, J. (2018) Ante el desafío de la memoria ¿disciplina o pluralismo interpretativo? Ayer, n. ${ }^{\circ} 111$, 2018, pp. 333-347

- JELIN, E. (2002) Los trabajos de la memoria. España: Siglo XXI, 2002

- JELIN, E. (2012) Los trabajos de la memoria. $2^{a}$ ed. Lima: Instituto de Estudios Peruanos, 2012

- JELIN, E. (2014) Memoria y democracia. Una relación incierta. Revista Mexicana de Ciencias Políticas y Sociales, vol. 59, n. ${ }^{\circ} 221,2014$, pp. 225-41 <http://www.revistas.unam. mx/index.php/rmcpys/article/view/47707> [Consulta: 13/11/18]

- JUDT, T. (2005) Postwar. A History of Europe since 1945. New York: The Penguin Press, 2005

- JULIÁ, S. (2011) Elogio de historia en tiempo de memoria. Madrid: Fundación Alfonso Martín Escudero y Marcial Pons, 2011

- JULIÁ, S. (2011) La memoria cotiza al alza. En JULIÁ, S (ed.) Elogio de historia en tiempo de memoria. Madrid: Marcial Pons, Ediciones de Historia, 2011

- LaVABRE, M. C. (2006) Sociologie de la mémoire et évènements traumatiques. En ARÓSTEGUI, J.; GODICHEAU,
F. (ed.) Memoria e historiografía de la guerra civil (1936-1939). Madrid: Marcial Pons, 2006

- LEY 2/2017, de 28 de marzo, de Memoria Histórica y Democrática de Andalucía. Boletín Oficial de la Junta de Andalucía, n. ${ }^{\circ}$ 63, de 3 de abril de 2017

- MACÉ, J. F. (2012) Los conflictos de memoria en la España post-franquista (1976-2010). Entre políticas de la memoria y memorias de la política. Bulletin Hispanique [en línea], 114-2 | 2012 : Varia, pp. 749-774. <https://journals.openedition.org/ bulletinhispanique/2150> [Consulta: 11/01/19]

- MARÍN, D. (2010) Anarquistas: un siglo del movimiento anarquista en España. Barcelona: Ariel, 2010

- MATE, R. (2018) Declaraciones publicadas en el artículo de GALINDO, J. C. ¿Se puede mentir en una novela sobre el Holocausto?, El País [en línea] 24/11/2018 <https://elpais.com/ cultura/2018/11/23/actualidad/1542966934_093230.html> [Consulta: 25/11/2018]

- MICHEL, J. (2010) Gouverner les mémoires, Les politiques mémorielles en France. París: PUF, 2005

- MICHEL, J. (2015) Mémoire publique et mémoire collective de l'esclavage. Revue indisciplinaire de sciences sociales. Espaces\&temps.net [en línea], 12 de mayo de 2015 <https:// www.espacestemps.net/articles/memoire-publique-etmemoire-collective-de-lesclavage/> [Consulta: 12/11/18]

- MISZTAL, B. A. (2001) Legal Attempts to Construct Collective Memory: The Necessity and Difficulties of Aiming for Both Truth and Solidarity. Polish Sociological Review, n. ${ }^{\circ}$ 133, 2001, pp. $61-75$

- MORENO, A; NúÑEZ, L. (2016) La cultura material del franquismo. Deconstruyendo la memoria histórica. La Linde, revista digital de arqueología profesional [en línea], 7-2016, pp. 152-181 <http://lalindearqueologia.com/la-cultura-material-delfranquismo/> [Consulta: 13/11/2018]

- MOSQUERA ADELL, E.; PÉREZ CANO, M. T. (2011) Refugios conocidos. De patrimonio de los arquitectos a patrimonio de todos. En DOMINGO, M.; MUÍ̃̃A, I. (dir.) Criterios de Intervención en el Patrimonio Arquitectónico del Siglo XX. Conferencia Internacional CAH2OthC. Documento de Madrid 2011. Madrid: Ministerio de Cultura, Secretaría General Técnica-Subdirección General de Publicaciones, Información y Documentación, 2011, pp. 403-410

- MOYA, L.; MONJO, J.; DÍEZ DE PABLO, A. (2017) La arquitectura ordinaria del siglo $\mathrm{XX}$ como patrimonio cultural: tres barrios de promoción oficial de Madrid. Revista EURE Revista De Estudios Urbano Regionales, vol. 43, n. ${ }^{\circ} 130,2017$, pp 269-294

- NAMER, G. (1987) Batailles pour la mémoire. Paris: L'Harmattan, 1987 
- NAMER, G. (1987) Mémoire et société. Paris: Meridiens Klincksieck, 1987

- NAMER, G. (1994) Les cadres sociaux de la mémoire. Paris: Albin Michel, 1994

- NAMER, G. (1997) La mémoire collective. Paris: Albin Michel, 1997

- NAMER, G. (1999) Les cadres sociaux de la mémoire. En RUANO-BORBALAN, J.-C. L'Histoire aujourd'hui. Paris: Sciences Humaines Éditions, 1999

- NAMER, G. (2000) Halbwachs et la mémoire sociale. Paris: L'Harmattan, 2000

- NAVAS CARRILLO, D. (2017) Los conjuntos de vivienda social como objeto patrimonial, el caso de Setúbal (19331983) Portugal [disponible en línea] Trabajo Fin de Máster, Universidad de Sevilla, $2017<$ https://idus.us.es/xmlui/ handle/11441/70025> [Consulta: 14/12/2018]

- NORA, P. (1978) Mémoire collective. En LE GOFF, J.; CHARTIER, R.; REVEL, J. (dir.) La nouvelle histoire. París: Retz-CEPL, 1984

- NORA, P. (1984) Entre mémoire et histoire. En NORA, P. (dir.) Les lieux de la mémoire. La République. París: Gallimard, 1984

- NORA, P. (dir.) (1984) Les lieux de la mémoire. La République. París: Gallimard, 1984

- NOTIMEX (2018) 50 años del 68: Gobierno de la CDMX retira del Metro placas con el nombre de Díaz Ordaz. Animal Político [en línea], 1 de octubre de 2018, <https://www.animalpolitico. com/2018/10/retiran-placas-diaz-ordaz/> [Consulta: 31/10/18]

- NÚÑEZ SEIXAS, X. M. (2005) Los vencedores vencidos: la peculiar memoria de la División Azul, 1954-2005. Pasado y Memoria. Revista de Historia Contemporánea, n. ${ }^{\circ} 4$, 2005, pp. 83-113

- ONKEN, E.-C. (2007) The Baltic States and Moscow's 9 May commemoration: analysing memory politics. Europe-Asia Studies, vol. 59, n. ${ }^{\circ}$ 1, 2007, pp. 23-46

- PASAMAR, G. (2003) Los historiadores y el "uso público de la historia": viejo problema y desafío reciente. Ayer, n. ${ }^{\circ 49}$, 2003, pp. 226-239

- PEMÁN, J. M. (1976) Mis encuentros con Franco. Barcelona: Dopesa, 1976

- PÉREZ, M. (2001) Ese artículo de lujo seriamente odioso. Archipiélago: Cuadernos de crítica de la cultura, n. ${ }^{\circ} 47,2001$, pp. 15-16

- PÉREZ CANO, M. T.; MOSQUERA ADELL, E. (2006) La Protección del Patrimonio Edificado. Catalógo de Bienes Inmuebles del Municipio de Almonte. Sevilla: Secretariado de Publicaciones de la Universidad de Sevilla, 2006
- PÉREZ ESCOLANO, V: FERNÁNDEZ-BACA CASARES, R. (2012) Cien años de arquitectura en Andalucía: el Registro Andaluz de Arquitectura Contemporánea, 1900-2000. Sevilla: Instituto Andaluz del Patrimonio Histórico. Junta de Andalucía, 2012

- PLAN Nacional de Conservación del Patrimonio Cultural del siglo XX (2015). Madrid: Ministerio De Educación, Cultura y Deporte, Secretaría General Técnica, Subdirección General de Documentación y Publicaciones, 2015

- QUEIRO QUIJADA, R. (2015) Patronato Municipal y Real Patronato de Casas Baratas de Sevilla. Aportaciones a la conformación de la ciudad a través de la vivienda social. 1913-1986 [en línea] Tesis doctoral inédita, Universidad de Sevilla, 2015 <http://hdl.handle.net/11441/36284> [Consulta: 19/02/2018]

- RANZ ALONSO, E. (2017) Relevancia de la Memoria Histórica en el ordenamiento jurídico y documental en España. Tesis Doctoral inédita, Universidad Carlos III de Madrid, 2017

- RECOMENDACIÓN sobre el paisaje urbano histórico (2011). París: Organización de las Naciones Unidas para la Educación, la Ciencia y la Cultura, 2011

- Algunas REFLEXIONES sobre autenticidad (2004). París: Organización de las Naciones Unidas para la Educación, la Ciencia y la Cultura, 2004

- RESOLUCIÓN 2005/66 sobre "el derecho a la verdad" (2005) 59a Sesión de la Comisión de Derechos Humanos de Naciones Unidas. 20 de abril de 2005

- REVERTE, J. M. (2012) Por qué fueron a Rusia. Cuadernos de Historia Contemporánea, vol. 34, 2012, pp. 15-29

- REYNAGA, G. (2008) Respuesta de las mujeres ayacuchanas frente a los problemas de la violencia política [en línea]. Tesis para optar el grado de Magister en Gerencia Social. Lima: PUCP, 2008 <http://tesis. pucp.edu.pe/repositorio/ handle/123456789/1106> [Consulta: 21/12/2018]

- RICHARD, N. (2007) Fracturas de la memoria; Arte y pensamiento crítico. Buenos Aires: Siglo XXI, 2007

- RICOEUR, P. (2003) La memoria, la historia, el olvido. Madrid: Trotta, 2003

- RICOEUR; P. (1998) La lectura del tiempo pasado: memoria y olvido. Madrid: Arrecife Producciones, 1998

- RODRÍGUEZ JIMÉNEZ, J. L. (2009) Ni División Azul, ni División Española de Voluntarios: El personal forzado en el cuerpo expedicionario enviado por Franco a la URSS. Cuadernos de Historia Contemporánea, vol. 31, 2009, pp. 265296

- SALAS, R. (1973) Historia del Ejército Popular de la República (4 T.). Madrid: Nacional, 1973 
a debate Memoria democrática en la construcción de la historia y el patrimonio

| coordina Josefina Cuesta Bustillo

- SCHACTER, D. L. (1999) En busca de la memoria. Barcelona: Ediciones B, 1999

- THEIDON, K. (2004) Entre prójimos. El conflicto armado interno y la política de la reconciliación en el Perú. Lima: Instituto de Estudios Peruanos, 2004

- THOMAS, H. (1961) La Guerra Civil Española. París: Ruedo Ibérico, 1961

- TODOROV, T. (1994) Face à l'extrême. París: Seuil, 1994

- TODOROV, T. (2013) Los abusos de la memoria. Barcelona: Paidós Ibérica, 2013

- VÁZQUEZ, F. (2001) La memoria como acción social. Barcelona: Paidós, 2001

- VELASCO MESA, C. (2017) Historia y memoria: un mismo combate. Aportaciones epistemológicas de Historia a Debate a las controversias acerca de la memoria histórica. Memorias: revista digital de historia y arqueología desde El Caribe [en línea], n. ${ }^{0} 33,2017$, pp. 120-141<http://rcientificas.uninorte.edu. co/index.php/memorias/article/view/10048/214421442950> [Consulta: 24/11/2018]

- VINYES R. (2009) El estado y la memoria. Gobiernos y ciudadanos frente a los traumas de la historia. España: RBA, 2009

- VINYES, R. (2011) Asalto a la memoria. Impunidades y reconciliaciones, símbolos y éticas. Barcelona: Los libros del lince

- VINYES, R. (2015) Los usos públicos del pasado en Europa: hacia una memoria sincrética. Años 90, vol. 22, n. ${ }^{\circ}$ 42, 2015, pp. 21-51

- VV. AA. (2005) Amnistía Internacional. Informe, 2005. El estado de los derechos humanos en el mundo. Madrid: EDAI, 2005

- WATERSON, R. A. (2009) The examination of pedagogical approaches to teaching controversial public issues: Explicitly teaching the Holocaust and comparative genocide. Social Studies Research and Practice, n. ${ }^{\circ} 4$ (2), 2009, pp. 1-24

- YEAGER, E.; HUMPHRIES, E. K. (2011) A Social Studies teacher's sense making of controversial issues discussions of race in a predominantly white, rural high school classroom. Theory and Research in Social Education, n. 39 (1), 2011, pp. 92-134 


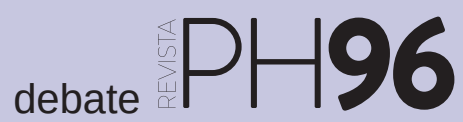

\section{La memoria franquista en el espacio urbano. Cuestiones metodológicas e historiográficas para las comisiones locales de memoria histórica}

César Rina Simón | Dpto. de Historia, Universidad de Extremadura

URL de la contribución <www.iaph.es/revistaph/index.php/revistaph/article/view/4275>

El espacio urbano está plagado de significaciones, de marcadores de identidad. Nuestra sociedad construye su memoria en diálogo constante con un espacio repleto de simbolismo. Monumentos, banderas, iconos, funcionalidad de los edificios, imaginarios locales y el nomenclátor actúan como recordadores o propiciadores de lo que se debe recordar. En los regímenes políticos contemporáneos, el sentido, forma y significado de estos marcadores viene determinado por las instituciones, que oficializan determinadas narrativas del pasado y hacen de su uso público uno de los principales referentes en la construcción de su legitimidad. De hecho, una de las constantes históricas de los dos últimos siglos ha sido el combate político por construir lugares de memoria y hacer de la calle un lienzo en el que transmitir valores, ideologías o lecturas del pasado. Estas cuestiones han sido centrales en los debates historiográficos de las últimas décadas a partir de los trabajos pioneros de Josefina Cuesta, Paloma Aguilar, Elizabeth Jelin —para el caso argentino- o Pierre Nora -para el francés-.

Si aceptamos la caracterización del espacio como constructor y fijador de la memoria colectiva, no podemos mirar para otro lado a la hora de realizar una lectura crítica de los símbolos aún visibles de la dictadura franquista, desde el momento en que como colectivo que se reafirma en unos valores democráticos y constitucionales hemos construido sus imaginarios desde la oposición al franquismo. No es posible desligar la práctica historiográfica del horizonte de las ideologías y del compromiso con determinado modelo de sociedad. Por eso mismo, ante la dificultad de establecer criterios funcionales de valoración de lo que es "memoria franquista" o no, se hace necesario abrir un debate social e his- toriográfico que trascienda del componente polemizador de los medios de comunicación y se enfrente a la lectura y resignificación del espacio urbano. La memoria ha sido una temática muy escurridiza para el oficio de historiador, sin embargo, éste puede aportar herramientas: manejo de fuentes y archivos, la experiencia metodológica y los conocimientos conceptuales precisos para participar en la localización de aquellos lugares de la memoria de la dictadura. La tarea no es fácil, en tanto que muchos de estos elementos han sido resignificados o bien han perdido su halo franquista. No es contradictorio, por tanto, el ejercicio de la historia como disciplina de la participación en los procesos de redefinición de la memoria colectiva en clave democrática.

Esta memoria se presenta en España de forma fragmentada. A diferencia del caso italiano, alemán o portugués, donde la construcción democrática se hizo desde una derrota o una revolución, la peculiaridad de la transición española radica en que se sustentó en un pacto en el que eran compatibles diferentes memorias siempre que su proyección no afectara al nuevo constructo político. Al no producirse una ruptura drástica con el pasado, la memoria de la dictadura se entrelaza con todo tipo de recuerdos relacionados con la violencia y la represión pero también con el desarrollismo, la paz social o la resistencia al comunismo. La primera entrada de Franco en el Diccionario biográfico de la Real Academia de la Historia constata la pervivencia de esta imagen de dictador benigno. Al mismo tiempo, al pervivir en algunas culturas políticas españolas memorias complacientes con el franquismo, el silencio, el olvido y no la reparación son defendidas en el debate mediático por grupos que en cierta medida hunden sus raíces en la dictadura. 
a debate Memoria democrática en la construcción de la historia y el patrimonio

| coordina Josefina Cuesta Bustillo

Una vez aprobada a nivel estatal la Ley de la Memoria Histórica 52/2007 de 26 de diciembre, y completada a nivel regional por algunas autonomías, se ha abierto el debate sobre cómo gestionar la memoria colectiva de la dictadura que aún pervive en nuestro espacio urbano. Han sido creadas centenares de comisiones municipales cuyo trabajo ha consistido en rastrear estos marcadores y realizar informes de cara a una posible revisión, que habría que abordar desde múltiples ópticas sociales. El trabajo de estas comisiones ha sido complejo. En primer lugar, por los espacios en los márgenes que la ley no recoge -fue anterior a la práctica de estas comisiones, pero no así a la trayectoria de numerosas asociaciones para la recuperación de la memoria histórica-. A su vez, la dictadura franquista, con su capacidad camaleónica para sobrevivir a diferentes contextos internacionales y por su longevidad, dificulta la labor de identificación de su memoria. No podemos olvidar que buena parte de los forjadores de nuestro sistema político actual provenían de las altas instancias de la dictadura, lo que impide focalizar el recuerdo en un período específico de cada personaje. El caso de Adolfo Suárez ejemplifica estas dificultades.

En estas páginas pretendo plantear algunos de los problemas teórico-metodológicos que hemos tenido los miembros de la Comisión para la revisión del callejero urbano y aplicación de la Ley de la Memoria Histórica del Ayuntamiento de Cáceres, integrada por cuatro historiadores: Fernando Jiménez Berrocal -jefe del Archivo Municipal y cronista-, María Jesús Criado -presidenta de la Asociación Memorial en el Cementerio de Cáceres, AMECECA-, José Hinojosa Durán -coordinador del Grupo de Estudios de Historia Contemporánea de Extremadura, GEHCEX-y el que firma estas páginas -profesor de Historia Contemporánea en la Universidad de Extremadura-. Los trabajos se prolongaron entre marzo de 2017 y febrero de 2018. El objetivo es participar en el debate historiográfico y social sobre qué hacer con la memoria del franquismo, cómo abordarla y cómo construir una memoria democrática a partir de una experiencia concreta. Como ha señalado recientemente Jesús Izquierdo Martín (Ayer, n. ${ }^{0} 111,2018$ ), el desafío de la memoria abre el horizonte interpretativo a modelos normativos o plurales cuyo debate será abordado a medida que avancen las comisiones locales para la identificación de los imaginarios franquistas. Los principales "puntos ciegos" de la Ley de Memoria Histórica fueron los siguientes:

$>$ Cruz de los caídos. Principal monumento franquista en la mayoría de municipios. Muchas fueron retiradas pero otras tantas perviven. No cabe duda de su significación franquista para conmemorar a los mártires del nacionalcatolicismo y a los caídos del fascismo. Durante la transición se cambió el rótulo "A LOS HIJOS DE ESTA CIUDAD QUE DIERON SU VIDA POR ESPAÑA, UNA GRANDE Y LIBRE. 18 DE JULIO DE 1936. ¡ARRIBA ESPAÑA! ¡SALUDO A FRANCO!" por el genérico "a la memoria de sus hijos muertos por la patria." De esta forma, al cambiar el mensaje, se pretendió resignificar el símbolo. Sin embargo, el emblema tenía tantas connotaciones franquistas que durante décadas ha seguido siendo el punto neurálgico de los nostálgicos de la dictadura. En la actualidad, desprovistas de esa impronta, perduran en los centros neurálgicos de ciudades y pueblos. En el seno de la comisión, no había duda de que se trataba de un fósil de la memoria franquista y más cuando a petición municipal, en 1938, se insistió en que tuviera una planta y unos perfiles visiblemente fascistas. Fue inaugurada por Pilar Primo de Rivera con todo el aparato ritual nacionalcatólico y fascista. Sin embargo, el planteamiento de su retirada ha generado un amplio debate público, alegando los defensores de su permanencia que una cruz es un símbolo cristiano, no franquista. En este sentido, los perfiles entre catolicismo y dictadura se difuminaron tanto que la valoración de todo tipo de símbolos o nomenclátor religioso resulta compleja para cualquier comisión con estos fines. En el caso que nos atañe, no cabe duda de su contenido y continente franquista.

$>$ Placas conmemorativas de cualquier hazaña o efeméride con mensajes eminentemente informativos sin presencia explícita de exaltación del régimen. También levantaron revuelo mediático, en tanto que se consideraban marcadores históricos de un acontecimiento, no políticos, y por tanto su retirada contradecía el espí- 
ritu de "recuperación de la memoria." Discernir entre la memoria franquista y la memoria aséptica, en un régimen político que asentó su modelo de legitimidad en la omnipresencia de prácticas y narrativas de exaltación totales, es tarea ardua complicada. Conviene contrarrestar los discursos ideológicos que rechazan la limpieza del callejero franquista, al que consideran un aséptico marcador del pasado. Estas posturas suelen ignorar los procesos constantes de reconstrucción simbólica del espacio urbano y, en la mayoría de los casos, esta defensa historicista del imaginario franquista desde el plano científico social esconde la perpetuación implícita de la memoria de la dictadura.

> Nomenclátor de las élites culturales de la dictadura, incluso casos en los que el nombre se puso en período democrático. Esta cuestión cronológica los deja al margen de Ley de Memoria Histórica, por lo que cabría abrir sus consideraciones también a la memoria franquista construida en democracia. En este punto, las comisiones encontramos un fuerte escollo a la hora de valorar el nomenclátor de artistas, periodistas o escritores que desenvolvieron su trabajo en actitud de connivencia con la dictadura o que incluso formaron parte de la estructura de estado, si bien su nombramiento respondió a méritos del ámbito cultural. Al respecto, los matices son inabarcables, y van desde el periodista José Ibarrola, autor de textos de exaltación de la represión en la prensa extremeña, a Angelita Capdevielle, líder de la Sección Femenina y con un papel destacado en la sociabilización del régimen pero cuyo reconocimiento tiene relación con su labor de recuperación del folklore regional, pasando por el alcalde Alfonso Díaz de Bustamante o Antonio Floriano Cumbreño, archivero y director del diario Falange. Podríamos marcar como pauta selectiva su participación activa y comprometida con el alzamiento y la dictadura, pero aun así cada casuística desbordaría la clasificación. Además, la participación en las altas estructuras del Estado deja de ser argumento en el momento en que muchos de estos personajes tuvieron una rápida conversión a los principios democráticos y constitucionales e incluso lideraron la Transición. Tampoco puede ser tomada en cuenta la afiliación a FET y las JONS, pues era prerrogativa de la escala de funcionarios. No en pocas ocasiones, muchos personajes con espacio en la memoria pública adaptaron sus afinidades políticas a los diferentes contextos y modelos de Estado, pasando algunos por fervientes republicanos, franquistas y demócratas en la misma biografía.

$>$ Nomenclátor historicista. El franquismo construyó su hegemonía desde una continuidad histórica -esencial, tradicional y religiosa - que enraizaba la dictadura con una serie de hitos históricos que la conectaban con el Imperio. Es por ello que fueron frecuentes denominaciones como Reyes Católicos. Es evidente el contenido político-historicista de este nomenclátor, pero consideramos que no puede ser materia de revisión en el espacio urbano, en tanto que forma parte de narrativas del pasado polisémicas. Cuestión diferente son las calles

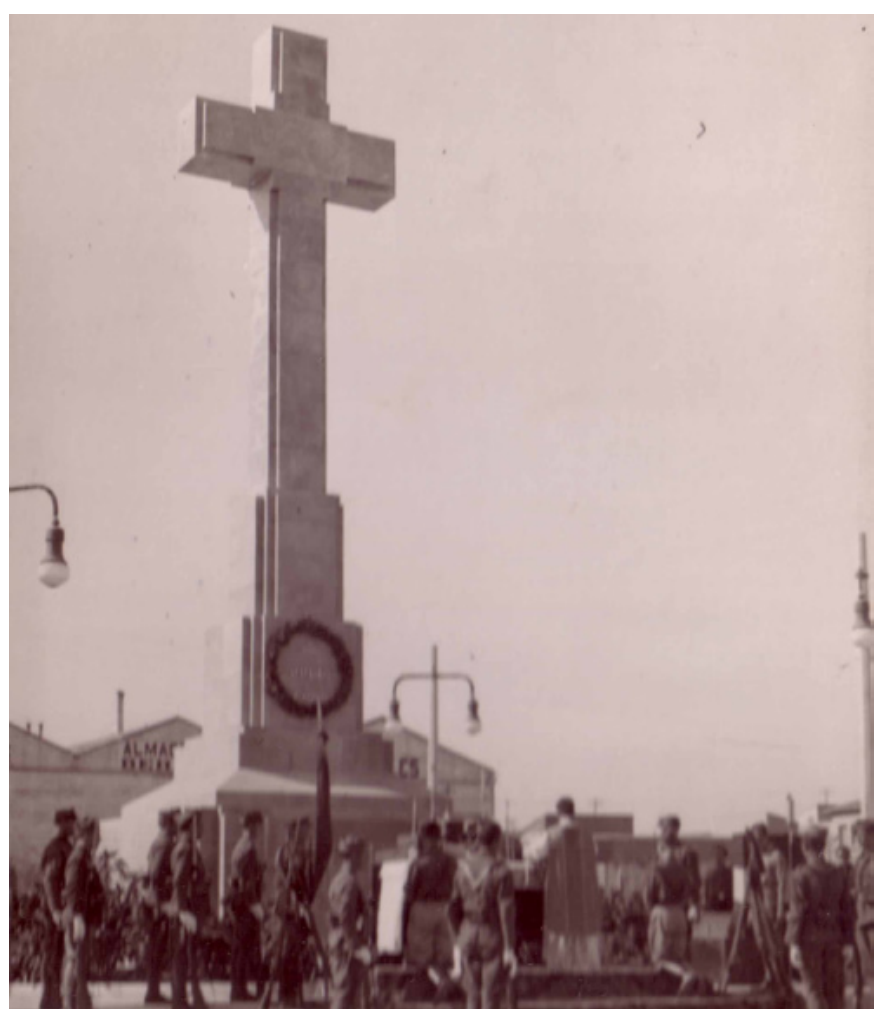

Jura de bandera Alféreces Provisionales ante la cruz de los caídos, 16 octubre 1938 | fuente Archivo Histórico Municipal de Cáceres 
a debate Memoria democrática en la construcción de la historia y el patrimonio

| coordina Josefina Cuesta Bustillo

dedicadas a personajes más cercanos históricamente al alzamiento, aunque fallecieron antes del 18 de julio, pero que fueron referentes fundacionales de los imaginarios franquistas. Nos referimos en el caso cacereño a Miguel Primo de Rivera, al que se le dedicó una calle en la década de los cuarenta para contentar de una vez al ejército, a las élites conservadoras y a Falange, y a José Calvo Sotelo, el protomártir de la dictadura, usado como símbolo legitimador de la sublevación. Ambos no son personajes del franquismo, pero sí su uso como referentes de la memoria franquista.

> Marcadores con múltiples significaciones según contextos. Determinadas instituciones tuvieron un papel destacado en la construcción de imaginarios franquistas, como es el caso del Regimiento Argel, responsable del alzamiento militar en Cáceres. Sin embargo, el significado de su monumento, además de por el cambio de placa, adquiere diversas lecturas, al tratarse de una institución con raigambre en la ciudad. En su origen, su erección tuvo un carácter eminentemente franquista, "dedicado al heroico comportamiento que ha tenido en el pasado Glorioso Movimiento Nacional", pero la suma de diversas memorias y olvidos en la comunidad lo convierten en un referente espacial con múltiples lecturas. En el espacio urbano entran en conflicto diferentes memorias que coexisten en el mismo tiempo y resulta complejo determinar su impronta franquista en el presente, no así en el pasado, ya que el monumento tuvo una dimensión clara de exaltación del alzamiento. Podemos comentar a su vez el nomenclátor dedicado a Alemania, Italia y Portugal, homenajes a los apoyos internacionales de la dictadura pero desprovistos en la actualidad de dicha significación. Cabría por último señalar las calles dedicadas a las victorias militares franquistas, cuyo nombre hoy en día hace referencia a un espacio geográfico o a una ciudad y no a un hito bélico.

$>$ Nomenclátor religioso. Este asunto es complejo para cualquier comisión, en tanto que suele hacer referencia a espacios ocupados por iglesias o conventos y, por tanto, son referentes precontemporáneos que la dictadura solo restituyó. O bien, nombramientos exnovo, cuyo fin fue arraigar a la dictadura con referentes de la cultura y de la religiosidad popular, pero cuyos términos y significantes trascienden con creces al franquismo.

Estos seis amplios interrogantes nos reafirman en la necesidad de profundizar en debates concretos en torno a la memoria y el olvido de la Guerra Civil y de la dictadura, superando la dialéctica a favor o en contra para preguntarnos qué y cómo recordar. El trabajo de las comisiones para la aplicación de la Ley de la Memoria Histórica ha localizado múltiples puntos de fuga a la hora de identificar qué es o no es memoria franquista. Así mismo, convendría poner en común los informes de dichas comisiones con el objetivo de reconocer problemas comunes o fallas en la ley, abrir los horizontes historiográficos a la labor desempeñada por las asociaciones para la recuperación de la memoria histórica desde la muerte del dictador e incluso llegar a establecer una guía metodológica que afronte estos interrogantes. No cabe duda que los símbolos y los mensajes que emite nuestro espacio urbano son polisémicos y su significados variables y coyunturales, lo que dificulta aún más los consensos, y más cuando coexisten con la memoria democrática otras de impronta nacionalcatólica.

En último término, la supervivencia cuarenta años después de marcadores simbólicos, monumentos y nomenclátor franquista constata las debilidades de las memorias democráticas. Si bien la aprobación de leyes de memoria histórica han contribuido a generalizar estos debates, sigue siendo necesario, también desde la historiografía, participar de la construcción de memorias que fortalezcan consensos e imaginarios democráticos en torno a un pasado que es siempre llamado por el presente y proyectado hacia el futuro. Tradicionalmente, la historiografía, y el resto de ciencias sociales, ha tenido una relación de alteridad con los usos normativos del pasado, relativizando nuestra capacidad profesional para convertirnos en jueces. Sin embargo, los procesos abiertos de redifinición del espacio urbano nos invitan a participar como gestores especializados de archivos, fuentes y testimonios, con el fin de contribuir con la construcción de una memoria colectiva asentada sobre pilares democráticos. 


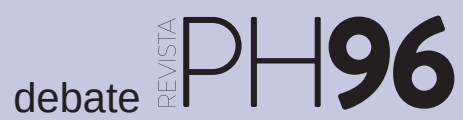

a debate Memoria democrática en la construcción de la historia y el patrimonio

| coordina Josefina Cuesta Bustillo

\section{Memoria democrática versus memorias democráticas}

Ignacio Muñiz Jaén | director del Ecomuseo río Caicena-Museo Histórico de Almedinilla (Córdoba)

URL de la contribución <www.iaph.es/revistaph/index.php/revistaph/article/view/4272>

Sin pretender enfrascarme en un debate terminológico sinfín, lo cierto es que se deben definir y analizar brevemente las palabras que utilizamos en un debate, no vaya a ser que hablemos de cosas diferentes utilizando los mismos términos, o de las mismas cosas empleando términos diferentes.

Memoria democrática, como memoria histórica, son términos que se han utilizado y se utilizan por el movimiento memorialista en España desde hace varias décadas para reivindicar a las personas y a los hechos vinculados con la lucha antifranquista, buscando Verdad, Reparación y Justicia (al abrigo de la legislación internacional en derechos humanos) para los hombres y las mujeres que por ello fueron represaliados.

Tres términos: memoria, democrática, histórica que nos lleva a transitar desde la psicología, pasando por la historia, hasta la política considerando que memorias hay muchas, así como definiciones variadas de democracia e interpretaciones históricas diferentes de los mismos hechos.

Desde mi perspectiva, en este debate me inclino a considerar la memoria (siguiendo la psicología dinámica) como el ejercicio de recordar el pasado, más o menos inmediato o lejano, en función de lo que se cree en el presente y de lo que se anhela para el futuro, de tal manera que en el hecho de recordar mezclamos tiempos diferentes: pasado-presente-futuro (SCHACTER, 1999). Por ello, el recuerdo que tenemos de un hecho concreto vivido o transmitido cambia de alguna manera en función del tiempo en el que nos situemos para rememorarlo, aspecto que no invalida que la memoria tenga que ser considerada (en la psicología, la política y la historia, por ejemplo) sino que le imprime un carácter dinámico y de riqueza en matices que más que dificultar puede ayudar a comprender de una manera más completa ese hecho rememorado (en función de sus repercusiones a través de los pasos del tiempo) como ya demostró Fraser en su trabajo (FRASER, 1979). El eco de esos pasos del tiempo crea por tanto memorias individuales, familiares, sociales, memorias transmitidas desde la cotidianeidad de la mesa camilla o desde la oficialidad de escuelas y televisiones, que pueden ser muy diferentes entre sí pero que se dan la mano a la hora de utilizar este término, adquiriendo también una dimensión ética y de obligación moral (CASTILLA DEL PINO, 2006).

En cuanto a la historia como ciencia, tiendo a no utilizar el término "objetividad" porque todo trabajo científico (no solo en la esfera de las ciencias sociales) está influenciado por una serie de condicionantes subjetivos que van desde los planteamientos teóricos de partida del investigador, sus influencias familiares, las académicas y las condiciones de elaboración de ese trabajo, hasta las censuras y autocensuras que uno se imponga, prefiriendo hablar de honestidad (haciendo explícito el planteamiento teórico y sin manipular datos, obviarlos o falsearlos) y de coherencia (a partir de una metodología científica concreta). A partir de ahí, de la honestidad y la coherencia, las interpretaciones de un hecho histórico concreto pueden ser diferentes en función de los planteamientos teóricos de partida, pero igualmente válidos.

En el tema que nos ocupa hay diferentes corrientes historiográficas, más o menos coherentes y honestas, que interpretan de manera muy diferente los hechos referidos a la Guerra Civil y la dictadura franquista. De esta manera, tenemos una historiografía franquista (revivida en la actualidad en una corriente filofranquista) que pasa por ser (con diferencia) la menos honesta y coherente (ARRARÁS, 1940), y que persigue justificar el golpe de estado del 18 de julio de 1936 acuñando una serie de 
a debate Memoria democrática en la construcción de la historia y el patrimonio

| coordina Josefina Cuesta Bustillo

tópicos repetidos, como pretender conectar el inicio de la guerra civil con la revolución asturiana (cuando fue precisamente la República quien acabó de manera expeditiva con la revolución), insistiendo en una violencia insoportable durante la II República que justificaría el golpe militar (cuando esa violencia fue la habitual en el contexto europeo donde se desarrollaba) e incluso negando, minimizando o justificando la tremenda violencia sistemática en la que se basó el Franquismo como uno de los pilares básicos en los que se sustentó el Régimen.

Esta corriente historiográfica evolucionó a finales de los años 60 en posicionamientos que reconocían que los franquistas "también habían matado, pero no tanto como los rojos" (PEMÁN, 1976), con un epílogo en lo que fue después el basamento de la Transición: "todos cometieron crímenes por igual" (SALAS, 1973), cabriola argumental para justificar olvidos y poder "pasar página".

Por otra parte tenemos la corriente historiográfica más extendida en la investigación sobre ese periodo histórico que es la llamada por Chomsky "liberal-comunista" (CHOMSKY, 2004) que, con todas las variantes, incide en los valores de "democracia liberal" de la II República en conexión con el régimen democrático que se abría en España a partir de 1977 pero obviando el proceso de revolución social que se vive en la zona republicana durante la guerra civil, e incluso achacándole a él toda la violencia ocurrida en esa zona (THOMAS, 1961). Por último tendríamos la historiografía libertaria que es la que se centra precisamente en el proceso revolucionario llevado a cabo por las organizaciones obreras durante la guerra civil, centrándose en las luchas sociales y entendiendo la propia contienda como una guerra social (MARÍN, 2010).

Todo ello nos lleva a plantear, finalmente, que el término "memoria democrática" puede llegar a ser confuso si con él hacemos referencia a un concepto de democracia concreto: la democracia entendida desde postulados liberales como "democracia liberal", desde postulados libertarios como "democracia horizontal", o incluso desde postulados franquistas como "democracia orgá- nica", por lo cual toda esa memoria a recuperar y reivindicar no debería salir de la esfera de los derechos humanos y de las disposiciones que teniendo en cuenta los mismos derechos se han hecho desde organismos como la ONU o desde asociaciones y colectivos como Amnistía Internacional (VV. AA., 2005), que son en su gran mayoría los que sigue el movimiento memorialista español buscando Verdad, Reparación y Justicia para con las víctimas de la dictadura franquista.

\section{BIBLIOGRAFÍA}

- ARRARÁS, J. (1940) Historia de la cruzada española. Madrid: Ediciones Españolas S. A., 1940

- CASTILLA DEL PINO, C. (2006) La memoria como moral. En CHECA, S.; DEL RÍO, A.; MARTíN, R. Andaluces en los campos de Mauthausen. Sevilla: Centro de Estudios Andaluces-Junta de Andalucía, 2006, pp. 13-15

- CHOMSKY, N. (2004) La objetividad y el pensamiento liberal. Los intelectuales de izquierdas frente a la guerra de Vietnam y a la Guerra Civil española. Barcelona: Península, 2004

- FRASER, R. (1979) Recuérdalo tú y recuérdalo a otros. Historia oral de la Guerra Civil española (2 vols). Barcelona: Crítica, 1979

- MARíN, D. (2010) Anarquistas: un siglo del movimiento anarquista en España. Barcelona: Ariel, 2010

- PEMÁN, J. M. (1976) Mis encuentros con Franco. Barcelona: Dopesa, 1976

- SALAS, R. (1973) Historia del Ejército Popular de la República (4 T.). Madrid: Nacional, 1973

- SCHACTER, D. L. (1999) En busca de la memoria. Barcelona: Ediciones B, 1999

- THOMAS, H. (1961) La Guerra Civil Española. París: Ruedo Ibérico, 1961

- VV. AA. (2005) Amnistía Internacional. Informe, 2005. El estado de los derechos humanos en el mundo. Madrid: EDAl, 2005 


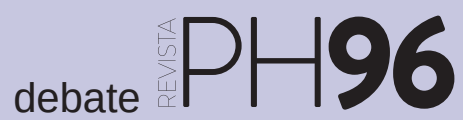

a debate Memoria democrática en la construcción de la historia y el patrimonio

| coordina Josefina Cuesta Bustillo

\section{Debates sobre la memoria como patrimonio colectivo}

Jordi Guixé Coromines | director del European Observatory on Memories

URL de la contribución <www.iaph.es/revistaph/index.php/revistaph/article/view/4277>

La amiga y maestra Josefina Cuesta, coordinadora de este debate, lleva toda la razón al referirse al mito de Antígona para tratar el tema de la memoria irresoluta en España. La necesidad de impulsar políticas de memoria democrática en España es una responsabilidad colectiva que solamente la soberbia de algunos gobiernos ha pretendido eludir. El trabajo de memoria en el siglo XXI es imperativamente transnacional, interdisciplinar, social y participativo, institucional, universitario y debería ser profesional.

Hablar de consenso o reconciliación en la España del 2018 es complejo, pues todavía se impone un relato entre vencedores y vencidos que impide avanzar en el trabajo de memorias -en plural-. No es lo mismo reconocer errores que reconocer culpabilidades. Es ahí donde no podemos entrar en lo políticamente incorrecto, pero hay una parte de bloqueo memorial que pasa imperativamente por reconocer culpabilidades de Estado. Errores, el pasado es muchas veces un gran Error, pero culpabilidades y responsabilidades de crímenes de Estado durante periodos de no guerra en este país no se han reconocido. La culpa en Alemania fue en parte impuesta por la derrota, por la judicialización, pero también por la nueva democracia que proclamó la memoria como herramienta reparativa. Algunos hablan ya de hipertrofia para el caso alemán, pero cuando entramos en detalles e investigaciones, vemos que el daño realizado nunca podrá ser suficientemente reparado. ¿Por qué en España no se puede realizar un proceso -no igual- pero parecido? Porque todavía hay orgullo de victoria y cierta impunidad chulesca.

Ante estas posturas, configuradas por muchos mitos, intereses de casta y por la timidez de políticas públicas de memoria, la Administración ha necesitado, delante y detrás, el empujón de asociaciones -sobre todo de vícti- mas-, de expertos y de proyectos profesionales o patrimoniales para impulsar una política de memoria irregular, mal estructurada y, sobre todo, low-cost. No es un caso único, pues en la mayoría de países la ciudadanía "ha tirado del carro", pero también el Estado lo ha seguido.

Una de las vías de implementación que más cuesta es la recuperación y creación de espacios patrimoniales memoriales. De recuperación de lugares de memoria. Pienso que responde al mismo miedo o timidez. Las excusas son presupuestarias, pero en definitiva los actores públicos no entienden que, precisamente, una manera de superar el bloqueo memorial en nuestro país es crear estos lugares. Lugares pedagógicos, de aprendizaje, de reparación de dignificación de un pasado traumático y/o violento, pero también de conservación e interpretación histórica y memorial. Llanamente podría afirmar que la memoria como proceso es más conflictiva durante las discusiones políticas que durante la práctica ejecución memorial.

La memoria democrática es patrimonio tangible e intangible, pero es patrimonio. La inmaterialidad del testimonio puede resignificar la memoria junto a la materialidad de un espacio, una fosa, una cárcel, una trinchera. Para que la discusión, los valores y el conocimiento emerjan en estos espacios patrimoniales, hace falta de intervenciones valientes y, muchas veces, esfuerzos presupuestarios. Una vez que se musealiza, se interviene, se grava un testimonio, el efecto reparador y educador sobrepasa el debate político y se convierte en una herramienta de consolidación y crecimiento democrático. Miles de ejemplos bastan. Pero nos encontramos que en nuestro país tenemos miles de bonitos museos y centros de interpretación de todo tipo, en cambio, nada de memoriales, museos de memoria, lugares recuperados o centros de interpretación de nuestro pasado. Un pasado denso y 
a debate Memoria democrática en la construcción de la historia y el patrimonio

| coordina Josefina Cuesta Bustillo

conflictivo, no lo ignoramos, con un enfrentamiento muy potente provocado por la Guerra Civil, pero ensalzada a la máxima división por una dictadura demasiado longeva.

$\mathrm{Y}$ respondo a las preguntas que se plantean en este debate.

La multiplicidad memorial es la clave para entender que estamos rodeados de diversidad memorial múltiple. Una cosa es conocer la historia; la otra decidir qué conmemoramos y cómo, qué memorias deben ser rescatadas del olvido por decencia democrática y justicia social; y qué memorias son o pueden ser nostálgicas de periodos dictatoriales. Es un tema muy complejo, pero también en términos memoriales hay líneas rojas de cómo debemos mimar y ser vigilantes con nuestra democracia y libertades. Imponer mitos no significa la equiparación memorial.

¿Cómo conjugamos memoria, experiencia, sentimientos y percepciones? Yo diría que con las emociones y a través de herramientas de transmisión e interpretación. En los lugares memoriales, en los medios públicos o el espacio público. Desde la narración histórica hasta el arte contemporáneo y la performance.

Por otro lado, pienso que la memoria es conflicto, proceso y transgresión, de ahí su ADN conflictual. Y que los procesos memoriales no deberían resolver nada. El enfrentamiento político en democracia se resuelve en el Parlamento democrático, nuestra ágora política y en las elecciones, donde expresamos nuestra opinión sobre las ideas y la gestión pública. Ese es el debate. Se evita un mal uso de la memoria desde la profesionalidad, conociendo antes de actuar, con memorias comparadas transnacionales para aprender de procesos y, sobre todo, desde la gestión social y autónoma de la memoria, lo más lejos posible del poder político que dicta memorias a la carta y al uso. No conviene ejemplos como la actual Polonia o Hungría.

En relación con la retirada de nuestros espacios públicos de símbolos asociados a totalitarismos, fascismos, dictaduras o épocas históricas en las que no se han res- petado los derechos humanos o su posible conservación para uso pedagógico... Cuando dirigí el censo de simbología franquista, primero investigamos y, luego, en un informe no vinculante, decidimos "mojarnos" y no destruir ni demoler todos los símbolos. De esto resultó que la conservación, museización, reinterpretación, traslado, pedagogía, memorialización, etc. son vías de avance democrático que impiden olvidar o crear espacios asépticos con la simple retirada de símbolos. De ahí hasta la realización de dos informes sobre el Valle de los Caídos y sobre Caídos de Pamplona defienden la teoría de no destruir todo, a pesar de la ofensa que ocasiona la nula intervención.

Para responder a la pregunta sobre cómo llevar a cabo la labor de difusión e interpretación de la memoria democrática sin que suponga una banalización de la historia me remito a lo anterior: con conocimiento y formación profesional y con memoria comparada transnacional. No debemos dejarnos llevar solamente por la opinión o acción mediática-política. En este sentido estamos elaborando una especie de decálogo profesional de memoria a escala europea avalada por otras redes de memoria consolidadas y profesionales.

Por último, comparto un proyecto de puesta en valor de la memoria democrática desde una perspectiva de género. Me refiero a todo el proceso de memoria participativa sobre la desaparecida Cárcel de mujeres de les Corts de Barcelona en el que estamos muy implicados. Todo un colectivo de mujeres de la ciudad han creado una plataforma y lleva más de 10 años impulsando un proyecto sobre la invisibilidad de género y memoria: invisibilidad resistente y represiva de las presas de dicha cárcel durante el franquismo; invisibilidad de género; invisibilidad patrimonial: la cárcel se destruyó en 1956 y ahora se encuentra un Corte Inglés; invisibilidad pública porque hasta ahora ha habido una falta total de conmemoración, marcaje, explicación, etc., de esta historia y memoria en el espacio y las políticas públicas de la ciudad. Para conocer el proyecto y el el blog del proceso memorial os remitimos a los enlaces: www.presodelescorts.org y https://presodedones.wordpress.com 


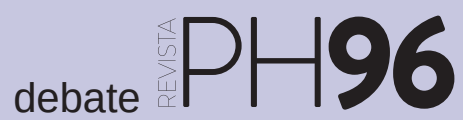

a debate Memoria democrática en la construcción de la historia y el patrimonio

| coordina Josefina Cuesta Bustillo

\section{Memoria democrática y verdad}

Jorge Benavides Solís | Dpto. de Urbanística y Ordenación del Territorio, Universidad de Sevilla

URL de la contribución <www.iaph.es/revistaph/index.php/revistaph/article/view/4284>

En los textos de invitación y forma de participar en el "debate", constato que se trata de reflexionar sobre la forma de cómo hacer operativos y prácticos los objetivos del artículo cuatro de la Ley $2 / 2017$, en el cual se precisa lo que se entiende por memoria democrática en Andalucía. En consecuencia, no es un debate (controversia) teórico acerca de la memoria, tal como la asume la Filosofía (RECOEUER, 1998; TODOROV, 2013), de la memoria colectiva, según la entendió y acuñó Halbwachs (París, 1950) o la Psicología Social (VÁZQUEZ, 2001). Siendo así, no hay espacio para el debate sino para un enriquecedor intercambio de ideas dirigidas no a justificar sino a cumplir con los propósitos de la Ley, para el mayor y mejor beneficio de la sociedad.

Con razón en la introducción al debate se dice que la "memoria colectiva se distingue de la historia" pero no está desvinculada de ésta (memoria histórica). Se trataría de ver cómo vincularlas recurriendo a la democracia; sin embargo, quizá hubiese sido mejor aproximarla al derecho universal, a la verdad (RESOLUCIÓN, 2005) porque ésta es menos relativa que la democracia.

La invitación al "debate" parte de un contenido con certidumbre implícita sobre la función de la historia y de la democracia que no se inscribe en el específico ámbito del patrimonio cultural o, mejor aún, de la herencia cultural por cuya protección vela el IAPH, sino de las diversas formas de gobierno entre las cuales se destaca la democracia, sin distinción de grados o de calidades. $\mathrm{Ni}$ las elecciones ni las leyes, que en el mundo la regulan y le posibilitan realizarse, son similares. Los historiadores y los gobiernos no hacen la historia. Eso sí, unos la interpretan y la escriben, otros la utilizan.

No hay democracias perfectas sino perfectibles porque, además, no son puntos de llegada sino procesos dependientes de múltiples variables con inciertos comportamientos. Actualmente, Estados Unidos goza de una democracia menos imperfecta que la de España o Rusia. En Cuba no está vigente el modelo europeo de democracia formal. En numerosos países no hay democracia y además no hay libertad, ni de pensamiento ni de acción (Arabia Saudita). Cosa parecida sucede en China y en numerosos países más. Pero todos protegen, a su manera, su herencia cultural, el patrimonio de todos, pero ignoran el significado y el contenido de la ciudadanía. Sin embargo, todos sus habitantes tienen derecho a la verdad.

La calidad de la democracia como forma de gobierno no está en directa proporción al grado de protección del patrimonio cultural, sino de otros factores y componentes. En cualquier caso eso sí, la posibilidad que se tenga para el ejercicio proactivo de la ciudadanía garantizará un mayor cuidado de la herencia cultural y una democracia de mejor calidad.

Sin embargo, si se habla de una específica memoria democrática, el asunto se inscribe, por una parte, en un ámbito del poder político (administrativo) que puede llegar a concretarse en leyes de amnistías y olvidos; y, por otra parte, en un ámbito concreto de trascendencia social y humana, si se toman en cuenta los asesinatos y las acciones legales de las dictaduras, de legitimidad dudosa en un periodo histórico y circunstancial (Andalucía).

En base a dichas consideraciones, convendría tomar como referencia comparativa las formas integralmente positivas de rescatar, hacer ostensible y difundir los resultados de una experiencia histórica negativa en otros países. Más específicamente con los que han sufrido las consecuencias de las nefastas acciones de las dictadu- 
a debate Memoria democrática en la construcción de la historia y el patrimonio

| coordina Josefina Cuesta Bustillo

\begin{tabular}{|lll}
\hline País & Años con dictadura & Leyes de amnistía \\
\hline Italia (Mussolini) & $1922-1943$ & D. Presidencial Togliatti junio/42 \\
\hline Portugal (Salazar) & $1933-1974$ & Acciones rupturistas con la dictadura \\
\hline Alemania (Hitler) & $1933-1945$ & Eliminación de símbolos nazistas \\
\hline España (Franco) & $1936-1975$ & Ley 46/1977 \\
\hline Chile (Pinochet) & $1973-1990$ & $\begin{array}{l}\text { La Comisión Nacional de Verdad y Reconciliación. Decreto Supremo 355 1990. } \\
\text { Informe Rettig 1991 }\end{array}$ \\
\hline Argentina (militares) & $1975-1983$ & $\begin{array}{l}\text { Ley de Punto Final Dic/1986. Corte Suprema declara inconstitucional indultos y } \\
\text { Leyes de Obediencia Debida y Punto Final, 2001 }\end{array}$ \\
\hline
\end{tabular}

ras en sus países, ahora con gobiernos democráticos (ver tabla adjunta).

La eliminación del prójimo por razones de guerra es una constante no superado por el "sapiens". Las sentencias de muerte por razones políticas, también. Incluso aplicada a las personas que únicamente han pensado (Sócrates, Cristo). Otro matiz tiene la represión del poder para imponer su voluntad omnímoda apoyada en dogmas o principios impuestos no discutibles de todo tipo: económicos, raciales, religiosos (inquisición, holocausto judío, genocidio armenio). En este último ámbito se inscribe el gobierno franquista, dictadura de similar comportamiento a otras: los dictadores eliminaron a miles de ciudadanos opositores a su régimen por pensamiento, palabra u obra.

Los espacios públicos en países reprimidos, con frecuencia, son convertidos en escenarios de la muerte como advertencia pedagógica (Irán, París de la Revolución Francesa, etc.).

En suma, la recuperación y la elaboración de la memoria colectiva, en términos operativos, tal como plantea el "debate", es responsabilidad de la administración. Las acciones para su recuperación, en todos los casos, deberían estar próximas a la verdad y al ejemplar comportamiento de los políticos. Convendría retirar los símbolos de los espacios públicos pero no la información histórica si los acompañan. Es el caso de las placas en obras civiles y edificios construidos en el período franquista: año y proyectista.

\section{BIBLIOGRAFÍA}

- HALBWACHS, M. (1950) La mémoire collective. Paris: Presses Universitaires de France, 1950

- RESOLUCIÓN 2005/66 sobre "EL DERECHO LA VERDAD"(2005) 59.a Sesión de la Comisión de Derechos Humanos de Naciones Unidas. 20 de abril de 2005

- RICOEUR, P. (1998) La lectura del tiempo pasado: memoria y olvido. Madrid: Arrecife Producciones, 1998

- TODOROV, T. (2013) Los abusos de la memoria. Barcelona: Paidós Ibérica, 2013

- VÁZQUEZ, F. (2001) La memoria como acción social. Barcelona: Paidós, 2001 


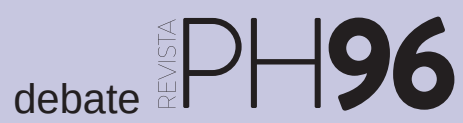

\title{
¿Qué hacemos con la División Azul? Sobre la necesidad de una memoria atenta a los detalles
}

\author{
Alfredo Francesch | Dpto. de Antropología Social y Cultural, UNED \\ URL de la contribución <www.iaph.es/revistaph/index.php/revistaph/article/view/4283>
}

Es difícil cuantificar el número de espacios públicos que permanecen en nuestros días dedicados a honrar la memoria de la División Azul o de sus caídos. Hace casi quince años, Núñez Seixas (2005) daba una cifra bastante reducida de poblaciones -en comparación con la totalidad de los municipios españoles- que contaran con alguno de tales espacios en nuestro país (incluyendo los dedicados a Muñoz Grandes y a algunos héroes locales). La cifra es reducida, he dicho, pero, también, asombrosa: no creo fácil encontrar en Europa lugares dedicados a unidades de la Wehrmacht. Porque eso, y no otra cosa, fue la División Azul: la 250. ${ }^{a}$ División, encuadrada en el Grupo de Ejércitos Norte, bajo el mando del mariscal de campo Wilhelm von Leeb, dentro del Plan Barbarroja.

Lo cierto es que las connotaciones que posee la División Azul no invitan a la empatía. El grito de guerra "Rusia es culpable"; la exhortación al "exterminio de Rusia", "exigencia de la historia y del porvenir de Europa" (arenga de Serrano Súñer el 24 de junio de 1941); la uniformidad feldgrau del ejército de la Alemania nazi (aunque con pequeñas modificaciones); el juramento de lealtad al Führer, Adolf Hitler (no al Caudillo, Francisco Franco); su papel como coartada en la política exterior del momento, tendente a escurrir el bulto ante los socios del Eje; todos estos elementos y muchos más no pueden sino provocar molestos sentimientos.

Incluso un episodio más moderno de la historia española, el intento de golpe del 23 de febrero de 1981, tiene entre sus protagonistas a dos antiguos divisionarios, el teniente general Miláns del Bosch y el general de división Armada, ambos condenados por la justicia a 30 años de reclusión. Todo esto resulta, cómo negarlo, perturbador.
La propaganda del régimen franquista, los libros, las películas de la época, han oscilado entre diversas ópticas, según autores y momentos, a la hora de presentar a la División Azul. Con todo, en mi opinión, podemos encontrar rasgos recurrentes. Presumo que un buen retrato compartido dibujaría a una multitud de millares de voluntarios, heroicos jóvenes idealistas, dispuestos a combatir hasta acabar con la tiranía soviética, dispuestos a devolver la visita a los rusos presentes en la Guerra Civil española. Sorprendentemente, este retrato parece haber calado con igual profundidad en la memoria democrática. Es cierto que, por medio de un sencillo reciclado, la multitud de voluntarios decididos a derribar el estado soviético pasa de estar compuesta por heroicos idealistas a estarlo por belicosos fanáticos. Pero, a mi juicio, esto no cambia sustancialmente el guión. Entonces...

Entonces tal vez sea precisamente el guión lo que deba cambiarse, tal vez sea la narrativa franquista la que debe levantar suspicacias y se deba escudriñar con más cuidado en la letra pequeña. Los pormenores del reclutamiento para la División Azul darán sentido al título de estas líneas y aclararán mis últimas afirmaciones. Son los detalles de la memoria.

En un principio, el esquema consistía en componer el cuadro de oficiales y suboficiales con militares profesionales y llenar la clase de tropa con voluntarios, principalmente falangistas. Esto hubiera dotado a la unidad de efectivos ideológicamente firmes con un personal al mando capacitado para sus misiones de combate. Pero las cosas no salieron según lo previsto. Por ejemplo, aparecieron sospechas cuando algunos oficiales se presentaron voluntarios junto a todo el personal a su mando, incluso compañías completas (REVERTE, 2012). No puede dudarse de que, en casos tan evidentes, se pusie- 


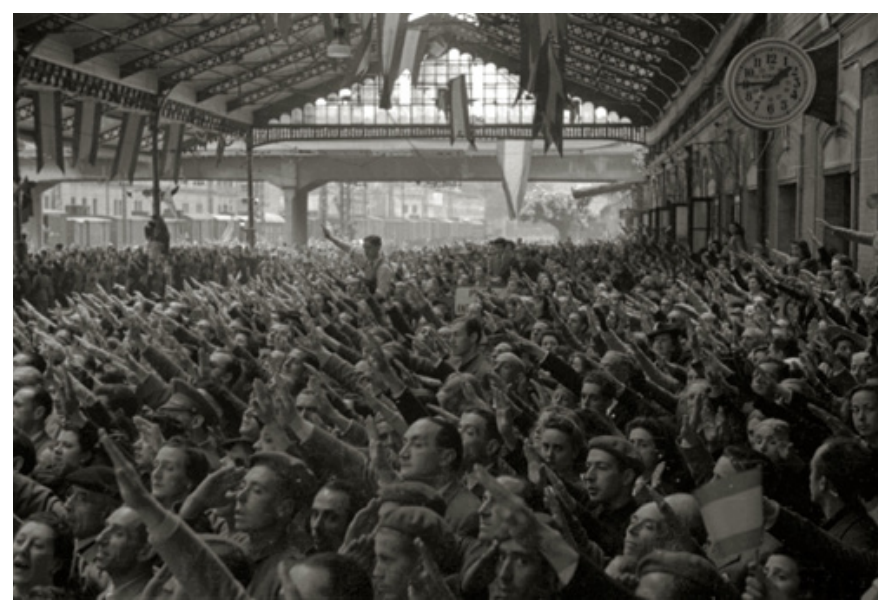

Llegada de integrantes de la División Azul a la estación del Norte | foto Fondo Kutxa Fototeka (Pascual Marín)

ron en práctica coacciones y presiones, que diluyen el carácter voluntario de aquellos soldados.

Fuera como fuere, el reclutamiento devino algo menos entusiasta de lo esperado. Así que hubo que rebajar las exigencias de fidelidad política. ¿Qué ofrecía la División Azul en una España paupérrima y hambrienta, como era la de 1941? De entrada, el rancho: comida. Algo nada despreciable. La extrema dureza, la crueldad y las pesadillas posteriores del Frente Ruso eran difíciles de imaginar, más cuando, en esos días, las tropas de Hitler parecían, sencillamente, invencibles. Y, por añadidura, los divisionarios recibirían doble paga: la de un soldado de la Legión española y la de un soldado de la infantería alemana. ¿Cuántos divisionarios sintieron crecer sus sentimientos antisoviéticos conforme disminuía su perspectiva de hambre y de miseria?

Otro número nada despreciable de "voluntarios" optó por la alternativa divisionaria para limpiar sus expedientes. Combatientes del bando perdedor, personas con un pasado político que dificultaba su presente hasta lo insuperable, o que querían limpiar no su pasado, sino el de sus familiares, no fueron raras. La documentación interna de la División Azul certifica la preocupación de los mandos por el número de soldados poco fiables (RODRÍGUEZ JIMÉNEZ, 2009). Y, los menos fiables de todos, hubo quienes decidieron formar filas con la única intención de pasarse y luchar por el bando soviético: los que querían devolver la visita en el sentido más educado de la expresión. Las cifras de desertores son reducidas en el estado actual de nuestros conocimientos, pero lo destacable es que fueron, en su mayor parte, desertores hacia delante, no hacia la retaguardia.

Se estima que formaron en la División Azul más de 40.000 personas, sumando las que se incorporaron en su inicio y los sucesivos relevos. No es sencillo calcular cuántos de ellos tuvieron que unirse forzadamente voluntarios a sus mandos, cuántos tuvieron que unirse para lavar su pasado político o el de sus familiares, cuántos purgaron el haber combatido en España en el bando equivocado, cuántos lo hicieron para pasarse o para, escuetamente, seguir vivos. No entraré a evaluar cifras. Mas, por corta que fuera la proporción, fueron muchos. $\mathrm{Y}$, por pocos que fueran, fueron demasiados.

Estas personas sufrieron una derrota detrás de otra: en un primer momento, la derrota en la Guerra Civil; la derrota de sus familiares, que ellos debían expiar; la derrota, estuvieran en el bando que estuvieren, de no poder sobrevivir en su país. Después, la derrota de unirse a una unidad de falangistas con aspiraciones a caballo entre lo mesiánico y lo imperial. Más tarde, la derrota militar de combatir junto a la Alemania nazi. Posteriormente, el que su presunta gesta fuera incómodamente ninguneada por el régimen en cuyo nombre partieron a la guerra. Ahora, hoy, la derrota de que se ignore su desventura en nombre de una memoria poco atenta a los detalles. La mala fortuna persiguió a estas personas, que nunca han estado en el lugar adecuado. Al parecer, ni siquiera hoy.

Comprendo que es inverosímil transformar el nombre de, digamos, la calle "Caídos de la División Azul" en algo así como "Integrantes de la División Azul obligados por las circunstancias y/o poco entusiastas, ideológicamente hablando". Pero mi trabajo no es encontrar nombres adecuados para las calles. Ni siquiera lo es, creo, impugnar la maltratada biografía de nadie. Sí lo es, con 
certeza, solicitar que la memoria preste atención a los detalles. Por eso vindico que la División Azul no fue tan azul, tan monolíticamente azul, y por eso no puede ser condenada a un olvido igual de monolítico. Tanta derrota justificaría algún honor. Por modesto que sea.

\section{BIBLIOGRAFÍA}

- NÚÑEZ SEIXAS, X. M. (2005) Los vencedores vencidos: la peculiar memoria de la División Azul, 1954-2005. Pasado y Memoria. Revista de Historia Contemporánea, 4, 2005, pp. 83-113

- RODRÍGUEZ JIMÉNEZ, J. L. (2009) Ni División Azul, ni División Española de Voluntarios: El personal forzado en el cuerpo expedicionario enviado por Franco a la URSS. Cuadernos de Historia Contemporánea, vol. 31, 2009, pp. 265296

- REVERTE, J. M. (2012) Por qué fueron a Rusia. Cuadernos de Historia Contemporánea, vol. 34, 2012, pp. 15-29 


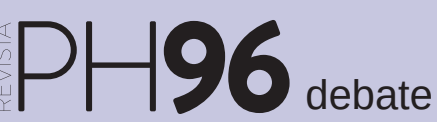

a debate Memoria democrática en la construcción de la historia y el patrimonio

| coordina Josefina Cuesta Bustillo

\section{El "No se olvida", ¿se puede olvidar?}

Francisco José Casado Pérez | arquitecto

URL de la contribución <www.iaph.es/revistaph/index.php/revistaph/article/view/4288>

Para México 1968 significó un momento de ruptura crítica de la memoria debido a la contraposición del gobierno sobre los Juegos Olímpicos y los reclamos públicos de grupos estudiantiles, situación que alcanzaría su punto decisivo de totalitarismo el 2 de octubre con la tragedia de la plaza de las Tres Culturas en Tlatelolco, Ciudad de México. Cincuenta años tuvieron que pasar para aquellos que esperaban la reivindicación histórica de dicha empresa de boca del propio gobierno. En este 2018 se llevaron a cabo exposiciones, programas especiales, reportajes e incluso se decretó este lugar de tantas tristezas como patrimonio cultural intangible y sitio emblemático de la ciudad; sin embargo, en paralelo a esta celebración solemne, en el Sistema Colectivo Metro se retiraba la placa conmemorativa sobre la inauguración de la línea 3 (dos años después de la tragedia) por el entonces presidente Gustavo Díaz Ordaz, principal figura del totalitarismo.

La decisión del Jefe de Gobierno -interino- de la ciudad, José Ramón Amieva Gálvez, de retirar todo elemento alusivo a las autoridades gobernantes durante el '68 se justifica así: "[...] a 50 años hay ciclos que se deben cerrar y estar acordes con el pensar y el sentir de la ciudadanía" (NOTIMEX, 2018). Pero ¿qué piensa la ciudadanía?, ¿cuál es ese sentir que dice o cómo se enteró? Aquí cabe la discusión que hermana familias y naciones: los acontecimientos traumáticos -vividos o ejercidos¿se deben visibilizar o desaparecer?

El supuesto de que todo ser humano es un ser narrativo (BOULLOSA, 2017: 122) radica en que las historias son el medio predilecto de transmisión del conocimiento e información: orientan los sentimientos así como también empatizan, pero no todo ello puede ser en un sentido unilateral debido a que también somos seres dialécticos. No podemos estar siempre del mismo lado, necesita-

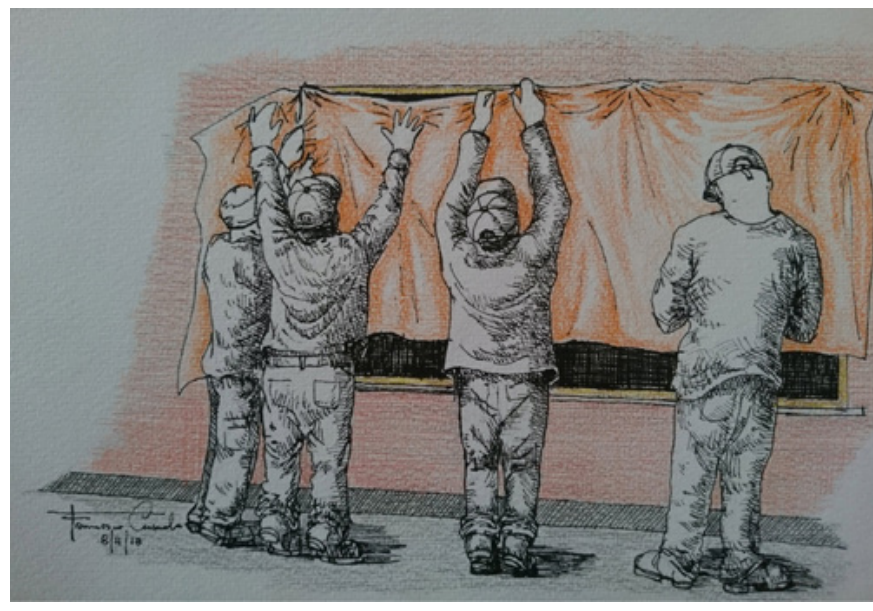

Dibujo "Memoria" (tinta y lápiz de color 17 x $24.5 \mathrm{~cm}$ ) que alude al retiro de la placa conmemorativa del ex presidente Díaz Ordaz de la línea 3 de metro en ciudad de México | dibujo Francisco Casado

mos cambiar y la frontera entre las historias provisionales y definitivas es un cabello cano y "El hecho de que nunca identifiquemos todas las causas ni relacionemos todos los actos humanos con la circunstancias que los han condicionado, no significa que fueran libres, sino que nunca sabremos hasta qué punto fueron necesarios" (BERLIN, 2000: 42).

Vivimos ambos tipos de historia al mismo tiempo y, ante ello, Tzvetan Todorov recalca que se debe "[...] aspirar a una historia que escape al maniqueísmo e intente arrojar una mirada crítica y lúcida sobre el pasado de nuestra comunidad" (GASCÓN, 2015), lo cual no solo requiere de la memoria, sino también de evidencias tangibles. Necesitamos del patrimonio como un soporte de las diversas convicciones de la sociedad en sus distintas escalas. En consecuencia, la facultad que tienen -el poder según Berlin (2000: 39)- las autoridades, tanto administrativas como académicas, debe tomar en consideración que el trabajo ejercido está supeditado a la 
sociedad y no al contrario. Juzgar deliberadamente, como en este caso, el retiro de un elemento conmemorativo de un acto ejercido por un personaje relacionado con otro acontecimiento podría considerarse un acto contra la memoria y la sociedad misma. ¿Por qué? Es fácil elegir qué se mira y qué se queda, pero hacerlo por medio de una justificación deliberadamente vaga como que ha cumplido su ciclo es sentenciar la ausencia de varias piezas del porvenir.

Desde la Segunda Guerra Mundial, algunos autores -especialmente en la filosofía como Günther Anders, Hanna Arendt, Jean-Paul Sartre, entre otros- aluden la premisa y menester de lidiar con -y en- nuestra memoria para poder sopesar la responsabilidad del hecho crítico de que somos el resultado de todo tipo de actos y el negar una siquiera equivaldría a perder el rumbo, a perder la identidad del ser. No olvidemos que los grandes avances de la medicina y la tecnología han sucedido gracias a las guerras, pero ¿seguiremos necesitando el erradicar(nos) para avanzar y a su vez recordar(nos)? Por ello, Isaiah Berlin enfatiza en su guiño a Arquíloco, el todo (la zorra) y lo esencial (el erizo), pero sin llegar a resolver una duda puntual: “¿Cómo es posible no llegar a la conclusión de que las historias existentes representan lo que según Tolstoi 'es tal vez apenas un 0.001 por ciento de los elementos que, en realidad, constituyen la verdadera historia de los pueblos?" (BERLIN, 2000: 31).

Quizás la respuesta es tan sencilla como vernos en el espejo y decir honestamente si estamos, o no, listos. Si verdaderamente tenemos la madurez emocional para enfrentar algunas de las infinitas cicatrices de la historia, en lugar de simplemente voltear hacia otro lado: "Nuestra ignorancia en cuanto a cómo suceden las cosas no se debe a la inherente imposibilidad de acceso a las causas primeras sino solo a su multiplicidad, a la pequeñez de las entidades últimas y a nuestra incapacidad para ver, oír, recordar, registrar y coordinar suficiente cantidad del material disponible" (BERLIN, 2000: 46).

A fin de cuentas debemos tomar el valor necesario para poder decirle a las generaciones futuras todo lo que existe en el mundo y no solo relegar nuestra existencia a un cuento de indios y vaqueros o una fábula de príncipes y brujos. A veces la crudeza es necesaria para dar cuenta de nuestra naturaleza y así poder establecer rutas más conscientes ante un mundo cada vez menos inocente aunque hayan tenido que pasar cincuenta años.

\section{BIBLIOGRAFÍA}

- BERLIN, I. (2000) El erizo y la zorra. México: Muchnik Editores, S.A., Editorial Océano de México, S.A., 2000

- BOUllosA, P. (2017) El corazón es un resorte. México: Penguin Random House Grupo Editorial, 2017

- GASCÓN, D. (2015) La memoria tiene una potencia que la historia nunca alcanza. Letras Libres [en línea], 11 de junio de $2015<$ https://www.letraslibres.com/espana-mexico/historia/lamemoria-tiene-una-potencia-que-la-historia-nunca-alcanza> [Consulta: 31/10/18]

- NOTIMEX (2018) 50 años del 68: Gobierno de la CDMX retira del Metro placas con el nombre de Díaz Ordaz. Animal Político [en línea], 1 de octubre de 2018, <https://www.animalpolitico. com/2018/10/retiran-placas-diaz-ordaz/> [Consulta: 31/10/18] 


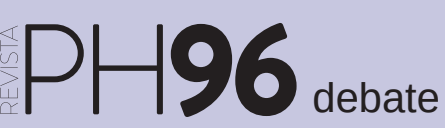

a debate Memoria democrática en la construcción de la historia y el patrimonio

| coordina Josefina Cuesta Bustillo

\section{Función simbólica del patrimonio}

Asunción Cobo Gómez | graduada en Humanidades y estudiante del máster Gestión cultural e Industrias creativas de la Universidad de Alcalá

URL de la contribución <www.iaph.es/revistaph/index.php/revistaph/article/view/4291>

Abordar desde una perspectiva imparcial el tema de "la memoria histórica" e íntimamente ligada a ella su patrimonio implica hacer un ejercicio de humildad, solidaridad, perdón, acogimiento e inmersión en los sentimientos del "otro". Desde que años atrás se elaboró la llamada Ley de memoria histórica, ésta ha permanecido semi dormida hasta la llegada, en mi opinión, de algunas fuerzas políticas que han aflorado en la escena pública en los últimos tiempos y han reavivado el debate. Evidentemente se ha comenzado por el elemento más representativo de la Guerra Civil, el Valle de los Caídos, un bien patrimonial distintivo de los que "ganaron" la guerra, si es que en una guerra gana alguien.

Por recordar mínimamente, este monumento se construye con el esfuerzo y la vida de muchas personas, presos republicanos, trabajadores a sueldo, personas

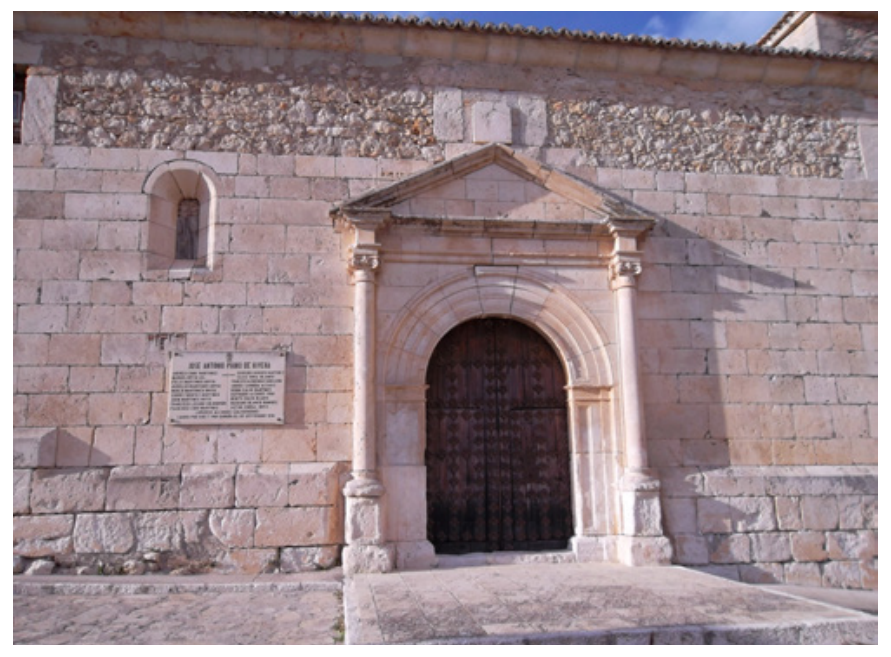

Lápida conmemorativa por los caídos en la guerra civil (1936-39) en la fachada principal de la iglesia situada en el municipio de Loranca de Tajuña (Guadalajara) | foto Oilisab afines a la causa franquista, etc., es decir un totum revolutum de individuos con ideas, afinidades, necesidades y situaciones muy distintas que hicieron posible esta construcción. Ciertamente el régimen franquista consideró siempre que "el valle" daba culto a los caídos del bando nacional, pero creo que esa visión debe ser desechada si nos atenemos a las personas que allí están sepultadas como consecuencia de las obras llevadas a cabo. Es llamativo que pocas veces se haya incidido en esta consideración pues creo que la misma es fundamental para que de forma definitiva, aquello sea considerado como el cementerio común de todos los caídos en la Guerra Civil (1936-39).

Es verdad que enterrar al dictador en aquel edificio no ayuda a restañar las heridas y esta sea la causa principal para que algunos propongan hasta su voladura, sin detenerse en valorar lo que este emplazamiento significa como valor histórico de primer orden. Pasados casi 80 años del fin de la contienda, superada la dura etapa de la postguerra y viviendo actualmente en un periodo democrático como nunca ha tenido España, es hora de valorar este patrimonio desde un punto de vista estrictamente cultural, histórico y por qué no, educativo para las generaciones futuras de lo que supone una guerra. Seguir empeñados en buscar quiénes fueron los buenos y quiénes los malos es un ejercicio que no lleva a nada positivo, muy al contrario, impide construir un futuro democrático sin vinculaciones pasadas, asumir el dolor sufrido por las familias de los dos bandos es tan fácil como ponerse en el lugar del otro.

Si nos detenemos brevemente en revisar lo que hoy es una gran parte de nuestro patrimonio histórico, tanto en España como en cualquier otro país de Europa, podremos comprobar que la mayoría de los edificios, monumen- 
tos de todo tipo, esculturas y hasta la pintura responden a representaciones de los periodos de dominación reinante en cada momento histórico. Solo por señalar algunos ejemplos: en la antigua Roma la Columna Trajana representa en sus bajo relieves, con todo lujo de detalles, la conquista de la Dacia por el emperador Trajano, si en aquellos momentos alguien se le hubiera ocurrido destruirla, hoy no podríamos observarla y valorar su riqueza escultórica. Igual ocurre con el obelisco de la plaza Vendôme en París, Napoleón decide erigir este monumento para resaltar sus hazañas, afortunadamente ahí sigue, aunque hubo intentos de destruirlo, hoy solo tiene un valor patrimonial y turístico.

Reconsideremos el tema y hagamos un ejercicio de sentido común, ¿Qué sería de nuestra memoria colectiva si gran parte del patrimonio que hoy poseemos hubiera sido volado o destruido por ideas políticas?, sin duda, esta acción irresponsable imposibilitaría en gran medida que las generaciones futuras pudieran conocer y de alguna manera evitar errores del pasado y seríamos mucho más pobres en todos los aspectos ya que se habría perdido una gran fuente de conocimiento y perspectiva histórica que estos monumentos nos facilitan en la actualidad.

Es paradójico que, siendo considerado nuestro país como una democracia consolidada, persistan actitudes tan totalitarias incapaces de conjugar "valor histórico" con "valor simbólico" y este enfrentamiento solo deja entrever que aún no hemos sido capaces de superar etapas pasadas de nuestra historia reciente. Las democracias fuertes y consolidadas han aprendido a mantener una cierta distancia con hechos históricos del pasado dejando de lado los sentimientos de unos y otros y considerando todo su patrimonio como algo identitario, propio, que forma ya parte de su bagaje histórico del que no podemos sustraernos ni olvidarnos y todos (historiadores, administración, experto en patrimonio y de una forma muy especial la misma ciudadanía) debemos hacer un esfuerzo por situarnos en posiciones "neutras", solo de esta manera nuestro patrimonio podrá ser considerado como algo ajeno a lo sentimental.
Ante esta situación creo que ha llegado el momento de hacernos algunas preguntas con el fin de intentar resolver la cuestión, propongo las siguientes: ¿El dolor por mis muertos es el mismo que el de los otros?, la respuesta es un sí rotundo; ¿Mis ideas políticas deben prevalecer sobre la de los otros?, absolutamente no; ¿Una guerra, entre hermanos, debe suponer un perdón mutuo?, no tengo duda alguna de que la respuesta debe ser sí. En mi opinión estas respuestas son claves para asumir lo que pasó. Pero no solo hemos de asumir estas respuestas como propias sino también aceptar algunos elementos externos a nivel simbólico, aunque puedan distorsionar nuestra actitud conciliadora, pues si queremos proyectar una idea de historia democrática se hace imprescindible convivir con ellos y permitir que calles, colegios, instituciones, etc. lleven nombres de todos los "participantes" en la Guerra Civil y admitir que lo ocurrido en ese enfrentamiento fue producto de un momento histórico concreto, en muchos aspectos difícil de entender para nuestra mentalidad actual. Su recuerdo solo debe servirnos como lección para no volver a incurrir en los mismos errores del pasado.

En cualquier caso, el exacerbado deseo de recordar acciones nefastas de una guerra y sobre todo a sus dirigentes no deja de parecerme algo morboso que nos impide avanzar hacia una sociedad democrática, igualitaria y consciente de su pasado. El recuerdo es necesario, pero cuando se convierte en obsesión anula cualquier posibilidad de asumir los hechos con serena imparcialidad. 


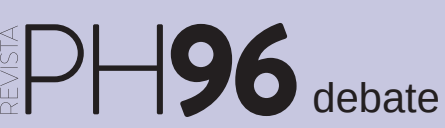

a debate Memoria democrática en la construcción de la historia y el patrimonio

| coordina Josefina Cuesta Bustillo

\section{La memoria democrática en el juego entre memoria y cultura}

María del Rosario Zavala | Facultad de Ciencias Políticas y Sociales, Universidad Nacional de Cuyo (Argentina)

URL de la contribución <www.iaph.es/revistaph/index.php/revistaph/article/view/4296>

Podemos pensarnos de muchas maneras. Sin embargo, nada se entiende si no partimos del análisis de nuestra propia situación. $Y$ desentrañarla supone insertarnos plenamente en nuestra cultura. La propuesta es escribir las situaciones de ese mundo, las constitutivas de la memoria de la cultura como proyecto.

Desde el punto de vista de una relocalización de nuestro campo de significaciones, dentro de las problemáticas propias de las comunidades específicas, en el marco de los debates sobre cultura y memoria, es difícil seguir hablando de la cultura como una categoría homogénea y totalizadora, por lo que partimos desde una idea de cultura procesual y cambiante. Es posible comprender a la cultura desde perspectivas abiertas a plantear otros modos de articulación entre las prácticas, los hechos y el mundo social. Bajo una idea que trata de comprender que el acceso a bienes y servicios culturales garantiza el desarrollo de la creatividad, la fantasía, la comprensión y la reflexión y que pueden transformarse en herramientas para la elaboración de un juicio crítico sobre la realidad social inmediata, así como medios para imaginar nuevos mundos posibles y nuevas formas de ser en el mundo.

La cultura se produce, circula y consume a través de los procesos sociales e históricos y de allí su complejidad, por la que se conjuga como una trama simbólica dada en la lógica de interacción de partes distintas, idénticas y similares, configurándose como un campo de posibilidades en el que se incluye de manera contingente el conflicto social. Por más pequeñas que sean, siempre hay espacios, prácticas e instituciones para nuestras representaciones.

Por su parte, la memoria se obtiene y construye de distintas maneras, con distintos materiales y mecanismos, conjugándose con los recuerdos del pasado de un grupo social, de una comunidad, de una sociedad, lo que contribuye al fortalecimiento de su identidad y así forma parte de los procesos culturales. De modo tal que las prácticas y procesos, principalmente culturales, deciden qué se recuerda y qué se mantiene en la memoria, repercutiendo en la identidad que a su vez decide sobre el sentido de esas prácticas y esos procesos. Entonces, la cultura entendida como una instancia comunicacional entre lo práctico productivo y lo significante se constituye por el despliegue del carácter en donde la identidad de los sujetos como tales debería evidenciarse.

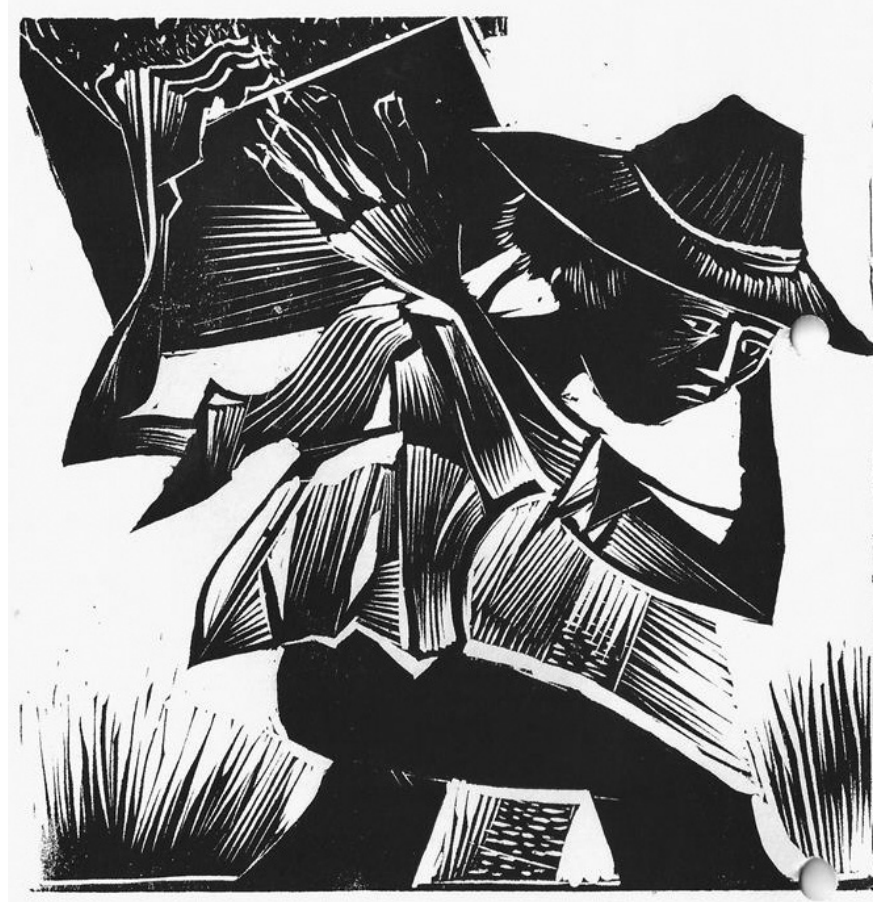

Las prácticas del arte, en postdictadura, se asocian al trabajo de una memoria particular que relaciona cultura y democracia. Detalle de folleto de una muestra por los derechos humanos en 1984 del Museo Municipal de Arte Moderno de Mendoza | fuente Archivo MMAMM, Mendoza 
Nos conocemos entre colonización y dominación, pero al mismo tiempo, contamos con la posibilidad de una comunicación destinada a romper las formas de exclusión, nuevas redes y conexiones, nuevas experiencias de interacción con una trama simbólica común. El riesgo del olvido y la impunidad hacen de éste un tema de la agenda cultural y política actual. Por lo que, en nuestra contemporaneidad, internarnos en los procesos culturales no solo trata de evidenciar la imposición de identidades, sino, sobre todo, de resaltar y rescatar esta dimensión como un largo y profundo proceso de revolución cultural, donde las formas culturales, en un contexto complejo, se transmiten como mensajes, como sistemas simbólicos.

A medida que la corriente cultural actual se va formando, surgen nuevos escenarios de producción, de su valor y de su sentido. Espacios emergentes que obligan a redefinir las posiciones de todos los productores, la delimitación del campo, la definición de los roles y la legitimidad de la cultura. El debate sobre el lugar de la cultura, como dimensión en proceso de configuración, y su vinculación con lo político, abarca espacios muy amplios. La construcción de los nuevos mundos simbólicos en la era de las trasnacionales, la desindustrialización y el avance de nuevas formas de acción indican la emergencia de una multiplicidad de prácticas culturales como parte de una nueva razón populista y de un nuevo proceso histórico.

Algo está irrumpiendo en la escena contemporánea y requiere ser abordado por nuestros análisis: la pluralidad, la diferencia y el antiautoritarismo. Esto implica una revisión de los acontecimientos de nuestra historia reciente, que necesitan ser tomados en cuenta para romper con los estigmas de una propuesta trunca y repensar las continuidades y las rupturas, al menos para no enclavarnos en la nostalgia y comenzar a quitar lo nefasto. Pues el valor sobre el tiempo pasado, presente y futuro se monta sobre diferentes configuraciones, en cada espacio simbólico presente. Es entonces una posibilidad hablar de la memoria democrática desde la cultura, como parte de una configuración cultural, en oposición al olvido, a la reconciliación y a la amnistía.
En este marco, el golpe dado por la dictadura militar argentina fue parcialmente saldado en la transición democrática y, luego de 30 años, encontraron una corta instancia de respuestas desde las políticas del estado (2003-2015). Pasado, presente y futuro se encadenan en una trama que alienta la revisión del sentido atribuido a determinados fenómenos. Y, demarcado por los pasados dictatoriales y los presentes portadores de las huellas de la represión estatal, el tema de la memoria se constituye como público.

\section{BIBLIOGRAFÍA}

- GRIMSON, A. (2011) Los límites de la cultura. Buenos Aires: Siglo XXI, 2011

- ECHEVERRÍA, B. (2001) Definición de la cultura. México: Ítaca, 2001

- JELIN, E. (2002) Los trabajos de la memoria. España: Siglo XXI, 2002

- RICHARD, N. (2007) Fracturas de la memoria; Arte y pensamiento crítico. Buenos Aires: Siglo XXI, 2007

- VINYES R. (2009) El estado y la memoria. Gobiernos y ciudadanos frente a los traumas de la historia. España: RBA, 2009 


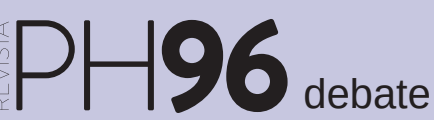

a debate Memoria democrática en la construcción de la historia y el patrimonio

| coordina Josefina Cuesta Bustillo

\section{Entre la memoria plural y la memoria crítica}

Olivia Muñoz-Rojas | ensayista e investigadora independiente

URL de la contribución <www.iaph.es/revistaph/index.php/revistaph/article/view/4304>

\section{Sobre el concepto de memoria democrática}

Antes de abordar algunas de las cuestiones planteadas en la propuesta de debate, me gustaría reflexionar brevemente sobre qué entendemos por memoria democrática. La orientación de las políticas de memoria dependerá de cómo entendamos este concepto. ¿Hablamos de una memoria construida democráticamente en el presente con la participación de toda la ciudadanía, desde una "pluralidad de visiones y posibilidades de apropiaciones diversas"? (JELIN, 2014) ¿Hablamos de una memoria que desde el presente aplica las exigencias de una democracia sobre el pasado? ¿O hablamos de una suerte de combinación de ambos significados? Si nos decantamos por el primero, asumimos que todas las memorias -incluso aquellas que no contribuyeron al desarrollo de una sociedad democrática-, en la medida en que siguen socialmente vivas, deben formar parte de la memoria colectiva de un país. Si lo hacemos por el segundo significado, reclamamos una memoria crítica que se desprende de los episodios antidemocráticos del pasado y reivindica aquellos que contribuyeron al desarrollo de la democracia. Una combinación de ambos significados buscaría un compromiso entre, por una parte, una memoria construida por toda la ciudadanía, incluso aquella que se identifica con sucesos antidemocráticos del pasado; y, por otra parte, lo fundamental de reforzar los valores democráticos, resaltando su continuidad histórica o, dicho en palabras de Josefina Cuesta Bustillo, "privilegiando genealogías democráticas".

En el contexto español, el concepto de memoria democrática se asocia, sobre todo, con la reivindicación de la memoria de los vencidos. Esto es, la memoria de la II República, de la lucha contra el bando nacional durante la Guerra Civil, del exilio y las víctimas de la represión franquista, de la lucha clandestina por la democracia y, finalmente, la memoria de la Transición. Es interesante señalar que, en el debate internacional, se trata de un concepto frecuentemente asociado al caso español. En otros contextos, hallamos conceptos como el de memoria pública que, de acuerdo a algunos autores, designa un espacio intermedio de negociación entre la memoria oficial o memoria de Estado y la memoria colectiva de una minoría o grupo social en particular (MICHEL, 2015).

\section{¿De quién es tarea construir la memoria colectiva?}

En todo caso, todo proceso de construcción de la memoria en una democracia debe ser una tarea colectiva de la que participan una pluralidad de actores (historiadores, expertos en patrimonio, las diferentes administraciones, asociaciones de la sociedad civil, etc.). Estamos ante un proceso dinámico, cambiante. La memoria colectiva como la memoria individual- es algo vivo, en constante revisión, en función de las experiencias e intereses del presente.

Al mismo tiempo, es innegable que sería deseable y útil social y políticamente que, en el caso que nos ocupa, existiera un mínimo consenso sobre la memoria oficial del pasado reciente que incluye la Guerra Civil, la dictadura y la transición a la democracia. Si bien el 20 de noviembre de 2002 todos los partidos condenaron en sede parlamentaria el alzamiento del 18 de julio de 1936 y se comprometieron a honrar a todas las víctimas de la Guerra Civil (CUÉ, 2002), hay partidos que se han desmarcado de dicha condena y compromiso desde entonces. Una declaración consensuada por el conjunto de los representantes políticos que reconociera las trágicas consecuencias de la Guerra Civil, condenara el régimen franquista por su carácter antidemocrático y reconociera, asimismo, la complejidad (¿incompletud?) de la Transición constituiría un paso adelante. Hay, asimismo, cuestiones concretas que, desde el punto de vista de los 
Derechos Humanos, parecen inapelables y que debieran formar parte de ese consenso. Entre ellas, el apoyo de las administraciones a los ciudadanos que desean localizar los restos de sus familiares asesinados por la dictadura.

Sin embargo, es posible que la pretensión de legislar exhaustivamente sobre el conjunto de aspectos simbólicos y materiales que conforman la memoria colectiva de un episodio tan complejo como una guerra civil y una experiencia tan polarizadora como una dictadura vaya en detrimento de la dinamicidad y crítica permanente que una democracia exige (sobre la relación entre ley y memoria ver, entre otros, MISZTAL, 2001). Dicha pretensión ofrece, asimismo, argumentos a quienes niegan la necesidad de desarrollar políticas de memoria y las tildan de partidistas y manipuladoras.

\section{¿'Patrimonializar' la memoria democrática?}

En consecuencia, más que desprenderse del pasado antidemocrático, conviene sumar la memoria de todas aquellas personas, entidades, etc. que lucharon por (re) establecer la democracia. En cualquier sistema democrático, las administraciones tienen la responsabilidad de fomentar los principios y valores democráticos. Una manera de hacerlo es, precisamente, recuperando y poniendo en valor las reivindicaciones y las luchas del pasado reciente que contribuyeron al legado democrático actual, en nuestro caso, desde la lucha contra la imposición de un sistema antidemocrático durante la Guerra Civil hasta la lucha de las mujeres durante la Transición. Parece evidente que, en el caso español, a raíz del carácter pactado que tuvo la Transición, esta labor ha sido insuficiente: si apenas se ha tocado la memoria de los vencedores desde entonces, tampoco se le ha dado a la memoria de los vencidos una presencia y visibilidad equivalentes. Desde las instituciones y la sociedad civil existe un margen de trabajo amplísimo en este sentido y, si se enfoca como una labor de naturaleza más constructiva que destructiva, es posible que genere menos resistencias.

Por ello, respondiendo a la pregunta sobre los símbolos franquistas en el espacio público y tal y como he expuesto en anteriores ocasiones, en términos generales, considero más útil para la convivencia democrática la realización de intervenciones críticas y artísticas de contextualización y resignificación de dichos símbolos que su retirada, así como la creación de nuevos memoriales democráticos. Como dice Cuesta Bustillo en el texto introductorio a este debate, no es lo mismo jugar o pasear en la plaza de la División Azul que en la plaza de la Libertad. Pero quizá es posible hacerlo en la plaza de la Libertad sabiendo que, no hace tanto, fue la plaza de la División Azul. Y que ésta no es un equipo de fútbol (como podrían pensar muchos niños hoy), sino una unidad de voluntarios españoles que se alistaron para luchar con los nazis durante la Segunda Guerra Mundial. De cualquier modo, es necesario abordar caso por caso, asumiendo que la controversia y la dilación en el proceso de toma de decisión sobre cada uno de los elementos materiales e inmateriales que nos lega ese pasado incómodo forman parte del trabajo de memoria que debemos realizar como sociedad. En este trabajo es fundamental nutrirse de las experiencias de otros países con retos similares. A fin de cuentas, podría decirse que la memoria democrática forma parte de un patrimonio global.

\section{BIBLIOGRAFÍA}

- CUÉ, C. E. (2002) El PP condena el golpe de Franco y promete honrar a todas las víctimas de la Guerra Civil. El País, 21 noviembre de 2002

- JELIN, E. (2014) Memoria y democracia. Una relación incierta. Revista Mexicana de Ciencias Políticas y Sociales [en línea desde 2015], vol. 59, n. ${ }^{\circ} 221$, pp. 225-41 <http://www. revistas.unam.mx/index.php/rmcpys/article/view/47707> [Consulta: $13 / 11 / 18]$

- MICHEL, J. (2015) Mémoire publique et mémoire collective de l'esclavage. Revue indisciplinaire de sciences sociales. Espacestemps.net [en línea], 12 de mayo de $2015<$ https://www. espacestemps.net/articles/memoire-publique-et-memoire-co Ilective-de-lesclavage/> [Consulta: 12/11/18]

- MISZTAL, B. A. (2001) Legal Attempts to Construct Collective Memory: The Necessity and Difficulties of Aiming for Both Truth and Solidarity. Polish Sociological Review, n. ${ }^{\circ}$ 133, 2001, pp. $61-75$ 


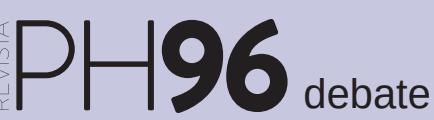

a debate Memoria democrática en la construcción de la historia y el patrimonio

| coordina Josefina Cuesta Bustillo

\title{
La exposición como medio de difusión y puesta en valor del papel de la mujer en el proceso de construcción de una memoria democrática
}

\author{
Jesica Serrano Granados | Universidad de Granada \\ URL de la contribución <www.iaph.es/revistaph/index.php/revistaph/article/view/4298>
}

Se entiende como memoria democrática el conjunto de aquellas acciones desarrolladas por los gobiernos de las diferentes comunidades autónomas de España para reivindicar a las víctimas de la guerra civil y del régimen franquista. Me gustaría tomar como punto de partida de esta aportación el último párrafo del texto introductorio de este debate "Solo cuando todos los españoles sean tratados por igual (...) solo cuando todas las clases de ciudadanos, también las ciudadanas y las minorías, y todas las memorias democráticas encuentren su hueco en las calles, en los monumentos, en los libros de texto, en el patrimonio inmaterial de nuestra cultura y de nuestras mentalidades, podremos hablar de una 'memoria en paz" con el fin de destacar la búsqueda de una igualdad real entre todos los ciudadanos y ciudadanas. En este sentido, si hablamos de memoria democrática creo de gran importancia dedicar un espacio en este debate al análisis de ciertas acciones que pretenden poner en valor a un colectivo que, en muchas ocasiones a lo largo de la historia, ha quedado relegado como es el constituido por las mujeres.

Las acciones que giran en torno a la recuperación de la memoria democrática se han llevado a cabo para reivindicar justicia hacia aquellas personas vinculadas con la lucha antifranquista que fueron represaliados durante la Guerra Civil española (1936-1930) y, posteriormente, por el régimen dictatorial (1939-1975). En este contexto, las mujeres constituyeron un colectivo que vio mermados sus derechos que hasta 1939 había conseguido a través de un proceso de lucha constante. Desde finales del siglo XIX hasta la II República, surgieron diferentes figuras que reivindicaron el feminismo en nuestro país y que especialmente durante los años del gobierno republicano vieron cumplidas muchas de sus reivindicaciones: el derecho al voto (1931), la ley de aborto y de divorcio (1936). A raíz del estallido de la Guerra Civil, las mujeres se organizaron en diferentes sectores para contribuir en la lucha antifascista accediendo a roles que hasta el momento habían sido relegados únicamente a los hombres. Al finalizar la guerra y la instauración de la dictadura, estas mujeres sufrieron una doble o triple represión basada no solo en su clase social o ideología política, sino también por el hecho de ser mujeres.

Reivindicar los avances de estas mujeres resulta fundamental para una democracia igualitaria en el presente. De esta manera, con el fin de desarrollar programas destinados a reivindicar su labor, hemos de partir de la difusión de esta parte de la historia, fundamental para crear conciencia de su importancia entre la sociedad. Por esta razón, a través de mi contribución me gustaría analizar la importancia de la exposición como medio de difusión. Desde el punto de vista patrimonial, es interesante utilizar la exposición como medio de comunicación y puesta en valor de nuestro colectivo, constituyendo el análisis documental de la labor expositiva un campo para la introducción de la perspectiva de género como categoría analítica.

El ejemplo en el que nos centraremos en este caso es la exposición titulada Las andaluzas y la política (19312006), organizada en el año 2006 con motivo de la celebración del 75 aniversario de la conquista del voto femenino por el Instituto Andaluz de la Mujer. Se trata de una exposición que toma como punto de partida la celebración del aniversario del sufragio universal en España en 1931 para desarrollar un análisis sobre los cambios de 


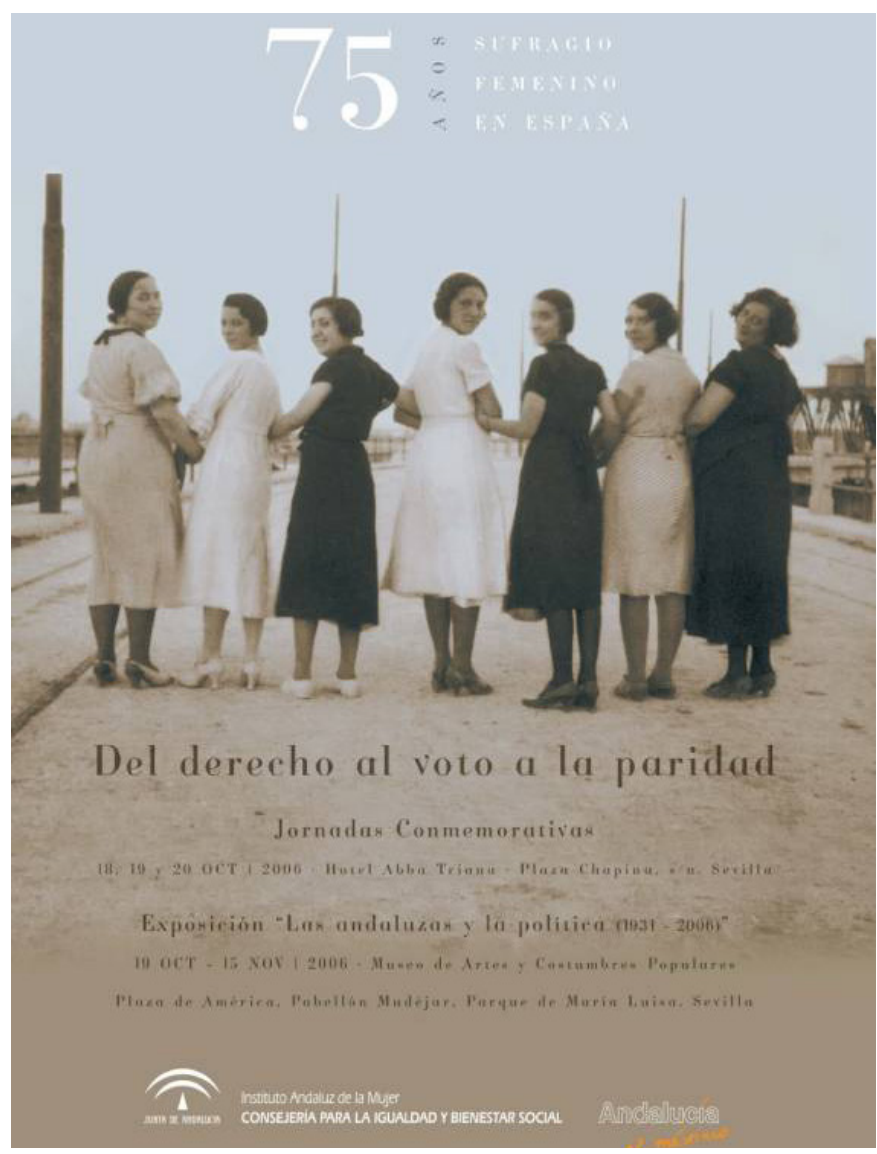

roles y los nuevos espacios a los que acceden las mujeres durante las primeras décadas del siglo XX, especialmente durante la II República, destacando el acceso a la educación y la política, aunque de forma muy restringida, y su posterior evolución durante la Guerra Civil, el régimen franquista y la transición.

Estos cambios en las relaciones de género, permitieron que tras el estallido del conflicto bélico en 1936 las mujeres se organizaran para contribuir en la lucha antifascista. La exposición pone de relevancia el cambio de roles y visibiliza el acceso de las mujeres a espacios atribuidos al género masculino como la miliciana en el frente, la mujer en armas, los puestos que ocupó en las fábricas desempeñado anteriormente por los hombres, así como aquellas que ocuparon puestos de secre- tario y dirección de diversas siglas políticas. Todas ellas, con la imposición del régimen dictatorial sufrieron una gran represión y vieron como de nuevo las relaciones de género de un cariz conservador que fueron implantadas por el régimen, las devolvían al rol de madre y cuidadora, limitada al hogar familiar.

El análisis mediante la perspectiva de género, nos permite observar cómo los roles desempeñados por hombres y mujeres se conforman a partir de una relación mutua en un contexto histórico y cultural concreto y, por lo tanto, permite destruir la consideración natural de las mismas. De ahí, su importancia para romper con las conductas de desigualad en el presente y comprender las que ocurrieron en la historia. Estas relaciones de género, al estar supeditas a un contexto cultural, se transforman fruto de cambios derivados de factores como el acceso a la educación y un contexto histórico marcado por un régimen político en buscar de una mayor igualdad, como podemos deducir del análisis de la exposición anteriormente citada.

A través de la crítica y el análisis de dicha exposición y otras muchas realizadas en torno a la mujer en la lucha por la democracia cabe destacar la importancia de aplicar la perspectiva de género a la hora de poner en valor el papel de las mujeres en el proceso de memoria democrática. La inclusión de la perspectiva de género, en este caso, nos permite asimismo observar como los pequeños cambios de roles basados en las diferencias de género, como el acceso a la educación, permiten cambiar las relaciones de género a niveles superiores, como el acceso a las cortes y, como consecuencia, el sufragio universal.

Para finalizar, me gustaría poner de relieve la importancia de iniciativas de difusión como la exposición Las andaluzas y la política (1931-2006) con el fin de ampliar su difusión a todos los sectores de la sociedad en tanto supone una labor fundamental para la concienciación de la sociedad hacia una memoria democrática igualitaria para todos los ciudadanos y ciudadanas. 


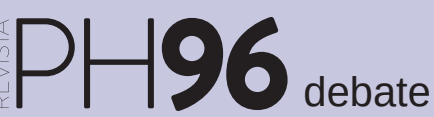

a debate Memoria democrática en la construcción de la historia y el patrimonio

| coordina Josefina Cuesta Bustillo

\title{
La memoria democrática como elemento de transformación ante la crisis de régimen
}

\author{
Daniel Martínez Castizo | historiador y antropólogo \\ URL de la contribución <www.iaph.es/revistaph/index.php/revistaph/article/view/4301>
}

Desde 2008, y sobre todo a raíz del movimiento indignado del 15M, el Estado español viene atravesando una crisis de régimen en el que amplios sectores progresistas de la sociedad cuestionan abiertamente las bases fundamentales de la Transición; esto es: monarquía, bipartidismo, partidos políticos, Constitución y organización territorial. Ello supone impugnar el relato dominante sobre el que dicho régimen se ha configurado y sostenido durante cuatro décadas (al socaire de la Ley de Amnistía y Pactos de la Moncloa), y a su vez, abrir espacio a la memoria democrática que fue silenciada durante el citado proceso histórico.

Para entender este último razonamiento, el de la impugnación del relato dominante a través de la crisis de régimen, hemos de partir del origen o construcción de la memoria de la Transición. La llamada reconciliación giró, principalmente, en torno a la "salvación" del establishment franquista, y no fue por puro capricho, sino porque para los Estados occidentales (Estados Unidos de América y Alemania), dicho grupo era un fiel aliado en el contexto de un mundo bipolar y, además, éstos estaban dispuestos a participar junto con los demócratas más moderados (apartando así a los grupos de izquierdas y progresistas) en la consolidación de un liberalismo democrático al estilo occidental capitalista.

Partiendo de esta premisa entendemos que dicho régimen, construido en base a un "olvido" de las violaciones de los Derechos Humanos de la dictadura, no fue creado para instalar una democracia como las que tras la segunda guerra mundial tuvieron como punto de partida (aunque posteriormente viraron hacia el liberalismo democrático) los principios de verdad, justicia y reparación. Con la Transición el Estado español pegaba un salto de "gigante" sin pasar por el trámite de hacer jus- ticia con el pasado más reciente, para instalarse así al nivel institucional y económico de los Estados europeos.

Dicho esto, y como planteaba al principio, debemos entender que la crítica a las bases del régimen conlleva irrevocablemente al enfrentamiento con la memoria hegemónica, de la misma forma que una crítica a dicha memoria supone enfrentarse a las bases económicas y políticas del régimen vigente. Esta cuestión estructural nos hace entender, no sin indignación, por qué las instituciones de la democracia española defienden desde 1978 el estatus quo obviando, una y otra vez, las peticiones de Naciones Unidas en las que se instan a condenar los crímenes del franquismo y anular las sentencias de sus tribunales.

Ello no ha impedido que desde su origen y hasta hoy, pese a tenerlo todo en contra, la memoria democrática haya subsistido gracias a la voluntariosa labor de los grupos y organizaciones memorialistas, así como, por qué no decirlo, de aquellos partidos políticos y sindicatos que no han perdido su condición de clase. Éstos han tenido que hacer frente, por una parte, a un contexto sociopolítico nada favorable, en el que las instituciones públicas estaban en manos de los mercados (conformado por muchos de los herederos de la élite franquista), y de otra, a una sociedad posmoderna que, con su actitud conformista, contempla la memoria democrática como una cuestión sectorial de un grupo determinado en un tiempo pasado.

Sabedores de todas estas dificultades, los grupos memorialistas reorientaron su lucha en dos ámbitos interrelacionados. Por una parte atender las demandas de las víctimas de dicha represión, y de otra, recuperar una memoria democrática que supere se apoye en los valores 
de la Segunda República en pos de un Estado defensor de la democracia y los Derechos Humanos. Hablamos, por supuesto, de una memoria en plural, transversal y construida desde abajo, que atienda a todos los sectores sometidos por el golpe militar, la dictadura y la represión.

Por todo ello y, hablando del presente contexto de crisis, debemos entender que hablar de memoria democrática y todo lo que ello conlleva en el ejercicio de su práctica, no es, como nos lo intentan hacer ver el establishment, ni un gesto casual ni oportunista. No es casual porque cualquier cuestionamiento de un régimen, sea éste de la ideología que sea, conlleva una crítica a su memoria, es decir, al discurso que da forma a su identidad nacional en torno a elementos seleccionados del pasado. Así las cosas, la crisis actual de régimen en el Estado español no puede escapar a la crítica de la memoria de la Transición.

Pero tampoco se puede acusar de oportunistas a los movimientos memorialistas o grupos políticos que intentan dar pasos hacia la recuperación de la memoria democrática aunque sea a través de pequeñas victorias-, puesto que ellos llevan décadas de lucha a contra corriente y, lo que se les presenta ahora como crisis, es una pequeña luz que les permite hacer visible las reivindicaciones.

La fórmula que se plantea en este momento histórico es más que evidente, y dice que: a mayor profundidad de la crisis mayor margen de maniobra para la memoria democrática y, a mayor margen de maniobra para la memoria democrática menos democracia liberal y economía de mercado o régimen. Y esta simpleza, que no significa otra cosa que ver a la memoria democrática como un elemento de transformación ante la crisis, es contemplada con miedo y estupor por el poder establecido y, por el contrario, con esperanzas por los amplios sectores progresistas descontentos con los resultados de la Transición.

De este razonamiento también deducimos que es estructuralmente imposible construir una memoria democrática (plural, transversal y construida desde abajo), sin acabar con el régimen actual. El resultado de cualquier acción que diga llevar el nombre de memoria democrática, y no suponga una alternación del status quo (como la llamada Ley de Memoria Histórica de 2007), no puede ser considerada como tal, pues dicha memoria debería chocar, como lo hacen los polos opuestos, contra el relato homogéneo y hegemónico del poder.

En resumidas cuentas, ante la crisis de régimen la memoria democrática es, desde el punto de vista estructural, un elemento de transformación del liberalismo democrático y la sociedad de consumo. 


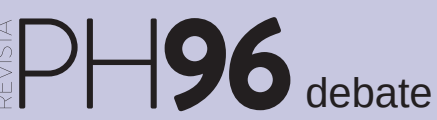

a debate Memoria democrática en la construcción de la historia y el patrimonio

| coordina Josefina Cuesta Bustillo

\title{
Memoria histórica y democrática con perspectiva de género
}

\author{
M. ${ }^{\text {a }}$ Cristina Ferrer González | docente e investigadora \\ URL de la contribución <www.iaph.es/revistaph/index.php/revistaph/article/view/4297>
}

El relato del devenir histórico ha llegado sesgado, incompleto e incluso, falseado, debido a que sistemáticamente se ha ignorado, negado o manipulado la aportación de las mujeres en la construcción del conocimiento y del desarrollo socioeconómico, tanto en el ámbito de la ciencia, la literatura, el arte o la historia. En consecuencia, la construcción de su memoria colectiva ha sido mermada, y sin lugar a dudas, esta exclusión obliga, no a escribir una nueva historia, sino a reconocer, incorporar, visibilizar y difundir toda su aportación. Ponerla en valor.

En su artículo 20, la Ley de Memoria Histórica y Democrática de Andalucía establece, como prioritaria, la investigación y pone el acento en aquella que tiene la mujer como protagonista, en un gesto de discriminación positiva, para compensar la invisibilidad en el relato histórico e incluso en el discurso de la Transición democrática.

Las mujeres tuvieron una vinculación importante con los movimientos sociales, civiles, obreros y políticos, entre otros. Pagaron un plus por representar los nuevos modelos de feminidad, más cercanos a la igualdad real, que rompían con los paradigmas tradicionalistas. En cualquier sociedad, y en la nuestra también, romper moldes, normas o estereotipos es una acto de heroicidad, y por ello sufrieron doble victimización, la de su ideología y la de ser mujer, dado que se querrá imponer un modelo patriarcal y único de ser mujer. Los castigos de género son comunes e inherentes a todo conflicto bélico y suponen un mayor grado de violencia contra las mujeres, que abarca desde la violencia sexual a la física y psicológica, pasando por las humillaciones y vejaciones.

La memoria histórica y democrática de un pueblo es un auténtico patrimonio material e inmaterial donde los recuerdos adquieren voz, los miedos se sienten, las ilu- siones se dibujan, las experiencias se comparten, se identifican, se respetan y se reivindican y donde los silencios obligados alzan su voz recuperando su identidad. El recuperar la memoria histórica y democrática con perspectiva de género es un acto de justicia, un deber, no solo de las instituciones políticas o gobiernos sino de las históricas, culturales y sociales, implicando a la ciudadanía en esa incorporación, con el objetivo firme de la recuperación y reparación de ese colectivo más velado.

No considero que recuperar y poner en valor una memoria implique el olvido de otras, y mucho menos que incorporar el género a los estudios e investigaciones sea infravalorar la aportación masculina. Sino más bien, como decía Montserrat Roig, cuando hablaba de las grandes silenciadas de la Segunda República, así se sustituye el tiempo de silencio por el tiempo de la palabra.

En la última década son muchos los trabajos que contemplan, relatan y vivencian la memoria democrática desde un perspectiva inclusiva, incorporando colectivos que, anteriormente, no eran tenidos en cuenta o eran tratados de manera muy marginal como son el colectivo de mujeres, el de migrantes y extranjeros, colectivos de diversidad cultural, sexual o religiosa. Antes se relataba más la memoria unilateral, patriarcal, heterosexual y con hegemonía de la Iglesia Católica.

Jorge Wagensberg afirmó que "Cambiar de respuesta es evolución. Cambiar de pregunta es revolución". Quizás es el momento de cambiar la pregunta. 


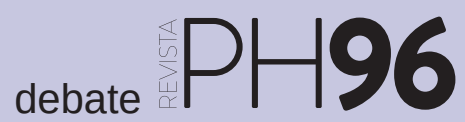

a debate Memoria democrática en la construcción de la historia y el patrimonio

| coordina Josefina Cuesta Bustillo

\section{El futuro de la memoria}

Carlos Barros | Red Académica Internacional Historia a Debate

URL de la contribución <www.iaph.es/revistaph/index.php/revistaph/article/view/4306>

La memoria histórica es un joven movimiento social, político y académico: no llega a 20 años de vida, si bien se refiere a hechos represivos que tuvieron lugar hace 80-40 años ${ }^{1}$. Iniciado en León en el año 2000 por familiares de inocentes fusilados por sus ideas y creencias democráticas, durante la Guerra Civil y el franquismo, no ha dejado de desarrollarse hasta hoy, buscando y encontrando siempre vías de actuación de ámbito local, regional, nacional e internacional, cuando los cambios electorales en las correspondientes instituciones públicas ponen en sordina las políticas de la memoria.

En el siglo XXI, la memoria histórica ha pasado en España por momentos de avance y de retroceso (y así será probablemente en el futuro), como una espiral que gira a izquierda y a derecha sin dejar de subir... En 2007, se promulga por parte del Gobierno Zapatero una Ley de Memoria Histórica que, pese a sus limitaciones, permitió llevar a cabo excavaciones de fosas y eliminaciones de símbolos del franquismo; cuatro años después, fue paralizada por el Gobierno Rajoy. En 2008, desde la Audiencia Nacional surge el histórico auto de Garzón para la persecución de los delitos de asesinato, tortura y demás crímenes de motivación política cometidos por las franquistas, sus instituciones y sus órganos represivos, entre 1936 y 1952; posteriormente neutralizado, por una mafia político-judicial que logró, en 2012, expulsar por nueve años a Baltasar Garzón de la judicatura. Entre 2011 y 2018, los Gobiernos del PP enterraron bajo llave la primera Ley de Memoria Histórica, so pretexto de la crisis económica (!). Así y todo, hubo en esta segunda década del nuevo siglo importantes progresos, al margen del Gobierno de Rajoy y su partido: A) Toma fuerza la causa contra el franquismo iniciada en 2010 por la jueza argentina María Servini, en razón del principio de jurisdicción universal; incluye el delito de tortura y amplía la pesquisa prevista por Garzón hasta la implantación de la democracia. B) Las comunidades autónomas no gobernadas por el PP han continuado apoyando la excavación de fosas, señaladamente Andalucía, y otras políticas de memoria amparadas por la Ley de Zapatero. C) El Gobierno vasco decreta en 2012 una Ley de Abusos Policiales $^{2}$ durante el franquismo, centrada en dar a conocer las desapariciones, los asesinatos y las torturas entre 1960 y 1978; también complementa cronológicamente el -por el momento- desautorizado pero justo auto del juez Garzón.

El éxito de la moción de censura del 1 de junio de 2018 que desplazó el Gobierno de Rajoy dando paso al Gobierno de Sánchez, con el apoyo de Podemos y los grupos nacionalistas, ha trazado un nuevo horizonte para el movimiento de la memoria. Se está demostrando que en España es posible una nueva mayoría parlamentaria que implemente políticas avanzadas de memoria histórica. Lo que no quiere decir que el día de mañana sucedan nuevos pasos atrás, políticamente hablando, que impulsen a su vez otros pasos adelante. Sobra añadir que las medidas que se han tomado o se puedan ir tomando, como la excavación de tumbas o el traslado de la tumba del dictador, tendrán después difícil marcha atrás, gobierne quien gobierne.

El nuevo gobierno socialista acaba de decidir la exhumación de Franco del Valle de los Caídos; anunció asimismo otras medidas todavía más importantes, reformando y ampliando la sobrepasada Ley de Memoria Histórica de 2007, todas ellas han sido cogidas del movimiento memorialista. Por ejemplo: incluir la exaltación del franquismo en el código penal; anular las sentencias de los tribunales franquistas; que el Estado, y no las familias, asuma de oficio las exhumaciones de las víctimas de franquismo; retirada de medallas y prebendas al torturador Billy el Niño; creación de una Comisión de $\operatorname{Verdad}^{3}$ (propuesta 
a debate Memoria democrática en la construcción de la historia y el patrimonio

| coordina Josefina Cuesta Bustillo

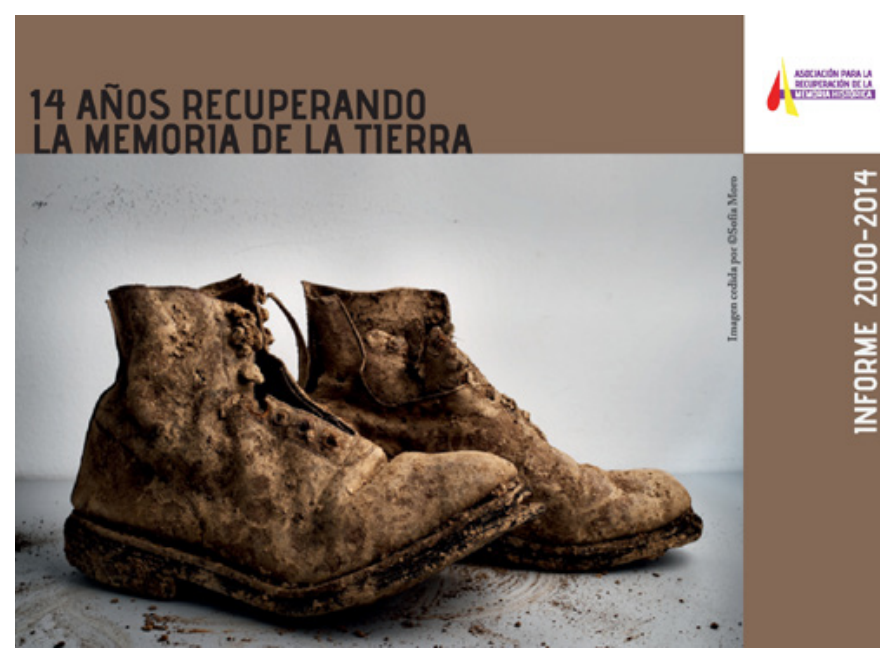

por Garzón en 20164) sobre el franquismo (1936-1978) para investigar la represión y obtener los testimonios de miles de víctimas, siguiendo el ejemplo de otros países (Sudáfrica, Argentina, Chile, Perú, Colombia, Bolivia, Guatemala, Brasil...) que también sufrieron dictaduras o conflictos armados y van por delante de España en sus respectivas transiciones a la democracia.

Como historiadores resulta incongruente que hayan surgido voces de colegas que consideramos progresistas, opuestos - por contrarios a la memoria histórica- 0 simplemente reticentes -fruto del desconocimiento, pensamos- a la formación por parte del Gobierno socialista de una Comisión de la Verdad para España. Obvian lamentablemente el salto de gigante que supondrá para la verdad histórica sobre la guerra y el franquismo, en especial para las nuevas generaciones y la no-repetición, saberlo todo de la criminalidad política entre 1936 y 1977. Implicaría además un avance trascendental en el cumplimiento de la vigente norma del derecho internacional que exige "verdad, justicia y reparación" para las víctimas de los delitos imprescriptibles de lesa humanidad. Historia y memoria no son antitéticos, como objeta el academicismo positivista (BARROS, 2013; 2016), tienen el deber de colaborar en su objetivo común: conocer la verdad histórica, que ha de publicitarse sin censuras ni temores fantasmales.
La decisión gubernamental de retirar a Franco del Valle de los Caídos ha hecho emerger, 80 años después de Guerra Civil, el franquismo sociológico oculto ${ }^{6}$, lo que nos permite cuantificar -aproximativamente- su nefasta influencia en la situación política actual. Solo un 29,9\% de los españoles encuestados estaba de acuerdo, en agosto de $2018^{7}$, en dejar como está el Valle de los Caídos. Un fenómeno minoritario, por tanto, que explica y posibilita el éxito de las presentes políticas públicas de la memoria del PSOE y Podemos.

El problema reside en que el $60 \%$ de los electores del PP y el $35 \%$ de los electores de Ciudadanos forman parte de esa minoría filo-franquista. Lo cual conduce a la derecha española, vieja y nueva, a enfrentarse a la memoria histórica y a mantener posiciones notoriamente conservadoras en todo lo relativo al desarrollo y actualización de la democracia en España. Posición inmovilista que no cederá hasta que esta nueva mayoría parlamentaria de progreso se estabilice y complete el Estado de derecho heredado de una Transición limitada por las circunstancias.

El 30\% o más -el auge global de la ultraderecha retroalimenta ahora la tradición franquista- del electorado español seguirá siendo franquista mientras eso esté permitido por un Estado democrático -y alentado por una derecha que ha abandonado el centro- que conserva todo tipo de secuelas del régimen totalitario en las cunetas, las calles, los edificios, las leyes, las instituciones y las mentalidades. La democracia dejará de estar bloqueada en su progreso cuando rebase plenamente el defecto originario, devenido estructural, causado por la ausencia de ruptura democrática en una transición tutelada por unas Fuerzas Armadas salidas del bando ganador de la Guerra Civil, sostenido por Hitler y Mussolini, de lo que quedan restos de fidelidad al "generalísimo" -solamente entre militares retirados, al parecer- como acaba de demostrarse a partir de la decisión gubernamental de exhumar a Franco ${ }^{8}$.

Como se dice coloquialmente: despacio que tengo prisa. Urge poner en práctica las medidas pro-memoria histó- 
rica más arriba enumeradas, sin perder de vista estratégicamente lo ineludible: Garzón tenía razón hace 10 años cuando quiso dar justicia a las víctimas del franquismo, "verdad, justicia y reparación", por este orden. Aprendamos de las experiencias ajenas. En Brasil funcionó entre 2011 y 2014, una Comisión de la Verdad ${ }^{9}$ $y$, en 2018, gana las elecciones Bolsonaro, derechista extremo y admirador de la dictadura 1964-1985. En Argentina, sin embargo, donde se creó la primera Comisión de la Verdad en 1983, se juzgaron a los represores, impidiendo de este modo que surgiera después un seguidor de Videla que pretendiera destruir la democracia desde dentro, como Hitler en 1933. Una democracia sin memoria es una democracia débil.

\section{NOTAS}

1. El genocidio armenio perpetrado por el Estado turco sucedió hace más de un siglo; solamente 29 países lo han reconocido hasta ahora -España no, por supuesto-. El movimiento memorialista del pueblo armenio sigue vivo, como se ve en la jornada mundial de cada 24 de abril...

\section{2. http://noticias.juridicas.com/base_datos/CCAA/pv- d107-2012.html}

3. Documento de la ONU para la formación de Comisiones de la Verdad, 2006: https://www.ohchr.org/Docu ments/Publications/RuleoflawTruthCommissionssp.pdf

\section{4. https://www.eldiario.es/andalucia/Baltasar-Garzon-Co mision-Verdad-franquismo_0_494501027.html}

\section{5. https://elpais.com/politica/2018/09/01/actualidad/1535 807558_045822.html}

6. Franquismo residual de tradición familiar que ha sido alimentado, desde 1977, por Alianza Popular que ha dado lugar, una vez desaparecida la UCD, al Partido Popular en 1989.
7. http://electomania.es/electopanel-agosto-i-los-espa noles-exhumarian-a-franco-y-convertirian-el-valle-delos-caidos-en-un-museo/

8. https://www.eldiario.es/politica/militares-retirados-ma nifiesto-Franco-vilipendiada_0_798621021.html

9. Informe final de la Comisión de la Verdad brasileña: http://cnv.memoriasreveladas.gov.br/

\section{BIBLIOGRAFÍA}

- BARROS, C. (2013) Historia, memoria y franquismo [en lí nea], 2013 <http://www.h-debate.com/wp-content/old-debates/ cbarros/spanish/articulos/memoria/Historia_memoria_y_ franquismo.htm> [Consulta: 15/11/2018]

- BARROS, C. (2016) El historiador y la memoria [en línea] En II Jornadas internacionales sobre memoria y comunicación "Las políticas de memoria histórica en Europa", Facultad de Geografía e Historia, Universidad de Sevilla, 28 de noviembre de 2016 <https://youtu.be/QaMQSdWdKJo> [Consulta: 15/ $11 / 2018]$ 


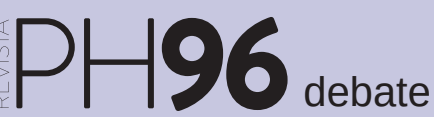

a debate Memoria democrática en la construcción de la historia y el patrimonio

| coordina Josefina Cuesta Bustillo

\title{
Compromiso democrático, patrimonio y memoria en la enseñanza de la historia
}

\author{
Emilio José Delgado-Algarra | Centro Académico y Cultural de Asia Oriental, Dpto. de Didácticas Integradas, Universidad de \\ Huelva
}

URL de la contribución <www.iaph.es/revistaph/index.php/revistaph/article/view/4303>

Agradeciendo de antemano la invitación para participar en tan interesante e imprescindible debate. Tras la lectura del resto de intervenciones incluidas hasta el momento y en relación con algunos resultados del proyecto de investigación "Educación Patrimonial para la Inteligencia Territorial y Emocional de la Ciudadanía" (EPITEC), financiado por el Ministerio de Economía y Competitividad (EDU2015-67953-P), con la cofinanciación de los fondos FEDER de la Unión Europea, voy a participar en el mismo desde el enfoque de una didáctica de las ciencias sociales comprometida y posicionándome a favor de la enseñanza de una historia con memoria donde se eduque para una ciudadanía informada, participativa, crítica y orientada a la justicia social. Así pues, desde un planteamiento de escuela entendida como motor de cambio social, se plantea como necesaria la selección, secuenciación y construcción de contenidos escolares partiendo de problemas actuales e históricos relevantes, el conocimiento cotidiano de los estudiantes (conocimientos previos y dificultades reales) y el conocimiento disciplinar que debe saber el docente para poder enseñar (ESTEPA, 2007). Como indica Aróstegui (2004), podemos hablar de tres fases de la memoria oficial en España: memoria de la exaltación, que abarca desde el final de la Guerra Civil española (1939) hasta el fallecimiento de Francisco Franco (1975); memoria de la reconciliación, que abarca desde la muerte de Francisco Franco hasta mediados de los 90 del siglo XX; y memoria de la reparación, que abarcada desde mediados de los 90 del siglo XX hasta la actualidad.

En plena etapa de memoria de la reparación, y ante la ruptura parcial que se produjo con el franquismo durante el proceso de transición a la Democracia, resulta necesario que en el contexto escolar se ofrezca al alumnado las herramientas necesarias para buscar, analizar y comprender la existencia de resquicios de la dictadura en el contexto urbano. La actividad no se encuentra exenta de dificultades, entre las que podemos resaltar la existencia de una serie de puntos ciegos en la Ley de Memoria Histórica que afectan al reconocimiento de algunos posibles resquicios del franquismo; puntos ciegos que introduce Rina Simon en el debate de este número. Es por ello que la enseñanza de una historia con memoria debe contar con orientación de un docente suficientemente formado al respecto $y$, en la medida de posible, involucrado en equipos para la recuperación de las memorias. Considerando la memoria como un asunto que genera controversia y volviendo a la importancia de la formación docente de cara a hacer frente a temáticas controvertidas en el aula, las investigaciones de Waterson (2009) y Yeager y Humphries (2011) destacan que a una buena parte del profesorado no se le ha enseñado a enseñar, a lo que se suma el hecho de que siga existiendo cierto temor a abordar temas controvertidos por temor a la reacción de la comunidad educativa. En este sentido, parece existir un tabú que es necesario superar desde la propia escuela, institución que tiene la corresponsabilidad de educar en democracia a las nuevas generaciones de ciudadanos. En otras palabras, superar dicho tabú desde la escuela resulta imprescindible para potenciar las funciones normalizadora y reparadora de la enseñanza de la historia y de las ciencias sociales en relación con las memorias en conflicto.

En consonancia con algunas de las aportaciones que se han sumado a lo largo de este debate, y desde un enfoque multidimensional, podríamos definir la memoria como "un recuerdo cargado de valores subjetivos relacionados con los momentos conflictivos de nuestra historia 


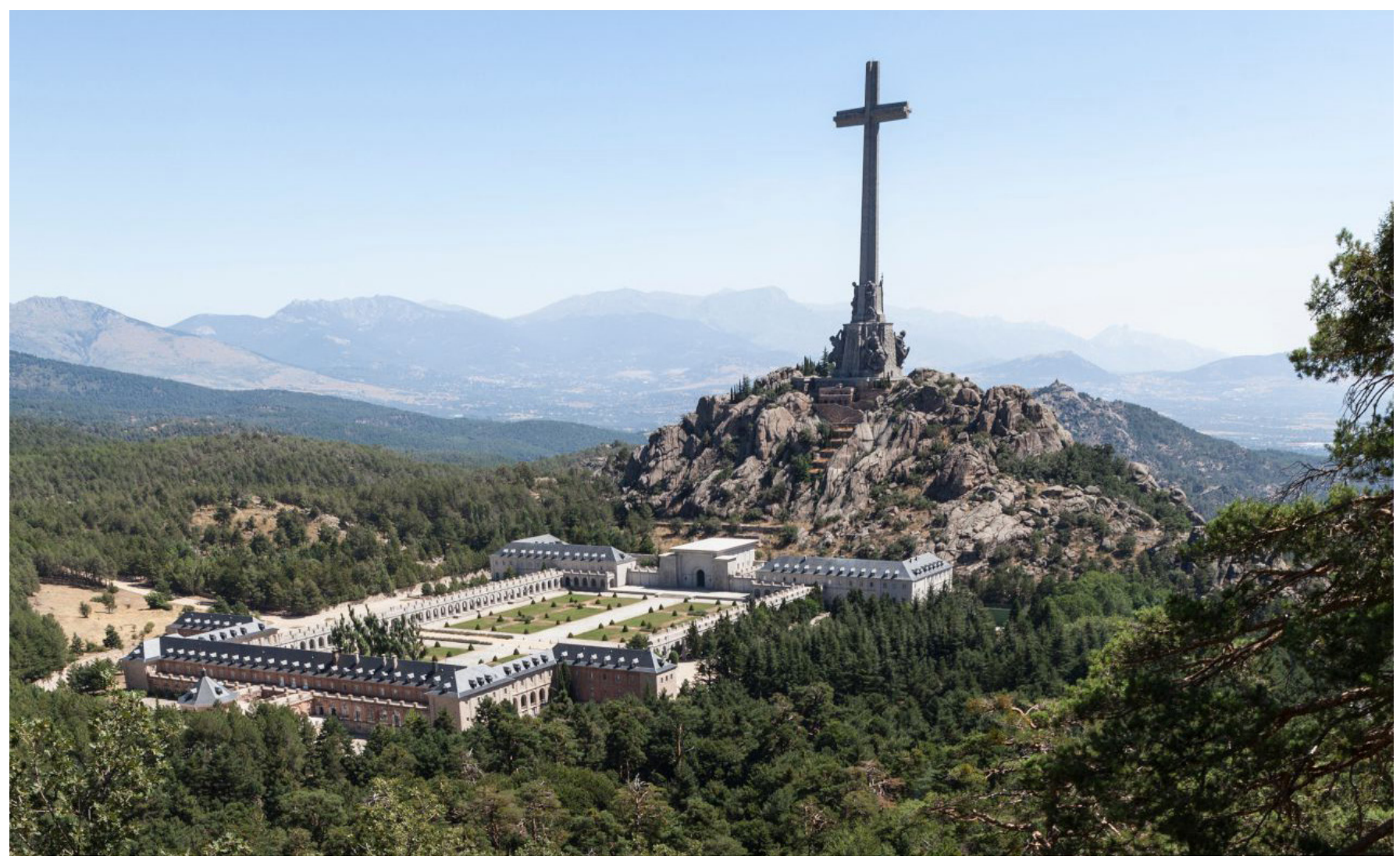

El Valle de los Caídos | foto Lahcène Abib pour Le Parisien Week End (LANGLOIS, 2018)

reciente, definiéndose a raíz de la experiencia personal de cada individuo en el seno de un grupo social determinado" (DELGADO-ALGARRA; ESTEPA-GIMÉNEZ, 2016: 523). De este modo, para analizar y comprender las memorias en el contexto escolar y en relación con la enseñanza de la historia, entran en juego 5 dimensiones claramente diferenciadas y a las que resulta necesario atender (CUESTA, 2011): individual, social, histórica, conflictiva y selectiva. Un ejemplo paradigmático de problemática donde se entrelazan patrimonio y memoria dentro de contexto español es el del Valle de los Caídos, en torno al cual, antes de la retirada de los restos de dictador, existen dos posturas irreconciliables: la de los que lo entienden como un lugar de paz y de oración por los caídos durante la Guerra Civil; y la de los que lo ven como medio propagandístico del régimen dictatorial de Franco. Con idea de establecer una analogía compara- tiva donde quede constancia de que este tipo de polémicas no es exclusiva de España, en contexto japonés, nos encontramos con espacio del Santuario Yasukuni, en torno al cual, los recuerdos de la guerra han contribuido a la internacionalización del conflicto mnemónico en tres etapas que van desde las disputas internas en torno a la labor de control llevada a cabo por el sistema de aprobación de los libros de texto hasta la internacionalización de la polémica suscitada desde 2001 al autorizarse textos escolares de historia revisada que, pese a ser de uso minoritario, rechaza la enseñanza de una historia considerada "no japonesa" (DELGADO-ALGARRA, 2018).

En líneas generales, la investigación ha puesto de manifiesto el potencial que la recuperación de las memorias tiene para la enseñanza de una historia que contribuye 


\section{a debate Memoria democrática en la construcción de la historia y el patrimonio \\ | coordina Josefina Cuesta Bustillo}

al compromiso con la democracia. El patrimonio, igualmente, se convierte en portador de memorias en conflicto. En este sentido, para fomentar desde la escuela el compromiso ciudadano con la Democracia, en términos metodológicos, se considera que, en la enseñanza de la ciencias sociales y de la historia, es importante partir de problemas socioambientales relevantes de la actualidad y fomentar la comprensión y el compromiso con los mismos a través de la historia. Para que esto sea posible, el docente debe tener una formación específica que le permita atender a las controversias sociohistóricas que puedan surgir o que se puedan plantear dentro del aula; ya que, en líneas generales, la atención a las memorias (como fuente de la historia) en sus cinco dimensiones, contribuye a la educación para una ciudadanía democrática, informada y participativa, comprometida con el presente, conocedora de su pasado y consciente de su futuro.

\section{BIBLIOGRAFÍA}

- ARÓstegul, J. (2004) La historia vivida. Madrid: Alianza Editorial, 2004

- CUESTA, R. (2011) Historia con memoria y didáctica crítica. Con-ciencia Social, n. ${ }^{\circ} 15,2011$, pp. 15-30

- DELGADO-AlgARRA, E. J.; ESTEPA-GIMÉNEZ, J. (2016) Ciudadanía y memoria histórica en la enseñanza de la historia: análisis de la metodología didáctica en un estudio de caso en ESO. Revista de Investigación Educativa, n. ${ }^{\circ} 34$ (2), 2016, pp. 521-534

- DELGAdO-AlgARRA, E. J. (2018) Education for Citizenship and Social Studies in Japan: Historical Evolution and Challenges for a Cosmopolitan Identity. En PINEDAALFONSO, J. A.; DE ALBA-FERNÁNDEZ, N.; NAVARROMEDINA, E. (ed.) Handbook of of Research on Education for Participative Citizenship and Global Prosperity. United States: IGI Global, 2018

- ESTEPA, J. (2007) Investigando las sociedades actuales e históricas. Proyecto curricular Investigando Nuestro Mundo (6 -12). Sevilla: Diada Editora, 2007

- LANGLOIS, B. (2018) Espagne: la dépouille de Franco bientôt

retirée de son mausolée? LeParisien, 20 de octubre de 2018 $<$ http://www.leparisien.fr/international/espagne-la-depouillede-franco-bientot-retiree-de-son-mausolee-13-08-2018-78519 84.php> [Consulta: 29/01/2019]

- WATERSON, R. A. (2009) The examination of pedagogical approaches to teaching controversial public issues: Explicitly teaching the Holocaust and comparative genocide. Social Studies Research and Practice, n. ${ }^{\circ} 4$ (2), 2009, pp. 1-24

- YEAGER, E.; HUMPHRIES, E. K. (2011) A Social Studies teacher's sense making of controversial issues discussions of race in a predominantly white, rural high school classroom. Theory and Research in Social Education, n. ${ }^{\circ} 39$ (1), 2011, pp. 92-134 


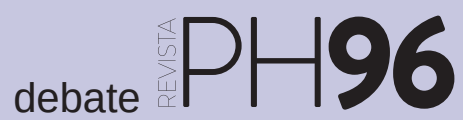

a debate Memoria democrática en la construcción de la historia y el patrimonio

| coordina Josefina Cuesta Bustillo

\section{Memoria, patrimonio y ciudadanía: una contribución desde una perspectiva didáctica}

Jesús Estepa Giménez | Dpto. de Didácticas Integradas, Universidad de Huelva

URL de la contribución <www.iaph.es/revistaph/index.php/revistaph/article/view/4299>

Cuando la revista me invitó a participar en este debate, entendí que lo que se esperaba de mí era una aportación desde una perspectiva educativa, pedagógica, o mejor didáctica y, en particular, de la didáctica de las ciencias sociales, área de conocimiento de la que soy profesor e investigador. Entiendo que tanto en algunas preguntas para el debate, como en el texto que lo presenta y en varias de las contribuciones que he podido leer, cabe el aporte de esta perspectiva, que puede facilitar una auténtica participación de la ciudadanía en la gestión y conservación de la memoria y de sus lugares/ espacios patrimoniales.

En lo que se refiere a las relaciones entre patrimonio, memoria y educación ciudadana, proponemos (ESTEPA; MARTÍN-CÁCERES, 2018) trabajarlas en el aula y en la formación inicial y permanente del profesorado mediante lo que denominamos antipatrimonio, uno de los subtipos de los que tratamos como patrimonios en conflicto. Con esta última denominación nos referimos a cuando el docente selecciona elementos patrimoniales no por sus valores estéticos o medioambientales, sino en atención a diversas causas que suscitan conflicto, ya sea de carácter ideológico, político, económico, carácter medioambiental o por interacción entre ellos. Esta selección intencionada tiene como fin propiciar en el alumnado habilidades y capacidades características del pensamiento crítico, la preocupación por estar y por permanecer bien informado, saber diferenciar hechos de opiniones, valorar la información y distinguir los intereses que favorecen cada opción, mantener la mente abierta para ser capaz de considerar puntos de vista divergentes al propio, tener flexibilidad para considerar alternativas y opiniones, honestidad para encarar los propios prejuicios, estereotipos y tendencias egocéntricas y/o sociocéntricas, $y$, por último, posicionamiento reflexivo para valorar los dilemas entre las tradiciones y la ética.

Con la enseñanza del antripatrimonio en particular, se trata de no olvidar las atrocidades cometidas en las guerras y en los conflictos violentos entre ciudadanos de un país o de varios países, constituyendo el patrimonio que engendraron otro elemento para educar históricamente en una ciudadanía no violenta, crítica y democrática. De este modo, se pueden establecer vínculos emocionales con las víctimas de esta barbarie, torturadas, asesinadas, represaliadas, marginadas o exiliadas, a través de las visitas presenciales/virtuales, historia oral o el análisis de documentación, preferentemente audiovisual, de los campos de concentración y exterminio nazi, como Dachau, Mauthausen y Auschwitz; las cárceles donde se ha torturado a presos políticos o miembros destacados de una etnia o confesión religiosa; los cementerios de víctimas de la I o II Guerra Mundial; Ios museos/centros de interpretación de la Inquisición; los centros de interpretación sobre el cambio climático, el genocidio judío, de la Paz en Guernika, de la Memoria y los Derechos Humanos en Santiago de Chile y Buenos Aires, o el Hirosima Peace Memorial Museum.

En el caso de España, la política sistemática contra la memoria histórica ha provocado la no consideración de cualquier patrimonio que pueda poner en cuestión el pasado franquista. Sin embargo, desde nuestra perspectiva, en la construcción de una historia con memoria, se debe trabajar con el alumnado -y no evitar por "falta de tiempo"- contenidos que van desde la Segunda República, pasando por la Guerra Civil, hasta la posguerra, incluyendo la implantación de la Dictadura, la violación sistemática de los derechos humanos de los vencidos, los desaparecidos, torturados, exiliados, pre- 
a debate Memoria democrática en la construcción de la historia y el patrimonio

| coordina Josefina Cuesta Bustillo

sos políticos, la expropiación de bienes, la represión de toda protesta, como parte de un proceso de educación para una ciudadanía crítica y comprometida con la memoria democrática de su pasado, los problemas del presente y la construcción de su futuro.

Así, tomando como ejemplo el Valle de los Caídos, una vez exhumados los restos de Franco y trasladados fuera del recinto, esta construcción debería reconvertirse en un memorial de las víctimas, no solo de la Guerra Civil, sino principalmente de la represión posterior. Solo así, podría considerarse un elemento patrimonial por los vínculos emocionales que se pueden establecer con las víctimas del franquismo. Como señalamos en un trabajo anterior sobre este monumento (DELGADO-ALGARRA; ESTEPA, 2014), este espacio alberga una serie de construcciones en torno a las cuales se genera una interpretación de la memoria dependiente del posicionamiento ideológico de los ciudadanos, de los usos que se hacen de los mismos y de los objetivos implícitos en cada posicionamiento. El profesorado tendría entonces en este elemento patrimonial un potente recurso didáctico para facilitar el análisis de la pluralidad mnemónica y de los intereses políticos e ideológicos implícitos en el mismo, de cara a educar a ciudadanos críticos y democráticos.

A modo de conclusión de esta breve aportación, reivindicamos que la educación puede suponer una contribución relevante para trabajar la memoria y sus huellas y testimonios a través del patrimonio. La atención en las víctimas, los disidentes, los olvidados, los vencidos y en los lugares de la memoria, significa otra manera de hacer historia y de enseñarla constituyendo un potente recurso didáctico, por un lado, en relación con los contenidos conceptuales, procedimentales y actitudinales y las competencias, como la empatía histórica, el trabajo con fuentes primarias y secundarias, la inteligencia emocional, la educación patrimonial y habilidades de pensamiento crítico y de análisis. Por otro lado, porque ante el empleo muy generalizado en la didáctica de la Historia de una metodología tradicional basada en la memorización de contenidos (ESTEPA, 2017), el tratamiento de estos temas controvertidos en el aula desde una posición de imparcialidad comprometida del docente hace necesario el uso de una metodología menos transmisiva por parte del profesorado y más activa en lo que se refiere al alumnado, para evitar el adoctrinamiento ideológico y favorecer actitudes reflexivas y críticas. Con estos nuevos contenidos y esta metodología más motivadora, se podrá alcanzar en la educación de los estudiantes un mayor compromiso con el presente, la comprensión de sus vínculos con el pasado y la reflexión sobre las posibles consecuencias que tienen determinados hechos y acciones en el futuro.

\section{BIBLIOGRAFÍA}

- DELGADO-AlgARRA, E. J.; ESTEPA, J. (2014) El Patrimonio como huella de la memoria histórica: análisis didáctico de dos monumentos en España y Japón. Clio: history and history teaching, n. ${ }^{\circ} 40,2014$

- ESTEPA, J. (2017) Otra didáctica de la Historia para otra Escuela. Huelva: Servicio de Publicaciones de la Universidad de Huelva, 2017

- ESTEPA, J.; MARTíN-CÁCERES, M. (2018) Competencia en conciencia y expresiones culturales y educación histórica. Patrimonios en conflicto y pensamiento crítico. En GÓMEZ CARRASCO, C. J.; MIRALLES, P. (coord.) La educación histórica ante el reto de las competencias. Métodos, recursos y enfoques de enseñanza. Barcelona: Octaedro, 2018, pp. 75-86 


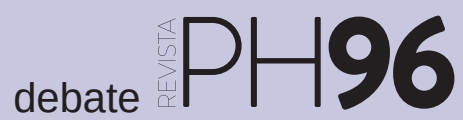

a debate Memoria democrática en la construcción de la historia y el patrimonio

| coordina Josefina Cuesta Bustillo

\section{El olvido está lleno de memorias: memorias y patrimonios de nuestro pasado reciente}

Andrea Moreno Martín | gestora de patrimonio cultural en el Ayuntamiento de Quart de Poblet

URL de la contribución <www.iaph.es/revistaph/index.php/revistaph/article/view/4309>

"Hay que recuperar, mantener y transmitir la memoria histórica porque se empieza por el olvido y se acaba por la indiferencia..." J. Saramago

Aunque parezca evidente, merece la pena matizar que no es lo mismo la historia que la memoria ${ }^{1}$. Sin embargo, en la naturaleza de esta última, el pasado histórico y el patrimonio son un elemento clave; pues en los procesos de construcción de las memorias, igual que ocurre con los patrimonios, el quid de la cuestión se centra en concretar qué merece o no ser recordado y quién tiene la potestad y la autoridad de decidir qué se olvida y qué se recuerda (CANDAU, 2002; RICOEUR, 2003; JELIN, 2012).

Con el paso del tiempo, los discursos políticos de la historia se reformulan o incluso se alteran. $Y$ aunque los hechos y la historia son los que son, a menudo la historia, como dijo Winston Churchill, la escriben los vencedores. Así sucedió en España, cuando los golpistas del 1936 acabaron con la legalidad y la democracia republicana y, autoproclamados "los nacionales", liberaron a la patria. En esa nueva España franquista, el final de la guerra no trajo la paz sino la victoria y el nacionalcatolicismo. Una victoria que durante cuatro décadas fue la esencia de las políticas de identidad, memoria y represión de la dictadura, cimentada en los tres pilares del régimen: el ejército, la iglesia y el Movimiento Nacional.

La memoria de esa "Nueva España" se construyó bajo los criterios antidemocráticos del franquismo y perduró como verdad/memoria de estado a través del adoctrinamiento, la censura, la violencia y la instrumentación del pasado y del patrimonio. Una memoria no de paz sino de victoria, que elaboró un nuevo discurso histórico de autolegitimación basado en una España de vencedores y vencidos.

Esa memoria franquista mandó al olvido ( $\mathrm{y}$ al paredón) a todo símbolo, recuerdo o memoria de la democracia republicana anterior y se convirtió en el credo de una España que vivió sometida al Caudillo durante los más de 14.000 días en que reinó el Generalísimo. Sin embargo, con la muerte del dictador en 1975, el franquismo sociológico no murió o, al menos, no lo hizo su memoria. Prueba de ello son algunas de las casuísticas que aún vivimos en la España de 2018 con temas como la exhumación de Franco, la retirada de la simbología, las fosas, las cunetas, los juicios... Y, en definitiva, ese debate mediático, social y político sobre la necesidad o no de las políticas públicas de memoria.

Resulta anacrónico que en la España actual aún perdure ese "no tocar peligro de muerte" en lo referente a Franco y la dictadura ${ }^{2}$. Huelga decir que la coyuntura actual debe ser entendida partiendo del status quo y la memoria que estableció la Transición como una suerte de pacto entre caballeros ${ }^{3}$. Pues como explica Vinyes, "el mito fundacional de la democracia" se amparaba en la seguridad y la convivencia para justificar la impunidad equitativa y la reconciliación como ideología de estado (VINYES, 2011: 11-30).

En su acepción más amplia (y no únicamente vinculada al franquismo), la memoria es una acción para la reparación y para paliar la invisibilización histórica y la discriminación de hechos, colectivos y/o personas, que debe refutar discursos políticos que defiendan una única verdad oficial. En este sentido, la memoria como constructo deber ser pública, social y democrática; sin pretensión de sustituir a la historia como discurso científico. 


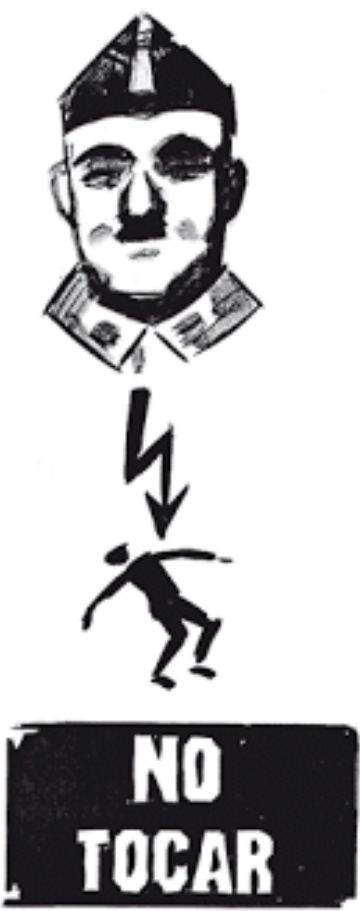

Viñetas para la memoria: "No tocar" | viñeta El Roto@ (El País, 6 de marzo de 2010)

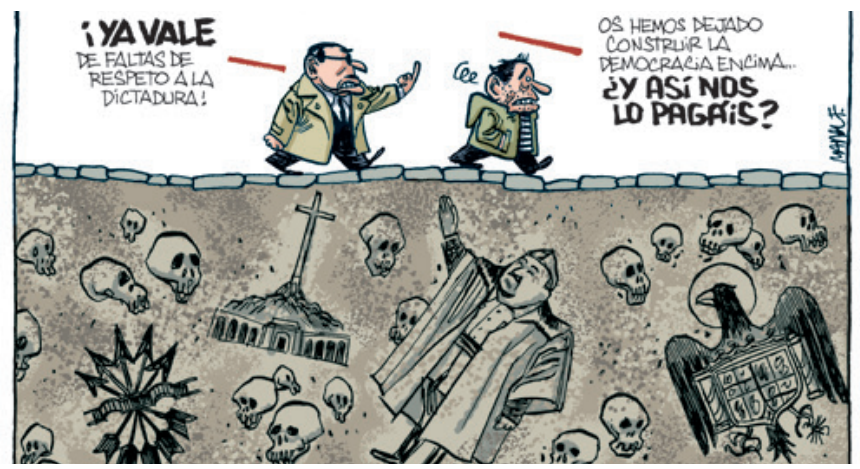

Viñetas para la memoria: "Un respeto" | viñeta Manel Fontdevila@ (Público, 1 de diciembre de 2011)

El dilema al que nos enfrentamos se centra entonces en si, como sociedad y como estado, somos capaces de renunciar a esa memoria heredada para poder construir nuestra propia memoria sobre el pasado reciente. Un proceso complejo pues la memoria democrática solo puede ser una memoria de memorias y de patrimonios.
No se trata de instaurar una única memoria nacional y de estado por encima de "las otras", sino de construir memorias desde abajo, que respondan a criterios democráticos y que sean patrimonializadas por la sociedad.

El matiz es importante y necesario: nuestra memoria no puede ser vehemente ni consentidora de ciertas nostalgias. La piedra fundacional de la memoria democrática en España debe asentarse en una ecuación sencilla pero que no todo el mundo asume: la guerra se produjo en España por un golpe de estado contra un régimen democrático y acabó con la instauración de una dictadura militar. Resulta evidente, pues, que las loas a los golpistas y la edulcoración de la dictadura no tienen cabida en un estado y una sociedad democrática. $Y$ en este tema, no hay debate posible.

No es cuestión de venganza, de honrar/olvidar "a los tuyos o a los míos", sino todo lo contrario. Paradójicamente, olvidar como opción "personal" de memoria no es en sí un problema, pues el olvido está lleno de memoria (como escribió Benedetti) y porque por largo que sea ese olvido, la historia no desaparece. El problema viene cuando el olvido se instaura como punto de partida de las políticas públicas y éste generaliza e institucionaliza la indiferencia, el desconocimiento y la uniformización de la memoria.

La memoria no debe ser solo discurso político de mera militancia sino una praxis y un derecho civil: una acción colectiva entre la ciudadanía, los profesionales y las instituciones. Se trata de reflexionar, haciendo partícipe a la ciudadanía, sobre nuestra historia (nuestro pasado y nuestro presente). Porque si la memoria se puede elegir, se puede construir, debemos ser parte activa en este proceso y generar una memoria colectiva democrática, inclusiva e intergeneracional.

Por consiguiente, el proceso debe ofrecer herramientas y vías para que la ciudadanía genere su propia opinión y potenciar así el pensamiento crítico, cívico y participativo; en un proceso de empoderamiento donde las personas asuman las decisiones y los recursos (MORENO; 


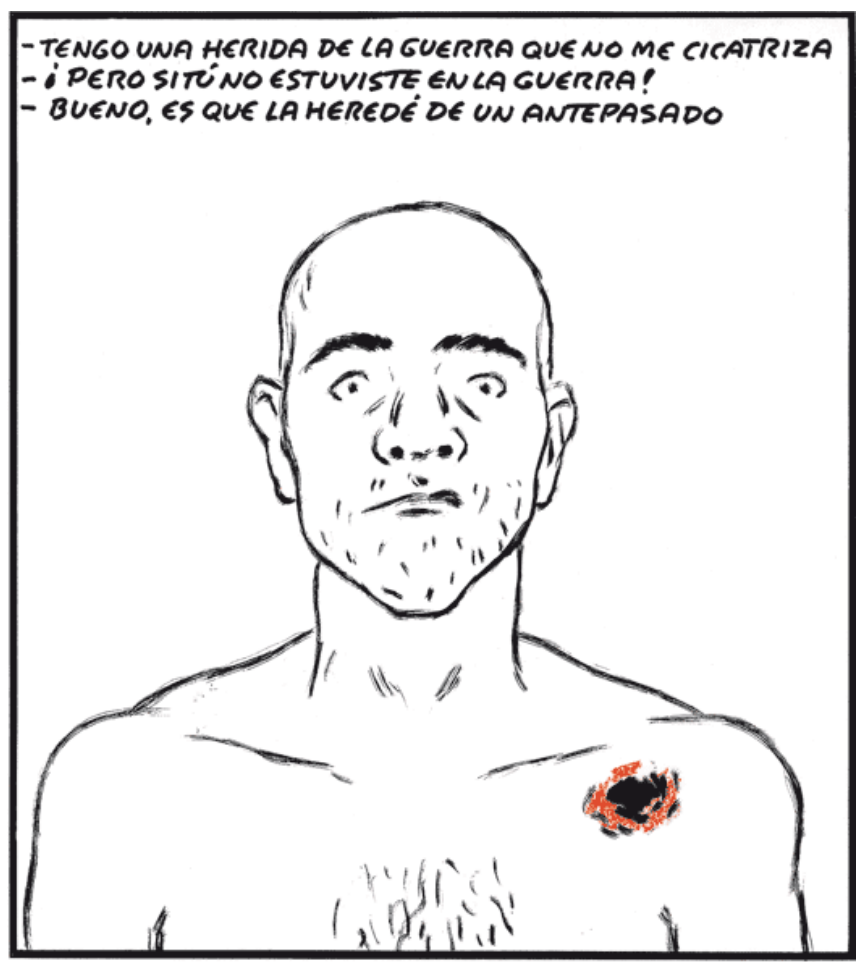

Viñetas para la memoria: "Tengo una herida de la guerra..." | viñeta El Roto@ (El País, 21 de abril de 2010)

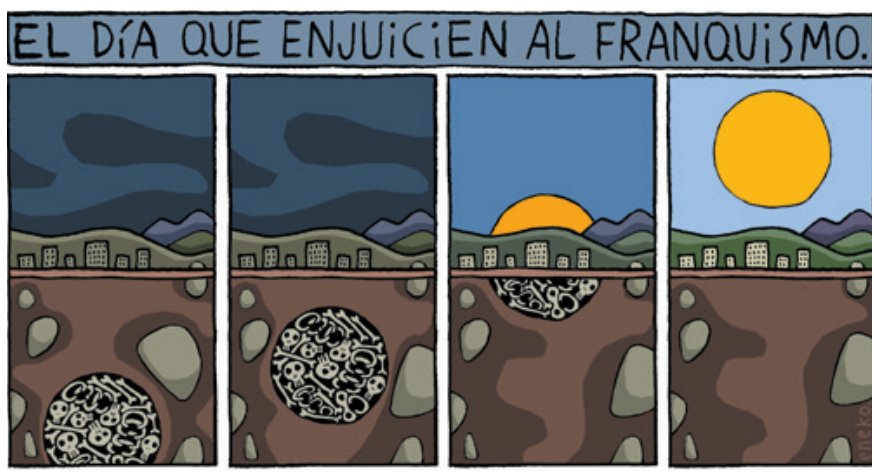

Viñetas para la memoria: "El día que enjuicien al franquismo" | viñeta Eneko@ (20 minutos, 29 de febrero de 2012)

NúÑEZ, 2016: 171-179). Y, en este sentido, la puesta en valor de espacios y lugares, la recuperación de testimonios, del patrimonio gráfico y documental y la cultura material, deviene crucial para divulgar y explicar qué fueron y supusieron para España un golpe de estado, una guerra y 40 años de dictadura nacionalcatolicista.
Es entonces tiempo de exhumar, dar luz y poner voz a nuestra historia desde la academia y la profesionalidad, pero también desde la calle y desde las instituciones a través de políticas públicas de memoria. Pues solo si somos capaces de patrimonializar esas memorias y esos conflictos, construiremos una memoria democrática ciudadana y evitaremos la "gentrificación ${ }^{4}$ memorial" de la que Vinyes nos advierte.

\section{NOTAS}

1. La historia es una disciplina científica que se centra en el estudio, análisis y explicación de los hechos y acontecimientos relativos a nuestro pasado, ya sea éste remoto o reciente. Los hechos son los que son; no se pueden cambiar. Lo que sí suele cambiar (desafortunadamente) es el uso que se puede hacer de ellos. La memoria, por contra, igual que el patrimonio, no existe; es un constructo social, cultural y político que se puede elegir y definir.

2.No obstante, hay que matizar que los nuevos marcos legislativos van dibujando un horizonte inédito en la gestión de los temas de memoria por parte del Estado y de los gobiernos autonómicos (DE LA CUESTA; ODRIOZOLA, 2018).

3. Y como muestra, solo citar las leyes de Reforma Política y de Amnistía de 1977 (ESCUDERO, 2013: 322-326).

4. Neologismo inglés acuñado desde la sociología y la geografía, que en el caso de la memoria describiría un proceso de transformación de las memorias diversas en un único relato memorial, construido desde arriba y que rechaza la naturaleza conflictiva de nuestro pasado reciente (VINYES, 2015: 34-35)

\section{BIBLIOGRAFÍA}

- CANDAU, J. (2002) Antropología de la memoria. Buenos Aires: Ediciones Nueva Visión, 2002 (Claves y Problemas) 
a debate Memoria democrática en la construcción de la historia y el patrimonio

| coordina Josefina Cuesta Bustillo

- De la CUESTA, J. L.; ODRIOZOLA, M. (2018) Marco normativo de la memoria histórica en España: legislación estatal y autonómica. Revista Electrónica de Ciencia Penal y Criminología [en línea], n. ${ }^{\circ} 20,2018$, pp. 1-38<http://criminet. ugr.es/recpc/20/recpc20-08.pdf> [Consulta: 13/11/2018]

- ESCUDERO, R. (2013) Jaque a la transición: análisis del proceso de recuperación de la memoria histórica. Anuario de filosofía del derecho, n. ${ }^{\circ} 29,2013$, pp. 319-340

- ESCUDERO, R. (coord.) (2011) Diccionario de memoria histórica: conceptos contra el olvido. Madrid: Libros de la Catarata, 2011

- JELIN, E. (2012) Los trabajos de la memoria. 2a ed. Lima: Instituto de Estudios Peruanos, 2012

- MORENO, A.; NÚÑEZ, L. (2016) La cultura material del franquismo. Deconstruyendo la memoria histórica. La Linde. Revista digital de arqueología profesional [en línea], 7-2016, pp. 152-181. <http://lalindearqueologia.com/la-culturamaterial-del-franquismo/> [Consulta: 13/11/2018]

- RICOEUR, P. (2003) La memoria, la historia, el olvido. Madrid: Trotta, 2003

- VINYES, R. (2011) Asalto a la memoria. Impunidades y reconciliaciones, símbolos y éticas. Barcelona: Los libros del lince, 2011

- VINYES, R. (2015) Los usos públicos del pasado en Europa: hacia una memoria sincrética. Años 90 , vol. 22, n. ${ }^{\circ} 42,2015$, pp. 21-51 


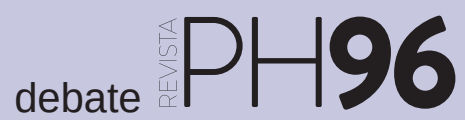

a debate Memoria democrática en la construcción de la historia y el patrimonio

| coordina Josefina Cuesta Bustillo

\section{La memoria histórica y su dimensión política, social y académica}

Custodio Velasco Mesa | Dpto. de Historia Contemporánea, Universidad de Sevilla

URL de la contribución <www.iaph.es/revistaph/index.php/revistaph/article/view/4302>

En el debate internacional acerca de la memoria histórica cabe distinguir tres grandes vertientes convergentes que implican a distintos actores sociales y que es importante identificar, no solo para comprender las tensiones y conflictos generados al respecto, sino también para intentar hallar vías que los resuelvan desde premisas democráticas.

Las polémicas remiten, en lo inmediato, a la estructural dimensión política inherente a la historia y, por derivación, a toda tentativa de poner de relieve un discurso contrahegemónico de la historia, es decir: remiten a los efectos que la emergencia de toda memoria silenciada tiene en la deconstrucción de relatos hegemónicos acerca del pasado. Relatos que, en particular desde el siglo XIX (cuando la opinión pública empezó a cobrar trascendencia política), han sido habitualmente utilizados como instrumentos privilegiados de propaganda al servicio del poder establecido, esto es: como herramientas para crear identidades colectivas, para generar adhesiones y cohesiones en torno a ese poder, para legitimar o facilitar -en suma- el ejercicio de la autoridad. En realidad, toda comunidad que ha adquirido algún grado de organización social ha desarrollado también algún tipo de narrativa y de política (educativa, de símbolos -materiales e inmateriales- o de concienciación) en relación con su pasado (CLOSA MONTERO, 2010: 3); y ello con independencia del tipo de régimen político adoptado. En ese proceder, a mayor grado de represión ejercida por la autoridad política, mayor ha sido la imposición de discursos hegemónicos o políticas memoriales que ensalzan los valores que representa el poder establecido, al tiempo que más elevada es la omisión o tergiversación de hechos y narrativas que contradicen esa propaganda. A la inversa, a mayor calidad democrática del régimen, mayor es la emergencia de memorias contra-hegemóni- cas, frecuentemente presentadas como una modalidad de la discusión y del conflicto político.

En todo caso, cabe destacar que, tanto en los contextos represivos como en los democráticos, la autoridad política, pese a su grado de control sobre los instrumentos de difusión de recuerdos, sobre leyes de memoria o sobre conmemoraciones oficiales, no tiene el monopolio de la memoria, como tampoco es su única depositaria. De ahí, precisamente, el conflicto al respecto, latente en periodos represivos, explícito en periodos democráticos. Los debates y tensiones en torno a la memoria son, en este sentido, síntomas de la gradual evolución que, desde finales del siglo $\mathrm{XX}$, experimenta la ciudadanía hacia una mayor expresión en el espacio público y, en consecuencia, hacia una mayor participación política dentro de las democracias incompletas de las sociedades complejas contemporáneas. Teniendo ello presente, no sorprende el alcance internacional que en los últimos años ha adquirido el conflicto entre memorias hegemónicas y contrahegemónicas. De hecho, difícilmente puede encontrarse en la actualidad un país que no experimente disputas ligadas a su(s) memoria(s) de traumas colectivos. Destacan los casos de Europa Central y del Este con relación al estalinismo, los de América Latina en relación con sus dictaduras y conflictos armados, el de Turquía (genocidio armenio de 1915) o el de Francia en lo que respecta al colaboracionismo nazi y a su pasado colonial; casos, todos ellos, donde se advierten tensiones o "guerras de memoria" con trascendencia en la construcción de identidades colectivas".

Junto a la estructural dimensión política, las polémicas acerca de la memoria tienen, asimismo, una inmediata y elemental dimensión humana y social, por cuanto afectan, en el presente, a sentimientos íntimos de víctimas, 
a debate Memoria democrática en la construcción de la historia y el patrimonio

| coordina Josefina Cuesta Bustillo

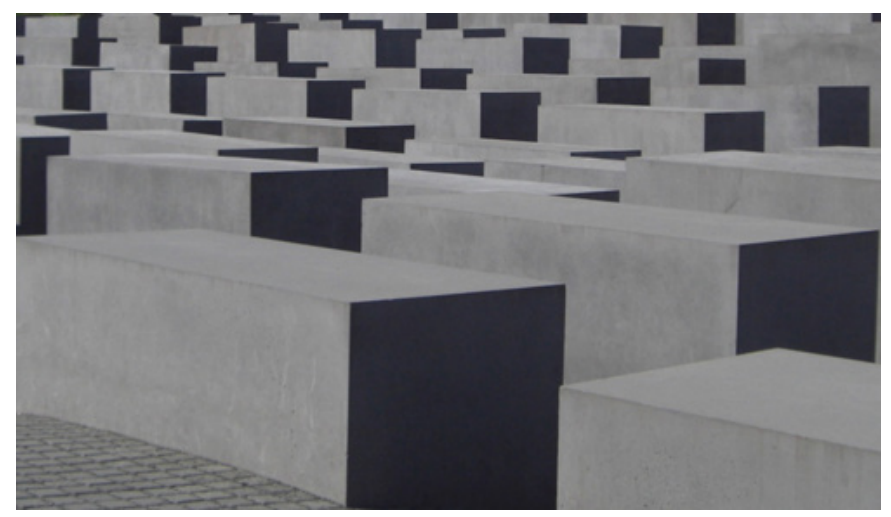

Memorial del Holocausto, Peter Eisenman, Berlín, 2005 | foto Custodio Velasco

que se han organizado para llevar a cabo sus reclamaciones. A decir verdad, la toma en consideración de la memoria constituye, en su origen, la reivindicación de individuos y colectivos que, desde finales del siglo $X X$, vienen solicitando justicia, reparación y verdad en relación con violencias colectivas silenciadas o tergiversadas por las narrativas hegemónicas en distintos contextos internacionales. Fueron, efectivamente, víctimas y familiares de éstas quienes, espontánea y autónomamente, emprendieron la creación de asociaciones mediante las que articularon sus demandas individuales y colectivas, interpelando con ello -directa o indirectamente- a distintos profesionales involucrados al respecto (BARROS, 2014: 154). Por una parte, apelaron a políticos y a jueces, teniendo como referentes los Juicios de Nüremberg de 1945 a los responsables del Holocausto. Como en otro lugar he destacado, el reconocimiento y tipificación en la ONU de crímenes de lesa humanidad (no susceptibles de ser amnistiados e imprescriptibles, a diferencia de los crímenes de guerra) y el posterior despliegue de legislaciones nacionales que penalizaban en distintos países el negacionismo del Holocausto, supusieron un poderoso estímulo para que diferentes movimientos memorialistas reclamaran para sí la consideración de víctimas de crímenes de lesa humanidad y el consiguiente reconocimiento -en materia de políticas de memoriapor parte de las administraciones públicas (VELASCO MESA, 2017: 127-128). Por otra parte, junto a políticos y a jueces, estas asociaciones también habrían de apelar a historiadores para que éstos -en su labor de esclareci- miento de la historia- tuvieran en consideración los testimonios de las víctimas, colaboraran en la localización de fosas comunes, contribuyeran, en suma, mediante sus investigaciones, a poner de relieve acontecimientos silenciados o tergiversados que permitieran precisar y reinterpretar relatos hegemónicos del pasado.

Con independencia, sin embargo, de esa interpelación directa o indirecta a profesionales de la historia, es obvio que las controversias acerca de la memoria incumben decididamente a los historiadores. De hecho, afectan a la propia epistemología de la historia y, en esa medida, tienen, junto a la política y a la social, una inequívoca dimensión académica. A este respecto, se distinguen dos posturas antagónicas. De un lado, la que considera que la memoria no es asunto de la historia ni, por consiguiente, de la atención del historiador ${ }^{2}$. De otro, la que reivindica lo contrario: la integración de la memoria en la historia y su consideración como fuente para el conocimiento del pasado ${ }^{3}$. A este último grupo se adscriben quienes consideran que el historiador, por elemental deontología profesional, no puede, en su tentativa de aproximación a la verdad histórica, desestimar o subestimar ninguna fuente de conocimiento del pasado, incluyendo los testimonios de las víctimas de tragedias colectivas, que son en ocasiones la única fuente existente en contextos represivos. Antes bien, debe incorporar -contrastándolos- esos testimonios a su labor de esclarecimiento y análisis de acontecimientos históricos. Conforme a ello, desde esta perspectiva la utilidad de la historia no se reduce a una utilidad científica, no se limita al conocimiento -lo más exhaustivo posible- del pasado, no consiste en un conocimiento, sin más, de ese pasado, sino en un conocimiento (lo más riguroso posible) y una reflexión sobre los hechos que, particularmente en el caso que nos ocupa, contribuyan a evitar la reedición de horrores colectivos. Y ello pasa, no ya por poner en evidencia esas tragedias, sino también por no exaltar, mediante distintas modalidades discursivas o comunicativas, los valores que las propiciaron.

Dicho esto, en el abigarrado debate acerca de la memoria, donde se mezclan sentimientos íntimos de víctimas 
(y sus reivindicaciones) con vertientes políticas y epistemológicas de la historia, cabe destacar que lo decisivo no es exactamente el acto de "propagar", bien mediante políticas con relación al pasado (incluyendo leyes sobre memoria, símbolos y conmemoraciones), bien mediante plataformas diversas de comunicación (prensa y medios audiovisuales), bien a través del estricto análisis de la historia. Ese acto de "propagar" es, se quiera o no, inevitable para todos los actores sociales partícipes en el debate. Lo decisivo es determinar qué es lo que se propaga, es decir: si lo que se propaga consigue o no transmitir y "desentrañar el significado de una experiencia" (MATE, 2018), si tiene (es) o no base documental y si se pone o no al servicio del conocimiento de los hechos, de la justicia y del respeto a los derechos humanos, también en el presente pues la memoria no trata únicamente del pasado (VELASCO MESA, 2017: 135), sin "disneyficaciones" que banalicen el recuerdo de las tragedias, sin sacralizaciones o mitificaciones, sin estériles competiciones en la escala del horror (TODOROV, 1994: 272), desde el respeto a la vida de todo ser humano.

De la respuesta que demos a esas cuestiones dependen no ya los avances en el conocimiento científico de la historia, sino también la superación de traumas colectivos y los progresos en la convivencia ciudadana. La Unión Europea parece haber comprendido la trascendencia del problema si se tiene en cuenta la promoción que viene realizando desde 2004 en favor del conocimiento de las memorias silenciadas de diferentes pasados traumáticos en Europa; y ello, mediante dos programas: "Europe for Citizens Programme" (2007-2013) y "Uses of the Past" (2014-2020). No en vano, en el espacio europeo han tenido lugar en los últimos siglos dos grandes trayectorias ideológicas contrapuestas que constituyen la médula de lo que se discute cuando se discute sobre la memoria. Por una parte, con particular énfasis desde fines del siglo XIX, se ha desarrollado una "cultura de la guerra" o de la violencia que, integrada en una "política de las emociones", desembocó en los totalitarismos del siglo $X X$, ahora reeditados en los (ultra)nacionalismos y filofascismos del XXI. No obstante, paralelamente a esa "cultura de la guerra", Europa también ha sido el suelo de una "cultura de la paz" que remite a los valores de la tolerancia y del consenso difundidos desde el racionalismo del siglo XVIII y sobre la que es necesario insistir como antemural frente a los totalitarismos y como referente fundamental para construir la convivencia democrática, imposible de articular plenamente sin el conocimiento y el reconocimiento de las tragedias colectivas silenciadas.

\section{NOTAS}

1. Sobre el caso de los países de Europa del Este en relación con la memoria de la dominación soviética, véase Closa Montero (2010: 11-19). En lo que respecta a la Europa occidental, los conflictos en torno a la memoria están experimentando una notable evolución desde que, entre 1945 y 1967, se viviera lo que J.-M. Chaumont denomina "tiempo de la vergüenza", caracterizado por focalizar el recuerdo en honrar a la Resistencia sin mención al Holocausto, y en los años setenta se advirtiera lo contrario: la glorificación de los rescatados del Holocausto (CHAUMONT, 1997; GENSBURGER; LAVABRE, 2005: 80). En ello coinciden Eva-Clarita Onken y Emmanuelle Droit, quienes consideran que tras 1945 se instala en países como Francia, Bélgica o Italia el mito de la Resistencia nacional; un consenso que, desde los años setenta, se empezará a fracturar, al tiempo que la memoria del Holocausto superaba el marco restringido de las comunidades judías (ONKEN, 2007: 31; DROIT, 2007: 103-104).

No obstante, esa memoria del Holocausto no entrará plenamente en la memoria oficial de países como Francia hasta los años 1990, integrando un más amplio movimiento que empezó a fijar desde los años ochenta la centralidad del Holocausto en la identidad y la memoria de la Europa occidental (JUDT, 2005: 820). Con todo, Francia ha evolucionado en las últimas décadas del régimen memorialista orientado a la exaltación de los héroes de la Resistencia a lo que J. Michel ha denominado "régimen victimo-memorialista", basado en una concepción 


\section{a debate Memoria democrática en la construcción de la historia y el patrimonio \\ | coordina Josefina Cuesta Bustillo}

plural de la memoria y en la noción de crimen contra la humanidad como fuente jurídica (MICHEL, 2010: 84 y ss.).

2. Exponente de ello es Pierre Nora, para quien memoria e historia, "lejos de ser sinónimos, se oponen completamente entre sí" (NORA, 1984: 19; 1978: 398-401).

3. Es la postura que defienden, entre otros, Carlos Barros, quien sostiene la integración de la memoria en la historia, al tiempo que concibe la historia con una esencial dimensión humana, hecha por historiadores, pero también por "los protagonistas actuales a través de su memoria colectiva (BARROS, 2011, 5 de diciembre).

\section{BIBLIOGRAFÍA}

- BARROS, C. (2011) Historia de la memoria, memoria de la historia [en línea] Conferencia impartida en la Escuela Nacional de Antropología e Historia, México D.F., México, 5 de diciembre de 2011 <https://www.youtube.com/watch?v=euRNzJOHMcl> [Consulta: 20/11/2018]

- BARRos, C. (2014) Historia, memoria y franquismo. Historia Actual Online, n. ${ }^{\circ} 33,2014$, pp. 153-171

- CHAUMONT, J-M. (1997) La concurrence des victimes, génocide, identité, reconnaissance. París: La Découverte, 1997

- ClOSA MONTERO, C. (2010) Negociating the Past: Claims for Recognition and Policies of Memory in the EU [disponible en línea]. Madrid: Consejo Superior de Investigaciones Científicas (España), 2010 (Serie Documentos de trabajo, n. ${ }^{\circ}$ 8, Instituto de Políticas y Bienes Públicos -IPP-). <http://hdl. handle.net/10261/24430> [Consulta: 14/11/2018]

- DROIT, E. (2007) Le Goulag contre la Shoah. Mémoires officielles et cultures mémorielles dans l'Europe élargie. Vingtième Siècle. Revue d'histoire, n. ${ }^{0}$ 94, 2007, pp. 101-120

- GENSBURGER, S.; LAVABRE, M-C. (2005) Entre devoir de mémoire et abus de mémoire: la sociologie de la mémoire comme tierce position. En MÜLLER, B. (2005) Histoire, mémoire et épistemologie. A propos de Paul Ricoeur. Lausanne: Payot, 2005, pp. 76-95

- JUDT, T. (2005) Postwar. A History of Europe since 1945. New York: The Penguin Press, 2005
- MATE, R. (2018) [Declaraciones publicadas en el artículo de GALINDO, J. C. ¿Se puede mentir en una novela sobre el Holocausto?, El País [en línea] 24/11/2018<https://elpais. com/cultura/2018/11/23/actualidad/1542966934_093230. html> [Consulta: 25/11/2018]

- MICHEL, J. (2010) Gouverner les mémoires, Les politiques mémorielles en France. París: PUF, 2005

- NORA, P. (1978) Mémoire collective. En LE GOFF, J.; CHARTIER, R.; REVEL, J. (dir.) La nouvelle histoire. París: Retz-CEPL, 1984

- NORA, P. (1984) Entre mémoire et histoire. En NORA, P. (dir.) Les lieux de la mémoire. La République. París: Gallimard, 1984

- ONKEN, E.-C. (2007) The Baltic States and Moscow's 9 May commemoration: analysing memory politics. Europe EuropeAsia Studies, vol. 59, n. ${ }^{\circ}$ 1, 2007, pp. 23-46

- TOdOROV, T. (1994) Face à l'extrême. París: Seuil, 1994

- VELASCO MESA, C. (2017) Historia y memoria: un mismo combate. Aportaciones epistemológicas de Historia a Debate a las controversias acerca de la memoria histórica. Memorias: Revista Digital de Arqueología e Historia desde el Caribe, n. ${ }^{\circ}$ 33, septiembre-diciembre 2017, pp. 120-141 


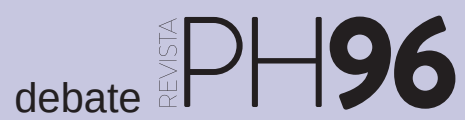

a debate Memoria democrática en la construcción de la historia y el patrimonio

| coordina Josefina Cuesta Bustillo

\section{La memoria brota de la experiencia, y viceversa}

Carlos García de las Bayonas Abelleira | estudiante del Máster Universitario en Patrimonio Cultural en el Siglo XXI: Gestión en Investigación, Universidad Complutense de Madrid

URL de la contribución <www.iaph.es/revistaph/index.php/revistaph/article/view/4312>

Desde la aprobación de la Ley 57/2007 de Memoria Histórica de España, el binomio "memoria histórica" ha tenido un difícil encaje en el panorama político español. Ciertamente, el vocablo, ora controvertido, ora polémico, puede dar para un debate en sí mismo, más allá del ámbito de la propia ley. Habrá quien lo considere redundante -un pleonasmo, vaya- en cuanto a que toda historia es un ejercicio de memoria desde la contemporaneidad y la subjetividad; una proyección del presente hacia el pasado con miras hacia el futuro. Habrá quien lo considere desleal a la expresión hermana de "memoria democrática" en cuanto a que, en términos históricos, ningún presente ha sido tan democrático como el nuestro. Habrá, incluso, quien lo considere un secuestro, en cuanto a que no da cabida a la pluralidad y a la colectividad.

En realidad, el término (de forma genérica) no es más que una convención social empleada para encerrar un concepto. En este caso, se trata de una acuerdo -fundamentalmente político- para referirse al esfuerzo grupal realizado en pos de la recuperación de la memoria republicana, de las víctimas de la Guerra Civil y la posterior dictadura franquista. Sea como fuere, el término debería reflejar la pluralidad, la mirada abierta, que se intuye en la idea. Por lo tanto, sería más positivo para el debate hablar de memorias (múltiples, cruzadas, compartidas), que no de una sola memoria (estanca, objetivizante, institucionalizada).

Más allá de devaneos dialécticos, considero de mayor provecho poner la atención en el proceso subyacente. Se hable de memoria (histórica, democrática, colectiva, crítica, pública, nacional, oficial, etc.) o memorias (inserte aquí el epíteto que prefiera), es necesario destacar que la cuestión mnemónica no deja de ser una activación simbólica. Quienes provengan del campo del patrimonio cultural o de la antropología conocen los riesgos que entrañan los procesos de activación patrimonial no consensuados, la patrimonialización sesgada o las apropiaciones con fines políticos, que "no pueden ni oscurecer ni, menos, sustituir o cambiar la Historia" (ARÓSTEGUI, 2009: 60). Experiencias internacionales como las de Alemania, Italia, Argentina o, más recientemente, Perú, entre otras, pueden ser edificantes en este sentido.

En España, en la actualidad, parecemos haber llegado a un impasse, después de un avance moderado y una sobrecarga de retrasos. Hasta ahora, las pocas acciones efectivas que se han llevado a cabo han estado dirigidas, fundamentalmente, desde las administraciones y únicamente porque la presión del asociacionismo ha encontrado algún resquicio entre tanto tapón institucional (VELASCO MESA, 2017). La discusión no se debería quedar en el plano de las instituciones porque la problemática de la desmemoria o de la patrimonialización de la "memoria oscura" (HERNÀNDEZ I MARTí, 2010) realmente atañe a toda la ciudadanía ya que implica una selección consensuada de recuerdos, experiencias, sensaciones y percepciones.

El debate, por lo tanto, debe ser multifocal. Desde el mundo académico y la investigación (a través de una historia comprometida), desde las asociaciones civiles, las plataformas ciudadanas, los medios de comunicación (que tanta repercusión tienen y tanto ruido producen), entre muchos otros, se debe favorecer el encuentro honesto de posturas, aunque algunas nos disgusten, aunque ciertas nos contradigan y otras tantas nos contraríen. Todo ello, por supuesto, partiendo de los principios democráticos actuales y teniendo en mente el aprendizaje y el compromiso social. 


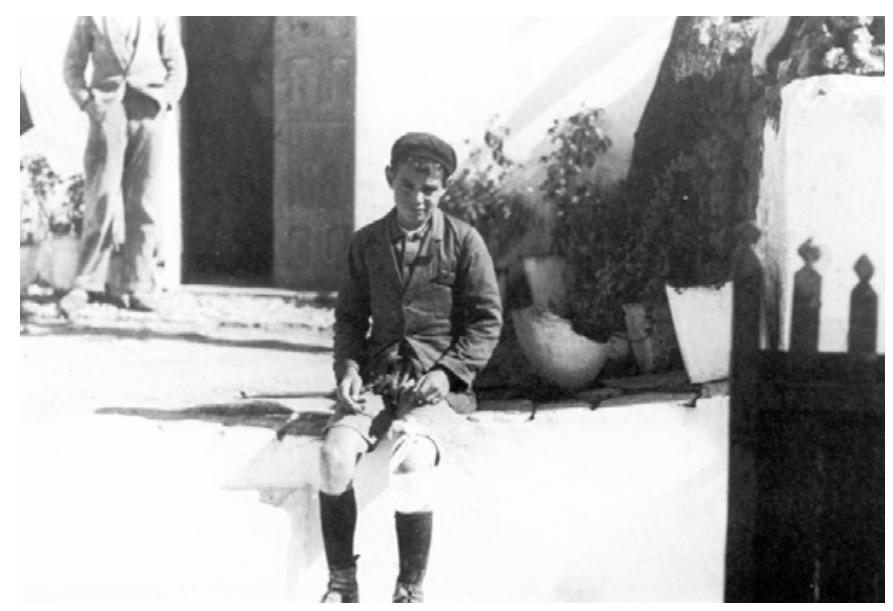

"El niño Salvador del Río (Benalup-Casas Viejas, 1933)" | fuente SERRANO GÓMEZ, 2000

En lo que al patrimonio respecta, me gustaría traer a colación la experiencia de Benalup-Casas Viejas como ejemplo de documentación, difusión e interpretación sin banalización. En dicha localidad gaditana abordaron la cuestión de su memoria con anterioridad a la aprobación de Ley 2/2017 de Memoria Histórica y Democrática de Andalucía. Concretamente, desde su segregación en 1991 de Medina-Sidonia (con el nombre de Benalup de Sidonia) y, más específicamente, desde que se cambiara su denominación a Benalup-Casas Viejas en 1999, la resignificación consciente de la localidad ha ido orientada a recordar los sucesos que allí acontecieron a inicios de la II República.

Tras un primer intento en 2009, en septiembre de 2018 la Dirección General de Bienes Culturales y Museos de la Junta de Andalucía incoó de nuevo el procedimiento para la inscripción en el Catálogo General del Patrimonio Histórico Andaluz como Bien de Interés Cultural (BIC), con la tipología de sitio histórico, del lugar de los sucesos de Casas Viejas. El intento de declaración estuvo acompañado por un exhaustivo ejercicio de documentación y una enorme implicación de muy diversos agentes, entre los que destacan los propios de la localidad (no hay más que consultar los trabajos del IES Casas Viejas disponibles online). Como resultado, queda una puesta en valor del patrimonio inmueble relacionado con los pro- pios sucesos, un ejercicio de memoria colectiva (a través de la oralidad, la inclusión de testimonios y la documentación gráfica) que incluyó la perspectiva de género, y un reconocimiento al valor simbólico del hecho en sí. En definitiva, retomo y cierro con la idea inicial de que el debate ha de ser plural y colectivo, aunque con matices. Para que verdaderamente sea un debate entre iguales y no una negociación, inevitablemente se ha de dignificar primeramente la memoria de los desaparecidos, de los torturados, de los represaliados. Todo ello, con el "derecho a la verdad" por delante. En lo que al patrimonio controvertido se refiere el atolladero epistemológico se vuelve harto estrecho porque nuestra responsabilidad ética con el pasado se hace una con el presente. Experiencias micro como el caso de Benalup-Casas Viejas u otros (como Belchite o el proyecto BAMSA), que brotan de la memoria y al mismo tiempo la alimentan, pueden ser claves en el camino del encuentro.

\section{BIBLIOGRAFÍA}

- ARÓstegul, J. (2009) La Ley de Memoria Histórica: reparación e insatisfacción. Patrimonio Cultural de España [en línea], n. ${ }^{\circ}$ 1, 2009, pp. 41-60 <http://ccfib.mcu.es/patrimonio/ docs/MC/IPHE/PatrimonioCulturalE/N1/08_PCE1_Ley_ Reparacion.pdf> [Consulta: 23/11/2018]

- HERNÀNDEZ I MARTí, G. M. (2010) La memoria oscura: El patrimonio cultural y su sombra. En RIVERA BLANCO, J. (coord.) VI Congreso Internacional "Restaurar la Memoria": La gestión del patrimonio: hacia un planteamiento sostenible, Vol. 2 (Comunicaciones), 2010, pp. 629-637 [en línea] <http://www. academia.edu/2201415/La_memoria_oscura._El_patrimonio_ cultural_y_su_sombra> [Consulta: 24/11/2018]

- SERRANO GÓmeZ, J. J. (2000) Los Sucesos de Casas Viejas (Cádiz, 1933). Catálogo de la Exposición fotográfica de Serrano y Sánchez del Pando. Cádiz: Fundación Provincial de Cultura de la Diputación de Cádiz, Ayuntamiento de Casas Viejas, 2000

- VELAsco MESA, C. (2017) Historia y memoria: un mismo combate. Aportaciones epistemológicas de Historia a Debate a las controversias acerca de la memoria histórica. Memorias: revista digital de historia y arqueología desde El Caribe [en línea], n. ${ }^{\circ} 33,2017$, pp. 120-141 <http://rcientificas.uninorte.edu. co/index.php/memorias/article/view/10048/214421442950> [Consulta: 24/11/2018] 


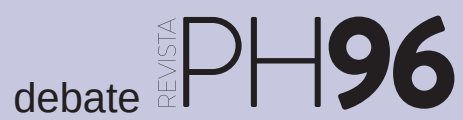

a debate Memoria democrática en la construcción de la historia y el patrimonio

| coordina Josefina Cuesta Bustillo

\section{¿Dónde están las mujeres en la memoria democrática?}

Asociación Herstóricas. Historia, mujeres y género

URL de la contribución <www.iaph.es/revistaph/index.php/revistaph/article/view/4319>

La historiografía tradicional, por su sesgo androcéntrico, suele ignorar la participación femenina. Las jerarquías de poder de nuestra sociedad provocan que haya relatos que son relegados o sistemáticamente ignorados porque el género, origen étnico, nivel socioeconómico u orientación sexual, religiosa o política, entre otras categorías, de quienes los protagonizan, no forman parte del discurso hegemónico.

Al transitar por nuestro entorno recibimos habitualmente información sesgada y ésta tiene un impacto sobre cómo percibimos a las personas que lo habitan y cómo entendemos nuestra historia, tanto la pasada como la que construimos colectivamente en la actualidad.

Encontramos espacios patrimoniales, monumentos, plazas y calles que homenajean a figuras masculinas, pero... ¿Dónde están las mujeres?

Es bastante común que los espacios patrimoniales ignoren la relación, usos y vínculos emocionales de estos mismos con la población femenina. En señales, paneles, guías y folletos se nos suele ofrecer información incompleta y si se hace alguna referencia a las mujeres que participaron en ese espacio, con frecuencia nos encontraremos con un mensaje paternalista y sexista.

La mayoría de las ciudades del estado español tienen menos de un $10 \%$ de nombres femeninos en sus calles (y entre éstas abundan nombres de vírgenes, santas y reinas). Algo similar ocurre con placas conmemorativas y esculturas, donde además de ser una presencia mínima, las representaciones femeninas son en su gran mayoría alegorías y diosas clásicas que se suman a los cuerpos femeninos cosificados y sexualizados de marquesinas y escaparates. Pasado y presente nos dan un mensaje cargado de estereotipos de género y relatan una historia muy sesgada que no tiene en cuenta a más de la mitad de la población y muchos menos a la que sufrió y sufre violencia institucional y violencias inherentes a su género.

Si nos centramos en la memoria democrática, encontramos un panorama similar. Al realizar el ejercicio de investigar, visibilizar y difundir la historia de las personas que lucharon por ideales democráticos, las que fueron represaliadas, forzadas al exilio, malvivieron bajo el estigma o resistieron en la clandestinidad, todas esas personas cuyas historias han sido borradas del relato histórico durante décadas, no debemos cometer el error de excluir los relatos femeninos porque las mujeres fueron, son y serán protagonistas de todos los episodios de la historia en multitud de roles y experiencias diversas.

En las últimas décadas se están realizando trabajos de investigación cuyas aportaciones a este campo son
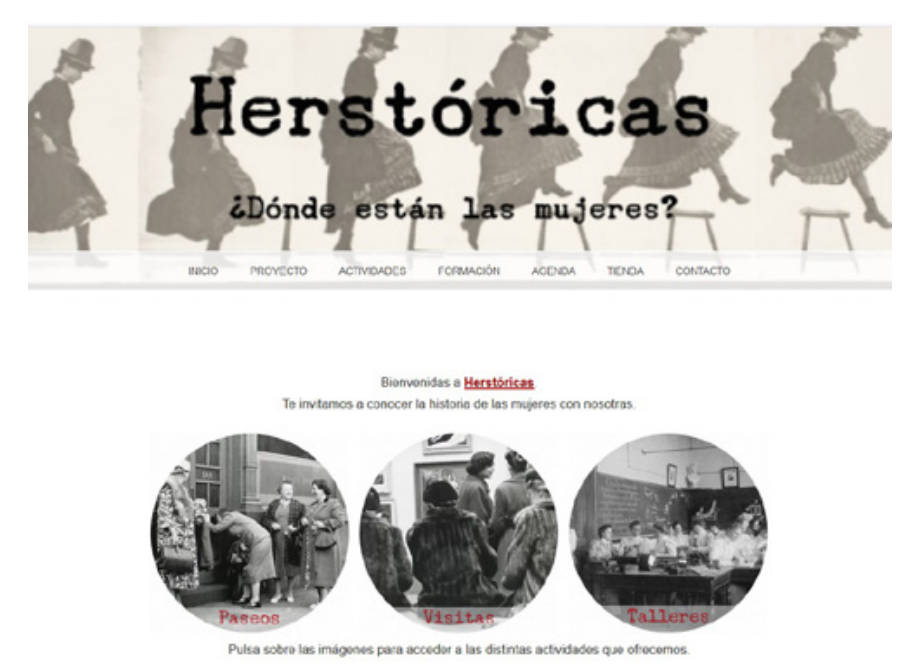

https://herstoricas.com 
a debate Memoria democrática en la construcción de la historia y el patrimonio

| coordina Josefina Cuesta Bustillo

fundamentales para una visión más inclusiva de la historia. Sin embargo, sus resultados no llegan a toda la sociedad; se hace necesario el realizar una transferencia de conocimientos accesible para la ciudadanía que promueva el interés y la curiosidad por conocer la historia de las mujeres, que establezca vínculos y convierta a las personas en partícipes de la activación del patrimonio y que genere una reivindicación colectiva para incluir mayor variedad de relatos históricos y de memoria democrática en centros educativos y en los espacios patrimoniales, culturales y sociales.

El preguntarse ¿Dónde están las mujeres? se convirtió en una cuestión recurrente y por ello decidimos desarrollar un proyecto cultural y educativo para visibilizar y valorar la aportación histórica de las mujeres en la sociedad y reflexionar sobre la "ausencia" de éstas a través de itinerarios interpretativos y talleres con perspectiva de género, entre otras actividades.

Desde el desarrollo inicial de la Asociación Herstóricas. Historia, mujeres y género, tuvimos claro que era imprescindible ampliar el espectro de relatos y hacerlo de una forma participativa. No nos limitamos a facilitar información, en todas las actividades generamos espacios seguros para el debate y el pensamiento crítico y para compartir desde las experiencias, saberes y emociones propias de cada persona.

Los contenidos viajan al terreno de las vivencias para construir conocimiento colectivo y conectar desde el relato personal, que promueve una implicación identitaria e incluso emocional con la historia de las mujeres de tal modo que ayude a que las personas participantes se "apropien" del espacio, del patrimonio y del relato de la historia.

Cuando realizamos itinerarios interpretativos y talleres con perspectiva de género queda patente la necesidad de quienes participan de querer dialogar y compartir las historias familiares que han sido silenciadas durante demasiado tiempo; reconocer las aportaciones de las mujeres que nos antecedieron y que fueron represalia- das; reivindicar su lugar en la historia y repensar y completar el imaginario colectivo.

Son frecuentes las catarsis colectivas provocadas tras escuchar historias protagonizadas por mujeres a través de sus familiares y amistades.

Para la facilitación de estas actividades partimos de la empatía, la escucha activa y el coaprendizaje; utilizamos recursos audiovisuales para contrastar realidades y ampliar imaginarios; rompemos la jerarquía habitual y las aportaciones de quienes participan se acogen al mismo nivel que las de quien facilita.

Trabajamos para que sea un proyecto abierto, accesible, inclusivo e integrador. Esto no es posible sin que la transversalidad sea una constante. El lenguaje cercano, el vocabulario inclusivo y la adaptación de los contenidos están al servicio de que se cree un espacio intergeneracional, plural y diverso. Todo ello al tiempo que se desmontan estereotipos y se cuestionan los roles de género. Quienes participan se convierten en agentes multiplicadores y dan continuidad al proyecto compartiendo en su entorno los planteamientos propuestos en las actividades, las historias compartidas, reconociendo los espacios femeninos en trayectos posteriores realizados en su cotidianeidad y contribuyendo a modificar el imaginario colectivo en torno a participación de las mujeres en la historia. Animamos a conocer la genealogía feminista y los logros, aportaciones y luchas de las mujeres que nos precedieron para tener más referentes femeninos diversos. Y reivindicamos la revisión de espacios patrimoniales, históricos y culturales para que se tengan en cuenta los espacios femeninos de memoria histórica y democrática. Así como planteamos que se realice una revisión de contenidos y la inclusión de relatos invisibilizados.

Creemos que es una tarea colectiva de la ciudadanía, los movimientos sociales y las instituciones el conocer, visibilizar y reivindicar la historia de las mujeres en general y la memoria democrática protagonizada por éstas en particular. 


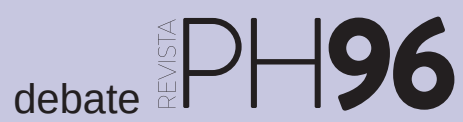

\title{
Cuando la memoria deja de estar en blanco y negro: las exposiciones participativas del museo de La Rinconada
}

\author{
Maribel Rodríguez Achútegui | museo de La Rinconada (Sevilla) \\ URL de la contribución <www.iaph.es/revistaph/index.php/revistaph/article/view/4322>
}

Me gustaría comenzar aclarando que los responsables de la actividad que nos ocupa no somos especialistas en memoria democrática. En realidad la línea de trabajo de la que hablamos se realiza desde el museo de La Rinconada, donde contamos con una colección arqueológica y paleontológica, aunque funciona como la institución patrimonial (en sentido amplio) de la localidad. Eso sí, desde la Delegación de Cultura y Memoria Histórica del Ayuntamiento de La Rinconada (Sevilla) se lleva ya mucho tiempo realizando trabajos como el catálogo de símbolos de exaltación del franquismo ${ }^{1}$, que ha permitido su posterior retirada, así como la colaboración con asociaciones memorialistas en diferentes jornadas y eventos. Ambas instituciones nos propusimos el objetivo de acercar estas temáticas a personas que no son habituales en las actividades memorialistas. En el análisis que realizamos nos pareció especialmente interesante dirigirnos a adolescentes puesto que, por una parte, están en la fase de creación de su ideario $y$, por otra, ejercen de amplificadores hacia sus familias y amistades.

Nuestras experiencias anteriores con este público nos llevaron a decidirnos por la metodología participativa, como forma de implicación de un colectivo que prefiere ser protagonista antes que receptor pasivo. Nuestra propuesta fue que un grupo de adolescentes realizara los trabajos necesarios para hacer una exposición en el museo sobre el Canal de los Presos, un gran obra de ingeniería realizada con los presos políticos de la represión franquista, para transformar en regadíos parte de las tierras del Bajo Guadalquivir y que en su trazado atraviesa nuestro término municipal.

La premisa de partida fue que las chavalas y chavales tendrían la autoría de la exposición y, por lo tanto, serían responsables del resultado final. Para el equipo del museo, esto suponía aceptar sus decisiones, aunque a veces no coincidieran con nuestro criterio, y comprometernos a vestir su trabajo para que el resultado fuera lo más profesional posible.

Contactamos con uno de los institutos de la localidad, el instituto de educación secundaria San José, y comenzamos los trabajos con el grupo de $3 .^{\circ} \mathrm{A}$ de la ESO, en colaboración con su profesor de historia Francisco Rivera Aguilar. Asimismo, para implicar al máximo número de personas, invitamos también al taller de fotografía de La Rinconada "Factoría creativa", quienes se prestaron inmediatamente a que el resultado de su trabajo artístico completara la exposición, con un conjunto de fotografías del canal. Finalmente la Asociación Comarcal Pro-Memoria Democrática Vega Media del Guadalquivir nos aportaría un contexto histórico a modo de introducción de la exposición y la Asociación Memoria, Libertad y Cultura Democrática nos ayudó facilitando las imágenes históricas y su interpretación del recorrido del canal y elementos significativos ${ }^{2}$.

Nos planteamos que el proceso tenía que conseguir que, por una parte, quienes participaban reflexionasen sobre la temática de la memoria democrática y, por otra, que lo hablaran en familia. Para ello les propusimos que hicieran una primera búsqueda de información tanto preguntado a adultos como en la red, y que nos contaran lo que más les había impresionado o interesado del tema. De la puesta en común de sus inquietudes salieron los cinco temas que se abordarían en la exposición, que iban desde el por qué de ese canal a las condiciones de vida de los presos, las consecuencias para las familias o las barriadas que surgieron en torno a los campos de concentración. 
a debate Memoria democrática en la construcción de la historia y el patrimonio

| coordina Josefina Cuesta Bustillo

A partir de aquí, 5 grupos de trabajo se encargaron de desarrollar cada uno de estos temas, seleccionar aquellos conceptos que les parecían más importantes y buscar información y apoyos gráficos. Por otra parte, desde el museo nos encargamos de rematar la redacción expositiva, aportar el diseño gráfico y ocuparnos de la producción final.

Llegado el día de la inauguración, se invitó a la comunidad educativa, asociaciones participantes y por supuesto a las familias y amigos del grupo autor. Se intentó dar la máxima importancia al evento, tanto en prensa y radio local, como con la presencia en la inauguración del alcalde y la delegada de Cultura y Memoria Histórica. Las chicas y chicos se enfrentaron a los micrófonos y cada grupo presentó las conclusiones de sus trabajos.

De todo este proceso lo que más nos llamó la atención a las personas que tutorizábamos los trabajos fue la gran perplejidad de esa generación, nacida y criada en democracia, ante la realidad de que el único delito de estos presos castigados con trabajos forzados había sido el pensar de forma diferente que los vencedores de la guerra.

Desde el museo hemos continuado con esta línea de trabajo $y$, tras esta primera exposición, hemos realizado en años sucesivos Tras-pasar la frontera: El exilio republicano y iAndaluces levantaos! De la dictadura a la autonomía andaluza. En la actualidad estamos preparando una nueva exhibición, en colaboración con el Centro de Estudios Andaluces, sobre la represión franquista, para la que ya estamos trabajando con dos institutos de la localidad y esperamos que se incorporen los dos restantes.

Para nosotros es muy importante destacar sobre todo algunas ideas que extraemos de la evaluación que nos hizo el alumnado participante. Por una parte, nombraron mucho la cercanía; les había impresionado que todo esto hubiera ocurrido, aquí, en nuestro pueblo. Por otro, descubrimos que, en muchos casos, era la primera vez que lo hablaban en su familia. Finalmente otra idea recu-

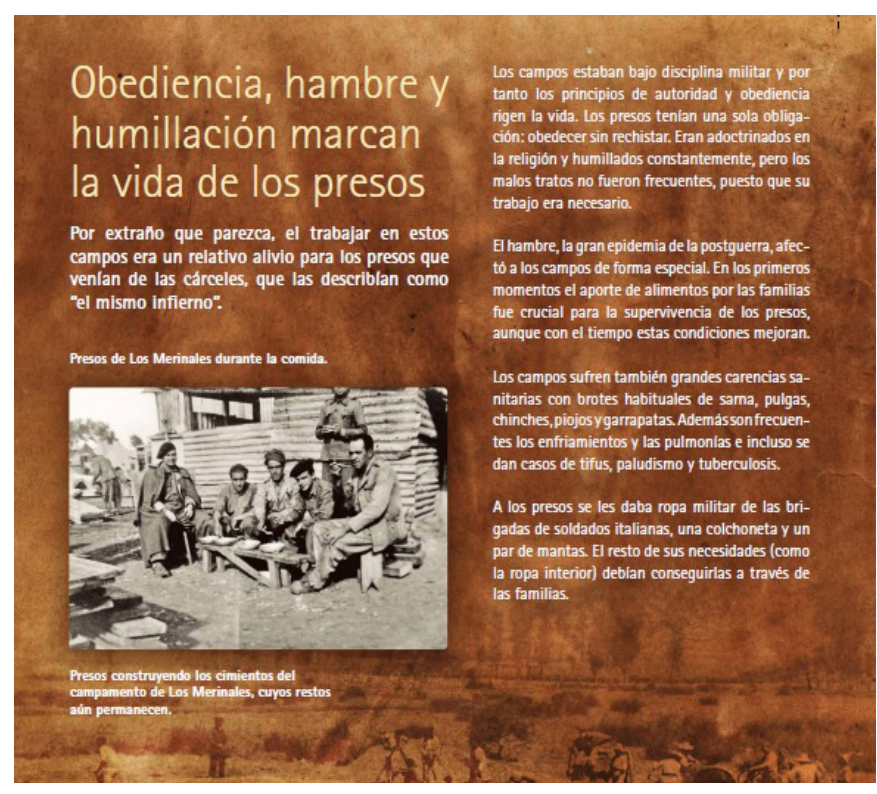

Detalle de uno de los paneles de la exposición | foto Fondo Espiral, Animación de Patrimonio

rrente la expresaré con las palabras que Lucía, una chica de 16 años, preparó para la inauguración:

“...Se nos presentó como un trabajo de historia, pero para nosotros ha dejado de ser eso. No es historia, no se ha dormido aún el pasado, algo que les sucedió a nuestros abuelos o bisabuelos. Tras las estadísticas y documentos que estudiamos, había personas, y gracias a este proyecto de investigación, hemos eliminado el efecto 'blanco y negro' y esta historia ha dejado de ser algo antiguo y oxidado".

\section{NOTAS}

1. Lara Cervera Pozo fue la encargada de realizar este catálogo.

2. Desde aquí queremos agradecer especialmente a Gonzalo Acosta Bono su colaboración y asesoramiento. 


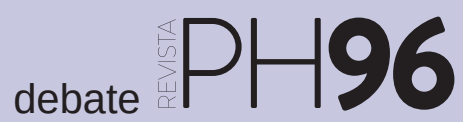

a debate Memoria democrática en la construcción de la historia y el patrimonio

| coordina Josefina Cuesta Bustillo

\section{Memoria, democracia y construcción de lo público}

Maria Chiara Bianchini | investigadora autónoma

URL de la contribución <www.iaph.es/revistaph/index.php/revistaph/article/view/4321>

Entre los varios temas que plantea este interesante debate, me referiré aquí a la cuestión de la memoria democrática, a cómo se define y a través de cuáles mecanismos o procesos puede ser promovida, específicamente desde el ámbito de la gestión del patrimonio construido y los monumentos. Retomo aquí algunas reflexiones que he desarrollado en mis estudios sobre los "patrimonios disonantes" en Chile y España (BIANCHINI, 2016), para proponer una discusión general sobre distintos modelos de "memoria democrática", que se materializan en el uso memorial del espacio público.

Por una parte, me parece importante reflexionar sobre la memoria democrática, porque esto implica cuestionar el significado de la propia palabra "democracia": re-pensar críticamente este concepto, "descolonizarlo", para volver a poner en discusión qué es lo que realmente significa, o, mejor dicho, qué es lo que queremos que signifique para nuestras sociedades. Pensar la memoria democrática significa pues aportar al debate actual sobre la democracia desde la perspectiva específica de los estudios y el activismo de la memoria. Por otra parte, considero que la cuestión del patrimonio construido y de los monumentos es un ámbito concreto muy interesante para entrar en este debate. Como varios autores han puesto de relieve, el patrimonio es la manifestación más visible y tangible de la memoria, es su "objetivación". Pero además de ser una expresión de la memoria, el patrimonio construido tiene que ver con lo público: con el espacio público y con la memoria pública. Los monumentos en torno a los cuales debatimos nos convocan porque expresan una memoria que nos pertenece a todas y todos, y su mantenimiento o destrucción deviene en un asunto político, en el sentido de que tiene que ver con la polis, con la gestión de lo colectivo y con el ejercicio de la ciudadanía. Preguntarnos acerca de la memoria democrática desde la perspectiva del patrimonio construido significa pues reflexionar sobre la construcción democrática de lo que es público.

A partir de esta pregunta, se puede plantear la memoria democrática por lo menos en dos maneras. Por un lado, una memoria democrática de tipo "liberal", que presupone la existencia de un espacio público que se presenta sustancialmente como un espacio "neutro", donde pueden coexistir memorias diversas, incluso contrarias. Esta idea, que en un principio puede parecer atractiva, tiene entre sus consecuencias la atomización del espacio público, su fragmentación en infinitas memorias "privatizadas" que no comunican entre sí, sino que, en el mejor de los casos, logran coexistir sin conflictos. $Y$ es esta coexistencia pacífica lo que se considera lo "democrático" de la memoria. Se trata de un concepto de "memoria democrática" que, a nivel de patrimonio construido, da lugar a ciudades en las que conviven monumentos que representan uno y otro de los bandos y las ideologías que han protagonizado lo principales conflictos del siglo XX. Sin embargo, lejos de darse en un espacio "neutro", la coexistencia de estas memorias y de sus símbolos patrimoniales reproduce a menudo las fronteras socio-económicas y étnicas de las ciudades contemporáneas, como en el caso de Santiago de Chile, favoreciendo una fragmentación memorial que implica a su vez una disolución de lo público.

Por otro lado, se puede pensar la memoria democrática como un discurso sobre el pasado basado en una selección explícita que se opera en virtud de determinados valores, que desde el presente se proyectan sobre el pasado en nombre de una cierta idea de democracia. En el caso español, por ejemplo, el concepto de "memoria democrática" emerge como reacción a una idea a-política de "memoria histórica", que promueve una reconciliación basada en la equiparación ética de "todas" las 
víctimas. En este sentido, la "memoria democrática" implica re-politizar el pasado, operando selecciones basadas en algunos valores que, sin embargo, no se ponen a debate. Si en el caso español estas selecciones son rechazadas por algunos sectores como "partidistas", en otros casos, las definiciones unívocas de la "memoria democrática" pueden incluso servir, paradójicamente, a ideologías retrógradas que sustentan regímenes autoritarios y censores. Es el caso de los nacionalismos católicos anti-comunistas actualmente en boga en algunos países de Europa oriental, que se basan en relatos del pasado radicalmente selectivos, a-críticos e impuestos desde arriba, y que, sin embargo, se auto legitiman como "democráticos", en oposición al pasado de dictadura.

En alternativa a estos conceptos de "memoria democrática", me interesa defender una tercera posibilidad, que implica cambiar el foco de la cuestión, pensando que lo "democrático" de la memoria tal vez no tenga tanto que ver con qué conmemoramos sino con cómo lo hacemos. Sugiero dejar en segundo plano los objetos y dedicarnos principalmente a los procesos. Los monumentos, en el fondo, no son más que piedras, cuyo valor reside principalmente en su capacidad de funcionar como "pretextos" o como "dispositivos" para generar el debate ciudadano, la cohesión social, la iniciativa desde abajo y la negociación entre ciudadanos e instituciones. Desde este enfoque de "memoria democrática" pueden abordarse los procesos de "recuperación" de sitios de memoria en América Latina -donde los ex centros de represión devienen en espacios para ensayar la gestión colectiva y asamblearia-, o la transformación de algunos monumentos dictatoriales en España o Europa -en torno a los cuales se movilizan comunidades de vecinos, se generan debates público, y se ponen en marcha ensayos más o menos exitosos de convergencia entre grupos ciudadanos e instituciones locales-. En esta perspectiva, el patrimonio construido es principalmente una oportunidad para desarrollar "ejercicios de democracia", tanto hacia dentro -en los procesos ciudadanos e institucionales que surgen alrededor de los monumentos y sitios de memoria-, como hacia afuera -en la relación con el resto de la ciudadanía y del espacio público-. En defini- tiva, y aún sin poder entrar aquí en ningún ejemplo concreto, me interesa aportar a este debate planteando que lo "democrático" de la memoria tal vez haya que buscarlo principalmente en el "patrimonio humano" que se genera en torno a los monumentos: en los experimentos, ensayos y aprendizajes inherentes a los procesos colectivos de construcción de la memoria pública.

\section{BIBLIOGRAFÍA}

- BIANCHINI, M. C. (2016) Patrimonios disonantes y memorias democráticas: una comparación entre Chile y España. Kamchakta, Revista de Análisis Cultural [en línea] n. ${ }^{\circ}$ 8, 2016, pp. 303-322 <https://ojs.uv.es/index.php/kamchatka/ article/view/9148> [Consulta: 07/12/2018] 


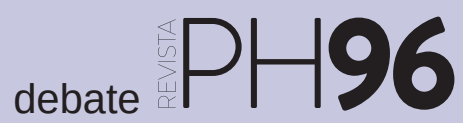

\section{El patrimonio contemporáneo en la construcción de la memoria democrática. La arquitectura que pervivió a los cambios de régimen del siglo $\mathrm{XX}$}

Juan-Andrés Rodríguez-Lora | Patrimonio y Desarrollo Urbano Territorial en Andalucía, Dpto. de Urbanística y Ordenación del Territorio, Universidad de Sevilla

URL de la contribución <www.iaph.es/revistaph/index.php/revistaph/article/view/4320>

Son numerosos los factores que pueden presentarse como un hándicap a la hora de patrimonializar la arquitectura que se construyó en el pasado siglo XX, especialmente la que respondía a conceptos nacidos desde el Racionalismo, el Movimiento Moderno y vinculados a las vanguardias históricas. A ello habría que sumar la componente de haber sido construida en la etapa de la Europa de los regímenes totalitarios.

Entre las múltiples negativas a reconocer estas arquitecturas como bienes culturales se encontrarían, por un lado, la relativa al tiempo necesario que debe transcurrir desde la construcción de un edificio hasta su reconocimiento patrimonial. Este valor temporal ha visto paulatinamente menguado su peso y longevidad con el paso de las múltiples leyes de patrimonio histórico que se han sucedido en nuestro ámbito geográfico. Pasando de valor imprescindible, e incluso de duración centenaria en las primeras leyes, a una reducción considerable del mismo, como así muestra el Plan Nacional de Conservación del Patrimonio Cultural del Siglo $X X$ (PLAN, 2015: 6).

Muy vinculado al hecho temporal, aparecería la particularidad de que se trata de elementos urbanos que se encuentran aún activos o lo han estado hasta hace poco con el cometido de responder a necesidades diarias de una sociedad contemporánea. Esta cotidianeidad implícita, sumada a un lenguaje despojado de ornato, pueden redundar en la ausencia de consideración de estos inmuebles como legado cultural, agudizándose en el caso de la población menos especializada en el concepto actual de patrimonio.
Habría que destacar, igualmente como obstáculo, el propio pensamiento de los arquitectos de los que surgen todas estas propuestas vanguardistas. Estos artífices modernos solían mostrarse beligerantes ante la idea de la pervivencia de los edificios una vez que han perdido su función, habitualmente con una postura crítica a la monumentalización (DE JONGE, 2017: 17).

Finalmente, otra de las dificultades que se presenta para estos casos es la relacionada con las connotaciones franquistas que pudieran emanar de los edificios construidos durante los años de régimen dictatorial. Este rechazo suele surgir bien a raíz de la simbología explícita que se colocaba en los edificios -cuestión abordada en la propia Ley 2/2017 en el artículo 32 de la misma (LEY 2/2017, 2017)-, o bien por ser edificios cuya construcción fuera promovida desde o durante el gobierno franquista, cuestión que sigue vigente en la actualidad y en que se centra la presente reflexión.

A pesar de lo explicitado anteriormente, los avances en el reconocimiento de esta arquitectura a nivel institucional e internacional cuentan con un recorrido que ya casi ronda el cincuentenario. Esta consideración por el patrimonio contemporáneo arrancaría en el año 1971, cuando numerosos expertos en esta materia se reunieron en Praga ante la preocupante desaparición de edificios del siglo XIX, pero también del siglo XX, abogando por su protección basándose en que "representan valores creadores que deben ser protegidos, de la misma forma que las creaciones de épocas precedentes" (DECLARACIÓN, 1971). Bien es cierto que, y no merecería ser pasado por alto, a efectos jurídicos, la pro- 

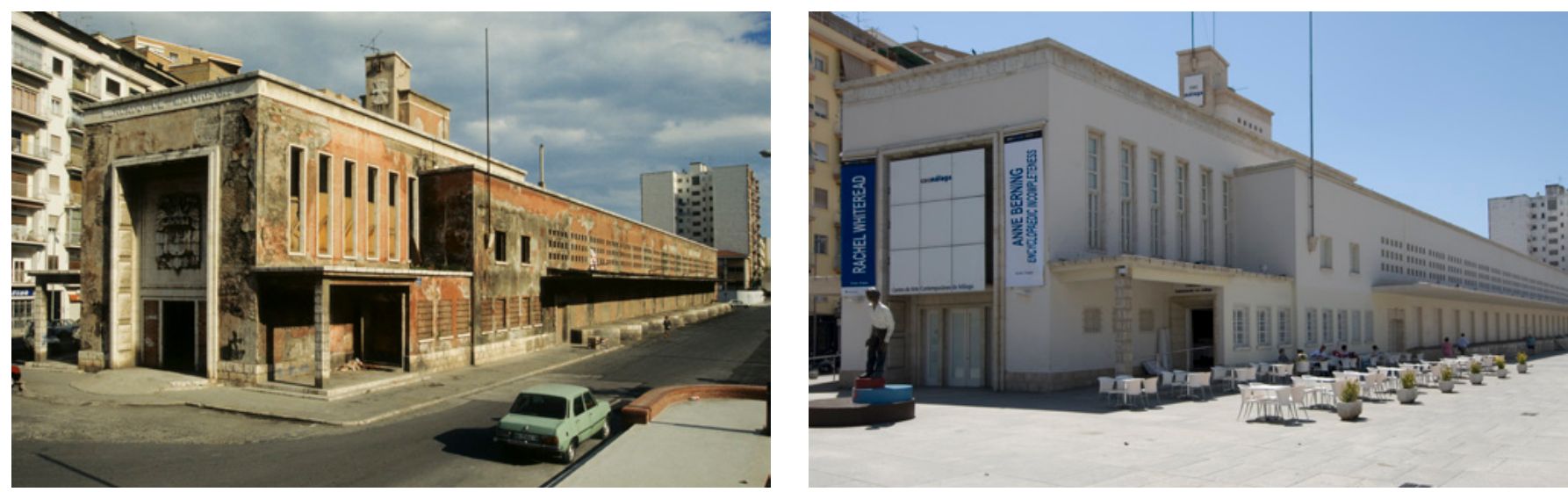

Mercado de Mayoristas en Málaga (1937-1944), de Luis Gutiérrez Soto, antes y después de su intervención, ejemplo de supresión de la simbología franquista una vez se interviene en democracia | fotos Fondo gráfico IAPH

tección que suelen recibir estos edificios por parte de las administraciones competentes en materia patrimonial es menor que la que otorgan a edificios de mayor recorrido histórico. Si pasamos al plano social, el reconocimiento patrimonial por parte de la población se encontraría en una situación aún más reducida.

Centrando la atención en la producción arquitectónica moderna del periodo de dictadura en España, son diversas las dificultades que en algunos casos pudieron encontrar estos proyectos a la hora de ser materializados. La apuesta por parte de distintos regímenes autoritarios por una arquitectura de aspecto más cercano al historicismo y con anhelos de monumentalidad tiene su reflejo en el caso español. La búsqueda de vínculos con tiempos pasados se topaba con el sentimiento rupturista que caracterizaba a las vanguardias. Este anacronismo provocado por la postura inicial del gobierno franquista se agudiza de manera especial en la arquitectura más oficialista, escenario con el que abocaron a múltiples arquitectos, con antecedentes y obras modernas de notable calidad (como es el caso del mercado de mayoristas de Málaga del arquitecto Luis Gutiérrez Soto), a construir edificios que no respondían a los conceptos desarrollados por la disciplina arquitectónica del momento (como el edificio que albergó el Ministerio del Aire en Madrid de 1943 a 1958, obra del mismo arquitecto).
Sin embargo, el proyecto moderno lograría en múltiples casos superar las dificultades de partida llegando a implantarse, incluso siendo aceptado y promovido, en el ámbito institucional y social de la época. De este modo, quedarían como legado para las generaciones posteriores ejemplos relevantes de arquitectura racionalista y moderna construida durante la dictadura. Como muestra de dicha trascendencia son diversos los edificios que se encuentran insertos en los inventarios especializados de este patrimonio.

En este sentido, a nivel peninsular destacarían los incluidos en el registro DOCOMOMO Ibérico y a nivel autonómico, para el caso de Andalucía, los del Registro Andaluz de Arquitectura Contemporánea (FERNÁNDEZ BACA-CASARES; PÉREZ ESCOLANO, 2012). Pero para construir una memoria democrática en torno a la arquitectura señalada también habría que mostrar, como así dilucidan las pertinentes investigaciones, las propuestas que no nacen en esta época, sino que se tratan de la continuidad de políticas y acciones que se habían venido haciendo en etapas previas. En este sentido se podría hacer referencia, entre otras, a la construcción de vivienda social, tema que venía preocupando en Europa desde finales del siglo XIX, como mostraron los congresos internacionales de "casas baratas", y cuyas medidas se comienzan a aplicar ya desde principios del XX (QUEIRO QUIJADA, 2015). 
Por ello, se hace necesario llevar a cabo acciones que abunden en la consideración patrimonial de estos edificios yendo más allá de las vinculaciones con el periodo en que se construyeron. La valoración objetiva de estos bienes se presenta indispensable en este cometido (PLAN, 2015: 19), pues realmente suponen una expresión contemporánea que ha ido traspasando los cambios de sistemas de gobierno del convulso siglo XX. Podría atenderse a otros valores intrínsecos de esta arquitectura bien sean por autenticidad, autoría, etc. (COSTA, 1999: 9), por la importancia del contexto y entorno en que se insertan (MOSQUERA ADELL; PÉREZ CANO, 2011: 409), o ampliando la óptica a lo que esta arquitectura supuso en el germen y construcción de la Unión Europea, cuya pérdida podría ahondar en el menoscabo de una identidad colectiva como así se hace patente en la Recomendación (91) 13 del Comité de Ministros de la Unión Europea (GONZÁLEZ MARTÍNEZ, 2013).

Esta arquitectura no solo sobrevivió a la época dictatorial y se consolidó en España -y en el resto de Europadurante dicha etapa, sino que su asentamiento supuso la base para otras expresiones tardías en torno a la misma a lo largo de la etapa final del siglo XX. Esta pervivencia a través de los cambios de sistemas experimentados, desde la Segunda República, pasando por la Dictadura hasta llegar a la democracia actual, merecería ser tenida en cuenta en la articulación de unos valores patrimoniales que vayan más allá de la etapa en que se construyó.
- DECLARACIÓN de Praga. Resolución para la protección de los monumentos culturales de los siglos XIX y XX, de 8 de octubre de 1971. Praga: Comisión de Resolución, 1971

- FERNÁNDEZ-BACA CASARES, R.; PÉREZ ESCOLANO, V. (coord.) (2012) Cien años de arquitectura en Andalucía. El Registro Andaluz de Arquitectura Contemporánea, 1.900-2.000 [en línea] Sevilla: Instituto Andaluz de Patrimonio Histórico, $2012<$ https://juntadeandalucia.es/export/drupaljda/RAACWEB_0.pdf> [Consulta: 04/12/2018]

- GONZÁleZ MARTínEZ, P. (2013) Aspectos Legislativos del Plan Nacional de Conservación del Patrimonio Cultural del Siglo XX. Madrid: Ministerio de Educación, Cultura y Deporte, Instituto del Patrimonio Cultural de España, 2013

- LEY 2/2017, de 28 de marzo, de Memoria Histórica y Democrática de Andalucía. Boletín Oficial de la Junta de Andalucía, n. ${ }^{\circ}$ 63, de 3 de abril de 2017

- MOSQueRA ADELL, E.; PÉREZ CANO, M. T. (2011) Refugios conocidos. De patrimonio de los arquitectos a patrimonio de todos. En DOMINGO, M.; MUÍNAA, I. (dir.) Criterios de Intervención en el Patrimonio Arquitectónico del Siglo XX. Conferencia Internacional CAH2OthC. Documento de Madrid 2011. Madrid: Ministerio de Cultura, Secretaría General Técnica-Subdirección General de Publicaciones, Información y Documentación, 2011, pp. 403-410

- PLAN Nacional de Conservación del Patrimonio Cultural del siglo XX (2015) Madrid: Ministerio De Educación, Cultura y Deporte, Secretaría General Técnica, Subdirección General de Documentación y Publicaciones, 2015

- QUEIRO QUIJADA, R. (2015) Patronato Municipal y Real Patronato de Casas Baratas de Sevilla. Aportaciones a la conformación de la ciudad a través de la vivienda social. 1913-1986 [en línea] Tesis doctoral inédita, Universidad de Sevilla, 2015 <http://hdl.handle.net/11441/36284> [Consulta: 19/02/2018]

\section{BIBLIOGRAFÍA}

- CostA, X. (1999) La coordinación internacional del proyecto de documentación y conservación del MOVIMIENTO MODERNO. En VV. AA. La arquitectura moderna en Andalucía: un patrimonio por documentar y conservar. La experiencia DOCOMOMO. Sevilla: Consejería de Cultura de la Junta de Andalucía, Instituto Andaluz de Patrimonio Histórico, 1999, pp. 6-11 (Serie Cuadernos, 11)

- DE JONGE, W. (2017) Sleeping Beauty. En KUIPERS, M.; DE JONGE, W. (dir.) Designing from Heritage. Strategies for Conservation and Conversion. Delft: TU Delft - Heritage and Architecture, 2017, pp. 14-29 


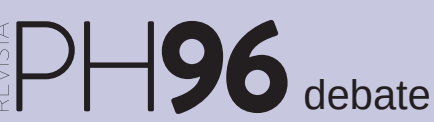

a debate Memoria democrática en la construcción de la historia y el patrimonio

| coordina Josefina Cuesta Bustillo

\section{Más allá de la connotación franquista. Una reflexión sobre la patrimonialización de las barriadas promovidas por el Instituto Nacional de la Vivienda}

Daniel Navas-Carrillo | grupo de investigación Patrimonio y Desarrollo Urbano Territorial en Andalucía, Dpto. de Urbanística y Ordenación del Territorio, Universidad de Sevilla

URL de la contribución <www.iaph.es/revistaph/index.php/revistaph/article/view/4307>

Esta contribución propone abordar el reconocimiento patrimonial de las barriadas residenciales de promoción publica construidas en España durante la dictadura franquista. Estos conjuntos surgen ante el déficit generalizado de vivienda -por el trasvase de población desde el campo a la ciudad- que caracteriza al conjunto de las ciudades europeas fundamentalmente durante el siglo $X X$. Es el momento de mayor crecimiento de las ciudades y, por tanto, el de mayor producción arquitectónica y urbanística de su historia urbana reciente. Sin embargo, se trata de bienes que en la mayoría de casos carecen de un reconocimiento patrimonial generalizado, tanto por parte de especialistas como de no especialistas. En consecuencia, no cuentan con niveles de protección comparables -en términos absolutos, ni proporcionalesa otras formas de vivienda, como el tejido residencial de los centros históricos o la propia arquitectura residencial unifamiliar moderna.

Hasta el momento, se ha realizado un importante esfuerzo en reconocimiento de estas piezas mediante la elaboración de los registros de la arquitectura del Movimiento Moderno (PÉREZ ESCOLANO; FERNÁNDEZ-BACA CASARES, 2012). Esto supone un paso innegable hacia la puesta en valor y conservación de estos conjuntos. Sin embargo, se ha detectado que estos conjuntos presentan algunas debilidades de cara a un reconocimiento generalizado y en consecuencia para su protección. Además de la asumida necesidad de establecer una distancia temporal con objeto de analizarlo desde valores históricos (BERNARD FEILDEN, 1995: 77), difícilmente pueden aplicarse criterios de representatividad y singularidad por su carácter de producción en masa.
Están desprovistas de cualquier atisbo de excepcionalidad en cuanto que son asociadas a la cotidianeidad (MOYA; MONJO; DÍEZ, 2017: 290). Además de no ser casos representativos de autenticidad e integridad por los altos índices de alteración que presentan muchas de las promociones.

En muchos casos, estamos ante conjuntos que presentan altos niveles de vulnerabilidad social y económica. Como reconoce el Plan Nacional de Conservación del Patrimonio Cultural del Siglo XX (CARRIÓN GÚTIEZ, 2015: 11), estas realizaciones presentan mayor vulnerabilidad que otras, atribuida a las características técnicas y funcionales de sus materiales y a su modo de producción. Lo que redunda en una ya percepción negativa por asociación al régimen franquista. Visión que en muchos casos se ha visto auspiciada por el debate sus-

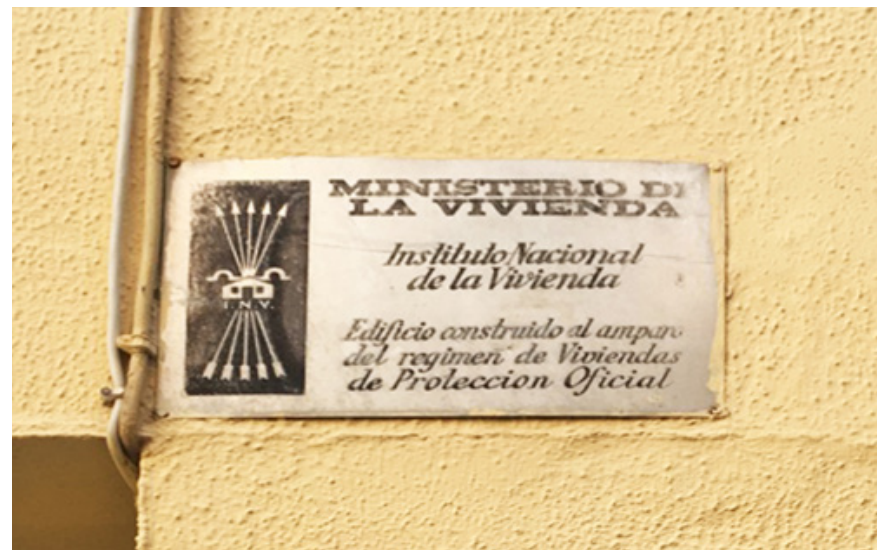

Placa del Instituto Nacional de la Vivienda. Grupo de Viviendas Ntra. Sra. de la Caridad (Sanlúcar de Barrameda, Cádiz) | foto Daniel Navas Carrillo (2018) 
citado en muchas ciudades españolas ante la retirada de las placas del Instituto Nacional de la Vivienda con yugo y flechas como consecuencia de la aplicación de la Ley de Memoria Histórica (RANZ ALONSO, 2017: 174-175; GONZÁLEZ DE LANGARICA MENDIZÁBAL; LÓPEZ DE MATURANA DIÉGUEZ, 2018: 29-30). Estas debilidades no solo condicionan el reconocimiento patrimonial de estos conjuntos, sino que, frente a otros patrimonios residenciales, como puede ser el de los centros históricos, carecen de atractivo para la inversión, quedando también fuera de las lógicas económicas que articulan el urbanismo actual. Hecho que aumentará el nivel de deterioro que estas viviendas presentan.

A pesar de estas consideraciones, se puede destacar una serie de potencialidades a partir de las cuales es posible realizar el juicio de valor necesario en cualquier proceso de patrimonialización. Por una parte, estamos ante referentes históricos de una política de vivienda concreta del pasado (PÉREZ CANO; MOSQUERA ADELL, 2006: 115), que supuso el modo de producción de ciudad que ha caracterizado el devenir del urbanismo europeo del siglo XX.

Por tanto, estos conjuntos deben ser valorados como parte del legado histórico de las ciudades, y acorde con las últimas consideraciones realizadas por UNESCO

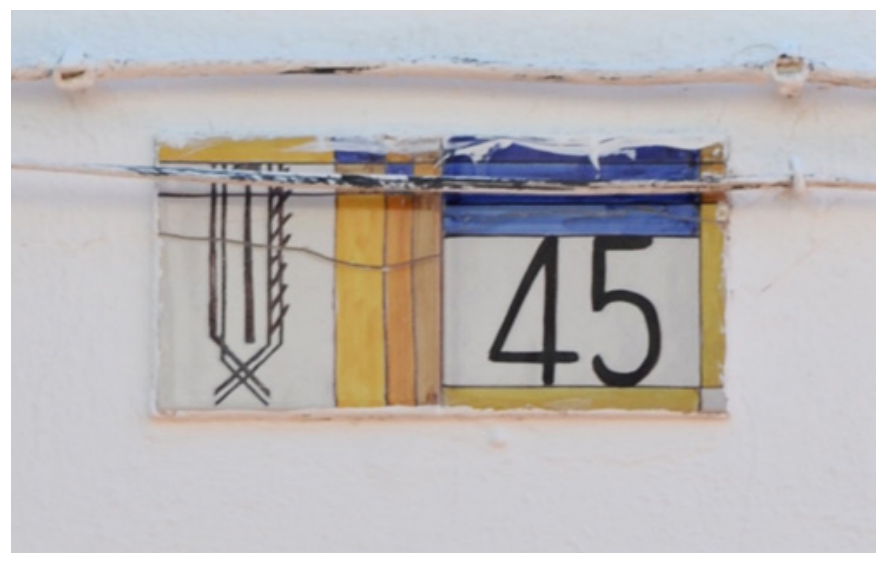

Azulejo de la Obra Sindical del Hogar y Arquitectura. Barriada Jesús Nazareno (Sanlúcar de Barrameda, Cádiz) | foto Daniel Navas Carrillo (2018)
(RECOMENDACIÓN, 2011) sobre el paisaje urbano histórico. Así mismo, la producción de vivienda social de esta época va a caracterizarse por quedar bajo la responsabilidad de una serie de arquitectos, quienes aglutinaron el desarrollo de un gran número de promociones. Muchos de estos autores cuentan con gran reconocimiento por la calidad arquitectónica y/o urbanística de sus obras, lo que puede advertirse como un factor determinante en su protección. Se trata de un patrimonio útil que responde a la función para la cual fue diseñado y, por tanto, puede ser portador de valores añadidos como el valor de uso. Así mismo también cabe la posibilidad de que los conjuntos posean un valor de originalidad o singularidad por el carácter experimental -funcional, técnica o social- que tuvieron muchas de estas realizaciones, lo que a su vez se relaciona con el valor científico o técnico en cuanto a la importancia y relevancia que su concepción ha tenido para la sociedad por su aspiración rupturista con los modos de habitar tradicionales.

Estos conjuntos han ido reconfigurando los límites de la ciudad a lo largo del siglo XX. En la actualidad poseen una posición estratégica en el tejido urbano actual, bien como charnela entre los centros históricos y los últimos desarrollos periféricos, bien por mantener su rol de límite urbano. Esto permite abordar su patrimonialización desde valores del lugar donde se implantan, en muchos casos en situaciones privilegiadas y próximas a la naturaleza, especialmente en el caso de ciudades de escala intermedia, así como valores de contexto en tanto que se insertan en una unidad de orden mayor en la que puede reconocerse cierta homogeneidad dentro del tejido urbano.

Por otra parte, no se debe olvidar que estas promociones surgen en la voluntad de los poderes públicos por compensar las desigualdades, por razones económicas, sociales y culturales, que existían en el acceso a la vivienda. Intentos que, en el caso de España, pero también en Portugal, se iniciaron en un contexto político de dictadura, pero que a nivel internacional era el reflejo de la creación de un nuevo orden social: el Estado del Bienestar (NAVAS-CARRILLO, 2017: 209). 
a debate Memoria democrática en la construcción de la historia y el patrimonio

| coordina Josefina Cuesta Bustillo

Estas viviendas supusieron, por tanto, un salto cualitativo en las condiciones generales de vida de la población, mucha de la cual hasta aquel momento había vivido hacinada en barracas sin unas mínimas condiciones de habitabilidad. Así, el valor social que puede ser intrínseco a algunas promociones juega un papel importante en el establecimiento de la identidad social y cultural de la población que allí reside. Lo que va a condicionar la interacción entre sus residentes, y lo que resulta de mayor interés patrimonial, va a generar en ellos un importante sentimiento de pertenencia al lugar y al colectivo que lo habita. Aunque no en todos lo casos, este sentimiento lleva asociado interés y preocupación por el estado de conservación, motivando su mantenimiento y rehabilitación. El valor social también puede ser traducido en el hecho de que se trata de un patrimonio compartido, en tanto que ha sido promovido por la administración pública. Cuestiones que, a juicio de este autor, quedan totalmente al margen del hecho de que estas viviendas fueran o no promovidas desde el gobierno franquista.

En base a esto, se puede afirmar que, frente a otras tipologías arquitectónicas del siglo $\mathrm{XX}$, que claramente carecen de aceptación por parte del público en general (HERNÁNDEZ, 2011: 70), los conjuntos de vivienda social pueden ser poseedores de valores "relacionados con los lazos emocionales de la sociedad [...] que tienen un fuerte impacto en su salvaguarda, conservación y restauración" (REFLEXIONES, 2004: 4). Lazos de la población que residen en estas viviendas, pero también el reconocimiento de su identidad como conjunto por el resto de la población local y, por tanto, desprovistos de cualquier significación política o ideológica.

\section{BIBLIOGRAFÍA}

- CARRIón gútiez, A. (2015) Plan Nacional de Conservación del Patrimonio Cultural del Siglo XX [en línea] Madrid: Secretaría General Técnica. Centro de Publicaciones. Ministerio de Educación, Cultura y Deporte, $2015<\mathrm{http}: / /$ www.culturaydeporte.gob.es/planes-nacionales/eu/dam/ jcr:fafab665-7e31-4da9-b897-180d8fd0eb0d/06-maquetadopatrimoniocultural-sxx.pdf> [Consulta: 29/11/2018]

- FEILDEN, B. (1995) Conservation of the 20th Century Building. Seminar on 20th century heritage. Helsinki: International Council on Monuments and Sites, 1995

- GONZÁLEZ DE LANGARICA MENDIZÁBAL, A.; LÓPEZ DE MATURANA DIÉGUEZ, V. (2018) Catálogo de símbolos y monumentos públicos existentes en Euskadi que supongan una exaltación de la guerra civil y de la dictadura. VitoriaGasteiz: Area Audivisual, 2018

- HERNÁNDEZ, F. (2011) Patrimonio arquitectónico y sociedad en América Latina. En HERNÁNDEZ LEÓN, J. M.; ESPINOSA DE LOS MONTEROS, F. (coord.) Criterios de Intervención en el Patrimonio Arquitectónico del Siglo XX. Madrid: Ministerio de Cultura, 2011, pp. 69-79

- MOYA, L.; MONJO, J.; DÍEZ DE PABLO, A. (2017) La arquitectura ordinaria del siglo $X X$ como patrimonio cultural: tres barrios de promoción oficial de Madrid. Revista EURE Revista De Estudios Urbano Regionales, vol. 43, n. ${ }^{\circ} 130,2017$, pp 269-294

- NAVAS CARRILLO, D. (2017) Los conjuntos de vivienda social como objeto patrimonial, el caso de Setúbal (19331983) Portugal [disponible en línea] Trabajo Fin de Máster, Universidad de Sevilla, 2017 <https://idus.us.es/xmlui/ handle/11441/70025> [Consulta: 14/12/2018]

- PÉREZ CANO, M. T.; MOSQUeRA ADELL, E. (2006) La Protección del Patrimonio Edificado. Catalógo de Bienes Inmuebles del Municipio de Almonte. Sevilla: Secretariado de Publicaciones de la Universidad de Sevilla, 2006

- PÉREZ ESCOLANO, V.; FERNÁNDEZ-BACA CASARES, R. (2012) Cien años de arquitectura en Andalucía: el Registro Andaluz de Arquitectura Contemporánea, 1900-2000. Sevilla: Instituto Andaluz del Patrimonio Histórico. Junta de Andalucía, 2012

- RANZ ALONSO, E. (2017) Relevancia de la Memoria Histórica en el ordenamiento jurídico y documental en España. Tesis Doctoral inédita, Universidad Carlos III de Madrid, 2017

- RECOMENDACIÓN sobre el paisaje urbano histórico (2011). París: Organización de las Naciones Unidas para la Educación, la Ciencia y la Cultura, 2011

- Algunas REFLEXIONES sobre autenticidad (2004). París: Organización de las Naciones Unidas para la Educación, la Ciencia y la Cultura, 2004 


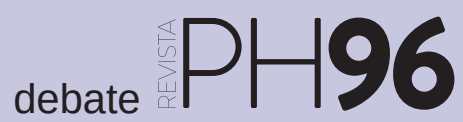

a debate Memoria democrática en la construcción de la historia y el patrimonio

| coordina Josefina Cuesta Bustillo

\title{
Memoria democrática en la construcción de la historia y el patrimonio
}

\author{
Dirección General de Memoria Democrática, Consejería de Presidencia, Administración Local y Memoria Democrática, Junta de \\ Andalucía ${ }^{1}$
}

URL de la contribución <www.iaph.es/revistaph/index.php/revistaph/article/view/4334>

Las políticas públicas de memoria impulsadas desde el gobierno andaluz se han desarrollado bajo la firme convicción de preservar e impulsar la memoria como un espacio público que crea espacios de convivencia y de respeto mutuo, a la vez que ayuda a asentar en nuestra tierra una verdadera cultura democrática fundamentada en los derechos humanos. Se trata de construir un relato común y compartido (que no uniforme) de la verdad acontecida; de recordar, reconocer y reparar a los que padecieron, por expresar sus ideas o murieron por defender los derechos de una sociedad libre como la que hoy disfrutamos; de cerrar definitivamente las heridas de las víctimas, reparando su sufrimiento y el dolor añadido por la falta de reconocimiento. De ahí la importancia de la Ley 2/2017, de 28 de marzo, de Memoria Histórica y Democrática de Andalucía, aprobada por el Parlamento andaluz sin votos en contra en esta legislatura y tiene como objetivo el de garantizar a la ciudadanía andaluza el derecho a conocer tanto la verdad de los hechos acaecidos como la protección, conservación y difusión de la memoria democrática como legado cultural de Andalucía.

La memoria es, ciertamente, de todos y todas, de los que tienen, por su formación, las herramientas para la construcción del relato, de los poderes públicos que tienen la obligación de activar políticas en las que recojan las demandas de la sociedad civil en materia de derechos humanos, y de la ciudadanía en general, sobre la que un relato verídico, objetivo y asumible por todos y todas, tiene efectos beneficiosos, por cuanto supone conocimiento para la divulgación y la pedagogía, pero también para la asimilación y la concienciación para la no-repetición de la barbarie. Se trata, por tanto, de una tarea compartida basada en la corresponsabilidad de todos los actores que actúan para la recuperación de la memoria histórica pero donde los poderes públicos deben estar en vanguardia fijando siempre la mirada en la doble utilidad de la memoria: como forma de reparar el agravio y como herramienta para construir un futuro mejor.

Es totalmente necesario patrimonializar la memoria democrática, y puede (y se hace) de muchas formas, desde las intervenciones encaminadas a la localización y recuperación de las víctimas en las fosas comunes, al señalamiento de los espacios emblemáticos vinculados a este periodo (lugares de memoria histórica y democrática) o a la monumentalización de los otrora espacios de oprobio e ignominia; desde la colaboración entre administraciones, entidades y asociaciones; desde la investigación y el conocimiento, la divulgación y la pedagogía. Y todo ello para cumplir con los principios de Verdad, Justicia, Reparación y garantía de No-Repetición.

¿Recuperar y poner en valor una memoria no implica el olvido de otras? Jamás si se hace bien, porque no existe además "una memoria", o no debiera existir al menos. Debe, en cambio, existir "la memoria", en el sentido del relato que se identifique y asuma colectivamente. Hay que hacerlo con rigor y desde el principio de cooperación, entendiendo la memoria como un proceso de recuperación de las historias de quienes fueron olvidados y sobre cuyas vidas o bien nunca se habló o bien sus relatos se tergiversaron por el régimen. La memoria es una mezcla de las experiencias vividas, de sentimientos y, sobre todo, de una enorme generosidad, es una voz que recuperamos para ayudarnos a mirar y entender nuestro pasado trágico de una manera crítica. Y, sí, tiene mucho de subjetivo pero una subjetividad que proviene del dolor y del padecimiento de miles de inocentes. 
a debate Memoria democrática en la construcción de la historia y el patrimonio

| coordina Josefina Cuesta Bustillo

No creemos en las verdades enfrentadas, sí contrapuestas, fruto del análisis del pasado que hacemos desde el presente. Esa contraposición no debe ser negativa sino todo lo contrario, un motor y una excelente herramienta para seguir dialogando, investigando, reparando el daño de todos los que sufrieron una violencia injustificada, por tanto, para resolver esa dicotomía quizás sea clave la profundización en la Verdad como es la única forma útil de cerrar las heridas del pasado.

Una cosa es la memoria y otra la historia, ambas son complementarias pero la historia profundiza en los hechos desde el análisis de procesos complejos desde una mirada más general. La memoria, en cambio, radica en el protagonista que aporta una mirada llena de texturas que enriquecen el análisis histórico y que se fundamenta en el padecimiento, el olvido, los silencios y la lucha contra la invisibilidad. La historia siempre está en riesgo de ser manipulada para lo cual es imprescindible, y volvemos a insistir, profundizar en la investigación rigurosa y en el conocimiento de la Verdad. Abordar el pasado, al igual que los requerimientos del presente, desde la seriedad y el rigor, sin trincheras políticas, solo atendiendo a lo que dicen las víctimas y establecen los organismos internacionales en materia de derechos humanos.

¿Retiramos de nuestros espacios públicos símbolos asociados a totalitarismos o preservamos con valor pedagógico? Ambas cosas son compatibles en determinados supuestos. En cualquier caso, se prohíbe la exhibición pública de aquellos elementos que enaltezcan el golpe militar y la dictadura franquista, que son contrarios a la propia dignidad de las víctimas o constituyen una exaltación del enfrentamiento.

Es, por tanto, retirar del espacio público esos elementos $y$, en otros casos, mantener y explicar por qué es un símbolo que constituye una ofensa contra las víctimas con arreglo a nuestras leyes de memoria. No hay una sola receta ni se puede hacer tabla rasa con todo, y por ello se encuentra actualmente en última fase de tramitación un decreto que regula un comité técnico compuesto por personas expertas que tendrá la última palabra en este tema.
Llevar a cabo la labor de difusión e interpretación de la memoria democrática sin que suponga una banalización de la historia se consigue desde el rigor, con escrupulosidad histórica, y con una selección "cuidada" de espacios de especial significación que representen el conocimiento de los hechos y el recuerdo a las víctimas, pero evitando que una proliferación exagerada provoque una pérdida de fuerza de mensaje y simbolismo, que se termine incurriendo en esa banalización a la que se refiere.

En relación con la puesta en valor de la memoria democrática desde una perspectiva de género, Andalucía es también un ejemplo en el tratamiento que desde las políticas públicas de memoria se ha otorgado de manera específica a la mujer, y desde varios ámbitos: tanto desde la aprobación de normativa que recoge indemnizaciones específicas a mujeres vejadas y ultrajadas como consecuencia de la represión franquista, como desde la investigación y divulgación (subvenciones en las que se ha valorado la perspectiva de género de los proyectos, documentales en las que el protagonismo era ostentado por mujeres), o intervenciones específicas en "fosas de mujeres" (las "17 rosas" de Guillena, las mujeres de Grazalema, las "niñas" de El Aguaucho, o la fosa de las mujeres de Higuera de la Sierra).

Nuestro compromiso e implicación con la cuestión de género es total, y así se confirma en el recientemente aprobado por Consejo de Gobierno I Plan Andaluz de Memoria Democrática, en el que se recoge, entre las líneas de actuación que deben regir este plan plurianual, las destinadas a este ámbito.

\section{NOTAS}

1. Contribución que llegó a revista $P H$ el 13 de diciembre de 2018. Con el Decreto 2/2019 de 21 de enero las competencias de memoria democrática pasan a corresponder a la Consejería de Cultura y Patrimonio Histórico de la Junta de Andalucía. 


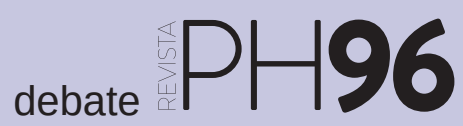

a debate Memoria democrática en la construcción de la historia y el patrimonio

| coordina Josefina Cuesta Bustillo

\section{Los caminos tortuosos de las defensoras de la(s) memoria(s) de la posguerra peruana}

José Ramos López | Círculo de Estudios José María Arguedas - UNSCH (Universidad Nacional de San Cristóbal de Huamanga, Perú)

URL de la contribución <www.iaph.es/revistaph/index.php/revistaph/article/view/4339>

Perú, una sociedad que mantiene cuentas pendientes con el pasado, se cobija bajo políticas de reparación obviando las políticas de memoria(s) reflejadas en la imperante cultura negacionista ${ }^{1}$, anclada en la memoria hegemónica protagonizada por héroes, excluyendo otras memorias en la patrimonialización promovida por el Estado. En este contexto, la sociedad civil nos da lecciones sobre experiencias de musealización de la memoria democrática y responsable.

Las narrativas sobre el conflicto armado interno² (19802000) han predominado la voz de hombres, situando las luchas por la memoria emprendida por las mujeres en el baúl del olvido, la sospecha y la indiferencia. Las líneas posteriores abordan la historia polivocal de mujeres que integran la Asociación de Familias Secuestradas, Detenidos y Desaparecidos del Perú (ANFASEP). Mujeres analfabetas, provenientes de comunidades campesinas, quechuahablantes que irrumpieron en el espacio público de los andes ayacuchanos un 2 de setiembre de 1983 para denunciar la desaparición de un familiar cercano.

A 35 años de vida institucional y 15 años de la entrega del Informe Final de la Comisión de la Verdad y Reconciliación han puesto en valor la memoria democrática desde una perspectiva de género, tales como el museo de la memoria de ANFASEP "Para que no se repita", inaugurado en 2006; La Hoyada: santuario de la memoria, lugar de memoria para el entierro digno de cuerpos exhumanos no identificados; intervenciones públicas performativas en torno a la memoria. Centramos nuestra atención en las mujeres rurales que compartieron su(s) memoria(s) para complejizar su agencia política y el papel de reconstruir la sociedad peruana.

\section{Rompiendo estructuras de dominación}

Nos encontramos con un conjunto de paquetes que complejizan la violencia y que el sujeto, que es mujer y procedente de la comunidad andina, está lleno de memorias (GAMARRA, 2002; DEL PINO, 2003), se moviliza a la ciudad y opta por diferentes mecanismos para poder solventarse, tener una vida digna, un techo propio y, en pocos casos, reclamar sus derechos. Ubicadas en los asentamientos humanos, caracterizados por abismales brechas sociales, económicas, étnicas donde se les percibe como "insignificantes: pobres, rurales, indígenas, mujeres. $Y$ vuelve a reaparecer la trenza de discriminaciones y desprecios." (DEGRÉGORI, 2015: 260). Empero, la vivencia del conflicto armado interno y la violencia rutinizada no terminan consumiendo y opacando a las actrices sociales. Si reparamos el uso, la invención y re-invención de la parafernalia de estrategias culturales para poder salir de estos ciclos de violencia, veremos que las actoras sociales innovaron nuevos sentidos de género, utilizaron su presupuesto cultural para desarrollar la capacidad de resiliencia.

En este contexto de la post-guerra, la mujer "se propone legitimar su presencia y respaldar sus espacios ganados ubicándose como sujeto social en las tareas de reconstrucción y desarrollo local" (CORAL, 1999: 359). Dicha autora nos muestra la participación en tres etapas: un antes, en el cual la mujer era invisibilizada, donde cumplía roles domésticos; luego, un periodo de conflicto, donde la mujer sufre una infinidad de vejámenes que se arraigan en lo más profundo de su subjetividad; y, por último, en la post-guerra, en el cual predominan las jefaturas y las mujeres son visibilizadas porque emprenden demandas sociales de reconocimiento y reparación por parte del Estado. 
a debate Memoria democrática en la construcción de la historia y el patrimonio

| coordina Josefina Cuesta Bustillo

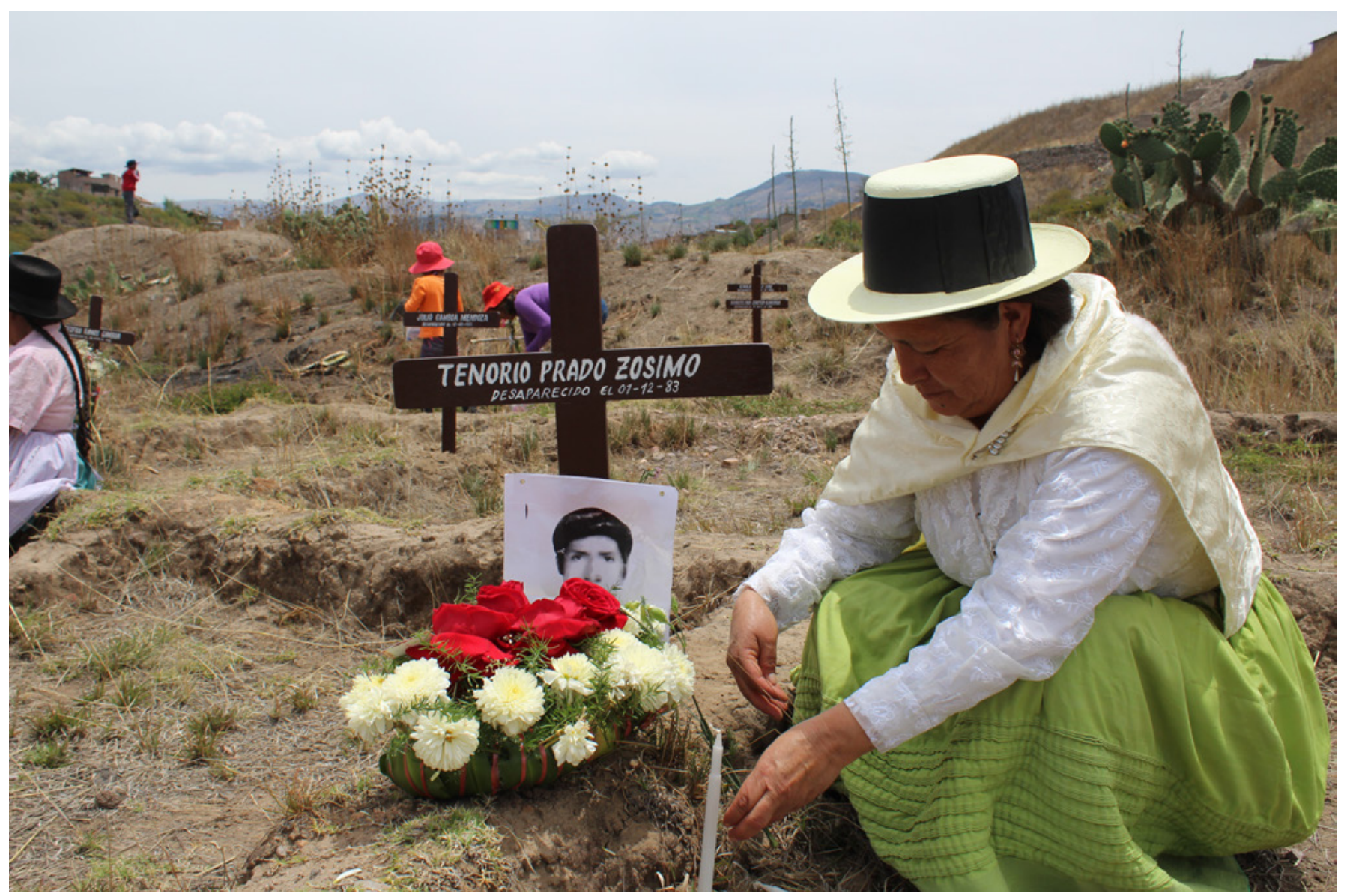

Adelina Mendoza, lideresa de ANFASEP, conversa con su esposo desaparecido en La Hoyada, Santuario de la memoria

La asignación casi completa de responsabilidades y la sobrecarga de trabajo hacia la mujer propiciaron un escenario fértil para la participación en espacios públicos y representativos. En consecuencia, las ideas sobre género entraron en un proceso de re-significación como "warmikunaqa qari hina karaniku"3, "Las mujeres pues tenemos más fuerza para podernos recuperar", "padre y madre he sido para mis hijos". Se contempla la anexación de los roles tradicionales que el varón cumplía para un nuevo sentido de género conocido como mujer "warmi-qari" (mujer-varón). La acepción anterior era una característica propia de las mujeres viudas que tenían mayor acceso a los espacios públicos, eran "warmisapas"4 (THEIDON, 2004: 131). Se empiezan a redefinir las estructuras de género y relaciones identitarias, las femineidades a partir de la situación de las masculinidades. Quienes estaban "ausentes", en sentido físico, en sus hogares.

Muchos de los testimonios recolectados por la Comisión de la Verdad y Reconciliación y la literatura antropológica sobre la violencia política nos muestran que las mujeres tienden a priorizar el bienestar de los "otros", así como comentar sobre los problemas de sus hijos, sobre cómo desapareció su familiar y las acciones de búsqueda irrenunciable. Dedicándole un reducido tiempo para sus sentimientos. Sin embargo, puede parecernos una paradoja pero a través del cuidado de los otros se cuida también ella. "No voy a las atenciones, ni al hospital para curarme. Mis hijos son primero, si están bien ellos yo tam- 
bién estoy." Una moral del cuidado (GILLIGAN, 1982), una maternidad hegemoniza las representaciones discursivas de sus vidas que las hace aparecer como heroínas. Adicionalmente impera un imaginario social sobre la capacidad desarrollada por las mujeres de hacer frente a la realidad adversa, de asumir con gran responsabilidad los espacios de representación, producto de una continuidad política venidera desde las organizaciones que proceden como comedores populares, organizaciones gremiales del mercado, organizaciones de búsqueda de personas.

\section{Estrategias culturales y ganando la posguerra}

"Lo que he sufrido me ha hecho abrir los ojos, hemos madurado mucho, las mujeres hacemos bien nuestros cargos, con responsabilidad; en cambio los varones se gastan bebiendo. Nosotras no"5

El dolor, la incertidumbre de sus familiares, la violencia experimentada se convirtieron en fuerzas motoras para sobresalir de su condición de mujer, víctima, desprotegida, relegada, y legitimarse en espacios económicos, sociales y políticos haciendo uso de un repertorio discursivo que cambia de acuerdo a la población. En las reuniones internas de ANFASEP, la representación discursiva de la mujer gira alrededor de la valentía, la fuerza de sobreponerse y la capacidad de resiliencia. Mientras que en reuniones multisectoriales la representación discursiva se agrupa en la victimización por la sociedad y el Estado poniendo énfasis en las constantes discriminaciones que experimentan y el poco compromiso de buscar la verdad.

Todo el repertorio de mecanismos culturales utilizados en la sociedad de la posguerra insiste en re-conocer la capacidad de resistir, sobreponerse y salir de experiencias dolorosas (GAMARRA, 2010). Es decir, la resiliencia cultivada por las mujeres les abrió un abanico de oportunidades, transitando del dolor hacia la acción y construcción de ciudadanía y desarrollo (REYNAGA, 2008). Los puntos de inflexión provocan una respuesta emocional y cognitiva permitiendo darle la vuelta al problema y buscar agujeros de escape para aprovecharlos de cierta

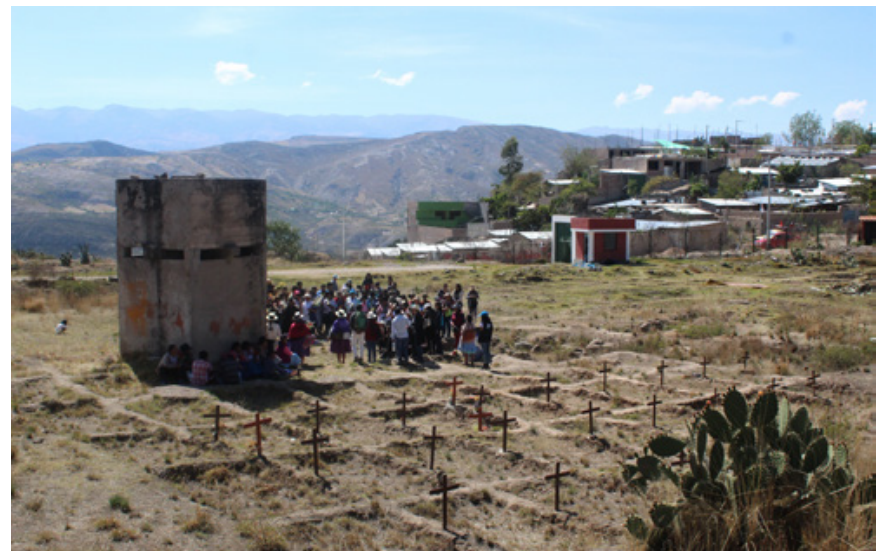

Madres ayacuchanas al costado del tanque de combustible, lugar donde los militares del cuartel "Los Cabitos N51" cremaron cuerpos en los años de violencia

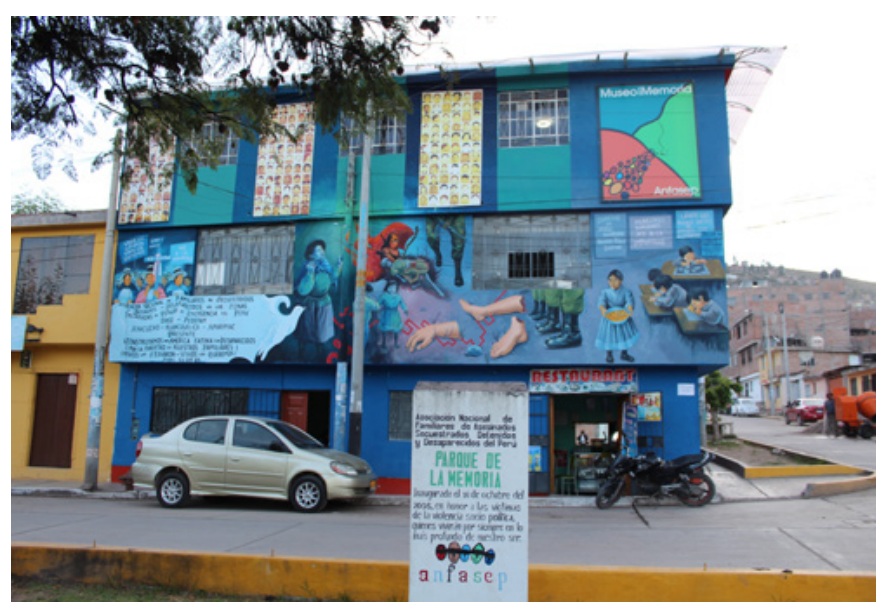

Museo de la memoria "Para que no se repita" muestra de manera pedagógica los años de violencia, gestionada por ANFASEP y ubicado en Ayacucho, Perú fotos José Ramos López (Ayacucho, 2019)

manera. La resiliencia no solo opera en aspectos psicológicos sino, más bien, en las distintas dimensiones de la vida. Pero tres componen las regularidades en la vida de las mujeres: primero, en las argucias económicas (responsabilidades sobrecargadas); segundo, en el ámbito público (mayor inserción); y tercero, el manejo de las emociones y sentimientos.

Entonces, abordar estos problemas debe de "contribuir a discernir lo que somos como país, incluyendo la 


\author{
a debate Memoria democrática en la construcción de la historia y el patrimonio \\ | coordina Josefina Cuesta Bustillo
}

exclusión y las desigualdades persistentes, la falta de ciudadanía y la débil institucionalidad política". Carlos Iván Degregori proponía que una política de memoria en el Perú debía contribuir a un "nunca más" de la violencia, pero también a un "nunca más" de la exclusión, un "nunca más" de poca ciudadanía y un "nunca más" de la extrema pobreza (DEL PINO; AGÜERO, 2014: 24). Es decir, dar un buen tratamiento y lectura cultural de la memoria para poder vivir en una sociedad, en la cual potenciemos la convivencia y coexistencia social con criterios tolerantes. Las experiencias anteriores son una forma de ganar la posguerra de poco a poco.

\section{NOTAS}

1. El otorgamiento del indulto al ex presidente Alberto Fujimori, sentenciado por la violación de derechos humanos mediante un grupo paramilitar Grupo Colina en los casos de Barrios Altos y La Cantuta, obedece a dicha memoria negacionista situada en el poder político de legisladores distorsionando el sentido de la reconciliación.

2. Categoría que hace alusión a los veinte años de violencia protagonizada por Sendero Luminoso, grupo alzado en armas, y las Fuerzas Armadas, ocasionando 2329 desaparecidos, 69.000 víctimas, más de 600.000 desplazados y aproximadamente 5000 sitios de entierro clandestino.

3. Las mujeres éramos como los varones.

4. Mucho más que una mujer o doblemente mujer.

5. Conversación con una socia de ANFASEP.

\section{BIBLIOGRAFÍA}

- DEGRÉGORI, C. I. (2015) Heridas abiertas, derechos esquivo. Derechos humanos, memoria y Comisión de la Verdad y Reconciliación, Obras escogidas (Vol. IX). Lima: IEP, 2015

- DEL PINO, P. (2003) Uchuraccay: Memoria y representación de la violencia política en los Andes. En DEGRÉGORI, C. I. Jamás tan cerca arremetió lo lejos: Memoria y violencia política en el Perú. Lima: IEP, 2003, pp. 49-93

- DEL PINO, P.; AGÜERO, J. C. (2014) Cada uno, un lugar de memoria. Fundamentos conceptuales del Lugar de la Memoria, la Tolerancia y la Inclusión Social. Lima: LUM, 2014

- CORAL, I. (1999) Las mujeres en la guerra: impacto y respuestas. En STERN, S. Los senderos insólitos del Perú: guerra y sociedad, 1980-1995. Lima: IEP-UNSCH, 1999, pp. 337-363

- GAMARRA, J. (2002) Las dificultades de la memoria, el poder y la reconciliación: documento de discusión. Ayacucho: IPAZ, UNSCH, 2002

- GAMARRA, J. (2010) Resiliencia social y cambio en comunidades campesinas afectadas por conflicto armado interno: el caso de las comunidades de Incaraccay y Tanquihua en la provincia de Cangallo, Ayacucho. Lima: IPEDEH, 2010

- GILLIGAN, C. (1982) La moral y la teoría: Psicología del desarrollo femenino. México: Fondo de Cultura Económica, 1982

- REYNAGA, G. (2008) Respuesta de las mujeres ayacuchanas frente a los problemas de la violencia política [en línea]. Tesis para optar el grado de Magister en Gerencia Social. Lima: PUCP. <http://tesis.pucp.edu.pe/repositorio/ handle/123456789/1106> [Consulta: 21/12/2018]

- THEIDON, K. (2004) Entre prójimos. El conflicto armado interno y la política de la reconciliación en el Perú. Lima: Instituto de Estudios Peruanos, 2004 


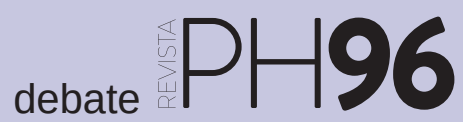

a debate Memoria democrática en la construcción de la historia y el patrimonio

| coordina Josefina Cuesta Bustillo

\title{
La historia es... Reflexiones sobre los conceptos de historia, memoria y patrimonio
}

\author{
Antonio Gisbert Santaballa | Departamento de Educación, Gobierno de Navarra \\ URL de la contribución <www.iaph.es/revistaph/index.php/revistaph/article/view/4340>
}

E. H. Carr publicó en 1961, hace ya 57 años, ¿Qué es la historia? (CARR, 1961), una obra fundamental para comprender los cambios paradigmáticos en historiografía de la segunda mitad del siglo XX. En el debate que se abre a raíz de la publicación de dicha obra, asistimos a la preocupación por parte de los historiadores de intentar responder a tan importante pregunta.

Las posturas antagónicas de Carr y Elton (1967), entre otros, al respecto se configuraron en base al contexto e ideología de cada uno de ellos (causalidad, análisis, macroestructuras, materialismo dialéctico del primero, frente a historia política, narrativa, personajes individuales, conservadurismo del último), y sin embargo revelan una preocupación común, preocupación que no solo se circunscribe al debate surgido a raíz de la publicación de ¿Qué es la historia?, sino que ha acompañado al estudio de la disciplina histórica desde su nacimiento y lo sigue haciendo: la preocupación por parte del historiador de intentar explicar su tarea, justificar la validez y funcionalidad de su disciplina, su lugar dentro de la sociedad, y en definitiva, establecer la naturaleza y definición de la historia como ciencia o conocimiento.

El propósito de este ensayo no es intentar responder la gordiana pregunta planteada por Carr, ni entrar en el eterno debate sobre la naturaleza y función de la historia, sino poner de relevancia los diferentes conceptos que operan en este debate: historia, memoria, patrimonio.

La función de la historia como ciencia es señalada por autores como Pérez Ledesma (2001: 15), como una constante desde el siglo XIX, adoptando diferentes formas. En un primer momento, la recién nacida disciplina pugna por convertirse en ciencia social, frente a otras cuya "utilidad" y "cientificidad" parecía más obvia (sociología, psicología...). El debate en el siglo XX viene marcado por el cambio de paradigma que supone la aparición de la Escuela de los Anales en Francia e historiadores anglosajones como Carr y Thompson. Esta "edad de oro de la historiografía" (PÉREZ, 2001: 17) sitúa a la historia como ciencia capaz de explicar el presente a través de las causas pasadas que lo han configurado y, por lo tanto, presenta una capacidad de transformar el futuro a partir de las claves que nos proporciona el estudio del cambio histórico.

Sin embargo, cambios en el contexto inmediatamente posterior tales como el auge del neoliberalismo en los años 80, la caída del Unión Soviética, la globalización... provocan la "defunción de la causalidad" (CANNADINE, 2005: 13), de las teorías de Carr, y al mismo tiempo, la aparición de otras formas y métodos de aproximación al conocimiento del pasado.

Es en este contexto de cambio y caída de paradigma donde surge un concepto básico en torno al cual se van

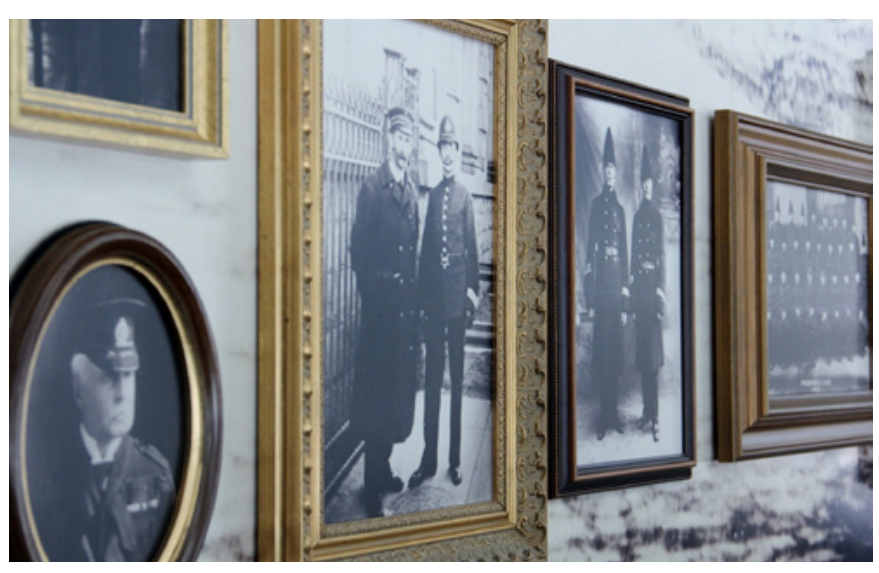

Historia, memoria y patrimonio | fuente pxhere 
a debate Memoria democrática en la construcción de la historia y el patrimonio

| coordina Josefina Cuesta Bustillo

a configurar los debates relativos a la función y legitimidad del conocimiento histórico: la memoria. La aparición de este nuevo concepto es señalada por varios autores como fruto de diferentes causas. La aparición de las Tecnologías de la Información y la Comunicación (CANNADINE, 2005: 13), que democratizan el conocimiento y abren el interés acerca del pasado a amplios sectores de la población, pero sobre todo, los cambios sociales y económicos derivados de la globalización, y con ellos, la búsqueda de identidad del individuo, de pertenencia a grupos más cercanos y tangibles que el superado y denostado concepto de "nación" (CASPISTEGUI, 2003: 193).

Veremos, pues, la importancia de la memoria en los debates historiográficos de los últimos años, al apoyar o rechazar su función y legitimidad a la hora de participar en la interpretación y tratamiento que se hace del pasado, junto a la historia. Algunos autores han visto en este proceso una dinámica actual a través de la cual el historiador abandona el ámbito estrictamente académico y se "profesionaliza", atendiendo a las demandas de la sociedad, la política, los medios de comunicación, la justicia... en definitiva, el "uso público de la historia" (PASAMAR, 2003: 226).

Es significativo el encendido debate surgido en torno al binomio memoria-historia entre los historiadores Santos Juliá y Sebastiaan Faber. Juliá establece una diferencia sustancial en el ámbito de aplicación de ambos conceptos, entre lo que compete a la historia y a la memoria, defiendo las funciones y límites de ambos (JULIÁ, 2011). Por el contrario, autores como Faber, Sánchez León e Izquierdo Martín consideran que asumir la existencia de la memoria e intentar reducirla a un coto cerrado, separado del conocimiento histórico, es un error. Este último discurso se centra en defender una interdisciplinariedad a la hora de abordar el conocimiento del pasado, entendiendo que memoria e historia pueden ser dos métodos complementarios. Conocimiento que, como señala Faber (2011: 471), siempre será relativo. De este modo, advierte sobre la falacia que a su juicio define la historia como garante de la "verdad", pues dicha verdad depen- derá del contexto y paradigma en el que se inserte el historiador, es decir, quién interprete y cuándo se haga esa interpretación del pasado histórico. En definitiva, dependerá de los cambios de paradigmas en historiografía a lo largo del tiempo.

Se defiende así un conocimiento del pasado dinámico, con conceptos que van evolucionando a lo largo del tiempo, y se asume que la sociedad de nuestro presente demanda una historiografía donde la memoria sirve para que realidades sociales alternativas, problemáticas identitarias, de grupos marginales o periféricos salgan a la luz y participen en la construcción del discurso que se hace sobre el pasado (FABER, 2011: 471).

Es curioso que ambos autores coincidan en acusar a la tendencia contraria a la que defienden (historia/memoria) de ser utilizada por el poder político y económico para la creación de identidades y la legitimación de procesos y situaciones presentes. Aspecto, el de la creación de identidades a través de una manipulación del discurso histórico, y de las relaciones entre memoria-historia, abordado por autores como Mario Carretero (2008) o Diane Brittan (1997: 11).

Otra mirada interesante hacia el concepto de memoria es la del historiador François Hartog, quien ha centrado una parte importante de su trabajo en definir el régimen de historicidad en el cual nos encontramos. Según el autor, hasta la caída del paradigma de Carr, el objetivo último de mirar hacia el pasado era construir el futuro. De este modo, las claves y causas que el conocimiento histórico nos daba podían emplearse en modificar las realidades presentes para construir un futuro mejor para la humanidad.

La caída del sistema en los años 80 ha dado como resultado, sin embargo, un régimen de historicidad presentista (ARAVENA, 2014: 229). Este régimen implica una pérdida de fe en el futuro, símbolo y causa de la caída de ideologías que buscan el futuro feliz (comunismo), la repetición de "errores" del pasado (limpiezas étnicas en Yugoslavia), una búsqueda de la autodefinición y la iden- 


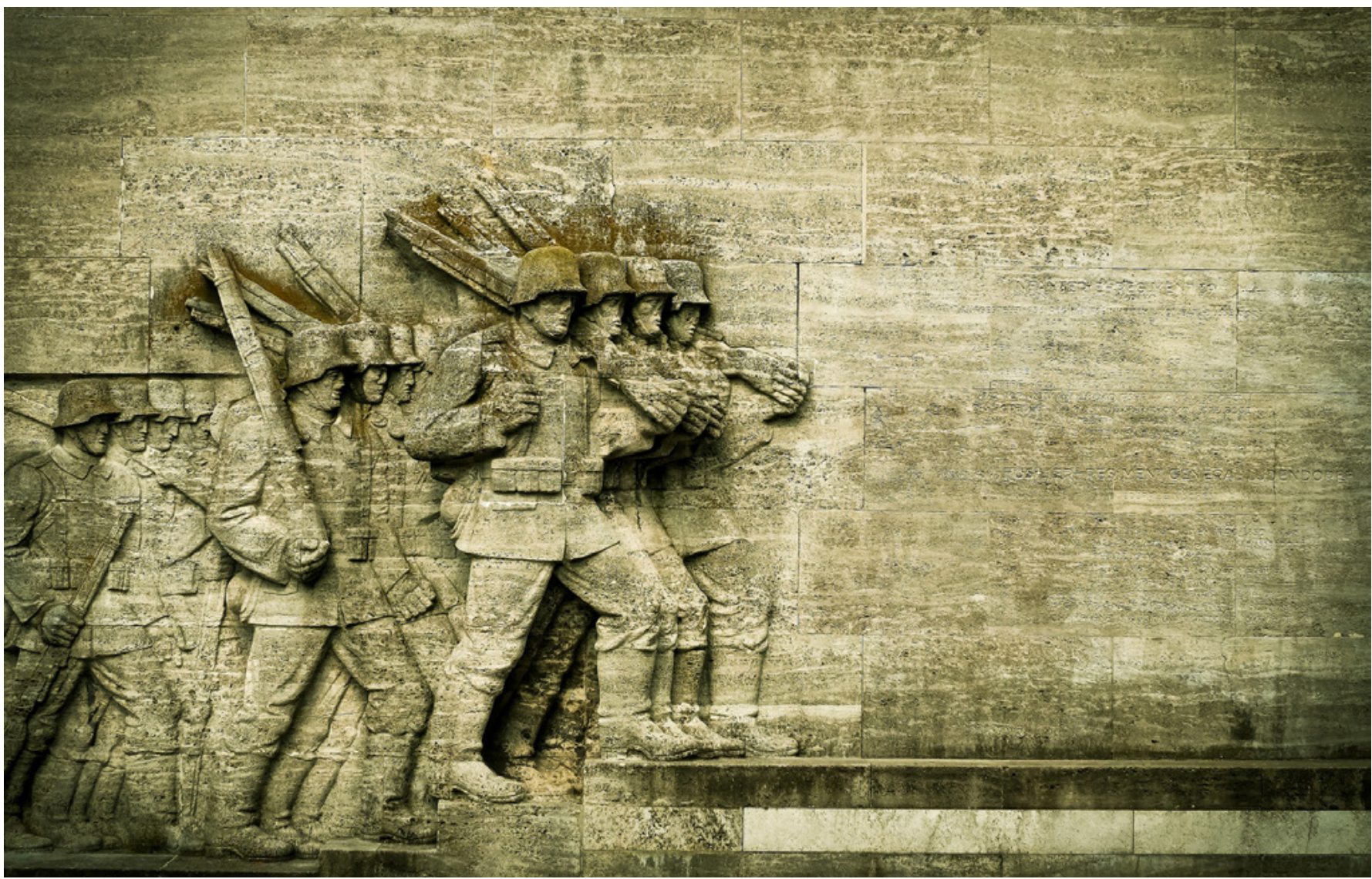

Memorial del 39 Regimiento de Fusileros (1914), en la Reeser Platz, Düsseldorf | fuente pxhere

tidad del individuo, la concepción del futuro como algo amenazante...

Es por lo tanto la memoria, y no la historia, la que ocupa el papel central en la relación que la sociedad busca establecer con el pasado. Un intento de afianzar sus raíces y su pertenencia a un grupo (no ya a una nación), simbolizada en la eclosión de "historias culturales", de la etnografía, de los memoriales. Lugares, memorias, tradiciones, que intentan salvaguardar la identidad y la esencia del individuo, en un presente siempre cambiante y ante la perspectiva de un futuro incierto, hacia el que no se quiere avanzar. Duby (1994) nos habla de manera significativa de un creciente interés y demanda de biografías de personajes históricos, insertados en un grupo de pertenencia, a través de los cuales se infieren modos de vida que ayudan a sobrellevar y entender la existencia en el presente.

Y es en esta tendencia hacia el conservadurismo presentista, en esta búsqueda de las raíces y del pasado, no como enseñanza de causas para transformar el futuro, sino en consuelo para sobrellevar el presente, donde cobra fuerza el concepto de patrimonio.

¿Y qué es el patrimonio, en palabras de Hartog (2005), sino un intento de salvaguardar los restos del pasado, y lo que ha llegado hasta nuestro presente, frente a un futuro amenazador?

Asistimos, pues, a un creciente proceso de patrimonialización de la cultura (ARIÑO, 2002: 129), esto es, la 


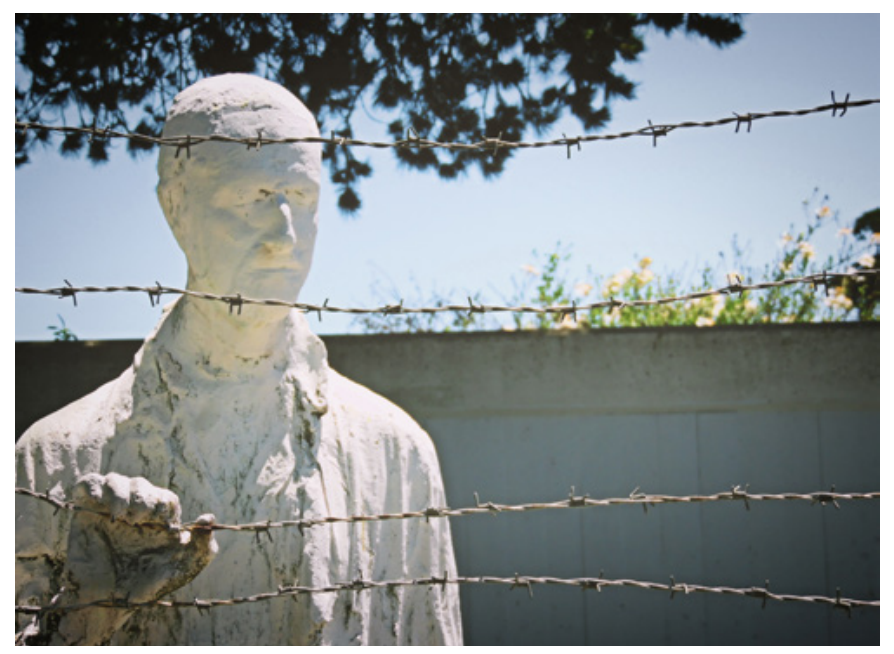

Memorial al Holocausto, Lincoln Park, San Francisco, California | fuente pxhere

búsqueda de elementos significativos, que se consideran dignos de preservación para el presente y el futuro. El concepto de patrimonio, por lo tanto, se convierte en algo dinámico e inestable, al tratarse de una construcción social que depende del sujeto colectivo, de la sociedad de cada momento. Es esta sociedad la que activa (o desactiva) espacios, objetos, y prácticas como patrimonio, cambiando también el concepto, el canon, sobre arte y cultura.

El patrimonio en un principio está relacionado con las producciones consideradas "grandes obra de arte", las producidas por la clase dirigente, que era la que ostentaba el liderazgo cultural. Más tarde, con el cambio conceptual que suponen las vanguardias, y la progresiva "democratización" del arte y la cultura, el concepto de cultura pasa a definir las manifestaciones o modo de vida que caracteriza a un pueblo.

Así, el patrimonio pasa a ser el icono que configura y refleja la identidad de un colectivo. Como consecuencia, se produce una eclosión y diversificación de distintos patrimonios (arquitectónico, histórico, artístico...), y del patrimonio intangible e inmaterial (usos, costumbres, destrezas artesanas, cantos, tradición oral...). La memoria, por lo tanto, es la que se va a convertir en gran generadora de patrimonio, arrebatando al Estado su carácter de "agente activador", que ostentó en exclusiva desde la formación de los Estados-nación.

La activación de patrimonio por parte de estas memorias, de esta diversidad de grupos que caracteriza el Estado moderno, es importante ya que persigue el reconocimiento del estatus de estos grupos, por medio de la legitimación y puesta en valor de sus símbolos. De su patrimonio.

La otra cara de la moneda, sin embargo, es la señalada por el propio Ariño y por autores como Homobono (2008: 62 ), y se refieren al hecho de que haber situado el concepto de patrimonio como importante agente legitimador puede provocar, y de hecho provoca, un intento de instrumentalizar las políticas relativas al patrimonio y la aparición de conflictos entre diferentes grupos y sensibilidades. Existe, asimismo, un creciente interés económico a la hora de "crear patrimonio". El reciente "turismo cultural" y sus posibilidades de explotación económica, de desarrollo y reconversión de ámbitos locales, va a hacer que cada vez sean más utilizados los criterios de tipo económico en las citadas "activaciones".

Peligros que Bermejo Barrera (2006: 292) define con el nombre de "ideología del patrimonio", y contra la que advierte, puede acabar provocando una trivialización de la cultura, en concreto de las disciplinas de historia, arqueología e historia del arte, trivialización que persigue despojar a dichas disciplinas de su capacidad de crítica política y social. Una nueva "defunción de la causalidad", celebrada por ciertas corrientes historiográficas, antes vistas.

En definitiva, podemos afirmar nuestro fracaso a la hora de intentar contestar a la famosa pregunta de Carr ¿Qué es la historia?. Nunca fue el objetivo de este ensayo, pero al poner de manifiesto la actualidad de los debates surgidos en torno a los conceptos y procesos que operan en el conocimiento del pasado (historia, memoria, patrimonio), demostramos la preocupación e interés del mundo académico y de la sociedad civil por la materia. La historia, por lo tanto, es. Existe, como existen la 
memoria y el patrimonio, y son grandes generadores de debate y nuevos conocimientos.

\section{BIBLIOGRAFÍA}

- ARAVENA, P. (2014) François Hartog: La historia en un tiempo catastrófico. Cuadernos de historia, n. ${ }^{\circ} 41,2014$, pp. 229-230

- ARIÑO, A. (2002) La expansión del patrimonio cultural. Revista de Occidente, n. ${ }^{\circ}$ 250, 2002, pp. 129-150

- BERMEJO, X. C. (2006) La ideología del patrimonio y el nacimiento de la historia basura. Gallaecia, n. ${ }^{\circ} 25,2006$, p. 292

- BRITTAN, D. (1997) Historia pública y memoria pública. The Public Historian, vol. 19, n. ${ }^{\circ} 3,1997$, pp. 11-23

- CANNADINE, D. (2005) ¿Qué es la historia ahora? Granada: Ediciones Almed, 2005

- CASPISTEgUI, F. J. (2003) Sobre el papel social del historiador o ¿para qué servimos? Memoria y civilización: anuario de historia, n. ${ }^{\circ}$ 6, 2003, pp.193-199

- CARR, E. H. (2010) ¿Qué es la historia? Barcelona: Ariel, 2010

- CARRetero, M. (2008) Documentos de identidad. La construcción de la memoria histórica en el mundo global. Buenos Aires: Paidós, 2008

- DUBY, G. (1994) Escribir la historia. Reflexiones, vol. 25, n. ${ }^{\circ} 1,1994$

- ELTON, G. R. (1967) The Practice of History. Londres: Fontana Books, 1967

- FABER, S.; SÁNCHEZ LEÓN, P.; IZQUIERDO MARTÍN, J. (2011) El poder de contar y el paraíso perdido. Polémicas públicas y construcción colectiva de la memoria en España. Política y sociedad [en línea], vol. 48, n. ${ }^{\circ} 3,2011$, pp.471-472 $<$ https://revistas.ucm.es/index.php/POSO/article/view/36423> [Consulta: 08/01/2019]

- HARTOG, F. (2005) Tiempo y Patrimonio. Museum International, n. ${ }^{\circ} 227,2005$, pp. 4-15

- HOMOBONO, J. I. (2008) Del patrimonio cultural al industrial. Una mirada socioantropológica. En PEREIRO, X.; Prado, S.; TAKENAKA, H. (coord.) Patrimonios culturales: educación e interpretación. Cruzando límites y produciendo alternativas. San Sebastián: Ankulegi Antropologia Elkartea, 2008, pp. $57-74$

- JULIÁ, S. (2011) La memoria cotiza al alza. En JULIÁ, S. (ed.) Elogio de historia en tiempo de memoria. Madrid: Marcial Pons, Ediciones de Historia, 2011
- PASAMAR, G. (2003) Los historiadores y el "uso público de la historia": viejo problema y desafío reciente. Ayer, n. ${ }^{\circ 49}$, 2003, pp. 226-239

- PÉREZ, M. (2001) Ese artículo de lujo seriamente odioso. Archipiélago: Cuadernos de crítica de la cultura, n. ${ }^{\circ} 47,2001$, pp. $15-16$ 


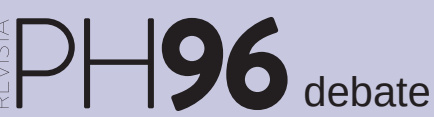

a debate Memoria democrática en la construcción de la historia y el patrimonio

| coordina Josefina Cuesta Bustillo

\title{
Arte silenciado, arte olvidado. La mujer creadora en la etapa franquista
}

\author{
Marcos Serrano-Carrillo | graduado en Bellas Artes \\ Mercedes Molina-Liñán | Dpto. de Historia, Teoría y Composición Arquitectónicas, Universidad de Sevilla \\ URL <http://www.iaph.es/revistaph/index.php/revistaph/issue/view/4344>
}

Cultura y resistencia fueron los vehículos de expresión que determinados artistas emplearon durante el régimen militar español, situación política que marcó la trayectoria creativa de muchas mujeres que supieron desarrollar una mirada artística diferente y personal en un contexto flagrantemente represivo para el mundo cultural.

El arte outsider o marginal, tradicionalmente olvidado, es el resultante del olvido mediático, por lo que se ha centrado en la elaboración de piezas artísticas sin más intención que la del deleite del propio artista, la rebelión, el consuelo o la liberación. Llevado a cabo por artistas cuyo sustento económico procedía en algunos casos de la más absoluta precariedad laboral, las mujeres, a pesar de ser víctimas de la represión del régimen, en su discreto silencio e intimidad adquieren un especial protagonismo creativo que parece haber desmerecido un lugar en la historia.

Profundamente perseguidas fueron, no en pocas ocasiones, condenadas por conductas consideradas "moralmente inaceptables", situación que provocaría el exilio de excepcionales creadoras. Tal es el caso de la española Remedios Varo (1908-1963), pintora compañera de Dalí y Lorca, que sobrevivió como ilustradora eventual en México y que no recibió, hasta cuarenta y cuatro años después de su muerte, un justo reconocimiento. Este se llevó a cabo gracias a la interesante novela que lleva por título La cazadora de astros, de Zoé Valdés, donde se relata la apasionante y desconocida vida de la artista (DIEGO DE, 2007).

O la situación de Josefa Tolrà (1880-1959), conocida como "la Pepeta de Cabrils", humilde campesina cuyos hijos murieron en la Guerra Civil española. Sin nin- gún tipo de formación académica, a la edad de setenta años comenzó a pintar, dibujar y elaborar bordados utilizando la expresión pictórica como elemento catalizador para "conectar con el más allá". Siendo reconocida como "medium", creó una serie de sorprendentes piezas a las que no daba valor real, pero que años después serían considerados como unos de los más importantes referentes de la vanguardia artística del momento en España (GARCIA, 2015).

Esta compleja situación marcará el escenario artístico de numerosas creadoras que, condenadas al ostracismo debido a su condición de mujer librepensadora, se verán obligadas a desarrollar su actividad en el exilio. La vida y obra de estas artistas se vieron directamente influenciadas por el régimen militar español, ya sea por haber sido perseguidas o completamente ignoradas.

El acceso a estudios superiores de la mujer en España era también algo muy complejo debido al rígido sistema social establecido por el franquismo. El ingreso de la primera mujer en una escuela de arte en Europa no se producirá hasta el año 1860 en la Royal Academy de Londres. En Francia no será hasta 1897 y con ciertas limitaciones, pues las clases de dibujo al natural con modelos les estuvieron prohibidas por indecorosas hasta bien avanzado el siglo XX (VAL, 2013).

En España, no sería hasta 1915, cuando abriría la "Residencia de señoritas" en Madrid, liderada por la pedagoga institucionalista María de Maeztu. En esta residencia, estudiarían artistas de importancia vital en el panorama artístico contemporáneo, dirigidas por profesoras como María Goyri, Victorina Durán, María Zambrano o Maruja Mallo. La Residencia fue prohibida 
tras la Guerra Civil, terminando su directora, como tantas otras mujeres, olvidadas y en el exilio (Argentina).

Las dificultades a las que las mujeres artistas han estado expuestas a lo largo de la historia responden a la relegación social a la que han sido habitualmente sometidas. Los conflictos que las creadoras padecían estaban básicamente motivados por su escasa o nula consideración como tales, situación que provocará el exilio, el olvido y la muerte, no solo física sino también artística, de muchas de ellas (MERINO HERNÁNDEZ, 2015).

El arte outsider en España, más en concreto el arte de la mujer, no sería reconocido públicamente hasta finales del siglo XX y lo fue gracias a la exposición "Visiones Paralelas, Artistas Modernos y Arte Marginal", realizada en el museo Reina Sofía en el año 1993 (GARCíA, 2010). Esto abriría un nuevo campo de interés hacia los artistas que prosperan al margen del mercado y de lo académico. Su sinceridad creativa y el vivo paralelismo vivencial que representan no pasaría desapercibido por los expertos, aunque de momento son grandes desconocidas.

A pesar de contar con unos importantes referentes españoles, aún encontramos en ese sentido un importante vacío en el arte outsider desarrollado por la mujer española. Aun siendo motivo de referencia en artículos periodísticos y otros medios de comunicación, consideramos que sus obras permanecen en gran medida ocultas, siendo en este momento muy dificultosa la búsqueda de referencias importantes sobre dichas artistas.

Entre la cantidad de artistas españolas que tuvieron que migrar al extranjero, un gran porcentaje eran mujeres de las que por el momento poco o nada se ha hablado. Nombres como Ángeles Santos (1911-2013), Carmen de Burgos (1867-1932), Julia Minguillón (1906-1965), Marga Gil Roesset (1908-1932), a los que le seguirían una larga lista de artistas y activistas españolas que sistemáticamente han permanecido silenciadas y olvidadas, cuyas obras podrían aportar un rico patrimonio al panorama artístico e intelectual de España y de Europa.

\section{BIBLIOGRAFÍA}

- DIEGO DE, E. (2007) Remedios Varo. Madrid: Fundación Mapfre, 2017

- GARCÍA, G. (2015) Arte outsider: la pulsión creativa al desnudo. Barcelona: Sans Soleil, 2015

- GARCÍA MUÑOZ, G. (2010) Procesos creativos en artistas outsider. Madrid: Universidad Complutense de Madrid, 2010

- MERINO HERNÁNDEZ, R. (2015) La Residencia de Señoritas y otras redes culturales femeninas. Salamanca: Ediciones Universidad de Salamanca, 2015

- VAl CuBero, A. (2013) La profesionalización de las mujeres artistas españolas. El caso de Maruja Mallo (19021995) y Amalia Avia (1926-2011). Papers, revista de sociología, vol. 98, (n. $\left.{ }^{\circ} 4\right), 2013$

\section{Nota}

Cuando esta contribución llegó, el artículo introductorio de esta sección a cargo de la coordinadora Josefina Cuesta estaba ya cerrado, de ahí que no se haga alusión a él. 


\section{$\mathrm{PH} 966_{\text {entrevista }}$}

\section{Maguelonne Déjeant-Pons: "Los cambios de calado que están experimentado nuestras sociedades y paisajes nos llevan a nuevos modelos económicos"}

URL de la contribución <www.iaph.es/revistaph/index.php/revistaph/article/view/4362>

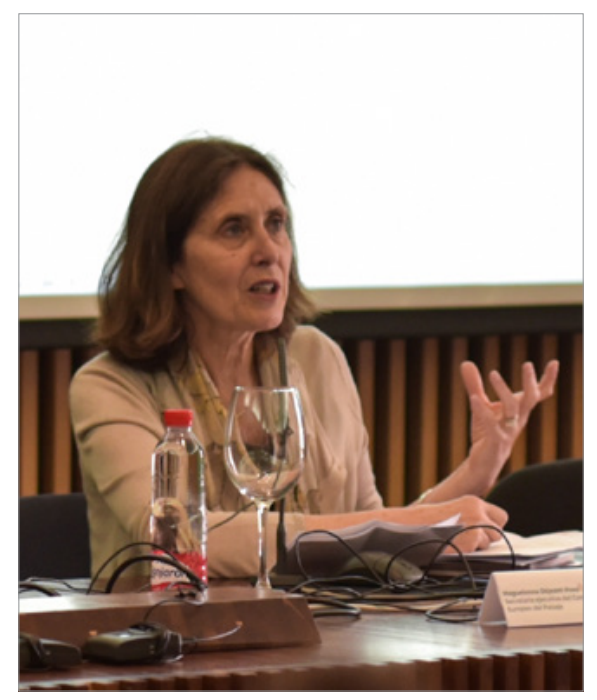

Maguelonne Déjeant-Pons durante su intervencón en el seminario internacional_re-HABITAR el Carmen | foto Fondo Gráfico IAPH (Matiss Andersons)
Maguelonne Déjeant-Pons es Secretaria Ejecutiva del Convenio Europeo del Paisaje del Consejo de Europa y responsable de las Jornadas Europeas del Patrimonio en la Dirección de Ciudadanía Democrática y Participación del Consejo de Europa.

Doctora en Derecho, ejerció profesionalmente como abogada en el Tribunal de Apelación de Montpellier y fue profesora universitaria, pero la mayor parte de su vida profesional, desde 1987, la ha desarrollado en el Consejo de Europa.

Desde que comenzara siendo Administradora en el Tribunal Europeo de Derechos Humanos y de la Dirección de Medio Ambiente y Autoridades Locales, ha ocupado la Secretaría de la Convención sobre la Conservación de la Vida Silvestre Europea y los Hábitats Naturales de Europa, la jefatura de la División de Medio Ambiente y Desarrollo Sostenible y la Secretaría de la Estrategia paneuropea de diversidad biológica y paisajística. También ha sido directora y editora de la revista Futuropa: for a new vision of landscape and territory.

Acompaña su dilatada labor profesional con la publicación de artículos y libros dedicados al desarrollo territorial, la protección de las zonas costeras y marinas, la diversidad biológica y paisajística, y el derecho humano al medio ambiente, y es miembro de la Asociación Europea de Derecho al Medio Ambiente, Consejo Europeo de Derecho Ambiental (CEDE) y de la Comisión de Derecho Ambiental (CEL) de la Unión Mundial para la Naturaleza (UICN). 
revista PH: El Convenio Europeo del Paisaje (Florencia, 2000) promueve la protección, la gestión y la ordenación de los paisajes europeos, en todas sus dimensiones, y organiza la cooperación europea en ese ámbito. Transcurridas casi dos décadas desde que se adoptara el convenio, ¿en qué grado se han cumplido los objetivos, y sobre todo, cuáles son los retos de futuro?

Maguelonne Déjeant-Pons: Desde la adopción del Convenio Europeo del Paisaje, se han producido avances importantes en la instauración de políticas del paisaje a nivel nacional, regional y local. Estas políticas promueven la mejora de la calidad de las condiciones de vida, partiendo de objetivos conjuntos. De esta forma, el concepto de paisaje se ha ido introduciendo paulatinamente en la agenda política de los gobiernos; se ha desarrollado una amplia red de cooperación internacional para apoyar la puesta en marcha del citado Convenio; las autoridades y ciudadanos reconocen cada vez más el concepto de paisaje definido por el citado Convenio; surgen nuevas formas de cooperación entre los diferentes niveles de gobierno (nacional, regional y local) y entre los ministerios o departamentos de un mismo estado o región; se están creando estructuras funcionales específicamente dedicadas al paisaje (observatorios, centros o institutos del paisaje); se adoptan leyes y normativas específicas sobre el paisaje; los estados y las regiones cooperan en los casos de paisajes de frontera; se han instaurado premios paisajísticos nacionales a partir del Premio Europeo del Paisaje del Consejo de Europa; han surgido programas universitarios dedicados al Convenio y se han organizado universidades de verano en torno al paisaje; se celebran conferencias bianuales, festivales sobre el paisaje, exposiciones centradas en los principios del Convenio; y las comunidades y organizaciones no gubernamentales se sienten cada vez más involucradas y van poco a poco actuando.

Para promover políticas innovadoras y eficaces, es importante conocer mejor las políticas llevadas a cabo por las partes integrantes del Convenio Europeo del Paisaje, a nivel nacional, regional y local. Para tal fin, es necesario que los Estados miembros completen dos de las herramientas que el Observatorio
Internacional del Paisaje ha establecido ${ }^{1}$ : el Sistema de información del Convenio Europeo del Paisaje y la Plataforma de información del Convenio Europeo del Paisaje del Consejo de Europa.

Hay programados una serie de eventos que tratarán temas relevantes para las políticas del paisaje como la XXII Reunión del Consejo de Europa, con un seminario, recientemente celebrado, para la aplicación del Convenio Europeo del Paisaje sobre "Agua, paisaje y ciudadanía ante el Cambio Global" (Sevilla, 14-16 marzo 2019); la X Conferencia del Consejo de Europa para la implementación del Convenio Europeo del Paisaje (Estrasburgo, 6-7 mayo 2019); la celebración de la VI sesión del Premio del Paisaje del Consejo de Europa (junio 2019); o la celebración del XX aniversario del Convenio con el lema la "Integración del paisaje en las políticas sectoriales" que tendrá lugar en Lausana (Suiza) del 19 al 21 octubre 2020.

De cara al futuro, considero que los retos y oportunidades son los que siguen:

$>$ Que los gobiernos comprometidos con los principios de gobernanza tengan en cuenta el incalculable valor del paisaje para el ser humano, y lo incluyan en sus políticas a nivel nacional, regional y local. Es también tarea de todos respetar el paisaje y cuidarlo, tanto en su forma como en su contenido, para las generaciones presentes y futuras.

> La apertura del Convenio Europeo del Paisaje a estados no europeos será una oportunidad para reafirmar la universalidad de la dimensión del paisaje en los derechos humanos y la democracia. Esta es una contribución por parte del Consejo de Europa en la implementación de la Agenda 2030 de las Naciones Unidas para el Desarrollo Sostenible.

PH: Si hablamos de la responsabilidad de las distintas regiones y sus administraciones con la implementación de las políticas europeas de paisaje, ¿cuál es su balance? ¿qué opina de Andalucía, de su Estrategia del Paisaje o de las iniciativas del IAPH en esta materia? 
M. D.-P.: Con relación a la responsabilidad de las regiones y sus administraciones, y las normativas para la implementación del Convenio Europeo del Paisaje, la Recomendación CM/Rec (2008)3 del Comité de Ministros del Consejo de Europa a los Estados miembros indica:

"Con el fin de asegurar la integración del paisaje en las políticas territoriales, es esencial involucrarse en el acuerdo, especialmente el acuerdo previo, entre los diferentes niveles de administración del territorio (administraciones del Estado y autoridades locales) y entre los diversos organismos y sectores de la administración del territorio del mismo nivel (acuerdo horizontal y vertical).

El acuerdo debería incluir tanto la formulación de estrategias generales como las decisiones operativas. De esta manera será posible superar una concepción de calidad ligada solamente a la protección de espacios específicos, y evitar el riesgo de políticas diferentes, e incluso contradictorias, por parte de los diversos sectores de la administración pública.

A nivel nacional podría ser útil, por tanto, la previsión de instrumentos y procedimientos para la concertación permanente y reuniones regulares entre los organismos con la responsabilidad administrativa central (ministerios) con objeto de definir y acordar estrategias y preparar dispositivos de concertación (por ejemplo, una conferencia permanente interministerial). Lo mismo po-

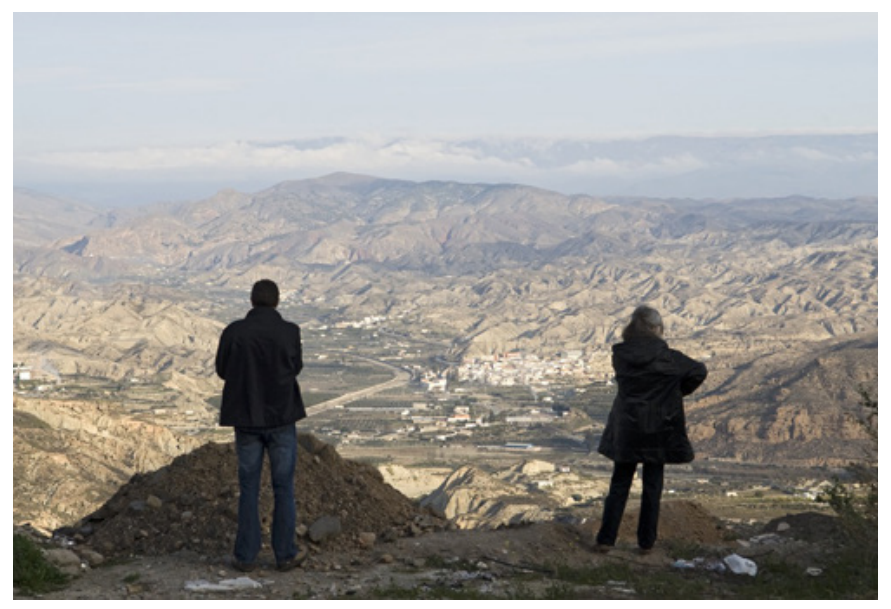

Alhama de Almería | foto Fondo Gráfico IAPH (Juan Carlos Cazalla Montijano) dría aplicarse verticalmente entre ministerios y niveles administrativos inferiores (por ejemplo, comisiones Estado-Regiones) y también entre los diferentes niveles administrativos. Pueden definirse otras modalidades de colaboración entre los diversos organismos e institutos (públicos y/o privados) especializados en problemas particulares, nacionales o locales, especialmente entre los responsables de los diversos sectores operativos en las regiones, en los organismos supramunicipales o en los municipios mismos.

Convendría igualmente prever organismos nacionales, regionales, locales, de carácter consultivo y de orientación de asistencia a los servicios técnicos y administrativos mencionados anteriormente (observatorios de paisaje, consejos de paisaje, centros e institutos de paisaje, etc.). Estos organismos podrían estar compuestos por representantes de las autoridades administrativas, las comunidades científicas y profesionales expertas en paisaje, y asociaciones.

Dentro de sus estructuras y las modalidades de administración del paisaje, cada Estado puede definir los criterios y modos de organización para la participación de la población.

Las autoridades públicas deben destinar recursos humanos y financieros a la política de paisaje: estos recursos pueden ser específicos, o de otros sectores (medio am-

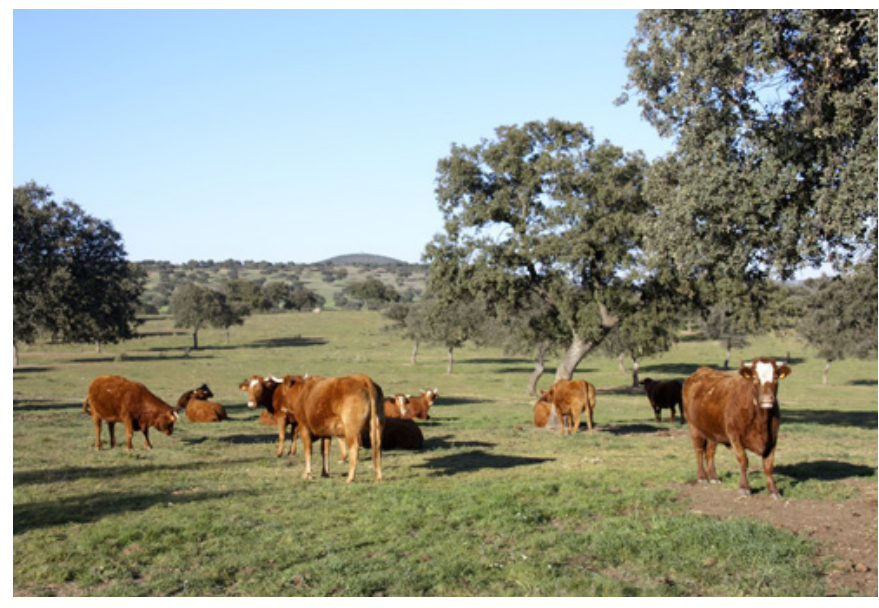

Santa Eufemia (Córdoba) | foto Fondo Gráfico IAPH (Silvia Fernández Cacho) 
biente, turismo, obras públicas, cultura, etc.), incluso con la introducción del paisaje en las políticas sectoriales anteriormente mencionadas."

Andalucía está trabajado en una línea muy innovadora. Se están adoptando instrumentos destacados, como la Estrategia de Paisaje de Andalucía. Gracias al trabajo de dos prestigiosas instituciones (el IAPH, con su Laboratorio del Paisaje, y el Centro de Estudios Paisaje y Territorio), Andalucía puede considerarse una región pionera en el desarrollo de investigaciones y políticas para la región, y en el marco de la cooperación, desarrollada junto con otros territorios a nivel internacional.

En lo que respecta a observatorios, centros o institutos, la misma Recomendación CM/Rec(2008)3 indica:

"Las fuertes dinámicas de los paisajes contemporáneos y los numerosos problemas vinculados con la protección, gestión y ordenación del paisaje necesitarían una observación continua y un lugar de intercambios; a estos efectos, la creación de observatorios, centros o institutos del paisaje podría ser pertinente. Estos observatorios, centros o institutos permitirían esta observación sobre la base de protocolos de estudio apropiados, movilizando una amplia gama de indicadores; permitirían también la recogida y el intercambio de información sobre políticas y experiencias. Podrían ser autónomos o formar parte de un dispositivo de observación más amplio.
Estos observatorios, centros o institutos del paisaje podrían ser creados a diversas escalas -local, regional, nacional o internacional-, empleando dispositivos de observación a escalas correspondientes. Debería ser posible un intercambio continuo entre ellos. Deberían permitir:

> describir el estado de los paisajes en periodos determinados;

> intercambiar información sobre políticas y experiencias de protección, gestión y ordenación, de participación pública y aplicaciones a diferentes escalas;

$>$ utilizar y, si es necesario, recopilar documentos históricos relativos a paisajes que pudieran ser útiles para conocer los procesos de evolución de los paisajes (archivos, textos, iconografía, etc.);

> elaborar indicadores cuantitativos y cualitativos que permitan evaluar la eficacia de las políticas de paisaje;

> suministrar elementos que permitan comprender las tendencias, realizar previsiones o escenarios prospectivos.

Los intercambios de información y experiencias entre Estados, regiones y colectivos territoriales, que ya se practican, deberían basarse en la ejemplaridad pero

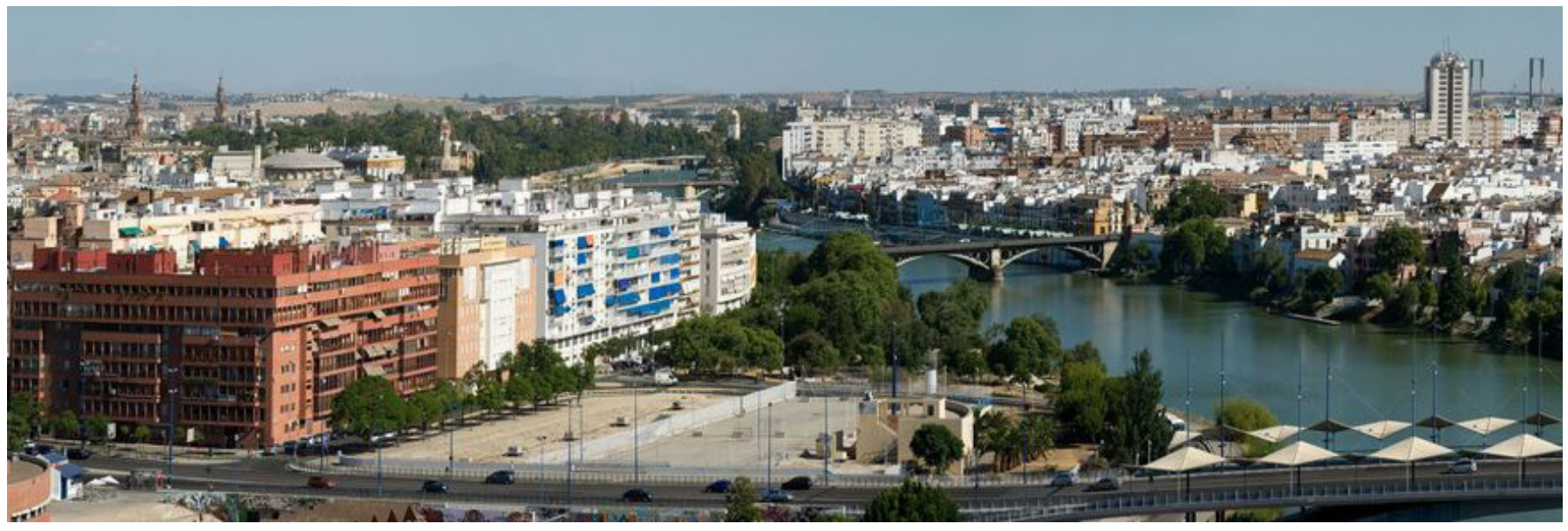

Vista panorámica del Río Guadalquivir desde la Torre Schindler (Sevilla) | foto Fondo Gráfico IAPH (Juan Carlos Cazalla Montijano) 
siempre situados en el contexto político, social, ecológico y cultural del paisaje original.

La decisión de la composición de los observatorios es una cuestión que corresponde a los organismos administrativos, pero deberían permitir la colaboración entre científicos, profesionales y técnicos de las administraciones y la población."

Asimismo, establece:

"11. Informes sobre el estado del paisaje y las políticas de paisaje

Los Estados y las regiones deberían redactar un informe sobre el estado de los paisajes de sus territorios, a los intervalos apropiados y a partir de la base del trabajo de los observatorios, centros o institutos del paisaje. El informe debería comprender un balance de las políticas aplicadas con el fin de verificar la eficacia de la legislación y las intervenciones desarrolladas.

Tal documento, elaborado por los organismos administrativos, observatorios, centros o institutos del paisaje u otros organismos, y/o en colaboración con estas entidades, podría comparar las dinámicas efectivas de los territorios con las orientaciones y medidas paisajísticas aplicadas; señalar los resultados, soluciones y problemas encontrados, e indicar nuevas orientaciones. El documento debería ser autónomo o integrado en un informe más amplio, en el que se dedique una sección específica al paisaje. Este documento no debería ser una sustitución para las reuniones regulares que los Estados deberían tener con el propósito de la aplicación del Convenio Europeo del Paisaje."

PH: El Convenio Europeo del Paisaje representa una importante contribución a la aplicación de los objetivos del Consejo de Europa: promoción de la democracia, de los derechos humanos y la búsqueda de soluciones comunes a los grandes problemas sociales. Usted ha señalado en varias ocasiones que, desde su definición en la década de los 50 del pasado siglo, el concepto de derechos humanos debe ser explorado y ampliado, teniendo en cuenta su "di-

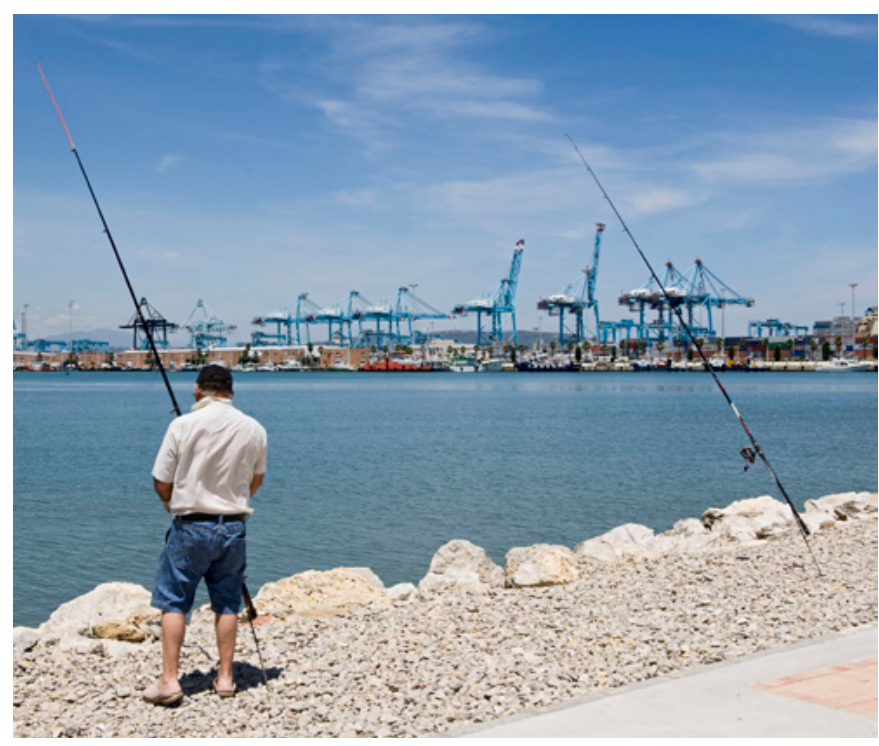

Bahía y Puerto de Algeciras (Cádiz) | foto Fondo Gráfico IAPH (Juan Carlos Cazalla Montijano)

mensión territorial y patrimonial". Explíquenos por qué el paisaje es un derecho de la humanidad.

M. D.-P.: Al hacer hincapié en el carácter territorial de los derechos humanos y la democracia, el Convenio Europeo del Paisaje responde a los objetivos del Consejo de Europa de manera dinámica y ambiciosa. El interés en alcanzar un desarrollo sostenible, basado en una relación equilibrada y armoniosa entre las necesidades sociales, la actividad económica y el entorno, sus partes se comprometen a cuidar las condiciones de vida para el beneficio de las generaciones presentes y futuras.

El Convenio señala que el paisaje es "un componente esencial del entorno de las personas, una expresión de la diversidad del patrimonio cultural y natural compartido, y un pilar de su identidad". Los paisajes de alta calidad juegan un papel importante de interés público en el ámbito cultural, ecológico, medioambiental y social, y constituyen un recurso propicio para la actividad económica.

La Recomendación CM/Rec(2017)7 del Comité de Ministros del Consejo de Europa a los Estados miembros sobre la contribución del Convenio Europeo del Paisaje al ejercicio de los derechos humanos y la democracia 
desde un enfoque de desarrollo sostenible establece que los gobiernos de los Estados parte del Convenio: "consideren la importancia que la calidad y la diversidad de los paisajes tiene para el espíritu y el cuerpo del ser humano, así como para las sociedades, en sus reflexiones y en el trabajo que desempeñan en relación con los derechos humanos y la democracia siempre considerando un desarrollo sostenible" y "diseñen las políticas del paisaje a largo plazo, de forma que se tengan en cuenta los entornos comunes para las generaciones presentes y futuras".

PH: Partiendo de los valores paisajísticos, naturales y culturales del paisaje, el Consejo de Europa aspira a preservar la calidad de vida y el bienestar de las personas. ¿Qué importancia tiene la participación ciudadana en la ordenación del territorio y en la conservación, protección y gestión del paisaje? ¿Pueden trazarse políticas de desarrollo sostenible espacial sin la participación pública activa?

M. D.-P.: El Convenio exige que los estados implicados definan una política del paisaje honesta en relación con la ciudadanía. En concreto, el artículo 5 del Convenio dispone que "cada parte se compromete a establecer procedimientos que permitan la participación del público en general, de las autoridades locales y regionales, y de otras partes interesadas en la definición e implementación de las políticas del paisaje". El artículo 6 añade

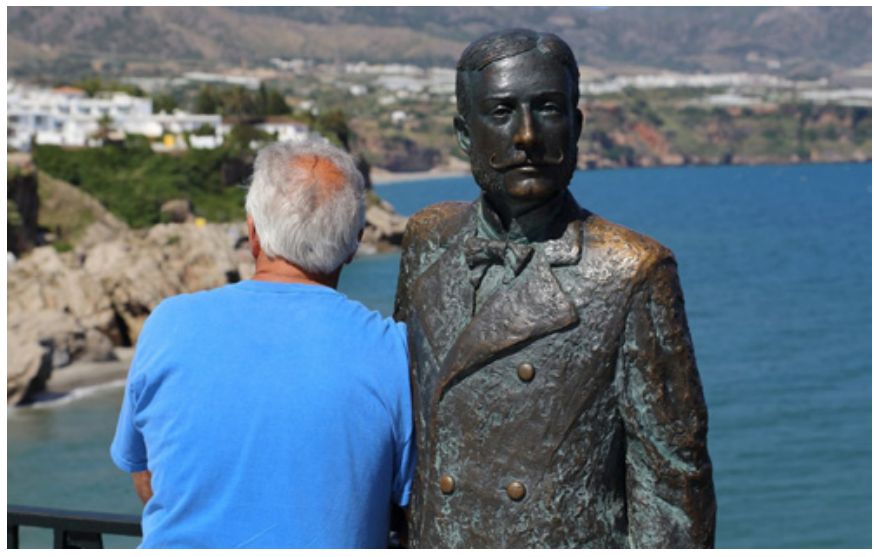

Detalle de escultura de Alfonso XII en el Balcón de Europa (Nerja, Málaga) | foto Fondo Gráfico IAPH (Víctor Fernández Salinas) que "una vez realizada la consulta pública, cada parte se compromete a definir los objetivos de calidad para los paisajes identificados y evaluados".

Cabe realizar algunos comentarios sobre el contenido de estos artículos, que están especialmente dedicados a la participación pública.

El término "público" debe entenderse como sociedad civil en el sentido amplio de la palabra, excluyendo a las autoridades locales y regionales y a otras partes interesadas a las que hemos aludido. En segundo lugar, se establece claramente que la participación del público en general debe estar presente tanto en la definición como en la implementación de la política del paisaje. Estos son dos niveles claramente diferenciados. Es más, el público debe participar en la definición de los objetivos de calidad del paisaje.

La definición de paisaje recogida en el Convenio Europeo del Paisaje, en común con la utilizada por otros organismos internacionales, destaca la relación del hombre con el medio ambiente. De ahí que sea lógico e incuestionable que el ser humano, como elemento en la identificación del paisaje, debería involucrarse también en su protección, gestión y mejora. De hecho, en el preámbulo del Convenio Europeo del Paisaje, los Estados miembros del Consejo de Europa expresan su deseo de "dar respuesta a los deseos del público de disfrutar de un paisaje de alta calidad y de ser parte activa en el desarrollo de los mismos".

Teniendo esto en cuenta, el Convenio subraya la necesidad de establecer procedimientos para la participación pública. El correspondiente informe explicativo del Convenio y la Recomendación CM/Rec(2008)3 del Comité de Ministros a los Estados miembros en relación con las normativas para la implementación del Convenio Europeo del Paisaje especifica los objetivos de esta participación:

> Cualquier acción emprendida con objeto de definir, implementar o controlar políticas del paisaje debería ir precedida y acompañada de procedimientos para la participación pública y la de cualquier otra parte interesada, al efecto de posibilitarles un papel activo en la formulación, 


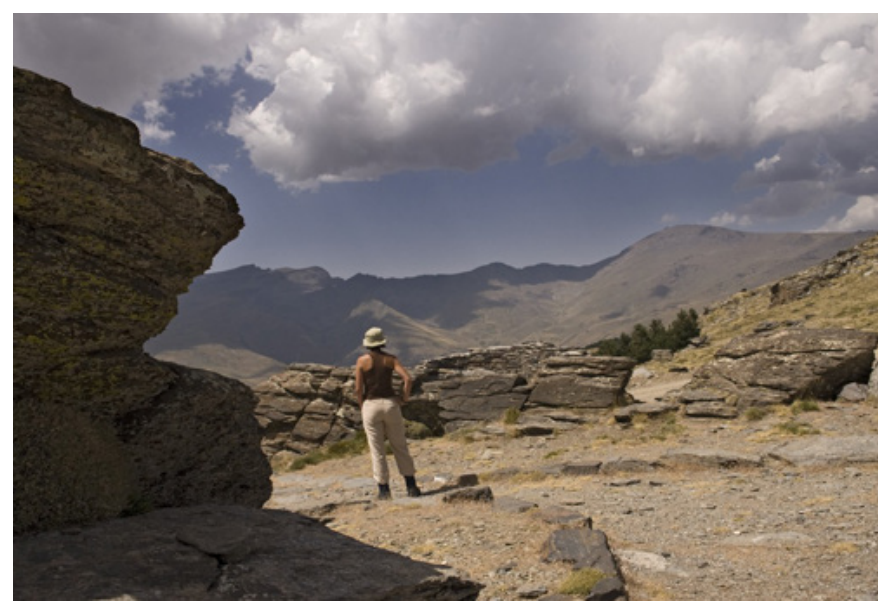

Vistas de Sierra Nevada desde Capileira (Granada) | foto Fondo Gráfico IAPH (Juan Carlos Cazalla Montijano)

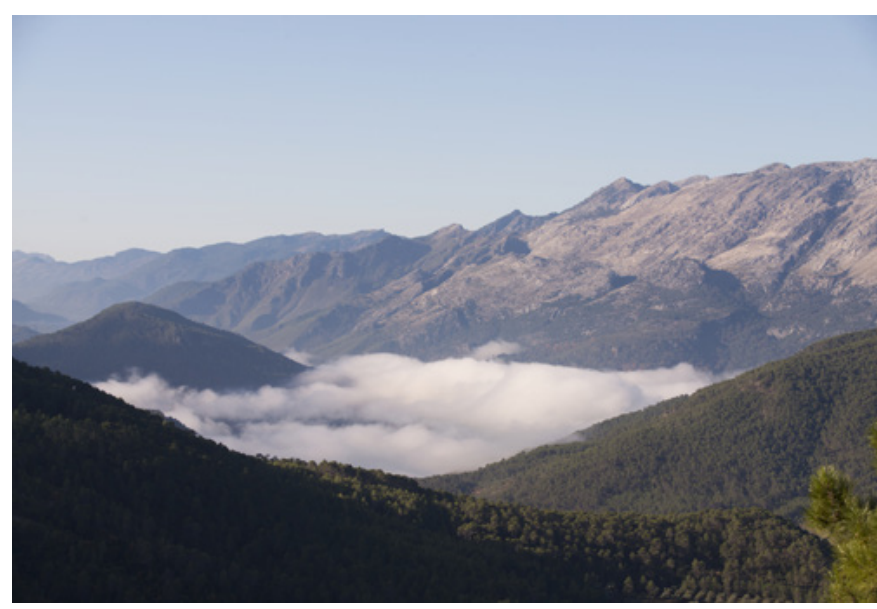

Vista desde el mirador de Huelguecillas (Hornas, Jaén) | foto Fondo Gráfico IAPH (Herce Pagliai, Manuel Millán)

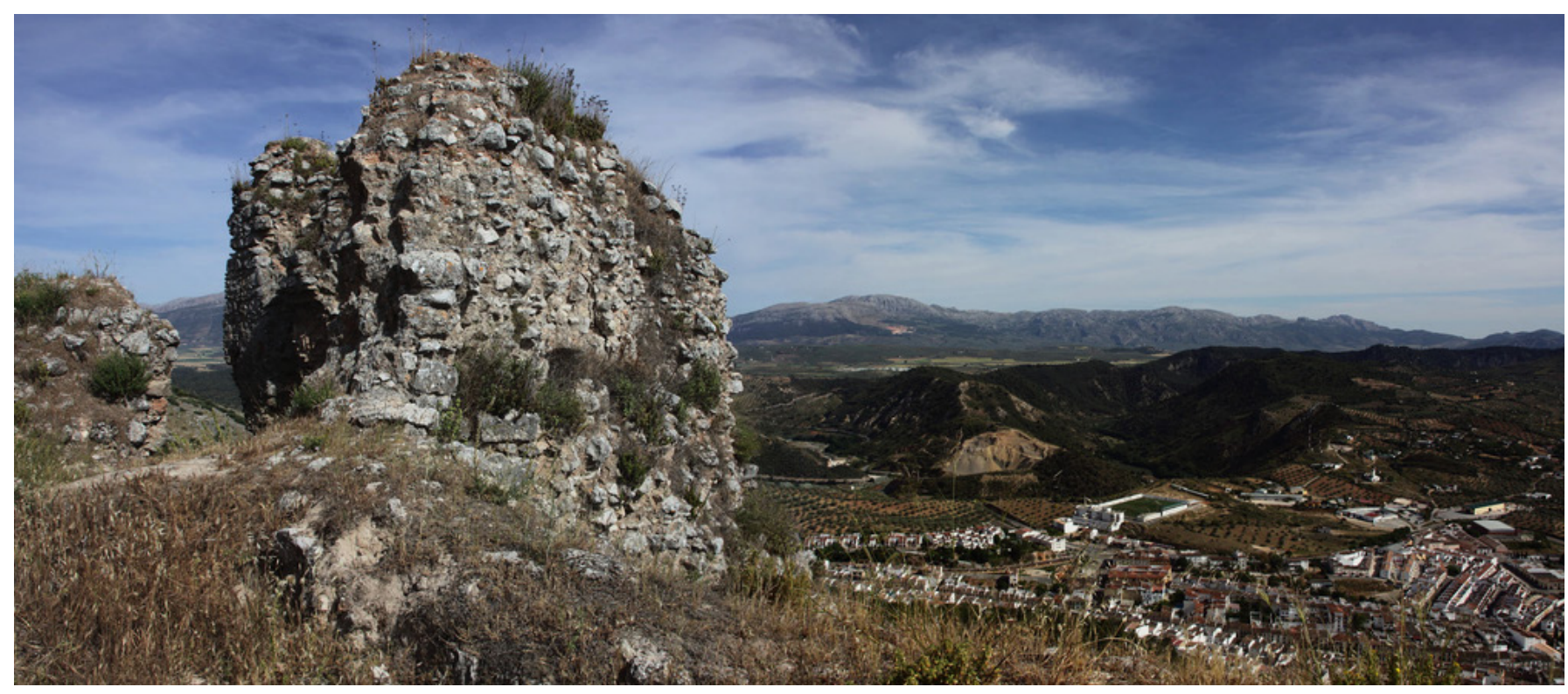

Paisaje de Archidona (Málaga) | foto Fondo Gráfico IAPH (Víctor Fernández Salinas)

implementación y control de los objetivos de calidad del paisaje;

$>$ La certidumbre de que estrechando las relaciones entre la población y su entorno se afianza el desarrollo sostenible repercutiendo en la totalidad del proceso de definición de la política del paisaje. Es más, la participación se considera un instrumento para reforzar la identidad de la población, que se reconoce en sus entornos;
> La participación pública, que puede entrañar contradicciones, debido a la diversidad de valores de los diferentes grupos sociales, debería entenderse como enriquecedora y como una oportunidad de validar el conocimiento y la definición de objetivos y acciones;

> La participación implica una comunicación en doble sentido; de los expertos y los científicos a la población, y viceversa. La población posee conocimiento empírico 
(conocimiento local y de la naturaleza) que pudiera ser de utilidad para completar y dar contexto al conocimiento especializado.

> Cada Estado debe elegir las formas de participación entre aquellos métodos más apropiados para afrontar los diferentes problemas identificados, teniendo en cuenta los usos imperantes en relación con la celebración de consultas y cotejos, las diferentes organizaciones administrativas, las características de las diferentes situaciones territoriales, los tipos de instrumentos operativos utilizados, los niveles de funcionamiento y la experiencia, tanto pasada como presente, a nivel internacional. En cualquier caso, la participación debe incluir a todas las partes interesadas: las autoridades locales, regionales y nacionales, la población directamente implicada, el público en general, las organizaciones no gubernamentales, los agentes económicos y los profesionales e investigadores del paisaje.

$>$ La participación debe estar presente en todas las fases del proceso de confección e implementación de las políticas del paisaje, especialmente en aquellos relativos a la evaluación del paisaje, la definición de los objetivos de calidad del paisaje, la toma de decisiones y la implementación de acciones a largo plazo. La participación debe considerarse como un sistema para la información mutua entre todas las partes interesadas. Es especialmente importante que haya participación a todos los niveles de la implementación, desde la fase de estudio inicial, hasta en la implementación de las acciones consensuadas, es decir, durante la ejecución de aquellos proyectos en que hayan participado todas las partes interesadas.

$>$ A la hora de definir los procesos de toma de decisiones, hay que tomar como referencia aquellos probados y testados, tales como las consultas públicas, las reuniones informativas y exposiciones educativas. Estos procesos puedes utilizarse también de forma simultánea.

La ciudadanía debería poder participar de dos formas: a través del diálogo y el intercambio entre todos los miembros de la sociedad (reuniones abiertas, debates, procedimientos de consulta y participación, entre otros ejemplos) y mediante procesos de participación públi- ca e implicación en las políticas del paisaje puestas en marcha por las administraciones locales, regionales o nacionales.

EI XVI Simposio Internacional CEMAT y la XII Reunión del Consejo de Europa para la implementación del Convenio Europeo del Paisaje, con título "Visión sobre el futuro de Europa en democracia territorial: el paisaje como una nueva estrategia de planificación espacial... Otra forma de considerar el territorio que incluye a la sociedad civil", celebrada en Tesalónica (Grecia) el 2-3 de octubre de 2013 y la XIII Reunión del Consejo de Europa sobre "Territorios del futuro: identificación y valoración del paisaje: un ejercicio en democracia", celebrada en Cetinje (Montenegro) el 2-3 de octubre, abordaron nuevos planteamientos sobre participación ciudadana a nivel nacional, regional y local ${ }^{2}$.

PH: En marzo de 2018 usted participó en el "Seminario Internacional_re-HABITAR El Carmen. Un proyecto sobre patrimonio contemporáneo", en el IAPH, donde se presentaban los avances del proyecto_reHABITAR sobre el desarrollo de una metodología de preservación de los valores patrimoniales de la vivienda social que implique a la ciudadanía. ¿Cuáles son las claves de las políticas de paisaje de regeneración urbana?

M. D.-P.: Participé con gran interés en ese seminario.

El Convenio define el paisaje como un "área, percibida como tal por la población, cuyo carácter es el resultado de la acción e interacción de factores naturales y/o humanos". También se indica que cada Estado Parte debe "reconocer el paisaje en la ley como un componente esencial del entorno de las personas, una expresión de patrimonio natural y cultural compartido, y como un pilar de su identidad". El paisaje se percibe independientemente de su belleza excepcional ya que el paisaje, en todas sus dimensiones, tiene un peso en la calidad de vida de los ciudadanos y debería tenerse en cuenta en las políticas del paisaje. El objetivo del Convenio es amplio: se aplica a todo el territorio de las partes y se refiere a las áreas naturales, urbanas y periurbanas, incluidas las zonas terrestres, las aguas continentales y las zonas 
marinas. Es decir, se refiere no solo a los paisajes excepcionales, sino a los "comunes", los paisajes cotidianos y las zonas deterioradas. Se considera el territorio como un todo, sin distinción de si es una parte urbana, periurbana2, rural o natural; o excepcionales, cotidianas o degradadas; no se limita a los elementos culturales, artificiales o naturales; el paisaje es una unidad cuyas partes constituyentes se consideran de forma simultánea en sus interrelaciones ${ }^{3}$.

Los nueve principios que presiden este enfoque del paisaje pueden aplicarse también a las políticas de regeneración del paisaje.

1. Considerar el territorio como un todo.

2. Reconocer el papel fundamental del conocimiento.

3. Promover la sensibilización.

4. Definir las estrategias del paisaje.

5. Integrar el paisaje en las políticas territoriales.

6. Integrar el paisaje en las políticas sectoriales.

7. Hacer uso de la participación ciudadana.

8. Alcanzar los objetivos de calidad del paisaje.

9. Desarrollar ayuda e intercambio de información mutuos.

PH: La defensa que se hace hoy del paisaje no es sólo cultural o social, sino también económica, entendiéndolo como recurso para salir de la crisis. Si la recuperación de la dimensión territorial puede convertirse en un factor de desarrollo de las comunidades, ¿cómo podría progresar esta idea de recurso en paisajes degradados o fuertemente antropizados?

M. D.-P.:La necesaria relación entre paisaje y economía parece ser un tema inagotable, puesto que, últimamente, incluye la percepción humana sobre su entorno y su relación con él.
Mientras que el valor "relativo" de partes del territorio, "de gran calidad paisajística", parece estar incrementándose, ya que estos espacios son cada vez menos comunes, el valor "absoluto" del paisaje tangible e intangible sigue siendo (y será) "inestimable", precisamente porque -paradójicamente- la imposibilidad absoluta de medirlo hace imposible valorarlo.

Los cambios de calado, algunas veces incluso revolucionarios, que están experimentado nuestras sociedades y paisajes nos llevan a nuevos modelos económicos que conducen a un desarrollo sostenible, a la viabilidad y al "atractivo sostenible" de los territorios, lo que hacemos tanto por el bien de las sociedades actuales como futuras. Surgen nuevas economías, que se ahora definen como positivas, circulares, cooperativas, funcionales, horizontales, contributivas, ecológicas, verdes, púrpuras, azules, de plata, de código abierto, simbióticas, compartidas o alternativas.

El paisaje, como resultado del uso que hace la población del territorio, refleja la mentalidad de una sociedad y su forma de vida. Esto, a su vez, inspira y origina una forma y un estilo de vida. Refleja el "arte de vivir" de una civilización.

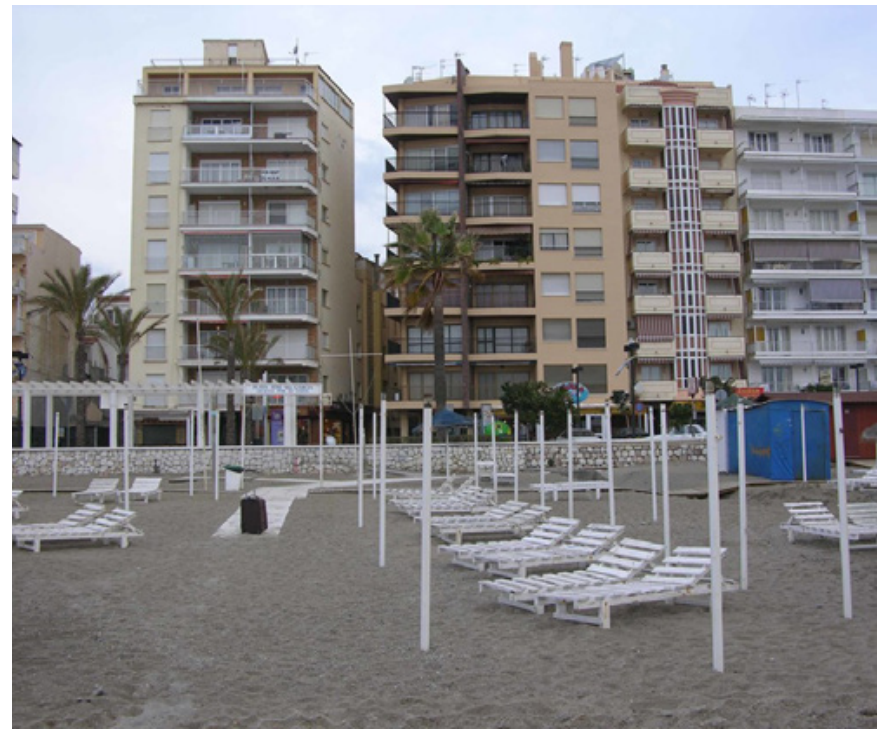

Vista parcial de la playa de Fuengirola (Málaga) | foto Fondo Gráfico IAPH (Víctor Fernández Salinas) 


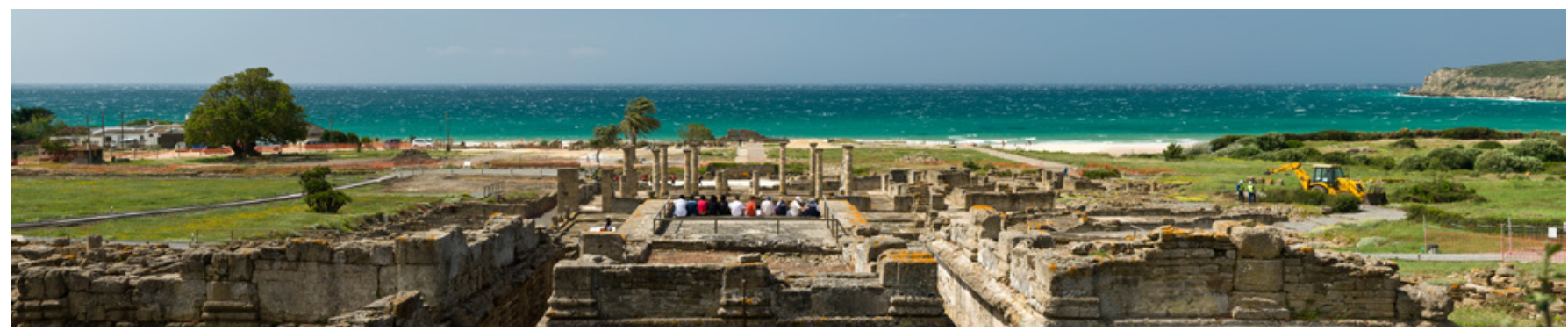

Ensenada de Bolonia (Cádiz), candidatura española para los premios del paisaje del Consejo de Europa en su edición 2018-2019 | foto Centro de Inmuebles, Obras e Infraestructuras del IAPH

El paisaje facilita muchos "servicios"; en términos sanitarios, de bienestar, recreacionales y turísticos, pero ofrece mucho más que esto: cuenta la historia de la Tierra y de la Humanidad, y modela la mente humana, que se inspira en ella y toma energía de ella.

Igual que modifica el comportamiento de la gente, su estado de ánimo y su espíritu, el paisaje es un factor vital en la economía; una fuerza motriz real, que no debe ignorarse. Las artes (literatura, pintura, la fotografía, la música, el cine) se inspiran en el paisaje. Los sectores de la agricultura, la alimentación, el turismo o la construcción, depende mucho del paisaje. La calidad del paisaje determina muchas veces el éxito de las iniciativas sociales y económicas, tanto públicas como privadas.

Por ello, es vital que estas políticas (también las económicas) tengan efecto directo o indirecto en el paisaje, para cuidar este capital. También deben involucrarse otras políticas: la planificación regional, el ordenamiento de la ciudad, la cultura, el medioambiente, la agricultura, los temas sociales, la sanidad, la educación, el transporte, la infraestructura, la energía y, por qué no, la publicidad.

\section{NOTAS}

1. Más información en <http://www.coe.int/en/web/landscape/landscape-observatory>.

2. Más información en <http://www.coe.int/en/web/landscape/workshops> y <http://www.coe.int/en/web/landscape/publications>.

3. En este sentido tuvo lugar la III Reunión del Consejo de Europa para la implementación del Convenio Europeo del Paisaje sobre Paisajes para áreas urbanas, suburbanas y periurbanas (Cork, Irlanda, 16-17 de junio 2005). Las actas se pueden consultar en European spatial planning and landscape, n. ${ }^{\circ} 82$.

4. Algunas experiencias de la Alianza del Premio del Paisaje del Consejo de Europa relativas a las políticas del paisaje para la regeneración urbana se pueden consultar en <http://www.coe.int/en/web/landscape/landsca pe-award-alliance>. 


\section{$\mathrm{PH} 96$,}

MORALES SÁNCHEZ, M. I. (ed.)

\section{"Digan lo que supieren...": Miradas y lecturas sobre el agua en Tempul}

\section{Cádiz: Edidáctica, 2018}

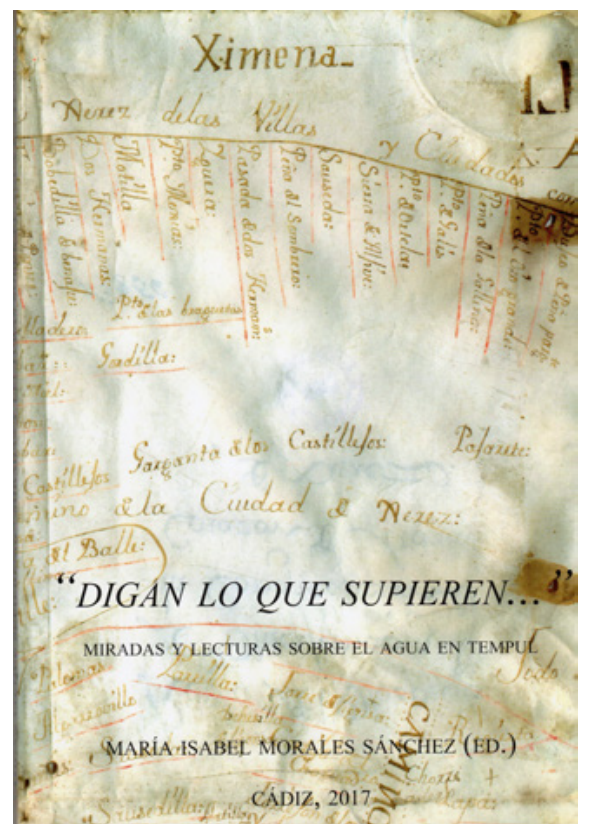

"Digan lo que supieren...". Se trata de la fórmula recogida en el "Pleito del Tempul", con la que se cuestionaba a los declarantes acerca de su experiencia vital y conocimiento del territorio -en este caso, en torno al citado manantial gaditano-, donde a mediados del siglo XVI el comendador de la Orden de Santiago, Fernando de Padilla, pretendiera fundar una población. Un proyecto, finalmente frustrado, que constituye una más de las innumerables piezas que conforman -a modo de puzle-, la realidad histórica de este paisaje cultural.

Partiendo de las propuestas lideradas desde la Universidad de Cádiz por parte de M. ${ }^{a}$ Isabel Morales acerca de la "cultura del agua", se edita la presente publicación, bajo el auspicio de la citada institución académica, los proyectos Aqva Dvcta y Tempul, y diversos grupos de investigación, todos asociados a la mencionada Universidad.

La obra, punto de partida para la investigación y reflexión acerca del citado manantial y las intervenciones históricas a su derredor, compila diversos artículos que abordan, desde distintos enfoques y métodos de análisis, algunos de los capítulos más relevantes para su comprensión como espacio vital dentro del extenso repertorio cultural del territorio gaditano.

Al cuerpo de la publicación precede la introducción, a cargo de la mencionada profesora Morales, quien expone de primera mano tanto la génesis de la obra -parte integrante de los proyectos que coordina en la línea de los "paisajes del agua"-, como las particularidades de las contribuciones de los destacados investigadores -procedentes de distintas disciplinas y de variada filiación-, que conforman el volumen.

El primer capítulo, firmado por Lázaro Lagóstena, nos adentra en el contexto fundacional de uno de los hitos más destacados del entorno de Tempul: su acueducto romano. Partiendo de las fuentes propias de la Edad Moderna, realiza un interesante recorrido por el espacio histórico, focalizando en el abastecimiento hídrico a la ciudad de Gades y en las implicaciones económicas y jurídicas que conlleva el uso y gestión del agua en el territorio.

A continuación, Emilio Martín diserta acerca de Tempul durante el Medievo, momento crucial en la posesión de la tierra, y, por tanto, en las intervenciones tanto económicas como materiales sobre la misma. Ello queda apoyado en un completo corpus documental que nos ilustra acerca de diversos epi- 
sodios acontecidos en Tempul, entre los que se encuentra el pleito antes citado.

El tercero de los capítulos, centrado ya en el período contemporáneo, corre a cargo de Cristóbal Orellana, quien realiza una importante aportación a las fuentes hasta ahora conocidas en las que se identifica la postura del cabildo jerezano respecto del finalmente malogrado proyecto de falansterio de Tempul, asociado a las corrientes furieristas.

Bajo las mismas coordenadas históricas, José Ramón Barros, autor del cuarto capítulo, da una vuelta de tuerca, en este caso, en lo referente a los proyectos de conducción de las aguas emprendidos por los ingenieros Ángel Mayo y Eduardo Torroja en distintas épocas. Partiendo de las intervenciones históricas, realiza un exhaustivo análisis de la pugna existente entre la actividad ingenieril y las cuestiones estéticas en lo relativo a la proyección de las obras públicas como hitos de ocupación del territorio, ejemplificando esta cuestión en el contexto y los casos citados.

Por último, Pablo Martínez, autor del quinto capítulo, se hace eco de las distintas relaciones que se establecen sobre el espacio en los albores del siglo $X X$, centradas en cuestiones ideológicas y técnicas: por una parte, la incidencia del pensamiento utópico europeo, y, por otra, la fotografía. Las confluencias generadas quedan inmortalizas bajo el objetivo del propio Martínez, en un proyecto visual que se incluye como cierre de la obra.

En suma, la publicación supera los convencionalismos de la historiografía tradicional, haciendo partícipe al lector del proceso de recuperación de la memoria de Tempul, su trascendencia histórica y su permanencia como referente. Al mismo tiempo, enriquece este planteamiento con los diversos puntos de vista que aportan cada uno de los autores, lo que dota a la obra de un carácter interdisciplinar y transversal esenciales en el análisis contemporáneo de la cultura y sus elementos.

María del Castillo García Romero | Dpto. de Historia del Arte, Universidad de Sevilla URL de la contribución <www.iaph.es/revistaph/index.php/revistaph/article/view/4354> 


\section{$\mathrm{PH} 96$,}

\section{HERRERO ROMERO, S.}

\section{De lo original a lo auténtico. La restauración de la Mezquita- Catedral de Córdoba durante el siglo XX}

\section{Córdoba: Cabildo Catedral de Córdoba, 2017}

Allí donde la historia de la arquitectura finaliza al hablar de la MezquitaCatedral, como ocurre en tantos otros edificios, comienza el riguroso estudio del arquitecto Sebastián Herrero sobre este excepcional monumento, haciéndonos comprender que el siglo XX ha sido decisivo, también, sobre cómo vemos y comprendemos su compleja realidad. Es por eso que, en el libro, antes de llegar a las conclusiones, hay un capítulo titulado La restauración como parte del proceso continuo de transformación en el que se hace referencia a la aceptación de la instancia histórica, al valor de la forma, a la importancia de la legibilidad del edificio y de su entorno pero también a las más recientes intervenciones sobre las cubiertas y las fachadas, la torre y el crucero. Algún día, la lectura crítica de las restauraciones de los monumentos, como la llevada a cabo por Sebastián Herrero, pasará a formar parte de la historia normalizada de éstos y no vistas como el inicio de su tergiversación, entre otras cosas porque muestran el aprecio de la gente por su patrimonio. Esa es, quizás, la lección más inmediata que podemos extraer de esta excelente publicación.

La referencia introductoria a lo que ocurre en el siglo XIX en la Mezquita, que los arqueólogos basaban en la tríada estudiar, excavar, restaurar, está relatado en base a los estudios del Nieto Cumplido, canónigo de la Catedral e investigador del período. Tras éste, se analizan cuidadosamente las distintas fases a las que fue sometido el monumento. De ellas son claves las dos primeras que tienen como responsables a Ricardo Velázquez Bosco y Antonio Flórez Urdapilleta, quienes son, como denomina la antropología social británica, los "personajes morales" responsables del período que va desde 1891 hasta 1929. Flórez fue discípulo de Velázquez Bosco y colaborador suyo en la Mezquita cuando era todavía estudiante de arquitectura. Velázquez Bosco, experimentado restaurador en varios monumentos, y Flórez estuvieron vinculados a la Institución Libre de Enseñanza que tanto influyó en el aprecio por el paisaje y los monumentos a través del magisterio de Giner de los Ríos y Cossío, y que proyectó su influencia para que tras la retirada de Velázquez Bosco en 1923 la responsabilidad de la conservación de la Mezquita recayera en Flórez y la de la Alhambra en Torres Balbás, dos ejemplos de lo que la I.L.E. consideraba una nueva visión de la arquitectura sobre los monumentos. Velázquez Bosco se hace cargo de las "reparaciones" (1891-1923) de las cubiertas, del espacio interior, fachadas e instalaciones de la Mezquita-Catedral. El libro analiza en detalle tanto la filosofía, el método y las técnicas utilizadas por este brillante arquitecto y buen historiador. Antonio Flórez (1923-1929), ya profesor en la Escuela de Arquitectura 
de Madrid, comienza su trabajo con un Plan General de Obras, similar al que Velázquez deja en la Alhambra y serviría de guía a Torres Balbás, y con él se inicia un giro restrictivo en las intervenciones y la valorización del monumento como documento histórico.

Tras ellos llega un breve período (1929-1936), el de los arquitectos conservadores, con Gutiérrez Moreno y Rodríguez Cano, de quien nuestro autor nos descubre su parentesco con Gómez Moreno, y la colaboración de Félix Hernández, quien en 1936 pasa a ser arquitecto conservador de Zona, cargo que pasaría a ser efectivo tras la guerra civil y al que guiaría su larga trayectoria (1940-1975), la "inquietud arqueológica" y un riguroso afán de conocimiento. Es al final de su trabajo cuando se ve involucrado en la polémica sobre la purificación original del edificio. La etapa más reciente se produce a partir de 1978 con la responsabilidad de Gabriel Ruiz Cabrero, en colaboración con Gabriel Rebollo. Sus trabajos en las cubiertas, el alminar, las fachadas y el crucero catedralicio son guiados por los problemas de la complejidad y la legibilidad, la imagen y la materialidad, el espacio y la luz... preocupaciones disciplinares que provienen de la exquisita sensibilidad de ambos, a lo que debe añadirse su interés por el entorno como parte fundamental del monumento. Todo ello brillantemente analizado por Sebastián Herrero, buen conocedor de su labor por haberse incorporado a la restauración junto a ellos en su tramo final.

Subyace en toda la obra que aquí reseñamos el interés por la evolución de la restauración de monumentos, viniendo a reflejar la de la cultura que se ocupa de estos símbolos. En monumentos-faro, como la Mezquita-Catedral de Córdoba, la Alhambra de Granada o las catedrales de León y Sevilla, entre otros, pueden encontrarse, por su interés y complejidad y por los arquitectos que se responsabilizaron de ellos, auténticas lecciones de arquitectura. Es en este sentido en el que el libro de Sebastián Herrero supone un trabajo excepcional, y de quien esperamos pronto nuevos estudios tan sensibles como éste, con un proceso metodológico cuyo rigor proviene de su origen como tesis doctoral, dirigidas por Gabriel Ruiz Cabrero y Sergio Martín Blas, ambos profesores de proyectos de la Escuela de Arquitectura de Madrid.

Julián Esteban Chapapría | Universitat Politècnica de València

URL de la contribución <www.iaph.es/revistaph/index.php/revistaph/article/view/4355> 


\section{$\mathrm{PH} 96$ reseñas}

\section{CENTELLAS SOLER, M.}

\section{Guía de arquitectura contemporánea. Roquetas de Mar}

Almería: Ayuntamiento de Roquetas de Mar, Colegio Oficial de Arquitectos de Almería, 2018

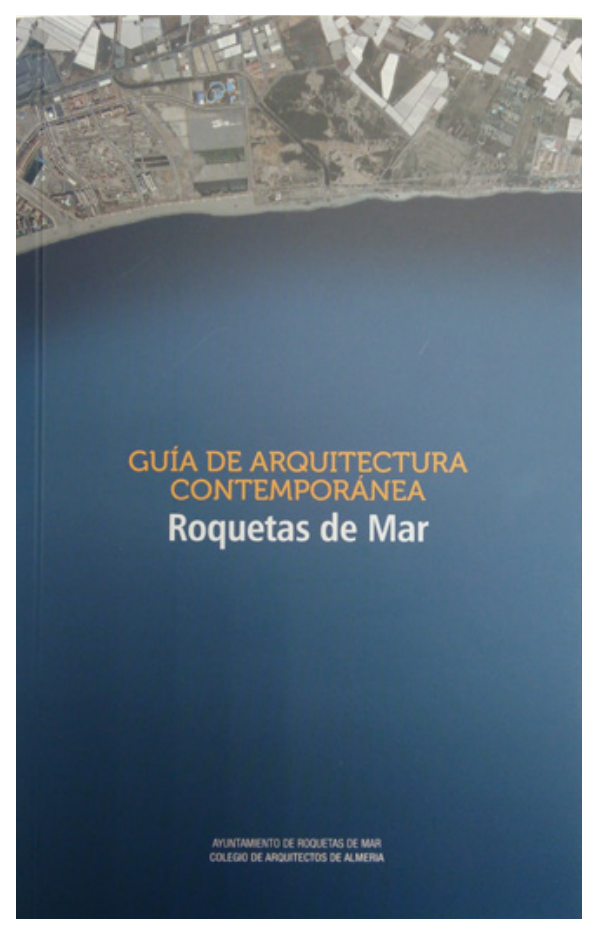

Lo sensorial se está convirtiendo, poco a poco, y según los expertos, en el gran valor de nuestro tiempo. Un libro de arquitectura como el que reseñamos tiene precisamente esa vocación: fijar nuestros sentidos. El autor señala, comenta y muestra lo que no debe quedar "invisible" para que sea recordado.

En cualquier territorio, la historia urbana es parte de su memoria, pero escribir sobre arquitectura no es sencillo. Por eso cuando se escribe sobre lo construido, y se hace bien, se amplifica con certeza la obra del arquitecto y se hace entendible el proyecto.

La Guía de Arquitectura Contemporánea de Roquetas de Mar, libro coeditado por el Ayuntamiento de Roquetas de Mar y el Colegio Oficial de Arquitectos de Almería, recoge las edificaciones, viviendas y proyectos más emblemáticos de este municipio del poniente almeriense desde la mitad del siglo XX hasta nuestros días. Muestra un interesante recorrido por 59 ejemplos de viviendas singulares, distintos poblados de colonización, edificios residenciales destacados y otras edificaciones públicas del municipio.

Cualquier guía de arquitectura, en nuestro tiempo, tiene dos dificultades de partida. Por un lado, el de la selección de la obra; y, por otro, el que se trate de edificación que, por ser contemporánea, es relativamente reciente. Respecto a lo primero, vemos que ninguna clasificación es forzosamente la actitud más justa. Escoger a unos y olvidar a otros es siempre un equilibrio delicado. En relación con lo segundo, tratar una arquitectura demasiado joven es enfrentarte con algo que aún está en pleno proceso de maduración y de cambio. Cerrar la clasificación de manera prematura puede dejar fuera a quienes deben estar dentro. Arquitecturas que por discretas puede que no sean recordadas.

Estas y otras circunstancias han originado que haya tardado en desarrollarse el presente estudio sobre la arquitectura de Roquetas de Mar, y que todavía no sean muchos los que se han dedicado a este tema. Sólo encontramos algunas publicaciones sobre la arquitectura del Mediterráneo, en general, y algunas otras revistas puntuales que muestran mucho y explican poco.

En el caso del libro que presentamos, el reto está superado. El autor es Miguel Centellas Soler. Buen arquitecto y de cualificado perfil investigador. Sabe encontrar, distinguir y seleccionar lo que perdura en el tiempo. Señala 
lo que hace ciudad y lo relaciona con lo que impulsa el desarrollo humano de un territorio. Miguel tiene además amplia experiencia en el ejercicio profesional y en la labor docente. Detrás de años de trabajo sobre el territorio almeriense, y numerosas publicaciones, centra sus estudios sobre la vivienda colectiva del siglo XX y los pueblos de colonización en España. Cualidades que se unen en esta publicación de 112 páginas para mostrar, de manera amena y precisa, el rico patrimonio arquitectónico y urbano de Roquetas de Mar, cómo ha crecido y se ha desarrollado en los últimos 70 años.

Es una guía dividida en pequeños fragmentos. En cierto modo independientes, pero con orden cronológico. Desde 1954 y la ampliación de los pueblos de colonización, hasta el 2017 con la rehabilitación del mercado municipal. Se nos presenta un catálogo de proyectos -según su autor- en torno a tres niveles: "un primer nivel con información, fotografías y planos (de la 1 a la 42), un segundo nivel en el que sólo salen las edificaciones con fotografía (de la 43 a la 56) y un tercer nivel en el que se hace referencia por escrito a proyectos singulares". Así encontramos un total de 59 viviendas singulares, 6 iglesias, un hotel, poblados de colonización, edificios de apartamentos, algún que otro espacio público y varias edificaciones singulares del municipio.

Todas las obras escogidas están bien localizadas en el territorio con la ayuda de buena cartografía. Cada selección se presenta con más fotografías que planos; y un breve texto descriptivo que justifica su elección. Este modo de trabajar hace fácil la compleja tarea de acercar lo específico al profano. En definitiva, Miguel Centellas, con su trabajo, hace entendible la arquitectura de Roquetas de Mar además de recordarnos que la buena arquitectura no tiene fecha de caducidad y que el tiempo no la desvirtúa, la consolida.

Jaime Vergara-Muñoz, Miguel Martínez-Monedero | arquitectos

URL de la contribución <www.iaph.es/revistaph/index.php/revistaph/article/view/4265> 


\section{$\mathrm{PH} 96$ reseñas}

\section{MODELADO DE INFORMACIÓN PARA ARQueología \\ Y ANTROPOLOGÍA}

Principios de Ingeniería de Software

para Patrimonio Cultural

César González-Pérez

\section{GONZALEZ-PÉREZ, C.}

\section{Modelado de información para Arqueología y Antropología: Principios de Ingeniería de Software para Patrimonio Cultural} sl: Create Space Independent Publishing Platform, 2018

Publicación que desarrolla teorías, metodologías y tecnologías para realizar el modelado de información en patrimonio cultural, tarea cada vez más requerida en el trabajo cotidiano de especialistas en arqueología, antropología, arte, historia arquitectura, investigadores, profesionales o gestores del patrimonio.

Realizando un recorrido desde la introducción al modelado conceptual, explicando su significado, conceptos, beneficios que implica su desarrollo y elaboración; la posibilidad de representación de la realidad para ayudar "a explorar áreas del mundo", "documentar", "comunicar" y generar nuevas perspectivas de conocimiento del objeto o espacio modelado, permitiendo lograr sistemas de base de datos o nuevas metodologías de trabajo de campo.

En el capítulo sobre los fundamentos del modelado conceptual, el autor nos introduce en los elementos constitutivos de la representación o modelo conceptual, especificando detalladamente: objetos, clases, atributos, tipos enumerados, asociaciones, generalización y especialización, que van a permitir implementar el desarrollo del modelo conceptual.

Respecto al modelado conceptual avanzando, afianza y brinda mayor especificidad de las posibilidades del manejo de los elementos como tipos enumerados, características y generalización avanzada; definiendo modelo de arquitectura como la organización en una estructura significativa, considerando aspectos como: la "vaguedad", "temporalidad", "subjetividad", "redefinición de características" y "meta información"; lo cual permite el manejo, actualización, una perspectiva objetiva y la posibilidad de apreciación del modelo generado a través de distintos espacios temporales.

Por su parte, un modelo de patrimonio cultural, que representa una parte de la realidad, considera el modelo de referencia abstracto del patrimonio cultural CHARM como ejemplo que permite utilizar los conceptos necesarios de forma exploratoria, facilitando la comunicación y la contrastación del modelo con otras fuentes de información, incorporando conceptos de "entidades valiosas", "valorizaciones" y "representaciones" propios de la naturaleza discursiva que da valor al patrimonio cultural.

Para la aplicación del modelo conceptual, nos brinda nuevas nociones y posibilidades al posterior desarrollo de un modelo conceptual, al poder establecer patrones de modelado, considerando también la construcción de 
modelos de calidad y la producción de modelos con modularidad, llegando a la discusión de la necesidad de equilibrio entre calidad, tiempo y recursos.

Asimismo, la publicación explica el proceso de construcción de un modelo, desde la opción de construcción desde el inicio de un caso o del trabajo sobre un modelo existente.

Concluye con la aplicación más requerida de un modelo conceptual: el desarrollo de sistemas de bases de datos que implica el manejo de tablas, columnas, filas, claves y relaciones; brindando también pautas de mapeos.

Permite a través de un ejemplo práctico, con un modelo conceptual básico la construcción de una base de datos relacional. Asimismo, la última sección contiene la solución de ejercicios sugeridos en los diferentes capítulos del libro.

La publicación de 578 páginas constituye un aporte, desde la introducción filosófica del modelado conceptual hasta su uso y aplicaciones. Un recorrido paso a paso, para poder gestionar amplitud y complejidad de datos, en un mundo cada día más digitalizado, con nuevas tecnologías de información y comunicación que deben manejar los especialistas del patrimonio cultural.

Silvia Isabel Quinto Fernández | arquitecta

URL de la contribución <www.iaph.es/revistaph/index.php/revistaph/article/view/4269> 


\section{$\mathrm{PH} 96$}

reseñas

\section{MINGUET MEDINA, J.}

\section{(Aspectos de) La Arquitectura después de Bretton Woods}

\section{Sevilla: Editorial Universidad de Sevilla, 2017}

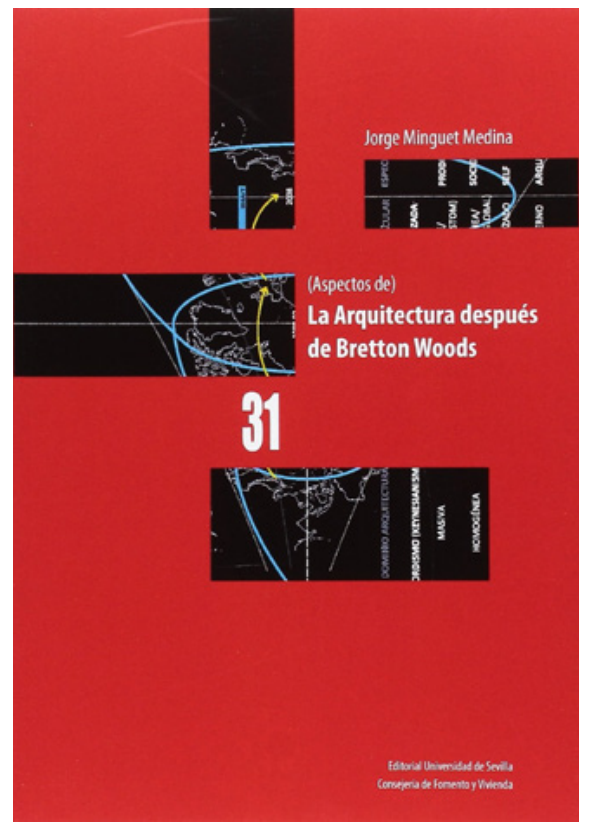

(Aspectos de) La Arquitectura después de Bretton Woods, de Jorge Minguet Medina, publicado dentro de la colección Kora y premiado por la BEAU de 2018, nos sitúa, desde su título, en el momento en que la connivencia de la arquitectura con lo económico queda al descubierto, mientras no para de dar forma(s) a las insensateces del capitalismo: la ruptura de los acuerdos de Bretton Woods en 1971. Al adentrarse en sus páginas, se descubrirá cuándo situar el punto - ¿final?- de esta otra historia de la arquitectura contemporánea: la caída de Lehman Brothers en 2008, o lo que es lo mismo, el comienzo de la(s) crisis global(es) de los mercados financieros.

Más bien el comienzo del fin para toda una generación de arquitectas y arquitectos, que se han formado y/o trabajado a caballo de dos siglos, y que han visto el tránsito desde el exceso y la espectacularización de la arquitectura de los años 90 , a su completo descrédito -coincidiendo con la crisis- al final de la primera década del siglo XXI. De hecho, el texto, con vocación de ensayo, toma tinte de narración de quien se ha visto, si no protagonista, al menos partícipe de todo lo acontecido.

Así se podría resumir, simplificando mucho, la historia que Jorge Minguet va a ir desentrañando en su libro. Para sintetizar, que es algo bastante más complejo, y así lo resalta el autor, hay que mirar el "cronograma-resumen" con el que el libro se abre y se cierra, y para más detalles, hay que avanzar en la lectura de las tres partes que componen el libro: "De lo general", que ocupa más de la mitad del texto, en la que el autor explicita las implicaciones de lo económico-productivo en la arquitectura; "De lo particular", en la que configura sus manifestaciones específicas; y "Coda", en la que avanza algunas conclusiones para el futuro (presente) de la arquitectura.

Evidentemente, esto altera los límites temporales de la investigación, más allá de lo que se proponía en un principio (algo del que el autor avisa desde las primeras páginas), y que se podría asumir como una necesidad contemporánea, si seguimos la definición de Agamben para la contemporaneidad: adherir al propio tiempo, y a la vez alejarse de ello.

En este sentido, el relato de Minguet hace posible la integración, que no la homogeneización, de las historias (frente a la Historia) de la arquitectura contemporánea, de modo que las relaciones cronológicas, y es de interés apuntarlo en una publicación que invita al debate sobre el patrimonio cultural, no sean -solamente- causales o progresivas, sino que dialoguen con el pasado, resituándolo en y desde el presente. 
Aún sin perder el carácter sistemático, necesario en todo trabajo de investigación, el texto rehúye cualquier intento antológico y hace de la incertidumbre un campo de estudio, en el que es posible reconocer los síntomas del presente, justamente allí donde se difuminan los límites de lo arquitectónico hacia otras modalidades de acción. De hecho, en el capítulo final, el autor realiza también un ejercicio de previsión acerca de la sostenibilidad como sustantivo, y no como adjetivo- en la arquitectura, como "idea central del cambio necesario de paradigma" (en términos culturales), y a la vez ya sujeta a "un proceso de positivación, de reversión de su componente crítica", en el que el arquitecto Andrés Perea Ortega -quien firma el prólogo del libroreconoce (y apoya) cierto "escepticismo".

Sin embargo, podría ser más beneficioso leer las preguntas que cierran el texto cómo una invitación a que los lectores participemos en la búsqueda de alternativas que detengan, cuando no reviertan, los ciclos que allí se analizan, y una exhortación a que llevemos estos interrogantes a nuestra vida cotidiana, ya que los "aspectos" a los que alude el título, no son otra cosa que lo que nos está pasando. Y se podría añadir un post scriptum para extender aquel "después" hasta nuestros días -los últimos diez años que no quedan incluidos en el análisis-, no para seguir reproduciendo la historia como un proceso lineal/cíclico, sino para verificar cómo estas reflexiones podrían redefinir la condición arquitectónica, alejándola de toda lógica proyectual partícipe del sistema de consumo y de mercado, y resignificarla ya no como producción sino como acción.

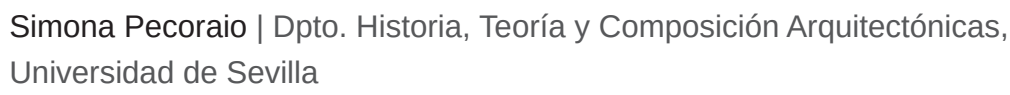

URL de la contribución <www.iaph.es/revistaph/index.php/revistaph/article/view/4263> 


\section{$\mathrm{PH} 96$ reseñas}

\section{PIZARRO MORENO, c. (coord.)}

\section{Sitio de los dólmenes de Antequera. Patrimonio Mundial de la UNESCO}

\section{Sevilla: Consejería de Cultura. Junta de Andalucía, 2017}

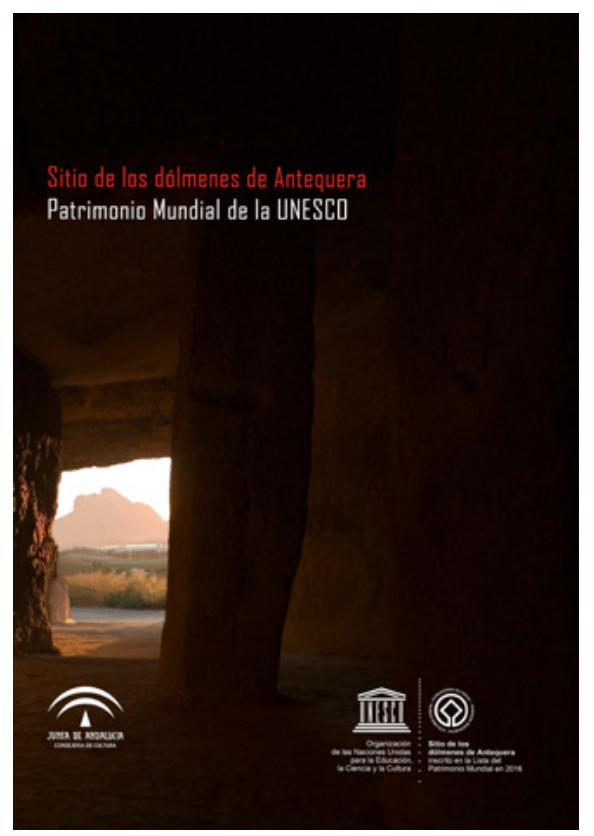

La vega antequerana ha sido poblada desde épocas muy remotas gracias a la fertilidad de sus tierras, siendo a la vez lugar estratégico de tránsito entre las rutas norte-sur y este-oeste de la Península Ibérica. Prueba de ello es una rica herencia de elementos construidos, a partir del neolítico en forma de asentamientos, lugares de servicio para las actividades agrícolas y ganaderas, y necrópolis. Estos lugares estaban estrechamente relacionados con el paisaje, vías de paso, ríos y, sobre todo, dos hitos geográficos: la sierra del Torcal y la Peña de los Enamorados. La propuesta de inscripción a Patrimonio Mundial de la UNESCO se basa precisamente en este valor especial para apoyar el significado único de este conjunto neolítico. Un bien en serie, por lo tanto, de tipo cultural, que engloba un conjunto monumental megalítico compuesto por los dólmenes de Menga y de Viera y el tholos de El Romeral, junto con los ya mencionados elementos naturales de la Peña de los Enamorados y la sierra de El Torcal. Se trata de elementos únicos, que no serían entendibles los unos sin los otros.

El re-descubrimiento de estos dólmenes -consta un uso alterno pero continuado a lo largo de todas las épocas históricas- data de mediados del siglo XIX en el caso de Menga, y principio del siglo XX para Viera y Romeral, despertando un inmediato interés que impulsan numerosos trabajos de investigación e interpretación. Pese a la alterna fortuna en la real protección y conservación de estos elementos, es a partir de los años 80 cuando empieza a gestarse la voluntad de solicitar el máximo reconocimiento otorgado por la UNESCO. Sin embargo, es solo a partir de 2004, cuando se reactiva el objetivo de inscripción como Patrimonio de la Humanidad, apoyado por el mismo Comité de Patrimonio Mundial, que sugiere y fomenta esta candidatura. La inscripción definitiva se produce en la cuadragésima sesión del Comité de Patrimonio Mundial, celebrada en Estambul en 2016.

El reconocimiento de los valores patrimoniales por parte de la UNESCO es un camino largo y complejo, al igual que la documentación requerida por los comités de expertos que la evalúan. La resolución significa el comienzo de una nueva etapa de gestión del sitio, que se enfrentará a nuevas presiones, siendo por lo tanto más que oportuna la reproducción del expediente presentado a los expertos de la UNESCO. Coordinada por Carmen Pizarro Moreno, la presente publicación aúna la documentación originalmente compuesta en dos volúmenes. El primero, Formulario, que sigue las directrices de la institución intergubernamental con la información esencial requerida en el expediente, en nueve capítulos que detallan la descripción de los cinco 
bienes propuestos, los criterios de excepcionalidad que justifican su máximo reconocimiento, los niveles de protección y riesgos que evaluar y mitigar. Se completa con información relacionada con la elaboración del expediente, un listado de la documentación publicada relacionada con el sitio, y un capítulo relacionado con el seguimiento del bien, indicadores y disposiciones para garantizar la conservación patrimonial. El segundo incluye seis anexos para la contextualización y profundización de determinados aspectos de interés, entre ellos capítulos sobre el megalitismo, sobre la arqueoastronomía de los Dólmenes de Antequera o sobre el arte prehistorico en la región.

La presente publicación incorpora en un único volumen la documentación presentada, haciendo accesible al público en general el corpus de textos, gráficos, e imágenes producido para este hito. Se trata ciertamente de una publicación de gran interés desde diferentes puntos de vista. En primer lugar para todo investigador, que encontrará una amplia documentación sobre los monumentos megalíticos de Antequera, y su contextualización en el ámbito regional y nacional. Tener acceso al expediente completo de inscripción del bien ofrece además la posibilidad de comprender y evaluar los requerimientos a este nivel como forma de transmisión de conocimiento y transferencia, que pueden ser útiles para su reproducción a escalas menores. Los textos que componen el volumen están escritos sin excesivos tecnicismos, siendo accesibles a un público muy amplio y variado, por lo cual cualquiera puede aprender sobre la historia del megalítico y el significado y excepcionalidad de los Dólmenes de Antequera. Puede incluso servir como una excepcional guía didáctica para quien se plantee realizar una visita, incluyendo estudiantes de varios niveles formativos. Es a la vez un compendio de todas las actividades llevadas a cabo en las últimas décadas, con un aparato fotográfico y de imágenes muy rico y valioso de cara a la documentación de esta etapa, y con una edición de alta calidad, como de costumbre en las publicaciones de la Consejería de Cultura. Posiblemente falte una introducción que ponga el volumen en el contexto que lo ha generado, especialmente de cara al futuro, ya que su origen viene explicado a lo largo del texto. Lo único que se puede desear es una amplia difusión del volumen en bibliotecas e instituciones no sólo de la comunidad autónoma, para ofrecer su acceso a todos los ciudadanos e investigadores interesados, algo todavía por hacer.

Guido Cimadomo | Dpto. de Arte y Arquitectura, Universidad de Málaga

URL de la contribución <www.iaph.es/revistaph/index.php/revistaph/article/view/4274> 


\section{$\mathrm{PH} 96$,}

\section{ARRIETA URTIZBEREA, I. (ed.) \\ El género en el patrimonio cultural \\ Bilbao: Universidad del País Vasco, 2017}

De la mano de cinco miradas diferentes, esta obra aborda el papel significativo y poco reconocido que ha tenido el género femenino como parte del valor del patrimonio cultural, concretamente su papel en su desarrollo, apropiación y conservación. El libro consta de seis capítulos, donde los autores manifiestan la intención que llevó a la elección de los casos analizados, con acciones donde el papel femenino busca ser revalorado.

A partir de esta presentación, Iñaki Arrieta Urtizberea refiere la situación que prevalece a mediados del siglo XX, donde la visión elitista, eurocéntrica y masculina sobre la interpretación del patrimonio cultural, comienza a ser cuestionada. El autor reflexiona sobre la vigencia que mantiene la brecha androcéntrica en el ámbito patrimonial, refiriendo que el patrimonio es una herramienta potente en las políticas de reconocimiento de género e igualdad.

Guadalupe Jiménez-Esquinas, en su artículo "El patrimonio (también) es nuestro. Hacia una crítica patrimonial feminista", sostiene que la política como herramienta estratégica tiene importantes consecuencias en la lucha por los recursos y la igualdad. Añade que desde la política puede abrirse la oportunidad de crear un nuevo marco, en el que no sólo se reivindique el papel silencioso de la mujer, sino que sea un mecanismo donde realmente participe la sociedad.

En "Caminando hacia la inclusión de las mujeres en los museos de España", M. ${ }^{a}$ Carmen Delia Gregorio profundiza en el trabajo continuo que se puede llevar a cabo en el cambio de consciencia en el campo museístico. Interesante resulta la reflexión sobre la "situación inversa" que puede desencadenarse sólo impulsando el reconocimiento del género: los espacios pueden interesar a determinados grupos y, en consecuencia, no se logre llegar al conjunto de la sociedad. En una reflexión final, se describe que las acciones llevadas a cabo en los centros patrimoniales referidos paulatinamente están cumpliendo su cometido.

Por su parte, Denis Chevallier expone las acciones que giraron en torno a exposiciones realizadas en el nuevo Museo de las Civilizaciones Europeas y el Museo del Mediterráneo de Marsella que tuvieron un fuerte impacto en la sociedad francesa, despertando con ello una gran polémica, sumada a la controversia planteada en ese momento: la legalización del matrimonio entre personas del mismo sexo. Es así como el "Bazar de género" logró su cometido a lo largo de siete meses. La autora relata que no se trataba de desafiar ni enfrentar los diversos pensamientos y creencias de la sociedad; por el 
contrario, se buscaba librar los obstáculos impuestos para poder vivir juntos en sociedad.

Un trabajo interdisciplinario procedente del vínculo entre la Universidad de Oviedo, La Ponte-Ecomuséu y UCL Institute of Archaeology plasma mediante esta investigación el impulso que supone reinterpretar la historia mediante el desarrollo de rutas. En "Itinerarios culturales (re)-interpretativos en La PonteEcomuséu, nosotras también hacemos historia", se ponen en contexto una serie de casos españoles donde se ha buscado corregir el sesgo ideológico y cultural. En los casos analizados, se concluye que en las rutas propuestas se ha logrado a través de la deconstrucción de momentos históricos la revalorización del pasado femenino.

Para concluir esta publicación, Anne Monjarte desmenuza en un interesante artículo el análisis de un grupo de cinco esculturas distribuidas por el espacio público de los barrios parisinos. Las esculturas reflejan en sí mismas el papel desempeñado, en este caso, por la mujer "del pueblo parisino". Este paisaje escultórico, revela la paradoja existente entre el género y la expresión artística masculina, donde si bien las mujeres eran consideradas para estar expuestas y representadas en una escultura, no eran las mujeres quienes decidían qué mujer debía representar al pueblo.

Gina Monserrat Núñez-Camarena | arquitecta

URL de la contribución <www.iaph.es/revistaph/index.php/revistaph/article/view/4268> 


\title{
$\mathrm{PH} 96^{\text {reseñas }}$
}

\author{
GÁMIZ GORDO, A.; RUIZ PADRÓN, L. \\ Malaga in the postcards of Purger \& Co. around 1905 \\ Málaga: Universidad, 2018
}

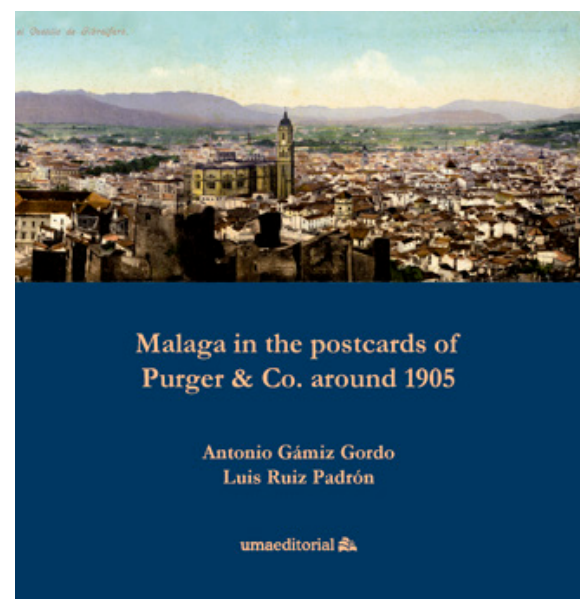

Este libro, publicado originalmente en 2017, cuya edición inglesa ve la luz ahora, es fruto de la enriquecedora colaboración de dos investigadores miembros del grupo "HUM-976. Expregráfica. Lugar, Arquitectura y Dibujo", los doctores arquitectos Antonio Gámiz Gordo y Luis Ruiz Padrón.

Antonio Gámiz Gordo es autor de variadas publicaciones sobre imágenes de paisajes y arquitecturas en distintas ciudades y épocas. Fue además director de la tesis doctoral "Málaga. Dibujos de ciudad y paisaje hasta 1850", leída por Luis Ruiz Padrón en 2016, quien es un prolífico y reputado dibujante con buena parte de su obra gráfica publicada. El primero de ellos cuenta en su colección particular con las postales malagueñas sobre las que versa este libro, analizadas de primera mano por sus autores, y el segundo ha estudiado la evolución urbana de su ciudad natal a través de sus imágenes.

El primer capítulo trata sobre los antecedentes de las tarjetas postales ilustradas en el transcurso del siglo XIX al XX. Plantea un preciso y acertado recorrido desde la invención de la fotografía a la producción industrializada de imágenes para su amplia comercialización. La casa alemana "Purger \& Co. München, Photochromickarte", uno de los grandes editores que trabajó en España y en otros países, produjo cerca de 80 postales sobre Málaga hacia 1905. A lo largo de los distintos epígrafes de este capítulo se refleja el importante valor documental espacial y temporal de las tarjetas postales, más allá de su valor emotivo y sentimental; se habla sobre la producción de imágenes desde la irrupción de la fotografía y sobre la aparición de métodos de impresión fotográfica con nitidez y bajo coste. También se trata el origen y evolución de las tarjetas postales ilustradas desde 1868: en la última década de esa centuria se añadieron imágenes al anverso de estas postales, y en el primer lustro del siglo XX vivieron una época dorada. Además, se revisan las principales colecciones de Málaga, entre las que destaca la casa Purger \& Co. por la variedad geográfica, tipológica y cromática de sus tarjetas postales, que combinaron la fotografía en blanco y negro con placas litográficas con diferentes tintes. Dicha casa produjo cerca de 1500 postales sólo en España, 800 de Andalucía. Las de Málaga fueron las primeras de esta editora en nuestro país.

El segundo capítulo, Paisaje y progreso en las postales de Málaga de Purger \& Co., plantea un recorrido por el paisaje urbano malagueño a través de estas imágenes. Se identifica la localización de la mayoría de ellas, que permiten reconocer su evolución urbana, en los siguientes apartados: Panorámicas de la ciudad y el puerto (figuras 1 a 18), Vistas de la ciudad histórica (figuras 
19 a 40), Vistas de las primeras periferias urbanas (figuras 41 a 62), Tipos populares malagueños (figuras 63 a 72) y Los jardines de la Concepción y San José (figuras 73 a 78).

El libro culmina con una interesante reflexión sobre el momento clave de transformación urbana que reflejan estos importantes testimonios de la ciudad. También se aporta un listado de postales de Purger \& Co. sobre Málaga y una amplia bibliografía sobre tarjetas postales, historia de la fotografía y sobre la propia ciudad.

Estamos ante un libro magníficamente editado en color que no solo se destina a interesados en la historia de la fotografía, de la tecnología, de la arquitectura, del urbanismo, de la jardinería, de la etnografía, de las costumbres populares... o del paisaje y el paisanaje malacitano hacia 1905 , sino que tiene vocación de dirigirse a un público amplio y diverso, con inquietud por recorrer los rincones de la Málaga que conociera Pablo Ruiz Picasso y por redescubrir "ese mito de un sur paradisíaco que ha pervivido hasta nuestros días".

Luis José García Pulido | Dpto. de Arte y Arquitectura. Universidad de Málaga

URL de la contribución <www.iaph.es/revistaph/index.php/revistaph/article/view/4246> 